\begin{abstract}
UNIVERSIDADE DE SÃO PAULO
FACULDADE DE FILOSOFIA, LETRAS E CIÊNCIAS HUMANAS DEPARTAMENTO DE TEORIA LITERÁRIA E LITERATURA COMPARADA

PROGRAMA DE TEORIA LITERÁRIA E LITERATURA COMPARADA
\end{abstract}

ARMANDO OLIVETTI FERREIRA

Recortes na paisagem:

uma leitura de Brazil e outros textos de Elizabeth Bishop

v.1

São Paulo 


\author{
UNIVERSIDADE DE SÃO PAULO \\ FACULDADE DE FILOSOFIA, LETRAS E CIÊNCIAS HUMANAS \\ DEPARTAMENTO DE TEORIA LITERÁRIA E LITERATURA COMPARADA \\ PROGRAMA DE TEORIA LITERÁRIA E LITERATURA COMPARADA
}

\title{
Recortes na paisagem: \\ uma leitura de Brazil e outros textos de Elizabeth Bishop
}

Armando Olivetti Ferreira

\begin{abstract}
Tese apresentada ao Programa de Pós-Graduação
em Teoria Literária e Literatura Comparada da

Faculdade de Filosofia, Letras e Ciências Humanas

da Universidade de São Paulo, para a obtenção do título de Doutor em Letras.
\end{abstract}

Orientadora: $\operatorname{Prof}^{\mathrm{a}} \mathrm{Dr}^{\mathrm{a}}$ Ivone Daré Rabello

v.1

São Paulo 
Quando acompanhado de um sentimento profundo, o abraço torna-se um verdadeiro acolhimento.

Elizabeth Bishop, Brazil, p.12.

Marlise Vaz Bridi

Ivone Daré Rabello

Fernando José Arouca 


\section{AGRADECIMENTOS}

A conclusão deste trabalho só foi possível graças à colaboração direta e indireta de muitas pessoas. Amigos, colegas e profissionais de diversas áreas responderam às minhas consultas não só com informações, mas também com palavras de incentivo e afeto. Manifesto minha gratidão a todos. E agradeço, especialmente:

À Prof ${ }^{\mathrm{a}} \operatorname{Dr}^{\mathrm{a}}$ Ivone Daré Rabello, orientadora deste trabalho. Sua confiança, desde o primeiro momento, foi fundamental.

À Prof ${ }^{\mathrm{a}} \operatorname{Dr}^{\mathrm{a}}$ Marlise Vaz Bridi, orientadora do Mestrado, por sugestões, apoio e carinho sempre presentes, desde aquela época.

Ao $\mathrm{CNPq}$, pela bolsa concedida, e aos funcionários do Departamento de Teoria Literária e Literatura Comparada da FFLCH/USP, especialmente ao Luiz Mattos Alves.

Aos $\operatorname{Prof}^{\mathrm{s}} \operatorname{Dr}^{\mathrm{s}}$ Maria Silvia Betti e Marcos Antonio de Moraes, pelas inúmeras sugestões que redirecionaram o trabalho a partir do exame de qualificação.

À Prof ${ }^{\mathrm{a}}$ Dr $^{\mathrm{a}}$ Elza Miné, pelos múltiplos e contínuos ensinamentos.

Ao Paulo Henriques Britto, poeta, tradutor de Bishop e especialista em sua obra, pela generosidade com que prontamente satisfez minhas dúvidas e curiosidades.

Aos professores Terrence Edward Hill e Valter Gonzales, pela revisão de minhas traduções, sempre acompanhada de novos ensinamentos, e ao Jaime Borelli, pela revisão dos capítulos introdutórios.

Ao Dean M. Rogers, responsável pelos arquivos de Elizabeth Bishop no Vassar College, e à equipe do setor de bibliotecas da Harvard University.

Ao Emmanuel de Macedo Soares, pelas valiosas informações relacionadas à sua família.

À minha irmã Priscila, pelo apoio inestimável na obtenção dos documentos arquivados no Vassar College. 
Este trabalho tem como objetivo anotar, traduzir e comentar uma parte da obra da escritora norteamericana Elizabeth Bishop (1911-1979), que viveu no Brasil durante cerca de vinte anos: seus textos de caráter jornalístico relacionados ao país. O mais extenso é o livro Brazil (1962), escrito sob encomenda dos editores da revista Life. O livro foi renegado pela autora, inconformada com as intervenções dos editores, e publicado sob coautoria. O cotejo entre os originais (preservados nos arquivos de Bishop, no Vassar College), o texto publicado em 1962 e as anotações da autora em seu exemplar (preservado na Harvard University) permite apontar as similaridades e, especialmente, os importantes contrastes entre a perspectiva de Bishop e a dos editores. Uma investigação sobre o momento em que o livro surgiu - na vida da autora e na história do Brasil e dos Estados Unidos auxilia a compreensão não só do texto, mas também de sua escrita e dos episódios associados à sua edição. O trabalho se completa com a tradução e a anotação de outros cinco textos, dois dos quais ainda inéditos mesmo em inglês, vestígios de um projeto abandonado por Bishop: a elaboração de um novo livro sobre o país.

Palavras-chave: Elizabeth Bishop (1911-1979); interpretações do Brasil, 1950-1970; literatura e sociedade - Brasil, século XX; tradução, anotação e comentários; literatura e jornalismo, século XX. 
The aim of this work is to annotate, translate, and comment a part of the writings by Elizabeth Bishop (1911-1979), the North-American writer, who lived in Brazil for approximately twenty years, focusing on her journalistic texts about that country. Her largest piece is a book called Brazil (1962) which was commissioned by the editors of Life magazine. However, the book was rejected by the author who refused to accept the interventions made by the editors. As a result, they co-authored it. Comparing the original (preserved in the Bishop archives at Vassar College) with the published text allows us to compare two different views of Brazil, to highlight similarities and especially the important contrasts between them. A research on the period the book was published - focused on the author's life, as well as on the history of both Brazil and the U.S.A. - helps to understand not only the text itself, but also how it was written and the episodes associated to its edition. The present work includes five additional texts, remains of a project that was abandoned by Bishop: the making of another book on Brazil. Two of these texts have remained unpublished to date, even in English.

Keywords: Elizabeth Bishop (1911-1979); interpretations of Brazil, 1950-1970; literature and society - Brazil, 20th Century; translation, annotation, and commentary; literature and journalism, 20th Century. 


\section{SUMÁRIO}

\section{volume 1}

Introdução

1 Uma autora, uma obra e um país

Projetos brasileiros, realizados ou não 18

Viagens narradas 21

A captação de um país 25

Brazil, 1962 - um livro renegado 34

Brazil, 1962 - buscando estabelecer um texto 39

\section{Escrever Brazil}

Fazendo algo por seu país 53

Um livro, uma série 57

De 1962 a 197060

Esquematizando o Brasil 65

Linguagem e intenções: um confronto 68

Escrevendo no Brasil, para americanos 75

Retratando um momento 78

3 Captando o outro: um país

Boa-vizinhança, guerra e autoimagem 101

Um país, um refúgio 105

Escritores e professores: algumas fontes

O Brazil de John dos Passos 112

“Uma miscelânea de paradoxos" 115

Personagens 118

Artes populares e sofisticadas 122

Arquitetura: admiração 127

Rascunhos e fragmentos 132

Para não concluir 


\section{volume 2}

4 Brazil - tradução e anotação 140

Nota sobre esta tradução de Brazil

Brazil 144

Cap. 1 Um povo caloroso e sensato 145

Cap. 2 A terra do pau-brasil 162

Cap. 3 O único império ocidental 179

Cap. 4 Três capitais 197

Cap. 5 Animal, vegetal e mineral 215

Cap. 6 As artes espontâneas 230

Cap. 7 As artes sofisticadas 247

Cap. 8 Grupos e indivíduos 274

Cap. 9 A luta por uma democracia estável 290

Cap. 10 Uma nação perplexa e indecisa 318

Índice (com a paginação da edição de 1962) 334

5 Fragmentos de um outro Brasil

(tradução e anotação de cinco textos de Elizabeth Bishop)

Suicídio de um ditador (moderado) [1954] 344

Uma nova capital, Aldous Huxley e alguns índios [1958] 347

Uma viagem pelo Amazonas [1960] 383

No trem do Encantado [1965] 399

Uma viagem pelo rio São Francisco [1967] 413

Bibliografia 


\section{Lista de quadros e ilustrações}

Quadro 1 - Complementos a Brazil (Vassar College, sumário do Folder 47.1)

Quadro 2 - Capítulos de Brazil: assuntos, sumário e títulos

Figura 1 - Página inicial dos originais de "Uma viagem pelo Amazonas". Vassar College, Special Collections.

Figura 2 - Página inicial dos originais de “Uma viagem pelo São Francisco”. Vassar College, Special Collections.

Figura 3 - Página inicial do capítulo 2 (“A terra do pau-brasil”) dos originais de Brazil. Vassar College, Special Collections.

Figura 4 - Foto tirada durante a visita de Elizabeth Bishop e Aldous Huxley ao Xingu, em 1958. Vassar College, Special Collections.

Figuras 5 e 6 - Assassinato de um político japonês e queima de documentos peronistas em Buenos Aires após a queda de Perón (1955). Fontes: reproduzidas, respectivamente, de Japan (1961, p.56-57) e The River Plate Republics (1965, p.103). New York: Time Incorporated. (Life World Library).

Figuras 7 e 8 - Getúlio Vargas no Palácio do Catete e manifestação “anti-EUA” em Recife. Fontes: reproduzidas de Brazil (1962, p.126 e 143). New York: Time Incorporated. (Life World Library).

Figuras 9 e 10 - Flagrante de eleição no Rio de Janeiro, e canteiro de obras da rodovia Belém-Brasília. Fontes: reproduzidas de Brazil (1962, p.150-151 e 1970, p.150-151, respectivamente). New York: Time Incorporated. (Life World Library).

Figuras 11 e 12 - Bonde e ônibus no Rio de Janeiro. Fontes: reproduzidas de Brazil (1962, p.16 e 1970, p.16, respectivamente). New York: Time Incorporated. (Life World Library).

Figuras 13 e 14 - Flagrantes do Grande Prêmio Brasil, Rio de Janeiro. Fontes: reproduzidas de Brazil (1962, p.49 e 1970, p.49, respectivamente). New York: Time Incorporated. (Life World Library).

Figuras 15 e 16 - Capa de Brazil (1962) e Foto do Carnaval carioca. Fonte: reproduzida de Brazil (1962, p.89). New York: Time Incorporated. (Life World Library).

Figura 17 - Esquema para a redação de Brazil [esboço]. Vassar College, Special Collections.

Figura 18 - Rascunho da carta enviada por Elizabeth Bishop aos editores de Brazil em dezembro de 1962. Vassar College, Special Collections.

Figuras 19 a 21 - Correções de Elizabeth Bishop em seu exemplar de Brazil (1962), Harvard University.

Figuras 22 a 25 - Brasília Palace Hotel (Fonte: Portal Vitruvius), Hotel Amazonas, Manaus (Fonte: Cavalcanti, 2001, p.318) e a casa de Lota de Macedo Soares, Samambaia, Petrópolis. (Fonte: Architecture d'Aujourd'hui, n.90, 1960).

Figuras 26 a 28 - Madalena Reinbolt, ex-empregada de Lota de Macedo Soares, e duas de suas obras: óleo sobre papel e bordado. Fontes: reproduzidas de Frota, 1975. 
Figuras 29 a 31 - A “Casa Mariana”, em Ouro Preto. (Fotos: AOF, 2006).

Figuras 32 a 36 - Livretos de cordel (Acervo AOF); Frases de pára-choques de caminhão (Vassar College, Special Collections); carrancas do São Francisco (Fonte: Paulo Pardal. Carrancas do São Francisco, 1981, p.61 e 92).

Página de abertura - v.1

Elizabeth Bishop em Samambaia, Petrópolis, 1954. Vassar College, Special Collections.

"Brazilian Landscape", aquarela e guache de Elizabeth Bishop. Vassar College, Special Collections.

\section{Página de abertura - v.2}

J.Borges. "O bicho de sete cabeças". Xilogravura, s.d. 30,5 x 47,5 cm. Reproduzido do catálogo de exposição A arte de J.Borges: do cordel à xilogravura. (Curadoria: José Octavio Penteado, Tânia Mills, Pieter Tjabbes). Brasília: Centro Cultural Banco do Brasil, 2004. 104p. p.74. 


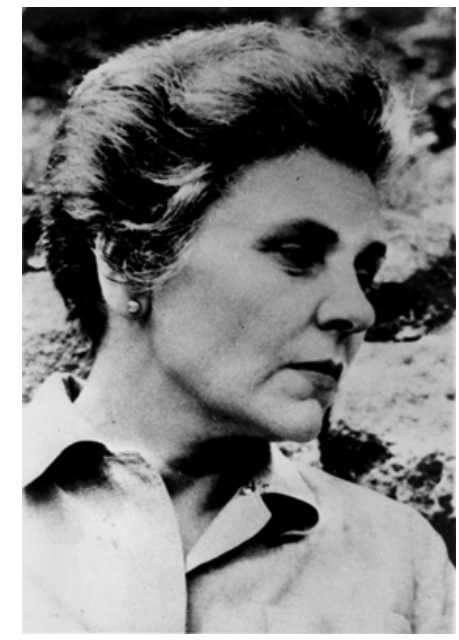

Elizabeth Bishop em Samambaia, 1954.

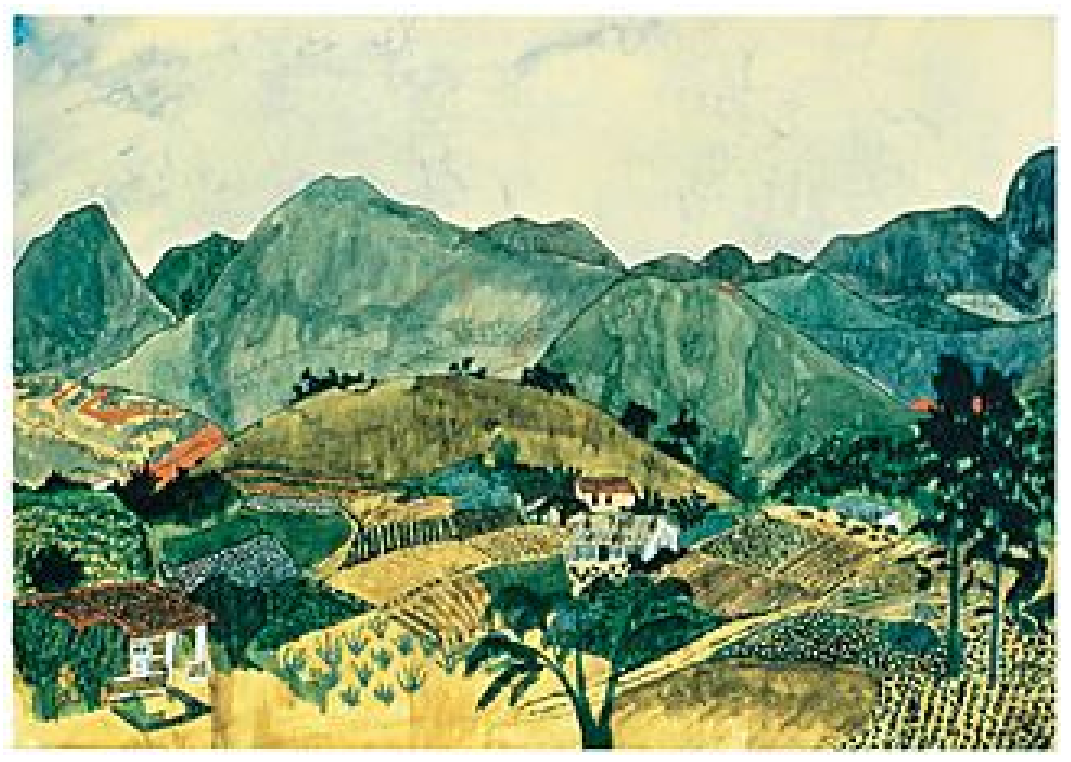

"Brazilian Landscape", aquarela e guache de Elizabeth Bishop, s.d.

Finalmente eu lhe mando uma pintura. Mas não estou muito satisfeita com ela, não ... Como o quadro é grande, se você gostar de alguma parte, pode recortá-la...

Elizabeth Bishop 


\section{Introdução}

A escritora Elizabeth Bishop (1911-1979) é um dos grandes nomes da literatura norteamericana do século XX, embora tenha publicado relativamente pouco - cerca de cem poemas e alguns textos em prosa - e seu nome permaneça, até hoje, pouco conhecido do grande público. Bishop recebeu vários prêmios literários ${ }^{1}$ e teve o reconhecimento de círculos intelectuais e acadêmicos, mas a timidez e os problemas de saúde a afastavam até mesmo das palestras com sessões de leitura de poesia, comuns em sua época. Só aos 55 anos aceitou lecionar em universidades, atividade usual entre os poetas norte-americanos. ${ }^{2}$ Além disso, passou longas temporadas afastada dos centros culturais de seu país: depois de se formar em literatura inglesa no Vassar College (em Poughkeepsie, no estado de Nova York), em 1934, esteve na França por duas longas temporadas (entre 1935 e 1937), passou nove anos em Key West, no extremo sul da Flórida (1938-1946), e a partir de 1951 viveu cerca de duas décadas no Brasil, entre Petrópolis (RJ) e o Rio de Janeiro até meados da década de 1960, depois em Ouro Preto (MG), numa casa colonial que comprou em 1965, restaurou cuidadosamente e visitou pela última vez em 1974.

Bishop escreveu no Brasil grande parte de sua obra ficcional e poética. Até mesmo a recuperação de episódios da infância, nos textos de cunho autobiográfico, é considerada consequência dos longos períodos de estabilidade emocional vividos no país por essa poeta que se definiu, certa vez, como "a pessoa mais solitária que já viveu". ${ }^{3}$ Bishop também produziu centenas de cartas que garantem a ela, por sua abrangência, como também pelas reconhecidas qualidades literárias, um lugar privilegiado entre os estrangeiros que visitaram o Brasil e sobre ele escreveram.

\footnotetext{
${ }^{1}$ Entre os prêmios concedidos a Bishop nos Estados Unidos destacam-se o Pulitzer (1955), o National Book Award (1969) e o National Book Critics Circle Award (1977).

${ }^{2}$ Em carta a James Merrill (22 fev. 1966), ela diz: "bem, finalmente resolvi perder a distinção de ser o único poeta americano (com exceção de você, talvez?) que não dá aulas...” (Bishop, 1995, p.487). A poeta aceitara lecionar por um semestre em Seattle, no estado de Washington.

${ }^{3}$ As palavras, de uma conversa com Robert Lowell em 1948, são citadas por Robert Giroux na Introdução à edição da correspondência da poeta (Bishop, 1995, p.8).
} 
Este trabalho investiga aquela que parece ser a parte menos conhecida e estudada da obra de Elizabeth Bishop: seus textos "jornalísticos" sobre o Brasil, especialmente o mais longo deles, um livro que escreveu em 1961, sob encomenda da editora norte-americana Time-Life, para a coleção Life World Library. Quando foi a Nova York para as revisões de provas, em novembro daquele ano, a poeta percebeu que os editores haviam alterado substancialmente o texto, "restando pouco das imagens, das construções e do humor" (Przybycien, 1993, p.72). Brazil foi publicado em 1962, depois de semanas de discussões e trabalho intenso, sob coautoria de "Elizabeth Bishop e os editores de Life", e ela imediatamente o renegou. Ainda assim, o livro traz "algumas marcas específicas da poeta", que "reaparecem sob outras formas na poesia, na prosa e nas inúmeras cartas" (ibidem, p.76).

A primeira parte deste trabalho focaliza a vida e a obra de Elizabeth Bishop, sobretudo seus textos em prosa relacionados ao nosso país. A seguir, aborda a história editorial do livro Brazil e propõe uma questão: a possibilidade de se estabelecer - no intuito de traduzir e comentar - um texto que foi renegado pela autora depois de extensamente alterado pelos editores. A dúvida que subjaz a essa investigação é: existiria uma versão "definitiva", neste caso? Não se trata, portanto, de promover uma edição crítica - até porque Brazil permanece como um texto cujo resultado editorial nem sempre é aquele desejado por sua autora. Tratase, antes, de fazer uma tradução anotada e comentada, em sentido amplo, uma vez que propõe assumir as contradições, expondo e destacando as diferenças significativas entre os originais e o texto publicado.

A segunda parte investiga o momento em que o livro surgiu - na vida da autora e na história do Brasil e dos Estados Unidos -, buscando a compreensão não só do texto, mas também de sua escrita e dos episódios relacionados à sua edição. O objetivo, aqui, é esclarecer o que teria levado Elizabeth Bishop a aceitar a encomenda desse livro em determinado momento e, em seguida, demonstrar uma rejeição absoluta a ele.

A terceira parte do trabalho aponta aspectos do livro - personagens, arquitetura, arte popular -, buscando compreender algo do "Brasil de Elizabeth Bishop". Nesse sentido, recorre a outras "interpretações" e a algumas das fontes utilizadas pela escritora. Num sentido necessariamente não conclusivo, apresenta-se uma questão que acompanha a feitura dessas "interpretações", sobretudo as que surgiram no século passado: quais são os significados resultantes da intenção de captar o país nesses textos cujo processo de construção é ele próprio testemunho de contradições?

A quarta parte consiste na tradução e anotação do livro Brazil, em cotejo com os originais datilografados, presentes nos arquivos da escritora, e com o exemplar que pertenceu 
a ela, onde constam várias anotações e correções manuscritas. O livro foi reeditado até 1970, mas sem nenhuma participação de Bishop. Ou seja: a coautoria "real" durou apenas alguns meses, no final de 1961. Depois disso, os editores atualizaram sucessivamente o texto, sobretudo os capítulos relacionados à política, à medida que o tempo corria e o país mudava. No mesmo período, Elizabeth Bishop dedicava-se, nos intervalos da poesia, ao projeto de um outro livro, o seu livro sobre o Brasil. Para tanto, continuou a anotar impressões de viagem, recolher material e escrever cartas detalhadas para sua companheira, Lota de Macedo Soares, durante as "excursões" pelo país. A queima dessas cartas, ${ }^{4}$ promovida após a morte da destinatária, assim como o retorno definitivo da escritora para os Estados Unidos, cancelariam esse projeto.

Na quinta parte deste trabalho estão traduzidos e anotados os cinco textos que parecem ser os mais significativos entre os que restaram desse projeto abandonado de "captação do país": uma narrativa sobre o enterro de Getúlio Vargas (1954), um texto jornalístico sobre o Quarto Centenário do Rio de Janeiro (1965) e três relatos de viagem: Brasília e Xingu (1958), rio Amazonas (1960) e rio São Francisco (1967). O único texto publicado enquanto a autora estava viva é o do Quarto Centenário, encomenda do jornal The New York Times. O texto sobre Brasília e o Xingu foi enviado à revista The New Yorker, que o rejeitou. Esse, por suas características, certamente poderia tornar-se um capítulo do livro. Os três outros não passam de esboços, mas permitem conhecer a escrita de Bishop, sua perspicácia, os saltos abruptos na descrição (partindo da paisagem distante para algum detalhe quase microscópico, e viceversa), os travessões obsessivos. Os relatos das viagens pelo Amazonas e pelo São Francisco são inéditos mesmo em inglês.

Este trabalho pretende mostrar que, em se tratando de Elizabeth Bishop, nada é tão simples como pode parecer à primeira vista. $\mathrm{Na}$ discussão relacionada às formas pelas quais a autora captava e apreendia o país, a pesquisa nos levou a questionar se, com seu olhar perspicaz, Bishop chegou, realmente, a compreender na totalidade a sua dinâmica históricosocial, fundada, por exemplo, em privilégios e favores. A própria autora escreveu, em 1962: "houve tantas crises políticas inexplicáveis (para os forasteiros) - aliás, a meu ver o Brasil em si é grande e cansativo demais... muito, muito mais complicado do que aquele livro açucarado da Life dá a entender". ${ }^{5}$ Nesse sentido, é com surpresa que Bishop comenta, em 1964, a visita de amigos "que vieram ao Brasil como turistas" e consideraram o livro "muito útil". Com a

\footnotetext{
4 As duas únicas "cartas de viagem" que se salvaram da destruição foram escritas na Amazônia no início de 1960. Foram traduzidas e anotadas em Ferreira (2003).

${ }^{5}$ Carta de 19 out. 1962 a Arthur Gold e Robert Fizdale (Bishop, 1995, p.454).
} 
justificativa de que "existe muito pouca coisa sobre o Brasil em inglês", a autora conclui, na mesma carta: agora "eu consigo encará-lo com mais calma". 6

De qualquer maneira, aquela que foi considerada por John Gledson "a visitante mais sensível e perceptiva que o Brasil talvez já tenha recebido" (2006, p.369) deu esta resposta em entrevista, pouco antes de sua morte:

Não tenho teorias sobre o Brasil, ao contrário de muitas pessoas. Imediatamente após minha chegada, construí teorias perspicazes sobre o país. Aos poucos, essas teorias evaporaram. O Brasil tornou-se meu lar. ${ }^{7}$

\footnotetext{
${ }^{6}$ Carta de 20 jan. 1964 a Anne Stevenson (Bishop, 2008, p.856).
}

${ }^{7}$ Entrevista concedida em 1977 (em Monteiro, 1996, p.80). 


\section{Uma autora, uma obra e um país}

Após a morte de Elizabeth Bishop, em 1979, o editor Robert Giroux (1914-2008) dedicou-se à organização de sua obra e publicou The complete poems: 1927-1979 (1983) e The collected prose (1984), mas foi apenas com o aparecimento de Elizabeth Bishop: life and the memory of it (1993), minuciosa biografia escrita por Brett Millier, ${ }^{1}$ e de One Art (1994), uma coletânea de 541 cartas organizada por Giroux a pedido de Alice Methfessel, testamenteira literária de Bishop, que um público mais amplo teve contato com a vida dessa escritora que pouco se expunha diretamente em seus poemas. Depois disso, surgiram nos Estados Unidos vários trabalhos acadêmicos relacionados à obra de Bishop, entre os quais se destaca Edgar Allan Poe and the Juke-box (2006), organizado pela pesquisadora Alice Quinn, extensa reunião de poemas inéditos - como o que dá título ao volume -, rascunhos e fragmentos rigorosamente anotados. Embora os críticos não tenham encontrado, entre esses inéditos, obras-primas como as publicadas pela autora ao longo de sua vida (Hacker, 2007), o livro de Quinn permite acesso aos projetos e temas que Bishop vinha gestando em seu lento e meticuloso processo criativo.

No Brasil, não só a poesia (Poemas do Brasil, 1999; O iceberg imaginário e outros poemas, 2001), mas também a prosa (Esforços do afeto e outras histórias, 1996, versão da Collected prose) e a correspondência de Bishop (Uma arte, 1995) ganharam tradução cuidadosa do poeta e professor Paulo Henriques Britto. Essa edição de sua correspondência, organizada por Carlos Eduardo Lins da Silva e João Moreira Salles, não se restringiu à seleção reunida por Giroux no ano anterior e trouxe, em apêndice, um conjunto de cartas

\footnotetext{
${ }^{1}$ No Prefácio (1993, p.xi), Brett Millier afirma que seu trabalho é uma "biografia crítica". Para separar a vida particular da escritora e o percurso público de sua obra, recorre a um artifício: "Elizabeth viveu a vida e escreveu os poemas; o trabalho e a reputação, no julgamento do mundo, pertencem a Bishop" (p.xiii). Quando a biógrafa se refere às emoções e intenções de Elizabeth, no entanto, alguns de seus comentários carecem de base documental, o que nos leva a considerá-los com reserva - atitude que procuramos manter, com muito mais vigor, diante de Flores raras e banalíssimas, de Carmen Oliveira (1995).
} 
inéditas destinadas a brasileiros ou relacionadas ao nosso país. A principal responsável pela inclusão desse valioso apêndice foi a pesquisadora paranaense Regina Przybycien, autora do mais completo estudo sobre a relação de Bishop com o Brasil, sua tese de doutorado Feijão preto e diamantes: o Brasil na obra de Elizabeth Bishop (1993). Tendo examinado os arquivos de Bishop e de alguns dos amigos com os quais a poeta se correspondia, Przybycien alertou os organizadores da edição brasileira para a existência, a importância e a localização desses inéditos, como nos informa o tradutor (Bishop, 1995, p.702).

A obra de Elizabeth Bishop atraiu a atenção de autores brasileiros com interesses diversos: Flora Süssekind (1993), por exemplo, comenta uma carta-poema enviada ao amigo Manuel Bandeira em "A geleia e o engenho"; Beatriz Jaguaribe (1998) analisa, entre outros aspectos, o estranhamento da norte-americana em nosso país; Silvia Anastácio (1999) escreve sua tese de doutoramento, voltada à crítica genética, tendo por base alguns de seus originais, e Silviano Santiago (1999) discute a poesia descritiva de Bishop em texto apresentado num colóquio internacional dedicado à escritora, realizado em Ouro Preto ${ }^{2}$ e posteriormente transformado em livro (Almeida \& Gonçalves, 2002). Os escritos de Bishop também alimentaram estudos sobre outros temas: Roberto Schwarz (1997), por exemplo, recorre aos comentários da norte-americana para iniciar uma discussão sobre a autoria de Minha vida de menina, de Helena Morley, e Nicolau Sevcenko (2000) inclui longos trechos de seu poema “Brazil, January 1, 1502” na abertura de uma reflexão sobre a história do país e seu destino no novo milênio. O inglês John Gledson (2006) cita o poema "Manuelzinho" e o texto jornalístico "On the Railroad named Delight" (1965) ao abordar cultura e identidade brasileiras, e classifica a autora como "a visitante mais sensível e perceptiva que o Brasil talvez já tenha recebido" (p.369).

Para o público brasileiro, Elizabeth Bishop só se tornou relativamente conhecida após a publicação de Flores raras e banalíssimas, de Carmen Oliveira (1995), narrativa de cunho biográfico que traz para primeiro plano a relação da escritora com Lota (Maria Carlota Costallat) de Macedo Soares, sua companheira desde 1952 até a morte desta, em 1967. A coletânea da correspondência e o livro de Carmen Oliveira, publicados quase simultaneamente, receberam resenhas ou comentários em dezenas de textos jornalísticos ${ }^{3}$ e, sobretudo no Rio de Janeiro, serviram para lançar nova luz sobre a esquecida imagem de Lota, a principal responsável pela definição geral do Parque do Flamengo, na década de 1960,

\footnotetext{
${ }^{2}$ Organizado pela UFOP, pela UFMG e pela University of North Carolina em 1999, o Colóquio teve 23 conferências, duas performances, 52 comunicações e o lançamento do livro Poemas do Brasil.

${ }^{3}$ Destacam-se, nesse conjunto, a edição de um caderno especial na Folha de S. Paulo (24 set. 1995) e textos de Antonio Callado (11 jun. e 5 jul. 1994, e 16 set. 1995), no mesmo jornal.
} 
coordenadora da construção desse marco urbanístico carioca e idealizadora da Fundação que hoje o defende. $\mathrm{O}$ mesmo processo de divulgação alimentou discussões sobre a política de meados do século XX e o golpe militar de 1964 (Veloso, 1997), como também sobre o comportamento do governador Carlos Lacerda (Callado, 1995), amigo e vizinho de Lota em Petrópolis, responsável pelo gesto que a transformaria em figura de destaque no Rio de Janeiro - o convite para que trabalhasse no projeto do Parque. ${ }^{4}$

Em 2001 estreou a peça teatral Um porto para Elizabeth Bishop, da escritora e jornalista Marta Góes. Seguindo os passos do livro de Carmen Oliveira, traduzido para o inglês e premiado nos Estados Unidos, ${ }^{5}$ a peça foi encenada em Nova York e no Vassar College. ${ }^{6}$ Mais recentemente, sob o enfoque do homoerotismo feminino no Rio de Janeiro das décadas de 1950 e 1960, a relação entre Lota e Elizabeth Bishop foi estudada em tese de doutorado de Nadia Nogueira (2005), depois transformada em livro (2008).

Nosso interesse pelo estudo da obra de Elizabeth Bishop surgiu com a leitura da edição brasileira de sua correspondência (1995), especialmente do apêndice que enriquecia e, ao mesmo tempo, redesenhava o retrato do país delineado na seleção original: algumas dessas 28 cartas inéditas tinham brasileiros como destinatários, as outras focalizavam paisagens, comportamentos ou episódios vividos pela poeta, mas quase todas revelavam, entre ela e o país, uma proximidade que não se manifesta nas demais setecentas páginas do livro. Essa percepção confirmou-se após o confronto entre as edições brasileira e norte-americana ${ }^{7}$ e ganhou nova força quando tivemos acesso aos arquivos da escritora, reunidos no Vassar College. O estudo das cartas trocadas por Bishop com brasileiros, sobretudo sua correspondência passiva, ausente das edições norte-americana e brasileira, levou à preparação de Pontos cordiais: as cartas brasileiras de Elizabeth Bishop (Ferreira, 2003), ${ }^{8}$ em que foram transcritos 26 documentos inéditos.

\footnotetext{
4 "Encarregada de chefiar o processo de criação do Parque", Lota fazia parte do "círculo íntimo petropolitano" chamado por Carlos Lacerda "para colaborar em projetos importantes de seu governo" (Cavalcanti, 2006, p.45).

${ }_{5}$ Rare and commonplace flowers, tradução de Neil K. Besner, Rutgers University Press, 2001. Os direitos para filmagem foram comprados pelo produtor Luiz Carlos Barreto.

${ }^{6}$ Escrito especialmente para a atriz Regina Braga e dirigido por José Possi Neto, o monólogo (A safe harbor for Elizabeth Bishop) foi apresentado nos Estados Unidos por Amy Irving, em 2006.

${ }^{7}$ As diferenças não se resumem à inclusão do apêndice: dezenas de cartas foram eliminadas na edição brasileira, entre as quais todas as anteriores à formatura de Bishop no Vassar College.

${ }^{8}$ As cartas transcritas abrangem o período de 1952 a 1971; entre os remetentes e destinatários estão os poetas Manuel Bandeira, Carlos Drummond de Andrade, João Cabral de Melo Neto e Vinícius de Moraes. As 13 escritas em inglês foram, também, traduzidas.
} 
O contato com os arquivos da escritora chamou nossa atenção para seus textos em prosa que focalizam o Brasil, certamente a parte menos conhecida e estudada da obra de Elizabeth Bishop. Na primeira seção de Esforços do afeto e outras histórias (1996), intitulada "Memória: pessoas e lugares", constam as narrativas "Viagem a Vigia", em que a autora relata um episódio de sua viagem à Amazônia, em 1960, e "Ida ao botequim", ambientada em Ouro Preto e até então inédita, ${ }^{10}$ além do prefácio que escreveu na década de 1950 para sua tradução de Minha vida de menina, da mineira Helena Morley. Mas os seus inéditos, incompletos e imperfeitos ou não, pareciam exigir, ao menos, uma leitura atenta.

\section{Projetos brasileiros, realizados ou não}

Pouco tempo depois de chegar ao Brasil, Elizabeth Bishop lançou-se a uma tarefa que podemos chamar de seu primeiro projeto literário relacionado ao nosso país: fascinada pelo livro Minha vida de menina, de Helena Morley, cuja leitura fora recomendada por vários de seus novos amigos - entre os quais Manuel Bandeira (Bishop, 1995, p.287) -, logo passou a traduzi-lo para o inglês, antes de tudo como "forma de praticar o português" (Millier, 1993, p.256). ${ }^{11}$ Graças ao auxílio de Lota, "que relutante, porém conscienciosamente, reviu toda a tradução, linha a linha, não uma vez, mas várias vezes” (Bishop, 1996, p.132), a escritora completou o trabalho em 1956, e a primeira edição norte-americana surgiu no ano seguinte. ${ }^{12}$ Em entrevista concedida na década de 1970, ela diria: "Traduzi completamente um livro brasileiro longo, o diário de uma garota. Está provavelmente cheio de erros, porque foi uma das primeiras coisas que fiz. Comecei a ler esse livro, tentando aprender português..." (em Monteiro, 1996, p.84).

Bishop passou uma semana em Diamantina (MG), em 1956, conhecendo a cidade onde o diário fora escrito, e suas impressões enriqueceram em grande medida o texto introdutório que acompanhou a tradução. A autora esperava que esse prefácio fosse bem recebido, embora o considerasse "bem simples". Além disso, informou a amigos que fora necessário "muito cuidado e tato", uma vez que Helena Morley (pseudônimo de Alice Brant)

\footnotetext{
9 "Viagem a Vigia", provavelmente escrito em 1967 (Bishop, 1996, p.308), foi publicado em The New Yorker em 1983, após a morte da autora.

10 "Ida ao botequim", provavelmente escrito em 1970 (Bishop, 1996, p.308).

${ }^{11}$ Todas as citações de obras em língua inglesa - caso da biografia escrita por Brett Millier (1993) -, quando não acompanhadas por outra indicação, foram traduzidas para este trabalho. A citação original consta em nota apenas quando implica considerações estilísticas ou documentais.

${ }^{12}$ The diary of Helena Morley (1957) foi publicado em Nova York por Farrar, Straus \& Giroux.
} 
e seu marido estavam vivos. Na mesma época ela recebeu o prêmio Pulitzer por seu livro Poems: North \& South - A Cold Spring (publicado em 1955), e afirma que esse fato a ajudou muito, "até com a família Brant!" 13 Entre os vários elogios recebidos por esse texto, destacase um comentário contundente de João Cabral de Melo Neto. Em carta escrita em Sevilha, a 2 de abril de 1957, o poeta afirma:

Não conheço Diamantina. Mas sua descrição eu a considero a melhor captação que já foi feita da atmosfera de uma cidade colonial brasileira. Seu prefácio me deixou melancólico, porque me mostrou as limitações dos poetas brasileiros. Pois todos os que têm escrito sobre essas cidadezinhas coloniais, ou se esquecem de que são poetas (ex. Manuel Bandeira no Guia de Ouro Preto), ou se limitam a dizer o que estão sentindo, isto é, o efeito exercido sobre eles pela atmosfera onde estão metidos. Seu prefácio dá a coisa, comunica-a, agarra a coisa por dentro. ${ }^{14}$

João Cabral vai ainda mais longe: fala dessa "incapacidade de pegar o touro pelos chifres" e a associa à nossa ascendência portuguesa. Numa generalização que lembra, em seu tom seco e exagerado, alguns comentários presentes nas cartas da própria Elizabeth Bishop, recomenda a ela que não perca tempo com a literatura portuguesa, pois "é toda ela assim, de descrição do que o autor está sentindo, mesmo nos mais objetivos (se é que há algum português objetivo)". Finalizando, o poeta ainda confessa sua preguiça e o "mau costume de deixar tudo para amanhã”, característica que a destinatária costumava deplorar nos brasileiros - embora também a assumisse.

Os elogios de João Cabral certamente provocaram forte reação em Elizabeth Bishop. Afinal, o poeta brasileiro que ela mais admirava, em razão das afinidades estilísticas, destacava sua capacidade de captar e descrever o país ou, ao menos, uma parte dele. Para Brett Millier, o prefácio a Minha vida de menina, "com cerca de 35 páginas, seu mais longo texto publicado em prosa" (1993, p.257), também permanece como "sua primeira e mais completa tentativa no sentido de descrever o Brasil primitivo e isolado para ela mesma e para uma audiência menos viajada" (p.286), ou simplesmente "para estrangeiros" (p.257). Sem o saber, João Cabral vinha corroborar o que poderíamos chamar de segundo projeto brasileiro

\footnotetext{
${ }^{13}$ As três citações são de carta a Pearl Kazin, 21 maio 1956 (em Bishop, 1995, p.336). As reações dos brasileiros - como também da própria autora - diante dessa premiação resultam em diversas passagens divertidas nas suas cartas da época.

${ }^{14}$ A carta encontra-se nos arquivos da escritora, Vassar College, Special Collections. Foi transcrita em Ferreira (2003, p.143-144).
} 
de Bishop, isto é, o desejo de escrever, em prosa, sobre o país. Esse desejo, como veremos, permaneceu irrealizado, mas acompanhou a escritora até o fim de sua vida.

Ainda na década de 1950 Bishop traduziu para o inglês os textos introdutórios e os comentários técnicos do livro Modern Architecture in Brazil, de Henrique Mindlin (1956), ${ }^{15}$ tarefa "urgente, intensa e complicada" em que trabalhou diretamente com o autor. Segundo a biógrafa Brett Millier, pela primeira vez Bishop se envolvia numa tarefa de escrita comercial com prazo definido; ela e Mindlin "trabalharam em conjunto muitas horas por dia durante semanas", e "Elizabeth apreciava o conhecimento de estilos e termos arquitetônicos adquirido ao longo do projeto" (1993, p.287).

Mas essa foi, realmente, sua única empreitada "comercial" de tradução. Ao longo dos anos Bishop iria verter para o inglês poemas de vários brasileiros, como também alguns contos de Clarice Lispector, mas nunca sob contrato ou atrelada a um prazo. Três contos de Clarice foram publicados na Kenyon Review em 1964, ${ }^{16}$ e poemas de Drummond, Bandeira, Joaquim Cardoso, Vinícius de Moraes e João Cabral foram incluídos em An Anthology of Twentieth-Century Brazilian Poetry (1972), organizada por Bishop e por seu amigo Emanuel Brasil, jovem funcionário das Nações Unidas que vivia em Nova York. ${ }^{17}$

Nos arquivos da escritora existem rascunhos das mais variadas traduções - trechos de livros sobre história e arquitetura, matérias jornalísticas, receitas culinárias e frases de párachoques de caminhão -, reunidos a outros documentos como matéria-prima para o livro que pretendia escrever sobre o país. De volta da Amazônia, em 1960, ela escreve em carta a Robert Lowell: "tenho tirado slides. Sempre achei que eram a coisa mais burguesa do mundo, mas realmente ficam lindos, de modo que tenho pronta uma pequena conferência sobre o Amazonas, outra sobre Cabo Frio etc. Quem é que vai ver esses slides, e quando, não faço ideia" (Bishop, 1995, p.414). Em 1968 Flávio de Macedo Soares, sobrinho de Lota e amigo da poeta, responde a um pedido de discos de canções infantis, ${ }^{18}$ e em carta de 1971 Bishop informa a Emanuel Brasil sobre os trabalhos, em andamento, na versão de duas canções de

\footnotetext{
15 A primeira edição brasileira sairia apenas em 1999, com tradução de Paulo Pedreira e organização de Lauro Cavalcanti.

${ }^{16}$ Segundo Brett Millier (1993, p.337), Bishop iniciou em 1962 a tradução de cinco contos de Clarice, "talvez por sugestão de Robert Lowell". Na Kenyon Review saíram "A menor mulher do mundo", "Uma galinha" e "Macacos".

${ }^{17}$ Bishop traduziu, para a Antologia: dois poemas de Bandeira ("O último poema" e "Tragédia brasileira"), dois de Joaquim Cardoso ("Cemitério da infância" e "Elegia para Maria Alves"), sete de Drummond ("Viagem na família", "Poema de sete faces", "Não se mate", "A mesa", "Infância", "No meio do caminho" e "Retrato de família") e um de Vinícius ("Soneto de intimidade"), além de trechos de "Morte e vida severina", de João Cabral (estes, já publicados na revista Poetry, out. 1963). "Cemitério da infância" e "Soneto de intimidade" haviam sido publicados na revista The New Yorker, em 1971.

${ }^{18}$ Carta de Flávio de Macedo Soares, 14 out. 1968, Special Collections, Vassar College. Flávio informa haver encontrado uma gravação de "Nesta rua", mas em versão diferente da solicitada por Bishop.
} 
Caetano Veloso, ${ }^{19}$ mas nada chegou a ser publicado. Nos Complete poems 1927-1979 constava a tradução de quatro sambas carnavalescos "anônimos" - embora seus autores sejam conhecidos -, e em coletânea de "poemas, prosa e cartas" organizada por Robert Giroux e Lloyd Schwartz publicou-se, em 2008, uma tradução de "A banda", de Chico Buarque. De qualquer maneira, é surpreendente a afirmação do também poeta Lloyd Schwartz (s.d.), em entrevista concedida a Rodrigo de Souza Leão há poucos anos, de que Bishop "ainda é considerada a maior tradutora de poesia brasileira vertida para o inglês". ${ }^{20}$

Emanuel Brasil esperava editar um segundo volume da Anthology em conjunto, mas Brazilian Poetry 1950-1980 sairia apenas em 1983, ${ }^{21}$ após a morte de Bishop, organizado por ele e por William Jay Smith. Entretanto, já no final de 1969 Bishop discutia o que incluir nessa nova antologia: em carta, Flávio de Macedo Soares responde à sua consulta com "dúzias" de sugestões sobre o que de melhor havia na poesia brasileira contemporânea. ${ }^{22}$ A morte prematura de Flávio (1970) e o retorno definitivo da escritora para os Estados Unidos parecem ter colaborado para afastá-la de mais esse projeto relacionado ao Brasil.

\section{Viagens narradas}

Segundo a biógrafa Brett Millier (1993, p.36), Elizabeth Bishop demonstrou o desejo de viajar pela América do Sul aos 17 anos, após a leitura do romance Green mansions, ${ }^{23}$ do escritor, naturalista e ornitólogo argentino - filho de norte-americanos - William Henry Hudson (1841-1922). Essa ideia, assim como as imagens da floresta tropical, "permaneceriam com ela por 25 anos” (p.36), até o final de 1951, quando partiu em expedição para circumnavegar o continente, tendo como objetivo primordial conhecer a Terra do Fogo. Em carta de

\footnotetext{
${ }^{19} \mathrm{Na}$ carta inédita, à margem, a autora diz: "I've been working on translations of 2 of Caetano's songs and think I almost have them... I'll send" (Carta a Emanuel Brasil, 3 maio 1971, Special Collections, Vassar College). Humberto Werneck afirma (em Góes, 2001, Prefácio, p.17) que Bishop pretendia traduzir "Não identificado", de Caetano, mas teria esbarrado "na impossibilidade de passar para o inglês a conotação fonográfica embutida em disco voador".

${ }^{20}$ Em entrevista de 2002 (sob o título "Ninguém fala português"), o poeta norte-americano Eliot Weinberger lembra que uma nova antologia de poesia brasileira, Nothing the sun could not explain: new Brazilian poetry (organizada por Régis Bonvicino, Nelson Ascher e Michael Palmer), surgiu nos Estados Unidos apenas em 1997, e afirma: "não conheço um só poeta americano que fale português".

${ }^{21}$ Wesleyan University Press, 1983, 187p. Edição bilíngue, como na Anthology.

${ }^{22}$ Entre as sugestões apresentadas por Flávio destacam-se Ferreira Gullar (incluído também na Anthology), Capinam, Mário Faustino ("he's the best") e Affonso Romano de Sant'Anna (carta de 11 nov. 1969, Vassar College, Special Collections).

${ }^{23}$ Publicado em 1904, Green mansions: a romance of the tropical forests é ambientado na Venezuela e na Guiana e focaliza um povo branco, fictício, que viveria no alto das montanhas. Bishop resenhou o livro para a publicação Blue Pencil, da Walnut Hill School, onde estudava, em novembro de 1928 (Millier, 1993, p.36).
} 
1946 ela comenta: "a prosa que eu tinha em mente seria um livro de ensaios sobre viagens a certas regiões da América do Sul; animais, prédios etc.” (Bishop, 1995, p.145).

Mas sua primeira viagem, empreendida com a colega Evelyn Huntington nas férias de verão do segundo ano da faculdade (1932), durou apenas três semanas e consistiu em caminhadas pela Terra Nova, no Canadá, outro "sonho que Elizabeth acalentara durante vários anos" (Millier, 1993, p.47). Ainda segundo a biógrafa, o diário mantido pela futura escritora durante essa viagem já permite notar "a intensa observação da paisagem e das pessoas e o interesse em saber por que as coisas estão dispostas dessa maneira" (p.47). É nesse ponto que Bishop aparece pela primeira vez como uma touring foreigner, presente no lugar mas não pertencente a ele. Quer "ficar para sempre", mas "acha isso impossível". A jovem anota "os sotaques e as expressões, os artefatos religiosos que decoram as paredes" (p.47), as ocupações das pessoas e o que elas comem. Frustrada por não ter conseguido visitar o vilarejo de St. Anthony, "praticamente inacessível", pergunta se não seria esse o padroeiro das "coisas perdidas", e parece não se conformar com a mudança de planos.

Em fevereiro de 1936, formada em Vassar e sustentando-se com um pequeno rendimento mensal proveniente da herança de seu pai, Bishop passou uma temporada em Paris e, de lá, partiu em direção ao Marrocos, com a amiga e ex-colega de faculdade Louise Crane. A principal razão para a escolha desse destino teria sido o fato de não poderem "resistir à tentação de ir ao país mais impróprio do mundo" (Millier, 1993, p.95) - inadequado para duas jovens desacompanhadas e cercado por uma aura de imoralidade. Nos diários e nas cartas ela não deixaria de fazer comentários característicos: "Gostamos tanto do Marrocos apesar da arquitetura mourisca, que é horrenda, e da atmosfera um tanto antipática que foi criada pela ocupação francesa (não há como não ficar do lado dos mouros) - que acabamos ficando mais tempo do que devíamos". ${ }^{24}$ De lá, contrariando as instruções do consulado norteamericano, foram em abril à Espanha, onde acabava de estourar a Guerra Civil, mas, diante do recrudescimento da situação política, tiveram de antecipar a partida. Após a temporada marroquina, as jovens consideraram a Espanha "depressiva", repleta de pessoas sem atrativos - “ao menos, na opinião das duas" (Millier, 1993, p.97) - e assolada pela destruição dos monumentos nacionais.

Segundo a biógrafa, é nesse momento que surge em Bishop o "ódio aos comunistas", anos depois reforçado pelo que ela veria no Brasil. E Millier completa: "ela não distinguia entre comunistas e fascistas" (p.98), o que aponta seu intrigante descaso - ao menos aparente - diante da política, motivo para inúmeras críticas que lhe seriam dirigidas ao longo da vida.

\footnotetext{
${ }^{24}$ Carta a Marianne Moore, 6 abr. 1936 (Bishop, 1995, p.51).
} 
Sua postura em relação aos comunistas teria sido motivada, simplesmente, pela "experiência ingênua" da jovem descrente, ${ }^{25}$ preocupada com o patrimônio histórico e artístico, ao observar igrejas queimadas. Bishop escreveria em carta dessa época: "Se você realmente quer ver o que os comunistas podem fazer, que belas coisas eles arruinaram, deveria vir aqui. A mais linda capela barroca de Sevilha quase foi queimada - o teto ficou todo chamuscado". ${ }^{26}$ Mas, em outra carta, Bishop amplia um pouco o foco ao comentar imagens e crucifixos arrancados de uma igreja em Barcelona e "amontoados de tal modo que de início passam a impressão de serem soldados mortos”. Destaca o caráter dramático nessa disposição dos objetos observada em foto do New York Times -, "despertando suspeitas" e tornando o fato "ainda mais coerente com o que já ouvi dizer a respeito do caráter espanhol". ${ }^{27}$ Suas suspeitas, porém, certamente não se estendiam ao jornal norte-americano que publicara tais fotos.

Bishop formou-se em Vassar durante a Depressão, quando "a atmosfera era de esquerda": nos anos 30, diz ela, "todos os intelectuais eram comunistas, exceto eu" (Monteiro, 1996, p.129). Em outro momento, afirma que "politicamente eu me considerava socialista, mas não gostava da escrita "socialmente consciente"” (p.22), e comenta seu choque ao ouvir o líder pacifista e socialista Norman Thomas (1884-1968), que ela considerou "estúpido". Completa, irônica: "Então tentei o anarquismo, brevemente" (p.22), e relembra:

Mas a época era radical. É engraçado. A garota que era a mais radical - ela se formou um ano antes de mim - foi casada durante anos com um dos chefes da TimeLife. Esqueci o nome dele. É muito famoso e não poderia ser mais conservador. Escreve editoriais chocantes. Ainda posso ver minha colega parada em frente à biblioteca com um tamborim, arrecadando dinheiro para esta ou aquela causa. (Monteiro, 1996, p.129)

Lembremos que nos Estados Unidos a escritora se identificava com o partido democrata - posicionou-se contra a Guerra do Vietnã e depois "deplorou o que seria o candidato ícone do yuppismo americano dos anos 80, Ronald Reagan” (Jaguaribe, 1998, p.103) -, mas no Brasil sempre esteve ao lado dos udenistas, em parte, talvez, por influência

\footnotetext{
${ }^{25} \mathrm{O}$ comportamento de Elizabeth Bishop leva algumas pessoas, entre as quais amigos seus, a considerá-la uma pessoa religiosa. Mas a "falta de fé" da poeta é comentada na Introdução de Robert Giroux a Uma arte (1995, p.14). Em carta a Anne Stevenson (8 jan. 1964), ela diz: "Eu nunca fui religiosa em nenhum sentido formal, e sou descrente" (em Bishop, 2008, p.862).

${ }^{26}$ Carta a Hallie Thomas (11 abr. 1936), citada em Millier, 1993, p.98.

${ }^{27}$ Carta a Marianne Moore, de 21 ago. 1936 (Bishop, 1995, p.55).
} 
de seu círculo no Rio de Janeiro e em Petrópolis, o grupo que se reunia em torno de Lota de Macedo Soares e Carlos Lacerda.

Por vezes, Bishop assume a ausência de reflexões sociais em sua obra poética, ou, ao menos, mostra-se consciente do questionamento que essa ausência poderia provocar. Em entrevista concedida no Brasil, em 1956, afirma: “Todo bom escritor leva em conta os problemas sociais de sua época, e, de algum modo, toda boa poesia reflete esses problemas" (Monteiro, 1996, p.9).

Quando seu livro North \& South foi publicado em 1946, logo após a Segunda Guerra Mundial, a autora persuadiu os editores a incluírem uma nota explicando que muitos dos poemas haviam sido escritos antes de 1942, o que, segundo ela, justificaria "a ausência de referências explícitas" ao conflito (Millier, 1993, p.74). Em 1954, já no Brasil, Bishop produziu dois esboços denominados "Suicídio de um ditador (moderado)" em que escrevia, em verso e prosa, sobre a morte de Getúlio Vargas. Pode-se intuir, aí, "a sugestão de uma indiferença natural diante da história - mesmo num evento incomparavelmente traumático" (Coelho, 2006). O poema, que seria dedicado ao político Carlos Lacerda, parecia estar enveredando "em caminhos emocionais e éticos de tal modo tortuosos que não admira ter sido abandonado" (ibidem).

Todavia, desde a adolescência é nítida nos diários de Elizabeth Bishop a percepção “das distinções sociais, dos preconceitos raciais e étnicos” (Millier, 1993, p.28) e de suas consequências, observadas entre familiares e vizinhos. Note-se que Bishop perdeu o pai antes de fazer um ano e passou parte da infância com a família materna, num vilarejo da Nova Escócia (Canadá), ambiente modesto, afetuoso e feliz. Depois do colapso emocional de sua mãe, internada pelo resto da vida num hospício, a menina foi levada de volta para os Estados Unidos,

sem ter sido consultada e contra minha vontade, para a casa onde meu pai nascera, a fim de ser salva de uma vida de pobreza e provincianismo, pés descalços, pudins de sebo, lousas escolares anti-higiênicas, talvez até mesmo dos erres invertidos da família de minha mãe. (Bishop, 1996, p.43)

As experiências traumáticas vividas nos anos seguintes, no convívio com os ricos e frios avós paternos, sem dúvida aguçaram o olhar da jovem também para os problemas relacionados à formação puritana. Comentários sobre esses temas e análises de comportamento aparecerão com frequência em suas cartas, até o final da vida, pontuando 
também os relatos das "expedições" da escritora pelas mais diversas regiões do mundo - Ilhas Galápagos, Peru, Portugal, Inglaterra, Itália, Escandinávia e Rússia, por exemplo. A intenção de produzir narrativas de viagem e descrições de lugares cristaliza-se claramente, porém, apenas no Brasil.

\section{A captação de um país}

Segundo Brett Millier, quando Bishop finalizou a tradução de Minha vida de menina e os originais foram enviados à editora, nos Estados Unidos, ela "encontrou seu modo de escrever sobre o Brasil" (1993, p.286). Ao mesmo tempo em que retomou textos iniciados anteriormente - trabalhava em cinco contos, em outubro de 1956 - e iniciou novos poemas, formalizou o plano de escrever um livro de "ensaios de viagem" sobre o país, "proposto pela primeira vez à editora Houghton Mifflin em $1946{ }^{28}$ e ao qual se dedicaria, com interrupções, pelos próximos 15 anos" (1993, p.286-287). A escritora pretendia vender seus textos individualmente, antes de reuni-los em livro, pois considerava essa escrita "um tipo de jornalismo lucrativo" (p.287). Esperava ser capaz de realizar a tarefa, embora só tivesse, até então, esboçado - e abandonado - duas narrativas no gênero, focalizando as "Dez mil ilhas", na Flórida, e a Ilha Sable, na Nova Escócia (Canadá).

Um percurso cronológico de leitura do Brasil nos textos em prosa de Elizabeth Bishop começa, necessariamente, com o esboço "Suicide of a (moderate) dictator" ["Suicídio de um ditador (moderado)"], de 1954. Esse breve texto, de duas páginas, foi abandonado, como também sua contrapartida em verso, mas ainda assim fornece um bom exemplo do "famoso olho" ${ }^{29}$ da autora para detalhes interessantes ou inesperados, agora direcionado ao nosso país. Deixando levar-se por uma descrição detalhada e extraordinariamente particular do enterro do presidente Getúlio Vargas, o leitor só é informado das circunstâncias em que se produziu o texto ao deparar com alguns comentários sobre as "tomadas" e a "câmera", confirmados por esta nota final: "Cinejornal que eu vi dia $1^{\circ}$ ou 2 de setembro - o suicídio aconteceu na manhã do dia 24" (Bishop, 2006, p.196). Não se sabe se a autora assistiu a esse cinejornal mais de uma vez, mas os detalhes mostram sua percepção aguda dos diferentes aspectos do episódio. Bishop nota a quase ausência de mulheres, "como é usual aqui, quando a multidão vai ficando cada vez mais apertada", o gesto do filho do presidente, "que empurra uma mulher" para

\footnotetext{
${ }^{28}$ Cinco anos antes, portanto, de sua chegada ao Brasil.

${ }^{29}$ Expressão de Robert Giroux na Introdução a Uma arte (1995, p.7).
} 
dentro do carro, e o comportamento das pessoas em fila, "espreitando ou lambuzando o vidro [do caixão] com um beijo". Mas percebe também o "devaneio" das "palmeiras esguias e altas, altas demais", que parecem estar "crescendo bem rápido" no dia quente e nublado, e destaca a flutuação do caixão sobre o povo, acompanhado pela coroa de flores - "gigantesco salvavidas enfeitado" em meio a uma "inundação repentina". Bishop aproveita para confrontar o que vê com "a nossa ideia norte-americana sobre essas coisas - nenhum dos nossos estofamentos em seda, travesseiros etc.". Se o filho de Getúlio "realmente" parece personagem de desenho animado, a observação indica, também, a constatação de comentários anteriormente ouvidos por ela, mais um fator que vem enriquecer o texto.

Dois anos antes, em outubro de 1952, Bishop recorrera a seu "livro de geografia" provavelmente um guia turístico comprado no exterior ${ }^{30}$ - para descrever Petrópolis a seus amigos americanos, mas pontuara a citação com alguns comentários: "No verão, as pessoas mais ricas (olha eu aí!) do Rio de Janeiro buscam as temperaturas mais baixas (nove graus) e a vida social mais intensa de Petrópolis, na parte mais alta da serra do Mar". ${ }^{1}$ A autora reconhece que o trecho "dá a impressão de que todo mundo vive sambando no alto da serra" e apressa-se em desmenti-la, descrevendo o isolamento e a quietude de sua própria experiência. E sempre recorrerá às mais diversas fontes - livros, revistas, jornais, filmes e anotações de conversas -, sem deixar de lado a observação direta com intenção crítica.

No prefácio à tradução de Minha vida de menina, Bishop expõe em detalhes não só a viagem que realizou a Diamantina, em 1956, mas também o contato que travou com a autora e sua família, no Rio de Janeiro. Até mesmo a conversa entre Lota de Macedo Soares e a filha de Helena Morley, dona Sarita, proporciona uma observação comparativa sobre nossas famílias abastadas: "Embora não se conhecessem, não demorou para que uma começasse a identificar os parentes da outra, o que acontece no Brasil tão depressa quanto no Sul dos Estados Unidos" (Bishop, 1996, p.197).

Comentando sua viagem a Diamantina, Bishop afirma: lá "estive por minha conta, ou por conta de meu português", uma vez que sua amiga Rosinha (Rosalina) Leão retornou ao Rio depois de dois dias, deixando-a só. Mas "não posso dizer que estivesse realmente sozinha, porque a pequena cidade demonstrou tal interesse pelos meus movimentos que as pessoas saíam de suas lojas para caminhar comigo, aonde quer que eu estivesse indo”. As meninas, a caminho da escola de freiras, paravam em fila, "com o nariz encostado na vidraça", para vê-la

\footnotetext{
${ }^{30} \mathrm{Na}$ bibliografia do livro Brazil (1962) a autora incluiu New World Guides to the Latin American Republics, em edição de 1950.

${ }^{31}$ Carta a Ilse e Kit Barker, 12 out. 1952 (em Bishop, 1995, p.254).
} 
comer. A maior parte do tempo, ela foi a única hóspede do hotel projetado por Niemeyer e inaugurado pouco antes, o que talvez justifique, em certo sentido, a atenção despertada na cidade. ${ }^{32}$ Atenção e carinho expressos, por exemplo, em carta enviada pelo velho jornalista Antônio Cícero de Meneses, ex-chefe do correio local, que a convida para um retorno à cidade e se coloca à disposição para os "muitos passeios pitorescos" que ela deixara de fazer nos arredores de Diamantina, "lugares bonitos e históricos, por terem inteira ligação com a época colonial da velha cidade que a Miss acaba de visitar". 33

A reunião de citações literárias, conhecimento adquirido em sua longa - mais de seis anos - vivência no país, transcrição de comentários alheios - de estrangeiros e brasileiros, incluindo indígenas - e observações pessoais durante uma "excursão" específica forma a matéria-prima daquele que seria o texto seguinte de Bishop focalizando o Brasil: "A new capital, Aldous Huxley, and some Indians" ["Uma nova capital, Aldous Huxley e alguns índios”], de 1958. Escrito logo após a viagem empreendida com um grupo que incluía o autor inglês e que teve por destino Brasília, ainda em construção, e uma aldeia indígena em Mato Grosso, esse texto se destaca dos demais inéditos por ter sido retrabalhado e finalizado pela autora, que no mesmo ano o apresentou à revista The New Yorker. Em 28 de agosto ela escrevia ao amigo Robert Lowell considerando essa "a melhor viagem que já fiz aqui" (Bishop, 1995, p.388). Dizia estar "terminando um longo texto sobre a viagem (e estou torcendo para conseguir publicá-lo, para podermos começar a construir a garagem)" e afirmava a intenção de "voltar lá algum dia, para passar mais um tempo" (p.389). A intenção de escrever e publicar se reforça quando comenta, na carta: por enquanto "não vou contar mais nada" (p.389). A revista que habitualmente publicava seus poemas, entretanto, recusou o texto, que permaneceria inédito por quase cinquenta anos, até julho de 2006, quando saiu na Yale Review. Segundo Barbara Page, que apresenta essa edição, a autora mostrou pouca surpresa diante da recusa da New Yorker: "o material simplesmente não combinava, Huxley não dissera nada de interessante - e eu senti que era estupidez de minha parte perder tanto tempo com isso". Ela pretendia, portanto, voltar a escrever "algo mais adequado" à sua “inclinação natural". ${ }^{34}$ É interessante notar que a New Yorker aceitara em dezembro de 1953 o conto "Na aldeia" - escrito no Brasil e ambientado no Canadá, focalizando a infância da autora -, mas só publicaria uma narrativa em prosa de Bishop envolvendo o Brasil em 1983,

\footnotetext{
32 Todas as citações desse parágrafo são de carta a Ilse e Kit Barker, 5 jun. 1956 (em Millier, 1993, p.286). Ainda nessa carta Bishop comenta sobre o hotel projetado por Niemeyer: "sua arquitetura é ruim", sem mais detalhes.

${ }^{33}$ Carta enviada em 28 jul. 1956 (transcrita em Ferreira, 2003, p.142). A carta encontra-se nos arquivos da escritora, Vassar College, Special Collections.

${ }^{34}$ Todas as observações constam na introdução de Barbara Page ao ensaio (Bishop, jul. 2006).
} 
após sua morte: trata-se de "Viagem a Vigia", escrita provavelmente em 1967 (Bishop, 1996, p.308, nota) e relacionada à sua viagem à Amazônia, de 1960.

Embora a autora tenha desistido de publicá-lo, o texto sobre Brasília permaneceu em seus arquivos e constitui um relato minucioso sobre aquele momento da história do país: Lota e seu círculo eram totalmente contrários à construção da nova capital, e Bishop compartilhava dessa opinião. Suas críticas, entretanto, são fundamentadas não só pelo conhecimento da arquitetura moderna - que poderia levá-la a elogiar a cidade e seus edifícios - mas também por seu senso prático e pela análise baseada no aspecto funcional das construções. Alguns de seus comentários são semelhantes aos que constam no texto jornalístico "Um sábio entre bugres", publicado no Correio da Manhã por Antonio Callado (1958), que também fazia parte do grupo. ${ }^{35}$ Os dois autores apontam a coexistência de épocas distintas da evolução da humanidade - Brasília e Xingu - no Brasil. Ambos citam a falta de corrimãos nas rampas, em Brasília, que quase provoca um acidente envolvendo Aldous Huxley, e destacam o encontro emocionante do sertanista Cláudio Villas Boas com o escritor inglês, no meio da selva. Mas Bishop, com seu artigo muito mais extenso e senso crítico mais agudo que o de Callado, descreve até as gotas de suor deixadas nas cadeiras do Palácio da Alvorada - onde "o ar condicionado é desnecessário", segundo a funcionária que recebeu os visitantes -, e vai ainda mais além, ao analisar, sarcástica, os apartamentos dos funcionários: "Niemeyer, justamente ele, não deveria ter achado necessário alojá-los no subsolo": "A caixa de cristal não é para eles, mas certamente existe espaço suficiente em qualquer direção e parece haver o dinheiro necessário para ao menos deixá-los viver sobre o solo, como seus patrões" (Bishop, jul. 2006). Numa longa sequência de comentários perspicazes, Bishop analisa não só o Plano Piloto mas também o Núcleo Bandeirante, onde vivem os operários que constroem a capital, os detalhes arquitetônicos do hotel e do Palácio e o comportamento das mais diversas personagens - moradores e visitantes, engenheiros, motoristas e garçons. Conclui seu artigo fazendo conjecturas sobre o futuro da cidade e do país, e, numa guinada surpreendente, cita uma crítica feroz à capital dos Estados Unidos, escrita em meados do século XIX. As observações do inglês Anthony Trollope, talvez justas na época da construção de Washington, soavam descabidas ou simplesmente absurdas, um século depois.

Em 1960 Elizabeth Bishop escreveu “A trip on the Amazon" ["Uma viagem pelo Amazonas"], original de nove páginas datilografadas, incompleto, que se encontra em seus arquivos. ${ }^{36}$ Sob o título manuscrito "On the Lauro Sodrê" - nome do barco em que viajou de

\footnotetext{
${ }^{35}$ Ver Figura 4, foto publicada na reportagem de Callado (1958).

${ }^{36}$ Vassar College, Special Collections, Elizabeth Bishop, Folder 55.4. Ver Figura 1.
} 
Manaus a Belém com a amiga Rosinha Leão e o sobrinho desta, Manoel, em fevereiro de 1960, o inédito descreve a viagem de avião do Rio a Manaus, esta cidade, as pessoas com quem a autora conviveu nesses dias e o início da viagem fluvial rio abaixo, passando por Itacoatiara, Uricurituba, Oriximiná, Óbidos, Juriti e Alenquer. Arquivado como parte do material que a autora reuniu como base para o livro que pretendia escrever sobre o Brasil, o texto é complementado por duas cartas enviadas a Lota - que ficara em Petrópolis -, uma escrita em Manaus (21 e 22 fev. 1960), a outra em Belém (28 fev. 1960). ${ }^{37}$ Estas, por sua vez, revestem-se de grande importância por serem os dois únicos "relatos de viagem" que sobreviveram à queima da correspondência de Bishop, realizada por Marieta (Maria Elvira), irmã de Lota, após a morte da destinatária. Anos depois, em maio de 1970, Bishop afirmaria a Ashley Brown, com evidente pesar: "A Lota havia guardado [as minhas cartas] com todo o cuidado para que eu pudesse usá-las - a viagem à Amazônia, Londres, todas as pesquisas que fiz" (Bishop, 1995, p.591).

Algum tempo depois da viagem pelo Amazonas começaria a nascer o mais longo texto de Bishop relacionado ao Brasil. A oportunidade para utilizar o conhecimento que vinha acumulando surgiu no início da década de 1960, quando um convite dos editores da revista norte-americana Life veio somar-se ao seu desejo de escrever um livro sobre o país. Em carta enviada a Robert Lowell em 25 de junho de 1961, Bishop anuncia que pretende

escrever um livrinho sobre o Brasil para a série The World Library, da Life. ${ }^{38}$ O livro é mais de fotos, pelo menos os que eu já vi - fotos magníficas, é claro, e um texto superficial de cerca de 55 mil palavras, de tudo um pouco - mas que não seja totalmente à maneira da Life. Tenho muito material, e acho que eu e a Lota vamos nos divertir bastante, incluindo no texto as nossas piadas preferidas, as pessoas de que mais gostamos etc. (Bishop, 1995, p.711-712)

A escritora comenta, nessa mesma carta, sua ideia de considerar a tarefa como "puramente comercial e uma espécie de penitência pelos meus anos de vagabundagem". E completa, entre parênteses: "Provavelmente ninguém nunca vai ler o texto mesmo!" (p.712).

\footnotetext{
37 As duas cartas estão transcritas e traduzidas em nossa dissertação Pontos cordiais: as cartas brasileiras de Elizabeth Bishop (Ferreira, 2003, p.147-165).

${ }^{38}$ Fundada em 1922, a Time Inc. lançou as revistas Time (1923), Fortune (1930) e Life (1936), entre muitas outras publicações. (Na realidade, Life já existia como uma publicação de humor desde 1888. A Time Inc. comprou seus direitos porque estava interessada no título. O apogeu da revista durou até 1972, quando deixou de ser semanal.) Hoje integrando o grupo Time Warner, a Time Inc. é a maior editora de revistas dos Estados Unidos e uma das maiores do mundo. A Time Life Inc., responsável pela edição da World Library, foi criada em 1961 como sua divisão voltada à publicação de livros. Em suas cartas, Bishop refere-se a ela indiferentemente como Life ou Time-Life.
} 
Ela parece alheia às motivações que poderiam estar levando a Life a incluir um livro sobre o Brasil em sua coleção sobre "Países do Mundo", naquele momento, ou, mesmo, pouco consciente dos interesses ideológicos envolvidos nesse projeto editorial.

Em carta a uma tia, escrita um mês depois, repete as observações feitas a Lowell e completa: "O mais provável é que ninguém leia o texto, mesmo, e só veja as fotos, que normalmente são maravilhosas - em cor e em preto e branco". Mas "escrever esse tipo de coisa é difícil" para ela, que tem de "cobrir todo o país - história, economia, geografia, esportes - tudo, ainda que de modo superficial". Quanto à Life, informa: "Não gosto da revista e não gosto deles - são pessoas iguais a esses vendedores que ficam pressionando a gente - mas quero ganhar dinheiro - e a esta altura de fato sei muita coisa sobre o Brasil, querendo ou não" (Bishop, 1995, p.434).

Seu contrato incluía "algumas viagens pelo Brasil e uma viagem a N[ova] Y[ork] com tudo pago, em outubro [de 1961], por um mês", para finalizar a edição. Como de hábito, Bishop entregou-se apaixonadamente ao trabalho, pesquisando ainda mais e retrabalhando o texto até a data de entrega. Em carta à amiga Pearl Kazin, de 13 de agosto de 1961, dirá: "estou aprendendo muito sobre o Brasil, e sinto que muitas histórias estão brotando dentro de mim, sem que eu faça nada" (Bishop, 1995, p.436). Mas suas preocupações não desapareceriam. Segundo Regina Przybycien (1993, p.72),

Ela, que passava, às vezes, mais de dez anos burilando um poema, até encontrar o tom exato, a palavra adequada, não admitia escrever um livro superficial sobre o Brasil ... É provável que também receasse ser julgada mercenária pelo público que admirava sua poesia ou, pior, que ele concluísse que seu talento poético se esgotara (um pesadelo que a perseguiria durante toda a vida) e, por causa disso, aceitara escrever literatura "menor".

Independentemente dos temores de Bishop, outras expectativas sombrias se concretizaram: ao chegar a Nova York para as revisões de provas, percebeu que os editores haviam alterado o texto, pouco restando do que havia de mais característico e pessoal. Depois de algumas semanas de discussões e trabalhos em busca de solução para as intervenções no original, o livro Brazil surge no início de 1962 como coautoria entre "Elizabeth Bishop e os 
editores de Life", e ela imediatamente escreve para vários amigos renegando o livro, comentando os problemas e apontando os erros que resistiram à sua intervenção. ${ }^{39}$

Segundo a biógrafa Brett Millier (1993, p.326), os editores propuseram que Bishop revisasse o texto três anos depois, mas a autora recusou. O livro ainda foi republicado em 1970, com alterações substanciais em três capítulos e substituição de várias fotos, mas Bishop não teve participação alguma nessa edição, embora seu nome ainda conste nos créditos. Apenas em 1984 - após a morte da autora - surgiria nos Estados Unidos uma edição radicalmente nova do livro, já sem o nome de Elizabeth Bishop. Trata-se, entretanto, de outra obra, uma vez que tanto os textos como as ilustrações foram substituídos. ${ }^{40} \mathrm{E}$, em 2008 , o primeiro capítulo do livro Brazil, "A warm and reasonable people" ["Um povo caloroso e sensato"], foi incluído na coletânea Elizabeth Bishop: poems, prose and letters, mas essa edição reproduziu fielmente o texto publicado em 1962, a começar pelo título, desconsiderando o fato de essa versão ter sido renegada pela autora.

Decepcionada, Elizabeth Bishop alimentaria durante anos o projeto de escrever um segundo livro sobre o país, não sujeito às intervenções que desvirtuaram o renegado Brazil. Para tanto, continuou pesquisando e recolhendo material. Em entrevista de 1966, disse:

Também estou planejando escrever um livro de prosa sobre o Brasil. O título provisório é Black beans and diamonds (Feijões pretos e diamantes). Deve ser uma combinação de um livro de viagem, uma memória e um livro de fotos. Eu me interesso muito por fotografia. Gostaria de fazer o Brasil parecer menos remoto e menos um objeto de fantasia pitoresca. Ele não é realmente tão distante de Nova York. Penso que desde os grandes naturalistas (Darwin, Wallace, Bruce e outros) não existiu muita observação cuidadosa do Brasil (ao menos, pelos estrangeiros). Exceto, talvez, por Lévi-Strauss. (Monteiro, 1996, p.29)

Logo após a publicação de Brazil, ainda em 1962, Bishop escreveu ao New Republic, de Washington, protestando contra a desinformação do periódico em relação aos eventos políticos brasileiros, expressa num artigo por ela considerado tendencioso. Em nítida reafirmação de seu prestígio, foi convidada pelos editores para escrever uma série de matérias ("Brazil letters") e chegou a considerar seriamente a tarefa, antes de abandoná-la (Millier, 1993, p.328). Em 1963, quando sua amiga Elizabeth Hardwick participou da criação do New

\footnotetext{
${ }^{39}$ Os originais datilografados, que utilizamos no cotejo com o texto publicado, também se encontram nos arquivos da escritora, no Vassar College, Special Collections.

${ }^{40}$ Diferentemente do livro original, este receberia edição brasileira, em 1992, pela Abril Livros.
} 
York Review of Books, mais uma vez foi convidada para colaborar enviando uma "Brazil letter", e novamente recusou (p.340).

No início de 1965 surgiria outro convite, desta vez para escrever um texto alusivo ao Quarto Centenário do Rio de Janeiro, a ser publicado pelo New York Times Sunday Magazine. O artigo "On the railroad named Delight" ["No trem do Encantado"] saiu na edição de 7 de março, e mais uma vez a autora enfrentou problemas: o jornalista Fernando de Castro, que vivia nos Estados Unidos, publicou no Correio da Manhã de 28 de março um artigo de página inteira denominado "Paternalismo e antiamericanismo" (Castro, 1965), crítica feroz a Bishop, que estaria "trepada nas muletas do seu racismo superioritário". Entre traduções livres e comentários ferinos, o jornalista completava citando versos que haviam feito sucesso "em outros carnavais": "Macaco, olha o teu rabo!".

Segundo Carmen Oliveira (1995), Bishop adoeceu por causa dessas ofensas públicas. Além disso, "o que a desesperava é que o leitor brasileiro não conhecia o seu texto, cheio de ironias e understatements, mas apenas a leitura abusada que dele fizera o tal Castro" (p.147). Ela já havia escrito ao New York Times protestando contra a seleção de fotos - alvo de muitos comentários de Fernando de Castro -, e contra o título do artigo, que não era de sua autoria (p.147). Escreveu uma carta ao Correio da Manhã, traduzida por Lota e publicada apenas um mês depois, na qual rebate várias das críticas, comenta as fotos e o título e chega a transcrever alguns trechos de seu original, concluindo: "E a moral da história, que deve ser óbvia a qualquer um, é que as relações inter-raciais são melhores no Brasil do que nos Estados Unidos. Mas, foi interpretada como prova de minhas "convicções racistas"” (Bishop, 27 abr. 1965).

Não encontramos outros textos relacionados ao artigo do New York Times em jornais do Rio de Janeiro e de São Paulo, nem mesmo comentários ao texto de Fernando de Castro ou à carta de Bishop. Tampouco na correspondência publicada, ou nas cartas inéditas a que tivemos acesso, há referências ao episódio. Entretanto, mais uma vez a intenção de escrever sobre o país se frustrava diante das críticas - infundadas ou não - que, se não traziam outras consequências, ao menos feriam Bishop num nível profundo e, segundo Carmen Oliveira (1995, p.145), afastavam-na dos amigos brasileiros. Seria ela realmente capaz de captar o país, se o jornalista brasileiro a chamava de "simplória, simplória mais que o normal" (Castro, 1965) e afirmava várias vezes que a americana "não pode compreender" o país e "revela absoluta incompreensão de tudo o que vê e que ouve"?

Bishop manteve o hábito de reunir material sobre o Brasil, como se comprova pelo fato de que, em seus arquivos, constam rascunhos de tradução datados até mesmo da década 
de 1970. Mas o único texto produzido por ela nessa época é o esboço de outro relato de viagem, "A trip on the Rio São Francisco" ["Uma viagem pelo rio São Francisco"], ${ }^{41}$ original datilografado e interrompido, de oito páginas, em que narra seu passeio a bordo de um "gaiola" entre Pirapora (MG) e Petrolina (PE), em 1967. Essa excursão, planejada por muito tempo, vinha mais uma vez apoiada em leituras: Bishop chega a citar o explorador inglês Richard Burton, do século XIX, nas considerações sobre a Cachoeira de Paulo Afonso, mas se baseia sempre nas informações da Quatro Rodas, "a revista mensal brasileira dedicada aos automóveis e às viagens", seu "único livro-guia confiável”, que publicara extensa reportagem sobre o tema ${ }^{42}$ pouco tempo antes.

A reunião e tradução dos seis textos aqui citados - desde o "Suicídio de um ditador (moderado)" (1954) até essa "Viagem pelo rio São Francisco" (1967) -, dois dos quais ainda inéditos mesmo em inglês, parece-nos tarefa fundamental para o conhecimento e a divulgação do que seja o "Brasil de Elizabeth Bishop", e serve de base para nosso estudo do tema. Pretendemos, assim, problematizar a observação de sua biógrafa:

Ela fez incursões bem-sucedidas pela escrita jornalística sobre o país, e viajou muito tendo em mente a produção de textos, mas as "narrativas de viagem" que sempre estava prestes a escrever jamais foram feitas. Embora ela tenha finalizado poemas sobre alguns desses mesmos assuntos, sentia-se incapaz de generalizar, a partir da riqueza de detalhes anotados em seus diários, para escrever prosa. Nos poemas, os detalhes falam por si. (Millier, 1993, p.287)

O livro Brazil (1962), tendo em vista suas próprias características e os percalços enfrentados na publicação, merece atenção especial. Afinal, estão em jogo, aí, vários aspectos importantes: as intenções dos editores norte-americanos, em plena Guerra Fria, na produção de uma série denominada "Países do Mundo"; o convite à poeta premiada para que escreva um livro semi-jornalístico sobre o Brasil; e o confronto entre editores e autora, que resultou na publicação afinal renegada por Bishop. A própria existência de Brazil nos leva a discutir a possibilidade de se captar a totalidade de um país numa obra com esse caráter. A tradução desse livro, anotada, constitui a quarta parte deste trabalho. Os cinco textos mais breves, também traduzidos e anotados, estão reunidos na quinta parte.

\footnotetext{
${ }^{41}$ Ver Figura 2.

42 "Sete dias nas águas do sertão", n.79, fev. 1967, p.82-101.
} 


\section{Brazil, 1962 - um livro renegado}

Elizabeth Bishop era capaz de trabalhar durante anos antes de considerar finalizado um poema, mas dificilmente alterava uma palavra depois da publicação (Monteiro, 1996, p.27). Nisso, contrapunha-se até mesmo aos amigos Marianne Moore e Robert Lowell, revisores compulsivos de textos já publicados, embora reconhecesse o cuidado no trato das palavras como a maior influência recebida de Moore (p.73).

Mas, como não existem edições perfeitas, Bishop certa vez surpreendeu um entrevistador ao corrigir, no exemplar a ser autografado, "um erro estúpido" (Monteiro, 1996, p.63) que deixara passar nos Complete poems. ${ }^{43}$ Em outra ocasião, justificou "de maneira espantosamente simples" o título inadequado dessa mesma coletânea: "ela vivia no Brasil naquela época e, na ida e volta das provas, entre o Rio e Nova York, por algum motivo apenas deixara passar a página de título errada de seus poemas reunidos" (p.138) e não completos. Nem sempre, entretanto, reagiu com calma às intervenções alheias. Ainda na juventude, um de seus textos - "um poema longo, o mais ambicioso que eu jamais tentara escrever até então" - teve o efeito de "despertar imediatamente o espírito crítico de Marianne [Moore] e sua mãe". Um dia após tê-lo enviado pelo correio, "Marianne me telefonou para dizer que ela e sua mãe haviam ficado acordadas até tarde da noite reescrevendo-o" (Bishop, 1996, p.173). Como resultado, a jovem poeta nunca mais deixou que Moore lesse seus originais (Monteiro, 1996, p.67), embora a amizade e a admiração tenham resistido por décadas, até a morte desta, em 1972.

Em determinados contextos não literários, entretanto, as intervenções poderiam ser úteis, embora ainda assim ridicularizadas por Bishop. Em 1950, quando ela trabalhou como consultora de poesia da Biblioteca do Congresso norte-americano, em Washington, era auxiliada por "uma secretária simpática" que talvez fizesse "a maior parte do trabalho": "Eu escrevia alguma coisa e ela dizia: 'Oh, não, a linguagem não está adequada', então reescrevia usando um jargão que deixava o texto mais difícil de entender" (Monteiro, 1996, p.131).

Tanto editores como críticos são alvo de sua ironia bem-humorada. Quando a revista New Yorker devolveu as provas de seu poema "Crusoe in England", informando que em dois versos havia "anacronismos" (Monteiro, 1996, p.86), Bishop teve de responder que "aquilo era intencional". E quando o crítico Richard Ellmann inseriu uma nota de rodapé em outro de seus poemas, "indicando que existia uma ilha com esse nome [St. John's] no Caribe”, a autora

\footnotetext{
${ }^{43}$ A autora substitui "What nothing" por "But no", na página 177 do exemplar, antes de autografá-lo.
} 
comentou que se referia a "St. John's, Terra Nova", no Canadá (Monteiro, 1996, p.87), o que lhe parecia óbvio.

De qualquer maneira, por mais vulneráveis que fossem as relações entre Bishop e seus editores, nada se assemelha à tempestade que se formou quando a autora foi com Lota a Nova York, em novembro de 1961, para as revisões de seu livro Brazil, justo um projeto que nascera despretensioso e com intenções nitidamente comerciais. Tudo despertava sua ira: as fotos, suas legendas, as alterações nos textos, os próprios títulos dos capítulos. Em carta a uma amiga, comenta:

Você ficaria assombrada ... com todos os 'poréns', 'entretantos', e 'mas' particularmente os 'mas' - a Time-Life os adora e aparentemente acha que nada significam - espalhados pelo texto, dando ao que resta dele um falso ar de ponderação e lógica, de equilibrar uma coisa em relação a outra etc. Também há centenas de 'quases', 'provavelmentes', 'alguns dos' - mas nenhuma dessas palavras aparece onde devia. $^{44}$

Sobre as ilustrações, por exemplo, aponta à amiga May Swenson: “A foto da página 89 é um embuste - um still de Orfeu do Carnaval - e a falsidade é evidente para qualquer um que já tenha assistido ao Carnaval daqui” (Bishop, 1995, p.715). A autora referia-se ao filme dirigido pelo francês Marcel Camus, em 1959, tendo por base o texto teatral Orfeu da Conceição, de Vinícius de Moraes. O filme ganhou a Palma de Ouro no Festival de Cannes e o Oscar de melhor filme estrangeiro - o que certamente contribuiu para a escolha da foto pelos editores, em lugar de documentos autênticos do Carnaval carioca.

Na mesma carta, Bishop diz, ainda: "A foto de São Paulo é horrorosa", e "Imagine um Rio de Janeiro sem nenhum pássaro, nenhum bicho, nenhuma flor". Ainda nesse aspecto, "eu insisti que devia haver pelo menos uma página de fotos de animais ... escrevi duas ou três páginas boas sobre a NATUREZA - o efeito dela sobre a linguagem - bichos de estimação pássaros de gaiola etc. - cortaram tudo". A autora comenta a inércia dos editores, pois "o que não falta é material, existem coisas maravilhosas - comecei a mandar listas para eles - e além disso eu sabia onde encontrar as coisas", e ensaia breves análises das motivações: quanto às imagens dos índios, "agora de repente eu entendi o motivo - eles têm medo da nudez" (p.715).

\footnotetext{
${ }^{44}$ Carta a Ilse e Kit Barker, 23 maio 1962, que não consta nas edições norte-americana e brasileira. Os originais encontram-se nos arquivos da autora (Vassar College, Special Collections); a tradução aqui reproduzida é de Regina Przybycien (1993, p.72).
} 
As legendas estavam "cheias de erros", pois, "segundo me disseram, eles não podem ser processados pelo que consta nas legendas, de modo que estão se lixando se elas estão corretas ou não" (p.715).

Depois de publicado Brazil, a autora agradeceu aos amigos que, apesar de tudo, elogiaram seu trabalho: "Você leu o livro com tanto cuidado, e se deu ao trabalho de separar o que talvez fosse meu do que sem dúvida não podia ser - tem frases que ficaram completamente sem sentido - pelo visto, na hora de encaixar o texto naquelas colunas, eles não ligam nem um pouco para o significado" (Bishop, 1995, p.715). Compromete-se a corrigir, "da melhor maneira possível”, os exemplares que pretende distribuir aos amigos brasileiros. É o que tentará fazer, também, no exemplar que permaneceu em seu poder, hoje preservado na biblioteca da Universidade Harvard.

Mesmo os comentários irônicos sobre Brasília, no capítulo 4, só haviam sido mantidos "porque por acaso o editor entende um pouco de arquitetura moderna - puro acaso. Ele não entende nada de nenhum outro assunto" (Bishop, 1995, p.715). Sobre a nova capital Bishop escreve, por exemplo, que "parece estar fora de escala; os edifícios se perdem na vastidão circundante, e mesmo dentro da cidade a sensação de estar em outro planeta - como todos dizem - é devastadora" (Bishop, 1962, p.58). E os comentários são pertinentes, não só pelo interesse crítico que a autora demonstra pelo assunto, mas também pela convivência com Lota, uma entusiástica incentivadora da arquitetura moderna. Lembremos que a casa de Samambaia (Petrópolis), projetada pelo modernista Sérgio Bernardes, fora premiada na $2^{\mathrm{a}}$ Bienal de São Paulo, em 1954, tornando-se "lugar de peregrinação obrigatória para os especialistas e aficionados" (Przybycien, 1993, p.91).

Sobre o mesmo editor, e sobre as regras de edição de texto vigentes na Life, diz a autora: "quando ele mudou, na p.103, a segunda ocorrência da palavra poetry [poesia] para verse [verso] e me mandou um telegrama dizendo que não havia nenhuma diferença - desisti, e desde então não nos comunicamos" (Bishop, 1995, p.715).

Os títulos dos capítulos também haviam sido substituídos. Diz a autora:

Os meus ... eram 'sugestivos', pelo menos eu achava! 2: A terra do pau-brasil. 3: O único império ocidental. 4: Três capitais. 5: Animal, vegetal, mineral. 6: As artes espontâneas. 7: As artes sofisticadas. 8: Grupos e indivíduos. 9: A república... Não 
tenho a menor dúvida de que eram melhores! Mas o mais horroroso de todos é 'Esplendores modernistas de uma capital na fronteira'. ${ }^{45}$

Na opinião de Elizabeth Bishop, apenas nos três primeiros capítulos a intervenção dos editores havia sido menos desastrosa. O livro se inicia com o rapto de um bebê Conceiçãozinha - num hospital do Rio de Janeiro, narrativa que se manteve quase intacta, ao passo que, em outros capítulos, várias sequências de parágrafos foram suprimidas. Mesmo as breves alterações aparentemente estilísticas, no entanto, por vezes exigem um olhar atento: o pai do bebê "ficou branco" de emoção no texto original (as aspas são de Bishop), mas, na versão publicada, apenas soluçou.

Alguns pesquisadores comentam que, apesar da revolta diante das alterações em seu livro, ao menos as avaliações políticas de Bishop "foram respeitadas justamente porque coincidiam em grau surpreendente" (Jaguaribe, 1998, p.106) com a opinião dos editores, mas essa afirmação, nem sempre suficientemente documentada, exige análise cuidadosa. A mesma autora, por exemplo, destaca a opinião de Bishop a respeito de Carlos Lacerda, "arauto do Brasil democrático e anticomunista”, embora essas palavras constem na legenda de uma foto, escrita, como vimos, pelos editores. Além disso, a leitura da correspondência de Bishop demonstra que as impressões sobre Lacerda advindas do relacionamento com ele eram ambivalentes. Bishop o considerava um dos homens mais inteligentes que conhecera, mas escreveu ao escritor e amigo Robert Lowell: "vou lhe dizer mais uma vez: sobre muitos aspectos, nós NÃO concordamos com o Carlos - e ele é mesmo perigoso, quando não há ninguém mais". 46

No capítulo 9, "Luta por uma democracia estável" - título dado pelos editores -, Vargas, que exilara o pai de Lota, o jornalista e político José Eduardo de Macedo Soares, é apresentado simplesmente como um "demagogo", mas também neste caso o texto não é de Bishop.

Muitas das mudanças executadas pelos editores dispensam comentários. Alterou-se, por exemplo, o trecho em que Bishop dizia haver, no Brasil, "cataratas mais espetaculares que as do Niágara", substituído por "quase tão espetaculares quanto Niágara" (p.45). Na opinião da autora, expressa em carta a May Swenson (10 abr. 1962), a intenção dos editores consistira apenas em "apresentar as ideias preconcebidas que eles têm de um país, sem nenhuma

\footnotetext{
${ }^{45}$ Bishop, 1995, p.715. Esse último (A Frontier Capital's Jet-Age Splendors), na realidade um subtítulo, encontra-se na p.59 do livro publicado.

${ }^{46}$ Carta a Robert Lowell, 8 jan. 1963 (Bishop, 1995, p.730). A relação com Lacerda é focalizada na segunda parte, "Carlos e Carlota, Lota e Lacerda", de Ferreira, 2003.
} 
interferência". Mas, numa carta destinada aos editores, ${ }^{47}$ Bishop é mais incisiva: inicia as observações relacionadas a esse trecho com "por favor, veja meu texto", e as encerra com um comentário grifado: "chauvinismo ignorante". É interessante notar o que a autora observou, em Nova York, em relação a outro livro da série World Library:

Na véspera de eu voltar para o Brasil eles estavam começando a preparar rapidamente um livro sobre a ÁFRICA, e estavam todos se babando com umas fotos coloridas de leões, zebras etc. - porque eles já sabem que na África existem leões. Não têm nenhum interesse por preguiças, jiboias (ontem uma jiboia atacou uma criança em Belém), tamanduás, borboletas, orquídeas - 4 mil espécies de peixes, saúvas, onças etc. (Bishop, 1995, p.716)

Num nível de intervenção mais profundo, o encontro de um inconfidente mineiro com o líder norte-americano Thomas Jefferson, em Paris, recebe na versão publicada um adendo: "talvez agindo sob falsas esperanças de ajuda americana". ${ }^{48}$ Esse comentário remete, sem dúvida, ao panorama político de 1960. E uma observação sobre Tiradentes - "ele carregava consigo, no bolso, a Declaração da Independência americana e gostava de lê-la em voz alta" foi simplesmente suprimida, embora verdadeira. ${ }^{49}$ Regina Przybycien $(1993$, p.75) lembra que a imagem evocava "os revolucionários de esquerda do século XX, carregando Marx e citando-o a toda hora", o que certamente provocava desconforto entre os editores da Life. Intervenções como essas nos levaram a promover o cotejo completo das duas versões, apontando similaridades e, sobretudo, os importantes contrastes entre elas.

As narrativas de viagens de Elizabeth Bishop pelos rios Amazonas e São Francisco permaneceram incompletas e em rascunho, mas por isso mesmo revelam a capacidade de observação da autora e seu método de trabalho, algo presente também na descrição do enterro de Vargas, outro breve esboço. O texto jornalístico que focaliza o Rio de Janeiro em seu Quarto Centenário, por sua vez, revela muito da visão de Bishop sobre a cidade e o Brasil num momento de profundo desencanto, quando pela primeira vez ela pensou em abandonar o país - movimento que começaria a concretizar um ano depois. Já o longo artigo escrito após a

\footnotetext{
${ }^{47}$ O rascunho dessa carta, datado de 19 dez. 1961, está arquivado no Vassar College, Special Collections, Box 47.1, e é utilizado em nossa discussão para o estabelecimento do texto de Brazil.

${ }^{48} \mathrm{O}$ trecho consta no capítulo 2 dos originais (Vassar College, Special Collections) e na p.31 do livro publicado, e já foi apontado por Regina Przybycien (1993, p.74).

${ }^{49} \mathrm{O}$ livreto, publicado em francês, encontra-se no Museu da Inconfidência, em Ouro Preto, e na etiqueta que o acompanha consta o título "O livro de Tiradentes", nome pelo qual era conhecido entre os Inconfidentes.
} 
viagem a Brasília, amplamente retrabalhado por Bishop, finalizado e entregue à New Yorker para publicação, permite vislumbrar, talvez, como seriam os capítulos de seu livro planejado e jamais escrito sobre nosso país. Finalmente, o livro Brazil, renegado pela autora, tem o mérito de confrontar duas perspectivas de compreensão do país: a da autora e a de seus editores.

A tradução de textos em prosa de Elizabeth Bishop, tarefa a que nos dedicamos neste trabalho, completa-se e se fundamenta com a inclusão de notas de rodapé no caso dos cinco textos mais breves, mas a tradução de Brazil exige nossa atenção para um problema de outra ordem, não apenas editorial: como chegar ao texto 'definitivo', se é que ele pode ser apontado?

\section{Brazil, 1962 - buscando estabelecer um texto}

As Special Collections do Vassar College, no estado de Nova York, reúnem grande parte dos arquivos de Elizabeth Bishop, onde se destacam conjuntos importantes de sua correspondência e centenas de originais. Entre estes encontra-se uma versão datilografada do livro Brazil, ${ }^{50}$ abrangendo nove dos dez capítulos publicados - não consta o capítulo 5 -, além de um sumário, alguns rascunhos, notas de leitura e correções. Mas uma parte dos arquivos de Bishop, sobretudo de sua biblioteca pessoal, está depositada na Universidade Harvard, em Cambridge, Massachusetts, e inclui o exemplar de Brazil que pertenceu à autora, hoje disponível na Houghton Library dessa instituição. Vários pesquisadores - entre os quais Regina Przybycien (1993) e Silvia Anastácio (1999) - comentaram o fato de haver inúmeras correções manuscritas nesse exemplar. Realmente, a ficha do livro anuncia tratar-se de um exemplar "from the library of Elizabeth Bishop; signed, heavily revised in manuscript, with numerous disclaimers by Bishop”. Aparentemente, a autora analisou essa edição com o mesmo rigor que demonstraria, anos depois, na correção dos trabalhos de seus alunos, na própria Universidade Harvard. ${ }^{51} \mathrm{O}$ depoimento de um aluno do curso de Poesia Moderna na turma de 1975 descreve, em detalhe, as anotações da professora:

\footnotetext{
${ }^{50}$ Vassar College, Special Collections. Elizabeth Bishop Papers: prose, Box 47, Folders 47.1 to 47.10. Ver Figura 3.

${ }^{51}$ Até mesmo o grande amigo Robert Lowell foi criticado - de maneira extremamente delicada - por erros em suas traduções, apontados e acompanhados, em carta, pelas respectivas correções: "Pois bem, há uma ou duas coisas que me incomodam porque parecem erros, estejam ou não erradas. E embora você se arrogue 'liberdade', não quero que seja criticado por ter cometido erros. (Por favor, me perdoe o tom professoral.)" (Bishop, 1995, p.430).
} 
Cada página tinha dúzias de correções, questões, eliminações e sugestões na letra miúda de Bishop ... Horrorizado, comecei a ler comentários nas margens como "Expressão horrível", "Frase desnecessária", "Palavra difícil de pronunciar", "Não existe no dicionário" - a maioria seguida por um ponto de exclamação, como sempre acontecia com o seu onipresente e indiscutível "Não!". Um "Melhor" ou "Sim" (sem ponto de exclamação) pouco servia para reviver minha autoconfiança. (em Monteiro, 1996, p.153)

Esse mesmo aluno afirma que, na leitura de poemas, Bishop agia com extremo cuidado, tão devagar como se eles estivessem escritos em língua estrangeira (p.142). Assim, era previsível encontrar uma análise minuciosa no exemplar de Brazil que pertenceu à autora. O exame desse volume, entretanto, mostrou-se mais desanimador que surpreendente: as alterações são breves e esparsas, e muitas vezes resumem-se a uma exclamação ou interrogação à margem do texto.

Em todo caso, os títulos dos capítulos estão riscados e existem várias observações irônicas, no estilo característico da autora. Na página de créditos, por exemplo, a informação "The text for the chapters of this book was written by Elizabeth Bishop" recebe um adendo: "more or less" - "mais ou menos" -, e no alto surge uma observação: "I am not responsible for chapter headings or captions - although I tried to correct captions”. É como se a autora, resignada após a inclusão da coautoria com os editores de Life, tivesse desistido de lutar contra o livro impresso - conclusão corroborada, como vimos, pela informação de que ela recusou a oferta para trabalhar numa reedição (Millier, 1993, p.326).

Diante disso, era preciso estabelecer regras que guiassem nosso trabalho de apresentação desse livro ao leitor brasileiro. Interessava buscar "a redação definitiva dada pelo autor" (Spina, 1977, p.91), o texto que traduzisse "um compromisso do autor para consigo mesmo e para com o seu público e o que servirá de excelente guia, na posteridade, para o tratamento crítico de sua obra, se ela o merecer...” (Houaiss, 1983, v.1, p.66). Esse texto é que seria vertido para o português. De um lado havia, entretanto, o original datilografado, obviamente preliminar e incompleto, uma vez que não foram documentadas as cinco semanas de trabalho árduo da autora em Nova York, no final de 1961, em permanente discussão com os editores em torno do texto alterado e complementado por eles. De outro lado, havia o livro publicado e renegado, um tanto corrigido pela autora no exemplar que hoje se encontra em Harvard. 
Optamos pelo estabelecimento de um texto "idôneo, fidedigno ... não propriamente crítico", centrado no exemplar que pertenceu à autora. Sem a "totalidade do rigor edótico", esse texto dispensaria "o aparato crítico indicador de variantes e discrepâncias", embora encerrasse "um sucedâneo desse aparato, para o fim informativo fundamental" (Houaiss, 1983, v.1, p.274) que motivou nosso trabalho de anotação e tradução.

A aceitação passiva do texto publicado, a exemplo do que se fez em 2008 com o primeiro capítulo de Brazil, incluído em livro organizado por Robert Giroux e Lloyd Schwartz, pareceu-nos incorreta - embora a própria autora reconhecesse que os três primeiros capítulos foram os que menos sofreram com a intervenção dos editores. Assim, optamos por apresentar lado a lado duas versões do texto: a coluna principal traz a edição de 1962, corrigida de acordo com as anotações de Bishop em seu exemplar de Harvard (HRV); em outra coluna, à esquerda, os trechos dos originais datilografados de Vassar (VAS) que diferem substancialmente dessa versão "definitiva".

Em rodapé, as notas editoriais que buscam contextualizar o livro estão acompanhadas pela descrição das emendas inseridas pela autora em seu exemplar de Harvard. E, a título de complementação, optamos por indicar as alterações e atualizações promovidas pelos editores na edição de 1970, lembrando que nela ainda consta o nome de Elizabeth Bishop.

Se, por um lado, constata-se a impossibilidade de apresentar como definitivo um texto que foi abandonado pela autora, por outro lado a publicação dos originais expõe o frescor da escrita de Elizabeth Bishop, exatamente nos pontos em que ela contrasta com a versão publicada.

A inclusão das observações relacionadas à edição de 1970 - quando o regime militar estava consolidado e o "milagre brasileiro" atingia o apogeu - permite, por sua vez, confrontar a postura dos editores norte-americanos em dois momentos muito diferentes nas relações entre Brasil e Estados Unidos. Além disso, houve alterações significativas no texto sobre Brasília, no final do capítulo 4, e sobre a história contemporânea do Brasil, nos capítulos 9 e $10 .^{52}$

Inicialmente, a análise dos originais de Vassar já nos aponta algumas surpresas arquivísticas. Os originais de Brazil estão arquivados sob a rubrica "Prose - Published", numa caixa ( $\left.n^{\circ} 47\right)$ contendo dez pastas (folders) assim descritas:

\footnotetext{
${ }^{52}$ Houve, também, duas reedições intermediárias, em 1963 e 1967, antes da última (1970), mas elas não diferiam amplamente da primeira, de 1962.
} 
Folder 47.1 - Brazil. Chapter outline, reading notes, early drafts, chapter corrections. TS, MS, 73p. [1960-62]

Folders 47.2 to 47.10 - Brazil. Draft, Chapters I to X (“no Chapter V”): I (17p.), II (33p.), III (44p.), IV (10p.), VI (12p.), VII (18p.), VIII (11p.), IX (16p.), X (7p.) [1960-62]

Na realidade, o Folder 47.1 (com 78, e não 73 páginas) não contém apenas os documentos relacionados ao livro Brazil [1960-62]. Estão aí, também, os rascunhos reunidos pela autora para o seu segundo livro - nunca finalizado - sobre o país: versões para o inglês de notícias de jornal, receitas de doces, frases de pára-choques de caminhões, rascunhos do texto jornalístico relacionado ao Quarto Centenário do Rio de Janeiro, de 1965, e assim por diante. Embora poucas páginas estejam datadas, os sinais que nos guiam nas demais são claros:

a) a velha máquina de escrever mecânica foi substituída por uma elétrica, resultando num texto com tipos mais claros e aparência muito mais 'limpa';

b) algumas páginas foram escritas no verso de rascunhos abandonados (de cartas, por exemplo), alguns deles datados;

c) os próprios textos referem-se, às vezes, a fatos posteriores a 1962.

Existem anotações datadas até mesmo de 1972, provando que a autora manteve esse projeto numa época em que estava retornando definitivamente aos Estados Unidos. Seguindo a ordem em que as cópias nos foram entregues, temos nessa pasta 27 itens, dez dos quais (28 páginas) são indubitavelmente posteriores à publicação de Brazil (Quadro 1).

Todo esse material afasta-se, portanto, das considerações sobre a edição e tradução de Brazil, mas alimenta nosso estudo sobre "o Brasil de Elizabeth Bishop" e seu projeto de escrever outro livro sobre o país. 
Quadro 1 - Complementos a Brazil (Vassar College, Folder 47.1)

\begin{tabular}{|c|c|}
\hline Item & Assunto \\
\hline$[\ldots]$ & {$[\ldots]$} \\
\hline 11 & $\begin{array}{l}\text { Anotações soltas, em geral datilografadas: um "Outline" (esboço), letras } \\
\text { de músicas (marchas de carnaval, sambas). }\end{array}$ \\
\hline 12 & $\begin{array}{l}\text { Rascunhos de comentários sobre viajantes: Maria Graham, Charles } \\
\text { Darwin etc. }\end{array}$ \\
\hline 13 & $\begin{array}{l}\text { "Rio de Janeiro 1565-1965", rascunho e anotações para o texto } \\
\text { comemorativo. }\end{array}$ \\
\hline 14 & $\begin{array}{l}\text { Anotações datadas de "1970", contando breves episódios vividos pela } \\
\text { autora no Brasil - no táxi, no trânsito etc. }\end{array}$ \\
\hline 15 & "More truck bumpers": mais duas frases de pára-choques de caminhões. \\
\hline 16 & $\begin{array}{l}\text { "A Carnival Story - a Story of Carnival" - rascunho com notícia de } \\
\text { jornal etc. }\end{array}$ \\
\hline$[\ldots]$ & {$[\ldots]$} \\
\hline 19 & $\begin{array}{l}\text { "Introductory Note", provavelmente para o novo livro; conta sua vinda } \\
\text { ao Brasil, onde viveu "por } 16 \text { ou } 17 \text { anos" (até 1967-1968). }\end{array}$ \\
\hline 20 & Lista de alimentos. \\
\hline 21 & $\begin{array}{l}\text { Doces - listas de nomes etc. "Também, para o capítulo de Ouro Preto... } \\
\text { pedras semi-preciosas...". }\end{array}$ \\
\hline 22 & Notícias traduzidas de $O$ Globo, 1967. \\
\hline
\end{tabular}




\section{a. 20 "Inow Sorhe")}

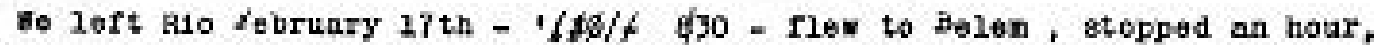

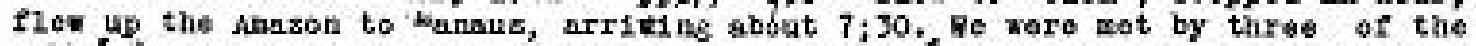

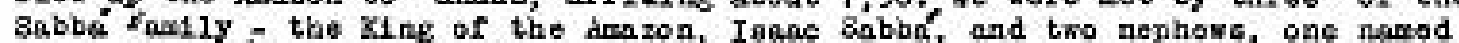

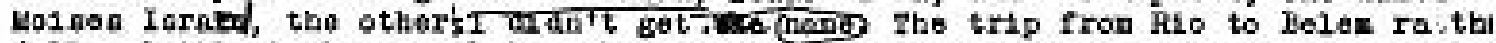

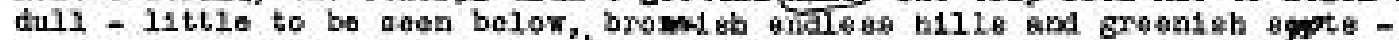
Fhe sirport bev, "rodera" and akendy very delapd tated - out s1de a nask, 1na1de

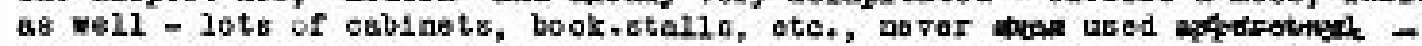

(two 11tis esbofodig etaring in the dooswh at ne) A rather nteo long otris of

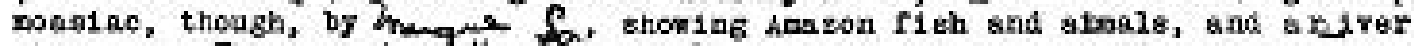

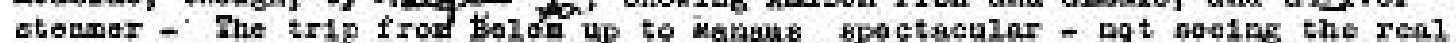
body of the river but thoisande of tribufiteries, a raet reph systen. It wae a gray doy eith aun ephring oves iqh while - the nat strobes looked like

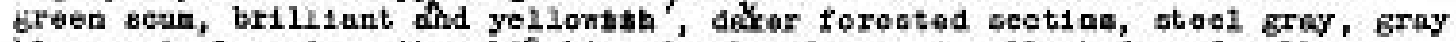
blue, stecly volus, thea bifeht nud-aolored ones in sll stades or yollov -

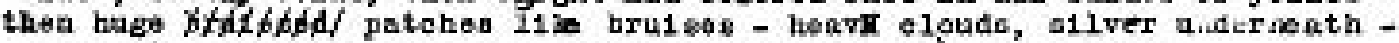

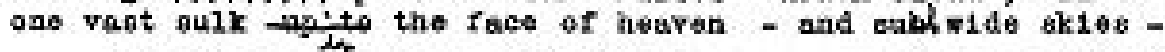

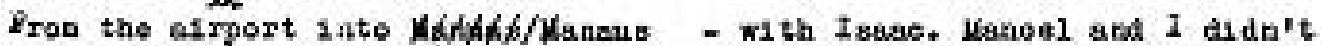
rexilze hts faprtabe at all and kept ankiag hazriblo faffec. Pin ot of the I akcplaned over the bosuties of the zlums, - Sho rosd passes over sereral bride el

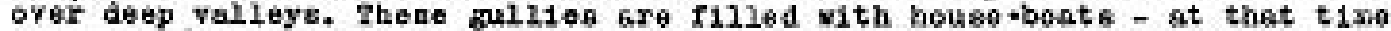

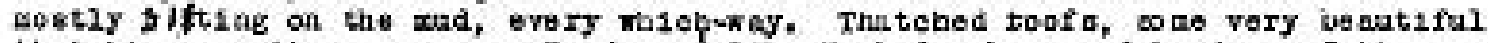

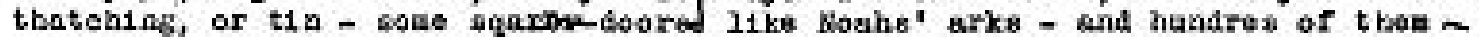

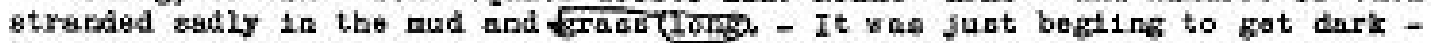

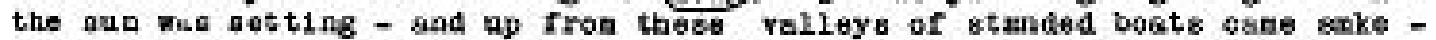
Sroke rove fron thase long deap rallfoes fu2l of atandod boate - ganplag

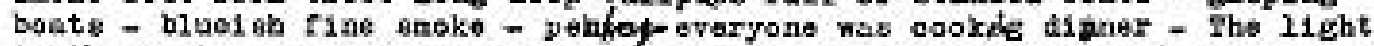
1n the wost was claer selon pink; the air full of high elear frog ealla - a different kind of frog than in Petrdpolia - Ir Sabba aeked kosinaba if uh "d

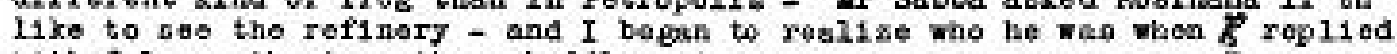
isth rolse ontbusase thex she 'dlore to.

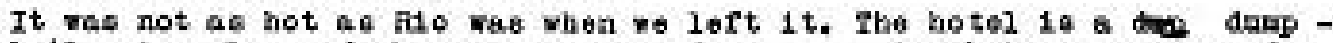

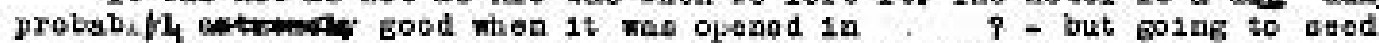

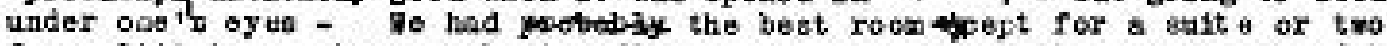
for politielaris, eto, on she top flooz - vegre on the 4th - really the 6 th -

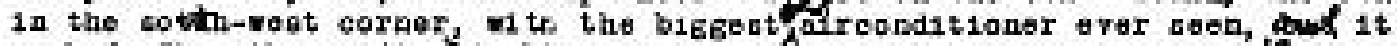

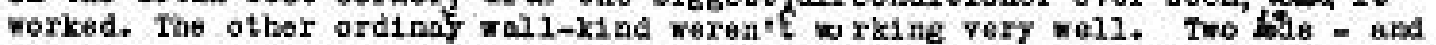
two hooks for ons haxmock. I baloony that looked orer nonle houses to tho rivor - the narket was bebind then - end to the right the doeks. Thres isree shipe. vere 1n. One, rather tired-look1as, was tho "dielrante dlaxnndrine" in which

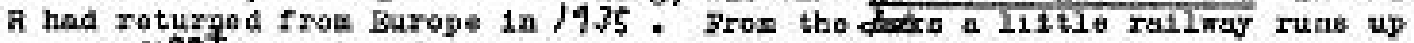

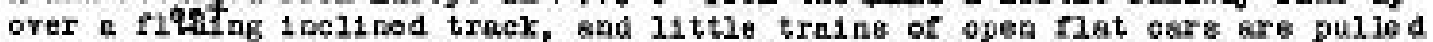

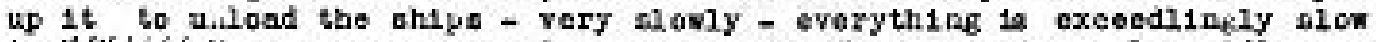

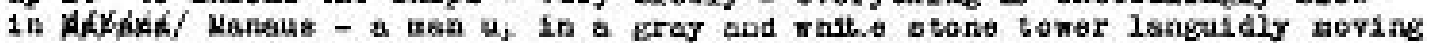
bandlee bpok and forth too direct the rasinsy. Thet night we ate as neser st the botelfind tried to go for a valr. Fhere aro alaoct no 8 truetianpe. Bone zhope and varahouged hare weak 11 ght kulbe - oal 40 wett one, Igd any - in

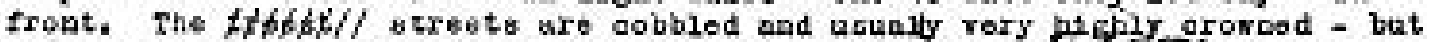

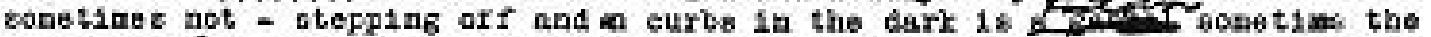

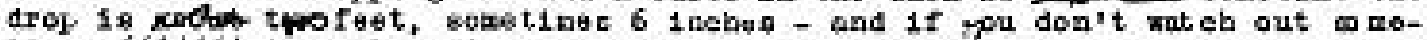

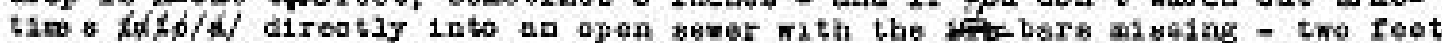
c. quare and bottorises -

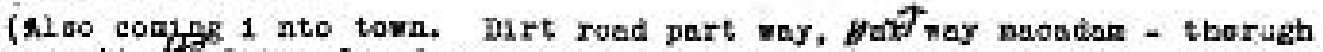

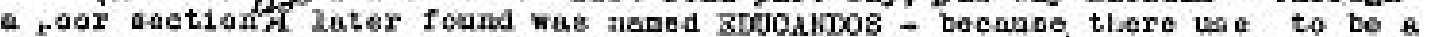

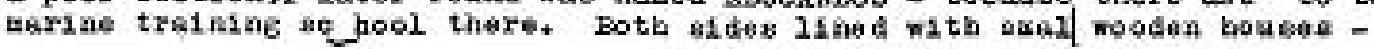

Figura 1 - Original de "Uma viagem pelo Amazonas", página inicial. Vassar College, Special Collections. 


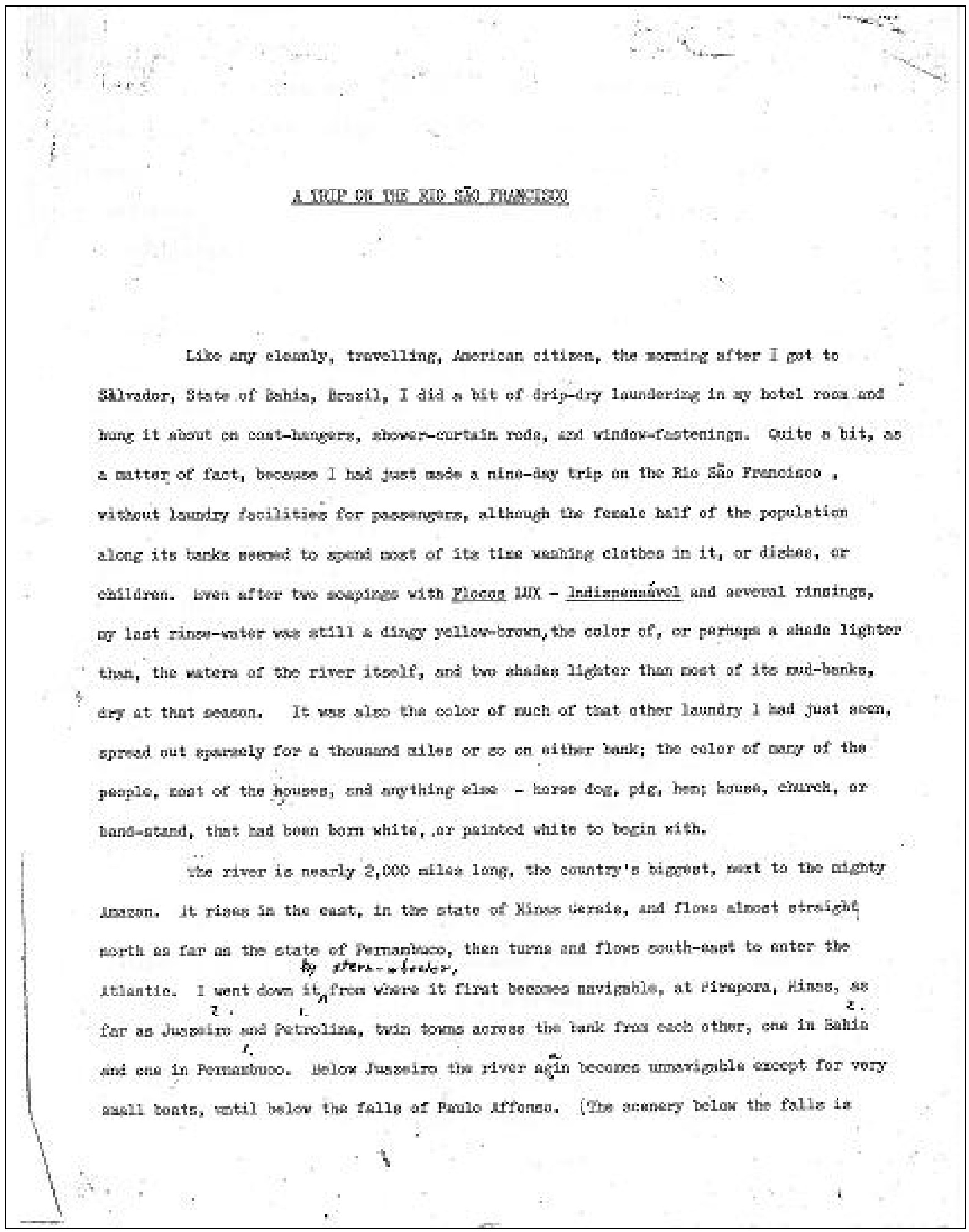

Figura 2 - Original da "Viagem pelo São Francisco", página inicial. Vassar College, Special Collections. 


$$
\text { [he foll Pre-Horel }
$$

\section{Chapter II}

At least as early as the niath entuxy a 1 and called "heudil" was already a lecend in Faroje. It has wherever bresilium cane fron, a wood obteinrd In trade with the Par Mast, much in dewad for dycie clith frt. (Perhpps all the sed wooless tile prasane weat in the

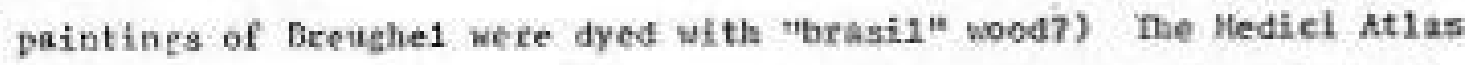

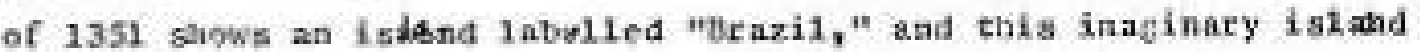
keeps te-amearine for several centurich, $/ d / H$ bontime in ne part

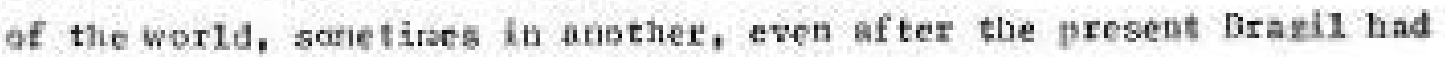

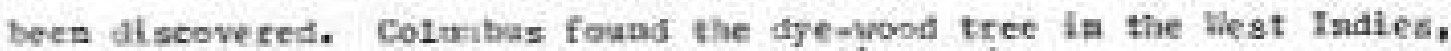

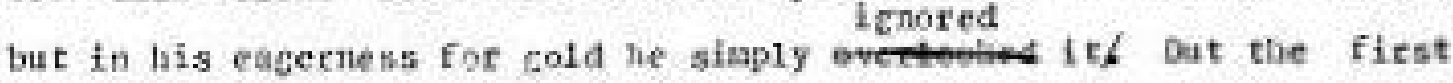
ships setht bock from the continent of south Ancrica ucre longed with

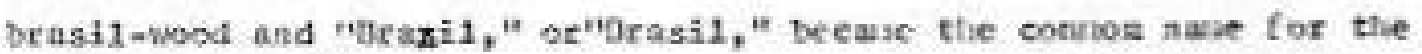

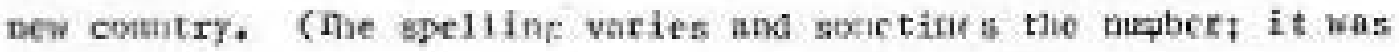

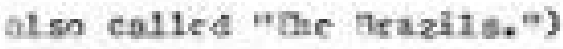

In nne of the narles of Rio de taneiro atands a fine, fiubsyant

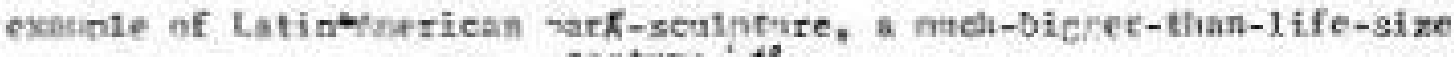

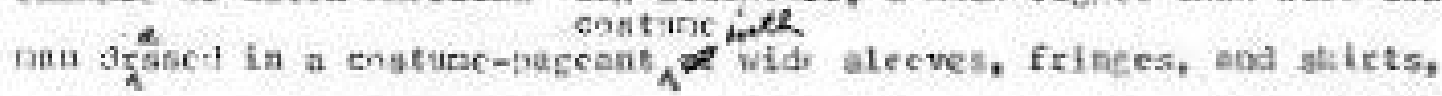

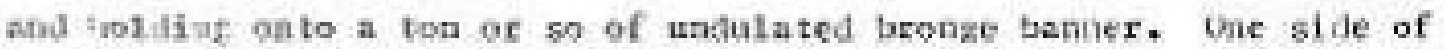

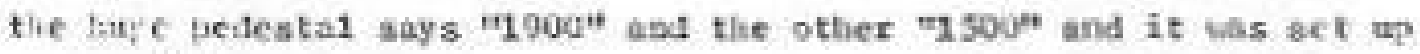

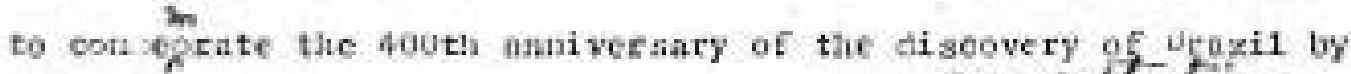

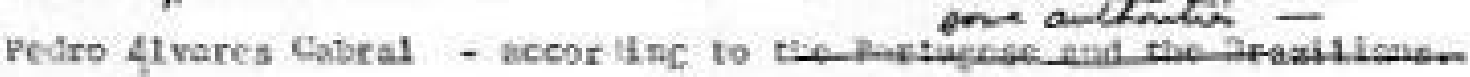

Figura 3 - Original de Brazil, página inicial do capítulo 2. Vassar College, Special Collections. 


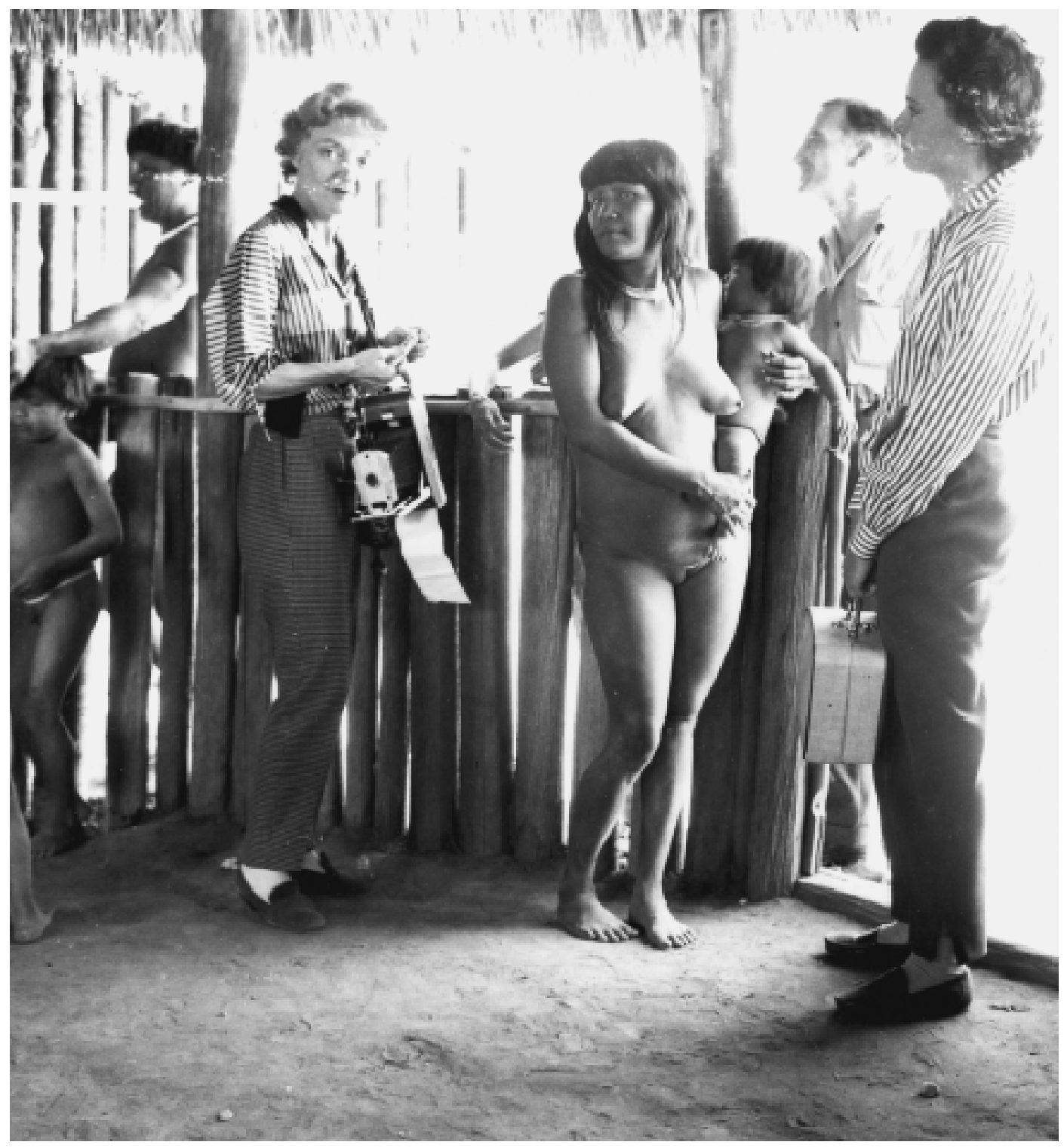

Figura 4 - Foto tirada durante a visita ao Xingu, em 1958. Vassar College, Special Collections. A Yale Review (jul. 2006) atribuiu sua autoria "possivelmente" a Elizabeth Bishop. Na realidade, a foto é da arquiteta Maya Osser e foi publicada originalmente no Correio da Manhã (Rio de Janeiro, 21 ago. 1958). Ilustrava o texto de Antônio Callado, com esta legenda:

“Em pleno posto Capitão Vasconcelos vemos à esquerda Laura Huxley, à direita Daphne Lynch e no meio, curumim à ilharga, uma cunhã camaiurá que é a única a fazer pose, vestida apenas com seu colar. Laura Huxley fez grande sucesso entre os índios com sua Polaroid de revelar e imprimir filmes na mesma hora."

Em seu texto sobre a mesma viagem, Elizabeth Bishop escreveu:

"Laura Huxley tinha passeado pelo lado de fora e estava abrindo um estúdio com sua câmera Polaroid; esses índios sabiam tudo a respeito de câmeras e ficaram muito contentes em posar, lado a lado, com os braços em torno do pescoço dos outros.” 


\section{2}

\section{Escrever Brazil}

O momento em que Elizabeth Bishop escreve Brazil é extremamente problemático em sua vida: os primeiros oito anos no país haviam sido desfrutados em um sítio nos arredores de Petrópolis, mas no final de 1960 Carlos Lacerda, amigo e vizinho de Lota de Macedo Soares, foi eleito para o governo do recém-criado estado da Guanabara e imediatamente a convidou para coordenar a implantação do que se tornaria o Parque do Flamengo - uma das mais importantes realizações de sua gestão. Encerrava-se a fase em que Lota e Bishop liam, “de modo intermitente, das sete da manhã até uma da madrugada todos os dias, coisas de todo tipo..." (Bishop, 1995, p.419), num lugar onde "o que tem de flora e fauna parece um sonho" (p.241), as nuvens "entram e saem pela janela do quarto da gente, tem cascatas, orquídeas, todas as flores que eu conheci lá em Key West, e mais frutas de clima temperado como maçãs e peras" (p.242). Elas praticamente se transferem para o Rio, onde a nova e agitada atividade pública de Lota vai destruir a antiga paz e confrontá-las com a realidade política do país. Em 1963 a norte-americana vai declarar-se, em carta ao amigo Robert Lowell, "uma pessoa que está paralisada por estar sentindo coisas demais ao mesmo tempo", e concluirá: "dou-me conta de que esta é exatamente a situação em que estou vivendo há mais ou menos dois anos" (p.462).

O Brasil também atravessa, nessa época, um período crítico: o presidente Juscelino Kubitschek inaugura Brasília em abril de 1960, e seu sucessor, Jânio Quadros, renunciará em agosto de 1961, depois de apenas oito meses no cargo. A mensagem de renúncia de Jânio é reproduzida em Brazil, ao lado da carta-testamento de Getúlio Vargas, de 1954, como documentos de nossa história contemporânea, e a posse do vice-presidente João Goulart, após uma crise que se resolveu com a adoção do parlamentarismo, é o último fato político registrado no livro. A industrialização empreendida por Juscelino, a inauguração da nova capital e a busca pela interiorização do desenvolvimento, associadas a uma vertiginosa 
urbanização, vão modificar radicalmente a face do país. Até mesmo a construção do Parque do Flamengo, vivenciada por Bishop, insere-se numa alteração urbana pela qual se constituem "novos locais de socialização ... rearticulando as relações do carioca com a cidade". Esse contexto vai sugerir "uma nova modernidade cujo modelo não é Paris ou Londres, e sim a América do Norte" (Parada, 1994, p.113).

No cenário mundial assiste-se à pior fase da Guerra Fria, com a construção do Muro de Berlim (agosto de 1961), e nas Américas as atenções se voltam para a recém-vitoriosa Revolução Cubana (1959), pois Fidel Castro progressivamente se alinha à União Soviética. Durante a redação do livro, Bishop recebe um telegrama de Nova York no qual os editores perguntam se ela já havia sido comunista, levando-a a incluir este comentário, entre parênteses, em carta à amiga Pearl Kazin: "Algum garoto que trabalha lá deve ter visto um poema meu na Partisan Review, e só de ver o nome da revista eles entraram em pânico" (Bishop, 1995, p.436).

O relacionamento de Elizabeth Bishop com a publicação mais importante da intelectualidade esquerdista norte-americana havia começado muitos anos antes, em 1938, quando os editores aceitaram seu poema "Love lies sleeping" e, pouco depois, ela venceu um concurso promovido pela revista com o conto "In Prison". Em 1939 publicou "Gregorio Valdes, 1879-1939”, reminiscências sobre um pintor primitivista que conhecera na Flórida, e ao longo dos anos surgiriam na Partisan Review outros poemas seus, como "Argument", em 1947. Ela se refere à revista, com a qual nunca perdeu contato, em carta escrita em 1952, pouco depois de sua chegada a Petrópolis: "é engraçado receber a Partisan Review trazida no lombo de um cavalo às vezes - mas também não devo dar a impressão enganosa de que a gente está num lugar muito remoto" (Bishop, 1995, p.255).

Quando, em 1956, a revista lhe ofereceu um auxílio de 2.700 dólares, Bishop comentou em carta: “A bolsa tem ajudado muito, financeiramente. (E acho que eles me deram porque ficaram com pena de mim depois de um 'ataque' que sofri nas suas páginas! Você leu? Não me incomodou muito; a distância endurece o coração.)" (p.345). Em razão da distância, talvez desconheça o que se passa na redação da revista, da mesma forma como continuará a associar, em 1961, a Partisan Review à intelectualidade comunista. Afinal, a verba para sua bolsa de 1956 viera da Fundação Rockefeller, um dos mais importantes meios de distribuição de dinheiro do governo norte-americano aos agentes culturais, durante a Guerra Fria. Numa súbita mudança de atitude, a Fundação passara a apoiar financeiramente a revista: 
O dinheiro [utilizado na bolsa de Bishop] viera da Fundação Rockefeller, ao ritmo de 4 mil dólares anuais, por três anos, para ser distribuído em fellowships literárias. Pode ter sido uma coincidência, mas é curioso que, a despeito das repetidas solicitações de auxílio financeiro, a Fundação Rockefeller havia recusado todos os pedidos dos editores da revista nos dez anos anteriores. (Saunders, 2000, p.337)

Essa afirmação consta no polêmico livro The cultural Cold War: the CIA and the world of arts and letters, da pesquisadora Frances S. Saunders, ${ }^{1}$ extensa investigação sobre a influência governamental norte-americana "no mundo das artes e das letras" ao longo de grande parte do século XX. O livro investiga, por exemplo, a mudança de rumos promovida nas fundações financiadoras de projetos culturais, naquele momento. Pouco após o término da Segunda Guerra Mundial, com a forte polarização política em dois blocos liderados, respectivamente, pelos Estados Unidos e pela União Soviética, o governo norte-americano resolveu atrair os intelectuais de esquerda buscando aproveitar-se de sua influência sobre o restante da sociedade. Um dos focos de análise de Saunders é o Congress for Cultural Freedom, organizado em 1950 e extremamente ativo até a década de 1960, o qual buscava ser visto como "a única organização internacional independente que proclamava o valor da liberdade de forma inequívoca" (Saunders, 2000, p.312). Seus objetivos aparentes, segundo uma publicação do próprio Congresso, seriam "opor-se a um mundo em que tudo serve para fins políticos" criando "plataformas das quais a cultura pudesse ser expressa sem vínculos com a política e sem confusão com propaganda, em que a preocupação imediata se relacionasse às ideias e às obras de arte em si” (p.312).

No campo das artes plásticas, o foco de Saunders recai principalmente sobre Jackson Pollock e o Expressionismo Abstrato: independentemente de suas qualidades, o artista e o movimento só foram aceitos na Europa após a "encomenda" de resenhas positivas na França e a distribuição de verbas entre galeristas e marchands. O curador de uma grande mostra em Paris, em 1952, membro do American Committee for Cultural Freedom, endossava o valor político da exposição ao anunciar a apresentação de "obras-primas que não poderiam ter sido criadas nem exibidas em regimes totalitários como os da Alemanha nazista ou da atual Rússia soviética e seus satélites" (Saunders, 2000, p.268).

\footnotetext{
${ }^{1}$ O livro foi traduzido e recentemente publicado no Brasil como Quem pagou as contas? A CIA na Guerra Fria da cultura (Rio de Janeiro: Record, 2008). Esse título é mais próximo ao da edição inglesa: Who paid the piper? (London: Granta, 1999), associado ao dito "Who pays the piper calls the tune", por vezes citado no Brasil como "Quem paga os músicos dá o tom" ou "define o repertório".
} 
Em entrevista concedida por ocasião do lançamento da edição brasileira de seu livro, em 2008, Frances Saunders sintetizou sua análise:

O que a CIA fez foi infinitamente mais sofisticado do que fizeram os nazistas ou os soviéticos. Não se tratava de armar estratégias para forçar pessoas a seguirem a linha oficial. Desenvolveu uma forma muito sutil de propaganda: o tipo em que as pessoas envolvidas em sua produção, e aquelas envolvidas em seu consumo, sequer sabiam o que é propaganda ... um dispositivo bem inteligente para encorajar a ideia de que os Estados Unidos são o campeão da liberdade, apesar do que esteja acontecendo em seu nome ou sob seus auspícios (o estabelecimento de ditaduras na América Latina, a interferência com esquadrões da morte, tortura etc.). (Simões, 2008)

Nessa mesma entrevista a autora afirma que o melhor retorno foi obtido exatamente "nas áreas dos periódicos e livros. A CIA tinha um programa de publicações e revistas bem abrangente e um bom orçamento - com o qual foi possível atrair algumas das melhores mentes da era pós-guerra e dar a essas pessoas a plataforma para transmitir suas ideias" (Simões, 2008). Seria Elizabeth Bishop uma dessas mentes? A tese exposta no livro de Saunders provocaria, no Brasil, a repetição de críticas observadas quando do lançamento na Inglaterra (1999) e nos Estados Unidos (2000): seu trabalho foi comparado a uma "lista negra ao contrário":

Quem foi financiado pela CIA? Quem sabia que estava sendo financiado? ... Pouca gente resistia, entretanto, a mordomias, bons pagamentos e viagens grátis: Mary McCarthy, Robert Lowell, Hannah Arendt, William Styron são citados entre os que, “sabendo ou não", participaram no mínimo de um ou outro convescote. (Coelho, 2008)

Em 1956, quando recebeu a bolsa proveniente da Fundação Rockefeller repassada pela Partisan Review, Bishop escrevia contos que retratavam episódios de sua infância, vivida no Canadá e nos Estados Unidos, e estava preocupada em finalizar a tradução para o inglês de Minha vida de menina, tendo de negociar com os editores para que ela fosse publicada em seu país. Esperava que o leitor norte-americano se encantasse - como ela própria se encantara com o diário da menina mineira do século XIX, e decepcionou-se com a repercussão modesta entre crítica e público. Envolvida, acima de tudo, com a parte literária desse projeto, censurou em cartas a falta de empenho dos editores e até mesmo o comportamento da autora, Helena 
Morley (pseudônimo de Alice Caldeira Brant), agora uma velha senhora muito rica, interessada unicamente no possível retorno financeiro da edição norte-americana (Bishop, 1995, p.380).

Preocupações com a gratificação pelo trabalho, no entanto, permeiam as cartas de Bishop ao longo de toda a vida, e a chegada de dinheiro é sempre festejada. Em 1958, quando envia à New Yorker seu artigo sobre a viagem a Brasília e ao Xingu, comenta que a publicação do texto - afinal, recusada - permitiria iniciar a construção da garagem em Samambaia (Bishop, 1995, p.389). Na mesma carta, sugere que se faça alguma coisa para que o Ministério das Relações Exteriores do Brasil convide sua amiga Marianne Moore para vir a Brasília e ao Mato Grosso, embora reconheça: "Acho que a nudez dos índios seria demais para ela" (p.389). A Robert Lowell, sugere: "Por que você não arranja uma bolsa Fulbright e vem para cá? ... Querem pessoas conhecidas para vir aqui dar uma conferência, ou mais de uma, nas cidades maiores, e pagam muito bem, e a taxa de câmbio no momento não podia ser melhor” (p.389).

"Apesar de suas reservas em aceitar apoio governamental" (Saunders, 2000, p.347), Lowell virá à América Latina em maio de 1962 com financiamento do Congress for Cultural Freedom, para participar de um encontro literário em Buenos Aires, e permanecerá no Rio por algumas semanas. ${ }^{2}$ Bishop se entusiasma com a vinda do grande amigo, uma vez que o pessoal do Departamento de Estado - equivalente ao nosso Ministério das Relações Exteriores - "comporta-se de maneira tão estúpida e grosseira" e "costuma mandar romancistas e professores enfadonhos e desimportantes" (p.347).

Até mesmo a vinda de Bishop à América do Sul, em 1951, só se havia concretizado graças a uma bolsa concedida pela faculdade Bryn Mawr. Entretanto, em 1966, no período em que pela primeira vez aceitou lecionar em uma universidade - em Seattle, Washington -, a escritora comentou em entrevista que "auxílios [grants], bolsas [fellowships] e ciclos de palestras de leitura [reading-tours] são apenas meios pelos quais o establishment acadêmico subsidia a mediocridade" (Monteiro, 1996, p.37). Se "todos os poetas latino-americanos são diplomatas" (Bishop, 1995, p.707), como disse certa vez em referência a João Cabral, ela própria deixava de ser, nessa época, "o único poeta norte-americano que não dá aulas" (p.487). No final da vida, em 1976, afirmará não conhecer nenhum poeta que se mantenha

\footnotetext{
${ }^{2}$ É justamente em 1962 que encontramos, na correspondência de Bishop a que tivemos acesso, as únicas referências a Nicolas Nabokov, personagem chave do livro de Saunders por sua função como agente cultural da CIA. Em carta a Lowell (5 abr.), ela pergunta: "QUEM custeia o Congress for Cultural Freedom? Eu realmente não estou sabendo de nada, além da Encounter e do Nicolas Nabokov..." (Bishop, 1995, p.444). Em carta posterior (8 out., p.723), refere-se a ele como "Nicolas", indicando, no mínimo, uma boa convivência.
} 
apenas com as publicações, “o que é bom”, pois "ninguém se lança à poesia para ganhar dinheiro" (Monteiro, 1996, p.60). No Brasil, todos são funcionários públicos; em seu país, professores universitários. E completará: "Eu tive sorte. Depois que publiquei meu primeiro livro de poesia, fellowships e outros tipos de auxílio chegaram nos momentos certos" (p.60).

Algumas encomendas, entretanto, exigem contrapartidas penosas - algo que Elizabeth Bishop só iria constatar em 1961, ao ser contratada pelos editores da revista Life. Quando, em agosto de 1958, ela e Lota receberam a visita do escritor norte-americano John dos Passos em Samambaia, souberam que ele estava no Brasil a convite do Itamaraty, com a incumbência de escrever uma matéria para a revista mensal Reader's Digest: “Isto já devia ter nos deixado com o pé atrás - e como nossas opiniões a respeito de Brasília eram violentamente contrárias, o principal tema de conversação tinha de ser evitado" (Bishop, 1995, p.388). Afinal, nessa época ela estava escrevendo por iniciativa própria o artigo que apresentaria à New Yorker, e não enfrentava - nem esperava enfrentar - nenhum constrangimento ao expor suas ideias e opiniões. John dos Passos estaria desfrutando da mesma liberdade? Os motivos que levaram a revista a recusar o ensaio de Bishop poderiam ser discutidos caso a autora tivesse demonstrado alguma revolta e questionado a atitude dos editores, mas ela preferiu considerarse responsável pela negativa. John dos Passos, que escreveu textos jornalísticos sobre a América Latina para diversas publicações norte-americanas, coincidentemente lançaria um livro sobre o país, Brazil on the move, ${ }^{3}$ na mesma época em que a Time Inc. publicou Brazil.

\section{Fazendo algo por seu país}

Em 1961, quando Bishop teve seu nome e seu trabalho associados à revista Life, o convite para a elaboração de Brazil partiu dos editores norte-americanos, mas a escritora estava ávida por contribuir, de alguma maneira, para o governo do presidente Kennedy, o qual logo anunciara o desejo de "uma relação produtiva com os artistas" (Saunders, 2000, p.344). Buscando apagar as marcas deixadas pelo terror do macartismo e pelo relacionamento pouco caloroso no período Eisenhower, Kennedy convidou 156 dos mais importantes artistas e intelectuais, americanos ou não, para a festa de sua posse. Um deles, Robert Lowell, pouco depois escreveria à amiga Elizabeth Bishop confidenciando que, pela primeira vez na vida, "sentia-se um patriota" (Millier, 1993, p.324). O Brasil também vivia, nos meses iniciais do

\footnotetext{
${ }^{3}$ Lançado nos Estados Unidos em 1963, o livro de John dos Passos foi traduzido por Pinheiro de Lemos e publicado em 1964 como O Brasil desperta (Rio de Janeiro: Record, 176p.).
} 
governo Jânio Quadros - empossado simultaneamente a John Kennedy -, muito do entusiasmo que restara dos tempos de Kubitschek, e Bishop percebia todos à sua volta - a começar por Lota, que trabalhava sem remuneração para o governo de Lacerda, na Guanabara - envolvidos em algum projeto importante. "Todos parecem estar encontrando sua verdadeira vocação nestes dias" (p.324), afirmou em carta de abril, e seu comentário incluía até mesmo a vizinha e amiga Mary Stearns Morse, ex-companheira de Lota, que acabava de adotar Mônica, uma garotinha brasileira. Nessa mesma época a escritora perguntou a Lowell se ele poderia mencionar "a alguém na Casa Branca" que ela "gostaria de fazer algo por seu país no Brasil” (p.324). Uma carta enviada a ela por Arthur Schlesinger - conselheiro do presidente Kennedy - em julho de 1961, pedindo "sugestões relacionadas ao envolvimento americano no país”, não passava de um gesto formal, segundo a biógrafa de Bishop, mas a iniciativa da escritora em "aproximar-se da arena política" foi "sem precedentes" (p.324). Em junho surgiu o convite da Time Inc. para que escrevesse o livro sobre o Brasil para sua série relacionada aos países do mundo, e a resposta positiva foi imediata.

Os problemas entre Bishop e os editores também surgiram logo. Em carta de agosto, ela informa à amiga Pearl Kazin:

O editor da Life me escreveu que "você não imagina como me ajuda preparar um esquema antes de começar a redação", e também: "ainda que possa parecer um trabalho cansativo..." (etc. e tal) uma bibliografia dos livros que estou usando "seria uma boa ideia" - ora, faça o favor, vá ensinar padre a rezar missa. Eles são simplesmente INACREDITÁVEIS. A coisa tem muito mais a ver com a fabricação de chantilly a partir de subprodutos de uma fábrica de plásticos do que com literatura ou mesmo com jornalismo. (Bishop, 1995, p.436)

No final de agosto, quando deveria ter escrito cem páginas, ela nem havia iniciado a redação, e a renúncia de Jânio vinha exigir novas considerações sobre a história brasileira contemporânea. Como escrevia muito devagar, Bishop não pôde aproveitar a verba disponível para viagens pelo país. Além disso, viu-se imediatamente em confronto com os editores em torno do que deveria ser incluído no livro: "o interesse de Elizabeth em flora e fauna" contrapunha-se ao dos editores, voltado para "pessoas" e política - "especificamente as circunstâncias relacionadas ao potencial do país para a democracia ao estilo norte-americano" (Millier, 1993, p.325). Sua ida a Nova York, na companhia de Lota, foi postergada de outubro para a primeira semana de novembro, e assim que chegou a escritora pôde constatar que o 
original fora "devastado pelo ataque dos editores da Time Inc., determinados em promover os Estados Unidos e o futuro democrático do Brasil” (p.325).

Millier afirma que as cinco semanas em Nova York foram exaustivas, pois, "pela primeira vez na vida, Elizabeth trabalhava vários dias seguidos sob pressão dos editores" (p.325), e sua aversão pelo livro crescia também por não ter simpatizado com eles. No final, seu único triunfo resumiu-se ao fato de ter finalizado o livro e conseguido "preservar intacta a maior parte dos três primeiros capítulos" (p.326). Ainda em Nova York, Bishop escreveria em carta:

Não deixa de ser uma experiência interessante - mas trabalhar com a Time, a Life etc. - isso nunca mais. Essa gente é inacreditável, e o que eles sabem sobre o Brasil cabe na cabeça de um alfinete - e, no entanto, são de uma audácia, uma arrogância, uma condescendência! Porém - consegui salvar uma parte do texto, e ele diz a verdade, mais ou menos - e algumas das fotos são bonitas - mas podiam ser muito mais. (Bishop, 1995, p.439-440)

De volta ao Brasil no final de dezembro, a escritora continuou discutindo com os editores por cartas e telegramas, na tentativa de recuperar, para o livro, algo do tom original. Afinal, "eles receberam muitas de minhas ideias com entusiasmo, só que não tomaram nenhuma iniciativa" (Bishop, 1995, p.715). Finalizando o embate, Oliver E. Allen, o editor da série, escreveria a ela em 19 de janeiro de 1962: "Nunca antes me senti forçado a tentar provar que eu ou minha equipe éramos honestos ou íntegros ou imparciais, e espero não ter de fazê-lo novamente" (Millier, 1993, p.327). Bishop, por sua vez, afirmou que teria processado a editora, se seu temperamento fosse um pouco diferente (p.327).

Cansada, no final de 1962 a escritora comenta com amigos americanos a dificuldade enfrentada em descrever o país: "houve tantas crises políticas inexplicáveis (para os forasteiros)". E completa: "aliás, a meu ver o Brasil em si é grande e cansativo demais... muito, muito mais complicado do que aquele livro açucarado da Life dá a entender" (Bishop, 1995, p.454).

Três motivos podem ter levado Elizabeth Bishop a essa reação diante dos rumos tomados por seu livro. O primeiro, que nos parece o mais tênue, seria a qualidade de seu próprio texto - escrito às pressas e envolvendo, até mesmo pelas características da encomenda, assuntos que a autora perfeccionista não dominava, alguns dos quais tivera de pesquisar superficialmente (Przybycien, 1993, p.72). O segundo motivo seria a instabilidade 
emocional de Bishop, sempre insegura e indecisa diante da possibilidade de receber críticas talvez justas. Regina Przybycien (1993), Brett Millier (1993) e Carmen Oliveira (1995) apontam a crescente e perniciosa influência das crises associadas ao consumo de álcool nos relacionamentos de Bishop com amigos e editores. Durante os períodos de depressão, o afastamento era quase inevitável. ${ }^{4}$ No final de 1961, todavia, a escritora ainda estava sob o efeito positivo dos anos de tranquilidade e estabilidade emocional vividos em Petrópolis na companhia de Lota, e talvez julgasse as crises de insegurança - e de alcoolismo - superadas para sempre.

O terceiro motivo parece ser o mais consistente. É possível que, diante do livro finalizado, a escritora tenha afinal se dado conta do projeto a que emprestara seu nome: a editora não era uma empresa jornalística qualquer, mas um dos mais importantes porta-vozes da ideologia norte-americana ao longo do século XX, especialmente durante a Guerra Fria. Para Henry Luce, proprietário da Time Inc., "a Guerra Fria era uma guerra santa", em que a editora estava comprometida com o objetivo principal de "vencer o comunismo por todo o mundo" (Saunders, 2000, p.281). ${ }^{5}$ Estaria ela preocupada com a opinião dos amigos, ou da intelectualidade nova-iorquina em geral, a seu respeito? Teria sido alertada - ou questionada por algum deles?

O cuidado de amigos e editores em não associar Elizabeth Bishop a publicações ou ideias de direita seria duradouro. Segundo Paulo Henriques Britto, tradutor de Bishop, é por causa dessa preocupação que as cartas escritas imediatamente após o golpe de 1964, nas quais ela se mostrava totalmente favorável aos militares, não foram incluídas na edição original (1994) da correspondência, 15 anos após sua morte, e quase ficaram de fora da edição brasileira (1995), também. Britto informa que o organizador, Robert Giroux, amigo e editor de Bishop, relutava em permitir a inclusão dessas cartas, preocupado com a imagem da escritora "entre a intelectualidade de esquerda norte-americana". 6

\footnotetext{
${ }^{4}$ Nos seus últimos tempos no Brasil, a autora processaria até mesmo alguns amigos, entre os quais Lilli Correia de Araújo, responsável por administrar a restauração de sua casa em Ouro Preto. Em carta de agosto de 1970, Bishop comenta: "Teve uma cena muito engraçada ... com a Lilli ... Os olhos dela se encheram de lágrimas e ela disse: 'Mas você está me processando'. E eu disse: 'Estou, sim', provavelmente com os olhos cheios de lágrimas também” (Bishop, 1995, p.597).

${ }^{5}$ Num episódio paradigmático, a revista Life publicara em abril de 1949 um conjunto de cinquenta fotografias de artistas, cientistas e intelectuais suspeitos de envolvimento com o comunismo, "prefigurando as listas negras do senador McCarthy" (p.52). A lista, supervisionada pelo próprio Luce, denunciava músicos (Leonard Bernstein e Aaron Copland), cientistas (Albert Einstein), arquitetos (Frank Lloyd Wright) e artistas (Marlon Brando e Charles Chaplin), por exemplo. Tratava-se da mesma revista que, em 1943, na pior fase da Segunda Guerra Mundial, "dedicara um número inteiro à União Soviética, com Stalin na capa, glorificando o povo russo e o Exército Vermelho" (Saunders, 2000, p.52), mas no pós-guerra adotou prontamente outra postura.

${ }^{6}$ Paulo Henriques Britto, em e-mail de 14 jan. 2003.
} 
Essas reservas, entretanto, talvez fossem inúteis. Para Beatriz Jaguaribe, poucos de sua geração "tiveram uma perspectiva tão conservadora do que deveria ser a atuação americana nas periferias do mundo", ou "possuíam uma postura tão defensiva em relação às críticas dirigidas por setores de esquerda aos Estados Unidos" (1998, p.104). Assim, o posicionamento de Bishop no Brasil poderia ser atribuído só até certo ponto ao “conservadorismo político americano de um modo geral" (p.103). Sua neutralidade confessa revela, no mínimo, certa incompreensão de um quadro que articulava cultura e política.

\section{Um livro, uma série}

Brazil é muito semelhante aos demais livros dessa série lançada nos primeiros anos da década de $1960 .^{7}$ Os autores são jornalistas, historiadores e escritores de alguma forma vinculados aos países sobre os quais escreveram: o historiador britânico Hugh Thomas escreveu sobre a Espanha, principal objeto de seus estudos; Alexander Eliot, editor de arte na Time (1945-1960), escreveu sobre a Grécia. O autor do livro sobre As Repúblicas Platinas (Argentina, Paraguai e Uruguai), J. Halcro Ferguson, trabalhou na embaixada britânica em Buenos Aires durante a Segunda Guerra Mundial, foi correspondente latino-americano do semanário britânico Observer por mais de uma década (desde 1948), e já havia escrito vários livros sobre o continente quando recebeu o convite. Edward Sedensticker, que escreveu sobre o Japão - o único livro da série comentado por Elizabeth Bishop em suas cartas ${ }^{8}$-, viveu no país por mais de uma década e traduziu para o inglês diversas obras literárias japonesas, tendo lecionado na Universidade de Tóquio. Ao comentar o livro de Sedensticker, ela não está preocupada com seu viés ideológico ou com suas qualidades literárias, busca apenas aproveitar o que lhe pareceu uma boa ideia complementar ao texto: a inclusão de um quadro sobre a pronúncia da língua japonesa. Quanto à interferência da Time-Life no trabalho dos autores, os quatro livros aqui citados saíram sob coautoria "com os editores de Life", como aconteceu no caso de Bishop, mas em vários outros tal expediente não foi necessário.

\footnotetext{
${ }^{7}$ A série contém 32 livros (complementados por um Atlas Mundial e por uma listagem de Países e Organizações Internacionais): África Tropical; África do Sul; Alemanha; América Central; Austrália e Nova Zelândia; Bálcãs; Brasil; Canadá; China; Colômbia, Venezuela e Guianas; Escandinávia; Espanha; Estados Unidos; Europa Oriental; França; Grã-Bretanha; Grécia; Índia; Índias Ocidentais; Irlanda; Israel; Itália; Japão; México; Mundo Árabe; Países Andinos; Países Baixos; Países Platinos; Rússia; Sudeste da Ásia; Suíça; Turquia.

${ }^{8}$ Ao menos na correspondência publicada em One Art (1994) e Uma arte (1995), e nas cartas inéditas a que tivemos acesso nos arquivos da autora (Vassar College, Special Collections).
} 
Ao lado de capítulos que descrevem a geografia, a formação histórica e a herança artística e cultural dos países, invariavelmente surgem nos livros da série World Library relatos superficiais sobre fatos da história contemporânea; o texto e as imagens se aproximam, então, do estilo jornalístico da revista Life. O Japão do pós-guerra ocupa grande parte do livro de Sedensticker, e os textos, que destacam "transição" e "crescimento", vêm acompanhados por fotos de jovens em roupas e atitudes ocidentais, "em busca de uma nova identidade", como afirma um subtítulo. A imagem chocante e emblemática da morte de um político moderado, atacado por "um jovem fanático", 9 é um forte exemplo do estilo jornalístico da Life. Também o livro sobre as Repúblicas Platinas passa da descrição geográfica e histórica à narração da "busca pela ordem" e pelas "novas lealdades", frases que aparecem até mesmo em títulos de capítulos. Na face jornalística do livro, uma das ilustrações mais contundentes apresenta a queima de documentos nas ruas de Buenos Aires, promovida por "uma multidão de classe média" durante a queda de Perón, em $1955 .{ }^{10}$ Consta na legenda, também, que o expresidente conseguiu fugir "com 50 milhões de dólares".

No capítulo sobre história contemporânea em Brazil, Getúlio Vargas, o "demagogo hábil" - como consta na legenda -, aparece em foto da década de $1930 .{ }^{11}$ Representa um país antiquado e tão imóvel quanto o homem retratado, e poderia estar no capítulo dedicado ao século XIX, ao lado de Pedro II. Não parece ser o líder que se aliou a Roosevelt durante a Segunda Guerra Mundial e promoveu mudanças substanciais no país. Juscelino Kubitschek também está imóvel e plácido, e é associado, na legenda, à herança varguista e não ao surto desenvolvimentista e à construção de Brasília. Já a agitação da política atual surge, por exemplo, no contraponto entre um jovem e dinâmico Carlos Lacerda, "que sempre combateu elementos esquerdistas", ${ }^{12}$ em sua mesa de trabalho, com papel e caneta nas mãos, e a imagem de uma manifestação a favor de Fidel Castro em Recife, organizada pela Liga Camponesa e animada por oradores "anti-EUA". ${ }^{13}$

Se a publicação de Brazil reforçava, como percebeu sua autora, as ideias preconcebidas de editores e leitores da revista Life, serviria apenas como documento dessas ideias. E exatamente por isso já mereceria atenção. Para Helouise Costa (1992), a chave do sucesso da revista encontrava-se "na amplitude do seu projeto editorial, traduzido poeticamente no primeiro exemplar" (p.65) e aqui transcrito:

\footnotetext{
${ }^{9}$ Ver Figura 5.

${ }^{10}$ Ver Figura 6.

${ }^{11}$ Ver Figura 7.

${ }^{12}$ O livro ignora o passado comunista de Lacerda (cf. Wainer, 1988, p.70-74).

${ }^{13}$ Ver Figura 8.
} 
Para ver a vida, para ver o mundo, ser testemunha ocular dos grandes acontecimentos, observar o rosto dos pobres e os gestos dos orgulhosos, para ver coisas estranhas - máquinas, exércitos, multidões, sombras na selva e na lua; para ver o trabalho do homem - suas pinturas, torres e descobrimentos; para ver coisas acontecidas a milhares de quilômetros, coisas ocultas por trás das paredes e dentro das casas, coisas perigosas, as mulheres amadas pelos homens e muitas crianças; para ver e ter prazer em ver, para ver e surpreender-se, para ver e instruir-se. ${ }^{14}$

Helouise Costa percebe, aí, uma reedição do "projeto oitocentista de inventariamento do mundo" (1992, p.65), mas com uma diferença fundamental: "mais do que registrar a vida em seus múltiplos aspectos, intenciona-se ensinar uma nova maneira de ver" (p.65). Se o material das revistas ilustradas "não é a notícia, mas a atualidade, num sentido mais amplo" (p.54), a própria Time-Life iria sistematizar seu método de trabalho na confecção das fotorreportagens:

$\mathrm{O}$ assunto pode ser qualquer coisa - uma ideia, uma pessoa, um evento, um lugar. A organização pode ser tanto cronológica quanto temática; essas coisas não importam, já que a forma em si é flexível. O que importa é que as imagens trabalhem juntas para enriquecer o tema ... Para que uma fotorreportagem tenha êxito, o todo tem que ser mais importante do que a soma de suas partes. ${ }^{15}$

Quando a editora norte-americana passa a empregar a técnica da fotorreportagem na confecção de livros, recorrendo quase sempre ao banco de imagens da revista, os temas são realmente variados. Na mesma época em que surgiu a coleção World Library, ${ }^{16}$ a editora publicou, por exemplo, um livro relacionado à Segunda Guerra Mundial (coautoria do exprimeiro ministro britânico Winston Churchill) e um ensaio sobre $O$ mundo em que vivemos (coautoria do escritor Lincoln Barnett). ${ }^{17}$

Segundo Helouise Costa, os temas das revistas ilustradas são passíveis de uma sistematização em cinco categorias: Artes e literatura; Natureza, paisagem e aventuras;

\footnotetext{
${ }^{14}$ Esse trecho do editorial (Life, 23 nov. 1936) encontra-se traduzido em Costa (1992, p.65).

${ }_{15}^{15}$ A definição consta em Photojournalism, da Time-Life (p.32), e a tradução é de Costa (1992, p.67-68).

${ }^{16}$ A World Library foi um dos primeiros projetos dos editores na área de livros, uma vez que essa divisão da Time Inc. surgiu em 1961.

${ }^{17}$ Mais recentemente, as obras em seu catálogo focalizaram desde paisagens fantásticas (Heaven on Earth: 100 places to see in your lifetime) e cenários bíblicos (Places of the Bible) até os ataques terroristas de 11 de setembro de 2001 (One Nation).
} 
Personalidades e nobreza; Ciência; Esportes. ${ }^{18}$ Os sumários da coleção World Library permitem comprovar uma classificação semelhante, excetuando-se apenas o destaque ao item "Ciência" nos livros que focalizam países menos desenvolvidos. Em Brazil, a sistematização dos "assuntos" está explícita numa indicação de "leituras posteriores", espécie de listagem "para saber mais", apresentada no final do livro (p.153-154): povo (capítulo 1), geografia e história (capítulos 2 a 4), economia (capítulo 5), artes (capítulos 6 e 7), indivíduos e grupos (capítulo 8) e política recente (capítulos 9 e 10). ${ }^{19}$

\section{De 1962 a 1970}

Embora Elizabeth Bishop não tenha participado das edições posteriores de Brazil, seu nome não foi eliminado do livro. Na última edição, de 1970, há alterações substanciais na parte que se refere a Brasília - embora nenhuma das fotos correspondentes tenha sido substituída ou atualizada - e nas seções relacionadas à política recente: todo o capítulo 10 foi reescrito, mas o título se manteve, e no capítulo 9, renomeado como "Militarismo versus democracia", dois longos trechos foram substituídos. Na parte iconográfica, as alterações fundamentais ocorreram exatamente nos dois últimos capítulos. Personagens importantes desaparecem (Lacerda e Juscelino dão lugar a Castelo Branco, Costa e Silva e Médici), e o foco também se adapta aos novos tempos: o flagrante de uma seção eleitoral, em página dupla, ${ }^{20}$ é substituído pelo canteiro de obras da rodovia Belém-Brasília, ${ }^{21}$ numa contundente adequação aos tempos do regime militar. O velho bonde é substituído pelo ônibus, no Rio de Janeiro, ${ }^{22}$ mas as filas, comentadas pela autora no final do livro, continuam iguais. A foto de São Paulo - criticada por Bishop em carta (1995, p.715) - foi substituída, e o público que comparece ao Grande Prêmio Brasil atualiza-se. ${ }^{23} \mathrm{O}$ confronto entre estas duas imagens expressa algumas das mudanças comportamentais ocorridas naquela década.

Nos capítulos relacionados às artes, quase nada mudou na edição de 1970: apenas se atualizaram as referências às personalidades já mortas. É importante notar que, nas duas edições, o único filme que merece destaque é Orfeu negro (1959), ${ }^{24}$ pela associação a

\footnotetext{
${ }_{18}$ A autora aceita e segue uma classificação proposta anteriormente, no Brasil, por Muniz Sodré.

${ }^{19}$ No Quadro 2 confrontamos esse esquema aos títulos - originais e publicados - dos capítulos.

${ }^{20}$ Ver Figura 9.

${ }^{21}$ Ver Figura 10.

${ }^{22}$ Ver Figuras 11 e 12.

${ }^{23}$ Ver Figuras 13 e 14.

${ }^{24}$ A autora reprova a utilização de um still desse filme para ilustrar o carnaval carioca (Figura 16).
} 
Vinícius de Morais. Ainda em 1970 ele é apresentado como "o mais conhecido da série de filmes recentes que trouxeram renome internacional para os realizadores brasileiros" (capítulo 7). Seu diretor, entretanto, é o francês Marcel Camus, e a produção é francesa, brasileira e italiana. A edição de 1970 deixa de citar, por exemplo, o Pagador de promessas (1962), de Anselmo Duarte, Palma de Ouro em Cannes, bem como Deus e o Diabo na terra do sol (1963) e $O$ dragão da maldade contra o santo guerreiro (1968), filmes que renderam a Glauber Rocha o prêmio de melhor diretor em Cannes. O Cinema Novo, portanto, não é nem citado.

A indicação bibliográfica “for further reading”, no final do livro (p.153-154), sofreu alterações importantes. Dos 86 títulos que constavam em 1962, 50 foram eliminados na edição de 1970, vários deles leituras características de Bishop: ${ }^{25}$ obras dos historiadores brasileiros Rocha Pombo (História do Brasil), Octavio Tarquinio de Souza (A vida de D. Pedro I) e Sérgio Buarque de Holanda (História do Brasil, em parceria com Souza), todas em português; o relato do naturalista Charles Darwin (The voyage of the Beagle), admirado por ela; dois guias de viagem (Nagel Travel Guide, 1955, e New World Guides to the Latin American Republics, 1950) e um livro sobre arquitetura, citado em seus textos (Henry-Russell Hitchcock, Latin American Architecture Since 1945). Três romances de Machado de Assis (Memórias póstumas de Brás Cubas, Dom Casmurro e Quincas Borba), em português, foram eliminados, embora tenham permanecido como destaques literários, em outro apêndice do livro. $^{26}$

Note-se que a necessidade de constante "atualização" de uma obra de gênero jornalístico poderia justificar ao menos algumas das substituições efetuadas na bibliografia de Brazil: das 56 obras incluídas na última edição (1970), 49 foram publicadas entre 1960 e 1970. Passaram a constar as edições em inglês de Quarto de despejo, de Carolina Maria de Jesus, ${ }^{27}$ e de Quarup, de Antônio Callado. Brasil, land of the future (1941), de Stefan Zweig, foi substituído por Brazil on the move (1963), de John dos Passos. Entre as análises sociológicas, políticas e econômicas incluíram-se edições em inglês que abrangem um conjunto surpreendentemente amplo: Roberto Campos (Reflections on Latin American

\footnotetext{
${ }^{25}$ Essa lista coincide, em grande parte, com a página de "Books I have used - in English", que consta entre as notas e rascunhos para a elaboração de Brazil (Vassar College, Special Collections).

${ }^{26}$ No Apêndice "Figuras importantes da cultura brasileira e suas obras principais", dois amigos de Bishop foram eliminados na edição de 1970 (os arquitetos Henrique Mindlin e Sergio Bernardes), e houve apenas três inclusões: Bruno Giorgi, Mário Cravo e Dias Gomes. Houve a substituição dos títulos originais de algumas obras literárias pelos das versões em língua inglesa (publicadas, aliás, na década de 1960). Note-se que $O s$ sertões, de Euclides de Cunha, antes definido como obra de "Sociologia", recebeu o título em inglês mas ganhou a rubrica de "Diários".

${ }^{27}$ Nas notas para Brazil (Vassar College, Special Collections) consta o lembrete para incluir o livro de Carolina, "if translated".
} 
Development), Caio Prado Jr. (The Colonial Background of Modern Brazil), Josué de Castro (Death in the Northeast), Celso Furtado (The Economic Growth of Brazil; Development and Underdevelopment; Diagnosis of the Brazilian Crisis), Octavio Ianni (Crisis in Brazil), Florestan Fernandes (The Negro in Brazilian Society), João Cruz Costa (A history of ideas in Brazil) e Gilberto Freyre (foram incluídos The Mansions and the Shanties e Order and Progress; já constava a edição norte-americana de Casa-grande \& senzala). Entre os estrangeiros, incluíram-se obras de Thomas Skidmore (Politics in Brazil: 1930-1964), Warren Dean (The Industrialization of São Paulo, 1880-1945) e June Hahner (Civilian-Military relations in Brazil, 1889-1898), por exemplo.

Embora o livro Brazil tenha feito parte de um projeto mais extenso da Time-Life, foi praticamente ignorado em nosso país. Em certo sentido, as previsões da autora “provavelmente ninguém nunca vai ler o livro, mesmo!” (Bishop, 1995, p.712) - se concretizaram, embora ela reconhecesse que o Brasil estava "muito precisado de publicidade bem-intencionada a esta altura dos acontecimentos (o governador [Lacerda] encomendou dezenas de exemplares para distribuir)": "como a Lota sempre diz, a maioria dos milhões de 'leitores' nem vai ler ... e, de qualquer modo, meu nome não significa nada para a maioria dos 'leitores"” (p.443). Os comentários dos amigos brasileiros concentravam-se nas fotos, e dos norte-americanos ela só recebeu elogios. Os créditos, nestes casos, eram rapidamente transferidos: "Não me elogie por comparar o Rio a 'dedos' - quem disse isso foi a Rachel de Queirós" (p.715). ${ }^{28}$ Quanto à repercussão nos jornais, "aqui têm saído diariamente manchetes sobre a introdução do [ex-embaixador] Cabot, 'valores espirituais' etc. e tal. Pois eu tenho o texto original da introdução que ele escreveu, e não contém uma palavra sequer da que aparece no livro..." (p.443).

Se, na década de 1960, o que atraía atenção e críticas no plano econômico era a ajuda financeira norte-americana mediada pela Aliança para o Progresso ${ }^{29}$ - da qual Carlos Lacerda era grande beneficiário, no estado da Guanabara -, no campo jornalístico e editorial o grande fenômeno norte-americano no Brasil era a revista mensal Seleções do Reader's Digest, cujo

\footnotetext{
${ }^{28}$ Note-se que Stefan Zweig, em seus diários de 1936, havia feito comparação semelhante, mas para ele os morros, e não a cidade, é que faziam o papel de dedos: "a cidade sempre recomeçada, sempre interrompida pelos promontórios que, como os dedos da mão, avançam...” (1986, p.264).

${ }^{29}$ Criada pelo presidente Kennedy em 1961, a Aliança para o Progresso foi um programa de ajuda econômica e social dos Estados Unidos para a América Latina. Buscava servir como alternativa ao comunismo e à recente revolução cubana e deveria durar dez anos, mas foi extinta pelo presidente Nixon no final da década, quando a atenção norte-americana concentrou-se no Vietnã. Hans Magnus Enzensberger (1985, p.265) afirma que "Não há colonização pacífica ... Cada 'Aliança para o Progresso' precisa de seus gorilas, cada 'penetração pacífica' depende de um comando de bombardeiros...".
} 
apogeu durou até meados da década de $1960 .^{30}$ Como relembra Maria Ligia Coelho Prado, leitora "voraz e ingênua" de Seleções nos anos 50, "tinha-se a falsa impressão de estar 'atualizado' ao acompanhar temas complexos sobre ciência, medicina ou política, apresentados superficialmente, mas recheados de exemplos comovedores”. A conscientização, para ela, viria muito depois:

Relendo alguns destes artigos, pergunta-se como foi possível que as ideias veiculadas naquelas matérias tivessem sido aceitas sem maiores críticas. Sem dúvida, essa postura dizia muito da própria formação conservadora da classe média brasileira dos anos 40 e 50. Junto com as "inofensivas" matérias, reforçava-se uma visão de mundo que pregava o american way of life como paradigma universal, que idolatrava o individualismo e a "saudável" competição entre os indivíduos e que pensava a América Latina como o lugar do atraso. ${ }^{31}$

Na análise de Mary Anne Junqueira, a revista Seleções, que chegou a ser considerada “a mais confiável do país" (2000, p.272) em 1950, segundo pesquisa do Ibope, aglutinava na América Latina as ideias de Oeste, wilderness e fronteira, palavras que "possuem sentidos sobrepostos, imbricados" (p.68). ${ }^{32}$ Esse novo Oeste, não mais guiado pela bússola, localizavase "ao sul do Rio Grande", a fronteira com o México. Sob a denominação de wilderness apareciam "a floresta tropical latino-americana e os países que fazem parte do complexo amazônico" (p.54). Quanto à "fronteira”, no século XIX "era a linha imaginária que separava o mundo civilizado do wilderness" (p.69), e ainda hoje faz parte da "mitologia popular nos Estados Unidos" (p.71), pois o conceito foi adaptado com sucesso às necessidades de uma república industrial. A alternativa proposta pela revista Seleções como "solução para exterminar os males latino-americanos estava baseada naquilo que imaginavam ter sido a grande experiência norte-americana: o domínio e transformação dos territórios selvagens, o confinamento dos índios e a construção de uma classe média tanto urbana quanto rural" (p.275). ${ }^{33}$ Junqueira conclui sua análise afirmando que, se "a leitura de Seleções nos informa

\footnotetext{
${ }^{30}$ Lançada em 1942, a versão em língua portuguesa de Seleções atingiu enorme sucesso especialmente na década de 1950 e primeira metade dos anos 60. Em 1970, seus escritórios mudaram-se do Brasil para Portugal. A revista existe ainda hoje, "mas perdeu as suas características originais e parte do seu público leitor" (Junqueira, 2000, p.9).

${ }^{31}$ Os comentários de Maria Ligia Coelho Prado estão na apresentação de Junqueira, 2000 (p.3).

${ }^{32} \mathrm{Na}$ revista Seleções, o termo wilderness permanecia às vezes em inglês. Quando traduzido para o português, tornava-se "selva" ou "sertão". Na edição em espanhol, surgia como desierto ou yermo. Ver exemplos e comentários em Junqueira (2000, p.55-64).

${ }^{33}$ Lembremos que Elizabeth Bishop critica, tanto em Brazil como em suas cartas, a ausência de uma classe média forte em nosso país.
} 
muito sobre o imaginário norte-americano ... nos revela particularidades sobre o imaginário brasileiro", sem as quais "teria sido impossível a realização de um dos maiores sucessos editoriais de todos os tempos" (p.277).

Quanto à Time-Life no Brasil, seus problemas surgiriam exatamente em meados da década de 1960, mas associados a um projeto muito mais abrangente, o de parceria no estabelecimento e consolidação da Rede Globo de Televisão. Essa parceria foi criticada pelos concorrentes da Globo, especialmente pelo empresário Assis Chateaubriand - proprietário dos Diários Associados, da revista $O$ Cruzeiro e da Rede Tupi de Televisão -, que se considerava prejudicado por ela. Chateaubriand via nesse projeto "uma conspiração, patrocinada pelo capital privado norte-americano, que pretendia dominar a opinião pública brasileira, via controle dos meios nacionais de comunicação de massa" (Polacow, 2000, p.180). Para esse empresário, "o plano era antes acabar com a concorrência, iniciando pelas revistas, para depois entrar fortalecido na disputa pela hegemonia no ramo da televisão" (p.180). Como resultado,

Os antigos grupos deram lugar a outros, como a Globo, infinitamente mais identificados com a modernização e com os interesses políticos dos militares (que passaram as próximas décadas comandando, entre outros aspectos da sociedade brasileira, tudo o que se relacionava com produção cultural nos grandes meios, através da censura - do entretenimento à informação). (Polacow, 2000, p.184)

A decadência do império de Chateaubriand ocorreu simultaneamente à expansão da Rede Globo (de Roberto Marinho) e da Editora Abril (da família Civita), "que também se supunha operar em parceria com o grupo Time-Life" (p.180), no apogeu da ditadura militar. ${ }^{34}$ Obviamente, esse tipo de envolvimento seria considerado muito mais importante, em nosso país, que a publicação de um livro como Brazil, em inglês, numa coleção que englobava todos os países do mundo e que era voltada principalmente ao norte-americano médio.

\footnotetext{
34 A nova versão da série "Países do mundo", da Time-Life, lançada na década de 1980, seria traduzida e publicada no Brasil em parceria com a editora Abril, em 1992.
} 


\section{Esquematizando o Brasil}

Não se sabe se os editores da Time-Life chegaram a impor algum esquema ou diretriz para a redação de Brazil, mas Bishop consultou livros da série - a referência ao do Japão consta nos seus originais - e seguiu sua linha geral. No final do livro, como nos demais, consta em Apêndice uma indicação bibliográfica em que os capítulos vêm indicados não por seus títulos, mas pelo "Assunto": geografia, economia, artes etc. No Quadro 2 confronta-se esse "Assunto" aos títulos (originais e publicados) dos dez capítulos, bem como ao "Sumário" datilografado pela autora e preservado nos seus arquivos. ${ }^{35}$

As alterações nos títulos merecem atenção. O capítulo 1, por exemplo, chamava-se "Paradoxos e ironias", mas a própria autora o transformou em "Miscelânea de paradoxos", talvez para evitar a conotação negativa. No livro publicado, entretanto, o título transformou-se em "Um povo caloroso e sensato", ao estilo da Life. O Sumário de três linhas apresentado pela autora foi seguido na redação desse capítulo, embora ela tenha eliminado a palavra “contradições” sem propor substituta. Dos itens listados nesse Sumário, apenas o "sentimento de inferioridade nacional" não consta explicitamente no original apresentado aos editores, nem no livro publicado.

Nos outros capítulos o Sumário também foi, quase sempre, seguido. Percebe-se seu caráter de rascunho pela lacuna na data de transferência da capital, de Salvador para o Rio de Janeiro (capítulo 4). E um erro aí presente não foi corrigido mesmo no último original: Bishop chama João VI de João I (capítulo 3), como se ele tivesse sido imperador do Brasil, e não de um Reino Unido.

Observe-se que a autora pretendia apontar, em seu livro, um vínculo entre Pedro II, “o mestre-escola da nação" (capítulo 3), e o presidente Jânio Quadros: "novamente o "mestreescola da nação'?" (capítulo 10). Bishop conhecia a anedota segundo a qual Pedro II respondeu, certa vez, que gostaria de ser "mestre-escola", caso não fosse Imperador. Essa é uma das características que ela admirava na personalidade do governante, ${ }^{36}$ embora não questione, no livro, o fato de que ele pouco fez pelo sistema educacional do país. Quanto a Jânio, Bishop o vê sob a imagem propagandeada de professor, embora mantenha uma interrogação cautelosa.

\footnotetext{
${ }^{35}$ Ver Figura 17.

${ }^{36}$ Havia um retrato de Pedro II na sala do apartamento de Bishop em Boston, em meio às fotos de seus amigos, como Robert Lowell e Marianne Moore. Ela gostava de mostrar a foto do imperador aos brasileiros, que em geral não o reconheciam (Monteiro, 1996, p.114).
} 
Note-se que no Sumário que abarca mais de quatro séculos de história apenas seis personagens políticas são nomeadas: João VI, Pedro I e Pedro II, no século XIX, e Getúlio Vargas, Juscelino Kubitschek e Jânio Quadros, no século XX. O vínculo une o Imperador e o presidente recém-eleito, que representa "a oposição no poder". Jânio vinha substituir Kubitschek, descrito por Bishop em suas cartas como herdeiro de Vargas e símbolo da corrupção no país. Até Brasília, a grande realização de Kubitschek, aparece aí associada a "problemas", e as suspeitas preliminares da autora seriam explicitadas na redação do capítulo: ela teme o tipo de político - certamente aventureiro - que seria atraído pela nova capital. $\mathrm{O}$ Sumário foi redigido em meados de 1961, antes, portanto, da renúncia de Jânio, quando Bishop e seus amigos, entre os quais se incluía o udenista Carlos Lacerda, ainda acreditavam nas promessas do recém-empossado, de "varrer a corrupção do país". O título do capítulo 10, “Uma nova esperança”, foi cortado pela autora, provavelmente logo após a renúncia de Jânio, e permaneceu em branco no original entregue aos editores.

Fora do campo da política institucional, no Sumário constam apenas quatro nomes sobre os quais a autora pretendia escrever: Portinari, amigo e ex-professor de Lota; Villas Boas (Bishop admirava os irmãos sertanistas e conheceu Claudio em sua viagem a Mato Grosso, em 1958); o marechal Rondon, mentor dos Villas Boas, também admirado por ela; e Santos Dumont, o único que não aparecerá no livro - embora seu nome conste não só nesse Sumário como também nos originais da autora, num lembrete para elaboração de texto.

A ausência de Santos Dumont merece atenção. No final do capítulo 8, lê-se nos originais: "Em apenas uma coisa o Brasil insiste firmemente, como a Rússia, em que realmente foi o primeiro, é na invenção do avião. [Santos Dumont aqui?]”. Bishop referiu-se algumas vezes a Santos Dumont com ironia, como numa carta de 1970 - "ele descobriu" o avião, segundo o pessoal daqui, caso você não saiba". E completou essa carta com um recado: se vier ao Brasil, "não vá falar nos irmãos Wright" (Bishop, 1995, p.584). Não se sabe por que o inventor não consta no livro publicado, apesar da intenção da autora em citá-lo, mas, por mais ingênua que pareça esta hipótese, é possível ter havido, entre os editores, a contrapartida à atitude brasileira: algo como "não vá falar em Santos Dumont” para o público norte-americano. Lembremos, por exemplo, a negativa da Time-Life em aceitar a existência, no Brasil, de cataratas mais exuberantes que Niágara (capítulo 3).

\footnotetext{
37 O tradutor das cartas, Paulo Henriques Britto, inseriu um sic ao perceber o uso inadequado do termo "descobriu" (discovered). Considerando o cuidado da autora na escolha das palavras, é possível supor que ela estivesse ironizando o termo usado por seus amigos brasileiros quando se referiam à invenção de Santos Dumont. Em inglês, a carta consta em Bishop, 1994, p.521.
} 
No capítulo 8, relacionado a "Grupos e indivíduos", Bishop pretendia escrever sobre "heróis populares" e chegou a nomear alguns deles: "O Diamante Negro, Pelé, a história de Carolina Jesus aqui. Os campeões de basquete de 1958. Maria Ester. Bruno Hermanny". A autora reúne, portanto, alguns nomes ligados ao esporte: os jogadores de futebol Leônidas (o "Diamante Negro") e Pelé, a tenista Maria Esther Bueno e o nadador Bruno Hermanny. Notese que, na realidade, os brasileiros foram campeões no futebol em 1958, e no basquete em 1959. Note-se, também, que ela aproveita para incluir Carolina Maria de Jesus, a autora de Quarto de despejo (1960), logo após os heróis negros do futebol. Nenhum desses "heróis" consta no texto publicado, e o livro da favelada paulistana, grande sucesso editorial no início da década de 1960, não consta nem mesmo nos trechos relacionados às artes (capítulos 6 e 7), embora a admiração por ela apareça também nas cartas de Bishop: “Gostei destas frases de uma [escritora] 'primitiva' brasileira, Carolina de Jesus: 'Ele é um repórter poliglota. Ele conhece os continentes'. Quero usá-las" (Bishop, 1995, p.724). A norte-americana copia as frases de Carolina com o mesmo cuidado dispensado às expressões populares, buscando a melhor maneira de vertê-las para o inglês e explicá-las aos amigos, ou mesmo utilizá-las em seus poemas: "casa de botão" (p.248), "olho d'água" (p.504) e "não presta” (p.570), por exemplo. Não existe, aí, a ironia com que repete, no final de uma carta, "a expressão que os pobres sempre usam aqui: 'Desculpe qualquer coisa'” (p.606).

Como se vê no Sumário, Bishop pretendia escrever, também, sobre os "tipos" brasileiros. Mas, da listagem inicialmente proposta, apenas o cangaceiro, generalizado como vaqueiro, receberá uma descrição detalhada sob o tema da "civilização do couro" (capítulo 6). Os bandeirantes, "enérgicos, cruéis e vorazes", são vistos sob os parâmetros da história oficial, associados ao "espírito de deslocamento" paulista - como anunciado no Sumário - e responsáveis por tornar "o jovem país consciente de sua extensão incomparável e de sua geografia impeditiva" (capítulo 2). O garimpeiro não será citado no livro, e o gaúcho aparecerá brevemente, na análise dos pampas e como qualificativo de Getúlio Vargas. ${ }^{38}$ Os baianos não serão descritos pela aparência, mas por um orgulho forte e contraditório: de uma perspectiva carioca, a autora apontará os "grandes contingentes de baianos que todos os anos se deslocam para o sul", embora a Bahia é que seja, para eles, a "terra boa”. Já a baiana será descrita pela sua roupa, “considerada 'tipicamente brasileira' (embora não o seja)”. A autora afirma que "nos concursos de beleza ou nos bailes a fantasia, sempre que uma brasileira quer aparecer 'caracterizada', veste-se à la baiana" (capítulo 4) - mas todo este último comentário desapareceu no texto publicado.

\footnotetext{
${ }^{38}$ Nas sugestões de fotografias para o livro, ela propõe Vargas "vestido como gaúcho".
} 
Uma de suas considerações generalizantes sobre a dieta brasileira também foi eliminada pelos editores: "A importância da nutrição no Brasil percebe-se no fato de que quanto mais rica e velha a família, as pessoas são mais altas e com ossos maiores. Às vezes, seus empregados domésticos do 'norte' ou do 'interior' parecem quase anões ao lado delas" (capítulo 8). A "cuisine do norte, em que se misturam pratos indígenas, africanos, mouros e mediterrâneos", havia merecido seus elogios, no início do livro, embora sob ressalva: "quando bem feita" (capítulo 1). E o nordestino mereceu um comentário geral: "depois de gerações de dieta pobre, produziu o cabeça chata, que também é normalmente baixo, um tanto raquítico, com braços e pernas finos e cabeça grande, mas ágil, e certamente prolífico" (capítulo 8). O trecho se assemelha à sua descrição de João Cabral em carta de 1958: "um típico nortista meio desleixado, raquítico, cheio de verrugas - gerações de clima quente e má alimentação...” (Bishop, 1995, p.707). Mais uma vez, a escritora não associa a dieta ruim à pobreza, mas a hábitos alimentares equivocados, algo que já observara em Petrópolis e no Rio. Todo o trecho, porém, foi eliminado na publicação. Não se pode esquecer que Bishop e Lota pretendiam traduzir para o português o livro do Dr. Spock, Meu filho, meu tesouro, nos primeiros tempos da norte-americana no Brasil, e que as preocupações relacionadas à alimentação infantil permaneceriam mesmo após seu retorno definitivo aos Estados Unidos. ${ }^{39}$

\section{Linguagem e intenções - um confronto}

As preocupações didáticas de Bishop, em Brazil, são claras. Logo no início dos originais, a escritora propõe a inclusão de um quadro que descreva ao leitor norte-americano a pronúncia da língua portuguesa, recorrendo para tanto ao nome da primeira personagem do livro, Conceiçãozinha:

(O $h$ depois de uma consoante é uma das coisas que fazem o português parecer tão estranho aos nossos olhos. Ele se pronuncia como $y$ : Con-say-son-zeen-ya.) [Talvez

\footnotetext{
${ }^{39}$ Nenhum editor se interessou pelo livro, embora Lota tenha chegado a traduzir vários capítulos (Bishop, 2008, p.804). Em carta à empregada Vitória, de Ouro Preto (1976), Bishop não vai culpabilizar apenas a culinária tradicional brasileira: "NÃO compre essas comidas para bebê que vêm em latinhas ... até mesmo purê de feijãopreto [em port.] é bom para o bebê porque contém ferro... Nunca lhe dê Maizena - o bebê fica gordo e pálido ... O açúcar, e bebidas como Coca-Cola (que são cheias de açúcar) fazem muito mal aos dentes..." (Bishop, 1995, p.761-762). O comentário completa-se em recado ao portador da carta: "Eu sei que a Vitória vai querer comprar aquela comida enlatada americana para bebês; as pessoas que ela conheceu antes de mim (Donald e esposa) davam essas coisas para o neném... (Além disso, comiam torta de maçã todo dia - e o casal e a criança pareciam três porquinhos.)" (p.762).
} 
um QUADRO explicando um pouco da pronúncia portuguesa, como no livro do JAPÃO. Diminutivos - inha - ão $-\mathrm{x}=\mathrm{sh}-$ etc. Talvez com formas de tratamento.]

No quadro publicado, entretanto, consta apenas uma listagem de termos portugueses e espanhóis, expondo as "similaridades e diferenças" (capítulo 1) entre as duas línguas. Para os editores, a comparação entre os diversos povos latinos e a abrangência da coleção em que o livro se insere são mais importantes que as peculiaridades de nossa língua. Note-se que a preocupação com a pronúncia brasileira aparece inúmeras vezes em cartas de Bishop aos amigos norte-americanos, seja com ironia, seja com simples intuito didático, como nestes exemplos: "caixa se pronuncia ky-ish-a. $\mathrm{O}$ 'x' se pronuncia como $s h$... Gosto de ouvir Texaco pronunciado Teshaco. (Outra coisa: aqui Buick rima com quick.)" (Bishop, 1995, p.445). Também os nomes próprios lhe interessam: Oscar (Osh-car, p.306), Judith (Zhew-deetchy, p.277), Alice (Al-iss-y, p.373), ou mesmo Elizabetchy. A insistência de Bishop em comentar a pronúncia brasileira de seu nome levaria a amiga Pearl Kazin Bell a nomear como "Dona Elizabetchy" (Bell, 1991) um artigo de memórias sobre ela.

Ao longo de Brazil, outros elementos complementam o texto, além das fotos: "O maior rio do mundo" (capítulo 2) compara o Amazonas ao Nilo e ao Mississippi em termos numéricos; um mapa aponta os "Principais produtos brasileiros" (capítulo 5) por região; uma "Canção do interior" ilustra a poesia popular e anônima (capítulo 6); "Carta-testamento de Vargas" e "Bilhete de renúncia de Jânio Quadros" (ambos no capítulo 9) documentam a história recente. É possível, entretanto, que apenas a "Canção" tenha sido inserida por solicitação da autora. Bishop chegou a sugerir, sem sucesso, a inclusão de mais um quadro na parte relacionada ao Brasil contemporâneo (capítulo 9), talvez se referindo ao quadro denominado "Períodos mais importantes da história", presente no livro sobre o Japão. Sua preocupação didática é nítida, também, quando propõe ao editor, entre parênteses: “Aqui, se você quiser, posso incluir um pouco de informação acerca dos dias da semana, que vêm do período [em branco]" (capítulo 1).

Sempre interessada em contrapor a vida brasileira a exemplos conhecidos do público norte-americano, Bishop aponta como as particularidades do idioma têm a ver com um modo de apreender a realidade. Assim, afirma que o uso dos diminutivos ilustra a tendência de tornar a língua "mais leve e mais suave", nessa "atmosfera de familiaridade, afeição, intimidade, que parece ser tipicamente brasileira". Associa essa linguagem ao sul dos

\footnotetext{
${ }^{40}$ Cem anos antes de Bishop, a francesa Adèle Toussaint-Samson dizia: "a língua brasileira, com todos os seus diminutivos em zinha, zinhos, tem uma graça toda crioula, e jamais a ouço sem lhe descobrir um grande
} 
Estados Unidos: "De fato, como vários escritores frequentemente observaram, muito da vida brasileira pode ser mais bem compreendido ou apreciado por norte-americanos familiarizados com o extremo sul de seu próprio país. (QUADRO?)" (capítulo 1). Nenhum quadro foi incluído aí, embora a sugestão tenha sido reiterada pouco adiante.

De acordo com a intenção expressa em suas cartas, de incluir no texto "as nossas piadas preferidas, as pessoas de que mais gostamos" (Bishop, 1995, p.712), a autora escreve: “Apelidos e diminutivos são muito comuns. ${ }^{41}$ 'Dona Baby', 'Dona Magu' (de Maria Augusta), 'Doutor Carlinhos' (mesmo que ele tenha mais de 60 anos e pese mais de 100 quilos). Mais uma vez, esta é uma reminiscência de nosso próprio Sul, com seus 'Miss Natties' e 'Mr. Billies'.” (capítulo 1). Essa “Dona Magu”, por exemplo, é sua amiga Maria Augusta Leão. No processo que tornou o texto impessoal, tais referências foram eliminadas.

Ao comentar as formas de tratamento, "quase tão complicadas quanto as russas", Bishop explica o uso de "Dona" e "Doutor", juntamente com a variante "abrandada de Senhor, Seu". Mas sua atenção às sutilezas no tratamento aparece também em outros textos, como em "Viagem a Vigia" (Bishop, 1996, p.135-144), em que narra um episódio de sua excursão à Amazônia:

Naquela manhã, pedi a M. para me avisar quando chegasse o momento místico em que ela trocaria de marcha e, em vez de chamá-lo de "doutor Ruy", passaria a tratá-lo de "você". Esse uso do pronome de tratamento é sempre um problema delicado, e eu queria ver como M., que tem excelentes maneiras à moda brasileira, o resolveria. Como Ruy era poeta e portanto poderia ser considerado sensível, e como o achávamos muito simpático, eu imaginava que a coisa fosse acontecer logo. (p.136)

A rapidez "em mostrar solidariedade" é exemplificada com a palavra coitado, uma das preferidas de Bishop, presente em várias de suas cartas: "Uma das primeiras - e mais úteis palavras que um estrangeiro aprende é coitado. Isso pode aplicar-se a qualquer um ou a qualquer coisa, sempre num tom de piedade e comiseração: Conceiçãozinha foi automaticamente chamada de coitadinha" (capítulo 1). Todo esse comentário, entretanto,

encanto ... Todas as suas denguices lhe caem bem e dão à língua brasileira um não-sei-quê que seduz mais o ouvido que a pura língua de Camões" (2003, p.173).

${ }^{41}$ Especialmente no grupo de amigos de Lota e Bishop, apelidos eram muito comuns. Os irmãos de Magu, Rosalina e Carlos, eram Rosinha e Caloca. Emmanuel de Macedo Soares, primo de Lota, nos informa (em $e$ mail de 31 jul. 2008) que o pai dela, senador e jornalista José Eduardo de Macedo Soares, cunhava apelidos para todos, personalidades públicas ou não. Insatisfeito com os apelidos Lota e Marieta, de suas filhas, chamava-as de Lotinha e Marietinha. 
inclusive a referência a Conceiçãozinha, que remetia aos parágrafos iniciais do capítulo, desapareceu no texto publicado.

É interessante notar a insistência da autora em desconsiderar o uso de "Doutor" na classe alta, independentemente de grau universitário. O texto publicado associa esse termo não só a "formação universitária" mas também a "um grau suficiente de prosperidade" (capítulo 1), mas Bishop cortou esta última referência em seu exemplar, ${ }^{42}$ ocultando algo que era e ainda é evidente por todo o Brasil. Estaria considerando apenas o que costumava ouvir em seu círculo de amizades, entre pessoas de mesma classe, um ambiente em que o termo "Doutor" era desnecessário? Certamente não, pois essa estrangeira atenta e minuciosa nunca deixou de notar o modo como os empregados se dirigem aos patrões, em nosso país. Afinal, num de seus comentários mais famosos, emitido em 1952, poucos meses após sua chegada ao Brasil, ela afirma: "Aqui você chega e o zelador, o porteiro, o cozinheiro abraçam você com carinho e a chamam de 'senhora' e 'minha filha' ao mesmo tempo" (Bishop, 1995, p.248).

Outra característica brasileira elogiada por Bishop, não só no livro como em suas cartas, é a miscigenação. Ao falar dos jogadores de futebol, comenta que são "de todos os tons, do branco ao preto retinto" (capítulo 8; também em Bishop, 1995, p.386), e entre os artistas e intelectuais destaca o fato de serem mulatos: Mestre Valentim, Aleijadinho, Padre José Maurício, Machado de Assis e Mário de Andrade (capítulo 7). No capítulo inicial, relacionado aos paradoxos brasileiros, consta este comentário: "Existe uma noção popular de que as belezas famosas devem ter uma ou duas gotas desse sangue correndo em suas veias; supostamente, isso as torna mais vivazes. Uma vez que todos querem ser tão claros, ou brancos, quanto possível, esta é mais uma das contradições que parecem não incomodar ninguém" (capítulo 1). ${ }^{43}$ Em seu exemplar, entretanto, a autora propõe que se elimine a referência às "gotas desse sangue". Uma vez que todo o trecho consta nos originais, Bishop corta, agora, seu próprio texto. E como não propõe substituição, apenas o corte, é possível supor que ela esteja preocupada com as reações ao comentário, ou insegura quanto à generalização. Em outros trechos relacionados à cor da pele, nos quais o que ocorre é a intervenção dos editores, a mudança não deixa dúvidas: o engenheiro André Rebouças, cujo exemplo abre o capítulo sobre "Grupos e Indivíduos", é citado como "negro" nos originais, mas torna-se "mulato" no texto publicado (capítulo 8).

\footnotetext{
${ }^{42}$ Ver, nas Figuras 19 a 21, exemplos de correções feitas pela autora em seu exemplar.

${ }^{43}$ A antropóloga norte-americana Janice Perlman, que estudou as favelas cariocas na década de 1960 e retornou há pouco em busca de seus antigos entrevistados, notou uma importante "revalorização das raízes negras" nessas comunidades: chamou sua atenção, por exemplo, um grande número de "deslocamentos" na maneira como essas pessoas reclassificaram, quarenta anos depois, a própria "cor" (de "branco" para "moreno"; deste para "mulato"; deste para "preto"). (Depoimento ao canal Futura, exibido em 21 out. 2008).
} 
No capítulo 1 de Brazil, Bishop explica a etimologia de "criado" recorrendo aos "irmãos de criação" e descreve uma cena que "ainda hoje se vê, de vez em quando" - uma velha senhora "de braço dado com uma menina negra bem vestida", sua "filha de criação". No capítulo 8, usa de sua observação para destacar, mais uma vez, um aspecto positivo do cenário brasileiro: "para um sul-africano ou norte-americano ou qualquer um que tenha vivido num país 'colonial', poder ouvir uma cozinheira negra chamando sua pequena e velha patroa branca de minha negrinha, como forma de afeto, é uma revelação - um sopro de ar fresco, afinal". O texto publicado, entretanto, refere-se ao norte-americano "liberal" - termo que a autora assinala em seu exemplar -, e desaparece a referência ao passado colonial dos Estados Unidos. Outro termo que merece nota é "negrinha" - também em inglês, my little nigger -, que, na edição de 1970, será alterado para "neguinha", e, no inglês, para my black one (literalmente, "minha preta") -, expressão que não carrega o sentido agressivo e pejorativo de nigger (crioula). ${ }^{44}$

Ainda nos comentários sobre ricos e pobres, patrões e empregados, Bishop mais uma vez generaliza: "Fora dos círculos elegantes, os pobres são magros e os ricos são gordos, e gordura é um sinal de beleza, como tem sido desde os tempos antigos" (capítulo 1). Isso é o que foi publicado, mas no original a autora afirmava, também, ser esse "um padrão antigo ... sem nada da ideia puramente anglo-saxônica de understatement". Transpunha, assim, para o âmbito das aparências a característica psicológica e linguística de "falar nas entrelinhas". Exageradamente ou não, abria espaço para essa reflexão também eliminada pelos editores.

A preocupação estilística em não repetir termos está presente logo no início do primeiro capítulo, quando Bishop propõe took place (aconteceu) e happens (acontece), embora no texto publicado a expressão se repita: took place e takes place. Quanto à escolha vocabular, várias vezes ela se exaspera na longa carta enviada aos editores em dezembro de $1961,{ }^{45}$ como na recusa aos termos teenage e step up: "NÃO USE A PALAVRA TEENAGE. POR QUE SER VULGAR? Eu disse young girl" (capítulo 8); "não use STEP UP EDUCATION. Por que SER VULGAR?” (capítulo 9). Mesmo sob seus protestos, raras substituições foram feitas. Várias vezes ela pede a eliminação de erros e redundâncias, como em: "Elsewhere (em outros lugares) deve ser EVEN [mesmo], e elimine elsewhere. - Vocês colocaram where na sentença seguinte" (capítulo 1), ou em "apenas abdicated [abdicou] -

\footnotetext{
44 Ao comentar a tradução de Minha vida de menina, Regina Przybycien observa que Bishop utilizou, para "pretinha", a expressão little nigger, "que se tornou tabu após a luta pelos direitos civis na América do Norte. Atualmente seu uso é ofensivo e implica uma declaração explícita de racismo" (1993, p.218).

45 Todos os comentários presentes nessa carta constam no rodapé da tradução de Brazil, na quarta parte deste trabalho, no intuito de expor a reação da autora diante do texto final apresentado pelos editores (ver Figura 18).
} 
para não repetir a palavra throne [trono] duas vezes na mesma sentença" (capítulo 3). Também essas solicitações foram, quase sempre, ignoradas pelos editores.

A carta de Bishop permite entrever, no cuidado com a linguagem, algo de seu confronto com os editores também no aspecto político. O comentário sobre a simpatia de Vargas aos países do Eixo no início da Segunda Guerra Mundial foi cortado, e ela escreve: "Esta é a simples verdade. Por que vocês insistem em absolver ditadores?". Por sua vez, a queda de Vargas no final da guerra não poderia, segundo ela, ser chamada de "expulsão", palavra forte demais. A postura política de Che Guevara é suavizada, pelos editores, com uma observação sobre suas "inclinações”, mas Bishop comenta: "Se vocês estiverem com medo de usar a palavra comunista ... NÃO DIGAM "DE INCLINAÇÃO COMUNISTA”, PELO AMOR DE DEUS!”. Na recente renúncia de Jânio, ela insiste na precisão: “do modo como vocês deixaram, implica que todo o país estava sob censura por um período indefinido, e que o Rio estava repleto de soldados - o que é completamente falso".

Detalhes demonstram a vivência da autora no país: onde constava "o fruto do caju contém a valiosa castanha de caju", por exemplo, Bishop informa: “ela não 'contém' a castanha. A castanha fica do lado de fora do fruto". E a busca por precisão se impõe em outros aspectos: ela diz que "a população não deve ser responsabilizada" pelos problemas do Rio de Janeiro: além do "tremendo crescimento populacional" da cidade, deveria constar "e falta de dinheiro" ou "falta de fundos governamentais". Da mesma maneira, o país nunca teria estado "indeciso" quanto às suas fronteiras, "o que não faz nenhum sentido". Quanto à vida do brasileiro, que "parece mais democrática", ela comenta: "EU NUNCA DISSE ISSO", e pede que se mude para "a atmosfera do Brasil parece mais democrática...”, ou "os hábitos e a atmosfera do Brasil parecem muito democráticos". É também em nome da precisão que Bishop altera o comentário sobre jogadores de futebol que, nas decisões de campeonatos, "perdiam todo o espírito de equipe". Para ela, "todo" parece "desnecessariamente severo".

$\mathrm{O}$ cuidado com a linguagem se expressa também nos momentos em que a autora desiste de encontrar a melhor solução, embora mantenha a pendência. Ao descrever uma cena de carnaval, narra o encontro de um homem com "suas duas amantes (ou duas de suas amantes). [deve haver um jeito melhor de dizer isso]" (capítulo 1). No texto publicado, ele apenas "esbarrou em suas duas amantes".

Lota estava envolvida demais com o Parque do Flamengo no momento em que Bishop escreveu Brazil, e isso certamente impediu que a auxiliasse na pesquisa e elaboração do 
livro. ${ }^{46}$ A autora parece não saber, por exemplo, que "polaca", no modo como os brasileiros se referiam à Constituição do Estado Novo (capítulo 9), inspirada no modelo polonês, também significa "prostituta", uma vez que polish não tem, no inglês, essa conotação. Assim, o termo não recebe nenhum comentário. No capítulo 2, Bishop poderia ter descoberto alguma solução para um belo jogo de palavras empregado por Pero Vaz de Caminha, ou, ao menos, tecido algum comentário sobre ele. É bem provável, entretanto, que Bishop nem tenha chegado a perceber a relação entre "ter vergonha" (ter acanhamento, recato), "a sua vergonha" (órgãos sexuais) e "fazer vergonha" (humilhar), na referência de Caminha às índias. O texto original da carta é este: "era tão bem-feita e tão redonda, e sua vergonha (que ela não tinha) tão graciosa, que a muitas mulheres da nossa terra, vendo-lhe tais feições, fizera vergonha, por não terem a sua como ela”. O jogo, infelizmente, perdeu-se na tradução para o inglês. ${ }^{47}$

Só a pressa pode justificar um comentário equivocado como este, sobre a Antropofagia: "Houve até mesmo um pequeno movimento interno a ele [Modernismo], autodenominado antropófagos, em seu desejo de ser brasileiros nativos e nada mais, e que lançou o "Manifesto Antropófago"” (capítulo 7). Tanto é que todo o trecho foi eliminado na publicação. Outro comentário incorreto associava o "período do Indianismo" ao final do reinado de Pedro II (capítulo 3) e relacionava os títulos nobiliárquicos indígenas ao desejo de "ter um índio (de preferência, um chefe) entre os ancestrais". Também esse trecho foi eliminado, mas, infelizmente, no corte desapareceu um paralelo divertido: "Os condes de Itaboraí [ancestrais de Lota], Tamandaré, os barões de Maracaju, Paranaguá - é como se os Estados Unidos tivessem tido seu conde Massachusetts ou barão Ohio”.

A intenção de incluir um bom número de anedotas enriquece o texto de Bishop, mas a pressa na escrita - ou, talvez, a falta de apoio de algum brasileiro - leva a equívocos, como no dito popular "Se plantando, dar", corrigido no livro para "Em se plantando, dá" (capítulo 2), ou na confusão entre "Senhor do Bonfim" (good end) e "Senhor da Boa Morte" (good death), também corrigida na publicação (capítulo 4), ou ainda neste comentário sobre a "viúva" de Machado de Assis: "Depois da morte de Machado de Assis um amigo visitou sua viúva. A senhora Machado de Assis lançou o olhar para a foto do marido sobre a mesa e fez seu único comentário conhecido acerca do fato de ela, uma mulher branca, ter-se casado com um mulato. 'Pena que ele era tão escuro', disse ela" (capítulo 8). Como se sabe, Carolina faleceu antes do marido, e, felizmente, todo o trecho foi eliminado.

\footnotetext{
${ }^{46}$ Lembremos que Lota reviu a tradução de Minha vida de menina, "linha a linha, não uma vez, mas várias vezes" (Bishop, 1996, p.132).

${ }^{47} \mathrm{O}$ texto de Bishop em inglês: "she was so well built and so rounded and her lack of shame was so charming, that many women of our land seeing such attractions, would be ashamed that theirs were not like hers".
} 


\section{Escrevendo no Brasil, para americanos}

Bishop escreve Brazil, como seus contos e poemas, para o leitor norte-americano. Assim, uma intervenção nítida - e necessária - dos editores consiste na eliminação dessa marca, que aparece, por exemplo, em "nossa literatura", "nossos artistas", "nosso Henry James", "nossos diferentes pontos de vista", "nosso país industrializado e de classe média" (todos no capítulo 7), "nossa cultura" e "nossos problemas raciais" (ambos no capítulo 10). Vários desses trechos, entretanto, são totalmente eliminados na publicação, e não apenas a referência específica aos Estados Unidos. Quando a autora fala dos "nossos pequenos fazendeiros", os editores optarão por "os fazendeiros americanos", mas, quando vai mais longe e propõe que o Brasil adote, em relação à literatura, a política norte-americana de "recuperar nossos Hawthornes e Twains, embora nunca na nossa escala estupenda e cara" (capítulo 7), o longo parágrafo é eliminado, levando consigo uma observação perspicaz que aproximava profundamente os dois países: "um colono compreende o outro".

Quando descreve o caráter do brasileiro, a autora aponta a preguiça, mas esta vem acompanhada por um atenuante, entre parênteses: "(embora a preguiça possa ser considerada uma virtude, também...)". Nesse ponto os editores promovem uma alteração fundamental: a preguiça torna-se, quando muito, uma “fraqueza atrativa ... às vezes" (capítulo 2).

Buscando fazer um paralelo entre os povos brasileiro e americano, Bishop recorre a expressões populares dos dois países e as aplica ao trabalho intelectual e artístico:

Existem dois ditados, um anglo-saxônico e outro brasileiro, que parecem um pouco semelhantes, mas têm significados muito diferentes. Eles ilustram muito bem nossos diferentes pontos de vista acerca da carreira do artista. Nós dizemos, puritanamente: "Ele fez sua cama e deve deitar-se nela". Os brasileiros dizem, suavizando: Cria fama e deita-te na cama. (capítulo 7)

Toda a comparação com o ditado norte-americano foi eliminada pelos editores, e a redação passou a ser esta: "Uma grande quantidade de talentos brasileiros genuínos parece ir para a cama - ou para a rede - cedo demais". De qualquer maneira, a observação preservada, "uma das poses prediletas dos escritores brasileiros em seus retratos consiste em deitar-se prazenteiramente numa rede com franjas", ecoa um comentário sarcástico expresso em carta de 1954: "Manuel Bandeira mandou-me uma rede de aniversário - e depois disso vi uma foto 
em que ele aparece escrevendo numa rede, de modo que acho que é este o espírito literário brasileiro" (Bishop, 1995, p.307). Também com base no que observa e ouve entre seus amigos, Bishop inclui no livro um comentário - eliminado na publicação - que associa, com certo exagero, o uso dos prenomes às marcas da nossa elite econômica e cultural:

A despeito de exemplos de democracia nas artes - Aleijadinho, Machado de Assis, Mário de Andrade e Portinari -, a maioria dos escritores e artistas vem da pequena classe alta inter-relacionada e culta; em vários níveis todos eles são primos, o que resulta numa sociedade de admiração mútua. Como no governo, as querelas transformam-se em disputas familiares; os prenomes são usados - mesmo em artigos críticos sérios; tudo se enfrenta pessoalmente demais, e a atmosfera é curiosamente "feminina". (capítulo 7)

É interessante notar que, logo no início do livro, consta que o sotaque brasileiro era visto, pelos portugueses, como "efeminado - charmoso quando as mulheres o falam, mas não uma língua para homens" (capítulo 1).

No final do capítulo 9, ao comentar a crise política surgida na renúncia de Jânio e resolvida com a posse de João Goulart e a adoção do Parlamentarismo, Bishop ressalta o "talento para o acordo" do brasileiro, mas lembra, entre parênteses, que essa expressão, assim como outra, "terra de promessas não cumpridas", é "quase uma bandeira vermelha para um brasileiro, atualmente" (capítulo 9). Mais um trecho eliminado pelos editores.

Ainda sobre o caráter do povo, Bishop afirma que "os brasileiros, dizem, "colhem a fruta sem terem plantado a árvore"”, citação acompanhada por um comentário: "Existe uma queda nacional por conseguir lucros rápidos em vez de lançar as bases para sólidas poupanças futuras. A história econômica brasileira quase poderia ser narrada em sua longa sucessão de booms espetaculares" (capítulo 5). Como se vê, o Brasil de Elizabeth Bishop reflete em grande medida as suas leituras, sua formação e a influência do círculo de amizades, mas a perspicácia da autora leva-a, por vezes, a emitir observações surpreendentes. Afirma, por exemplo, que "Às vezes os brasileiros parecem confundir familiaridade com democracia, embora a atitude pareça mais um resquício dos tempos da escravidão..." (capítulo 1), que como já apontou Przybycien (1993, p.80) -, "faz lembrar o clássico estudo de Sérgio Buarque de Holanda sobre o brasileiro como homem cordial". Mas Raízes do Brasil não consta na bibliografia consultada para a redação de Brazil, e o autor nem mesmo é citado na correspondência de Bishop. Se por um lado essa ausência denota as importantes lacunas nos 
estudos empreendidos pela norte-americana para a elaboração de seu livro sobre o Brasil, por outro valoriza ainda mais sua argúcia.

Bishop leu desde relatos de viajantes do século XIX (Maria Graham, Richard Burton e Charles Darwin, entre outros) e interpretações do Brasil, como Os sertões, de Euclides da Cunha, e Casa-grande e senzala, de Gilberto Freyre, até tratados sobre a arquitetura barroca em Minas. ${ }^{48}$ Em carta de 1955 ela comenta sobre Casa-grande e senzala: "Há um livro surpreendente sobre o Brasil que realmente dá uma ideia das coisas, traduzido como The masters and the slaves, de Gilberto Freyre", e completa: "fascinante e deprimente" (Bishop, 1995, p.324). E em 1962 recomendará Os sertões: “um livro realmente maravilhoso, cujo nome em inglês é Rebellion in the backlands - leiam se encontrarem" (p.725).

Alguns dos comentários soam exagerados, mesmo para o leitor brasileiro - "quando o céu se encobre os cearenses saúdam uns aos outros, 'Que belo dia!’” (capítulo 2) -, mas é bem possível que a autora esteja apenas reproduzindo a frase ouvida em suas viagens, ou na voz de algum conhecido. "Quase todos os brasileiros são potencialmente cariocas" (capítulo 4) parece ser uma observação ouvida entre amigos e incluída no livro sem questionamento. Bishop afirma, também, que "no Rio ainda se diz que os bons paulistas, quando morrem, vêm para o Rio" (capítulo 4), mas este comentário foi eliminado pelos editores. ${ }^{49}$

Outra marca constante da autora está na sua identificação como moradora do Brasil e, por vezes, do Rio de Janeiro, como nesse "vêm para o Rio", ou em "baianos que vêm para o Rio" (capítulo 4), “o imigrante europeu que vem para o Brasil” (capítulo 8) e "os portugueses ainda vêm numa taxa de 17 mil por ano" (capítulo 8), embora ela ainda se apresente como estrangeira, como vimos na referência às "nossas" - americanas - características. A carioca do Leme relata sua experiência específica, "Olhamos pela janela de um arranha-céu e vemos uma família construindo sua casa com barro e galhos" (capítulo 7).

A experiência de viagem aparece, por sua vez, num comentário sobre Manaus, "o ‘bife-stek Carlos Gomes' ainda consta nos menus dos restaurantes da cidade” (capítulo 7), presente em carta escrita logo após seu retorno da Amazônia, em 1960: "no menu havia

\footnotetext{
${ }^{48}$ Alguns exemplos encontrados entre seus livros, hoje pertencentes à biblioteca do Vassar College: The Golden Age of Brazil, 1695-1750: Growing Pains of a Colonial Society, de C. R. Boxer; Impressions of Latin America: Five Centuries of Travel and Adventures by English and North Americans, de MacShane (Ed.); Imagens do passado de Minas Gerais, de P. Scheier; Subsídios para o estudo da arquitetura religiosa de Ouro Preto, de P. F. Santos, e uma edição americana de Sobrados e mocambos, de Gilberto Freyre, além de um livro sobre Camões (Luis de Camoens and the epic of the Lusiads, de Henry H. Hart) e traduções de Fernando Pessoa (Selected Poems) e Guimarães Rosa (The third bank of the river, and other stories).

${ }^{49}$ Várias cartas sofreram cortes em One art (1994) e só foram publicadas na íntegra (ou sob outros recortes) em 2008. Por exemplo, Bishop escreve a Pearl Kazin (22 fev. 1954) que Lota e seus amigos divertem-se muito ao comentar a realização de um festival de cinema em São Paulo, "mas eu sinto que isso se deve, em grande parte, ao ciúme que os cariocas sentem em relação a São Paulo" (Bishop, 2008, p.800).
} 
'bifstek Carlos Gomes' todos os dias” (Bishop, 1995, p.414). Dessa mesma viagem vem a referência a uma médica do Sesp, o Serviço Especial de Saúde Pública, que permanece anônima: "Certa noite, a bordo de um navio que descia o barrento Amazonas, uma jovem médica contava suas histórias" (capítulo 8). Amigas ou conhecidas de Bishop são citadas como exemplo em suas áreas de atuação. Lota de Macedo Soares não consta entre as brasileiras de destaque, talvez por pudor, mas lembremos que ela só se tornou uma figura pública no Rio de Janeiro à medida que a construção do Parque do Flamengo avançou. Além disso, sua relação com o país sempre foi conflituosa. Em carta a Robert Lowell, de 1960, Bishop afirmou: "A Lota não tem o menor interesse por nada que seja brasileiro ou 'primitivo', você sabe. Ela diz que quando viaja quer mais civilização e não menos - por isso vou [a Paraty] com dois vizinhos" (Bishop, 1995, p.416).

\section{Retratando um momento}

Como todo trabalho de cunho ao mesmo tempo jornalístico e literário, o livro de Bishop focaliza um momento do país mas pretende, também, distanciar-se para captar o passado e lançar hipóteses sobre o futuro. As estatísticas reunidas pela autora foram sistematicamente atualizadas pelos editores: desde a idade em que os brasileiros se casam, o número médio de filhos e a taxa de mortalidade infantil (capítulo 1) até o volume das reservas de ferro (capítulo 2). No capítulo 9, entretanto, ela insiste na qualidade de suas fontes e escreve a eles: "de acordo com as melhores estimativas daqui, Brasília custou no mínimo um bilhão de dólares. Onde vocês encontraram 600 milhões, e por que deveriam estar mais corretos que os economistas brasileiros acerca dessa estimativa necessariamente grosseira?".

Bishop critica as "estradas inadequadas" e a "falta de refrigeração" (capítulo 1), preocupada com as terríveis perdas de produtos antes de chegarem aos centros consumidores, e os problemas de transporte aparecem várias vezes no livro (capítulos 1, 3, 4, 5, 6 e 10), mas ela não deixa de perceber que "o desenvolvimento da aviação está alterando esse panorama (capítulo 2). Considerações sobre a economia se espalham por todo o livro, acompanhadas por sugestões fundadas no bom senso, mas às vezes perdidas em generalizações impróprias: “Os brasileiros referem-se invejosamente ao Mississippi; se eles tivessem um Mississippi, as coisas teriam sido bem diferentes. Provavelmente é verdade" (capítulo 2). Quando comenta a recente inauguração, em Cabo Frio, de um complexo industrial voltado à carne de baleia, que "tem sido anunciada para um público até certo ponto relutante, nos mercados litorâneos, como 
a carne mais barata que existe" (capítulo 5), a autora parece ignorar que a proibição de sua caça já estava sob intensa discussão. ${ }^{50}$

Algumas mudanças de hábitos apontadas pela autora refletem sua longa vivência no país: "a sala de jantar substituía a sala de estar, até que houve, recentemente, mudanças no estilo" (capítulo 1). No capítulo sobre as artes espontâneas, transparece seu entusiasmo pelo Carnaval, e ela aproveita para deplorar as mudanças incorporadas nos últimos anos, como a adoção de alto-falantes ou a presença de fotógrafos entre os sambistas, atrapalhando sua passagem: "No Rio, durante os dois últimos carnavais, os espectadores finalmente assobiaram e vaiaram alguns fotógrafos particularmente detestáveis" (capítulo 6).

A autora está atenta para o processo de urbanização e o descreve, também, por suas consequências sutis: "um homem em Goiás sabe o nome e os hábitos de todos os animais e pássaros; mas as pessoas das regiões que sofreram com a decadência da agricultura são maus fazendeiros, doentios, para quem qualquer inseto é apenas um bicho, ou toda árvore é a “cinco-folhas' e tudo está sujeito à destruição" (capítulo 8). Esse trecho, eliminado na publicação, parece ecoar um comentário emitido em Petrópolis, dez anos antes: "aqui existem muitos pássaros, mas ninguém sabe o nome deles" (Bishop, 1995, p.246). Afinal, os proprietários das casas eram cariocas que veraneavam nas montanhas, e seus empregados eram, quase sempre, migrantes. O bisneto de Pedro II visitou a casa de Lota e mostrou saber "o nome de cada planta do jardim ... de cada árvore nas montanhas", e com isso mereceu da norte-americana este elogio, num poema apenas esboçado: "Se isso não é patriotismo, o que seria?" (Bishop, 2006, p.142).

Mudança, evolução e desenvolvimento são termos que aparecem ao longo do livro e lhe dão um sentido geral otimista. Mas, na análise da evolução histórica do país, a simpatia de Bishop pelo imperador Pedro II levou-a a elogiar a permanência dos seus Conselheiros, após o advento da República: "é natural que, restaurando-se a ordem e com o país começando a prosperar, os homens do velho regime imperial, mais dotados e mais bem preparados para a tarefa, tenham voltado ao poder" (capítulo 9). E algumas de suas observações sobre o comportamento dos militares brasileiros, "que tradicionalmente se viam como guardiães da moralidade pública" (capítulo 9), foram reunidas, no texto publicado, a afirmações contundentes, demolidas dois anos depois: eles "jamais quiseram ficar permanentemente no poder. Nas situações em que tomaram o poder, nunca o mantiveram por muito tempo" (capítulo 9).

\footnotetext{
${ }^{50}$ Apenas em Santa Catarina a caça seria mantida até o início dos anos 70. Foi mundialmente proibida em 1986.
} 
Quadro 2 - Capítulos de Brazil: assuntos, sumário e títulos

\begin{tabular}{|c|c|c|c|c|}
\hline & Assunto & $\begin{array}{l}\text { Título } \\
\text { original } \\
\text { (Bishop) }\end{array}$ & $\begin{array}{l}\text { Sumário } \\
\text { (Bishop) }\end{array}$ & $\begin{array}{l}\text { Título } \\
\text { publicado } \\
\text { (Life })\end{array}$ \\
\hline 1 & $\begin{array}{l}\text { O povo } \\
\text { brasileiro }\end{array}$ & $\begin{array}{l}\text { "Paradoxos [e } \\
\text { ironias]", } 51 \\
\text { depois } \\
\text { substituído por } \\
\text { "Uma } \\
\text { miscelânea de } \\
\text { paradoxos" }\end{array}$ & $\begin{array}{l}\text { O paradoxo que ilustra as [contradições] brasileiras } \\
\text { em geral; a explosão populacional versus alta } \\
\text { mortalidade infantil. Grande variedade de paradoxos } \\
\text { grandes e pequenos: vastas fontes de riqueza e } \\
\text { pobreza assustadora; luxo e ascetismo; esnobismo e } \\
\text { "familiaridade"; orgulho e complexo de inferioridade } \\
\text { nacional; vitalidade e "preguiça" etc. E alternância } \\
\text { de regimes corruptos e extravagantes com regimes } \\
\text { que promovem reformas ocasionais puritanas. }\end{array}$ & $\begin{array}{l}\text { Um povo } \\
\text { caloroso e } \\
\text { sensato }\end{array}$ \\
\hline 2 & $\begin{array}{l}\text { Geografia } \\
\text { e história }\end{array}$ & $\begin{array}{l}\text { "A terra do } \\
\text { pau-brasil" }\end{array}$ & $\begin{array}{l}\text { O apelo à imaginação do Brasil lendário. Primeiros } \\
\text { descobridores e seus relatos. Os índios. A } \\
\text { extravagante beleza física do país. Flora e fauna } \\
\text { exóticas, e alguns naturalistas. Os portugueses e os } \\
\text { dois primeiros séculos. [primeiros escravos] }\end{array}$ & $\begin{array}{l}\text { Terra } \\
\text { subdesenvolvida } \\
\text { e lendária }\end{array}$ \\
\hline 3 & $\begin{array}{l}\text { O século } \\
\text { XIX }\end{array}$ & $\begin{array}{l}\text { "O único } \\
\text { império } \\
\text { ocidental" }\end{array}$ & $\begin{array}{l}\text { Chegada de Dom João I (sic); Dom Pedro I e a } \\
\text { independência de Portugal. O reinado de } 40 \text { anos de } \\
\text { Dom Pedro II, “o mestre-escola da nação”. Ideias } \\
\text { republicanas em ação. Emancipação dos escravos. } \\
\text { Abdicação. Problemas da nova República - alguns } \\
\text { [ainda não resolvidos]. }\end{array}$ & $\begin{array}{l}\text { Século de honra } \\
\text { e orgulho }\end{array}$ \\
\hline 4 & $\begin{array}{l}\text { Três } \\
\text { capitais }\end{array}$ & $\begin{array}{l}\text { "Três capitais } \\
\text { [e outros } \\
\text { lugares]" }\end{array}$ & $\begin{array}{l}\text { Bahia até (......), Rio de Janeiro até 1960. Brasília. } \\
\text { Vida urbana e vida das pequenas vilas, velhas e } \\
\text { modernas. O espírito de "deslocamento" e a } \\
\text { "fronteira deserta". São Paulo. }\end{array}$ & $\begin{array}{l}\text { Mudanças nos } \\
\text { centros de } \\
\text { governo }\end{array}$ \\
\hline 5 & Economia & $\begin{array}{l}\text { "Vegetal, } \\
\text { mineral e } \\
\text { animal" }\end{array}$ & $\begin{array}{l}\text { Açúcar, apogeu e declínio. Café, o “único produto”. } \\
\text { Ouro, joias, reservas minerais; riqueza mineral } \\
\text { intocada. Criação de gado no sul. Dificuldades de } \\
\text { transporte. Os tipos: baiano, [antiga fazendeira], } \\
\text { cangaceiro, garimpeiro e gaúcho. Bandeirante, } \\
\text { baianinha. }\end{array}$ & $\begin{array}{l}\text { O lento despertar } \\
\text { de um gigante }\end{array}$ \\
\hline
\end{tabular}

\footnotetext{
${ }^{51}$ No quadro, os colchetes indicam trechos riscados pela autora.
} 


\begin{tabular}{|c|c|c|c|c|}
\hline & Assunto & $\begin{array}{l}\text { Título } \\
\text { original } \\
\text { (Bishop) }\end{array}$ & $\begin{array}{l}\text { Sumário } \\
\text { (Bishop) }\end{array}$ & $\begin{array}{l}\text { Título } \\
\text { publicado } \\
(\text { Life })\end{array}$ \\
\hline 6 & As artes & $\begin{array}{l}\text { "As artes } \\
\text { espontâneas",52 }\end{array}$ & $\begin{array}{l}\text { Carnaval. Artes populares e festas: bumba-meu-boi, } \\
\text { reisados, marítimas, Iemanjá etc. A Igreja: São João, } \\
\text { São Pedro e São Jorge. Desenvolvimento do samba. } \\
\text { Canções populares, HUMOR. }\end{array}$ & $\begin{array}{l}\text { Habilidades } \\
\text { graciosas e } \\
\text { populares }\end{array}$ \\
\hline 7 & As artes & $\begin{array}{l}\text { "As artes } \\
\text { sofisticadas" }\end{array}$ & $\begin{array}{l}\text { Arquitetura brasileira contemporânea mais } \\
\text { importante. Influências estrangeiras no passado e no } \\
\text { presente. Poucos marcos na literatura brasileira. } \\
\text { Jornalismo. A importância dos “poetas" na América } \\
\text { Latina. Música séria. Portinari, e alguns jovens } \\
\text { artistas; trabalhos em preto e branco. [Dificuldades] }\end{array}$ & $\begin{array}{l}\text { Um respeito } \\
\text { merecido pelas } \\
\text { artes }\end{array}$ \\
\hline 8 & $\begin{array}{l}\text { Indivíduos } \\
\text { e grupos }\end{array}$ & $\begin{array}{l}\text { "Indivíduos e } \\
\text { grupos" }\end{array}$ & $\begin{array}{l}\text { Relações raciais. Negros, índios, portugueses; } \\
\text { imigrantes. General Rondon e Villas Boas. Mulheres. } \\
\text { Santos Dumont. Esportes e a sociedade que se } \\
\text { modifica - futebol. }\end{array}$ & $\begin{array}{l}\text { Um cenário } \\
\text { social em } \\
\text { mudança }\end{array}$ \\
\hline 9 & $\begin{array}{l}\text { Política } \\
\text { recente }\end{array}$ & $\begin{array}{l}\text { "A nova } \\
\text { República" }\end{array}$ & $\begin{array}{l}\text { O legado, bom e ruim, de } 30 \text { anos de Vargas. } \\
\text { Comunicações, trabalhadores migrantes, cidades } \\
\text { superpovoadas, analfabetismo e saneamento etc. } \\
\text { Eleições. Energia, irrigação, [saúde] }\end{array}$ & $\begin{array}{l}\text { A luta por uma } \\
\text { democracia } \\
\text { estável }\end{array}$ \\
\hline 10 & $\begin{array}{l}\text { Política } \\
\text { recente }\end{array}$ & $\begin{array}{l}\text { ["Uma nova } \\
\text { esperança"] }\end{array}$ & $\begin{array}{l}\text { Kubitschek e a inflação. Problemas trazidos por } \\
\text { Brasília. A “oposição” no poder [afinal]. O novo } \\
\text { estado da Guanabara. Quadros - (São Paulo) } \\
\text { novamente o "mestre-escola da nação"? }\end{array}$ & $\begin{array}{l}\text { Uma nação } \\
\text { perplexa e } \\
\text { indecisa }\end{array}$ \\
\hline
\end{tabular}

52 Seguimos, aqui, a tradução proposta por Paulo Henriques Britto (em Bishop, 1995, p.715). Numa versão literal, os capítulos 6 e 7 seriam "As artes inconscientes" e "As artes intencionais". 


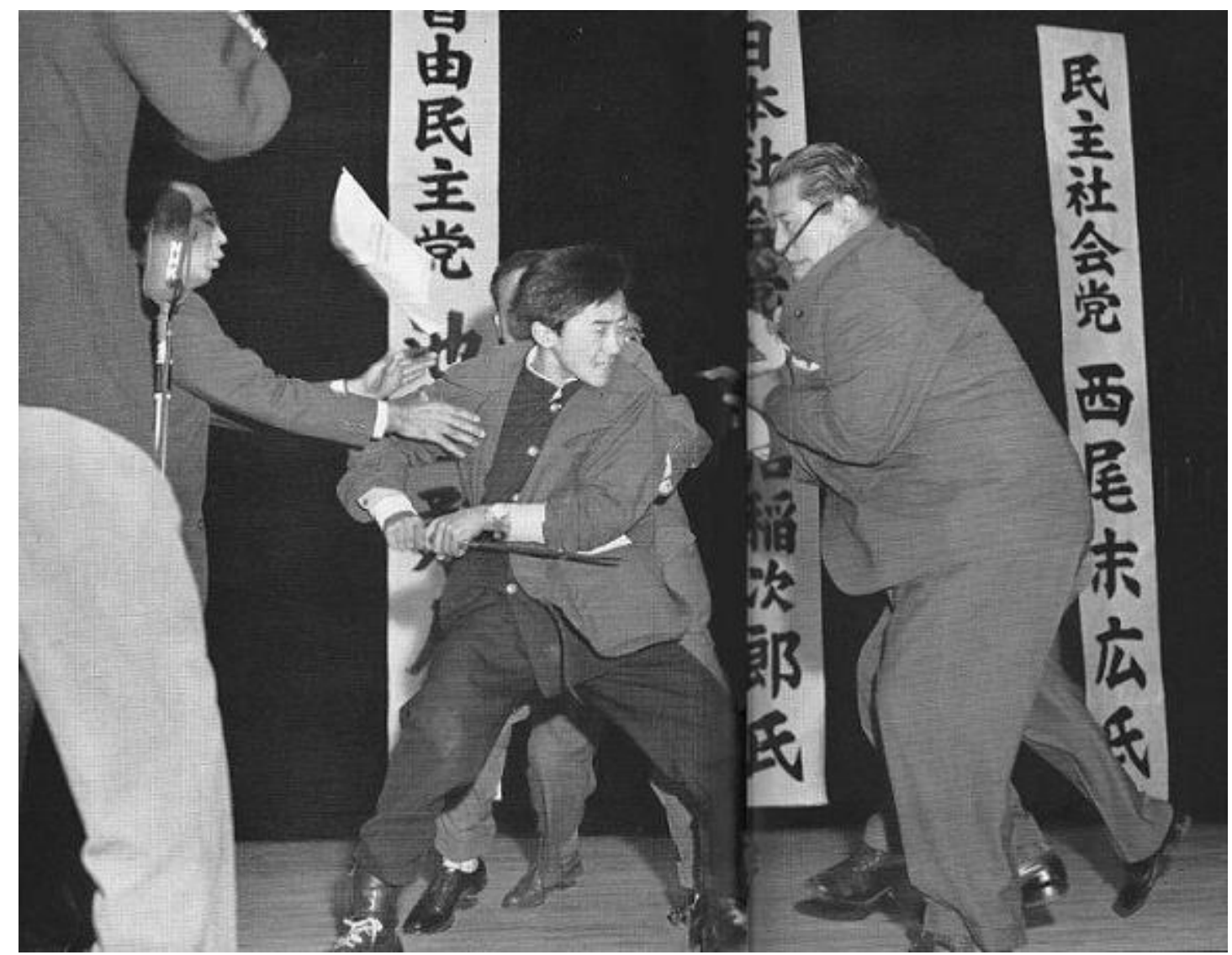

Figura 5 - No livro dedicado ao Japão, em página dupla, um político "moderado" é morto por um jovem "fanático". (Life World Library, Japan, 1961, p.56-57)

Figura 6 - No volume sobre as Repúblicas Platinas, uma multidão "de classe média" queima documentos peronistas em Buenos Aires. A legenda ainda afirma que Perón "conseguiu fugir com 50 milhões de dólares". (Life World Library, The River Plate Republics, 1965, p.103)

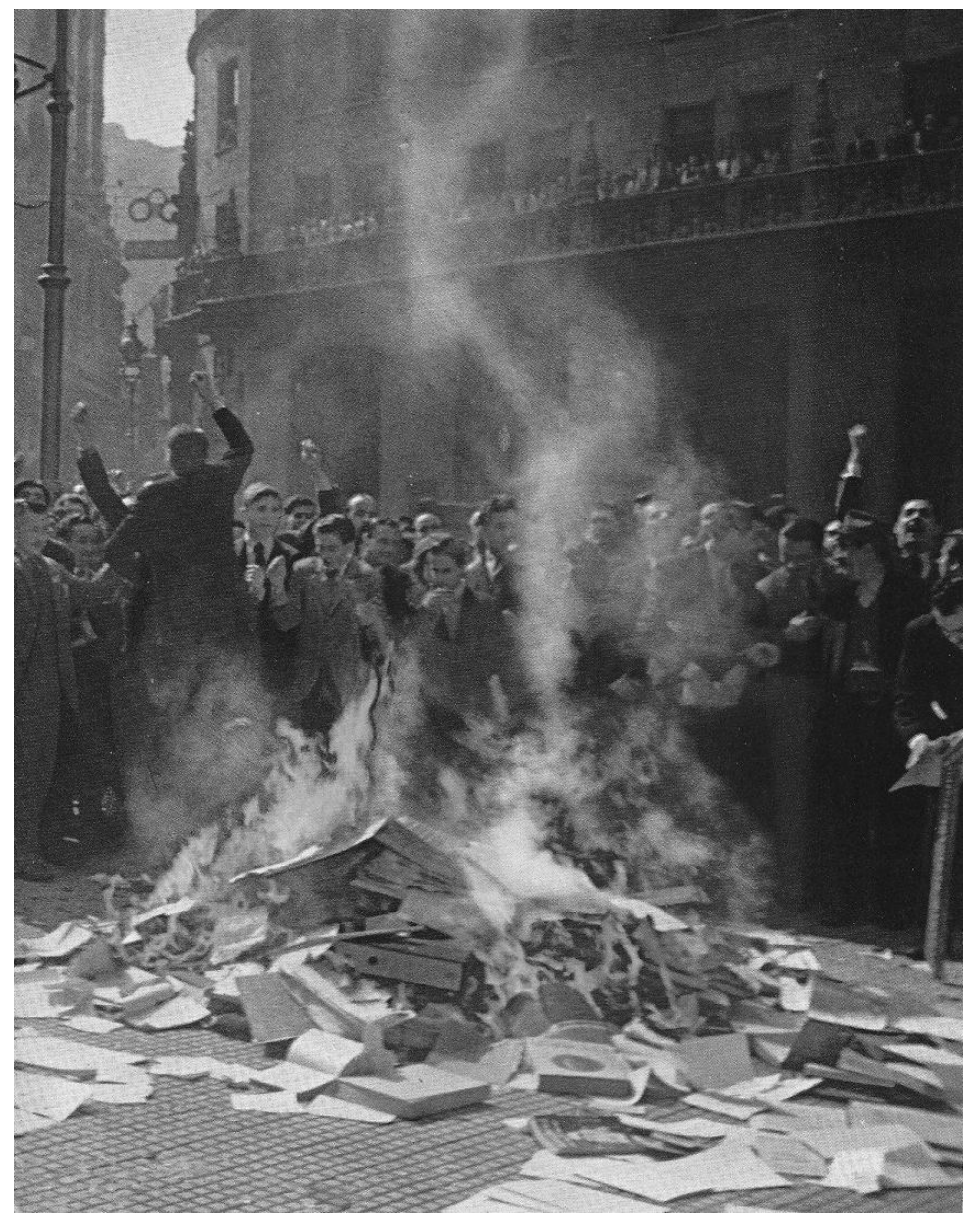




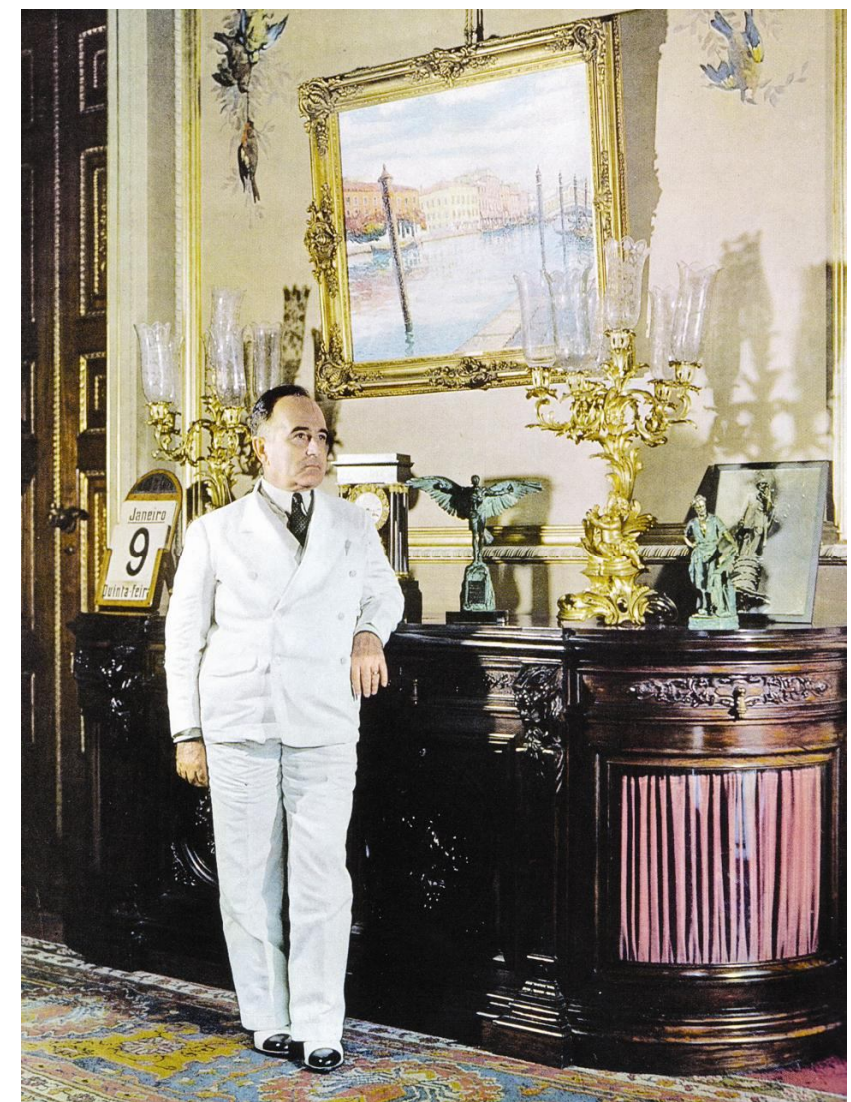

Figura 7 - Getúlio Vargas, "hábil demagogo", é apresentado em foto de 1936 como ícone do Brasil antiquado. (Life World Library, Brazil, 1962, p.126)

Figura 8 - No início da década de 1960, manifestação a favor de Fidel Castro, comandada em Recife por oradores "anti-EUA". (Brazil, 1962, p.143)

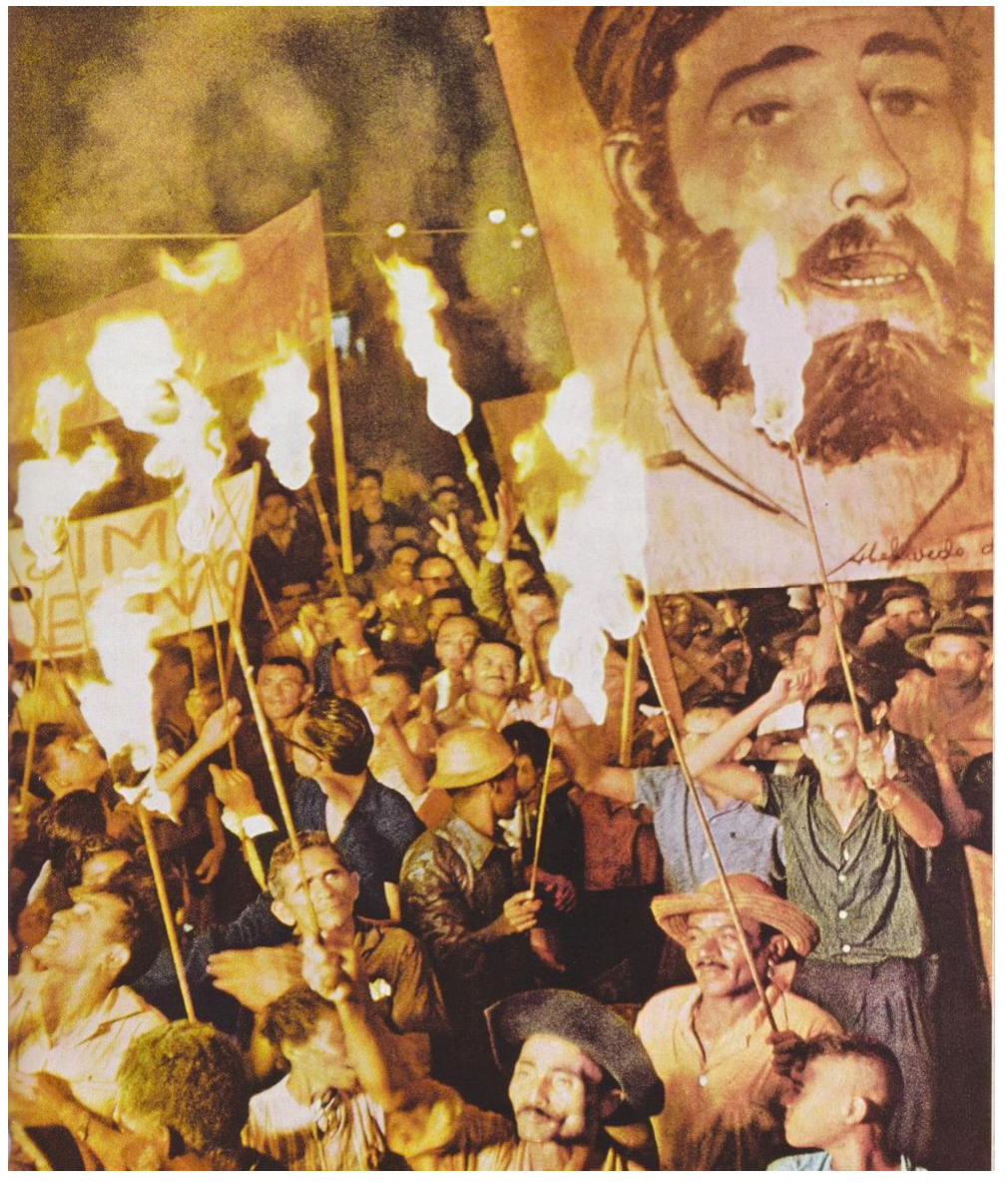




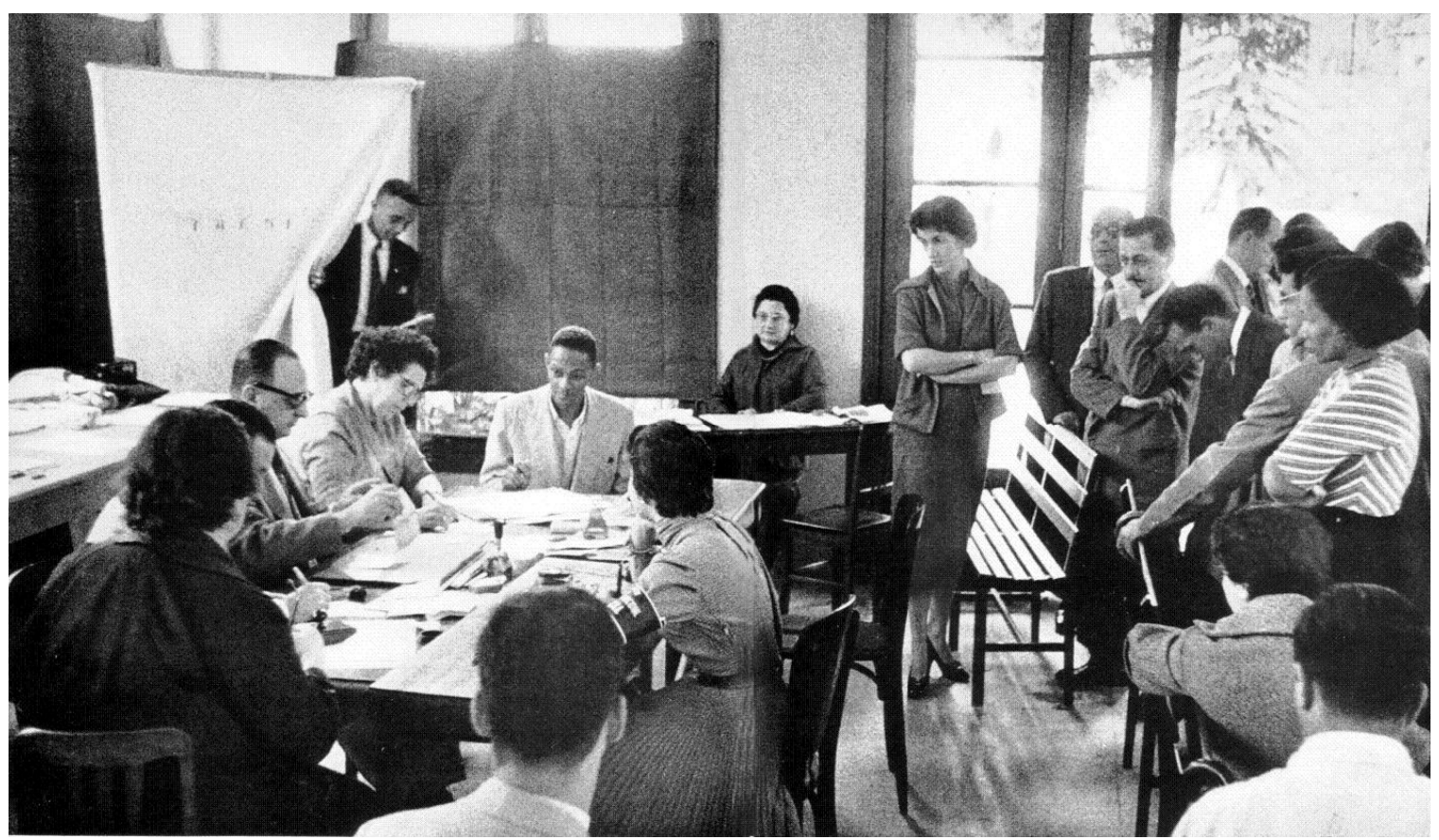

Figura 9 - Na edição de 1962, flagrante de uma eleição no Rio de Janeiro. (Brazil, 1962, p.150-151)

Figura 10 - Na edição de 1970, a foto é substituída por uma imagem do canteiro de obras da rodovia Belém-Brasília. (Brazil, 1970, p.150-151)

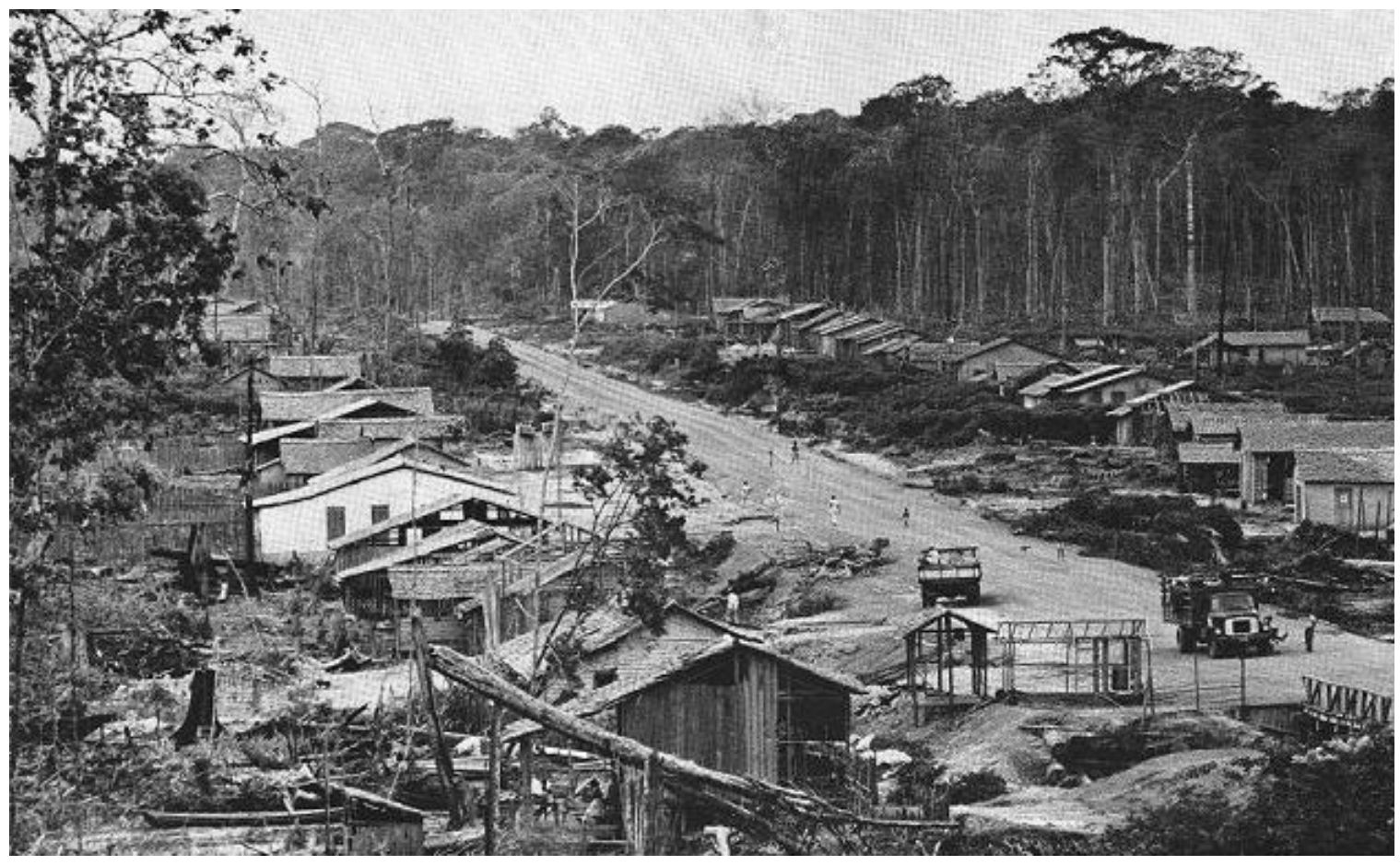




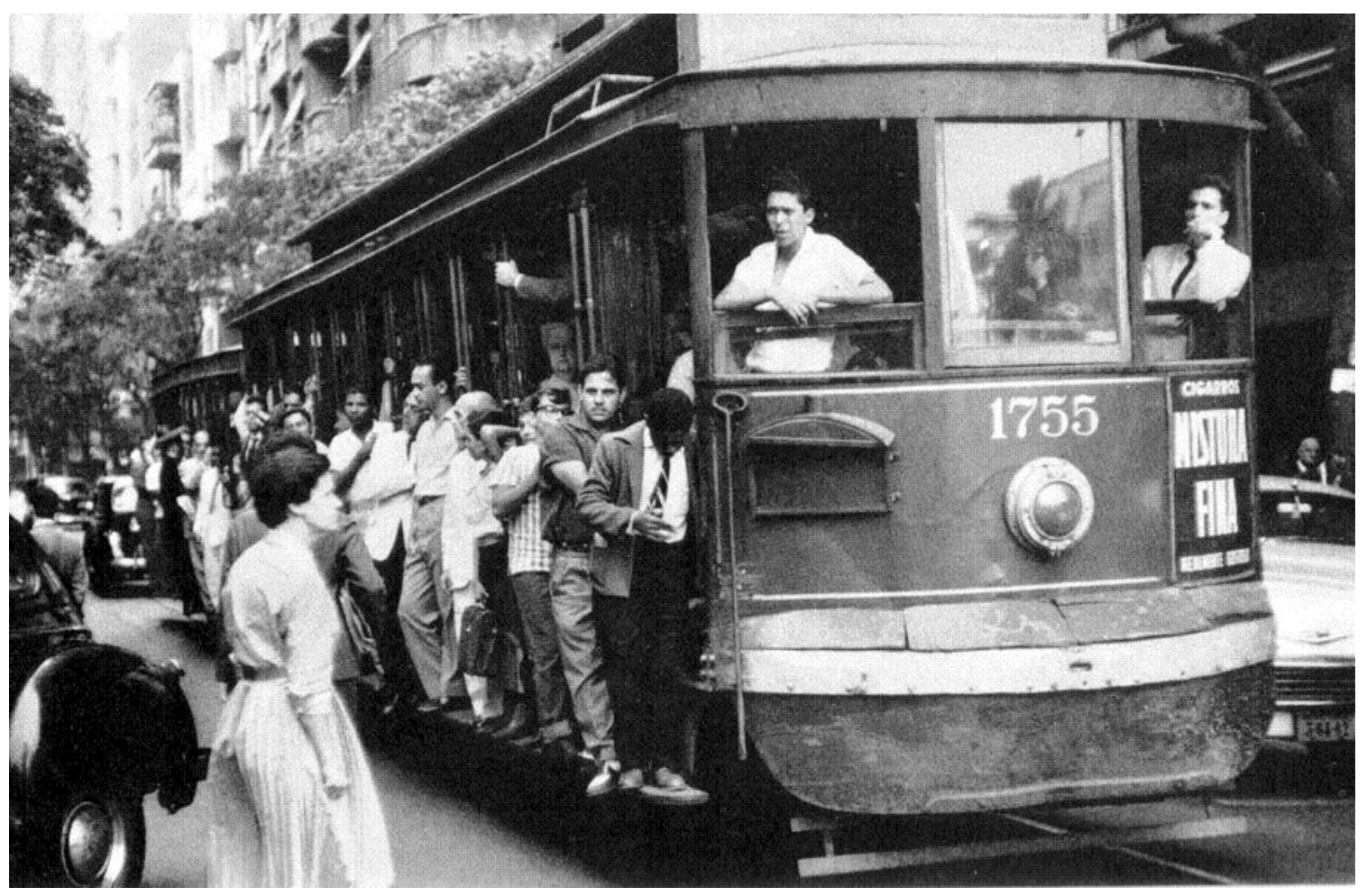

Figura 11 - Elizabeth Bishop comenta, no capítulo 10, a paciência dos trabalhadores à espera de condução no Rio de Janeiro. (Brazil, 1962, p.16)

Figura 12 - Na edição de 1970, os bondes foram substituídos por ônibus, mas as filas são as mesmas. (Brazil, 1970, p.16)

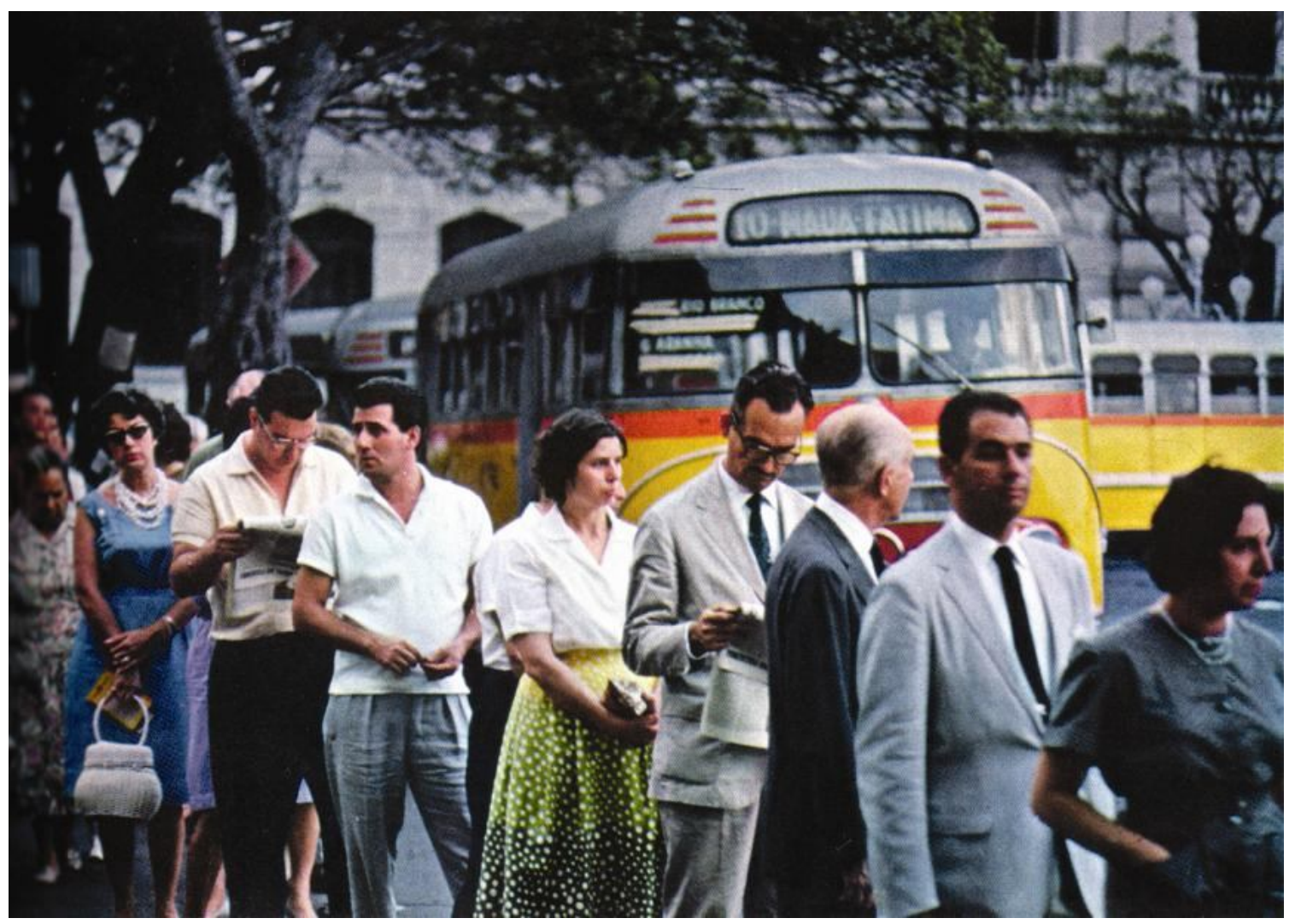


Figura 13 - Grande Prêmio Brasil, no Rio de Janeiro. (Brazil, 1962, p.49)

Figura 14 - Grande Prêmio Brasil, no Rio de Janeiro. (Brazil, 1970, p.49)
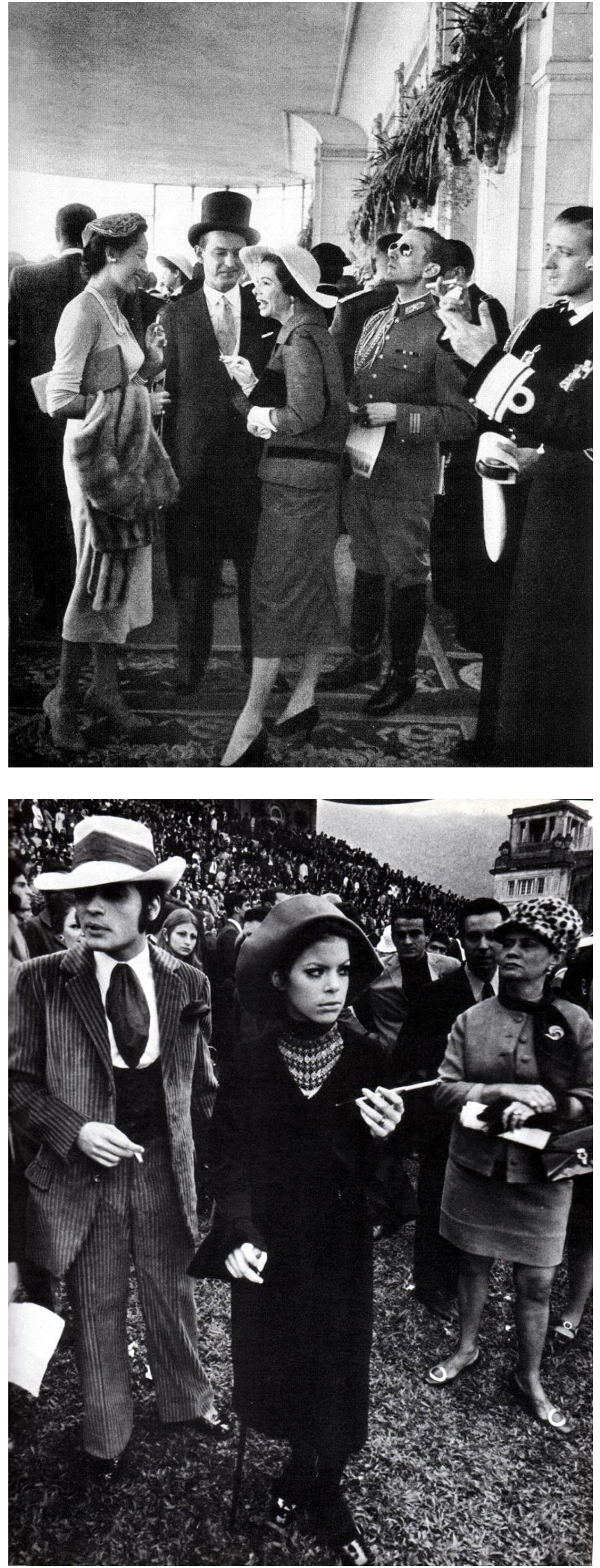
Figura 15 - A capa de Brazil, publicado em 1962 como coautoria de "Elizabeth Bishop e os editores de Life". A mesma capa foi mantida até a última edição, de 1970.
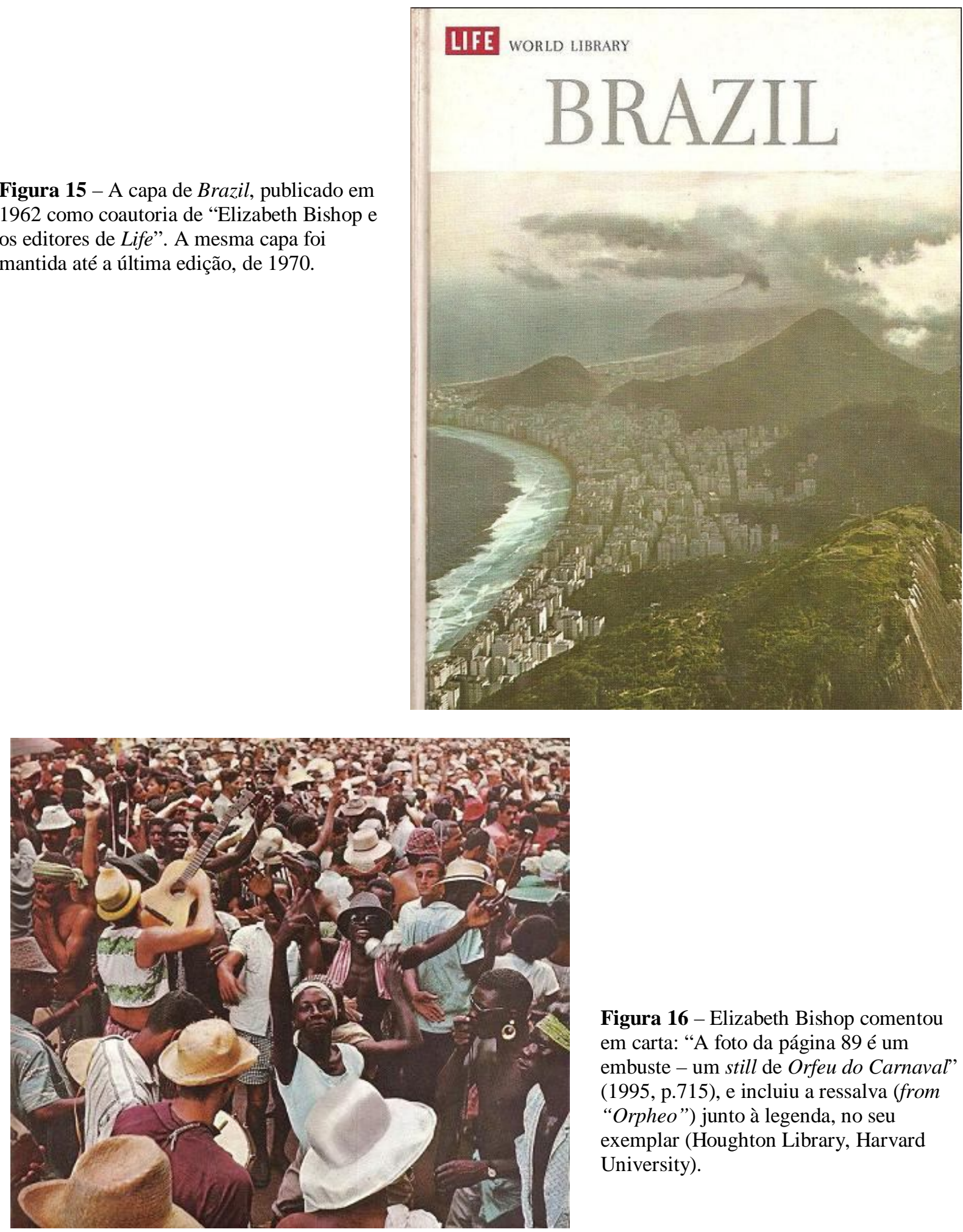

Figura 16 - Elizabeth Bishop comentou em carta: "A foto da página 89 é um embuste - um still de Orfeu do Carnaval" (1995, p.715), e incluiu a ressalva (from "Orpheo") junto à legenda, no seu exemplar (Houghton Library, Harvard University).

\section{frenzy is usually good-humored and sober.

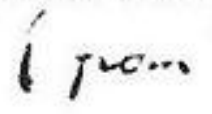

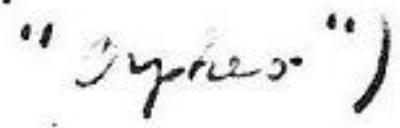




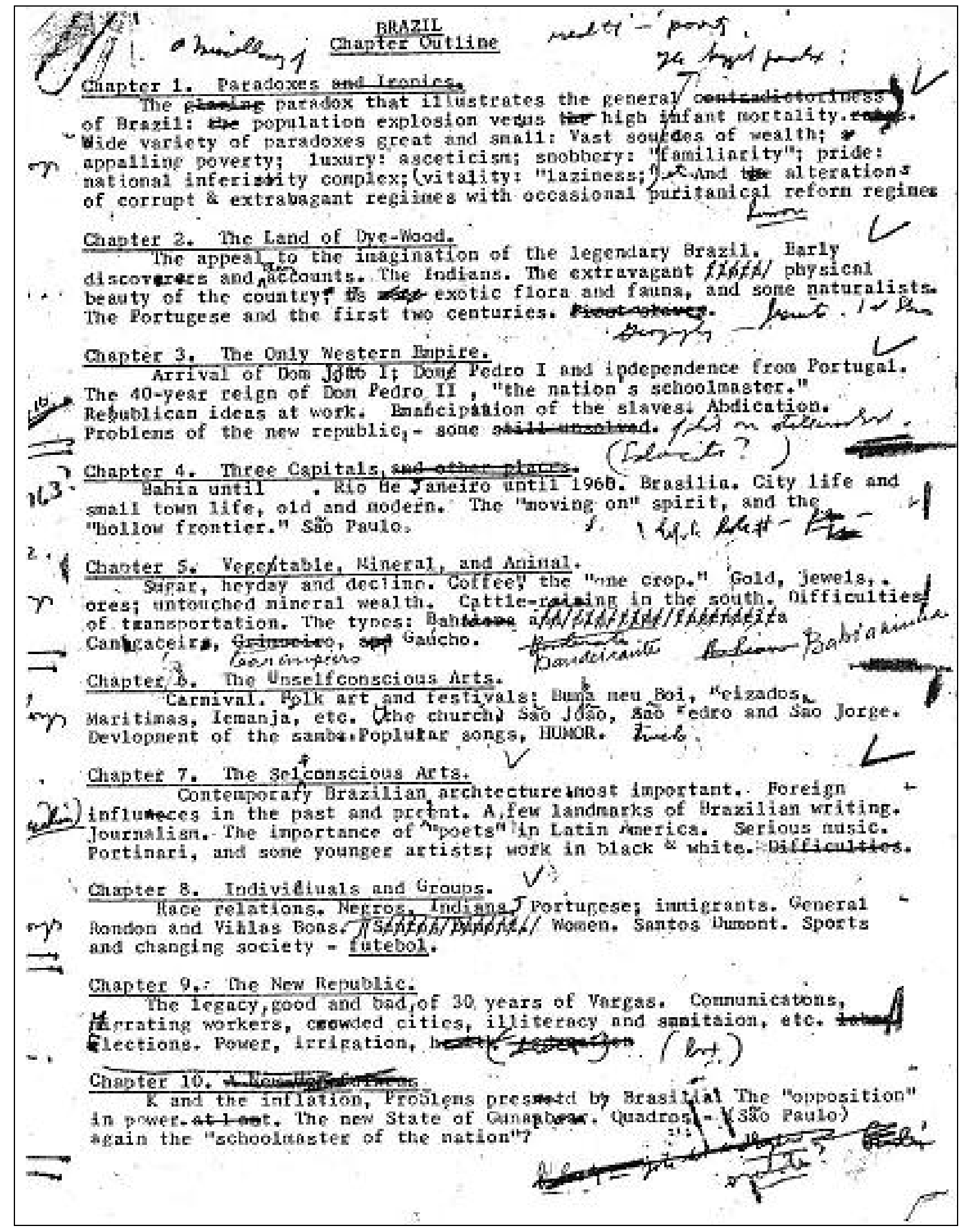

Figura 17 - Esquema para a redação dos capítulos de Brazil. Vassar College, Special Collections. 


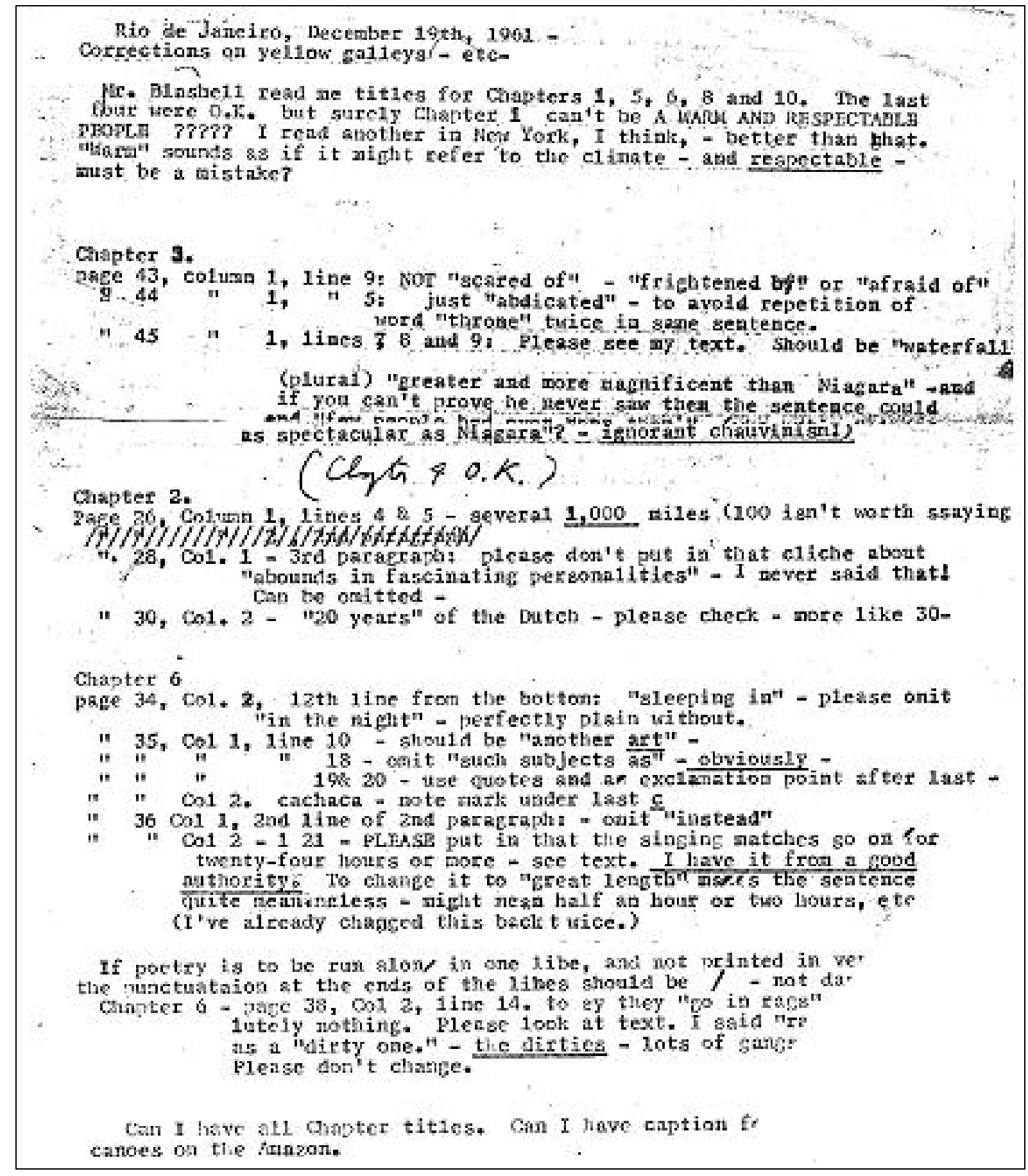

Figura 18 - Rascunho de carta de Elizabeth Bishop aos editores de Brazil, 19 dez. 1961, página inicial. Vassar College, Special Collections. 


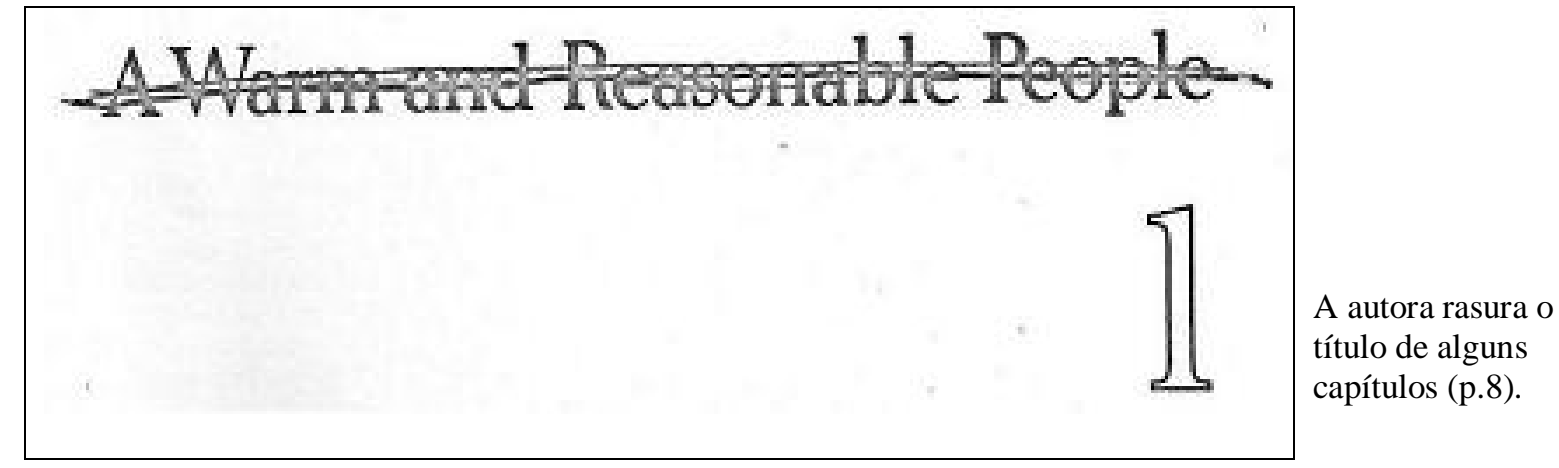

2

Undeveloped

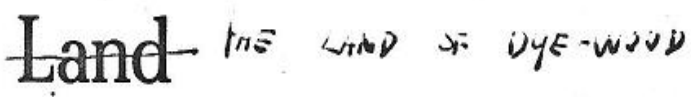

of Legend-

Alguns títulos de capítulos são substituídos pelos originais, como "A terra do pau-brasil" (p.25).

\section{AFrontier Gapital's Jet-Age Splendors-}

A autora rasura alguns subtítulos (p.59). magnificent city the federal goternment has planted in their midst,

the country's current inflation, the soaring cost of living, the shifts of power in the govern.
Observação na legenda de uma foto de Brasília: trata-se da inauguração da cidade (p.9).

Figura 19 - Correções de Elizabeth Bishop em seu exemplar de Brazil (1962), Harvard University. 


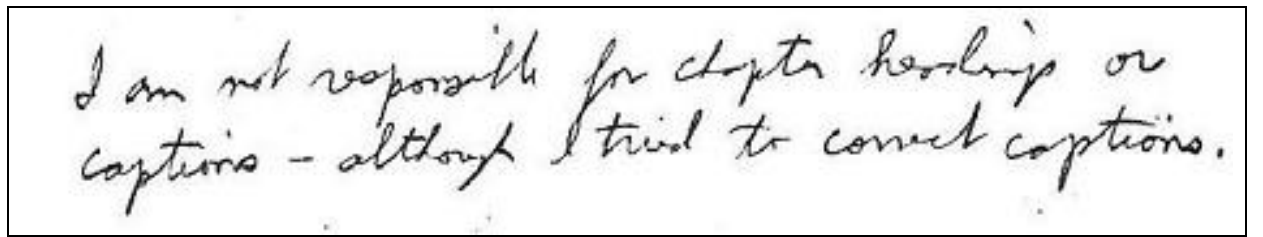

Junto ao Sumário (p.5), a autora informa que não é responsável pelas legendas, e que tentou corrigi-las.

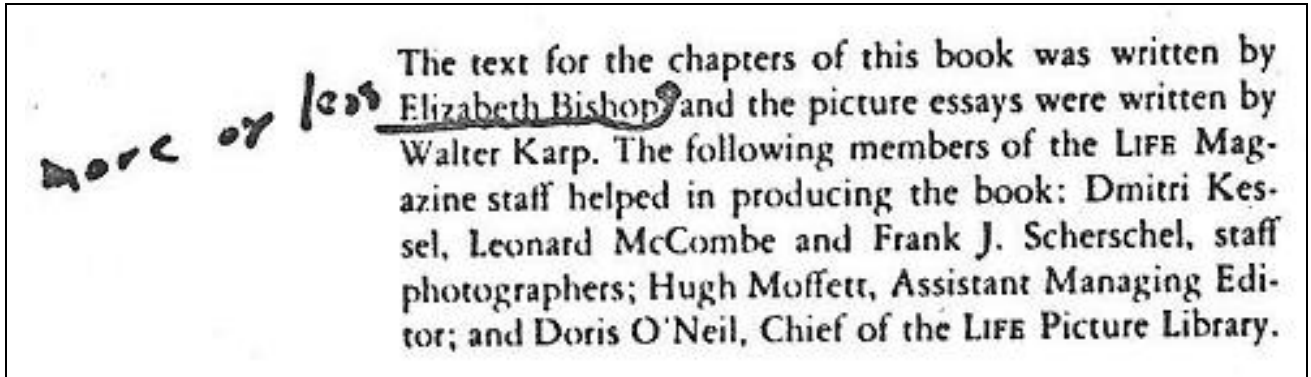

O texto foi escrito "mais ou menos" por Elizabeth Bishop (p.6).

All of these things and more are treated in this book published by the Editors of LiFE. The magnificent picture eșsays supplement Miss Bishop's beilliantext in order to bring the reader a better understanding of our South American sister republic. It is a timely volume. For misunderstanding is the handmaiden of ignorance; and friendship, understanding and cooperation between Brazil and the United States were never more necessary than they are today.

Na Introdução, assinada pelo exembaixador John Moors Cabot, a autora rasura o "brilhante" que qualifica seu texto (p.7).
In the Mato Growo, Intromo receive inoculations at a rural clinic.

$$
\text { trazilien }
$$

A foto retrata brasileiros, e não índios. A correção será feita na edição de 1970, onde eles se tornarão camponeses (p.149).

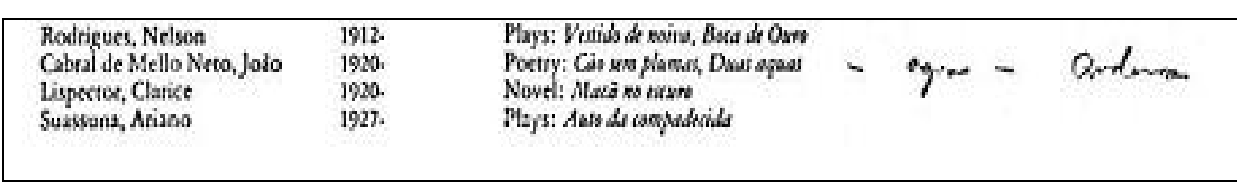

The sabia, a rather fat thrush, is to Brazilian poetry what the nightingale is to English verse Carlos Gomez uses its song in the interlude of poctry. his opera The Slave, and 19th Century Brazilian literature is full of sabiás.
Correção (águas) e complementação (Quaderna) na obra de João Cabral (p.155).

Figura 20 - Correções de Elizabeth Bishop em seu exemplar de Brazil (1962), Harvard University. 

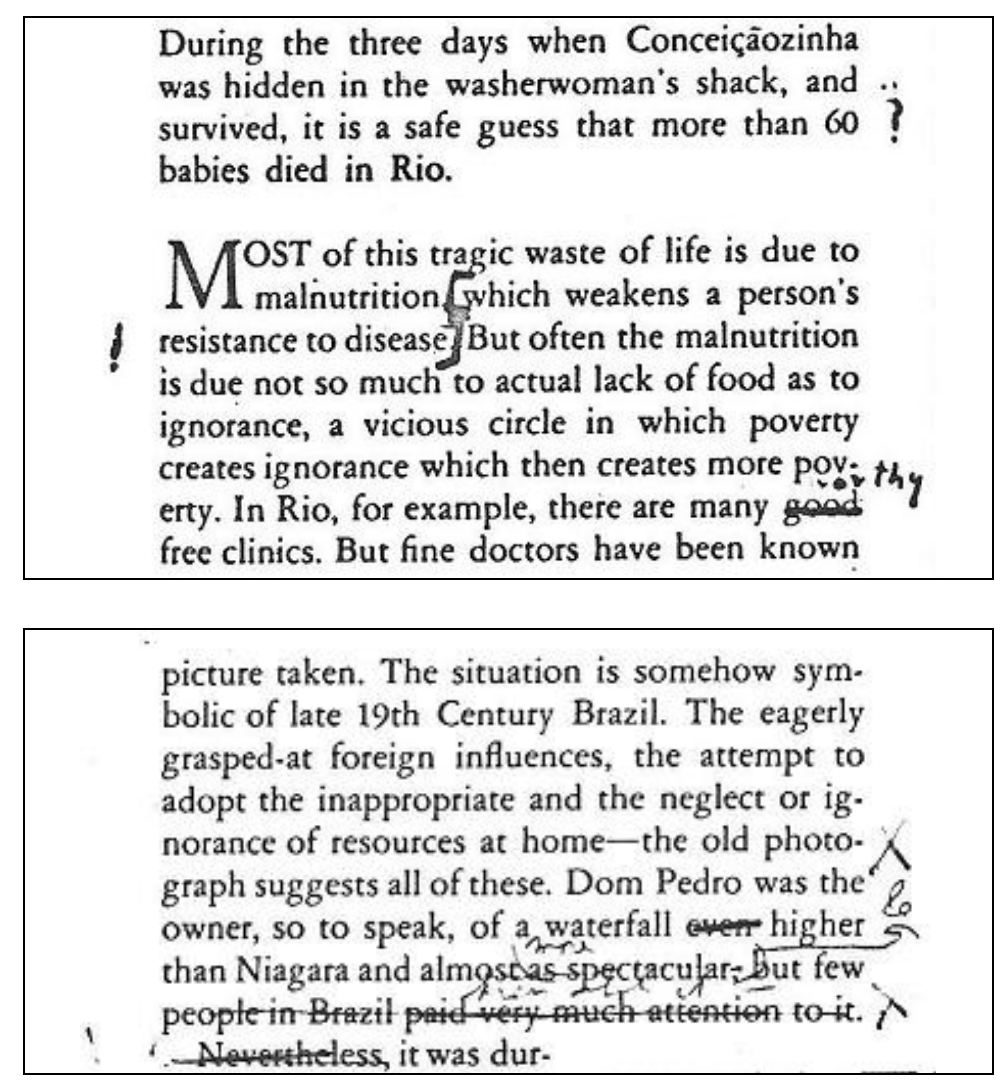

Neste trecho, dúvida, corte e substituição (p.11).

Nos comentários sobre as cataratas de Iguaçu e Niágara, a autora busca recuperar a redação original (p.45).

\begin{abstract}
$\mathrm{AT}^{\mathrm{T}}$ the center of this industrial complex lies the city of São Paulo itself. It was a quiet town of 25,000 people 0 nly 80 years ago. Today it covers 535 square miles and, with a population of 4.8 million, is the eighth largest metropolis in the world. Its traffic problem is even worse than that of New York, and it has a bustling, cosmopolitan atmosphere, although with its white, modern skyscrapers and many ? parks it remains intensely Brazilian.
\end{abstract}

GEW countries show greater respect for the arts and for culture than Brazil-and in few countries is the respect more merited. For example, there is certainly more good contemporary architecture in Brazil today than in any

$x$ other of the morld's under-industrint cenn. tries. None of the cities along the coast, from Recife to Pôrto Alegre, is without its small but ever-growing cluster of modern "skyscrapers." A Brazilian skyscraper is not necessarily very high, busa 10 - or 12 -story building thrusts so far above earlier, lower buildings that it qual.
Nos comentários sobre São Paulo, corte, dúvida e inversão de trecho (p.72).

Figura 21 - Correções de Elizabeth Bishop em seu exemplar de Brazil (1962), Harvard University. 


\section{3}

\section{Captando o outro: um país}

No início do século XXI, quando as fronteiras econômicas entre as nações se desfazem, enfraquecendo a vigência de conceitos políticos e culturais clássicos em nome de certa "globalização", pode parecer irrelevante interpretar um país e confrontá-lo aos demais, como se buscava fazer há algumas décadas. Para muitos dos que se orientam apenas pela perspectiva econômica, as diferenças fundamentais entre as nações podem resumir-se, hoje, à distância, em nível de desenvolvimento, que as separa do modelo norte-americano a ser alcançado. Afinal, o desaparecimento do bloco soviético marcou o fim da Guerra Fria e a configuração de um mundo unipolar. Mas é nesse ambiente que acontecem os ataques de 11 de setembro de 2001 e o governo dos Estados Unidos se sente levado a enfrentar, ou engendrar, um novo "outro", um novo inimigo.

Os ataques terroristas aguçaram a curiosidade de políticos norte-americanos para o modo como o restante do mundo vê seu país e seu povo. Assim, não surpreende que se lancem, nos anos seguintes a 2001, estudos como America against the world: how we are different and why we are disliked [Os Estados Unidos contra o mundo: como somos diferentes e por que não gostam de nós], de Andrew Kohut e Bruce Stokes, publicado em 2006. Mas não temos, aí, uma interpretação no sentido tradicional: esse livro, que reúne dados do Pew Global Attitudes Project, 2002-2005, promovido pelo conceituado Pew Research Center, baseia-se em pesquisas de opinião pública realizadas em países com diferentes graus de desenvolvimento, entre os quais o Brasil, e concentra-se na elaboração e descrição de dezenas de tabelas e gráficos. Esses elementos, que em interpretações sociológicas e econômicas mais vigorosas não passam de ferramentas, tornam-se aqui protagonistas, e a 
questão principal dos autores consiste em descobrir, observando essas sequências de números, "como nossas atitudes alimentam o crescimento do antiamericanismo". 1

No Prefácio de America against the world, a ex-secretária de Estado e ex-embaixadora de seu país nas Nações Unidas Madeleine Albright lembra que ela mesma já foi uma imigrante nos Estados Unidos, que lhe abriram as portas quando o comunismo tomou o poder na Tchecoslováquia, onde nasceu. Albright afirma que, até poucos anos atrás, nunca teria imaginado prefaciar um livro com esse título, afinal, "os americanos haviam cruzado dois oceanos para ajudar a salvar a Europa e a Ásia do fascismo e do imperialismo" (em Kohut \& Stokes, 2006, p.ix). Seria preciso investigar os motivos que levaram a existir, agora, um abismo entre "como nos vemos e como os outros nos veem", a ponto de os americanos não mais poderem "estar seguros em relação ao respeito, apoio e, sim, afeição dos povos de outros países” (p.ix). Segundo a ex-secretária de Estado, um dos modos de analisar o problema consistiria em considerá-lo um "gigantesco mal-entendido". Sem nenhum traço de ironia, sugere: "Se ao menos as pessoas soubessem que somos em geral religiosos, amamos nossos filhos, somos generosos e temos objetivos elevados, certamente voltariam a gostar de nós" (p.x). Tudo isso em torno da meta principal: "restaurar a imagem e a liderança dos Estados Unidos em todo o globo" (p.x).

Aos que questionam "o que podemos aprender com as pesquisas", Madeleine Albright responde com um exemplo: uma grande pesquisa de opinião pública realizada na antiga União Soviética entre 1989 e 1991, às vésperas do seu colapso, apontou não só "um enorme entusiasmo pela democracia, vista como um conceito abstrato", mas também "uma enorme ignorância acerca do que esse sistema de governo iria, na realidade, implicar" (p.x). Pesquisas como essa permitem, segundo Albright, conhecer algo a respeito das expectativas de outros povos e, assim, prever reações, o que certamente auxilia na definição de estratégias políticas e econômicas: para os autores do livro, os resultados do estudo realizado na União Soviética "anteciparam dificuldades a serem enfrentadas na transformação da vida política e econômica, do comunismo para a democracia e o capitalismo" (p.xvi).

Questões semelhantes a essas levaram à realização de outra grande pesquisa, em 2001, inicialmente voltada para o estudo "do impacto e das consequências da globalização", mas seus objetivos foram ampliados e alterados após o 11 de setembro, e as respostas obtidas estão em America against the world. Segundo Albright, o importante agora é definir estratégias para que seu país não perca a hegemonia: se os Estados Unidos não conseguirem permanecer

\footnotetext{
${ }^{1}$ A frase aparece com destaque na apresentação que consta na capa do livro.
} 
como líderes, "um vácuo será criado e outros seguramente o preencherão, e é impossível prever as consequências disso" (p.xi).

As pesquisas de opinião pública desempenham papel fundamental na política americana há décadas, diferentemente da maioria dos outros países, mas só durante a Guerra do Vietnã seus resultados passaram a ser levados em conta "pelos que decidem a política externa dos Estados Unidos" (Kohut \& Stokes, 2006, p.xv). Atualmente, esse comportamento vem sendo copiado "pela maior parte do mundo" (p.xv). Mas os autores de America against the world não questionam as consequências da divulgação dessas estatísticas, tampouco a possibilidade de sua manipulação. Na Conclusão do livro, afirmam ter "demonstrado, com dados, que os americanos apresentam padrões de pensamento e de valores que os distinguem dos europeus e de outros povos" (p.220). Embora "todos os povos sejam virtualmente excepcionais em alguns aspectos", o excepcionalismo americano é importante apenas porque seu "poder e sua influência são excepcionais num mundo unipolar" (p.220). Algumas das conclusões, entretanto, parecem minimizar esse excepcionalismo: "os americanos não são mais religiosos que muitos muçulmanos do Oriente Médio ou católicos da América Latina" (p.221), ou "o nacionalismo americano é muito mais benigno que o imperialismo britânico do século XIX" (p.223), ou ainda "a intervenção no Iraque tornou-se uma guerra impopular não porque foi vista como uma ação incorreta, mas porque não funcionou" (p.223). De qualquer maneira, é o excepcionalismo americano que "define as atitudes em relação aos Estados Unidos por todo o mundo", e está "inextricavelmente relacionado ao antiamericanismo" (p.225). Sobre todo o livro paira uma questão: por que o mundo inteiro não se uniu de imediato em torno dos Estados Unidos, após os ataques de 11 de setembro de 2001 ?

A análise dessa série de pesquisas que envolveu mais de 90 mil pessoas (como se lê na p.245 do livro), mil delas no Brasil, inclui a constatação de que o individualismo americano "não vai mudar". Em todo caso, se os americanos querem "encontrar um modus vivendi com seus críticos, tanto o mundo como os americanos terão de se adaptar" (p.225). Essa expectativa pode parecer nova na voz dos autores de America against the world, mas já teve destaque em outras épocas, sobretudo no período anterior à Segunda Guerra Mundial, quando se instaurou a política da "Boa Vizinhança" e os Estados Unidos procuraram consolidar sua influência na América Latina diante da escalada do nazifascismo. ${ }^{2}$ Entre as estratégias de

\footnotetext{
${ }^{2}$ A política da Boa Vizinhança foi proposta por Roosevelt em 1933, com o objetivo de "acabar com a intervenção armada norte-americana na América Latina..." (Junqueira, 2000, p.149). Posteriormente transformou-se em instrumento para barrar a crescente influência alemã na região, mas "já sinalizava o lugar dominante que os Estados Unidos ocupariam depois da guerra. Certas políticas ... constituíram-se em bases das políticas do pós-guerra" (p.149).
} 
aproximação, promoveu-se o intercâmbio de intelectuais para a realização de palestras, documentários e textos, jornalísticos ou não. Era preciso "mostrar o norte-americano como simpático e bem-intencionado, e ... mostrar aos norte-americanos que os latino-americanos não eram povos de culturas tão distantes da norte-americana” (Junqueira, 2000, p.150).

Mas não seria adequado esperar de intelectuais respostas simples, unívocas, ou conclusões semelhantes às das "pesquisas de opinião", ainda mais quando pudessem gozar de liberdade na escrita. Um livro aparentemente despretensioso, mas revelador do relacionamento entre Brasil e Estados Unidos em meados do século XX, é Gato preto em campo de neve (1941), de Érico Verissimo (1905-1975), escritor brasileiro que se beneficiou da "Boa Vizinhança" e percorreu aquele país durante três meses, no início de 1941, fazendo em 14 cidades "quase trinta conferências" (p.417) programadas pelo Departamento de Estado norte-americano. ${ }^{3}$ Nas mais de quatrocentas páginas do livro, Verissimo segue a receita mas não se restringe a um relatório inteiramente previsível: discute essa política de intercâmbio, descreve o desconhecimento mútuo de Estados Unidos e América Latina e reflete sobre a possibilidade e os meios de o estrangeiro interpretar um país vasto e contraditório.

Verissimo cita, por exemplo, o comentário que ouviu do escritor Hendrik van Loon, de origem holandesa: "Boa vizinhança é besteira. Você acredita em good will e em todas essas bobagens? Se você gosta de mim, vem à minha casa, conversa comigo, come à minha mesa. $\mathrm{E}$ amanhã eu faço o mesmo na sua casa. Tudo isso natural, sem discursos nem publicidade. Passamos a vida inteira ignorando a América do Sul. E agora, de repente, toca a fazer boa vizinhança a todo o vapor! É ridículo" (Verissimo, 1941, p.151). E o escritor britânico Aldous Huxley, entrevistado pelo brasileiro na Califórnia, comenta: "Não é mesmo curiosa a maneira como aqui em Hollywood eles interpretam o good-will? Põem o visitante entre duas moças bonitas em trajos de banho e batem fotografias... Não foi o que fizeram com o senhor?" (p.381).

Érico Verissimo descreve as contradições enfrentadas em seu papel de agente da boa vizinhança: um funcionário do Departamento de Estado providencia para que não se reviste sua bagagem na chegada aos Estados Unidos (p.34), mas o colega da alfândega promove um verdadeiro inquérito:

— Quem foi que lhe pagou a passagem? — indaga o funcionário, erguendo para mim um par de olhos azuis e aguados.

\footnotetext{
${ }^{3}$ O mesmo programa levou aos Estados Unidos, entre outros, Sérgio Buarque de Holanda, Pedro Calmon e Luís Jardim.
} 
- O governo americano.

- Por que motivo?

Hesito um instante e, para encurtar a história, resumo a duas palavras:

- Boa vizinhança.

— Que veio fazer?

— Viajar, ver pessoas e coisas. E fazer conferências... se não houver outro remédio.

- Tem passagem de volta garantida?

- Claro.

— Onde está?

— Vou recebê-la mais tarde.

— De quem?

— Do governo americano. (p.32-33)

Depois de percorrer milhares de quilômetros pelos Estados Unidos, Verissimo confessará ter sentido a impressão de que "somos pobres 'nativos', afilhados duma senhora muito rica e caritativa - madrinha América - que nos dá prêmios de viagem, bolsas de estudo e matrículas gratuitas, para que sejamos sempre bons meninos" (p.220). Os mexicanos, segundo ele, logo perceberam "a febre pan-americanista" que levava o país vizinho a procurar "palmeiras verdes, muchachos, señoritas, rumbas e congas", e se organizaram "para explorar esses sentimentos. Abrem bazares ... abrem cabarés com nomes pitorescos...” (p.317). Segundo o escritor e roteirista James Hilton, também entrevistado, "por causa da política de boa vizinhança os 'homens maus' dos filmes não podem nunca ser brasileiros, peruanos, mexicanos, argentinos. Têm que ser necessariamente norte-americanos... ou ingleses” (p.312).

Érico Verissimo viaja pelos Estados Unidos propondo-se a "ver tudo com imparcialidade" (p.413), e afirma, entre parênteses, não ter "o menor desejo ou intenção de incensar homens de governo do Brasil ou da América do Norte" (p.417). ${ }^{4}$ Tem em mãos uma cine-Kodak e, em vez de paisagens naturais, prefere filmar os "companheiros de viagem" (p.19). Após um jantar, quando é obrigado a "fazer um speech", fala "com a Kodak na mão" e, invertendo os papéis, termina "com a objetiva no olho, filmando em cores naturais a pitoresca e variada sociedade que aqui temos hoje" (p.227).

Verissimo considera natural o fato de fazer anotações sobre o país que visita, uma vez que "a gente passa a vida comparando" (p.43). Não tem a pretensão de interpretar ou sintetizar o país, nem mesmo de "haver compreendido os Estados Unidos, nem de ser

\footnotetext{
${ }^{4}$ No que se refere a outros governos, Verissimo limita-se a repetir, buscando não se posicionar, o que dizem seus entrevistados. Por exemplo, Somerset Maugham sobre Portugal e seu ditador: "tem um bom governo. Salazar é indiscutivelmente um grande homem" (p.238).
} 
portador de palavras, fórmulas ou imagens capazes de chegar a uma definição, a uma pintura completa" (p.392). Afinal, "como penetrar a alma dum povo tão complexo, como percorrer todo um território humano e geográfico tão tumultuosamente vasto, rico e vário - no curto espaço de três meses?" (p.7): "a simples e pura tentativa de descrever Nova York chega a ser de um ridículo doloroso" (p.124). Compara sua tarefa à montagem de um jogo-de-armar e conclui: "não será insensato tentar armar o jogo com elementos tão escassos?". Seu objetivo é declaradamente modesto: "Se com estas páginas eu tiver dado a você alguns momentos de leitura agradável e a ilusão de que viajou comigo, declaro o meu alvo atingido e passo tranquilo ao próximo livro" (p.9).

De que adianta criar expectativas? Decepcionado com as "casas tristes" do bairro boêmio de Manhattan, que "está longe de ter a cor e o romance que eu imaginava" e onde é maltratado por um italiano, Verissimo confessa que "nem sempre ... a gente pode ajudar a realidade...” (p.161). Em Hollywood, confessa: "Manda a verdade que se diga, em prejuízo do pitoresco, que nem sempre estamos topando com coisas invulgares e que nem a todas as horas Hollywood é a animada feira das originalidades" (p.331). Os prédios de Nova York "na realidade são menos claros, menos limpos e menos novos" (p.39), confrontados à idealização de quem só os conhecia por fotografias. E o escritor não esconde a decepção diante do Mississippi, em Nova Orleans, "um feio rio de águas pardas" onde "o famoso cais não oferece o menor atrativo" (p.270). Horrorizado com a poluição de Chicago, espera que a cidade tenha "um lado poético" e completa: "tentar descobrir-lhe esse segredo não será acaso um ótimo divertimento para os dez dias que aqui vou passar?” (p.219). A tabuleta de uma estação ferroviária informa que o escritor está em "Newton", mas, como a cidade não consta no seu mapa, "não tem existência oficial” (p.289). Ao descrever o interior luxuoso da Casa Branca, o ficcionista tem "a leve impressão de estar mentindo", mesmo depois de "dez anos de romance" (p.48). Em outra ocasião, ao visitar uma feira livre no bairro judeu de Chicago, afirma:

Não creio possa eu dar em palavras uma ideia do que estou agora vendo. Descrição exige método, lógica, clareza, disposição harmoniosa dos períodos ... O escritor de ficção se alvoroça diante do material vivo que se lhe oferece tão fácil e abundante. Mas a criatura humana reage contra esse alvoroço. E dessa luta confusa fica apenas uma sensação de mal-estar, constrangimento e fria tristeza. (p.229) 
Uma das qualidades que nos atraem em Gato preto em campo de neve ${ }^{5}$ está na clareza com que Verissimo expõe as fontes em que se apoia ao construir seu livro: "os dados sobre famílias foram colhidos numa publicação do Ladies' Home Journal" (p.403), e "muitas das informações" sobre cinema "tirei de um admirável livro de Margaret Thorp, America at the movies" (p.323). O autor também confessa, em nota, sua intervenção posterior na transcrição de entrevistas:

Este diálogo não foi taquigrafado, mas as palavras aqui reproduzidas são exatamente as de Mr. David Daiches [da Universidade de Chicago], pois tive o cuidado de mais tarde confrontar e enriquecer minhas notas com os escritos desse ensaísta. O mesmo se passou nas subsequentes entrevistas com W. Somerset Maugham, Thomas Mann e James Feibleman. (p.223)

Por todo o livro Verissimo quer informar seu leitor: faz longos levantamentos sobre o teatro norte-americano (p.171-179) e sobre a imprensa (p.180-182); ao falar do cinema, conta a história de Hollywood, e, quando se refere aos desenhos animados de Walt Disney, descreve as etapas de sua elaboração (p.365-366). Nos comentários sobre a censura no cinema, copia o Código criado em 1934 pela Legião Nacional da Decência, "amparada pela igreja Católica" (p.353-356).

Verissimo explica o significado de todos os termos que o leitor brasileiro, em sua opinião, desconhece: de pickets ("um tipo de greve", p.128) a cops (“tiras", p.130), por exemplo. A cafeteria aparece como "instituição representativa dos ideais americanos do 'mind your own busines' (cuide da sua vida), do 'cash and carry' (pague e leve), do 'live and let live' (vive e deixa que os outros vivam) e dum conceito esportivo de democracia" (p.50). Para as damas bem vestidas, um verbo tem "um sentido quase sagrado: to shop - fazer compras, ir às lojas” (p.308). Por fim, “dating é uma instituição sagrada. Quebrar um date (encontro, entrevista) é cometer um pecado mortal" (p.400).

Tudo merece atenção e registro: as casas que "não têm muros, nem cercado de espécie alguma" (p.55) - tanto que os filhos de um brasileiro, em San Francisco, "deixam os brinquedos na rua durante a noite; no outro dia está tudo aí. Ninguém toca neles" (p.307). Verissimo espanta-se com as "lojas de 5 a 10 centavos" (p.330); com as mulheres "metidas

\footnotetext{
${ }^{5}$ Logo de início, Verissimo explica que o título do livro "não tem nenhum sentido secreto ou simbólico. Referese apenas a um gato preto e anônimo que atravessou um campo de neve no Colorado, quando eu passava de trem" (p.7). Quando descreve a cena, todavia, confessa a "fascinação" experimentada naquele momento: "Um misterioso alguém está procurando dizer-me alguma coisa por meio dessas imagens em negro e branco. Mas quem? Quê?" (p.298).
} 
em calças compridas de homem, blusas de jersey e lenço na cabeça" (p.330); com a predileção pelas cores fortes, tanto na pintura das casas (p.55) como nos ingredientes dos sanduíches ("sempre o gosto pela cor!", p.41), ou na "horrenda gelatina verde que sabe a menta" (p.89). Nas cidades, o brasileiro percebe a falta de "lugar para deixar o automóvel" (p.111, 247). ${ }^{6}$ No comportamento, o "gosto pelas abreviaturas familiares" (p.308) e o hábito das "paradas festivas" (p.180). Nesse país que "tem horror às coisas mórbidas" (p.414), os remédios são vendidos em drugstores alegres que nada têm a ver com nossas farmácias, ${ }^{7}$ e o escritor não encontra "durante toda a viagem uma única pessoa de luto fechado" (p.414).

As roupas "boas e limpas" do povo chamam a atenção do escritor brasileiro, pois revelam "um nível de vida bastante mais alto que aquele que estamos habituados a ver nas grandes cidades sul-americanas" (p.38): é difícil "encontrar-se uma criatura de aspecto sujo" (p.134). Além disso, Verissimo viu "operários fumando a mesma marca de cigarros que fumam os patrões" (p.402). Mesmo os raros homens que o abordaram para pedir dinheiro "trazem boas roupas e estão de barba feita" (p.134).

A ironia está presente no livro: o visitante lê que "as mulheres americanas enviúvam cedo porque matam os maridos com alimentos em conserva e interiores superaquecidos" (p.36); na festa de uma sociedade literária, "algumas damas me parecem tão antiquadas que lembram velhos álbuns de família ... diviso fisionomias fechadas, expressões eruditas..." (p.118); interrogado por uma antropóloga que vive "nos domínios da estatística”, encolhe-se, "perdido na mais absoluta das ignorâncias", e conclui: "Ela deve ter alma, sim, mas é uma alma fria e eficiente de arquivo" (p.91-92). No Museu de História Natural, em Nova York, umas "duas dúzias de homens e mulheres, com ar douto, escutam em silêncio" a "voz brasileiríssima de Jararaca a gemer: Maта̃e eи quero" (p.171). Se lhe pedissem para ilustrar a principal diferença entre os dois povos, responderia com base numa homenagem recebida: "os rotarianos do Brasil nunca teriam coragem de cantar uma canção em que os visitantes são comparados com as flores da primavera", as "florinhas de maio" (p.374).

No final do livro, Verissimo utiliza um apêndice com mais de trinta páginas, "Diálogo sobre os Estados Unidos" (p.389-420), entre "o leitor" e "o autor", para resumir sua apreciação das características mais gerais do país. Enumera, por exemplo, "costumes, gostos e preceitos de acordo com os quais eles pautam a sua vida"; o último da lista já foi citado várias

\footnotetext{
${ }^{6}$ Quando Elizabeth Bishop volta aos Estados Unidos em 1968 e vai morar em San Francisco, comenta em carta: “Agora ... como todos os membros da grande classe média baixa americana passo boa parte do tempo procurando vaga para estacionar" (Bishop, 1995, p.555).

7 Ver, por exemplo, o comentário de Bishop sobre uma farmácia de Manaus, na "Viagem pelo Amazonas" (1960): "enorme, sombria, como um celeiro...".
} 
vezes: o "amor às cores vivas". E faz outros comentários: ali "não há a vergonha de ser operário" (p.398); "são um país de fundo religioso ... basta dizer que em inglês o uso da palavra hell (inferno), damn (maldição, danação) é blasfêmia; e o nome de Deus nunca é pronunciado em vão" (p.393); "procuram heróis - na história, no cinema, no teatro, nos livros, nos esportes, na vida cotidiana" (p.401). Os homens "não usam perfumes", e as mulheres "se perfumam com discrição e com um certo mau gosto. O perfume que mais senti durante toda a minha viagem foi o de gardênia" (p.403). Ao comentar um concurso de chapéus femininos, Verissimo conclui que os americanos são "um povo quase totalmente destituído do senso de ridículo", diferente dos latinos, entre os quais "a malícia, o espírito crítico e o horror ao ridículo nos tiram às vezes toda a espontaneidade" (p.393). E mais:

Os americanos são românticos, mas dum romantismo sem nenhum exagero meridional. Não têm o choro frouxo nem são muito expansivos em gestos e palavras. O abraço não é muito usado na América do Norte. Os homens, mesmo quando amigos íntimos ou parentes chegados, despedem-se com um simples aperto de mão. (p.412)

Vinte anos depois, a norte-americana Elizabeth Bishop dedicará vários parágrafos do primeiro capítulo de Brazil às características emocionais do nosso povo, com atenção especial para o hábito do abraço, também comentado em suas cartas. Se no século XIX o imperador Pedro II chocou o tímido escritor quaker norte-americano Whittier, ao tentar abraçá-lo (Brazil, p.44), em 1958 um dos jogadores da seleção brasileira de futebol "perdeu a cabeça e tentou abraçar o rei [da Suécia], à maneira brasileira” (Bishop, 1995, p.386). Os jogadores, aliás, "se abraçam e se beijam e choram de entusiasmo quando fazem um gol” (p.386).

\section{Boa vizinhança, guerra e autoimagem}

Érico Verissimo conhece os Estados Unidos em tempos de preparação para a guerra. Assim, aguça seu olhar de jornalista e permanece atento às condições de vida e aos hábitos da população. Em Nova York, visita a família de um desempregado que vive às custas do Estado. Em Washington conhece o Federal Writers' Project, que oferece a "escritores obscuros um ordenado razoável ... para que eles se entreguem à redação de livros de utilidade pública”. Esses livros são guias das cidades norte-americanas, "mas guias de caráter literário, com um esboço histórico, a descrição dos lugares pitorescos e românticos, estudos de caráter 
sociológico, econômico, político e artístico" (p.51-52). No inverno de 1941, esses escritores são "cerca de quatro mil".

Em Nova York o escritor nota "mulheres de rosto pintado e de expressão blasé. Homens pálidos com ar de fim de raça". E vem a saber que são "franceses ricos fugidos à invasão alemã ... São criaturas perfumadas, artificiais e melancólicas. Deploro-as porque no fundo elas parecem saber que isto é o fim ... bebem champanha e falam mal da América de que eles agora precisam, mas que no fundo desprezam” (p.36-37).

Os americanos com quem conversa declaram-se "decididamente favoráveis a um auxílio absoluto" à Inglaterra, atacada pelos nazistas, "mas repelem a ideia da guerra” (p.136). Verissimo transcreve um depoimento: "Como é que a gente vai querer guerra com a vida que leva? Comemos três vezes por dia. Não nos falta nada. Somos felizes. Para que guerra?" (p.136). E anota o que lê num cartaz: "Não permitamos que nossos rapazes vão, como em 1918, regar com seu sangue as papoulas de Flandres" (p.326). Na Califórnia, o brasileiro assiste a uma conferência de Henry Luce, "proprietário das revistas Time, Life e Fortune", que faz "a apologia da China e concita a colônia a auxiliar o povo chinês na sua luta contra os invasores" japoneses (p.389).

Verissimo afirma que em nenhum momento se deixou intimidar pelo fato de ser um visitante convidado em época de guerra. Diz que emitiu suas opiniões livremente, não só nas conversas particulares mas também nas conferências. Critica os homens de negócios norteamericanos que "só nos sabem descrever em termos de dólares e de capacidade aquisitiva" (p.142): "conheço dezenas de comerciantes do Brasil que sempre preferiram fazer negócio com firmas alemãs, por causa das condições que estas lhes ofereciam" (p.80). Só agora o "bom vizinho" está começando a descobrir o Brasil; "espero que não seja tarde demais" (p.142), diz ele, e completa: a maior homenagem que pode prestar aos anfitriões é "ser sincero". Quando lhe perguntam se é verdade que "nos clubes de aviação do Rio Grande do Sul há muitos alemães", responde: "e nos clubes de golf, muitos americanos" (p.377). Numa palestra, chega "a extremos de franqueza que fazem o cônsul brasileiro ... levar as mãos à cabeça, horrorizado. Mas o auditório sorri, tolera e aplaude” (p.243). Depois, esse cônsul lhe dirá: "Se você fizesse uma conferência assim em qualquer país sul-americano, usando dessa mesma franqueza, a esta hora estaria na Assistência ou na cadeia” (p.244).

O cônsul brasileiro em Boston, por sua vez, escreve artigos nos jornais, faz conferências e mantém numa estação de rádio local uma "hora do Brasil" (p.206). Está indignado com a revista Friday, que 
acaba de publicar uma reportagem perversa em torno de nosso país. Reproduzindo fotografias escolhidas com malícia e comentadas com o evidente propósito de criar sensação, procura o semanário nova-yorquino provar que o Brasil não passa dum conglomerado de negros e índios governados por meia dúzia de brancos, os quais por sua vez são dominados por elementos estrangeiros. (p.205-206)

Verissimo anota tudo o que se relaciona com o nosso país: em Saint Louis, encontra numa exposição duas salas dedicadas a Portinari; Guiomar Novais está fazendo recitais elogiadíssimos (p.291); Carmen Miranda, acompanhada pelo "Bando da Lua", "está fazendo furor num ato variado" (p.310). Em compensação, Mocambo é um café "em estilo brasileiro" onde a orquestra "brasileira" é composta "de muchachos centro-americanos" (p.359). A Smithsonian Institution desconhece Bartolomeu de Gusmão e Santos Dumont em um hangar todo dedicado à história da aviação, e o empregado do museu responde "com um encolher de ombros" (p.85) à reclamação do brasileiro.

As preocupações de Verissimo também revelam, é claro, o seu próprio mundo: "nunca tentamos [os latino-americanos] desmentir a lenda corrente de que não passamos dum bando de índios e negros preguiçosos que se alimentam de banana, de rumba e de macumba sob céu de trópico, de sol tórrido" (p.51); "cobras? Eu tinha 12 anos quando vi a última. Negros? Menos que nos Estados Unidos. Índios? Longe de ser um problema capital” (p.90). Também numa conferência repete que "não somos apenas um punhado de índios e negros", e, consciente de sua aparência "de índio", afirma que "isso não prova nada contra o que afirmei, pois é sabido que, conquanto eu tenha nascido no Brasil, não posso ser considerado um "produto de exportação"” (p.271).

Muitos de seus comentários mais grosseiros são dirigidos aos negros: o músico mulato “com uma cara grotescamente suína” (p.194), o porteiro de "andar paquidérmico" (p.216), a camareira "preta mal vestida e lerda" (p.253). No Harlem, “o bairro negro de Nova York", onde "a fisionomia das casas não é nada amiga" (p.143), o escritor brasileiro ouve um pregador, Father Divine, o qual fala "com uma deliciosa incoerência" (p.145) e propõe que os Estados Unidos "comprem as Américas Central e do Sul e transformem as três Américas numa única Democracia" (p.144).

Depois de se acostumar ao inglês do norte do país, o escritor viaja ao Sul e tem dificuldade em entender "estes criados pretos que falam num tom de quem chora ou de quem está morrendo de preguiça ou sono" (p.254). Apesar da série de comentários desse tipo, o brasileiro condena o preconceito e a segregação racial que observa no Sul do país, onde "as 
caras escurecem. Não é que haja apenas maior quantidade de pretos. É que existem tipos morenos" (p.254). Em Washington, “onde o Norte e o Sul se encontram", ele percebe “a pequena distância da monumental avenida, mas separado dela por um sólido muro de preconceito (como dar uma expressão pictórica a preconceito?), um cortiço pobre, onde negrinhos descalços jogam base-ball na lama” (p.92-93).

O que concluir sobre a "política da boa vizinhança" e as relações entre Estados Unidos e Brasil? Verissimo fecha seu livro afirmando que "se os brasileiros forem espiritualmente diferentes dos americanos, hão de rejeitar, repelir naturalmente os ideais e padrões de vida destes. Se não forem, não há razão para que não os assimilem” (p.419).

O gaúcho volta aos Estados Unidos em 1943, mais uma vez a convite do Departamento de Estado, para lecionar na Universidade da Califórnia. Leva a família e permanece no país até o final da guerra. ${ }^{8}$ O antropólogo Roberto da Matta (1997), que considera Verissimo "um dos mais inteligentes observadores da cena brasileira pelo contraste comparativo com o mundo americano" (p.196), recorre aos seus "famosos diálogos" travados nos Estados Unidos para ilustrar, por exemplo, a incapacidade brasileira de responder "não sei” (p.197). Da Matta embasa, com suas citações, parte de uma discussão que contrapõe o caráter brasileiro ("Você sabe com quem está falando?") ao americano ("Quem você pensa que é?", p.197).

Assim, por mais que Verissimo considere - ou finja considerar - seus comentários sobre os Estados Unidos como uma colagem descompromissada, décadas depois de sua publicação ainda é possível contradizer o autor e encontrar, em seu livro, tanto "predicado literário" como "valor informativo" (p.332), além de importante conteúdo ideológico. Ou seja, à sua revelia ou não, é possível encontrar, diluído no detalhado espelho norte-americano, tanto o rosto do Brasil como o do próprio autor.

Note-se que a publicação desse livro não sofreu injunções dos patrocinadores da viagem, tampouco dos editores. Tudo indica que Érico Verissimo realmente expressou seus pontos de vista com liberdade, mesmo quando se afastava do que certa visão norte-americana, ou antiamericana, poderia prever.

\footnotetext{
${ }^{8}$ As novas experiências estão descritas em A volta do gato preto (1946). Verissimo retorna aos Estados Unidos em 1953, a convite do governo brasileiro, para assumir a direção do Departamento de Assuntos Culturais da União Pan-Americana, na OEA, cargo que ocupa até 1956; depois disso, visita o país várias vezes.
} 


\section{Um país, um refúgio}

Um dos escritores entrevistados por Érico Verissimo durante sua primeira viagem aos Estados Unidos foi o austríaco Stefan Zweig (1991-1942), extremamente popular na época, o qual the falou "com muito carinho do Brasil" (p.200), país que visitara em 1936. Quando Verissimo entrevista o alemão Thomas Mann na Califórnia, pouco depois, este comenta que Zweig "falou do Brasil com grande entusiasmo" (p.294). O escritor gaúcho estava testemunhando, talvez sem o saber, um acordo em certo sentido semelhante aos da Boa Vizinhança. Em poucos meses Zweig seria acolhido no Rio de Janeiro pelo governo Vargas, o mesmo que fechava as portas para outros judeus perseguidos por Hitler, negara visto de entrada para Lévi-Strauss, extraditara Olga Benário, a companheira de Luís Carlos Prestes, e ainda não se havia posicionado claramente na guerra. E, no mesmo ano, Zweig iria publicar o livro Brasil: um país do futuro (1941), a sua interpretação do país. O jornalista Alberto Dines, prefaciador de uma nova tradução desse livro para o português (2006), comenta que o escritor austríaco fez "efetivamente um negócio com o governo brasileiro: em troca do livro, que pretendia escrever desde o término da primeira viagem, receberia junto com a mulher um visto de residência permanente" (p.8). Em fevereiro de 1942, todavia, menos de seis meses após a publicação, o casal se suicidou em Petrópolis, inserindo um fecho de trágica ironia à escrita do livro e ao seu título.

Dines afirma que esse título transformou-se "em cognome, sobrenome, estigma e vaticínio. País-promessa, terra do nunca, nação do amanhã - a expressão pode ser entendida em todos os sentidos" (em Zweig, 2006, p.7). Ressalva, entretanto, que "até hoje não se sabe exatamente o que o austríaco pretendia dizer com esse sugestivo e enigmático jogo de palavras (um país ou $o$ país, do futuro ou de futuro?)” (p.7). Ainda segundo ele, a ideia do título não foi do escritor, mas do tradutor para o inglês, "que o pescou em francês na epígrafe da obra" (p.7). ${ }^{9}$

O livro de Zweig foi "massacrado pelos críticos" brasileiros, pois, como lembra Dines, "era proibido encantar-se com um país dominado por uma férrea ditadura onde a máquina da propaganda oficial era a única que se manifestava livremente" (p.8). Os defeitos do livro não estavam apenas no elogio monótono às qualidades do país e de seu povo, mas também no

\footnotetext{
${ }^{9}$ A epígrafe, onde consta "Un pays nouveau ... une terre d'avenir ...", reproduz o conselho de um diplomata austríaco ao embaixador francês Gobineau, em meados do século XIX, "quando este hesitava em aceitar o cargo de enviado ao Brasil” (Zweig, 2006, p.11).
} 
eurocentrismo de seu autor: tudo, para o bem ou para o mal, era tomado de um ponto de vista externo. Segundo Dines, entretanto, "poucos perceberam que Zweig condenava a miséria" (p.9) e a contrapunha a um "projeto de civilização": o economista Roberto Simonsen, por exemplo, havia oferecido valiosos subsídios que o escritor "soube recortar e encaixar no seu canto de louvor" (p.9). O livro de Zweig é, assim, pródigo no destaque dos aspectos positivos, e não perde oportunidades para vislumbrar, nos pontos negativos, problemas facilmente superáveis num futuro não muito distante.

Em nota final denominada "A aventura de traduzir Zweig", a tradutora Kristina Michahelles lembra que o livro não é uma obra-prima literária e comenta a impressão de que o autor "poderia ter caprichado mais, relendo alguns trechos, riscando as repetições de palavras, depurando o texto em termos estilísticos" (em Zweig, 2006, p.261). Informa que trabalhou "ora concordando com ele, ora contestando-o, sentindo uma vontade danada de transgredir as normas da tradução e editar as repetições de palavras, de consertar os (raros) erros históricos, até mesmo de acrescentar informações - enfim, atualizando a utopia zweiguiana" (p.261). Mesmo assim, louva as metáforas inusitadas do escritor "incomparável e intuitivo", que reaparecem em vários trechos desse livro escrito às pressas.

Se nos questionamos sobre a escrita de Brasil: um país do futuro, preocupados com a possibilidade de não ser mais que uma colagem de informações oficiais, fornecidas pelo governo como subsídio à encomenda, é reconfortante encontrar as mesmas observações nos diários do escritor, produzidos durante sua primeira viagem ao país, em 1936. Nestes, a chegada ao Rio de Janeiro (p.156-159), por exemplo, é saudada pela "fragrância macia da terra", que se mistura à do mar, de modo que "somos banhados de doçura e a acolhida é realmente de um calor meridional" (Zweig, 1986, p.264). O ar, na cidade, é "ao mesmo tempo límpido e macio - sentimos o perfume das florestas próximas" (p.266). No livro, essas primeiras impressões ainda dirigem o autor, pois lemos que "o ar subitamente fica mais úmido e doce, chega mais macio às mãos e à boca, há um vago odor, gerado nas profundezas das imensas florestas com o hálito das plantas e a umidade das flores, aquele odor indescritível dos trópicos, quente, úmido e fermentado que nos inebria e cansa ao mesmo tempo de maneira suave" (2006, p.156). Mesmo detalhes que poderiam ter sido alterados permanecem no livro: o viajante que chega vê o Corcovado sob "sua cruz" (1986, p.264 e 269) - como o Cristo é visto de longe -, e a observação continua presente no livro publicado cinco anos depois (2006, p.157).

Para o leitor de hoje, é curioso percorrer o livro de Zweig anotando acertos e erros em suas previsões sobre o futuro do país. No Rio de Janeiro, o austríaco percebe que os bondes e 
a zona de prostituição do Mangue têm seus dias contados. Mas imagina que as favelas também possam desaparecer da paisagem carioca - algo que aconteceu nas décadas seguintes apenas em algumas áreas privilegiadas (Catacumba, na Lagoa Rodrigo de Freitas, ou Praia do Pinto, no Leblon), enquanto no restante da cidade elas se multiplicavam ou, às vezes, eram substituídas por arremedos de bairros planejados, caso da Cidade de Deus e da Vila Kennedy.

Zweig teria se encantado com o "pacto de convivência" brasileiro, baseado na possibilidade de conciliação, o qual se combinava às "extraordinárias riquezas do país" e era "diametralmente oposto ao rancor racial e ao desvario político imposto pelo nazifascismo", como lembra Alberto Dines no prefácio (p.7).

$\mathrm{Na}$ Introdução ao livro, Zweig reconhece ser impossível ter uma visão completa de um país "que ainda nem consegue se perceber como conjunto" (p.17), no qual os dados estatísticos são ultrapassados antes mesmo de se tornarem "palavra impressa" (p.17). Afirma, porém, que, "pela sua estrutura etnológica, caso tivesse acompanhado a loucura nacionalista e racista da Europa, o Brasil deveria ser o país mais dividido, menos pacífico e mais conturbado do mundo" (p.21).

O próprio romancista reconhece que, "por honradez", não pode "fornecer conclusões definitivas, previsões e profecias sobre o futuro econômico, financeiro e político do Brasil" (p.17). E Alberto Dines, saudando a nova tradução para o português no início do século XXI, "numa hora marcada pela perplexidade", finaliza seu prefácio perguntando: "Zweig errou ou foi o Brasil que escolheu o modelo errado?" (p.9).

\section{Escritores e professores: algumas fontes}

Ainda durante a Segunda Guerra Mundial, em 1944, Gilberto Freyre proferiu na Universidade do Estado de Indiana, nos Estados Unidos, uma série de conferências que logo seria transformada no livro Interpretação do Brasil. Como diz Omar R. Thomaz na Introdução a uma recente edição desse livro, o intelectual pernambucano traduzia aí "sua ambição de interpretar não apenas o Brasil, mas as possibilidades de novas civilizações em espaço tropical" (p.9). Percebia-se naquela época a necessidade de investigar a realidade brasileira em confronto com outros países e regiões: a Europa, "atormentada diante de uma tentativa radical de lidar com a diversidade étnica e religiosa no interior de uma mesma fronteira nacional"; os Estados Unidos, "que ainda não tinham superado a divisão entre o Norte e o Sul do país", e mesmo a África e a Ásia, onde se previa “a inevitável 
descolonização". Para todas essas regiões, "a simples ideia da existência de uma possível superação de conflitos pela via relacional, e mesmo pela miscigenação, poderia ser um alento" (p.10). Freyre, sociólogo formado nos Estados Unidos com bom trânsito no meio acadêmico norte-americano, autor de Casa-grande \& senzala (1933) e de Sobrados e mocambos (1936), duas importantes "interpretações do Brasil" escritas na década anterior, parecia reunir os requisitos para falar, ali, de seu país. O livro teve grande repercussão e, pouco depois da guerra, foi traduzido para vários idiomas. É interessante notar que, quase vinte anos depois, quando Elizabeth Bishop escreveu Brazil (1962), fez constar na bibliografia esta obra de Freyre ao lado de apenas duas outras que tematizavam interpretações do país: Os sertões, de Euclides da Cunha, e Casa-grande e senzala, do próprio Freyre.

O Brazil de Bishop tem vários pontos em comum com os dois livros de Freyre, não só no elogio da miscigenação e do caráter conciliador do brasileiro, mas também no olhar atento para detalhes da vida cotidiana. Na sua Interpretação, Freyre descreve alimentos (2001, p.289), comenta a assimilação de expressões (p.208, 296), o uso generalizado de apelidos (p.214) e a opressão à mulher (p.132), por exemplo, e ressalta a importância da cultura popular: "a falta de instrução não quer necessariamente dizer ignorância: há, para compensála, um fundo de natural sabedoria, de imaginação e de humor que não deve ser desdenhado nunca" (p.85). Num processo comum em seus escritos, ${ }^{10}$ recorre aos comentários de estrangeiros. Um deles, o socialista norte-americano Waldo Frank (1889-1967), merece elogios especiais: "considero o autor de South American journey um dos poucos americanos que têm escrito" páginas de interpretação "proveitosas tanto para estrangeiros como para os brasileiros eles mesmos" (p.184). Esse autor, também envolvido na política da boa vizinhança, teria sabido buscar além do que é "metropolitano ou pitoresco", do que revela “extremo de progresso ou de primitividade e de arcaísmo", e, para Freyre, "é entre esses dois extremos antagônicos que se vai encontrar o verdadeiro Brasil com a sua variedade de situações regionais ou sub-regionais" (p.185).

$\mathrm{Na}$ mesma época em que intelectuais como Freyre e Frank cruzavam o continente, buscando estreitar laços ou, ao menos, despertar interesses entre Estados Unidos e Brasil, intelectuais europeus ensinavam em nossas recém-fundadas Universidades e buscavam interpretar o país. O sociólogo francês Roger Bastide (1898-1974), por exemplo, chegou em 1938 para substituir Claude Lévi-Strauss na Universidade de São Paulo, e aqui ficou por mais de 15 anos; depois de retornar à França, escreveu Brasil: terra de contrastes (1958). Outro francês, Jacques Lambert, veio em 1939 para atuar na recém-fundada Faculdade Nacional de

\footnotetext{
${ }^{10}$ Ver, por exemplo, Ingleses no Brasil, de 1948, elaborado com base em documentação minuciosa.
} 
Filosofia, no Rio de Janeiro, e escreveu Os dois Brasis (1959). As duas interpretações logo se consagraram, e, por sua própria abrangência, ultrapassaram o universo acadêmico. A de Bastide, por exemplo, é apontada por Paulo Duarte como "uma divulgação do Brasil”, e não como "propriamente uma análise sociológica" (em Bastide, 1964, p.9). Os dois autores destacam a coexistência de "idades históricas diversas" no Brasil, relacionada à profunda desigualdade no desenvolvimento socioeconômico entre as diferentes regiões, numa interpretação que remonta, por exemplo, a Euclides da Cunha e outros pensadores das décadas anteriores, e que se manteria viva, sob alguns enfoques, ainda por alguns anos. Lambert diz:

Entre o velho Brasil e o novo existem séculos de distância; no correr dos anos a diferença dos ritmos de evolução ocasionou a formação de duas sociedades, diferentes porque não são contemporâneas. Isto explica por que os observadores estrangeiros, e às vezes os próprios brasileiros, hesitam em se pronunciar sobre o verdadeiro caráter do país. Existem dois países, entre os quais é difícil distinguir o verdadeiro... (Lambert, 1969, p.105)

Bastide, por sua vez, enumera os contrastes observados no país - "de terras e vegetação, de raças e de etnias, de costumes e de estilos de vida" (1964, p.217), mas destaca a "harmonização dos contrários" e lembra que tais contrastes, ainda assim, permanecem brasileiros: as nossas "civilizações antagônicas" seriam, na realidade, "complementares" (p.217). Note-se que nenhuma dessas obras consta na bibliografia de Brazil de Elizabeth Bishop, tampouco entre os livros que pertenceram à escritora. Mas desde o início seus comentários se mostram afinados com elas, e a autora observa contradições e contrastes em vários aspectos do país - o que permite deduzir que o pensamento hegemônico sobre a rítmica do capitalismo era, ainda, o da coexistência de etapas históricas diversas. O primeiro capítulo, com efeito, foi nomeado como "Miscelânea de paradoxos" - título substituído, na edição, por "Um povo caloroso e sensato". Logo nas primeiras páginas do livro a autora afirma que "homens de duas, três ou mais eras da história europeia vivem no Brasil, hoje" (capítulo 1, p.12). As cidades costeiras seriam "habitadas por homens do século $\mathrm{XX}$ envolvidos com problemas do século XX: progredir no mundo e evoluir socialmente, como pagar escolas, médicos e roupas". Nas regiões vizinhas a "população rural ou semi-rural leva uma vida defasada em pelo menos meio século, antiquada nos aspectos agrícola e social”. Mais para o interior, "o tempo parece ter estacionado no século XVII". E, "por fim, se alguém se aventura um pouco mais longe, entra no mundo atemporal e pré-histórico dos índios". Não se 
investigam - como se depreende - as razões históricas da coexistência dessas "temporalidades diversas".

Note-se que, no texto de 1958 sobre sua viagem a Brasília e o Xingu, num grupo em que a principal personagem era o escritor britânico Aldous Huxley, Bishop afirmava que "podemos grafar a história moderna do Brasil num brevíssimo resumo com os três nomes conectados pela viagem de Huxley, partindo de Itamarati [uma vez que a sede do Ministério, no Rio, fora a residência dos barões do Império que portavam esse nome] para a segura e democrática insipidez do nome 'Brasília', e depois mais além, até as tribos que estão definhando ao longo do rio Xingu..."."11

Em vários trechos de Brazil a autora continua próxima a essas interpretações do país. Bishop afirma, por exemplo, que "os brasileiros referem-se ao Mississippi com inveja; se eles tivessem um Mississippi, as coisas teriam sido bem diferentes" (p.29), e Jacques Lambert comenta que o Paraguai e o Paraná formam um Mississippi, "porém, entrecortado de corredeiras" e "dirigindo-se para o estrangeiro". Assim, "realiza o que Jefferson não queria tolerar e conseguiu evitar com a compra da Luisiana" (1969, p.155).

Bishop aponta várias vezes a deficiência nos transportes como um dos principais problemas para o desenvolvimento do país: "por causa de estradas inadequadas, transporte insuficiente e falta de refrigeração, cerca de 40 por cento de todos os alimentos produzidos se estragam antes de chegarem aos grandes centros consumidores" (p.11), ${ }^{12}$ ecoando o alerta de Lambert: "todas as missões econômicas que, desde 1945, vêm visitando o Brasil, têm repetido aos brasileiros, que o sabem muito bem, que o problema fundamental da economia brasileira é o dos transportes" (1969, p.159).

Em outros trechos, parece nítido o apoio em Euclides da Cunha e Gilberto Freyre. A topografia brasileira, na página inicial de Os sertões (2000, p.7), é descrita a partir da Serra do Mar, na perspectiva de quem atravessou o Atlântico, e o mesmo ocorre no capítulo 2 de Brazil (p.28). E a detalhada descrição do sertanejo nordestino, cujas "vestes são uma armadura..." (Os sertões, p.102), ecoa no texto de Bishop: "sua roupa lembra muito as armaduras medievais..." (Brazil, p.84), seguindo em paralelo a descrição de gibão, colete, perneiras e assim por diante.

É importante notar que, das principais interpretações do Brasil surgidas nas décadas de 1930 e 1940, Bishop se aproxima sobretudo de Casa-grande \& senzala, obra que conhecera numa boa tradução para o inglês e cujas qualidades literárias costumava elogiar. Não se pode

\footnotetext{
${ }^{11}$ Ver "Uma nova capital, Aldous Huxley e alguns índios" (1958), na última parte deste trabalho.

${ }^{12}$ No texto de 1958 Bishop afirmava: "hoje $50 \%$ de toda a produção se estraga antes de chegar aos mercados".
} 
esquecer, também, que, sob certos aspectos, o universo de Lota na fazenda Samambaia tinha algo em comum com as casas-grandes nordestinas: "É incrível como a gente acumula uma ‘família' de dependentes no Brasil”' (Bishop, 1995, p.467). Como suas ancestrais, fazendeiras, Lota vai reunindo empregados e seus familiares, envolvendo-se nos problemas particulares, intrometendo-se quando possível nos destinos. ${ }^{13}$ Note-se que, ao esboçar um Sumário para a elaboração de Brazil, Bishop havia incluído, entre os "tipos" a serem descritos, a "antiga fazendeira".

Regina Przybycien (1993, p.80) elogia a perspicácia de Bishop, apontando a coincidência entre o que se lê no capítulo inicial de Brazil e em alguns trechos de Raízes do Brasil, de Sérgio Buarque de Holanda, até mesmo porque em nenhum momento a autora norte-americana afirma ter lido esse livro. O terceiro autor da "geração de 30", o marxista Caio Prado Jr., cuja Formação do Brasil contemporâneo surgiu em 1942, parece totalmente desconhecido por Bishop.

O historiador Fernando Novais (1983) comenta, a respeito dessas obras clássicas: "Sérgio Buarque formula mais explicitamente a questão da identidade nacional ... Caio Prado Jr. e Gilberto Freyre formam um curioso contraponto. Ambos se ligam às classes dominantes, de duas regiões que entretanto evoluem de forma divergente”. Em São Paulo, terra de Prado, a elite está em "franca ascensão econômica"; no Nordeste, a decadência econômica provoca o declínio do "peso de suas elites no conjunto da nação" (p.70). Novais afirma que Gilberto Freyre, talvez por isso, "analisa sempre o Brasil a partir de seu passado, isto é, daquilo que deixou de ser", enquanto Caio Prado Jr., ao contrário, "pensa sempre o país pelas suas potencialidades, isto é, pelo que ele pode vir a ser". E conclui: "Se esta visão talvez possa considerar-se utópica, a primeira é seguramente nostálgica" (p.70). Não é à toa que, como lembra John Gledson (2006, p.368), atacar Freyre tornou-se, com o passar dos anos, "quase um passatempo, tanto para brasileiros quanto para brasilianistas". O autor inglês destaca a importância de Freyre, por exemplo, na construção da ideologia que define o Brasil como "o maior exemplo de democracia racial no mundo" (p.368).

Um olhar sobre as pessoas com quem Bishop convivia em Petrópolis e no Rio de Janeiro talvez lance luz sobre vários aspectos do que ela escreve em Brazil. Nos originais constava, por exemplo, uma observação entre parênteses que revela algo sobre esse grupo: "Até hoje, os brasileiros de classe alta são surpreendentemente pouco familiarizados com seu próprio país, e mesmo sua geografia" (p.45). Note-se, ainda, que a história de vida de Lota

\footnotetext{
${ }^{13}$ Cf. o capítulo "A cozinheira é uma artista”, em Ferreira, 2003 (p.47-54).
} 
pode ser descrita pela diminuição constante do patrimônio herdado, ${ }^{14}$ algo que se aplica também à sua irmã Maria Elvira (Marieta), casada com um homem que "não chega aos pés dela", como se lê em carta de Bishop - entre aspas, uma vez que o comentário é, sem dúvida, de Lota (1995, p.267). A mesma postura parece explicar, ao menos em parte, as opiniões "violentamente contrárias" (p.388) à construção de Brasília, não só de Lota e Carlos Lacerda, mas de todo o seu círculo, ou "o ciúme que os cariocas sentem de S[ão] P[aulo]", como a norte-americana afirma em carta de 1954 (Bishop, 2008, p.800).

Por mais defasadas que sejam, as fontes em que Bishop se apoiou na elaboração de Brazil - que também refletem certo "filtro" associado à visão de mundo das pessoas com quem convivia - reforçam a constatação de pesquisa cuidadosa. Mas, sem dúvida, sua escrita ganha vivacidade nas páginas em que ela se desvincula de suas fontes "bibliográficas" para recorrer à observação pessoal, às anedotas, aos comentários inesperados e à ironia.

\section{O Brazil de John dos Passos}

Um paralelo interessante ao Brazil de Elizabeth Bishop é Brazil on the move, de John dos Passos, publicado em 1963. São vários os pontos que aproximam os dois textos: o escritor norte-americano - de ascendência portuguesa - viera ao Brasil pela primeira vez em 1948, como repórter da revista Life; escreveu artigos jornalísticos sobre o país e utilizou anotações dessa época na elaboração de seu livro. Dos Passos também esteve em Brasília em 1958, e na mesma ocasião visitou a casa de Lota e Bishop, em Petrópolis, trazido por Carlos Lacerda. Como o escritor viera a convite do Departamento de Estado para escrever uma matéria para a Reader's Digest ${ }^{15}$ Bishop intuiu que suas opiniões seriam favoráveis à nova capital. Ele ainda voltaria ao país em 1962, para redigir Brazil on the move.

John Dos Passos parece não ter enfrentado problemas com os editores na publicação de seu livro, até porque este foi incluído em uma série bem diferente daquela da Time-Life: a Armchair Traveller Series reunia autores como Aldous Huxley, Somerset Maugham e John Steinbeck, e não obedecia a um programa específico, predeterminado.

É interessante notar que Dos Passos, como Bishop, recorre com frequência a anedotas e comentários irônicos. O livro se inicia com um breve diálogo que ainda hoje é sempre repetido: questionado por um arcanjo sobre o excesso de maravilhas reunidas no Brasil, o

\footnotetext{
${ }^{14}$ Cf. o capítulo "Retalhando o paraíso" em Ferreira, 2003 (p.39-41).

${ }^{15}$ Carta a Robert Lowell, 28 ago. 1958 (em Bishop, 1995, p.388).
} 
Criador teria respondido, "espere até ver o povo que vou colocar lá" (1963, p.1). ${ }^{16}$ Mas o escritor logo passa a questionar o lugar-comum: fala da "geografia inconveniente", dos "rios que correm na direção errada" - como já apontara Lambert -, das "montanhas que estão no lugar errado" (p.1), do clima e do terreno hostis na Amazônia, das secas nordestinas e das doenças tropicais, para concluir que "a maior qualidade do Brasil são os brasileiros" (p.2). A facilidade de assimilação e a tolerância com relação às diferenças são comentadas por Dos Passos como notável característica, e ancestral, de nossa cultura. Para comprová-la, remete a uma anedota do século XV: quando um ministro exigiu que o rei português Dom Manuel expulsasse os judeus, este teria respondido: “Qual de nós vai sair antes, você ou eu?” (p.3).

Como são inúmeros os pontos de contato entre as concepções de Dos Passos e de Bishop sobre o país e seus aspectos culturais, é preferível destacar os menos esperados e as discordâncias. Note-se, por exemplo, que os dois autores referem-se ao encontro de um jovem inconfidente com Thomas Jefferson, na França, mas Dos Passos inclui com naturalidade o comentário, "perguntando se o Brasil teria ajuda da América do Norte caso se tornasse uma República independente" (p.5), frase que tanto exasperou Bishop no embate com os editores.

Os deslizes em Brazil on the move denotam a insuficiência de pesquisa consistente: logo no início do livro, o escritor omite o açúcar ao nomear as primeiras riquezas da Colônia, afirma que D. João VI teria fundado uma universidade e informa incorretamente a data da abolição da escravatura. Os erros de grafia nos termos em língua portuguesa são constantes, embora esse problema possa ou deva ser creditado aos editores. Mais importante é notar que, assim como Bishop, Dos Passos aproveita para explicar ao público norte-americano o significado de nossas palavras: "saudade", "bandeirantes" e "cariocas", por exemplo.

A principal diferença entre os dois livros é o recurso de Dos Passos às entrevistas e à elaboração de perfis das personalidades com quem se encontra, o que aproxima seu texto das matérias publicadas em revistas como Reader's Digest, Time e Life. Seus "heróis" brasileiros são, por exemplo, o empreendedor Bernardo Sayão (entrevistado no canteiro de obras de uma "colônia agrícola" fundada por ele no Brasil Central), Israel Pinheiro (administrador da construção de Brasília) e o governador Carlos Lacerda (brindado com um capítulo elogioso de quase quarenta páginas, denominado "O homem mais perigoso", onde o político é chamado de "destruidor de presidentes").

\footnotetext{
${ }^{16}$ A página inicial do livro de Dos Passos é utilizada por Rocha (2004) na discussão sobre a "Dialética da marginalidade", em que focaliza os aspectos perversos do que havia se tornado a concepção da "malandragem" como aspecto cultural do brasileiro.
} 
O livro de Dos Passos não poupa elogios às pessoas e às instituições. O Sesp (Serviço Especial de Saúde Pública), criado graças à ajuda do governo norte-americano, é tema de um subcapítulo. O escritor também tece comentários sobre a Guerra Fria e a Aliança para o Progresso.

Entre os políticos brasileiros, nomeia os líderes mais importantes de várias tendências - além de Lacerda, cita Jânio Quadros, Ademar de Barros, Magalhães Pinto, João Goulart, Leonel Brizola e Miguel Arraes - e, sempre que possível, pontua os comentários com anedotas: sobre os "interesses estrangeiros" que teriam levado à renúncia de Jânio, Ademar respondera a um jornalista: "Haig \& Haig, Teacher's, Johnnie Walker...” (p.167).

É interessante notar que Bishop reserva esse tipo de comentário aos políticos mais antigos: Campos Sales (denominado "presidente Selos", por causa das inúmeras taxas destinadas à recuperação econômica, p.128) e Café Filho ("O que o mordomo diz quando bate na porta do presidente, de manhã? Hora do Café”, p.132), por exemplo, mas o longo parágrafo em que eles constavam foi eliminado pelos editores. $\mathrm{O}$ tom geral dos principais trechos relacionados à política não abre espaço, entretanto, para a ironia, e ainda busca apontar outros aspectos do país: o funeral de Vargas, no Rio, "ou melhor, a procissão que carregou seu caixão pelas ruas até o aeroporto ... foi uma amostra assustadora e tocante de histeria de massa" (p.132); mas este trecho também foi eliminado pelos editores. ${ }^{17}$

Dos Passos comenta em detalhes o "almoço de domingo" em Petrópolis, na casa de "Dona Lota", "a mais moderna das casas brasileiras" (p.141), e descreve o grupo ali reunido: o arquiteto que a projetou (Sergio Bernardes, nomeado), um eminente historiador (Octavio Tarquínio de Sousa) e "algumas pessoas interessadas principalmente em pintura e escultura" (p.156), mas em nenhum momento fala da escritora norte-americana que ali vivia. Ao descrever a casa, comenta que "merece ser vista", mas afirma que para algum cético ela talvez se pareça "com o modelo de uma estação ferroviária antiquada" (p.156).

Lota receberá vários elogios no trecho dedicado ao Parque do Flamengo. Essa mulher que "usa calças listradas" dirige sua grande equipe "com palavras amáveis", mas "com rigor" (p.170). E nessa equipe ela reuniu alguns dos mais importantes "arquitetos, escultores e planejadores urbanos" do mundo, "muitos dos quais trabalham aí sem salário" (p.170) - como a própria Lota, aliás.

Lacerda e Lota são algumas das personagens em que Dos Passos se apoia para falar do dinamismo e entusiasmo que encontrou no país e que permeia as mais de duzentas páginas de Brasil desperta, título da edição brasileira. Um dinamismo que o norte-americano encontra

\footnotetext{
${ }^{17}$ Ver, na última parte deste trabalho, "Suicídio de um ditador (moderado)" (1954).
} 
não só nos canteiros de obras, mas também nas pequenas cidades do interior do Nordeste. São poucos os parágrafos em que o autor se permite falar da indolência ou da falta de perspectivas, e nesses casos o objeto de sua crítica é claro: "a burocracia brasileira ... é um pouco especial, por causa do horror dos intelectuais brasileiros ao trabalho produtivo, um dos males da herança portuguesa" (p.19), ou "o Brasil cresce à noite, enquanto os políticos dormem" (p.99), comentários que ele afirma ter ouvido. Nesses trechos, entretanto, aproveita para fazer o contraponto com seu país. Nos Estados Unidos "nós também sofremos com a burocracia", mas o burocrata certamente teve um trabalho braçal nos tempos de estudante, ou, ao menos, "arranjou lenha para a lareira de casa ou cortou a grama do jardim". Na maior parte da América do Sul, "ao sair da escola você pertence a uma raça diferente daquela do homem que carpiu seu jardim" (p.19).

\section{"Uma miscelânea de paradoxos"}

O fato de Bishop iniciar seu livro pela descrição de paradoxos e contradições "que parecem não incomodar ninguém" (p.15) nos remete ao ensaio de John Gledson, "Brasil: cultura e identidade" (2006), onde o autor inglês cita e elogia a poeta norte-americana. ${ }^{18}$

Partindo, como Bishop, da constatação de que "o Brasil é um país de paradoxos”, de que "quanto mais perto se chega, mais complexo e mais contraditório se mostra" (p.359), Gledson exprime sua questão central: "o que, se é que existe, faz do Brasil uma nação, uma comunidade com uma cultura e uma tradição comuns, com símbolos comuns com os quais se identifica?" (p.360). Para chegar à resposta, lembra que é preciso considerar até mesmo a existência dessa comunidade, ou a sua fragilidade, aludindo à divisão do Brasil em "dois países", a "Belíndia", como na definição formulada pelo economista Edmar Bacha, na década de 1970. Depois de enumerar os aspectos positivos do país - unidade linguística, extensão, riqueza e o fato de ser considerado "a maior democracia multirracial do mundo" -, Gledson passa aos "problemas, paradoxos e omissões": o fato de o Brasil ainda ser constantemente considerado um "gigante adormecido", sua profunda desigualdade, a corrupção generalizada e o quase consenso, entre seus habitantes, de que é "ingovernável”, ou mesmo "o ingovernável governado pelo incapaz de governar" (p.360-361). Ao menos um dos problemas apontados

\footnotetext{
${ }^{18}$ Gledson reconhece no ensaio, que surgiu como aula inaugural de sua cátedra de estudos brasileiros na Universidade de Liverpool, em 1994, a "ambição desmesurada do título", e o considera "talvez pessoal em demasia” (p.18), mas também por isso ele merece atenção.
} 
pelo autor inglês seria controlado, temporariamente ou não, pouco depois: a inflação, que naquela época chegava a "30\% ao mês" (p.361).

Para compreender o país e seus paradoxos, Gledson recorre à literatura, "em parte porque é complexa, em parte porque pode com frequência ser irreverente e cética, pode funcionar como um bom guia" (p.361). Nesse sentido, analisa um conto, uma canção popular, um breve poema e um capítulo de livro de memórias. ${ }^{19}$

Gledson aponta o "mito paradoxal" que "situa todas as virtudes dos brasileiros na informalidade, no indefinível, no inexprimível" (p.367):

de uma maneira meio depreciativa, os brasileiros falam com frequência que o país e as próprias vidas dependem em grande medida de uma coisa misteriosa chamada "jeitinho" ou de ter algo chamado "jeito", palavra significantemente intraduzível, que em geral que dizer fazer o impossível, desviando-se de algum obstáculo burocrático mediante algum tipo de manobra parcialmente legal. (2006, p.367)

A encarnação do "jeitinho" seria o "malandro", outro termo difícil de traduzir ou mesmo explicar aos estrangeiros, algo que "tem a ver com agressividade, desonestidade, preguiça e embuste" (p.373). ${ }^{20}$ John Gledson não cita viajantes, nesse ponto, mas vários deles debruçaram-se, nas mais variadas épocas, sobre esses dois importantes aspectos do que se poderia chamar de "identidade brasileira", alguns buscando construir definições, outros limitando-se ao relato de episódios esclarecedores. Veja-se apenas um exemplo, contundente, vivido em 1960 por Simone de Beauvoir e incluído em A força das coisas, de 1963:

Na manhã seguinte, em Belo Horizonte, novamente esperamos muito tempo pelo motorista. No caminho, compreendemos a razão de seus atrasos: a mala do carro estava cheia de relógios e joias, que ele pretendia revender nas cidades onde íamos parar. Explicou a [Jorge] Amado que acumulava a função de motorista com a de policial, que the proporcionava contatos proveitosos com gente que exercia um ofício muito importante no Brasil: os contrabandistas. Ele lhes confiscava ou comprava a preço baixo mercadorias que os habitantes de Brasília, isolados do mundo,

\footnotetext{
${ }^{19}$ Os textos escolhidos por John Gledson são: o conto "O espelho", de Machado de Assis; o samba "Não tem tradução", de Noel Rosa, o poema "Morro da Babilônia", de Drummond, e um capítulo de Memórias do cárcere, de Graciliano Ramos (p.361).

${ }^{20}$ Gledson não se refere, nesse ponto, ao ensaio "Dialética da malandragem", de Antonio Candido (2004, p.1746), publicado pela primeira vez em 1970, onde já se analisava a questão em seus aspectos históricos, nem aos "Pressupostos, salvo engano, de 'Dialética da malandragem"”, de Roberto Schwarz (2002, p.129-156), de 1979.
} 
compravam a preços altíssimos. Descrevia suas tramoias com uma inocência tipicamente brasileira - disse-nos Amado, encantado. (Beauvoir, 1995, p.480)

Note-se que é Jorge Amado quem capta e transmite à estrangeira as atividades profissionais complexas do motorista, mas a "inocência" deste, como também o encantamento do romancista, dizem muito sobre as condições de trabalho e certa naturalização do "jeitinho". Simone de Beauvoir encerra o assunto sem tecer outros comentários ou propor conclusões que sem dúvida considera desnecessárias -, mesmo porque ainda tem muito a narrar sobre sua viagem, e é assim que agem muitos dos "estrangeiros", mas Gledson, em seu ensaio, vai concatenar esse a outros problemas. Tendo por base o "fato central" de que no passado "os negros foram excluídos do que se convencionou chamar de ideologia nacional" (p.366), o autor inglês lembra que apesar disso "os símbolos coletivos surgidos a partir da década de 1930 têm uma forte ligação com a população negra" (p.366): o carnaval, a música popular e o futebol. E aponta mais um paradoxo, "inusitado e quase perverso": "tomar os símbolos nacionais de um grupo ainda tão espoliado" (p.368).

Gledson recorre a Elizabeth Bishop para discutir outro paradoxo relacionado a esse: o fato de "o país estatisticamente mais desigual do planeta" contar com "uma ideologia de intimidade social, de convivência entre classes e raças admitida" (p.369). Lembra que a escritora foi chamada de racista por causa do comentário que fecha seu artigo de 1965 sobre o Rio de Janeiro, publicado no New York Times: Bishop refere-se a um anúncio de fogão em que aparecem a patroa branca e a empregada negra beijando-se. ${ }^{21}$ Naquela ocasião, parece ter havido má-fé do jornalista Fernando de Castro (1965), ou má interpretação do que constava no artigo, como a autora, depois, procurou demonstrar. "Bishop não é tão ingênua quanto à democracia racial brasileira quanto pode parecer" (p.370), diz John Gledson, e o comentário presente no texto do New York Times "não resume de jeito nenhum sua reação complexa ao país” (p.370). Mas, ainda assim, algo escapa à norte-americana. Talvez, para Gledson, o fato de que "de certa forma, a intimidade atua como um substituto para a democracia - igualdade espiritual, mas não legal" (p.371). Com esse comentário, Gledson parece revelar que não leu Brazil, apesar das coincidências - até mesmo na ênfase aos paradoxos - entre seu ensaio e o livro de Bishop:

Às vezes os brasileiros parecem confundir familiaridade com democracia, embora a atitude pareça antes um resquício dos dias de escravidão, ou do feudalismo, ou mesmo do

\footnotetext{
${ }^{21}$ Ver a tradução, "No trem do Encantado" (1965), na última parte deste trabalho.
} 
Império Romano, quando todo homem rico tinha à sua volta um conjunto de amigos pobres e parasitas. Todavia, um senso de responsabilidade natural subjaz nessas relações e contribui um pouco para o conceito atual de democracia - mais difícil e de alguma forma mais amplo. (Brazil, p.13)

Gledson cita Roberto da Matta, que chega a comparar a sociedade brasileira, muito estratificada, ao sistema de castas da Índia, e repete: "é justamente porque tudo é demarcado com precisão em termos de classe, e porque 'todos sabem o seu lugar', que a intimidade é possível" (p.371). Bishop, em seu livro, afirma que "o sistema simples de divisões em classes e categorias parece o do século XIX - quase dickensiano, se um escritor tão remoto diante de tudo o que é brasileiro pode ser mencionado em conexão com o Brasil”' (Brazil, p.114), mas o trecho foi eliminado pelos editores.

Bishop está escrevendo, segundo Gledson, "bastante conscientemente, de um ponto de vista norte-americano" (p.371), e essa é uma das razões para que ele admire seu trabalho: "ela amava o Brasil, mas também tinha a percepção da sua posição como norte-americana e da dificuldade dessa posição" (p.380). Tomando como exemplo seus poemas "The squatters' children" ["Filhos de posseiros"] e "The burglar of Babylon" ["O ladrão da Babilônia"], ele afirma: "Bishop era modesta demais para achar que poderia se fundamentar onde nunca morou: seus poemas sobre favelas têm um olhar deliberadamente externo" (p.437, nota 43).

\section{Personagens}

Ao analisar o livro Brazil, Regina Przybycien (1993) questiona-se: "O que fazer? Ignorar o livro, tirá-lo da bibliografia da poeta sobre o país?” (p.76). Embora aponte a importância de existirem, nesse livro, marcas que reaparecem em outros textos da escritora norte-americana, Przybycien comenta que as informações reunidas no segundo capítulo "são mais ou menos as que se pode encontrar nos compêndios oficiais de história do Brasil" (p.7576). Nesse sentido, poderíamos dizer o mesmo sobre grande parte do terceiro capítulo (sobre o Império), do quarto (sobre as três capitais) e do nono (sobre a República). Também as riquezas do país, no quinto capítulo (“Animal, vegetal e mineral”), são descritas de maneira um tanto esquemática - mas seus originais não estão disponíveis para cotejo.

Os dois capítulos dedicados às artes (6 e 7) merecem atenção especial, dada a preferência da autora pelas "artes populares" em detrimento das "sofisticadas", assim como os 
dois capítulos (1 e 8) onde ela discute o povo brasileiro e seu "caráter". A inclusão do primeiro capítulo numa coletânea publicada nos Estados Unidos, em 2008, parece demonstrar a permanência do interesse despertado por esse texto. Regina Przybycien afirma que após a narração do rapto de "Conceiçãozinha" segue-se "uma série de generalizações sobre o Brasil a partir da história, as quais ... são mais ou menos lugar-comum” (p.77), mas a maneira como Bishop busca expor e compreender aspectos do comportamento das classes populares parecenos, ainda hoje, surpreendente. A mesma pesquisadora, por sinal, percebe que "o fato de ter escolhido a narrativa do rapto de uma criança para abrir o livro e, a partir daí, descrever a posição da criança na família brasileira, parece significativo sob vários aspectos” (p.77). Além disso, note-se a maneira admirável como Bishop tece uma sequência que consegue abarcar, em poucas páginas, os contrastes entre explosão populacional e alta mortalidade infantil, entre a extrema variedade do país e a unidade linguística, e ainda abordar a miscigenação racial, as formas de tratamento, o sentimentalismo e o hábito da tolerância, tudo entremeado por ditos populares e anedotas.

É interessante notar que, assim como o bebê "Conceiçãozinha" se destaca no primeiro capítulo, em meio a personagens anônimas e protagonistas de anedotas, é Pedro II quem sobressai no terceiro, e esse vai-e-vem entre figuras "históricas" e gente do povo enriquece o texto e, não raro, surpreende o leitor. Diferentemente de John dos Passos (1963), Bishop não recorre a entrevistas e poucas vezes cita personalidades, preferindo, como já anunciara em cartas, as anedotas. Apenas o economista Eugênio Gudin ganha destaque no último capítulo, numa longa citação retirada de $O$ Globo, sem dúvida por apresentar uma "receita" para o futuro do Brasil que se ajusta perfeitamente à visão da autora: é necessária a "formação de um núcleo de homens educados" para aumentar a produtividade nacional, e, para tanto, devemos "importar centenas de técnicos e professores e enviar milhares de estudantes para o exterior" (p.148), diz Gudin. ${ }^{22}$ No capítulo 2, é Pero Vaz de Caminha quem merece citações e elogios por sua argúcia na descrição da terra recém-descoberta. A carta-testamento de Getúlio Vargas e o bilhete de renúncia de Jânio Quadros aparecem como elementos acessórios ao texto, mais por seu caráter documental que por especial interesse da autora.

Nem mesmo Carlos Lacerda, amigo de Bishop, deixa de ser o político, a figura pública, para mostrar em Brazil os aspectos de sua vida particular presentes no livro de Dos Passos. No trecho dedicado aos índios e à Amazônia, o Marechal Rondon e os irmãos Villas Boas são elogiados, mas quem mais se destaca é a médica do Sesp (Serviço Especial de Saúde

\footnotetext{
${ }^{22}$ Merece destaque o empenho de Bishop no sentido de enviar Flávio (1942-1970), o brilhante sobrinho de Lota, para estudar em Harvard. Cf. Ferreira, 2003, p.183-194.
} 
Pública) que Bishop conhecera em sua viagem de barco pelo Amazonas, em 1960. A discussão sobre o papel da mulher brasileira vai se iniciar com a narração da coragem dessa mulher "pequena, animada e de pele escura, provavelmente com sangue índio" - e "gorda", como consta nos originais -, que, logo no início da carreira, 15 anos antes, desafiara um grupo de homens rústicos e recusara encobrir um assassinato. E Bishop conclui: "Essa médica era uma mulher brasileira 'moderna'. Não existem muitas como ela, mas seu número vem crescendo" (p.116).

Outras mulheres são elogiadas, entre as quais a amiga Rachel de Queirós, que pouco antes recusara o convite de Jânio Quadros para assumir o Ministério da Educação. Bishop também se refere a outras escritoras (Helena Morley, Clarice Lispector), engenheiras (Carmen Portinho e Bertha Leitchik - eliminadas na publicação) ${ }^{23}$ e uma embaixadora (Odete de Carvalho) -, mas sua atenção parece tender para aquela médica do interior que, no entanto, permanece anônima. E note-se que o elogio de Bishop às "normalistas" ("muitas delas em vilas remotas, em escolas que se restringem a um quarto numa casa, em condições comoventes", p.117), eliminado pelos editores, só poderia ter sido escrito por alguém que conhecia realmente o país e seu povo.

O culto aos heróis e aos grandes feitos é constante em revistas como Reader's Digest, Time ou Life, mas em Bishop a admiração recai, quase sempre, no trabalhador anônimo e dedicado, no artesão em luta pela subsistência. Nesse sentido, sua visão do homem comum aproxima-a de nossos modernistas, em especial Mário de Andrade. ${ }^{24}$

No campo das artes plásticas, a obra contemporânea reproduzida em Brazil é uma gravura de Maria Bonomi (p.102), escolha editorial que se justifica até pelo fato de a artista ter vivido em Nova York no final da década de 1950. Mas outra artista merece atenção na vida brasileira de Elizabeth Bishop, até mesmo por sua ausência nos poemas, contos e textos jornalísticos - ela não é citada em Brazil -, embora seja personagem importante nas cartas de Samambaia. Trata-se da cozinheira Madalena dos Santos (1919-1977), ${ }^{25}$ empregada de Lota.

Pouco tempo depois de chegar ao Brasil, Bishop refere-se a essa cozinheira que começara a pintar durante uma ausência das patroas, "o que prova que a arte só floresce no ócio, creio eu" (Bishop, 1995, p.247). Madalena revelou-se "uma pintora primitiva maravilhosa, de modo que daqui a mais algum tempo vamos estar vendendo os quadros dela

\footnotetext{
${ }^{23}$ Não conseguimos encontrar justificativas para a eliminação desses dois nomes.

${ }^{24}$ Bishop certamente desconhece os textos de Mário de Andrade sobre arte popular, mas essa coincidência de interesses entre os dois escritores aponta para a necessidade de estudos específicos que comparem as interpretações modernistas produzidas em São Paulo com as da norte-americana.

${ }^{25}$ Ver Figura 27. Cf. o capítulo "A cozinheira é uma artista”, em Ferreira, 2003 (p.47-54).
} 
na $57^{\text {th }}$ Street e vamos todas ficar ricas" (p.247). A cozinheira será incentivada e ganhará tintas e pincéis, uma vez que "a Lota tem uns vasos que Portinari fez para ela, e somos obrigadas a reconhecer que os da cozinheira são muito melhores" (p.247). Madalena casa-se com o jardineiro, descendente de alemães, e adota o sobrenome Reinbolt. Aos poucos, entretanto, suas atividades artísticas começam a atrapalhar as tarefas na cozinha, e ela perde o emprego: as patroas tinham de "escolher entre a Arte e a Paz", e concluíram "que a tranquilidade valia mais do que desfrutar uma obra-prima todo dia" (Bishop, 1995, p.259).

$\mathrm{O}$ caso de Madalena merece destaque, também, porque representa uma tentativa de passagem do anonimato para o mercado "oficial" da arte. Sua biografia é apresentada desta maneira no catálogo de uma exposição coletiva realizada cinquenta anos depois de sua "descoberta": "Cozinheira da paisagista Lota de Macedo Soares e da poeta Elizabeth Bishop em sua casa de Petrópolis, começou a fazer tapeçarias inteiramente por acaso. De tanto pintar as pedras do jardim, ganhou de Lota agulhas e linhas de lã” (Moura, 2001). O crítico completa o comentário lembrando que as obras agora expostas foram "adquiridas nos anos 70 de uma amiga de Lota", ${ }^{26}$ o que confirma o interesse do grupo pelas tapeçarias, ao menos no início da carreira de Madalena. Em depoimento gravado em 1974, ela informa que nasceu em Vitória da Conquista (BA) em 1919, nunca aprendeu a ler e vive desde 1949 em Petrópolis. Madalena não se refere a Elizabeth Bishop, mas Lota aparece algumas vezes em seu depoimento. Suas obras ganharam o reconhecimento do mercado e se valorizaram, mudando de mãos, mas ela não conseguiu escapar ao universo onde nasceu, uma vez que "trabalha num pequeno quarto destinado aos caseiros ... Os patrões permitem que ela venda os tapetes nessa casa de campo onde há trabalhos seus na parede, de propriedade da família. Os vizinhos de nível socioeconômico igual ao da artista apreciam muitíssimo o seu trabalho" (Frota, 1975, p.123).

No limite entre o anonimato e o reconhecimento, entre a profissão de cozinheira e a dedicação à arte, Madalena personifica a vocação que busca se expressar em condições adversas, aproveitando, se possível, as chances que aparecem. Os novos patrões terão sido, talvez, mais tolerantes - ou mais interesseiros - que Lota e Bishop, diante da presença de uma artista na cozinha da casa de veraneio. Mas chama atenção o fato de que, na maturidade da artista, apenas "os vizinhos de nível socioeconômico igual” ao dela sejam citados como seus admiradores. Como chama atenção, também, o fato de que os seus trabalhos, na parede da casa, são "de propriedade da família".

\footnotetext{
${ }^{26}$ As Figuras 26 e 28 reproduzem duas obras de Madalena Reinbolt, um óleo e uma tapeçaria, respectivamente.
} 


\section{Artes populares e sofisticadas}

Como lembra Regina Przybycien, para Bishop "o Brasil verdadeiro estava no humor e na arte do povo" (1993, p.85). A poeta elogiava os diferentes aspectos do artesanato e da arte popular, temerosa diante de seu possível desaparecimento. Quanto à arte "culta", "são poucos os artistas brasileiros que escaparam de sua crítica negativa": "além de imitativa", Bishop considera a arte brasileira "demasiado provinciana, o que de certo modo é um paradoxo" (p.90). Afinal, a imitação significa "uma tentativa de aproximação dos modelos dos grandes centros de cultura, enquanto o provincianismo implica um fechar-se em si mesmo, um produzir dentro dos estreitos limites da própria cultura local" (p.90).

No campo da literatura, é possível creditar parte do desconhecimento de Bishop, ou de sua interpretação, às deficiências com a língua, como ela mesma afirma em carta de 1955 sobre Manuel Bandeira, na qual faz restrições à sua poesia, "mesmo sabendo que muito do charme da linguagem me escapa" (Bishop, 2008, p.809). E, como afirmou uma de suas amigas, "Lota achava que aqui não havia gente do nível cultural de Elizabeth" (Pereira, 1995), o que exprime não só o menosprezo de Lota em relação a tudo o que é brasileiro, mas também uma espécie de justificativa antecipada para a prevenção da americana diante de alguns aspectos de nossa cultura.

No capítulo 6 de Brazil, dedicado às artes "espontâneas", Bishop elogia os "cantadores" com seus versos "em formas e metros muito antigos", uma arte "que só pode desenvolver-se numa língua como o português, repleta de rimas e assonâncias" (p.86). Destaca o analfabetismo de muitos desses artistas populares, cujo trabalho baseia-se na memória, e nota que a preservação e divulgação de seus versos - na forma dos livretos de cordel - depende de outros, que se dediquem à transcrição dos textos. Seus exemplos de literatura de cordel, entretanto, apontam outra função, o caráter informativo desses "jornais do sertão": cita "Getúlio no Céu", que apareceu logo após a morte do presidente, o recente voo do cosmonauta soviético Yuri Gagárin e a renúncia de Jânio Quadros. Note-se que os editores eliminaram os comentários da autora sobre as capas, muitas delas xilogravuras de grande valor artístico: "as capas de alguns desses panfletos também são obras de arte; embora o texto seja mal impresso, em papel barato, repleto de erros de grafia e de impressão, a folha externa 
é ornamentada com rústicas mas comoventes gravuras" (p.86). ${ }^{27}$ Também foi eliminado pelos editores um longo comentário sobre a arte da carpintaria (p.86), "uma especialidade que a industrialização ainda não alterou" (p.86) e que Bishop admirava. Com a eliminação desse comentário, perdeu-se também uma digressão sobre a indústria caseira relacionada às peças e aos móveis de madeira: as indústrias de farinha de mandioca, vinho e pasta de caju.

No trecho dedicado às peças em cerâmica, mais uma vez constata-se a experiência da escritora: as "árvores inteiras repletas de pássaros" (p.84), por exemplo, estão no relato sobre a viagem pelo Amazonas (1960), onde se lê: “os pássaros pareciam muito grandes - e quando eles pousavam numa árvore menor, percebia-se de onde vêm as cerâmicas da Bahia - aquelas com grandes pássaros todos empoleirados em pequenas árvores - pássaros brancos". ${ }^{28}$

Outro tema de destaque no capítulo sobre arte popular são as carrancas utilizadas nos barcos cargueiros do rio São Francisco, "a criação mais notável no campo da escultura" (p.86), embora seja "um costume que está morrendo rápido". Ela tem uma bela carranca, "comprada a prestações" depois que sua admiração foi endossada por um comentário elogioso que comparava esses objetos à arte românica. A peça é descrita em carta de 1960: "Já lhe falei da minha carranca? ... Preciso lhe mandar uma foto - ela, ou ele, sei lá, é um diabo com chifrinhos, mas um rosto simpático e bobo, língua um pouco para fora e longos cabelos louros - entalhada em madeira, cerca de metro e vinte de altura, já quase sem tinta” (Bishop, 1995, p.710-711). ${ }^{29}$

Depois de abordar o teatro e a dança populares, Bishop dedica toda a parte final desse capítulo ao Carnaval, "um dos maiores espetáculos populares que ainda restam no mundo" (p.88). Como em outros aspectos da cultura brasileira admirados por ela, a autora não se restringe aos elogios; nota que "o comercialismo e uma falsa ideia do que interessaria aos turistas são, em parte, os culpados" por algo que vê como decadência. "Hollywood exerceu um efeito devastador, também”, diz ela, apontando as fantasias que procuravam imitar os últimos sucessos do cinema no Carnaval carioca. Em carta de 1958 ela já havia completado o relato com alguns comentários sobre outro aspecto, a desorganização: "Era para ter começado às sete, mas na verdade começou às dez, e em vez de ir até as três ou quatro a coisa só foi terminar às onze e meia do dia seguinte ... Eu realmente torço para que o Carnaval não acabe nunca - mas seria tão bom se eles respeitassem o horário mais um pouco!” (Bishop, 1995,

\footnotetext{
${ }^{27}$ Ver dois exemplos de capas de livretos de cordel nas Figuras 32 e 33. A página de abertura do volume 2 deste trabalho reproduz uma xilogravura de J.Borges, "O bicho de sete cabeças". Esse artista, nascido no interior de Pernambuco e hoje amplamente reconhecido, iniciou a carreira como criador de capas para os livretos.

${ }^{28}$ Ver o texto completo na última parte deste trabalho.

${ }^{29}$ Note-se que a autora não comenta o deslocamento da carranca, de seu uso original, nos barcos, para o interior das casas, como objeto de decoração. Ver exemplos dos dois usos nas Figuras 35 e 36.
} 
p.382). Ela acompanhava o desfile das principais escolas de samba na avenida, todos os anos, e em seu livro lastima: "grande parte do divertimento carnavalesco também foi destruída pela proibição de fantasias e carros alegóricos relacionados aos políticos, à Igreja e aos militares. Algumas das melhores mostras de inteligência e humor eram inspiradas nesses velhos e infalíveis objetos de sátira" (p.88). Outro sinal de decadência da festa popular seria o fato de compositores comerciais estarem se dedicando também ao Carnaval, o que levou à divulgação das músicas com meses de antecedência, motivo pelo qual "todo o charme se perdeu".

Com a modernização, perde-se o melhor do Carnaval, da mesma maneira como as igrejas perdem o que têm de melhor quando as imagens antigas são substituídas pelas “contemporâneas, sentimentais, em gesso pintado, produzidas por indústrias" (p.86). Mas, embora seja saudosista em cultura popular, ela é progressista no que se refere às facilidades trazidas pela tecnologia - contanto que não interfiram no que seria o fundamento da cultura.

Essa opção pela cultura popular que deveria permanecer alheia ao comercialismo e às influências estrangeiras levou alguns críticos a apontarem o total desconhecimento de Bishop em relação às outras formas de cultura brasileira. $\mathrm{O}$ contraponto mais nítido envolveria $\mathrm{o}$ "samba de morro", de um lado, e a "bossa nova", de outro. Beatriz Jaguaribe, por exemplo, afirma: "É relevante notar que nas cartas selecionadas de sua coletânea não há menção à bossa nova, cuja gestação ocorreu justamente nos anos de sua vivência brasileira" (1998, p.101). Mas outras cartas, sobretudo as trocadas com Flávio, sobrinho de Lota, desfazem essa impressão: o jovem, que aos 16 anos já escrevia sobre jazz no Diário Carioca, o jornal do avô, parece ter sido, durante anos, o principal interlocutor da norte-americana no que se refere a vários aspectos da cultura brasileira. Em carta de 1963, Bishop informa a uma amiga novaiorquina que Flávio vai providenciar “discos de bossa nova realmente bons” (Bishop, 1995, p.735), melhores que os disponíveis nos Estados Unidos; anos depois, quando a escritora inicia a organização da Antologia de poesia brasileira contemporânea, ele a informa sobre o que há de melhor na nova geração. ${ }^{30}$ Em cartas posteriores à morte de Lota aparecerão novos dados: ela está "tocando Bethania na hi-fi de São Francisco" (Bishop, 1995, p.751), ou mesmo trabalhando na versão de "duas canções de Caetano". ${ }^{31}$

Merece atenção, entretanto, o texto que Bishop escreveu em 1965, por encomenda do New York Times, sobre o Quarto Centenário do Rio de Janeiro, exatamente no que se refere à cultura popular. O jornalista Fernando de Castro chega a dizer, em sua crítica enviesada a esse artigo, que "o nosso afamado Carnaval lhe aparece como um desfile sensaborão de gente de

\footnotetext{
${ }^{30}$ Sobre a correspondência entre Bishop e Flávio de Macedo Soares, ver Ferreira, 2003, p.183-194, 205-209.

${ }^{31}$ Carta a Emanuel Brasil, maio 1971.
} 
cor (niggers), e Mrs. Bishop revela absoluta incompreensão de tudo o que vê e que ouve" (Castro, 1965). ${ }^{32}$ Mas o que interessa, aqui, são os quatro sambas vertidos ao inglês e incluídos no artigo. Eles constam nos Complete poems - 1927-1979 (1983) da autora, na seção "Translations from the portuguese" (p.263-264), e são reproduzidos na coletânea de Poems, Prose, and letters (2008), sempre como "anônimos", mas seus autores são bem conhecidos. ${ }^{33}$ Não sabemos se Bishop teve alguma influência na omissão dos autores - que pode estar relacionada ao não-pagamento de direitos autorais -, mas o fato de as quatro músicas serem consideradas "anônimas" apenas reforça a sua notória preferência pela arte que permanece alheia à comercialização em grande escala e à industrialização, como se o anonimato garantisse isso. As três últimas estão em publicações como o anuário Carnaval 1965 “Quatrocentão”, com letra e cifras musicais, e a primeira, "Vagalume”, que é de 1954, surgiu no catálogo daquele ano. Além disso, nos Complete poems lê-se este comentário:

No Rio de Janeiro, dúzias de novos sambas são compostos todo ano, para o Carnaval. Embora os sambas relacionados ao amor sejam mais numerosos que todos os demais, alguns sempre se referem a eventos mundiais, tais como a descida do homem na lua, a política brasileira e a vida em geral. Esta amostra de 1965, um ano após a revolução 'de direita', comenta ou ridiculariza as faltas de luz, as trocas no governo e os péssimos trens urbanos. (em Bishop, 1983, p.263-264)

Nos rascunhos desse artigo, preservados nos arquivos da autora, constam letras de tom bem diferente: a jovem vai à praia "vestindo só uma serpentina"; o médico "receitou twist" para quem não dormia e estava triste; alguém relaciona "mulher bebendo, mulher fumando" ao fim do mundo. Há, também, esta nota: "citar o samba do Salgueiro". A escolha final, como se vê, pode transmitir uma visão deturpada do universo carnavalesco para quem não conhece outros sambas e marchas, mesmo porque a nota nos Complete poems afirma que "os sambas relacionados ao amor" são "mais numerosos que todos os demais".

Outro aspecto negativo nessa seleção de sambas está relacionado à própria tradução: empenhada em manter o ritmo e, se possível, as rimas, Bishop traduz incorretamente o nome de um bairro, Encantado - enfeitiçado -, por Delight, e o termo será utilizado pelos editores do New York Times no título do artigo, do qual ela discorda. Em outro verso, Bishop deixa

\footnotetext{
${ }^{32}$ Note-se, por exemplo, que o termo niggers não consta no texto de Bishop, apenas na crítica de Castro.

${ }^{33}$ As músicas são "Vagalume", de Vitor Simon e Fernando Martins; "Cassa o mandato dele" (na realidade, uma marcha), de Paquito, Romeu Gentil e Moreira da Silva; "Juvenal", de Wilson Batista e Jorge de Castro; e "Vem cá mulata", de Fernando Roberto, José Garcia e Jorge Martins.
} 
escapar na tradução, provavelmente por não tê-la percebido, uma referência irônica à repressão política: "Eu vou pra Espanha; você vai pr'a Uruguay" - a rua que leva ao quartel, não o país. Em sua versão, temos: "Some have fled to Uruguay; some have fled to Spain". Além disso, desapareceram na versão publicada uma referência a Clementina de Jesus e a citação de poemas (não nomeados) de Bandeira e Drummond, anunciadas nos rascunhos.

Os comentários de Bishop sobre o teatro fazem um apanhado do que estava em cartaz, mas suas afirmações de que "o teatro no Rio está em geral muito defasado em relação às outras artes”, e “a atuação está num tipo de 'bolsão’ histórico, por milagre inalterada desde 1910, mais ou menos", são no mínimo injustas. Mesmo que se refira apenas ao teatro "comercial”, uma vez que escreve para o público do New York Times, não é possível que ela e Lota ignorem o trabalho do Teatro do Estudante do Brasil, fundado por Paschoal Carlos Magno em 1938, ou as experiências de Maria Clara Machado ${ }^{34}$ com seu Teatro Tablado, fundado em 1951 (Prado, 2002, p.392). No artigo, Bishop também não comenta os contratos estabelecidos entre o governo da Guanabara - de seu amigo Carlos Lacerda - e grupos teatrais para comemorar o Quarto Centenário, o que levou peças de grupos importantes, como $O$ santo milagroso, de Lauro Cesar Muniz, "a um circuito de teatros na periferia da cidade: Meyer, Madureira...” (p.491). Também não cita a "caça às bruxas" que atingiu o teatro logo após o golpe: a perseguição não se restringiu aos CPCs (Centros Populares de Cultura) e a grupos como o Teatro de Arena, mas, em São Paulo, alcançou membros do Teatro Brasileiro de Comédia, "que, não fazia muito, era tido como 'templo da burguesia'” (p.484).

Bishop escreve para os norte-americanos e, por vezes, explicitamente em nome deles, como no trecho em que cita o espetáculo Opinião, "o show mais visto por várias semanas":

O que deprime os norte-americanos no público do "Opinião" não é a vaga "mensagem" (considerada audaciosamente de esquerda no Rio) ou o seu amadorismo (que é simpático). É a súbita, triste, estranha sensação de déjà vu: tudo relembra peças montadas por estudantes universitários por volta de 1930 mostrando mineiros do Kentucky, punhos cerrados e poses desajeitadas.

O aspecto musical do espetáculo é destacado pela presença "de spirituals norteamericanos irrelevantes e canções de presos", e não pelas composições brasileiras importantes - a única citada é a que dá nome ao espetáculo - que, sem dúvida, poderiam transmitir e

\footnotetext{
${ }^{34}$ Bishop demonstra conhecer Maria Clara (como também seu pai, o escritor Aníbal Machado) ao encontrá-la em Manaus, em 1960, como consta em carta enviada a Lota. (Ver Ferreira, 2003, p.155).
} 
significar algo mesmo para os "norte-americanos no público" que não conhecessem a língua portuguesa. A má-vontade de Bishop para com o teatro, entretanto, não se restringe aos grupos brasileiros. Anos depois, seus comentários sobre a presença do grupo vanguardista nova-iorquino Living Theatre em Ouro Preto - cujos componentes seriam presos poucos meses depois, durante o festival de inverno de 1971 - também remetem à sua juventude: "Me deram duas peças para eu ler - achei muito, muito parecidas com as coisas de Vassar dos anos 30" (Bishop, 1995, p.604). ${ }^{35}$

Os comentários de Bishop no campo do teatro e do show musical parecem exigir considerações sobre outras artes. Depois de passar por Manaus e conhecer o Teatro Amazonas, em 1960, a norte-americana escreve em carta que nunca ouviu o Guarani, e que “desconfia de que seja ruim" (Bishop, 1995, p.413-414). Nos originais do livro Brazil, informa que a ópera conheceu "considerável sucesso em 1870, embora tenha sido cruelmente chamada de 'a melhor obra de Meyerbeer"' (p.102), complemento eliminado na publicação. ${ }^{36}$ Pouco depois de escrever o livro, Bishop promoverá audições completas da Aída para amigos, em Petrópolis, valendo-se de suas coleções de discos (Bishop, 2008, p.847), e recusará o empréstimo das gravações de Wagner a um vizinho alemão que "canta suas árias sem parar". Considerando a popularidade alcançada no Brasil por algumas das árias do Guarani, como também pela Abertura dessa ópera, o desconhecimento de Bishop parece indicar certa prevenção. Ainda mais porque nos arquivos da escritora existe uma solicitação para que se inclua, no final de Brazil, uma "lista de discos" em que deve constar "[Guiomar] Novaes tocando V[illa] L[obos]".

\section{Arquitetura: admiração}

A área que merece mais atenção de Elizabeth Bishop em nossa cultura "sofisticada" é, por uma série de motivos, a arquitetura. Seu interesse aparece em carta de 1946, quando pela primeira vez ela comenta sua vontade de escrever um livro de "ensaios sobre viagens a certas regiões da América do Sul" (Bishop, 1995, p.145). Os "prédios" constituiriam um dos temas

\footnotetext{
${ }^{35}$ Brett Millier (1993) informa que Bishop chegou a ser associada, pela polícia, às atividades do grupo "que escandalizou a cidade com suas cenas de nudez e humor grosseiro" (p.440). A escritora havia permitido que os atores se hospedassem em sua casa, após seu retorno aos Estados Unidos para mais um período letivo (p.444446). Segundo Millier, depois disso a reputação da poeta em Ouro Preto "afundou ainda mais" (p.440), comentário que lemos com reserva.

${ }^{36}$ Note-se que, no Brasil, o que normalmente se comenta sobre a ópera de Carlos Gomes são os elogios contundentes de Verdi.
} 
desse livro. Cinco anos depois, quando a viagem se concretiza, a escritora passa a viver numa casa modernista premiada antes mesmo de sua conclusão: "a Lota tem um terreno enorme, e está no momento construindo uma casa moderna, grande e sofisticada, numa encosta de granito negro ao lado de uma cascata - o lugar não podia ser menos prático. ${ }^{37}$ Nós estamos meio que acampadas na obra, ocupando um terço da casa, usando lampiões de querosene etc." (p.239-240). Bishop afirma que "essa é a única casa dele [Sérgio Bernardes] realmente boa, e é boa mesmo, mais por causa do bom gosto da Lota e por ela ter brigado com ele o tempo todo do que por qualquer outra coisa" (p.275). A casa passou a ser visitada por especialistas, amantes da arquitetura e curiosos, não só por suas características, como também por sua localização, na parte mais alta da Fazenda Samambaia, em plena Serra dos Órgãos. Em 1958, quando Lota recebeu a visita do escritor inglês Aldous Huxley, este irritou a feliz proprietária porque "foi à varanda, olhou em volta, virou-se e voltou para dentro da casa" sem dizer uma palavra (Page, em Bishop, 2006).

Desde o início a americana percebe a paixão de Lota por arquitetura, engenharia, urbanismo e construções em geral: "Ela quase nunca anda sem uma trena, uma colher de pedreiro ou uma chave de fenda..." (Bishop, 1995, p.384). Uma carta de 1953, sobre o relato do explorador inglês Richard Burton, do século XIX, que "detesta o barroco e gosta mais que tudo de uma boa avenida larga e reta", fornece pistas sobre o humor e a perspicácia de Lota: "Diz Burton a respeito de Ouro Preto: 'Como vão fazer quando forem instalar tubulações de gás e água?' (tudo lá é tortíssimo). Comentou a Lota: 'Ha-ha-há, senhor Burton, eles sabiam perfeitamente que nunca iriam instalar canos de gás e água"” (p.282).

O relacionamento de Lota com pedreiros e demais trabalhadores, durante a construção da casa, também fornecerá material para que a estrangeira conheça um pouco sobre vários aspectos do país; linguagem e relacionamento, por exemplo:

A Lota acha que um ângulo de 15 graus nos canos não é suficiente, e gritava a plenos pulmões: "José, você sabe muito bem que isso basta para xixi, mas para xixi junto com cocô [em port.] ... etc. É assim mesmo que falam os portugueses e os brasileiros, e estou me acostumando perfeitamente. Acho que essa franqueza toda faz com que aqui seja muito mais fácil a gente se relacionar com as pessoas do que, por exemplo, na Nova Inglaterra... (p.283-284)

\footnotetext{
${ }^{37}$ Ver Figuras 24 e 25. Na II Bienal de São Paulo, em 1954, a casa recebeu o primeiro prêmio do concurso para arquitetos com menos de quarenta anos.
} 
Em Petrópolis, Bishop conviveu com outros arquitetos, como Carlos Leão e Henrique Mindlin. Com Mindlin, trabalhou na versão para o inglês de seu livro Arquitetura Moderna no Brasil (1956), ocasião que lhe serviria para aprender muito sobre "estilos e termos arquitetônicos" (Millier, 1993, p.287). Assim, é natural que ela tenha muito a dizer sobre o assunto, não só nas cartas mas também em seus escritos “jornalísticos”. Quando vai a Diamantina, em 1956, hospeda-se no hotel recém-inaugurado, projeto de Oscar Niemeyer, e critica em carta sua "arquitetura ruim" (p.286), embora não indique o que motivou o comentário. Em compensação, após a viagem de 1958 ao Centro-Oeste, descreve em detalhes e critica o Brasília Palace Hotel, ${ }^{38}$ também projeto de Niemeyer: a ausência de corrimãos, o calor excessivo nos corredores, os ruídos que "vazam" do banheiro vizinho ao seu quarto, até mesmo a altura inadequada do espelho em sua penteadeira. Em Manaus, na viagem de 1960, seu alvo será o Hotel Amazonas, projeto de Paulo Ribeiro, ${ }^{39}$ criticado sobretudo pela decadência nos serviços: “deve ter sido bom quando foi aberto, em 1947”. Suas observações parecem perspicazes, pois em pouco tempo o hotel será convertido em prédio de apartamentos, mantendo-se apenas as lojas no pavimento térreo.

A referência à casa e aos hotéis, aqui, tem seus motivos: os comentários são sempre práticos, baseados na adequação dos edifícios ao uso. Mas em Brasília ela descreverá em detalhes também o Palácio da Alvorada, que conheceu em uma breve visita. A estrangeira não deixa de se maravilhar com as colunas "que parecem mergulhar no chão", "um triunfo arquitetônico" neste que é "sem dúvida um dos mais belos edifícios projetados por Oscar Niemeyer". E descreve: "Se alguém imaginar uma sequência de grandes pipas brancas equilibradas de cabeça para baixo, depois agarradas por mãos gigantes e apertadas nos quatro lados até que seu desenho se atenue de maneira elegante, terá conseguido visualizar essas colunas". Mas não deixa de notar os equívocos na decoração e o desgaste provocado pelo sol nos painéis de jacarandá.

Essa admiradora da arquitetura moderna não se deixa levar, apenas, pela aparência dos edifícios ou pela rígida obediência a fórmulas. Por todos os seus textos os elogios, como também as restrições contundentes, podem recair sobre qualquer tipo de prédio ou cidade, às vezes inesperadamente. É a presença de opiniões soltas, sem justificativa, sobretudo nas suas cartas, que muitas vezes provoca a ira de críticos ou leitores. Em textos como Brazil (1962), ou mesmo "Uma nova capital..." (1958), ela busca o tempo todo embasar seus julgamentos, mas nas cartas encontram-se afirmações soltas que parecem forjadas apenas por suas

\footnotetext{
${ }^{38}$ Ver "Uma nova capital, Aldous Huxley e alguns índios" (1958), na última parte deste trabalho. Ver Figura 22.

${ }^{39}$ Ver Figura 23.
} 
idiossincrasias ou, mesmo, por seu humor: "a arquitetura mourisca é horrenda" (Bishop, 1995, p.51), “já percebi que são só os meus amigos míopes ou quase cegos que dizem que gostam de Nápoles" (p.225), ou "Belo Horizonte, a cidade mais feia do mundo" (p.584).

Em Brasília, a escritora analisa não apenas os prédios, mas também a própria concepção da cidade que se está erigindo em ritmo febril: as estradas, os acessos, o fato de existir um alojamento gigantesco, e distante, para abrigar os operários - o Núcleo Bandeirante, cuja perenização ela já prevê. Note-se que Lota e seu círculo de amigos, como também Bishop, eram totalmente contrários à construção de Brasília, ou mesmo à interiorização do desenvolvimento do país ao modo como estava sendo empreendida por Juscelino Kubitschek, mas a escritora busca embasar seus comentários apenas no que vai percebendo: ela não pode negar o fascínio diante do Palácio da Alvorada, mas tampouco ignora as "gotas de suor nas cadeiras" desse prédio onde o ar condicionado "é desnecessário", segundo a funcionária que recebe o grupo de visitantes.

Bishop vê semelhanças entre o Palácio e a casa de Niemeyer, no Rio de Janeiro, visitada anos antes, e levanta algumas "suspeitas de amadora" que vai confirmar depois, no livro de um especialista (Hitchcock, 1955). Mas o modo como exprime sua conclusão, relacionada ao alojamento dos empregados, nada tem de erudito: "em ambos os casos [a casa de Niemeyer e o alojamento no Palácio] sua solução para os problemas práticos parece ter sido a mesma: colocá-los sob a terra, como uma dona de casa preguiçosa que empurra a tralha da casa para longe da vista, sob uma enganadora cama bem arrumada".

Pronta para criticar o comunista Niemeyer, Bishop encontra munição farta nesse alojamento dos empregados escondido no subsolo, e lembra: "Nos velhos tempos, os escravos viviam nos porões úmidos das casas cariocas; ainda hoje, os quartos e banheiros de empregados nos modernos e luxuosos apartamentos de Copacabana chocam a sensibilidade dos estrangeiros", mas é estranho encontrar o mesmo tipo de problema naquela que é chamada de "a cidade mais moderna do mundo". A escritora completa citando Hitchcock (1955), em seu julgamento sobre a casa carioca de Niemeyer: "É possível que apenas o projetista e sua família considerem essa residência confortável...”.

Brazil foi escrito em 1961, três anos depois de sua visita, quando a cidade já estava inaugurada, e nesse livro o ceticismo de Bishop ganha outros tons: "Brasília tem sido chamada de cidade 'ultrapassada', considerada ao menos 35 anos defasada pelos planejadores urbanos contemporâneos" (capítulo 4, p.58), ou "os prédios se perdem na vastidão circundante, e mesmo dentro da cidade a sensação de estar em outro planeta - como todos dizem - é devastadora" (p.58). Embora reconheça que "talvez seja muito cedo para julgar 
Brasília de um ponto de vista prático", insiste em que "as evidências são desanimadoras". Independentemente das considerações arquitetônicas e urbanísticas, sua observação final vai para "a qualidade dos homens que ela vai trazendo à política" (p.58), aventureiros, sem dúvida, em seu julgamento. No entanto, os comentários sombrios da escritora chocam-se com o conjunto de fotos deslumbrantes, exibidas ao lado de seu texto, que mostram prédios, esculturas e o horizonte do Planalto Central. Note-se que na edição de 1970 os editores suavizaram alguns dos comentários de Bishop. Além disso, a consolidação da capital nos seus primeiros dez anos de vida levou à reelaboração de todo o texto dedicado à cidade, e, assim, modificou-se também sua comparação com o Rio de Janeiro.

A relação de Bishop com o Rio é tempestuosa, como se constata em várias de suas cartas e no texto comemorativo do Quarto Centenário (1965), mas em Brazil o capítulo sobre "As três capitais" é finalizado com um elogio à cidade, que "continua sendo o coração e a alma do país" (p.58). E nos originais havia também este adendo: "No Rio ainda se diz que os bons 'paulistas', quando morrem, vêm para o Rio".

No campo da arquitetura, como se viu, o interesse de Bishop não se restringe à comparação entre os estilos. Ela percebe, por exemplo, que em muitas cidades a Igreja do Rosário, construída e frequentada pelos negros, "é quase sempre a maior e mais deslumbrante de todas" - "lançando uma estranha luz complementar sobre a instituição da escravidão no Brasil” (p.100). A escritora cita Hitchcock (1955) mais uma vez, ao apontar a "incrível negligência na manutenção dos edifícios públicos" (p.98) no país, e comenta o "horrível estilo neobarroco de edifícios públicos" (p.101). A sede do Ministério da Educação e Saúde ganha elogios: "Enquanto Washington, por exemplo, estava bem presa aos greco-romanos quando se projetou o novo edifício da Suprema Corte, o Brasil estava inaugurando o que ainda é considerado um dos melhores exemplos de arquitetura moderna" (p.98). ${ }^{40}$ Érico Veríssimo, por sua vez, elogia exatamente “o 'Supreme Court Building', que, para o meu gosto, é uma das quatro mais belas obras de arte de Washington" (Verissimo, 1941, p.86).

A admiração de Elizabeth Bishop não se limita ao modernismo, é claro, tanto que em 1965 ela compra uma das casas mais antigas de Ouro Preto, aquela que tem "o telhado mais bonito" da cidade (Bishop, 1995, p.481), e a restaura cuidadosamente. ${ }^{41}$ A escritora passará longas temporadas nessa casa, mas diversos problemas vão provocar sua volta definitiva para os Estados Unidos, em 1974. Depois disso, ela tentará vendê-la sem sucesso. No poema One

\footnotetext{
${ }^{40}$ Lota havia trabalhado com Portinari, seu professor, na confecção do painel de azulejos para esse edifício.

${ }^{41}$ Ver Figuras 29 a 31.
} 
art (1999, p.185), a obra-prima em que aborda a questão da perda, Elizabeth Bishop escreverá: "Ah! e nem quero lembrar a perda de três casas excelentes", duas das quais, como ela especificou numa entrevista, ${ }^{42}$ ficavam no Brasil.

\section{Rascunhos e fragmentos}

O Brasil de Elizabeth Bishop não se reduz, é claro, aos textos publicados durante sua vida e aos que estão arquivados como "prosa inédita", cinco dos quais são traduzidos neste trabalho. Os arquivos da escritora reúnem, na pasta de "rascunhos", um material fragmentário e rico, que desperta curiosidade para o tipo de uso que a autora lhe daria. Não constam em seus textos, por exemplo, as divertidas frases de pára-choques de caminhões que Bishop anotava e traduzia, mas elas estão preservadas, ${ }^{43}$ o que demonstra o interesse em seu uso posterior. Chama atenção, também, a reunião das mais diversas notícias de jornal: uma delas refere-se ao coronel alagoano morto por um soldado - este fora recriminado por estar de chinelos, e não de coturnos (em português), no posto de sentinela. Existe, também, a tradução (em cinco páginas) de uma longa reportagem publicada no Jornal do Brasil em 1970, após a morte da sambista Nair Pequena, da Mangueira, sob o título "Uma história do Carnaval". Material para um capítulo sobre o Rio, talvez?

Em carta de 1969 lê-se um comentário relacionado ao projeto de escrever "a segunda versão" de seu "artigo sobre Ouro Preto", "se bem que na verdade ainda não escrevi uma linha" (Bishop, 1995, p.569). E, nos arquivos, existe a tradução (em duas páginas) da "História de Nossa Senhora do Ó”, sem dúvida material de referência para esse mesmo artigo. Nos arquivos ainda encontramos este comentário, de 1971: "Também para Ouro Preto, talvez como introdução, algum tipo de prosa ou poema com os nomes das pedras semipreciosas, cristais etc.”, acompanhado por observação manuscrita e bilíngue: “Good idea. Não é?”.

Esses fragmentos e os textos da "prosa inédita" talvez representem pouco diante de um projeto grandioso como a elaboração de um livro sobre o Brasil. Mas, sem dúvida, demonstram a variedade de temas e interesses da escritora. Vão, portanto, somar-se a outros documentos, sobretudo às novas cartas inéditas que continuam surgindo e que trazem mais peças para a construção desse "Brasil de Elizabeth Bishop".

\footnotetext{
${ }^{42}$ Comentário de Paulo Henriques Britto na Introdução a Poemas do Brasil (1999, p.53).

${ }^{43}$ Ver Figura 34.
} 


\section{Para não concluir}

Este trabalho pretendeu investigar os textos "jornalísticos" de Elizabeth Bishop sobre o Brasil e destacar seus pontos principais, mostrando a relação complexa que a escritora construiu, ao longo do tempo, com o país. Todos os textos reunidos nas duas últimas partes, a começar pelo caso exemplar do livro Brazil, tiveram uma história editorial conturbada, quando esta chegou a existir. Afinal, três dos textos não passam de esboços abandonados. Nos demais, o que houve foi, em certo sentido, uma série de discussões entre autora e editores, de recusas e intervenções desautorizadas, de problemas enfrentados na relação com jornalistas e leitores. O inverso do que se observa na carreira da poeta Elizabeth Bishop, esta sim, uma sequência de reconhecimento desde sua estreia em livro. Como se viu, até mesmo um periódico como a revista The New Yorker, que habitualmente aceitava os poemas de Bishop, e que continuaria publicando alguns deles até muito depois de sua morte, recusou um dos seus textos mais extensos e bem trabalhados sobre o Brasil.

Continuando, em certo sentido, a investigação iniciada anteriormente com a comparação de coletâneas diferentes - americana e brasileira - das cartas de Elizabeth Bishop, em confronto com exemplos de sua correspondência inédita, este trabalho buscou mostrar a riqueza e também as contradições presentes nos seus textos não poéticos.

A explicação para a mudança de atitudes de Bishop em relação ao livro Brazil (1962) - da aceitação da encomenda à rejeição absoluta - mostrou-se complexa. Naquela época a escritora estava influenciada pela euforia norte-americana do início do governo Kennedy, querendo "fazer algo pelo seu país" (Millier, 1993, p.324), enquanto, no Brasil, todos à sua volta estavam envolvidos em algum projeto importante, todos pareciam "estar encontrando sua verdadeira vocação" (p.324). Até mesmo Lota de Macedo Soares, que nunca "trabalhara" - no sentido de atuar em projetos alheios -, envolvia-se cada vez mais nas obras do Parque do Flamengo, do governador Carlos Lacerda. Note-se que o último capítulo do livro, como num reflexo da situação, recebeu o título prévio de "Uma nova esperança", que, depois, a própria autora rasurou - provavelmente ao saber da renúncia de Jânio Quadros. 
A rejeição de Elizabeth Bishop ao livro parece ter sido baseada em três fatores: (1) a qualidade do texto, motivação sempre assumida pela autora; (2) a instabilidade emocional de Bishop, sempre insegura à espera de críticas, numa atitude exacerbada nessa época em que Lota deixava de desempenhar o papel protetor e, em certo sentido, maternal, materializado em presença e apoio ininterruptos; (3) o fato de que os editores (Time-Life) não eram uma empresa jornalística qualquer, mas um dos mais importantes porta-vozes da ideologia norteamericana ao longo do século XX, especialmente durante a Guerra Fria.

Quanto a este último fator, é possível que Bishop tenha sido, até certo ponto, ingênua, que tenha se conscientizado da situação apenas no confronto com os editores em torno de seu escrito, como afirma repetidamente nas cartas. Suas críticas, entretanto, não questionam a ideologia da Time-Life, embora apontem a ignorância dos editores e a intenção de "apresentar as ideias preconcebidas que eles têm de um país, sem nenhuma interferência" (Bishop, 1995, p.715).

É possível, também, que Elizabeth Bishop estivesse preocupada com a opinião de seus amigos da intelectualidade de esquerda nova-iorquina. Essa razão foi levada em conta por seu editor preferido 15 anos após a morte da poeta: ao organizar a coletânea da correspondência de Bishop, em 1994, Robert Giroux não permitiu que se inserissem as cartas relacionadas ao golpe de 1964, nas quais era patente o posicionamento político da escritora, e custou a aceitar a inclusão dessas cartas, em apêndice, na coletânea brasileira, publicada no ano seguinte. É nesse apêndice que os leitores puderam ler comentários como estes, sobre o golpe: "a oposição a Jango subestimava sua própria força" e "nós somos os 'rebeldes'!" (Bishop, 1995, p.737), ou "agora a discussão é se vão ou não expulsar do Congresso todos os parlamentares sabidamente comunistas" (p.738), ou ainda, "o Primeiro de Abril aqui se chama Dia da Mentira, de modo que agora estão dizendo que 'a verdade veio à tona no Dia da Mentira'" (p.739). Apenas em cartas escritas posteriormente, sobretudo em Ouro Preto, algumas das quais publicadas em 2008, Bishop mostra-se consciente da repressão e do que significava viver sob a ditadura: "Um casal de Belo H[orizonte], arquiteto e esposa, almoçou aqui comigo e, voltando para casa, foi pego numa barreira [em port.] pela polícia, ou seja, foram presos, por quatro ou cinco horas, porque eles tinham um gravador no carro" (Bishop, 2008, p.880).

A última questão abordada neste trabalho, relacionada à intenção de captar o país em textos cujo processo de construção é ele próprio testemunho de contradições, permanece, obviamente, em aberto, e se transfigura num amplo convite à leitura.

Se até mesmo interpretações consagradas, como a de Roger Bastide, podem ser vistas como "uma divulgação do Brasil", e não como "propriamente uma análise sociológica" - 
como disse Paulo Duarte na apresentação de Brasil: terra de contrastes (Bastide, 1964, p.9), o que esperar de uma obra decididamente jornalística, escrita às pressas, em que o texto corre o risco de passar despercebido em meio a imagens fotográficas de grande efeito? $\mathrm{O}$ embasamento em pesquisa, a riqueza de detalhes e a argúcia dos comentários não escondem a dificuldade de Elizabeth Bishop em compreender certos aspectos do Brasil, em especial sua dinâmica de privilégios e favores, ou a força da classe média que crescia em grande velocidade, longe da fazenda Samambaia. Ainda, e mais decisivamente, escapam à escritora algumas contradições historicamente determinadas entre campo e cidade, ou entre arte popular e sofisticada. Associado a esses aspectos está, sem dúvida, seu pouco conhecimento da literatura brasileira que, como sabemos, tem como "destino" a descoberta e a interpretação do país, desde o século XIX.

Embora os poemas "brasileiros" de Bishop despertem críticas daqueles que esperam encontrar, aí, um conteúdo político explícito, a divulgação, em 2006, de um esboço abandonado de poema - "Suicídio de um ditador (moderado)" - sobre a morte de Getúlio Vargas provocou troca de farpas envolvendo jornalistas gaúchos e paulistas em torno da palavra "ditador" (Coelho, 2006). E, de vez em quando, algum carioca ainda se mostra magoado diante destas observações: "o Rio é uma cidade debilitante, totalmente relaxada e corrupta" (Bishop, 1995, p.231), e "não é uma cidade maravilhosa, apenas o cenário mais maravilhoso para uma cidade" (Bishop, 1965). Ou seja, a escritora tímida e reservada, avessa às aparições públicas, à poesia "confessional" e à arte politicamente "engajada" - em qualquer direção - continua exaltando ânimos, por diferentes motivos, quase trinta anos após sua morte.

Tomando de empréstimo o comentário de Érico Verissimo (1941), também ele envolvido na interpretação e divulgação mútua dos Estados Unidos e do Brasil, seria plausível dizer: "a prosa que segue não tem nenhum predicado literário, mas estou certo de que não será destituída de valor informativo. Amanhã talvez não valha mais nada, nem como uma coisa nem como outra" (p.332). Mas não se pode negar que a leitura dos textos de Elizabeth Bishop, tanto em Brazil como nos remanescentes de seu projeto abandonado, é informativa, por vezes comovente, não raro surpreendente e, acima de tudo, agradável. 


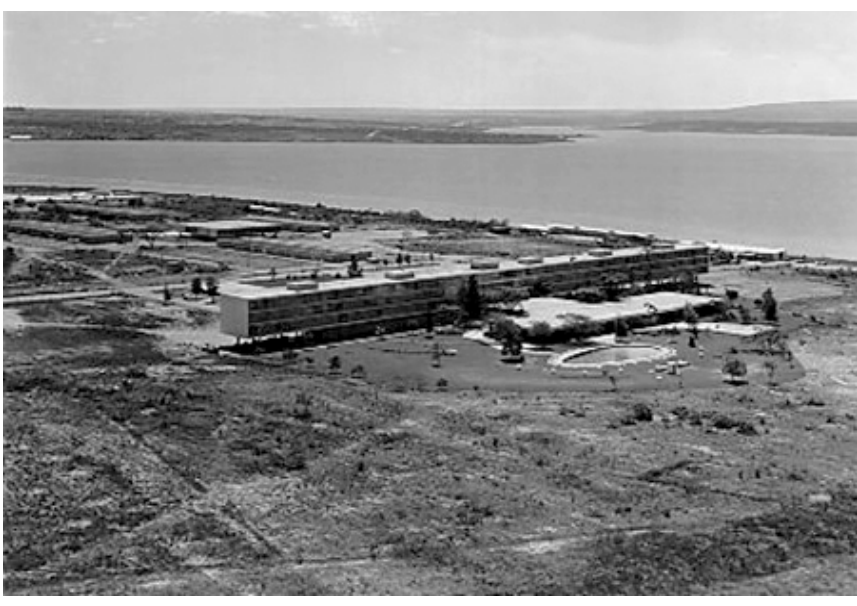

Figura 22 - O Brasília Palace Hotel, projeto de Oscar Niemeyer, em foto do início da década de 1960. (Fonte: Portal Vitruvius)

Figura 23 - O Hotel Amazonas, Manaus, projeto de Paulo Ribeiro. (Fonte: Cavalcanti, 2001, p.318)
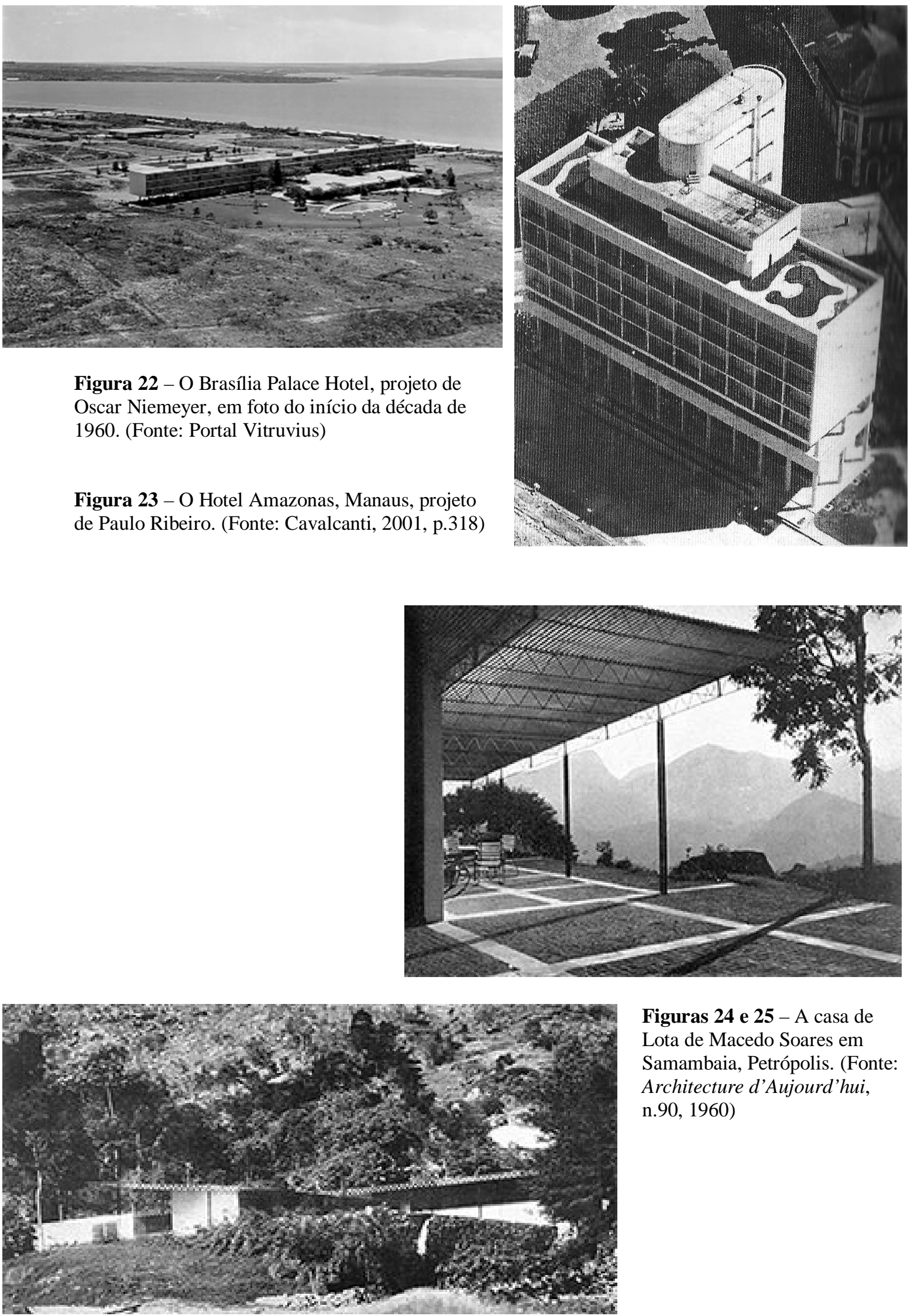

Figuras 24 e 25 - A casa de Lota de Macedo Soares em Samambaia, Petrópolis. (Fonte: Architecture d'Aujourd'hui, n.90, 1960) 


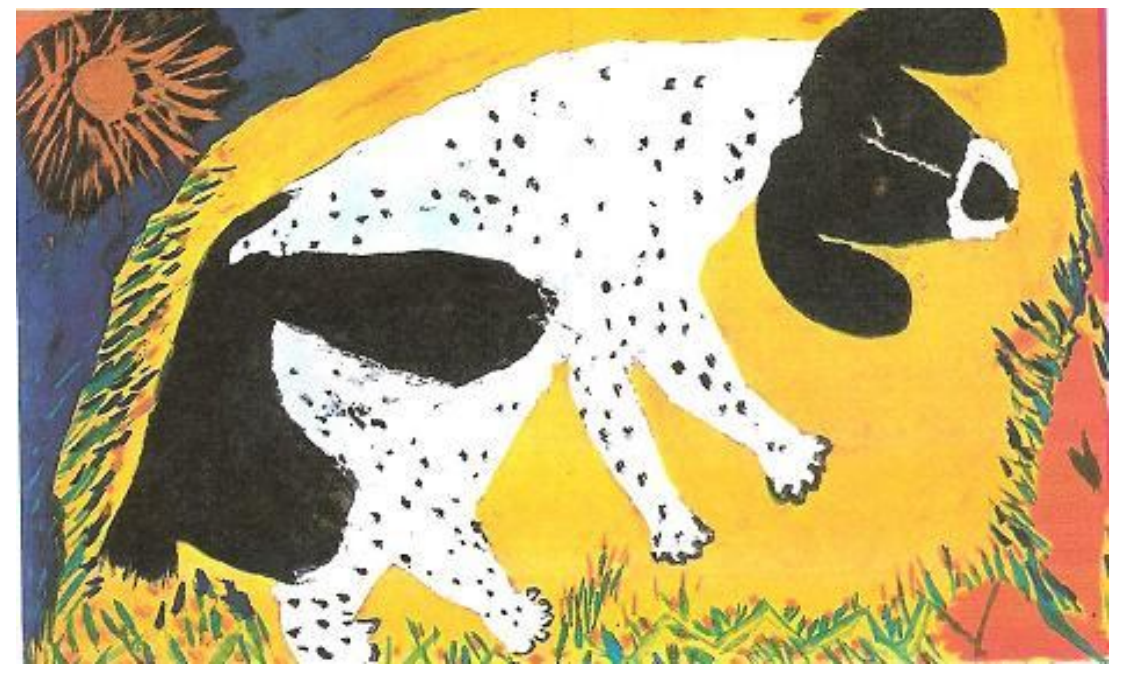

Figura 26 - Madalena

Reinbolt. Cachorro (c.1950).

Óleo sobre papel, 55 x $87 \mathrm{~cm}$.

Col. Mary Morse. (Fonte:

reproduzido de Frota, 1975)

Figura 27 - Madalena dos Santos Reinbolt. (Fonte: Frota, 1975)
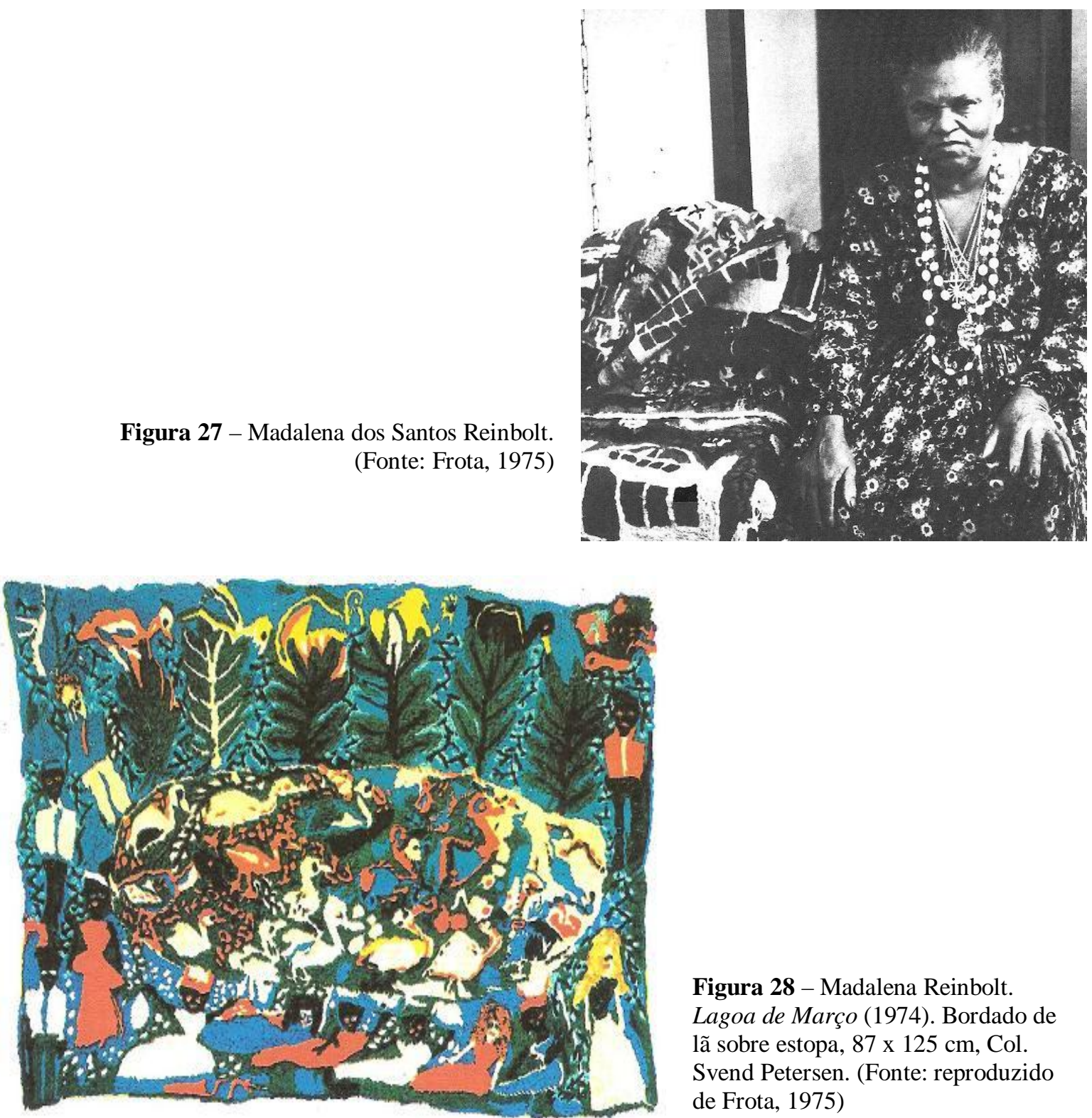

Figura 28 - Madalena Reinbolt. Lagoa de Março (1974). Bordado de lã sobre estopa, 87 x $125 \mathrm{~cm}$, Col. Svend Petersen. (Fonte: reproduzido de Frota, 1975) 

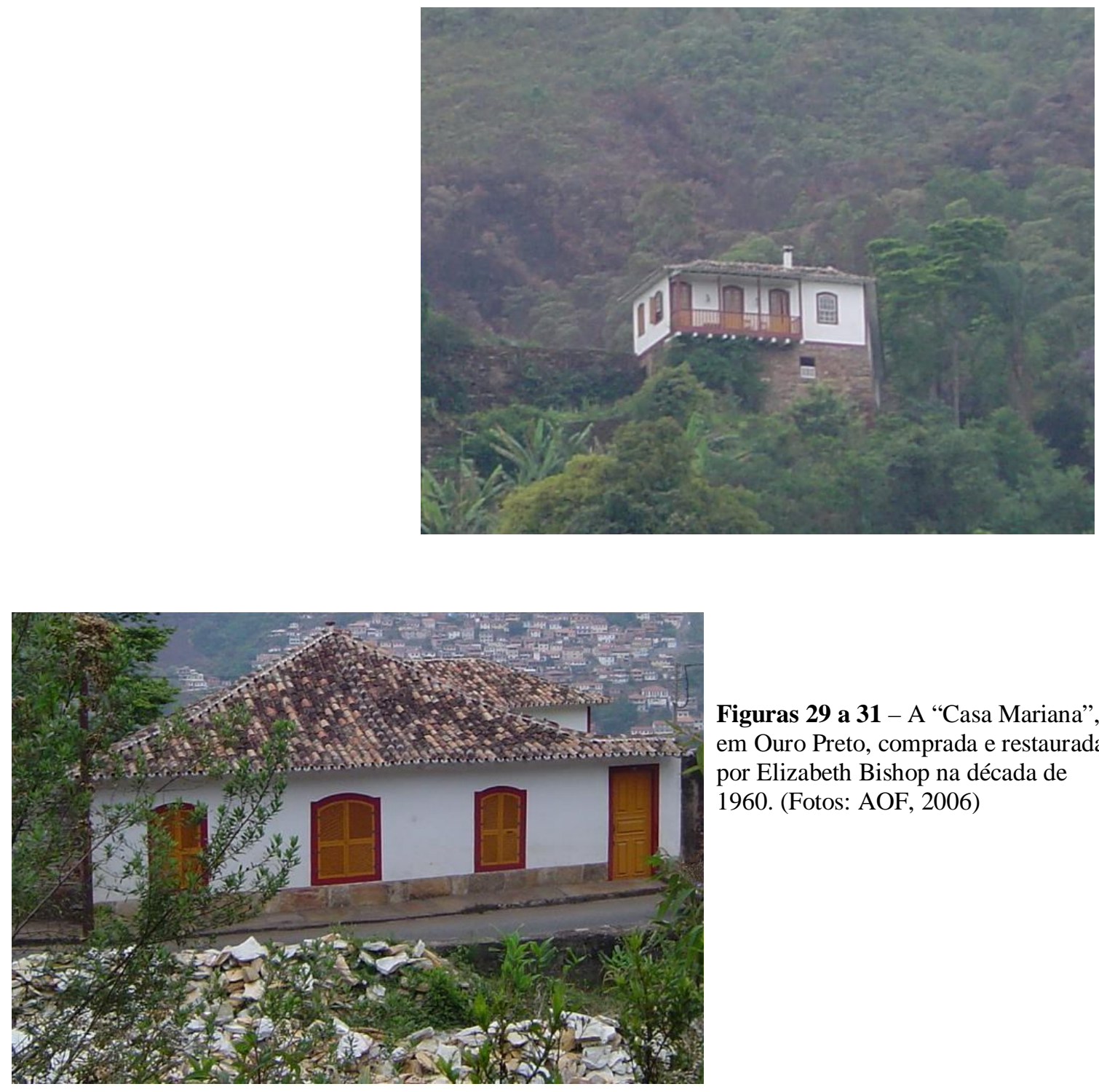

Figuras 29 a 31 - A "Casa Mariana", em Ouro Preto, comprada e restaurada por Elizabeth Bishop na década de 1960. (Fotos: AOF, 2006)

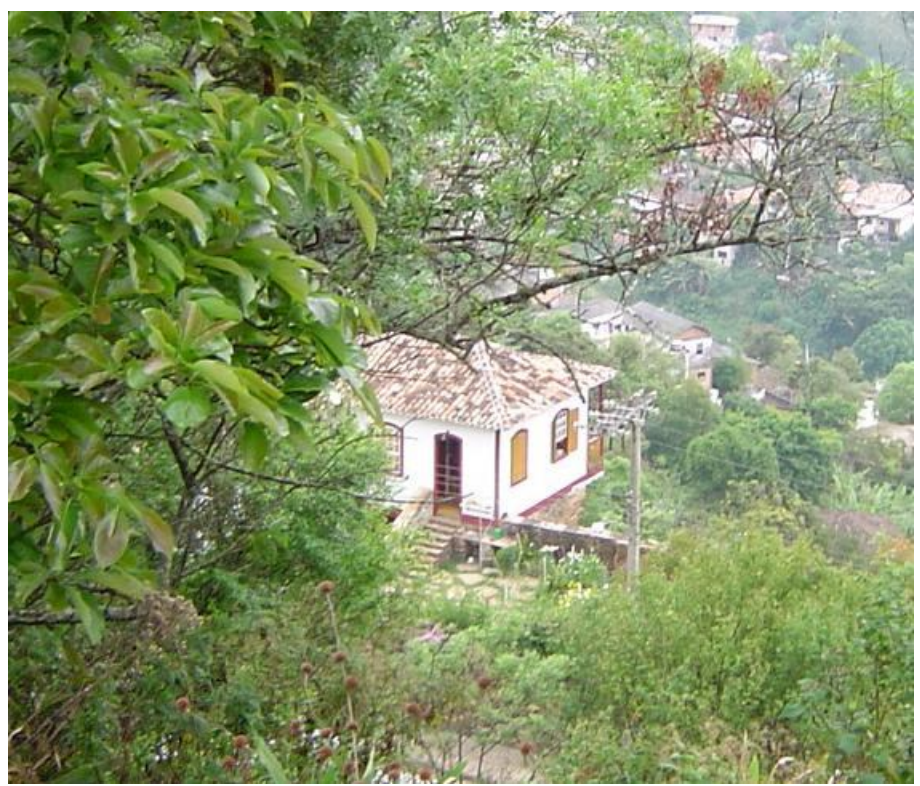




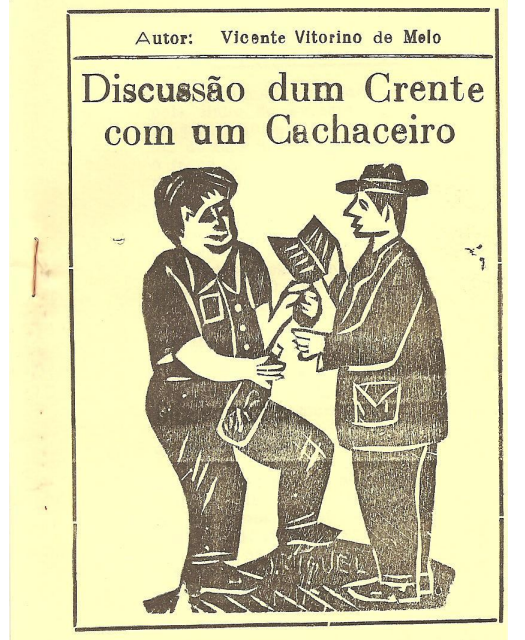

TRUCK-BUMPERS

IOO!IEN \& IISTE I COME!

in PASSTNCTRS - lit'nut tight skirts

IV O!LAN * STIT, TIIF RJ:ST BRATITIIAN PIRODUCT

IT DOFEN'T PAY RUT IT'S AMIJSING

(on a beaten 'p old truck) LOVE WAS MY RUIN

OUT OF THE WINDOW, NOSEY

GOD GUIDES, I STEER

WIO HITS F!ROM SE!IIND IS A COWARD

DON'T CRY - I'LE, SONN SE BACK

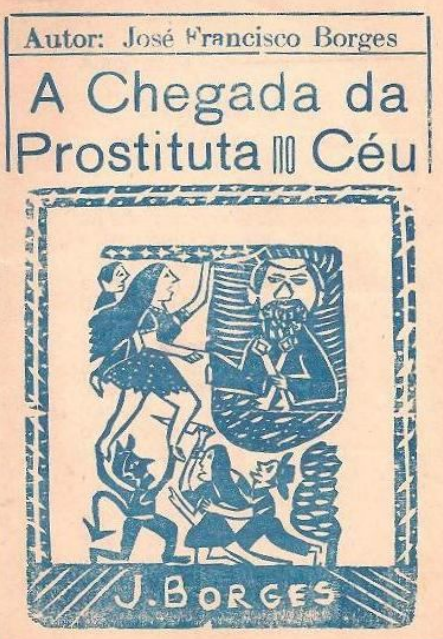

Figuras 32 e 33 - Capas de livretos de cordel. (Acervo AOF)

Figura 34 - Frases de pára-choques de caminhão reunidas por Elizabeth Bishop. Vassar College, Special Collections.

Figuras 35 e 36 - Carrancas do rio São Francisco, em uso e como objeto de decoração. (Fonte: Paulo Pardal. Carrancas do São Francisco. Rio de Janeiro: Serviço de Documentação da Marinha, 1981. p.61 e 92)
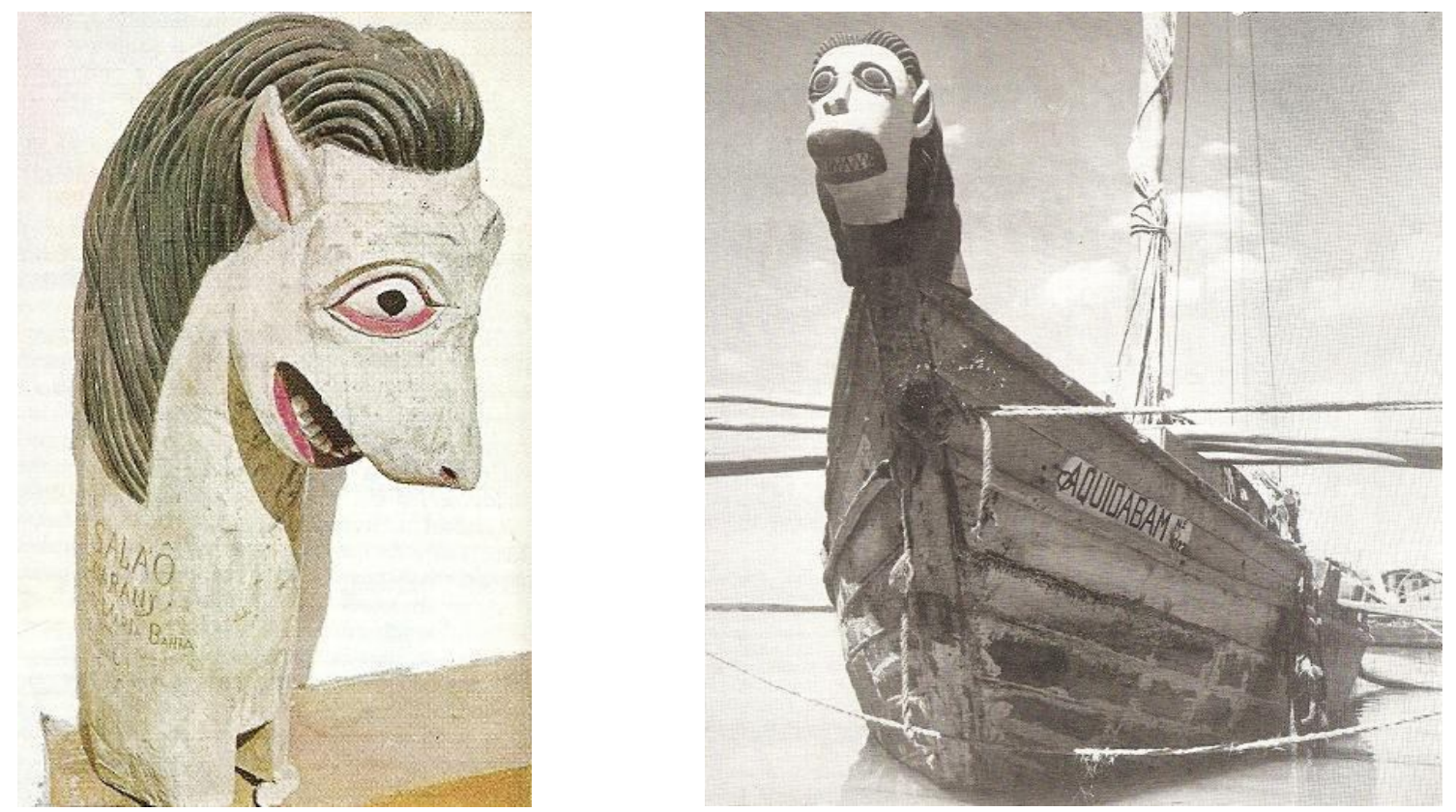


\begin{abstract}
UNIVERSIDADE DE SÃO PAULO
FACULDADE DE FILOSOFIA, LETRAS E CIÊNCIAS HUMANAS DEPARTAMENTO DE TEORIA LITERÁRIA E LITERATURA COMPARADA PROGRAMA DE TEORIA LITERÁRIA E LITERATURA COMPARADA
\end{abstract}

\author{
ARMANDO OLIVETTI FERREIRA
}

Recortes na paisagem:

uma leitura de Brazil e outros textos de Elizabeth Bishop

v.2

São Paulo

2008 


\begin{abstract}
UNIVERSIDADE DE SÃO PAULO
FACULDADE DE FILOSOFIA, LETRAS E CIÊNCIAS HUMANAS DEPARTAMENTO DE TEORIA LITERÁRIA E LITERATURA COMPARADA PROGRAMA DE TEORIA LITERÁRIA E LITERATURA COMPARADA
\end{abstract}

Recortes na paisagem:

uma leitura de Brazil e outros textos de Elizabeth Bishop

Armando Olivetti Ferreira

Tese apresentada ao Programa de Pós-Graduação em Teoria Literária e Literatura Comparada da Faculdade de Filosofia, Letras e Ciências Humanas da Universidade de São Paulo, para a obtenção do título de Doutor em Letras.

Orientadora: $\operatorname{Prof}^{\mathrm{a}} \mathrm{Dr}^{\mathrm{a}}$ Ivone Daré Rabello v.2

São Paulo 


\section{Sumário do Volume 2}

4 Brazil - tradução e anotação 140

Nota sobre esta tradução de Brazil $\quad 140$

Brazil 144

Cap. 1 Um povo caloroso e sensato $\quad 145$

Cap. 2 A terra do pau-brasil 162

Cap. 3 O único império ocidental 179

Cap. 4 Três capitais 197

Cap. 5 Animal, vegetal e mineral 215

Cap. 6 As artes espontâneas 230

Cap. 7 As artes sofisticadas 247

Cap. 8 Grupos e indivíduos 274

Cap. 9 A luta por uma democracia estável 290

Cap. 10 Uma nação perplexa e indecisa 318

Índice (com a paginação da edição de 1962) 334

5 Fragmentos de um outro Brasil 343

(tradução e anotação de cinco textos de Elizabeth Bishop)

Suicídio de um ditador (moderado) [1954] 344

Uma nova capital, Aldous Huxley e alguns índios [1958] 347

Uma viagem pelo Amazonas [1960] 383

No trem do Encantado [1965] 399

Uma viagem pelo rio São Francisco [1967] 413

Bibliografia 422 


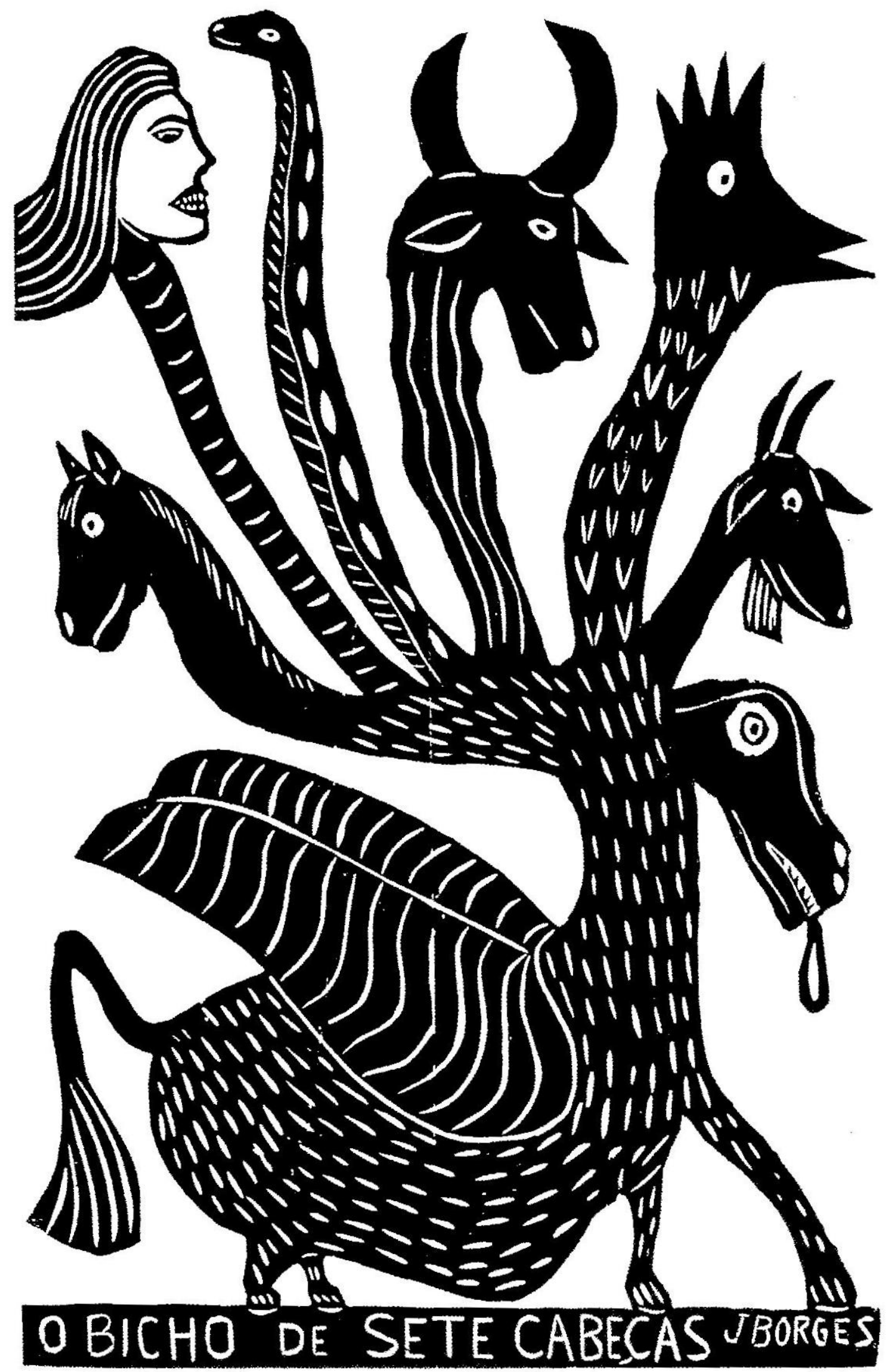




\section{4 \\ Brazil}

\section{Nota sobre esta tradução de Brazil}

\section{1) Versões confrontadas:}

[VAS]: os originais datilografados da autora, hoje nas Special Collections do Vassar College. Não existem originais do capítulo 5 .

[1962]: primeira edição de Brazil, sob autoria de "Elizabeth Bishop e os editores de LIFE".

[HRV]: exemplar (da primeira edição) que pertenceu à autora e foi anotado por ela. Hoje na Houghton Library, da Universidade Harvard.

[1970]: última edição de Brazil. Contém alterações significativas nos trechos sobre Brasília (final do capítulo 4) e sobre a história contemporânea do Brasil (capítulos 9 e 10, este último praticamente reescrito). Mantém-se a coautoria de "Elizabeth Bishop e os editores de LIFE", como nas edições de 1963 e 1967. Em nenhuma dessas três reedições houve participação de Bishop.

\section{2) Diagramação da página:}

Na coluna principal (em corpo 12), à direita, consta o que consideramos a versão 'definitiva' da autora, ou seja, seu exemplar anotado, preservado em Harvard [HRV]. 
Na coluna secundária (em corpo 11), à esquerda, constam as diferenças significativas entre os originais datilografados, preservados no Vassar College [VAS], e a versão 'definitiva' [HRV].

No extremo direito da página (em corpo 8), consta a paginação de [1962].

Nas notas de rodapé numéricas (em corpo 10) constam:

1) diferenças significativas entre [HRV], [1962] e [1970];

2) solicitações da autora aos editores, reunidas em carta de 19 dez. 1961;

3) indicação de elementos acessórios (quadros, mapas etc.) em [1962] e [1970];

4) reprodução de anotações da autora em [HRV], quando esclarecedoras;

5) nossos comentários, quando a tradução não é óbvia;

6) nossas justificativas, quando discordamos de [HRV].

Nas notas específicas deste trabalho (asteriscos) (em corpo 10), também em rodapé, constam nossas anotações sobre termos, expressões, conceitos e incorreções. As notas mais significativas são comentadas nos capítulos introdutórios deste trabalho. Nos pontos onde há notas numéricas, eventuais comentários são incorporados a elas.

\section{3) Padronização:}

a) quando não há diferenças significativas entre as versões, ou não há, nos originais [VAS], texto correspondente ao publicado [HRV], a coluna secundária (à esquerda) permanece em branco. Quando há, nos originais [VAS], trecho sem correspondente no texto publicado [HRV], a coluna principal permanece em branco.

b) trechos dos originais datilografados [VAS] são apresentados incluindo-se ao menos o último termo invariante anterior e o primeiro invariante posterior ao trecho alterado, entre reticências acompanhadas por espaços. O início do trecho segue, sempre que possível, o alinhamento de seu correspondente na coluna principal. Quando a diferença surge já no início do parágrafo, não há reticências iniciais. 
c) termos e expressões que constam em português nas versões originais ganham itálico nesta tradução. Quando o termo aparece em português e em inglês (ao menos em uma das versões) ou quando pode haver dúvida na leitura, recebe nota de rodapé. Os raros termos grifados em inglês continuam grifados ao serem traduzidos.

d) aspas duplas dos originais são mantidas nesta tradução, e servem para indicar tanto destaque como citação.

e) não se usa bold (negrito) nesta tradução.

f) a grafia dos prenomes e dos termos em português foi atualizada e padronizada: posto e não pôsto; Porto Alegre e não Pôrto Alegre; Getúlio e não Getulio.

g) erros (grafia, acentuação), tanto nos originais como nos textos impressos, são corrigidos, mas apontados em nota de rodapé: getúlismo; parliamentarismo; promesas.

h) erros óbvios são corrigidos. Por exemplo: “África oriental”, nos originais do capítulo 2, é substituída por “África ocidental” nesta tradução.

i) medidas: as unidades são transpostas para o Sistema Internacional (SI): quilômetros (e não milhas), quilogramas (e não libras), graus Celsius (e não Fahrenheit) etc. As medidas originais constam em nota quando há dúvida ou alguma consideração relevante.

j) remissivas (chamadas para notas de rodapé) localizam-se depois da pontuação (quando houver), entre espaços, após o termo ou trecho correspondente.

k) paragrafação: segue-se a paragrafação das versões publicadas: recuo na primeira linha, exceto no parágrafo inicial de capítulos e subcapítulos, onde se adota maiúscula (caixaalta) nas primeiras palavras e alinhamento à esquerda.

1) a carta aos editores (rascunho de 19 dez. 1961) é traduzida para o português. Algumas palavras foram datilografadas em maiúsculas (caixa-alta), e esse destaque é mantido na tradução. Os trechos citados pela autora permanecem em inglês quando pretendemos apontar a motivação estilística presente no comentário (inclusão de sinônimos para evitar repetições, por exemplo). Essa carta, por ser única, consta nas notas como "carta aos Editores", simplesmente. 


\section{4) Padronização das notas:}

a) termos e expressões em inglês constam nas notas em itálico, sem aspas: backlands; soccer football.

b) termos e expressões em português, quando destacados, constam entre aspas simples: 'sertão'; 'chamam de preguiça'.

c) citações constam entre aspas duplas; citações dentro de citações, entre aspas simples.

d) títulos de livros constam em itálico; títulos de capítulos, contos e poemas, entre aspas duplas. 


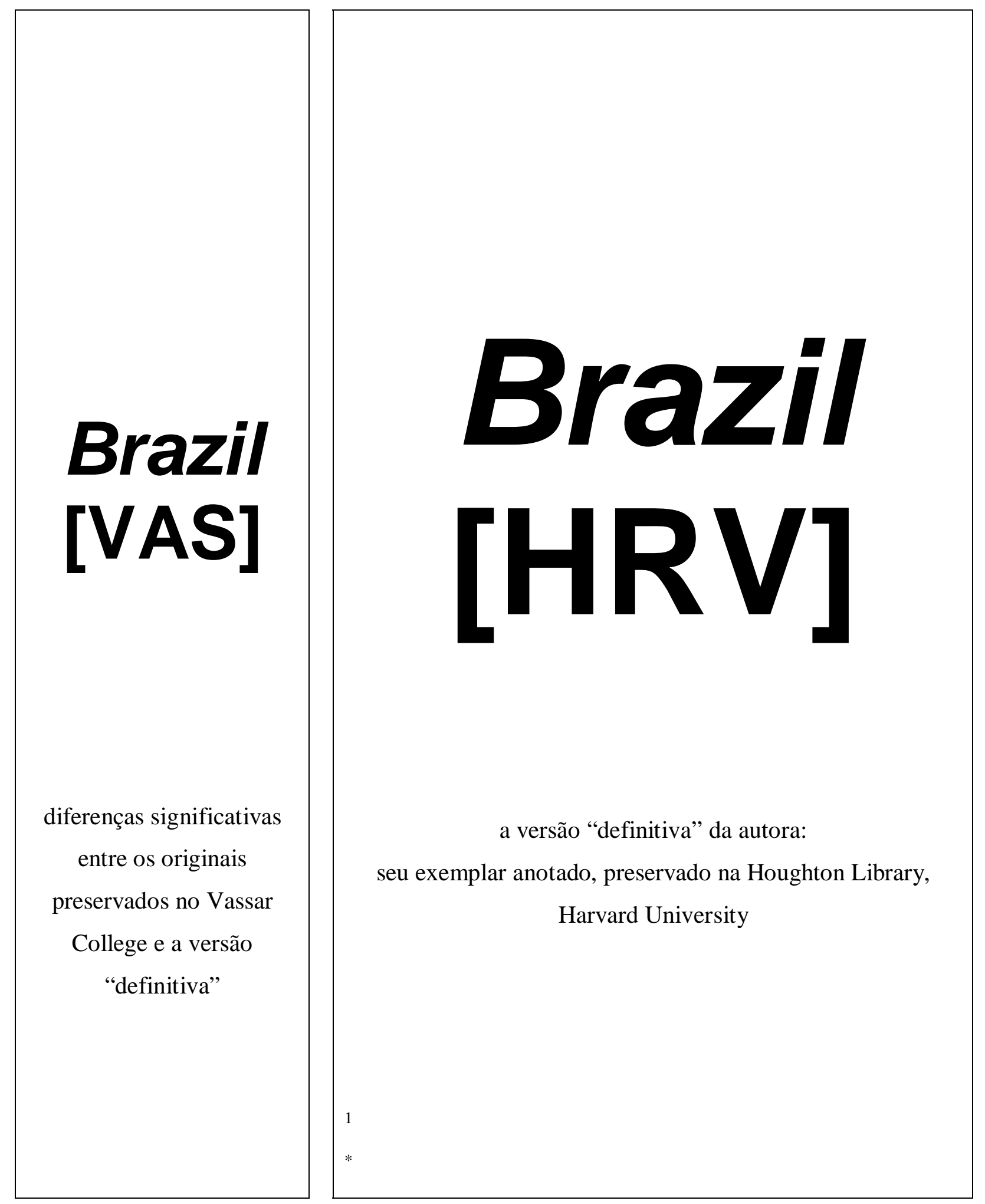

1 Notas gerais.

Notas específicas deste trabalho. 


\section{Uma miscelânea de paradoxos}

\section{Um povo caloroso e sensato ${ }^{1}$}

(O $h$ depois de uma consoante é uma das coisas que fazem o português parecer tão estranho aos nossos olhos. Ele se pronuncia como $y$ : Con-sayson-zeen-ya.) *

... custo de vida, os feitos do novo presidente, Jânio Quadros - talvez ...

[Talvez um QUADRO explicando um pouco da pronúncia portuguesa, como no livro do JAPÃO.

Diminutivos - inha - ão $-x=$ $\mathrm{sh}-$ etc. Talvez com formas de tratamento.]
RECENTEMENTE aconteceu ${ }^{2}$ no Rio de Janeiro um daqueles dramas de "interesse humano", o mesmo pequeno drama que acontece ${ }^{3}$ com tanta frequência em Nova York ou Londres ou Roma: um bebê recém-nascido foi raptado da maternidade. Seu nome era Maria da Conceição, ${ }^{4}$ mas os jornais logo o abreviaram, ao estilo brasileiro, para Conceiçãozinha. ${ }^{5}$

Conceiçãozinha ocupou as manchetes por uma semana, e durante esse tempo é certo que a inflação, ${ }^{6}$ o terrível custo de vida, as trocas de poder no governo - talvez até mesmo os resultados do futebol - ficaram em segundo plano para a maioria dos leitores.

A equipe do hospital foi interrogada. Uma débil mental que vagava pelas imediações foi detida. A polícia vasculhou bueiros, moitas e as favelas, os famosos bairros pobres do Rio, nas encostas dos morros. De alguma forma o rapto foi ocultado da mãe, mas o pai, um jovem funcionário público, foi fotografado em sua mesa de trabalho, em desespero. E 
... notícia, ele "ficou branco", chorou e disse, ...

... abraçando o chefe de polícia.
Conceiçãozinha foi encontrada três dias depois, sã e salva. Uma das enfermeiras da maternidade, que havia sofrido um aborto pouco antes, foi quem raptou a menina.

ATÉ aí tudo isso poderia ter acontecido em Nova York, Londres ou Roma. Mas agora a história torna-se brasileira. O amante da enfermeira branca, um mulato, proprietário de uma pequena mercearia, havia prometido uma casa se ela tivesse um filho, e já havia dado o equivalente a 50 dólares para o enxoval do bebê. Assim, a enfermeira - determinada, como ela disse aos repórteres, "a ter um lugar decente para viver", com "atmosfera caseira", e também porque ela realmente queria ter um filho - ocultou seu aborto e disse ao amante que o bebê nasceria em tal dia. Enquanto isso, ela deixou Conceiçãozinha com sua lavadeira, uma senhora idosa que morava num barraco de favela. A enfermeira foi presa quando levou comida para elas. O bebê estava gordo e passava bem. A lavadeira, analfabeta, não sabia nada do tumulto nos jornais e jurou completa inocência. Quando o pai recebeu a boa notícia, chorou e disse, "Esta é a emoção mais forte que eu já senti na minha vida". Ele foi fotografado abraçando os policiais. Conceiçãozinha foi levada de volta para a maternidade, onde "os médicos a aclamaram e as enfermeiras choraram". Trezentas ou quatrocentas pessoas estavam reunidas do lado de fora. $\mathrm{O}$ bebê, de fraldas, foi levado a uma janela, mas a multidão gritou: "Mostre a carinha dela!". E assim ela foi mostrada "para aplausos e vivas".

No dia seguinte o drama continuou num nível mais calmo, mas num estilo ainda mais brasileiro. A família do pai e a da mãe brigaram para ver qual delas teria a honra de abrigar a criança e sua mãe em primeiro lugar. Uma das avós impediu que o chefe de polícia fosse convidado para ser o 
... planícies pantanosas ao norte ...

... peregrinações e penitências e para o pagamento ...

Esta pequena história reúne ...

... são muito fortes. Eles são católicos, ao menos na aparência. São muito mais francos ...

... atrasado: as lavadeiras são analfabetas; há débeis mentais soltos, pessoas que nos Estados Unidos estariam recolhidas em instituições; e os hospitais podem não ser administrados com a eficiência que consideramos apropriada. Assim, tudo é previsível. padrinho de Conceiçãozinha, porque "isso é sempre um assunto de família". E o pobre pai teve de enfrentar o cumprimento de suas promessas. * Se o bebê fosse encontrado vivo, ele havia prometido (1) encomendar quatro missas; (2) parar de fumar por um ano; (3) levar duas velas de um metro, assim como um bebê de cera, de tamanho natural, até a Igreja de Nossa Senhora da Penha; e (4) subir a escadaria dessa mesma igreja de joelhos, carregando uma vela acesa. Essa igreja do século XVIII fica empoleirada no alto de uma penha ou rocha de formato estranho, que desponta no meio das planícies ao norte da cidade. É uma igreja muito utilizada para peregrinações e para o pagamento de promessas. Os degraus são 365 .

A HISTÓRIA de Conceiçãozinha reúne uma quantidade surpreendente de informações acerca da vida dos brasileiros, de seus hábitos e caráter. A maior parte, é claro, é o que se espera encontrar em qualquer país latino-americano. Brasileiros adoram crianças. Eles são profundamente emotivos e não se envergonham disso. Os laços de família são muito fortes. Eles são católicos apostólicos romanos, ao menos no comportamento exterior. São mais francos que os anglo-saxões acerca de amor fora do casamento, e são tolerantes à miscigenação. Também - como se espera num país muito pobre e em vários sentidos atrasado - muitas pessoas são analfabetas; há débeis mentais soltos, pessoas que em outros países estariam recolhidas em instituições; e os hospitais nem sempre são administrados com eficiência moderna. Assim, tudo é previsível.

Mas não é só isso. Essa história logo faz pensar num dos piores, e mais chocantes, problemas do Brasil: a

\footnotetext{
* A autora sempre grafa promesas, corrigido na publicação.
} 
... leite em pó, se ele perceber que é importante). Pais gostam de "arrumar" seus filhos; os bailes a fantasia infantis são parte importante do famoso Carnaval, todos os anos.

O Brasil é um país católico. Não existe ...

... e 8 ou 9 parecem ser ...

.. 55 por cento da população está abaixo dos 17 anos de idade. Casar-se cedo é normal, 21 ou 22 anos para o rapaz, 17 ou 18 para a menina, e um bebê ...

... infantil é a [em branco] maior do mundo. Nas regiões mais pobres e distantes, em mortalidade infantil. Por que toda essa preocupação sentimental, quase histérica, em torno de um bebê, quando a taxa de mortalidade infantil brasileira ainda é uma das mais altas do mundo? Os detalhes da história de Conceiçãozinha merecem exame não apenas pela luz interessante que lançam sobre essa coisa contraditória, o caráter brasileiro, mas também porque o problema trágico e insolúvel que eles apresentam é quase um paradigma de vários outros problemas do país, grandes e pequenos.

Primeiro, existe a óbvia devoção às crianças. Como em outros países latinos, bebês estão por toda parte. Parece que todos sabem conversar com crianças pequenas e niná-las, e isso inconscientemente. Dizem que dois tipos de pequenos negócios nunca vão à falência no Brasil, lojas de roupas infantis e de brinquedos. O trabalhador mais pobre vai gastar uma quantia desproporcional de seu salário numa roupa de batismo (ou em leite, se ele perceber que é vital para a saúde de seu filho). Pais gostam de arrumar seus rebentos; os bailes a fantasia infantis são parte importante do Carnaval todos os anos, por todo o país.

No Brasil católico não existe divórcio nem controle de natalidade legalizado, $\mathrm{e}^{7}$ famílias grandes são a regra. Às vezes as famílias chegam a ter 20 filhos ou mais, e cinco ou seis parecem ser a média. ${ }^{8} \mathrm{O}$ Brasil é um país muito jovem; mais de 52 por cento ${ }^{9}$ da população está abaixo dos 19 anos de idade. Casar-se cedo é normal, e um bebê no primeiro ano é garantido. Crianças são quase sempre bem-vindas - as primeiras três ou quatro ao menos ${ }^{10}-\mathrm{e}$ adoradas.

E mesmo assim a taxa de mortalidade infantil continua pavorosamente alta. Nas regiões mais pobres e distantes do

\footnotetext{
7 [1970]: 'não existe divórcio, o controle de natalidade é malvisto, e'.

${ }^{8}$ [1962, 1970]: 'ou seis são a média'. A autora aceitou a atualização: a média teria caído de 'oito ou nove' para 'cinco ou seis', mas em seu exemplar [HRV] corrigiu 'são' para 'parecem ser' a média.

9 [1970]: 'mais de 50 por cento'.

${ }^{10}$ [1962, 1970]: 'ou quatro delas ao menos'. Em [HRV] a autora eliminou 'delas' [of them].
} 
grande parte do Nordeste ...

A cidade do Rio, capital do país até 1960, ainda é uma das piores.

... sobreviveu, é possível que mais de 300 bebês tenham morrido apenas no Rio.

... desse terrível desperdício de vida deve-se apenas à fome, ou ao menos à desnutrição.

... gratuitas, mas os médicos desistem ...

Alimentos impróprios, remédios para vermes, xaropes para dormir, amuletos - tudo isso ...
Nordeste e na Bacia Amazônica, ela chega a 50 por cento durante o primeiro ano de vida, e às vezes é ainda mais alta. As cidades do Recife e do Rio, com suas grandes favelas, são duas das piores. Durante os três dias em que Conceiçãozinha ficou escondida no barraco ${ }^{11}$ da lavadeira, e sobreviveu, é quase certo que mais de 60 bebês morreram no Rio. ${ }^{12}$

A MAIOR parte desse trágico desperdício de vida deve-se à desnutrição. ${ }^{13}$ Mas a desnutrição muitas vezes se deve mais à ignorância que à falta de alimento, um círculo vicioso em que pobreza cria ignorância e esta cria mais pobreza. No Rio, por exemplo, existem muitas clínicas conceituadas e gratuitas. ${ }^{14}$ Mas os bons médicos ${ }^{15}$ desistem, depois de trabalhar nelas por anos; eles não suportam ver as mesmas crianças trazidas dia após dia, mais doentes, mais fracas e afinal morrendo porque os pais são ignorantes demais, ou supersticiosos demais, para seguir instruções simples.

As massas de pessoas pobres nas grandes cidades, e os pobres e nem-tão-pobres do "sertão", ${ }^{16}$ amam seus filhos e os matam gentilmente, aos milhares. Alimentos impróprios, comida estragada, remédios para vermes, xaropes para dormir - tudo isso tem um preço muito alto: "pequenos ${ }^{17}$ anjos" em caixões forrados de papel e enfeitados de dourado, azuis para meninos e cor-de-rosa para meninas.

Todavia, a população do Brasil cresce rápido. A expectativa de vida aumentou de maneira considerável nas

\footnotetext{
${ }^{11}$ [VAS]: hut [cabana]; [1962, 1970]: shack [barraco], termo que será usado ao longo do livro.

12 [HRV]: na margem a autora anota: '?'.

13 [1962, 1970]: 'desnutrição que enfraquece a resistência da pessoa às doenças'. [HRV]: além de eliminar o trecho, a autora anota na margem: '!'.

${ }^{14}$ [1962, 1970]: 'clínicas boas [good] e gratuitas'. [HRV]: a autora substitui good por worthy.

${ }^{15} \mathrm{Na}$ carta aos Editores: "Seção 1, par. 11, linha 8: But the good doctors have been known, etc. ELIMINE o the. Deve ficar But doctors have been known - Vocês estão indicando todos os médicos. No mesmo período, ELIMINE a few [algumas]". Apenas a primeira das duas alterações foi aceita; a segunda refere-se a "algumas instruções simples", no final do período.

${ }^{16}$ Backlands, entre aspas, termo que aparecerá várias vezes ao longo do livro; no português, 'sertão', lembrando que Os sertões, de Euclides da Cunha, foi publicado nos Estados Unidos (em tradução de Samuel Putnam, 1957) como Rebellion in the backlands.

${ }^{17}$ [1962, 1970]: "os pequenos anjos". Em [HRV] a autora elimina o artigo.
} 
... e começa a se desenrolar uma nova folha verde.

Esta não é apenas uma figura de retórica. É um símbolo perfeito do Brasil e de seus contrastes, e do que vem acontecendo nele desde o descobrimento. O Brasil ...

... violentado, mas crescendo com vigor.

... choca e entristece não só ... últimas décadas. ${ }^{18} \mathrm{~A}$ forte $\mathrm{e}$, ao que parece, crescente vitalidade do Brasil brilha através das mais terríveis estatísticas de mortalidade. É como a bananeira, que cresce por toda parte no país. Corte-a deixando apenas um toco acima do chão, e em questão de horas surge ${ }^{19}$ um novo broto e começam a se desenrolar novas folhas verdes.

REALMENTE, a bananeira é um excelente símbolo para o país e para o que aconteceu e ainda está acontecendo nele. O Brasil impressionou todos os primeiros exploradores como um "paraíso natural”, um “jardim”, e em seus melhores momentos ainda nos dá essa impressão - um jardim abandonado, violentado e, até agora, em grande parte não cultivado, mas ainda assim crescendo com vigor. Grandes reservas foram desperdiçadas, mas outras ainda maiores estão lá, esperando. Excluindo a ocorrência de algum desastre mundial, a prosperidade material parece prestes a chegar. Mas é a má administração e o desperdício das riquezas humanas e materiais ao longo do tempo o que choca não só o estrangeiro, mas também o brasileiro sensível, educado. Para dar apenas um exemplo: por causa de estradas inadequadas, transporte insuficiente e falta de ${ }^{20}$ refrigeração, cerca de 40 por cento ${ }^{21}$ de todos os alimentos produzidos se estragam antes de chegarem aos grandes centros consumidores.

Taxas de natalidade e de mortalidade infantil explosivas, ${ }^{22}$ grande riqueza e pobreza degradante - estes são os dois grandes paradoxos. Mas eles vêm acompanhados por muitos outros, menores, repetindo seu padrão, sobrepondo-se

\footnotetext{
${ }^{18}$ [HRV]: a autora insere colchetes em 'aumentou ... décadas', certamente no intuito de conferir ou eliminar o trecho; na margem: '?'.

19 [1962, 1970]: 'em questão de dias surge'. Os editores parecem ter duvidado do surgimento tão rápido dos brotos, como constava nos originais. [HRV]: a autora substitui 'dias' por 'horas'.

${ }^{20}$ [1962, 1970]: ‘insuficiente e uma falta generalizada de refrigeração'. [HRV]: a autora elimina $a$ widespread.

${ }^{21}$ [1970]: '30 por cento'.

22 [1970]: 'Taxa de natalidade explosiva e alta mortalidade infantil,'.
} 
... tocante, [predisposição para discutir] combinada ...

... brasileira e nos sucessivos governos: períodos ...

... de uma região para outra [e parecem orgulhar-se disso]. a eles e com eles interagindo: patriotismo apaixonado e tocante, ${ }^{23}$ combinado com constante autocrítica e menosprezo; luxo e inatividade (ou a admiração por ambos) combinados com explosões de energia; ${ }^{24}$ extravagância e orgulho, com sobriedade e humildade. Os mesmos contrastes aparecem ao longo da história brasileira, períodos de desperdício e corrupção alternando com períodos de reforma, nos quais “se põe a casa em ordem". 25

O Brasil é muito grande e muito diversificado. Os brasileiros variam de maneira extraordinária de uma região para outra. ${ }^{26}$ Um homem pode ser "carioca" (do Rio - supõese que o nome derive de uma expressão indígena que significa "casa do homem branco"), "paulista" (de São Paulo), "mineiro" (do estado de Minas Gerais) ou "baiano" (do estado da Bahia), ${ }^{27}$ e ele se orgulha das peculiaridades de sua região.

Mas isso não ocorre apenas na geografia, também em sua história o Brasil é variado. Homens de duas, três ou mais eras da história europeia vivem no Brasil, hoje. As cidades costeiras - de Belém, na foz do Amazonas, a Porto Alegre, no Sul - são habitadas por homens do século XX envolvidos com problemas do século $\mathrm{XX}$ : progredir no mundo e evoluir socialmente; como pagar escolas, médicos e roupas. Nas regiões vizinhas existe uma população rural ou semi-rural que leva uma vida defasada em pelo menos meio século, antiquada nos aspectos agrícola e social. E para as pessoas das vilas pesqueiras, para aqueles que vivem nas margens dos grandes rios, para os vaqueiros e mineiros - todos os habitantes do

${ }^{23}$ [VAS]: a própria autora cortou a chip on the shoulder (predisposição para discutir); [1970]: elimina-se 'e tocante' [and touching].

${ }^{24} \mathrm{Na}$ carta aos Editores: "Seção 1, último par., deve ser: 'luxo e inatividade (ou a admiração por ambos) combinados com ascetismo e explosões de energia;' etc.'. No texto publicado continuou faltando 'ascetismo'. [HRV]: na margem, asceticism.

${ }^{25}$ Na carta aos Editores: "Última palavra da Seção 1 - Eu não escrevi housecleaning [limpeza da casa], e prefiro a palavra original, qualquer que seja ela". Em [VAS] constam duas opções, ambas cortadas: carefulness e in which it was carefully nurtured. Os editores mantiveram housecleaning.

${ }^{26}$ [VAS]: a própria autora eliminou 'e parecem orgulhar-se disso'.

27 [1970]: '(do estado da Bahia ou de sua capital, Salvador),'. 
(Aqui, se você quiser, posso incluir um pouco de informação acerca dos dias da semana, que vêm do período de [em branco]) ${ }^{*}$

\section{A história de}

"Conceiçãozinha" ilustra que a tendência é de torná-la mais leve e mais suave com os diminutivos. Cria-se uma atmosfera de familiaridade, afeição, intimidade, que parece ser tipicamente brasileira. O mais próximo exemplo desse tipo de fala é o modo pelo qual os homens de meia-idade do Sul dos Estados Unidos referem-se aos seus "dads". De fato, como vários escritores já observaram, muito da vida brasileira pode ser mais bem compreendido ou apreciado por norte-americanos familiarizados com o extremo sul de seu próprio país.

(QUADRO?) interior - o tempo parece ter estacionado no século XVII. Por fim, se alguém se aventura um pouco mais longe, entra no mundo atemporal e pré-histórico dos índios.

MAS existe um fator que une todo o Brasil mais estreitamente que alguns países europeus cuja área não é maior que a de um estado brasileiro: sua língua. O Brasil é o maior país onde se fala a língua portuguesa. Seu português difere daquele falado em Portugal tanto quanto o inglês americano difere do inglês britânico. Mas por todo o Brasil a língua é uniforme num grau surpreendente, e os brasileiros não encontram dificuldade em compreender uns aos outros.

É uma língua difícil e solene, e algumas de suas formas gramaticais provêm direto do latim da República Romana. Os brasileiros tendem ao descuido com a precisão gramatical, ao menos na fala, e ao abrandamento da língua com constantes diminutivos (Maria da ${ }^{28}$ Conceição tornou-se Conceiçãozinha). De fato, os portugueses consideram o português brasileiro "efeminado" - charmoso quando as mulheres o falam, mas não uma língua para homens.

Não apenas o uso constante de diminutivos, mas também as formas de tratamento ajudam a criar uma atmosfera de familiaridade, afeição e intimidade. As formas de tratamento ${ }^{29}$ brasileiras são quase tão complicadas quanto as russas, e costumam ser comparadas a elas, mas em geral as

\footnotetext{
* Nesta página e na seguinte, mais exemplos de recados da autora ao Editor.

${ }^{28}$ [1962, 1970]: '(assim como Maria da Conceição'. [HRV]: a autora elimina 'assim como' [as].

29 [1970]: nomenclature substituída por designations, com as alterações respectivas de singular por plural.
} 
[Apelidos e diminutivos são muito comuns. "Dona Baby", "Dona Magu" (de Maria Augusta), "Doutor Carlinhos" (mesmo que ele tenha mais de 60 anos e pese mais de 100 quilos). Mais uma vez, esta é uma reminiscência de nosso próprio Sul, com seus "Miss Natties" e "Mr. Billies".]

Coitado: isso pode aplicar-se a qualquer um ou a qualquer coisa, sempre num tom de piedade e comiseração: Conceiçãozinha foi automaticamente chamada de "coitadinha".

... "um acolhimento" - o pai de Conceiçãozinha deu um "abraço de urso" no chefe de polícia.

... dá a mão a um negro pobre e ... mulheres são chamadas de Dona,${ }^{30}$ seguido pelo prenome ou apelido, e os homens de Doutor, se tiverem formação universitária ou, se não ${ }^{31}$ a tiverem, utiliza-se uma forma abrandada de Senhor, Seu, também seguida pelo prenome.

BRASILEIROS são muito rápidos, não só no aspecto emocional mas também no físico. Como os heróis de Homero, homens podem mostrar suas emoções sem cair em desonra. Seus admiráveis jogadores de futebol $^{32}$ abraçam e beijam uns aos outros quando fazem gols, e choram dramaticamente quando erram. Os brasileiros são rápidos também ao mostrar solidariedade. Uma das primeiras - e mais úteis - palavras que um estrangeiro aprende é coitado.

Parte do mesmo sentimentalismo da vida social aparece no uso do abraço. ${ }^{33}$ Os brasileiros dão as mãos sempre, e os homens ao mesmo tempo se abraçam ${ }^{34}$ com o braço livre. As mulheres também se abraçam e beijam rápido os dois lados do rosto: esquerda! direita! Quando acompanhado de um sentimento profundo o abraço torna-se um verdadeiro "acolhimento". 35

Um homem rico dá a mão a um pobre e o abraça, e também lhe dá dinheiro, tenta arranjar um emprego para ele e

\footnotetext{
${ }^{30}$ [1962, 1970]: 'Dona', 'Doutor' e 'Seu' em português, entre aspas.

31 [1962, 1970]: 'formação universitária ou um grau suficiente de prosperidade [or a sufficient degree of prosperity], ou, se não a tiverem, utiliza-se'.

${ }^{32}$ Em português e inglês [soccer football].

${ }^{33} \mathrm{Em}$ português e inglês [embrace].

${ }^{34}$ [1962, 1970]: 'se abraçam casualmente com o braço livre'.

${ }^{35}$ Becomes a real embrace.
} 
... tolerância. Às vezes, é difícil dizer se isso é mesmo tolerância: respeito, admiração ou "amor" são as primeiras e mais importantes emoções; sofisticação, ignorância - às vezes fica-se em dúvida. pagar as contas do médico de sua esposa, uma vez que cresceram juntos na mesma fazenda, fizeram juntos a primeira comunhão e talvez sejam até "irmãos de criação", um sistema de adoção parcial que vem dos tempos da escravidão. Os empregados nas casas ainda são chamados de criados, um termo que em outra época significava terem crescido no seio da família. Mesmo hoje ainda se vê, de vez em quando, uma velha senhora ${ }^{36}$ elegante caminhando de braço dado com uma menina negra bem vestida, ou tomando chá ou um refrigerante com ela numa casa de chá; a menina é sua "filha de criação", ela a está criando.

Em tais relações existe uma completa naturalidade de ambos os lados. Às vezes os brasileiros parecem confundir familiaridade com democracia, embora a atitude pareça antes um resquício dos dias de escravidão, ou do feudalismo, ou mesmo do Império Romano, quando todo homem rico tinha à sua volta um conjunto de amigos pobres e parasitas. Todavia, um senso de responsabilidade natural subjaz nessas relações e contribui um pouco para o conceito atual de democracia mais difícil e de alguma forma mais amplo.

Lar e família são muito importantes no Brasil. Mas, como não existe divórcio, surgem situações estranhas: há segundos e terceiros "casamentos", não reconhecidos pela lei mas socialmente aceitos, nos quais se reúnem grupos desencontrados de filhos. Essas situações apenas dão aos brasileiros ocasião para exercitar seu talento único para a tolerância gentil. De fato, no espírito de conciliação os tribunais decidiram, há mais de duas décadas, ${ }^{37}$ que daí em diante ninguém poderia ser, do ponto de vista legal, chamado de ilegítimo. ${ }^{38}$

\footnotetext{
${ }^{36}$ [1962, 1970]: 'uma senhora elegante'.

37 [1970]: 'de três décadas,'.

38 [HRV]: na margem: traço vertical, junto às duas últimas linhas.
} 
${ }^{42}$ Muitos pobres não se casam; custa caro demais. [E todos os tipos de uniões são reconhecidos, e muitas crianças são batizadas porque isso lhes dá "uma chance melhor na vida". O amor é o mais importante.]

... é o lema. Emocionalismo superficial contrasta com a lógica latina que subjaz; sentimentalismo e retórica com fatalismo e fortes [instintos]. O pai de Conceiçãozinha pôde mostrar desespero e chorar em público - mas ele também barganhou com seus santos, de maneira comercial.
Existe uma anedota relacionada com o Rio de Janeiro e seus amados, decrépitos bondes. ${ }^{39} \mathrm{Um}$ bonde vem deslizando, lotado como sempre, com homens ${ }^{40}$ pendurados, parecendo um enxame de abelhas. Ele reduz a velocidade, sem chegar a parar, e um homem alto e desajeitado desce; assim que salta do estribo ele cai, aterrissando de maneira humilhante. Os outros passageiros riem. Ele se levanta, recompõe-se e grita com grande dignidade: "Cada um desce do bonde do seu jeito".

Esta é a frase perfeita a respeito da crença brasileira sobre tolerância e convivência: a cada um deve permitir-se que desça do bonde do seu jeito. ${ }^{41}$

A maior tolerância estende-se, é claro, ao amor, porque no Brasil essa é sempre a emoção mais importante. O amor é o elemento constante em quase todas as notícias de jornal, cenas de rua ou conversas familiares. Se o almoço está atrasado mais ou menos uma hora porque a cozinheira estava distraindo-se com seu belo menino de entregas, a patroa vai repreendê-la, até mesmo perder a paciência (para os brasileiros, as mudanças de humor são rápidas, também), mas haverá compreensão nas entrelinhas, e as desculpas da cozinheira serão francas, meio irônicas, talvez indecentes do ponto de vista anglo-saxônico. "Uma coisa de cada vez" é o lema. ${ }^{43}$ Oposta à constante preocupação com amor é a falta de sentimentalismo diante de casamentos arranjados. Pode haver emocionalismo superficial, mas sempre permeado pela lógica latina e pela aceitação direta. ${ }^{44}$

\footnotetext{
${ }^{39}$ Em português [1970]: 'com o Rio de Janeiro e os bondes, ou carros abertos, que trafegavam ruidosamente em suas ruas'.

40 [1970]: 'vinha deslizando, com homens'.

${ }^{41}$ [HRV]: na margem: traço vertical na extensão do parágrafo.

42 [VAS]: a própria autora excluiu o trecho 'E todos ... importante'. O restante foi excluído na publicação.

43 First things first, que poderia ser traduzido também como 'Primeiro, o mais importante'. O período seguinte foi muito alterado em relação aos originais, mas a própria autora já havia eliminado ‘instintos', sem indicar substituta.

${ }^{44}$ Neste ponto (p.14) consta o QUADRO: "Português e Espanhol: suas similaridades e diferenças".
} 
... sinal de beleza. Esse é um padrão antigo, clássico, que se mantém através dos tempos, e sem nada da ideia puramente anglo-saxônica de "understatement"."

... fábrica". As longas esperas por refeições são comuns e a inglesa Maria Graham reclamou disso em 1820 , e Darwin em 1830. Paciência! Calma! Espera ai ${ }^{47}$ - são as mais comuns de todas as expressões.
Uma brasileira fazendo compras em Nova York ficou desconcertada diante da etiqueta que garantia, numa camisa colorida de algodão que ela havia comprado para o marido: "Desbota". Num país tão rico como os Estados Unidos, por que alguém quereria usar roupas que desbotam? Por que os americanos gostam de vestir jeans desbotados? É claro que isso é falso romantismo e apenas mais um exemplo da criancice dos anglo-saxônicos quando comparados aos latinos, mais adultos? Os valores são realistas ${ }^{45}$ no Brasil. Fora dos círculos elegantes, os pobres são magros e os ricos são gordos, e gordura é um sinal de beleza, como tem sido desde os tempos antigos. ${ }^{46}$

Os brasileiros são rápidos em vários sentidos, mas eles podem ser terrivelmente lentos. A mesma patroa que repreende sua cozinheira por estar flertando vai reclamar das refeições sempre atrasadas. Mas, se alguém perguntar, com ingenuidade, "Por que não almoçar todos os dias à 1 da tarde?", ela responderá: "Bem - isto não é uma fábrica”. ${ }^{48}$

ENTRE os primeiros colonizadores no Brasil havia os grandes “capitães”, nobres portugueses empobrecidos e filhos caçulas buscando enriquecer rápido, acostumados a ter lacaios feudais e escravos à sua volta. Eles e os portugueses desqualificados 49 que também chegaram nos primeiros tempos logo estabeleceram uma tradição de posse de escravos índios e negros. Um resultado é que desde esse tempo o trabalho físico é visto com desprezo. De todas as atitudes herdadas essa é a mais difícil de superar entre os brasileiros, livres de tantos

\footnotetext{
* Understatement: 'falar nas entrelinhas', suavizando o sentido, geralmente inserindo uma fina ironia.

${ }^{45}$ [1962, 1970]: 'Os valores são simples e realistas no Brasil'.

46 [HRV]: '?' na margem.

47 [VAS]: datilografado Patiencia! Calma! Espera-ai [sic].

${ }^{48}$ [HRV]: a autora anota na margem: (cut) [cortar].

49 Of low rank.
} 
... luxo, mesmo que você não possa desfrutar dela, permanece uma estranha indiferença diante do simples conforto. É claro que isso se deve, em parte, ao clima. As camas brasileiras são, via de regra, duras como pedra mas isso faz sentido num clima tropical, assim como assoalho de pedra ou de cerâmica, e móveis de madeira ou taquara. A ideia inglesa de "aconchego e aquecimento" é tão estranha como a ideia de "chá" - que é frequente nas receitas médicas. Mas suas velhas casas de paredes grossas e pédireito alto são frescas; as redes (copiadas dos índios), ainda usadas no norte, são confortáveis para dormir em clima quente. No frio -

... sala de jantar (a sala de jantar substituía a sala de estar, até que houve, nos últimos tempos, mudanças no estilo) sob um lustre. outros preconceitos. Os brasileiros de classe alta que visitam o atarefado continente norte-americano não podem compreender por que tanta ânsia por trabalho. Um menino rico cortando a grama? Mais romantismo! Um emprego vitalício no governo, trabalho em escritório, ou, se possível, trabalho algum, é o sonho do homem pobre. Um miserável e doentio coletor de impostos, que sustenta a mulher e os seis filhos com dificuldade, mas que carrega com orgulho uma pasta e leva duas canetas-tinteiro no bolso, vai tremer de raiva se sua posição social for mal interpretada: "Eu? - Todos sabem que eu nunca fiz trabalho braçal na vida!".

MAS ao lado da admiração por uma vida de ócio e luxo permanece uma estranha indiferença diante do conforto físico. Mesmo no frio - e pode fazer muito frio ao sul de São Paulo ou nas regiões mais altas do interior - não existe calefação de nenhum tipo. As pessoas apenas vestem mais roupas. Nas pequenas cidades em junho e julho, os meses mais frios, é comum ver uma agradável, antiquada cena brasileira: toda a família, avós, pais, bebês, padrinhos, ao lado de alguns primos distantes e noivos, usando pulôveres ou talvez robes por cima das roupas, todos sentados em volta da mesa da sala de jantar sob um lustre. Cada um fazendo aquilo que quer: lendo o jornal, jogando cartas ou xadrez, ou discutindo com veemência as opiniões dos outros. Mesmo ${ }^{50}$ os grã-finos, os elegantes, os ricos cosmopolitas da alta classe, aqueles que adotaram o "fim de semana inglês", quando se transferem para Petrópolis ou outros lugares turísticos, todos sempre aparentam estar acampando no inverno. Em salas congeladas, senhoras com casacos de minke sobre as calças compridas e mantas sobre os joelhos e cavalheiros usando cachecóis

\footnotetext{
${ }^{50} \mathrm{Na}$ carta aos Editores: "Seção 3, par. 3, linha 17: Elsewhere [em outros lugares] deve ser EVEN [Mesmo], e elimine elsewhere. - Vocês dizem where na sentença seguinte. TAUTOLOGIA!". A alteração não foi feita. [1962, 1970]: 'Em outros lugares, mesmo'.
} 
... ao contrário dos de outras raças, sempre ...

... fantásticos. A cuisine do norte, em que se misturam pratos indígenas, africanos, mouros e mediterrâneos, é merecidamente famosa quando bem feita. assistem a filmes depois do jantar, a diversão mais chique do momento. Talvez bebam uísque, também para serem chiques, mas é muito mais provável que tomem cafezinhos, as pequenas xícaras de café fervente e muito doce. Os pobres, enquanto isso, bebem os mesmos cafezinhos, empilham todas as roupas sobre o corpo e vão para a cama cedo.

Os brasileiros são um povo muito sóbrio. Dois ou três cafezinhos fornecem combustível suficiente para que eles conversem e discutam durante toda a noite. O capitão Joshua Slocum (Sailing alone around the world), ${ }^{51}$ navegante $\mathrm{e}$ escritor do final do século XIX, comandou, quando jovem, um navio pela costa da América do Sul. Ele fala mais de uma vez de "meus sóbrios marinheiros brasileiros", os quais, ao contrário dos de outras nacionalidades, sempre retornavam sem ressaca depois de uma noite no porto.

Talvez por serem os brasileiros, em geral, indiferentes tanto à culinária quanto ao conforto físico, a comida é muito ruim. ${ }^{52}$ A dieta básica consiste em arroz, carne seca e feijão preto, cozido com muito toucinho e alho e servido com farinha de mandioca, a ser espalhada sobre o feijão. Todavia, existem muitos pratos refinados, feitos com vinte ou trinta ingredientes, e fantásticas sobremesas com nomes ainda mais fantásticos, como baba-de-moça, travesseiro-de-noiva ou mãebenta (pequenos bolos).

A CONVERSAÇÃO durante as noites estimuladas por cafeína vai alternar política, assuntos imobiliários (um passatempo ${ }^{53}$ favorito em todas as classes) e lembranças de família. Orgulhosos de sua lógica latina, os brasileiros

\footnotetext{
${ }^{51}$ Slocum, Joshua (1848-1909). Sailing alone around the world: the first solo voyage around the world. New York: Sheridan House, 1900.

${ }^{52}$ [HRV]: na margem: (cut).

53 [1970]: 'política, eventos esportivos (um passatempo favorito em todas as classes)'.
} 
... passatempos populares.

Mais uma vez é difícil distinguir, dizer se as pessoas estão sendo muito sofisticadas, ou apenas tolerantes. É verdade que elas fazem coisas totalmente inesperadas: a filha de um expresidente torna-se freira carmelita. $\mathrm{O}$ herdeiro de uma família famosa desaparece e depois é encontrado vivendo com duas garotas pobres e vários filhos, como uma espécie de catador de lixo. Filhos extraconjugais do marido são adotados pela esposa. E essas coisas não acontecem apenas nas classes altas. No último ano, durante o Carnaval, ... também se orgulham um pouco de sua reputação de "loucos". Traços de família são valorizados; tal família será famosa por seu mau humor ou por sua obstinação ou por seus olhos verdes - porque a aparência, também, é muito importante. O nariz característico da família, bem desenhado, será percebido até nos recém-nascidos. Essa preocupação com a boa aparência talvez provenha do fato de que muitas famílias antigas têm algum sangue negro. Existe uma noção popular de que as belezas famosas devem ter uma ou duas gotas desse sangue correndo em suas veias; ${ }^{54}$ isso as tornaria mais vivazes. Uma vez que todos querem ser tão claros, ou brancos, quanto possível, esta é mais uma das contradições que parecem não incomodar ninguém.

Criticar o país, ridicularizar o governo e falar da "estupidez nacional" utilizando exemplos pavorosos e apócrifos são também passatempos prediletos. Às vezes é difícil dizer se as pessoas estão irritadas de verdade ou apenas excitadas, se são tolerantes ou indiferentes a qualquer necessidade de tolerância, ingênuas ou muito sofisticadas. ${ }^{55}$ Os brasileiros são instáveis: ${ }^{56}$ há pouco tempo, durante o Carnaval, um negro que dançava pela calçada com sua mulher de repente esbarrou em suas duas amantes. ${ }^{57}$ Houve uma pequena confusão e alguns puxões de cabelos, mas uma hora depois todos os quatro foram vistos sambando, alegres, de mãos dadas. ${ }^{58}$ Quando perguntaram à esposa por que tolerava aquilo, ela respondeu desesperançada, mas com orgulho: "Ele me contou tudo. Ele fala de um jeito tão bonito!".

\footnotetext{
${ }^{54}$ [HRV]: na margem: (cut).

55 [HRV]: na margem: (cut).

56 'mercurial'.

57 [VAS]: a autora fica em dúvida ao descrever a situação, "suas duas amantes (ou duas de suas amantes)", e comenta entre parênteses: "deve haver um jeito melhor de dizer isso".

${ }^{58} \mathrm{Na}$ carta aos Editores: "Par. 7, linha 12. - Deve ser 'dançando o samba juntos, de mãos dadas' [holding hands] - NÃO 'E DANDO AS MÃOS' [and holding hands] QUE SIGNIFICA ALGUMA COISA BEM DIFERENTE. SINTAXE, POR FAVOR". O trecho não foi alterado; a correção foi feita apenas nesta tradução.
} 
... hamletiano, "O mundo está fora dos eixos. Oh! Maldita sorte!...." ${ }^{59}$ - sentindo melancolia sob um peso intolerável de responsabilidade $\mathrm{e}$ consciência, e incapaz de ação, cobrindo sua profunda ansiedade com um humor deliberadamente alegre e surrealista que não significa frivolidade, embora pareça.

... extravagante. Um noticiário cinematográfico recente continha uma longa sequência de cenas de um exercício naval - os dois submarinos lançavam seus torpedos, aviões circulavam e soltavam bombas, os velhos canhões do forte de Copacabana davam tiros que atravessavam a baía. $\mathrm{O}$ narrador terminou seus comentários num tom de voz perfeitamente normal, dizendo que a munição gasta nesses exercícios custou mais que todos os navios e aviões envolvidos, quando estes foram comprados. Houve um silêncio momentâneo e então a audiência gargalhou.

Frivolidade? Desesperança?

Sanidade, bom humor e paciência que subjazem a tudo? Parecia ser a reação hamletiana em larga escala.
Povos mais taciturnos costumam desconfiar dos faladores, e acham que estes desperdiçam sua energia. É comum encontrar entre os intelectuais um tipo de brasileiro hamletiano, incapaz de trabalho sério ou ação, que parece estar escondendo uma ansiedade profunda debaixo de palavras, palavras, palavras, uma loucura fingida, um humor com a intenção de ser extravagante, que não significa frivolidade embora se pareça com ela. $\mathrm{O}$ humor grosseiro dos pobres, as charges brutais nos jornais e revistas, os meninos que riem de aleijados e de mulheres feias - isso está diretamente alinhado com o humor dos antigos romanos; mas o humor dos intelectuais é muito diferente, oblíquo, polido e um pouco extravagante.

${ }^{59}$ [VAS]: “The world is out of joint, oh cursed spite”, final do I Ato de Hamlet (Shakespeare, v.1, Tragédias. São Paulo: Abril Cultural, s.d., p.227). No texto publicado permaneceu apenas a segunda citação de Hamlet: “Words, words, words", Ato II, Cena 2 (p.237). 
... longe demais. (Duelos, como ainda existem na Argentina, estão fora de moda. Os argentinos veem brasileiros como "loucos"; e o Brasil vê a Argentina como "vulgar".) O Brasil nunca teve uma grande guerra. Nunca quis mais terra, uma vez que já tem tanta que não sabe o que fazer com ela. Os assassinatos são quase todos crimes passionels - como também os suicídios. $\mathrm{O}$ amor é a paixão pela qual são feitos sacrifícios reais, independentemente do que os políticos possam dizer. Os raros linchamentos (Como o Sr. Lynch imortalizou-se!) acontecem porque alguém matou ou estuprou uma criança.

... temperamento clássico brasileiro: "uma coisa de cada vez".
Eles se divertem com suas revoluções nas quais em geral não se derrama sangue: "Ninguém lutou naquela revolução - era época de chuvas”. Como a modalidade portuguesa de touradas, na qual não há morte, as revoluções brasileiras (ou golpes) às vezes parecem ser pouco mais que manobras políticas e retóricas. Os discursos de um homem, sua coragem moral e física, são admirados, mas violência real é ir longe demais. ${ }^{60}$ Duelos ainda existem na Argentina, mas eles estão fora de moda no Brasil. O país não entra numa grande guerra há cerca de um século. Quase nunca quis mais terra, uma vez que já tem tanta que às vezes não sabe o que fazer com ela.

AS PIADAS dizem ainda mais. Existe uma ótima, que talvez nem seja brasileira em sua origem, sobre um homem que anda pela rua com um amigo. Ele é insultado de modo grosseiro por um estranho, e não diz nada. $\mathrm{O}$ amigo tenta despertar seus instintos belicosos, "Você não ouviu o que ele disse? Vai suportar isso? Você é homem ou não?". E o outro responde: "Sim, sou homem. Mas não fanático". Este é o verdadeiro temperamento brasileiro.

\footnotetext{
${ }^{60}$ [1970]: ‘é ir longe demais. Essa pode ser uma das razões pelas quais a luta amarga e frequentemente brutal que irrompeu em 1969 entre estudantes terroristas e o governo pareça ter despertado tão pouco interesse para o brasileiro comum'.
} 
... mangas largas, franjas e um saiote, segurando ...

\section{... comemorar o} quadricentésimo aniversário do descobrimento do Brasil por Pedro Álvares Cabral de acordo com algumas autoridades. À medida que ...

... se Cabral realmente descobriu o Brasil ou não. Porém, muitos deles agora concordam em que ele o fez, em 1500, logo depois da Páscoa.

... roupas vermelhas. (Talvez todas as roupas de lã vermelha usadas pelos camponeses nos quadros de Brueghel tenham sido tingidas com "brasil".) $\mathrm{O}$ Atlas Medici de 1351 mostra uma ilha denominada "Brazil", e essa ilha
2

[p.25]

\section{A terra do pau-brasil ${ }^{61}$}

EM um dos parques do Rio existe um exemplo belo e extravagante de escultura latino-americana para parques, um homem muito maior que o tamanho natural, vestido com roupas suntuosas, mangas largas enfeitadas com pele, ${ }^{62}$ segurando um estandarte de bronze, ondulado, de cerca de uma tonelada. Num lado do pedestal consta "1900" e no outro, "1500". A estátua foi erguida para comemorar o que as autoridades acreditam ser o quadricentésimo aniversário do descobrimento do Brasil pelo navegador português Pedro Álvares Cabral. À medida que a cidade cresceu, essa estátua foi sendo transferida, mais ou menos da mesma maneira pela qual os historiadores se esquivaram do problema de decidir se Cabral deveria ser chamado de descobridor do Brasil ou não. Mas todos concordam em que ele ao menos foi o primeiro a declarar isso - em 1500, logo depois da Páscoa.

Mas uma terra denominada "Brasil" constituía uma lenda na Europa ao menos desde o século IX. Onde quer que ela estivesse, era de lá que o bresilium vinha, uma madeira obtida em comércio com o Extremo Oriente e muito necessária para o tingimento de roupas vermelhas. Colombo encontrou a árvore do pau-brasil nas Índias Ocidentais, mas em sua avidez por ouro simplesmente a ignorou. Porém, os primeiros barcos europeus que retornaram do continente sulamericano estavam carregados com pau-brasil, e "Brazil", ou "Brasil", tornou-se o nome comum para o novo território.

\footnotetext{
${ }^{61}$ [HRV]: a autora substitui o título, "Terra subdesenvolvida e lendária" [Undeveloped Land of Legend], pelo original.

${ }^{62}$ [1962, 1970]: 'enfeitadas com pele e um saiote [and a skirt], segurando'.
} 
imaginária continua a reaparecer durante séculos, às vezes numa parte do mundo, às vezes em outra, mesmo depois de o Brasil atual ter sido descoberto. Colombo ...

... território. (A grafia varia, e às vezes o número; ele também foi chamado "Os Brasis" [The Brazils]).

... 13 pequenos barcos ... ele se desviara de seu curso cerca de [em branco] milhares de milhas para oeste.

... astrônomos, navegadores e matemáticos da época ...

É possível que os portugueses estivessem interessados em passar à frente dos espanhóis, os quais estavam muito ocupados explorando as terras mais ao norte.

... descobertas. (E isso tornou as coisas mais difíceis para os historiadores.) Mas ...
Pedro Álvares Cabral deveria estar a caminho da Índia, no comando de uma frota de 13 barcos; se isso fosse verdade, ele se desviara várias centenas ${ }^{63}$ de milhas de seu curso. Como os melhores astrônomos, matemáticos e professores de navegação da época estavam a serviço da corte do rei D. Manuel I de Portugal, parece quase impossível que o desvio de Cabral tenha sido acidental. É possível que os poderosos portugueses estivessem interessados em passar à frente dos espanhóis, os quais estavam explorando as terras mais ao norte.

Teoricamente, não deveria haver rivalidade entre as duas potências. Dois anos após a primeira viagem de Colombo, de 1492, Portugal e Espanha, então no ápice de sua era dos descobrimentos, haviam dividido todo o mundo não-cristão entre eles, num gesto majestoso. O Tratado de Tordesilhas, sancionado pelo papa, deu a Portugal todas as terras a leste de uma linha situada 370 léguas * a oeste das ilhas de Cabo Verde; todas as terras a oeste dessa linha pertenciam à Espanha. A posição exata dessa linha era sempre vaga, e a rivalidade entre os dois países tão forte que mesmo após a assinatura do tratado cada um buscou ocultar do outro suas descobertas. Mas Portugal acreditava, ou fingia acreditar, que todo o Brasil estivesse contido em seus territórios. O

\footnotetext{
${ }^{63} \mathrm{Na}$ carta aos Editores: "p.26, col. 1, linhas 4 \& 5 - vários milhares de milhas ('centenas' não é correto)". O texto não foi alterado, e, na realidade, a opção dos editores também é correta.

*Em [VAS] consta miles; a autora confunde léguas com milhas.
} 
... o Brasil e os índios, ou a pequena parte de ambos que ele viu, tem sido ...
... uma forte impressão. (Em 1531 um barco francês levou para a Europa três mil peles de onça, trezentos macacos e "seiscentos papagaios que já falavam algumas palavras em francês".) Num mapus mundi publicado um ano após ... resultado é que quase metade da América do Sul tornou-se uma colônia portuguesa, enquanto a maior parte da área restante foi colonizada pela Espanha.

NA nau capitânia de Cabral havia um mercador nobre chamado Pero Vaz de Caminha, contratado como escriba. A carta maravilhosamente vívida que ele escreveu para o rei D. Manuel, descrevendo o Brasil e os índios Tupi, a primeira das muitas tribos que os portugueses encontrariam, tem sido chamada de "a primeira página da História do Brasil" 64 e, com igual justiça, "a primeira página da literatura brasileira". Após um breve relato da viagem, Caminha anuncia com calma:

Neste dia, a horas de vésperas, houvemos vista de terra! Primeiramente dum grande monte, mui alto e redondo; e doutras serras mais baixas ao sul dele; e de terra chã, com grandes arvoredos: ao monte alto o capitão pôs nome - o Monte Pascoal e à terra - a Terra da Vera Cruz.

O monte, situado no que é hoje o estado da Bahia, ainda tem o mesmo nome. O rei, no entanto, substituiu Vera Cruz por Santa Cruz, que permaneceu o nome oficial até a metade do século, quando, sob protestos eclesiásticos, tornouse Brasil. Mas nos primeiros mapas aparece tanto "Brasil" como "Terra dos Papagaios". Além do pau-brasil, araras foram levadas para a Europa, e suas cores brilhantes, grande tamanho e fortes gritos causaram, sem dúvida, uma forte impressão. Num mapa-múndi publicado na Europa um ano após o retorno de Cabral, o litoral do Brasil não passa de uma suposição, mas os bosques de Caminha estão lá, alinhados de modo formal como num jardim português, e sob eles está um

\footnotetext{
${ }^{64}$ [HRV]: a autora substitui History of Brazil por Brazil's history.
} 
... do Sul”. Ela está na bandeira; a mais alta condecoração é a Ordem do Cruzeiro do Sul; ...

... no outro. (Exatamente na mesma direção, a maior igreja do Rio de Janeiro, Nossa Senhora da Candelária, onde todas as cerimônias religiosas oficiais eram celebradas até a mudança da capital em 1960, fica numa praça cercada pelos bancos mais ricos do país, de certa maneira ilustrando uma tese sobre as relações entre Igreja, Estado e grandes grupos financeiros. Ou, ainda, a conversa dos brasileiros pode saltar das verdades eternas de santo Tomás de Aquino para os negócios imobiliários, e voltar em seguida.) grupo de araras gigantes, para dar aos exploradores uma ideia do que iriam encontrar.

MESMO que o nome Vera Cruz não fosse muito original no século XVI, era uma escolha óbvia para Cabral. Ele era cavaleiro da Ordem de Cristo, e as velas e os estandartes traziam estampada a cruz vermelha da Ordem. Os homens desembarcaram para celebrar o domingo de Páscoa com uma missa, e levantaram uma cruz. E por muitas noites, no mar, eles tinham visto as estrelas brilhantes do Cruzeiro do Sul lá no alto; o astrônomo da frota escreveu ao rei para descrever essa constelação tão útil. Desde então, o Brasil sentiu-se como a única "Terra do Cruzeiro do Sul”. A mais alta condecoração destinada aos estrangeiros é a Ordem do Cruzeiro do Sul; a moeda atual, o cruzeiro, tem esse nome por causa dela - e existem milhares de bares, restaurantes, empresas e produtos com esse nome. E, coerentemente com a transição abrupta que os brasileiros fazem entre o material e o espiritual, a nota de mil cruzeiros traz ${ }^{65}$ um retrato de Cabral num lado e uma gravura da Primeira Missa no outro.

\footnotetext{
${ }^{65}$ [1970]: 'a nota de mil cruzeiros carregou durante muito tempo um retrato'.
} 
... selvagem. Ele torna-se quase lírico, como todos os primeiros viajantes, diante desses primeiros e poucos dias idílicos de lua-de-mel no maravilhoso século em que os países e os continentes se casaram e novos países foram concebidos. Em seu estilo não científico, ele foi também o primeiro de uma longa lista de naturalistas e etnólogos, alguns deles entre os maiores do mundo, que desde então se fascinaram pela América do Sul e pelo Brasil.

... sem causa". Existe até mesmo uma insinuação de inveja, talvez o primeiro traço do Indianismo romântico e do "Bom Selvagem" que mais tarde iria colorir a imaginação brasileira tão fortemente. Os índios eram "limpos, gordos e formosos", e pareciam ...
Caminha era um bom repórter. Ele descreve a aparência e o comportamento dos índios, sua comida e suas casas, a estranha e nova vida selvagem. Os índios eram amigáveis e dóceis - dóceis demais para o seu próprio bem. ${ }^{66}$ Presentes foram trocados, um dos quais terrivelmente profético: os índios deram aos portugueses cocares de sua bela arte plumária, e em troca os portugueses lhes deram um gorro vermelho ${ }^{67}$ usado pelos trabalhadores. Os índios assistiram à missa e imitaram os homens brancos, ajoelhando-se, fazendo o sinal-da-cruz e cantando um hino deles próprios.

Ainda bem que os portugueses não tinham o zelo missionário sedento de sangue dos espanhóis. Mas Caminha, talvez por sentir o que se esperava dele, escreveu: "E pois Nosso Senhor, que lhes deu bons corpos e bons rostos, como a bons homens, por aqui nos trouxe, creio que não foi sem causa". Os índios eram "tão limpos, tão gordos e tão formosos" que pareciam mais saudáveis e fortes que os próprios portugueses. Entre as mulheres, Caminha comenta de uma delas que "era tão bem-feita e tão redonda, e sua vergonha (que ela não tinha) tão graciosa, * que a muitas mulheres da nossa terra, vendo-lhe tais feições, fizera vergonha, por não terem a sua como ela". Os portugueses sempre foram romanticamente atraídos por mulheres de raças mais escuras; durante muito tempo haviam tido esposas mouras e concubinas negras, e ainda havia muitas escravas negras em Portugal. No Brasil, seria natural iniciar uma miscigenação impetuosa no primeiro momento.

\footnotetext{
${ }^{66}$ MAPA: “Um estranho novo mundo para os europeus...”. É esse o mapa comentado no texto. No original, em outro parágrafo, a autora completa o comentário: 'para o seu próprio bem, como se provaria mais tarde' .

${ }^{67}$ [1962, 1970]: 'os gorros vermelhos usados'.

* O jogo de palavras entre 'ter vergonha', 'suas vergonhas' e 'fazer vergonha' perdeu-se na tradução de Bishop.
} 
... Se plantando, dar. [sic]

Essa frase é hoje um dito

popular, mas seu sentido

alterou-se, de uma promessa

para uma advertência a

alguém que esteja

desperdiçando oportunidades

óbvias. Seguramente, essa ...

... consolá-los. Esperava-se que os homens condenados aprendessem a linguagem dos índios e os convertessem à Fé Verdadeira.

... tem inúmeros heróis degredados e semilendários. De fato, suas personalidades formam uma equipe reunida de maneira estranha:
Caminha relatou que não se viu nem ouro, nem prata, nenhum outro metal. Mas completou dizendo que o interior ${ }^{68}$ parecia ser muito grande: “Águas são muitas; infindas. E em tal maneira é graciosa que, querendo-a aproveitar, dar-se-á nela tudo...”. A frase, Em se plantando, dá, é hoje um dito popular, mas seu sentido alterou-se. Ela já significou uma promessa, ${ }^{*}$ mas hoje é usada como uma advertência irônica a qualquer um que desperdice oportunidades óbvias. Essa simples inversão de sentido revela muito acerca da longa história das riquezas e das possibilidades brasileiras não aproveitadas desde o ano de 1500 .

AO PARTIR, Cabral deixou dois degredados, os quais foram vistos pela última vez lamentando sua sorte enquanto os índios tentavam consolá-los. Os homens condenados tinham ordens de aprender a linguagem dos índios e de convertê-los à fé verdadeira. Essa era a prática usual dos portugueses; ninguém sabe quantas centenas desses miseráveis foram deixadas ao longo da costa pelas expedições seguintes. Muitos desapareceram para sempre, mas aqui e ali um sobreviveu e tornou-se um "grande chefe", tomou muitas índias como esposas e gerou muitos filhos. As filhas caboclas (metade índias e metade portuguesas) dos primeiros aventureiros estavam prontas para casar-se com a próxima geração de portugueses, e dessa maneira uma sólida fundação estava lançada para uma raça mista e facilmente miscigenável.

A história brasileira dos primeiros tempos tem inúmeros degredados, ${ }^{69}$ devotos missionários jesuítas (a Ordem de Santo Inácio de Loyola havia sido fundada em

\footnotetext{
${ }^{68}$ A autora escreve 'interior', mas na carta de Caminha consta 'sertão': “o sertão nos pareceu...”. Ao longo do livro, aparecerá algumas vezes este último termo em português, como também em inglês, backlands.

* Note-se que promise pode referir-se a promessa e, também, a esperança.

${ }^{69}$ [1962, 1970]: 'tem inúmeras personalidades fascinantes [abounds in fascinating personalities]: degredados,'. $\mathrm{Na}$ carta aos Editores: "p.28, col. 1, $3^{\circ}$ parágrafo: por favor, não ponha esse clichê, 'tem inúmeras personalidades fascinantes' - Eu nunca disse isso! Pode ser eliminado".
} 
degredados, devotos

missionários jesuítas (Loyola estava apenas começando sua grande obra) e nobres portugueses, quase sempre filhos caçulas, que se tornaram os capitães-mores, os "grandes capitães".

... para saquear, como as que os espanhóis encontraram na costa ocidental do continente, e, durante ...

... quadrados. E, embora seja verdadeiro que os animais domésticos (incluindo cães e gatos) importados dos países do norte sofrem em seus primeiros anos, e que suam durante os verões brasileiros (de janeiro a março) em suas "roupas de inverno", dizer que as estações são invertidas é forte demais. $\mathrm{O}$ equador não é exatamente a moldura inferior de um espelho. Caminha supôs o clima "semelhante" [ao de Portugal], e, embora ele na realidade não o soubesse, estava mais ou menos correto.

... Santarém, distante da foz um terço de seu
1540) e nobres portugueses, quase sempre filhos caçulas, que se tornaram os "grandes capitães" nomeados pela coroa e aos quais foram dados poderes quase monárquicos. Mas essa equipe reunida de maneira estranha não encontrou nenhum ouro; não havia cidades para saquear, e, durante o primeiro quarto de século o Brasil permaneceu quase intocado. Os colonizadores não tinham como saber quão vasta era a nova terra - ou quão promissora ela haveria de se mostrar nos séculos seguintes.

Todos hoje sabem ${ }^{70}$ ao menos dois fatos acerca desse meio-continente que se transformou no Brasil: ele é maior que os Estados Unidos antes de o Alasca ter-se tornado um estado, e as estações são o inverso daquelas no Hemisfério Norte. ${ }^{71}$ Ele é grande, estendendo-se desde o norte do Equador até o sul do Trópico de Capricórnio, e para o oeste até os pés dos Andes - uma área de 8,5 milhões de quilômetros quadrados. Mas dizer que as estações são invertidas é simples demais; todos os acidentes geográficos combinam para alterar o padrão. Caminha supôs o clima "temperado", e, embora sua conclusão se baseasse na mais escassa evidência, estava mais ou menos correta.

O Brasil é tropical e subtropical, com poucos extremos de temperatura. O Amazonas corre quase paralelo ao equador, e por incrível que pareça a temperatura média em Santarém, a 700 quilômetros de sua foz, é de apenas 25 graus Celsius.

\footnotetext{
${ }^{70}$ [1962, 1970]: 'hoje parecem saber'.

71 [HRV]: na margem: ' $X$ ', junto a 'estações são o inverso daquelas no Hemisfério Norte'.

* Atualmente (2008), a média anual em Santarém varia de $25^{\circ}$ a $28^{\circ} \mathrm{C}$.
} 
comprimento, é de apenas

$25^{\circ} \mathrm{C}$. No sul, mais frio, as geadas são raras, até em São Paulo. Se for possível generalizar acerca desse vasto país, o norte-americano poderia dizer que ele é todo um pouco quente demais. Nunca tão quente como Nova York numa onda de calor prolongada, nem tão frio como o inverno em Washington (DC) - no seu conjunto, falta um pouco de variedade.

O clima quente ainda é responsabilizado, por vários historiadores, incluindo Toynbee, e por muitos brasileiros, também, quase continuamente, pelo ...

... a preguiça possa ser considerada uma virtude, também). De acordo com a teoria usual, o homem precisa de estações alternadas e do estímulo do clima frio para manter-se vigoroso e "evoluir" adequadamente. Mas isso pode ser falso. A "preguiça" bem pode deverse mais a saúde precária, alimentação deficiente e tédio, do que ao clima. $\mathrm{O}$ homem é o mais adaptável dos animais. À medida ...

... para sempre - e os brasileiros terão um item a menos para sobrecarregar suas consciências.

... costa. As montanhas nunca ultrapassam os 3 mil metros, e a mais alta encontra-se
Nas regiões mais frias do sul, geadas são raras. No seu conjunto, as estações têm pouca variedade. No entanto, a quantidade de chuva varia demais. Mais de 2 mil milímetros caem por ano na Bacia Amazônica, ao passo que em alguns lugares do Nordeste quase não chove. O estado do Ceará é tão seco e o brilho do sol tão monótono que quando o céu se encobre os cearenses saúdam uns aos outros, "Que belo dia!".

OS BRASILEIROS costumam responsabilizar o clima pelo atraso no desenvolvimento do país e por quase tudo de errado com ele. O clima é responsabilizado pela preguiça que eles consideram seu pior defeito (embora às vezes a preguiça seja considerada uma fraqueza atrativa, também). ${ }^{*}$ Mas o que 72 chamam preguiça pode dever-se mais a saúde precária, alimentação deficiente e tédio, do que ao clima. À medida que se conhecem mais as doenças tropicais, a nutrição e a psicologia, e a população pobre do Brasil melhora sua condição de vida, de modo que se torna mais saudável e tem mais emprego, a ideia moralista e fora de moda de "preguiça" pode desaparecer para sempre.

A maior parte do Brasil consiste num vasto planalto, com apenas uma cadeia de montanhas atravessando-o de norte a sul, bem próximo à costa. Ao norte, essas montanhas desaparecem, deixando as vastas planícies costeiras para a

\footnotetext{
* Alteração importante: no texto publicado, a preguiça deixa de ser uma 'virtude' para tornar-se uma 'fraqueza atrativa'.

${ }^{72}[1962,1970]:$ 'Mas o que os brasileiros chamam preguiça'.
} 
perto do Rio de Janeiro. Ao norte elas desaparecem em direção ao Amazonas, ${ }^{*}$ deixando ...

... rios Uruguai e Prata, deixando planícies para a criação de gado. Mas na maior parte da costa a linha de montanhas ... tem sido o maior de todos os obstáculos para o crescimento do Brasil. As serras formam uma barreira natural que por quatrocentos anos manteve todas as cidades e a maior parte ...

... bem diferentes.

Provavelmente, é verdade. Grandes ...

... São Francisco, corre para o norte, mais ou menos no meio do país. Ele, também, ...

... cidades importantes, e serve a um comércio ainda pequeno. Ferrovias foram construídas muito devagar e em pequenos trechos, servindo a uma ou duas cidades apenas. Durante séculos ...

... ao mesmo tempo, ou um cultura da cana-de-açúcar; ao sul, as montanhas declinam em direção aos rios Uruguai e Paraguai, deixando vastas pradarias utilizadas na criação de gado. Mas a linha quase contínua de montanhas entre as planícies costeiras e o interior mais frio e de maior altitude tem sido um grande obstáculo para o crescimento do Brasil. As serras formam uma barreira que por mais de quatrocentos anos tem mantido a maior parte da população concentrada ao longo do extremo oriental do país, como diante de uma fortaleza.

OUTRA deficiência geográfica é que embora existam rios extensos e navegáveis, eles nunca serviram para desbravar o país ou para desenvolver a economia em nenhum grau. ${ }^{73} \mathrm{Os}$ brasileiros referem-se ao Mississippi com inveja; se eles tivessem um Mississippi, as coisas teriam sido bem diferentes. É quase verdade. Grandes ${ }^{74}$ barcos podem subir 3.500 quilômetros do Amazonas, um rio que faz o Mississippi parecer quase estreito. Mas o Amazonas não banha cidades muito importantes ou centros industriais - nem atravessa muitos locais adequados ao desenvolvimento de tais centros. O segundo rio mais importante, o São Francisco, também é navegável, mas antes de chegar ao Atlântico ele é interrompido pela Cachoeira de Paulo Afonso; e, como o Amazonas, ele não banha cidades importantes. Ferrovias foram construídas muito devagar. Durante séculos o comércio e as comunicações se fizeram apenas pela navegação costeira, ou por tropas de mulas ao longo de trilhas ou caminhos ruins demais. O desenvolvimento da aviação está alterando esse panorama, e, ao mesmo tempo, estradas capazes de suportar

\footnotetext{
${ }^{*}$ Elas se dirigem ao norte, mas não ao Amazonas. Em 1962 definiu-se o da Neblina (AM) como o pico mais alto. ${ }^{73}$ [HRV]: na margem: ' $\mathrm{X}$ ', junto a 'em nenhum grau'.

74 [1970]: 'bem diferentes. Estão quase certos. Grandes barcos'.
} 
pouco depois disso, estradas capazes de suportar caminhões começam, finalmente, a conectar as cidades e vilas de norte a sul, e do leste aos poucos núcleos que existem no oeste.

... 50 mil espécies ...

... valiosas para o homem.

... palmito. Existem muitas madeiras valiosas e belas: teca, mogno, jacarandá, paumarfim e cedro - algumas delas tão duras que só podem ser cortadas com máquinas especiais.

... muito carvão, e o que existe é de baixa qualidade, um fato que impediu o desenvolvimento de ferrovias $\mathrm{e}$, até recentemente, o crescimento das indústrias de ferro e aço. Mas - para citar a assustadora lista fornecida pelos The New World Guides, existe: bauxita, bismuto, bário, amianto, cromo, cobre, ouro, ferro (15 milhões de toneladas, cerca de 25 por cento das reservas mundiais), caminhões começam, afinal, a conectar as ${ }^{75}$ cidades costeiras e dirigem-se para o interior.

Mais da metade do Brasil ainda é coberta por florestas. O país abriga, numa avaliação imprecisa, mais de 40 mil espécies de plantas, e ninguém sabe quantas delas podem ser valiosas. Além de todas as árvores frutíferas, nativas ou a princípio importadas, como as bananeiras, existem árvores que fornecem borracha, cacau, castanha-do-pará, bálsamo, resinas, fibras, celulose e tanino. As palmeiras ${ }^{76}$ produzem óleos e ceras, além de sementes, cocos e palmito, o coração da palmeira. $^{77}$

Até onde as pesquisas minerais já avançaram, a superfície foi pouco inspecionada. É possível que não exista muito carvão ou petróleo, ${ }^{78}$ mas o Brasil tem grandes quantidades de bauxita, bismuto, bário, amianto, cromo, colúmbio, ${ }^{79}$ cobre, ouro, ferro (65 bilhões de toneladas, cerca de um terço das reservas mundiais), grafite, magnesita, tântalo, estanho, calcário, manganês, níquel, diamante, ${ }^{80}$ zinco, rádio, titânio, mica, cristais de rocha, tungstênio e materiais radiativos.

\footnotetext{
75 [1970]: 'caminhões finalmente conectam as cidades'.

76 [1962, 1970]: ‘As palmeiras, sozinhas, produzem'. [HRV]: na margem: '?'.

77 [VAS]: a autora comenta as madeiras, mas o trecho foi eliminado no texto publicado: teca (teak) é utilizada em carpintaria, marcenaria e construção naval. De suas folhas extrai-se tinta avermelhada; pau-marfim (satinwoods) é madeira clara utilizada especialmente na confecção de móveis.

78 [1962, 1970]: 'Não existe muito'; a autora inseriu 'provavelmente' [probably] na margem, em [HRV].

${ }^{79}$ [HRV]: colúmbio sublinhado. Hoje, esse metal é denominado nióbio (Nb).

${ }^{80}$ [VAS]: a autora cita a lista de minerais dos Guides, incluindo 'muitas outras pedras semipreciosas' junto a diamantes. Em relação às reservas de ferro, note-se a disparidade entre os originais e o texto publicado.
} 
Existe uma indústria nacional de petróleo,

Petrobras, que vai progredindo e que é fonte de grandes divergências. Mas importantes geólogos brasileiros e estrangeiros supõem não haver grandes depósitos de petróleo no Brasil. E todo esse tesouro de Ali Babá estava escondido para os exploradores e comerciantes do século XVI - escondido no futuro e sob o solo. Eles continuaram arriscando navios e vidas no que Lévi-Strauss denominou artigos "derrisórios": pimenta e outras especiarias; e do Brasil, apenas ...
... São Vicente, hoje um subúrbio do porto de Santos repleto de prédios de
Mas todo esse tesouro estava escondido para os exploradores e comerciantes do século XVI - escondido no futuro e sob o solo. ${ }^{81}$ Eles continuaram arriscando vidas e navios ao contornar o Cabo da Boa Esperança em busca de especiarias do Oriente. Do Brasil vinham apenas pau-brasil ${ }^{82}$ e curiosidades: mamíferos, * pássaros, peles e alguns índios, também. ${ }^{83}$

Por volta de 1526 , as coisas começaram a mudar. O poder de Portugal passou a diminuir, e seu domínio sobre as colônias do Extremo Oriente logo se enfraqueceu. A viagem em torno do Cabo da Boa Esperança não era mais lucrativa; Portugal descobriu que "para cada grão de pimenta derramava-se uma gota de sangue". Além disso, havia repetidos rumores acerca de ouro no Brasil. Os portugueses começaram a enviar frotas para patrulhar a costa e manter afastados franceses e holandeses, que também tinham interesse nessa região. ${ }^{* *}$ Um agente real foi enviado e iniciouse a colonização efetiva.

A PRIMEIRA vila foi São Vicente, hoje um subúrbio de Santos, ${ }^{* * *}$ o porto de São Paulo. A segunda foi Olinda, no distante Nordeste; os primeiros a chegar teriam exclamado

${ }^{81}$ [HRV]: na margem: traço vertical junto às 3 primeiras linhas do parágrafo.

82 [1962, 1970]: 'apenas madeira e curiosidades: pau-brasil,'. Em [HRV] a autora transfere 'pau-brasil' da lista de curiosidades para o lugar de 'madeira'.

* 'Animais' substituído por 'mamíferos', nesta tradução, para diferenciá-los dos 'pássaros'.

83 [VAS]: neste ponto a autora inclui um comentário manuscrito: "Desisti aqui - tenho de adicionar mais geografia depois, provavelmente...".

** 'País' substituído por 'região', nesta tradução, considerando a época a que o texto se refere.

*** São Vicente também poderia ser descrita como 'cidade-gêmea' de Santos, e não como seu subúrbio. 
apartamentos; a segunda foi Olinda, no distante Nordeste, hoje um subúrbio de Recife.

... se estendiam

indefinidamente terra adentro até encontrar as terras também indefinidas da Espanha. (Sem dúvida, os maiores exemplos de "cultivo em terraços" já vistos.)

Como Lévi-Strauss diz: "Depois de fartar-se de ouro, o mundo sentiu fome de açúcar, mas o açúcar, por sua vez, consumia escravos". Os índios eram primitivos demais; eles conheciam apenas o que hoje seria chamado de vida absolutamente "permissiva", nas sombras das florestas; quando forçados ao trabalho nos campos, eles apenas desistiam e morriam.

Nesse primeiro século, os franceses estabeleceram-se em torno do que hoje é o Rio, e duas vezes ...

... no mês de janeiro embora o "rio" não existisse. Essas primeiras cidades costeiras do Brasil têm os nomes simplificados que os navegadores lhes deram: Rio, Bahia (Baía), Recife (cujos habitantes ainda chamam de "o" Recife), Fortaleza etc.
Oh! Linda! ${ }^{84}$ ao ver suas praias brancas, enfeitadas por palmeiras. A costa foi dividida em intervalos de 240 quilômetros mais ou menos, a extensão das "capitanias", ou doações, que se estendiam terra adentro. Foi na região em torno da Bahia que o açúcar floresceu primeiro e o sistema de plantation se estabeleceu. Escravos negros começaram a chegar da África já em 1535. Como o antropólogo francês Claude Lévi-Strauss diz em Tristes trópicos: "Depois de fartar-se de ouro, o mundo sentiu fome de açúcar, mas o açúcar, por sua vez, consumia escravos". ${ }^{85}$ Os índios não eram bons escravos; acostumados à vida nas florestas, eles [p.30] apenas desistiam e morriam ${ }^{86}$ quando forçados ao trabalho nos campos.

Na metade do século XVI os franceses tentaram por duas vezes estabelecer-se perto de onde hoje é o Rio de Janeiro, e duas vezes foram expulsos. Depois da primeira expulsão os portugueses fundaram uma nova vila, ${ }^{*}$ e depois da segunda vitória deram-lhe o nome de São Sebastião do Rio de Janeiro, em honra do santo em cujo dia os franceses haviam sido vencidos, no mês de janeiro. Aquilo que os primeiros exploradores tomaram pela foz de um rio, era na verdade apenas uma baía. ${ }^{87}$

\footnotetext{
${ }^{84}$ Entre travessões, a explicação: - that is, "beautiful”-.

${ }^{85}$ Tradução de Rosa Freire d'Aguiar, na edição da Companhia das Letras, 1996, p.86.

${ }^{86}$ [HRV]: a autora sublinha 'à vida ... morriam'; manuscrito ilegível.

* Town, e não city; daí a opção por 'vila', e não 'cidade'.

${ }^{87}$ QUADRO: "O maior rio do mundo".
} 
... região tropical e para uma sociedade católica, escravocrata, muito espalhada ao longo de uma costa muito mais longa. Recebendo grande ...

... domésticas. Uma queixa especial referia-se aos têxteis: exceto pelas coisas mais rústicas, usadas pelos escravos, nada poderia ser tecido. A impressão era ilegal, portanto não havia jornais e revistas, e muito poucos livros. Afinal descobriu-se ouro, mas os ourives foram impedidos de trabalhar com ele. Cada vez mais se lê sobre as forjas destruídas, mas os tesouros que permanecem nas sacristias das velhas igrejas brasileiras provam que essa restrição deve ter sido quase sempre ignorada.

Os jesuítas, que vieram em grande número durante os primeiros cem anos, tentaram proteger ...
Os 250 anos seguintes repetiriam a história habitual de desgoverno e exploração das colônias de além-mar, por parte dos europeus. O período lembra a história das colônias norteamericanas sob o domínio inglês, transplantada para uma região tropical e para uma sociedade escravocrata, católica romana. Recebendo grande riqueza do Brasil, a Coroa portuguesa monopolizou o comércio da colônia. Havia impostos injustos e restrições, uma vez que tudo deveria ser importado da Metrópole, pois nenhuma indústria era permitida, com exceção das mais simples manufaturas domésticas. A impressão era ilegal, portanto não havia jornais, e muito poucos livros eram importados. ${ }^{*}$ Quando afinal descobriu-se ouro, ele foi explorado com trabalho escravo e levado sob vigilância militar diretamente para o Tesouro real.

Os jesuítas tentaram proteger os índios da escravidão, nas capitanias. Reuniram-nos em vilas, cada uma delas organizada em torno de uma igreja, converteram-nos e os ensinaram - em outras palavras, "civilizaram” os índios. Sem dúvida, os missionários salvaram milhares deles da escravidão ou do massacre, mas os índios morriam de qualquer maneira, de varíola, sarampo ou inanição, e sua cultura primitiva, mas única, suas habilidades e artes morreram ${ }^{88}$ com eles, ou misturaram-se aos poucos com a cultura dos portugueses e dos escravos negros.

\footnotetext{
* O texto publicado explicita o que não estava claro nos originais: todos os livros eram importados.

${ }^{88}$ [1962, 1970]: 'suas habilidades e artes diminuíam [diminished] com eles'. [HRV]: a autora simplesmente elimina 'diminuíram', e assim passa a dizer que 'suas habilidades e artes morreram com eles', recuperando o sentido presente nos originais.
} 
... implicando um senso de identidade e alguma cooperação entre os habitantes do norte, ao menos, foi a expulsão dos holandeses. Por vinte anos haviam controlado a costa do norte, e durante o mesmo período dominaram a colônia portuguesa de Angola, na África, segundo eles, pelos tão necessários escravos negros, e nos séculos XVII e XVIII a África ocidental e o Brasil nortista, açucareiro, complementaram-se.

... ocasionais, ouro, prata e pedras preciosas foram afinal descobertos em ...
O primeiro evento que poderia ser considerado "nacional", implicando alguma cooperação entre os habitantes e algum senso de identidade como país, foi a expulsão dos holandeses protestantes. Por vinte anos ${ }^{89}$ eles haviam controlado a costa do Nordeste, durante o mesmo período em que dominaram a colônia portuguesa de Angola, na África, mas foram expulsos em 1654, um triunfo para a Igreja católica e para o Brasil.

Depois de quase um século de rumores e descobertas ocasionais, o ouro foi afinal descoberto em quantidade ${ }^{90}$ no que hoje é o estado de Minas, em 1698. Foi lá que ocorreu o primeiro desenvolvimento real do interior do Brasil, graças, sobretudo, aos esforços dos famosos bandeirantes. Eles vinham da região em torno de São Paulo, descendiam ${ }^{91}$ de portugueses e de meninas indígenas, e eram enérgicos, cruéis e vorazes. Viajavam em bandos armados, ou bandeiras, acompanhados por suas esposas, filhos, gado e escravos índios, e faziam longas jornadas e ataques selvagens, sempre em busca de ouro ou mais escravos, até mesmo atacando e destruindo as vilas jesuíticas e forçando seus próprios irmãos de sangue à escravidão. Eles penetraram fundo no interior, até os atuais estados de Minas Gerais, Goiás e Mato Grosso. Descobriram os itens mais glamourosos da riqueza mineral

${ }^{89}$ Na carta aos Editores: “p.30, col. 2 - 'vinte anos' dos holandeses - por favor, verifique - mais provável trinta”. O texto não foi alterado. Os holandeses dominaram a região por 24 anos, de 1630 a 1654. [VAS]: a própria autora eliminou um comentário, 'construindo fortes ao longo do rio Amazonas' .

* A colônia aparece, aqui, como se já fosse independente de Portugal.

${ }^{90}$ [1962, 1970]: 'em grande [good] quantidade'.

91 [1962, 1970]: 'de São Paulo, a maioria deles descendia'.

** 'Bandeirantes' vem das 'bandeiras' (portuguesas) ou estandartes que eles portavam, mas o texto parece associá-lo etimologicamente a 'bandos' (bands). Em artigo anterior a este livro (“Uma nova capital...", 1958), Bishop mostrou já conhecer o significado correto. 
... nos locais por onde passaram os bandeirantes.

... Vila Rica (hoje Ouro Preto, por causa de um ouro escuro, avermelhado) era a capital, e havia muitas outras: Mariana, São João D'el Rey, Morro Velho e Queluz, para citar algumas. Diamantina, hoje ...

... em 1870. Durante o século do boom mineiro, talvez um milhão de escravos tenha sido levado para essa região, e sua riqueza rivalizava com aquela da Bahia, a maior e mais velha capital do açúcar, no norte.

... teve lugar o evento mais importante do século XVIII, um evento que deveria ser de particular interesse ... brasileira - diamantes e pedras semipreciosas, além do ouro e, sem querer, tornaram o jovem ${ }^{92}$ país consciente de sua extensão incomparável e de sua geografia impeditiva.

Uma pequena, mas brilhante, constelação de vilas mineiras apareceu nos locais das importantes descobertas dos bandeirantes. O termo "vila mineira", no entanto, sugere algo diferente dessas cidades em miniatura - ricas, postos avançados e isolados da cultura e do racionalismo do século XVIII. Vila Rica (hoje Ouro Preto) era a capital. Diamantina, hoje quase desconhecida fora do Brasil, foi famosa na Europa como o centro diamantífero mundial até a descoberta das jazidas de Kimberley na África, em 1870.

FOI nesse grupo de vilas pequenas e florescentes que teve lugar um evento de grande importância para a história brasileira e de particular interesse para os norte-americanos, em 1789. Foi uma tentativa trágica e mal-sucedida de obter a independência de Portugal, e leva o estranho nome de Inconfidência Mineira, significando, mais ou menos, a "Conspiração de Minas". 93

Os níveis de cultura e educação nessas cidades deviam ser mais altos que em outras partes do Brasil naquele tempo, e além dos proprietários de minas havia muitos professores, advogados e oficiais do Exército. Um grupo de seis desses

\footnotetext{
${ }^{92}$ [HRV]: a autora destaca 'jovem' com um círculo; na margem: '?'. Destaque-se que a colônia aparece aí como 'país'.

93 'The Minas Conspiracy'.
} 
... "escola", e não apenas isso, mas naquelas montanhas estéreis, resplandecentes de jazidas, eles se chamavam de Árcades, usavam pseudônimos de pastores e realmente escreviam poemas pastorais - e épicos ...

... vitoriosa Guerra de Independência Americana.

... "Tiradentes". Ele sempre levava a Declaração de Independência americana no bolso, e gostava de lê-la em voz alta. $\mathrm{O}$ grupo ...

... fundar uma república, Jefferson, aparentemente, como um diplomata, ... jovens escrevia poemas e denominava-se "Escola". Além disso, naquelas montanhas estéreis, resplandecentes de jazidas, eles se chamavam de "Árcades", imitando as “academias" literárias do Rio e da Bahia, que eram, por sua vez, imitações tardias de instituições similares na Itália renascentista. Os poetas adotavam nomes de pastores gregos e escreviam longos poemas pastorais - e épicos e satíricos, também. Tal artificialidade não parecia permitir que fossem muito longe, mas havia talentos verdadeiros ali. Eles também se ressentiam do domínio português e eram apaixonados por história e política. Exaltavam-se, acima de tudo, com a recente e vitoriosa Revolução Americana, ${ }^{94}$ que se tornou sua inspiração.

A eles se juntaram outros intelectuais e oficiais do Exército, um dos quais tornou-se o líder do movimento. Ele era um alferes ${ }^{95}$ chamado Joaquim José da Silva Xavier. Costumava atuar também como dentista, por isso seu apelido era "Tiradentes". ${ }^{96} \mathrm{O}$ grupo correspondia-se com Thomas Jefferson, e em 1787 um deles foi ao seu encontro na França, onde ele era ministro plenipotenciário dos recém-criados Estados Unidos. Jefferson, em viagem para recuperar a saúde, com cautela encontrou o brasileiro no anfiteatro romano de Nîmes. Samuel Putnam, ${ }^{97}$ em seu livro sobre a literatura brasileira chamado Marvelous Journey, diz que "esse evento, do qual muitos norte-americanos nunca ouviram falar, logo se tornou para os brasileiros um dos mais fortes laços entre sua democracia e a nossa".

Quando o brasileiro lhe pediu que o aconselhasse sobre como fomentar uma revolução e fundar uma república (e sobre a possibilidade de ajuda norte-americana, é claro),

\footnotetext{
94 [HRV]: a autora inclui '?' junto a 'vitoriosa Revolução Americana'.

95 Lieutenant [em português, tenente], o termo correspondente na hierarquia militar atual.

${ }^{96}$ Tanto no original como nas duas edições, também em inglês: Toothpuller.

${ }^{97}$ Putnam, Samuel. Marvelous Journey. New York: Alfred Knopf, 1948.
} 
... mas a conspiração em Minas prosseguiu, com audácia.

... terreno salgado, no bom e velho estilo medieval.

... mas também a primeira tentativa de um movimento literário no país.

... como fizeram nossos obstinados pequenos fazendeiros de 1776.

... contra Portugal havia começado, embora a independência só viesse a ocorrer 33 anos depois, e de forma alguma sob uma revolução.
Jefferson, como diplomata, não poderia prometer nada além de apoio moral. O jovem morreu na viagem de volta ao Brasil, mas a conspiração em Minas, talvez agindo sob falsas esperanças de ajuda americana, ${ }^{98}$ prosseguiu, com audácia. $\mathrm{O}$ complô foi descoberto, e todos os conspiradores punidos de maneira severa. Tiradentes foi enforcado e esquartejado. Sua casa foi destruída e o terreno salgado, como na Antiguidade, para que, simbolicamente, sua casa e sua descendência fossem destruídas para sempre.

A PEQUENA "Escola de Minas", se é que ela pode ser chamada de escola, se desfez, e assim se destruiu não apenas o primeiro movimento pela independência do Brasil, mas também uma das primeiras tentativas de um movimento literário local. ${ }^{99}$ Os poetas árcades de 1789 , corajosos mas pouco práticos, não conseguiram libertar seu país nem guerrear, como fizeram os obstinados fazendeiros americanos de 1776. * Mas Tiradentes permanece como o maior herói do Brasil. O "Dia de Tiradentes" é feriado nacional, e quase todas as cidades no Brasil têm sua rua ou praça Tiradentes. Enquanto o século XVIII se encerrava, a rebelião contra Portugal convertia-se ao menos em um sonho - embora a independência só viesse a ocorrer 33 anos depois, ${ }^{100}$ e por meios não tão drásticos como uma guerra revolucionária.

\footnotetext{
98 [HRV]: a autora destaca 'talvez agindo sob falsas esperanças de ajuda americana'; na margem: '?'.

${ }^{99}$ A autora utiliza o termo indigenous.

* Os 'nossos pequenos fazendeiros', dos originais, tornam-se os 'fazendeiros americanos' [American farmers] no texto publicado.

${ }^{100}$ [1970]: 'só viesse a ocorrer em 1822, e'.
} 
... de Shakespeare: gritos e trompetes; pequenos exércitos no palco, pequenos exércitos fora do palco; Bolívar aqui, Bolívar lá; sangue derramado, ...

... enquanto todos os outros países se rebelaram ...

... o Brasil conseguiu permanecer politicamente unido. ...
... - ou melhor, com a típica proliferação tropical de espécies, " há dois pretendentes, primos-irmãos.

... estabilidade vivido pelo Brasil no século XIX deu ...

... Mas o orgulho é matizado com saudades, nostalgia, às vezes até mesmo com desespero. ...

\section{O único império ocidental ${ }^{101}$}

3

[p.41]

A HISTÓRIA da América do Sul no século XIX lembra as cenas de batalha nas peças de Shakespeare: alarmes e trompetes; pequenos exércitos no palco, pequenos exércitos fora do palco; sangue derramado, cenas de morte e pausas na ação para belos discursos. Mas o Brasil distinguiu-se do resto do continente de duas maneiras. Primeiro, enquanto todas as outras colônias sul-americanas se rebelaram contra o domínio espanhol e afinal se transformaram em nove repúblicas, o Brasil, ao tornar-se independente de Portugal, permaneceu politicamente unido. Houve pequenas guerras civis e secessões, algumas das quais se estenderam por vários anos, mas ele sempre se recompôs. E, segundo, o Brasil não passou por uma verdadeira guerra de independência. Ele foi governado pela dinastia portuguesa de Bragança até 1889, e ainda existe um pretendente Bragança ao trono - ou melhor, há dois pretendentes, primos-irmãos.

O longo período de relativa estabilidade deu ao país grandes vantagens: um forte sentimento de unidade nacional e quase um século de história do qual ele ainda se orgulha. Mas o orgulho é matizado com nostalgia, e às vezes até mesmo [p.42] com amargura. Os brasileiros sentem que sua honra nacional, a reputação internacional e o crédito no exterior - e mesmo o tamanho e prestígio de sua Marinha - nunca mais foram tão altos.

${ }^{101}$ [HRV]: a autora substitui o título, "Século de honra e orgulho" [Century of Honor and Pride], pelo original.

* A família dividiu-se em dois ramos: o de Vassouras e o de Petrópolis. A visita do herdeiro do segundo ramo à casa de Lota e Bishop, em Samambaia, é tema do poema inacabado “The Pretender” (Bishop, 2006, p.142). 
... Napoleão. Todos sabem que ele criou um império e coroou a si mesmo Imperador. Mas não é tão conhecido o fato de que, como subproduto ...

... exato. Nada comparável ao Império Romano, é claro. Esse ...

... no século XIX, com revoluções estourando como trovoadas em todos os países vizinhos ...

... articulavam o tempo todo.

Muitos dos novos países do Hemisfério Ocidental consideravam o velho sistema monárquico o melhor meio para estabilizar seus governos. A Argentina procurou sem sucesso, durante anos, um príncipe europeu adequado, e tentouse a experiência no México, mas ela falhou de maneira tétrica, com Maximiliano. Até os Estados Unidos tiveram seu pequeno movimento para tornar Washington o fundador de uma dinastia. Mas, ...
A HISTÓRIA brasileira moderna começa com Napoleão. O mundo lembra-se dele por ter criado um império nos primeiros anos do século XIX e por ter coroado a si mesmo Imperador da França. Mas poucas pessoas percebem que como subproduto do império napoleônico também se criou o Império do Brasil, o qual durou muito mais tempo que o de Napoleão - 67 anos, para ser exato. Esse período foi muito longo no século XIX, quando revoluções estavam estourando como trovoadas nos países vizinhos, e quando as forças do liberalismo, do igualitarismo e do republicanismo se fortaleciam e articulavam sem parar por todo o mundo ocidental.

Alguns grupos entre os novos países do Hemisfério Ocidental ainda consideravam a monarquia a melhor forma de governo, e a mais estável. Após a guerra de independência dos Estados Unidos surgiu um pequeno movimento para transformar George Washington em rei, e a Argentina durante seu período revolucionário, no início do século XIX, andou procurando um príncipe europeu adequado. A experiência concretizou-se no México, na década de 1860, com Maximiliano, e falhou de maneira tétrica. Mas, da maneira paradoxal como as coisas parecem acontecer no Brasil, o que trouxe ao país a independência política de Portugal foi a chegada da família real portuguesa.

Em 1807 Napoleão estava buscando forçar Portugal a fazer parte de sua aliança contra a Inglaterra, e seus exércitos estavam se aproximando de Lisboa. Maria I, a rainha portuguesa, havia enlouquecido muito antes disso, e seu filho, D. João, era o regente. Portugal vinha sendo quase um protetorado econômico da Inglaterra por cem anos. Encurralado, como disse o historiador norte-americano C. H. Haring, "entre o imperialismo militar de Napoleão e o 
... Grã-Bretanha, e os ingleses decidiram, por segurança, transferir ...

... esposa indiferente (que era meio louca, ${ }^{102}$ também), seus filhos ... espremidos em 42 ou 43 navios mercantes.

... de onde vinha toda a sua riqueza - e todo o seu açúcar.

... de Virgílio (de acordo com os relatos dos tutores), e comparava a situação ...

... Octavio Tarquinio de Sousa, o melhor historiador brasileiro do período imperial, ... imperialismo econômico da Grã-Bretanha”, D. João, indeciso como sempre, vacilou. No último momento ele pendeu para a Grã-Bretanha. Então, instigado pelos ingleses e ansioso por salvar seu trono, ele decidiu transferir a família real e a corte para o Brasil.

Foi uma das mais estranhas hégiras da história. Quase em pânico, a rainha louca, D. João, sua esposa indiferente, seus filhos e toda a corte portuguesa - cerca de 15 mil pessoas - foram espremidos em cerca de quarenta navios mercantes. Com uma escolta inglesa eles partiram para o Brasil, a colônia desconhecida e romântica de onde vinha a maior parte de sua riqueza - e seu açúcar. A viagem foi um pesadelo repleto de tempestades, enjoos, comida racionada e água suja. Os cortesãos reclamavam tanto que uma ordem real definiu que "apenas assuntos náuticos" fossem discutidos. Enquanto isso, Pedro, o príncipe herdeiro de 9 anos, travava com seus tutores discussões eruditas sobre a Eneida de Virgílio, sem dúvida comparando a situação de seu pai com a de Eneias. Todavia, como diz Octavio Tarquinio de Sousa, ${ }^{103}$ o famoso historiador do período imperial brasileiro, "D. João salvou a dinastia, e levou consigo, intactos, os maiores tesouros do reino, incluindo obras de arte, joias e livros [60 mil dos quais se tornariam o núcleo da Biblioteca Nacional brasileira] para as terras onde ele iria fundar um grande império".

DEPOIS de 52 dias terríveis eles chegaram à Bahia, e foram recebidos com um júbilo frenético. Diz a história que a pobre e perturbada rainha Maria, ao ver negros saltitando em torno de sua cadeirinha, pensou estar no inferno e gritou que os demônios a perseguiam. Depois de um mês foram para o Rio, para celebrações tão grandes quanto essas. D. João já havia
... à Bahia, que não foi considerada suficientemente segura para eles, e então continuaram a viagem até $o$ Rio. Foram recebidos com um júbilo frenético. Apenas ...

\footnotetext{
102 A autora eliminou, no original, 'provavelmente', junto a 'meio louca' [probably a little mad], assim como 'oito', o número de filhos do casal.

${ }^{103}$ Souza, Octavio T. de. A vida de D. Pedro I. 3v. Rio de Janeiro: J. Olympio, 1952.
} 
... ao estabelecer máquinas impressoras, jornais, ourives e muitas pequenas indústrias. O Brasil sentiu-se mudar de uma colônia muito prejudicada para uma potência independente, quase da noite para o dia.

... uma cidade litorânea quente e imunda de cerca de 20 mil habitantes, ...

... de seu novo lar e de seus costumes descontraídos.

... políticas. Não havia carruagens; a comida era ruim; eles tinham medo das tempestades com relâmpagos que saltavam de um pico a outro em torno da baía (como eles ainda fazem), medo dos escravos negros, medo das doenças tropicais, - e é verdade que eles morriam como moscas durante os primeiros anos.

Mas a permanência da corte durante 13 anos transformou o Rio numa capital e modificou ...

... desenvolvida; os impostos diminuíram; o primeiro ...

... Jardim Botânico (ainda famoso). O príncipe regente gostava de música e de teatro. Ele trouxe uma orquestra consigo; ele também tornouse um admirador da música e decretado a abertura dos portos brasileiros para todas as nações amigas, o que na prática significava a Inglaterra. Ele também ganhou popularidade ao estabelecer uma máquina impressora; a indústria metalúrgica foi iniciada, e a têxtil, expandida. As artes e as ciências foram incentivadas. Quase que da noite para o dia o Brasil sentiu sua mudança de uma colônia explorada para uma potência independente.

O Rio era uma cidade quente e imunda de cerca de 60 mil habitantes, sem um sistema de esgoto ou de abastecimento de água. A família real, de maneira extravagante, estabeleceuse e começou a gostar de seu novo lar e dos costumes descontraídos do país. Mas a corte em geral detestava tudo, e em troca era detestada pelos brasileiros - uma reação que traria sérias consequências políticas. Habitações e meios de transportes eram escassos; a comida era ruim; as damas e os cavalheiros da corte exilada estavam em pânico ${ }^{104}$ diante das doenças tropicais e das tempestades com relâmpagos que saltavam de um pico a outro em torno da baía.

MAS a permanência de uma corte europeia sofisticada durante 13 anos transformou o Rio na capital da nação e modificou o estado dos negócios ${ }^{105}$ em grande parte do Brasil. A administração da justiça foi um pouco desenvolvida; o primeiro banco foi fundado; estabeleceram-se a academia naval e as escolas de medicina e cirurgia, assim como uma biblioteca e um Jardim Botânico. Em 1814, com Napoleão vencido, Portugal estava livre da ameaça da França, e em 1816 D. João convidou uma missão francesa de arquitetos, pintores e escultores para visitar o Brasil. Ele iniciou a

\footnotetext{
${ }^{104} \mathrm{Na}$ carta aos Editores: "p.43, col. 1, linha 9: NÃO usar scared of - frightened by ou afraid of.". Mas a expressão foi mantida.

105 State of affairs.
} 
dos entretenimentos dos negros. Em 1815 Portugal estava livre da França, e em 1816 ele convidou uma Comissão Francesa, arquitetos, músicos, pintores e escultores, ...

Mais uma vez ele vacilou, aparentemente em parte porque não poderia suportar aquela viagem oceânica uma segunda vez. Mas, ainda por insistência e sob os auspícios dos ingleses, ele afinal anunciou uma constituição para Portugal, outra para o Brasil, e partiu. Antes disso ele escreveu uma carta para D. Pedro, chorando, na qual

... coletar, - e cerca de três mil portugueses. ${ }^{106}$

Essa partida estabeleceu uma espécie de precedente terrível para as futuras abdicações ou "renúncias" (sob a República), que são sempre discutidas com base na infeliz carreira de João VI. Nem todos os que abdicaram encheram os bolsos de maneira tão acintosa como ele, e eles partiram por razões muito diferentes, mas a peculiar instituição brasileira de deixar o país para governá-lo melhor havia sido estabelecida. construção de um palácio real nos limites da cidade. A rainha louca morreu, afinal, e seu filho, D. João, tornou-se João VI de Portugal e do Brasil.

Mas, em torno de 1820 as forças liberais em Portugal exigiram o retorno de D. João, caso ele quisesse salvar seu trono. Mais uma vez ele vacilou, em parte por causa de seu amor pelo Brasil, em parte porque não poderia suportar aquela viagem oceânica uma segunda vez. Ele outorgou duas novas constituições, uma para Portugal e uma para o Brasil, e então - sob a insistência dos ingleses - partiu. Antes disso ele teve uma conversa com o príncipe-herdeiro, D. Pedro, na qual profetizou a separação entre Brasil e Portugal e aconselhou seu filho a tomar a coroa para si. Ele também esvaziou o cofre do Banco do Brasil e levou consigo todas as joias que conseguiu coletar.

Sua partida foi a primeira de várias abdicações ou "renúncias" ao poder no Brasil, quase sempre discutidas com base na infeliz carreira de João VI. ${ }^{107} \mathrm{Nem}$ todos os que abdicaram encheram ${ }^{108}$ os bolsos de maneira tão acintosa como ele, e as razões para as renúncias variaram, mas essa foi a primeira ocorrência daquilo que se tornaria um fenômeno muito brasileiro.

D. Pedro não teve boa formação. Ele conduzia a vida luxuosa mas relaxada da classe alta ${ }^{109}$ de brasileiros de sua

\footnotetext{
* A autora parece ignorar o fato de ser esse um Reino Unido. Nos originais consta que d. João era "VI de Portugal e I do Brasil".

106 [VAS]: a própria autora substituiu 'os remanescentes dos 15 mil vindos com ele' pelos 'cerca de três mil portugueses'.

${ }^{107}$ [HRV]: ' $\mathrm{X}$ ' junto a 'infeliz carreira de João VI'.

108 [1970]: 'Nem todos os governantes, ao partir, encheram os bolsos'.

109 [1962, 1970]: 'relaxada da pequena [small] classe alta'.
} 
... cavalariços, e um mulherengo desde os 13 anos mais ou menos. Ele é, todavia, um caráter fascinante: brilhante, a despeito de sua educação falha, enérgico, mimado, devasso e neurótico - e sofria de ataques epiléticos ocasionais. [Maria Graham, a escocesa que esteve no Rio na década de 1820 e foi tutora dos filhos de D. Pedro por um breve período, deixou um bom retrato de sua personalidade e da vida na corte e na cidade.] No fundo ele era bondoso (devotado a todos os filhos, sustentou a todos, legítimos e ilegítimos) e queria ser um bom governante, ...

... o início. O Brasil queria um rei, mas não "um rei excessivo"; e D. Pedro era autocrático.

Ordens começaram a chegar de Portugal; algumas das odiadas taxas e restrições foram restauradas. Durante uma viagem a São Paulo, chegou uma ordem para que retornasse imediatamente a Portugal, para completar sua educação. Ela the foi entregue quando ... época; era amigo de escravos e cavalariços, e desde a adolescência ${ }^{110}$ seus casos amorosos foram notórios. Com um caráter fascinante, D. Pedro era um neurótico brilhante, enérgico, esbanjador e devasso. Ele sofria de ataques epiléticos ocasionais. No fundo ele era bondoso, generoso para com suas amantes e devotado a todos os filhos, não só os legítimos. Queria ser um bom governante. Mas a corte ainda era essencialmente portuguesa e impopular entre os brasileiros. D. Pedro confiou nela e as coisas começaram a andar mal, quase desde o início.

Não muito tempo depois da partida de D. João, o governo português começou a enviar ordens restaurando algumas das antigas restrições coloniais. Uma ordem exigia que D. Pedro retornasse imediatamente a Portugal, para completar sua educação. Durante uma viagem a São Paulo, ${ }^{111}$ novas ordens arrogantes chegaram, e lhe foram entregues quando ele estava em seu cavalo às margens de um riacho, o Ipiranga. D. Pedro leu as ordens, ergueu o sabre e gritou "Independência ou morte!". Esse foi o famoso Grito ${ }^{112}$ do Ipiranga, e o dia, 7 de setembro, é o "Quatro de Julho" brasileiro.
Os primeiros versos do hino nacional brasileiro ainda mais complicado e

\footnotetext{
${ }^{110}$ [HRV]: a autora sublinha 'desde a adolescência' [from his teens]. Na carta aos Editores, afirma que o termo teenage deveria ser substituído. O mesmo problema reaparece no capítulo 8, p.117.

111 [1970]: 'a São Paulo, em 1822, novas ordens'.

112 Também em inglês, Cry.
} 
difícil que "The Star-

Spangled Banner", o hino nacional norte-americano descrevem a cena. A simples palavra grito é sinônimo da Independência, e tem tantos significados para o brasileiro como, digamos, "cerejeira" para o americano.

... liberal, e muito avançado, e a ...

... constantes, soldados estrangeiros criaram ...

... tolerantes brasileiros. Sua famosa amante, Domitila, que ele tornou Marquesa de Santos, envolvia-se nos negócios do Estado, e ele era culpado pela morte de sua primeira esposa, Leopoldina, amada pelo povo.

... governante muito mais magnânimo, muito superior a seu pai e honestamente bemintencionado. O Brasil sempre foi difícil de governar.
D. PEDRO foi proclamado imperador de um Brasil independente. No entanto, reinou apenas nove anos. Ele se considerava um liberal, e avançado, e a Constituição promulgada por ele em 1824 permaneceu válida até o fim da Monarquia. Mas houve revoltas constantes, mercenários criaram problemas, diferenças e necessidades regionais não foram reconhecidas, e a vida privada do Imperador tornou-se escandalosa demais, até mesmo para os tolerantes brasileiros.

Depois da morte de D. João VI, D. Pedro tornou-se herdeiro do trono de Portugal. Ele concedeu a coroa a sua filha, ${ }^{113}$ Maria da Glória, mas seu próprio irmão mais novo, [p.44] Miguel, estava em Viena e em seguida voltou para Portugal, buscando tomar o poder. Rebeliões estouraram por todo o Brasil. A guarda pessoal de D. Pedro desertou. E assim, ele também abdicou, ${ }^{114}$ e foi à Europa para lutar pelo direito de sua filha ao trono português.

D. Pedro I havia sido um governante magnânimo, muito superior a D. João VI. ${ }^{115}$ Governar o Brasil estava além de seus poderes. E o governante que D. Pedro deixou em seu lugar tinha apenas 5 anos de idade.

${ }^{113}$ [HRV]: a autora sublinha 'filha'.

${ }^{114} \mathrm{Na}$ carta aos Editores: "p.44, col. 1, linha 5: apenas abdicated - para não repetir a palavra throne duas vezes na mesma sentença". A repetição só foi eliminada nesta tradução.

115 [1962, 1970]: 'muito superior a D. João VI e bem intencionado'. 
... de tutores e padres. Ele era sério, aplicado, culto, e um notável linguista; escreveu poesia razoável sobre todas as ocasiões importantes de sua vida; e por 49 anos deu o melhor de si para governar seu país. Os nove anos de sua regência foram repletos de discussões amargas, e afinal os dois partidos, Liberais e Conservadores, concordaram em que apenas a figura do jovem imperador poderia unificar o país conturbado. Isso foi explicado a D. Pedro, de 14 anos, que respondeu com outra frase histórica famosa: "Quero agora". Ele foi coroado aos 15 anos, usando a feia coroa coberta de diamantes agora exposta no Museu de Petrópolis, e sobre seu manto uma capa amarela de penas do peito de tucanos, símbolo da herança indígena de seu país.

... gênio; mas era bem diferente dos demais da dinastia ...

... altura, sem contar a cartola habitual; olhos azuis ...

... seu dever. Governou sob a constituição outorgada por seu pai em 1824: o governo era monárquico, constitucional e representativo, e as leis eram feitas por duas casas
EXCETO por ter sido tão vigoroso quanto ele, D. Pedro II era quase o oposto de seu pai instável e devasso. Ele foi cuidadosamente educado, até mesmo educado com excessivo cuidado por uma governanta muito querida e por uma série de tutores. Ele se tornou sério, aplicado e culto, e por 49 anos deu o melhor de si para governar seu país.

D. Pedro II não era um gênio, mas um homem notável da dinastia Bragança, e em vários aspectos era muito mais avançado que seus conterrâneos. ${ }^{116}$ Ele foi um imperador imponente: cerca de 1 metro e 90 de altura, olhos azuis herdados de sua mãe, que era alemã, e uma longa barba eriçada que logo se tornou branca. Ele sentia-se mais inclinado para a vida intelectual que para a política, mas sempre cumpriu seu dever. O governo era monárquico, constitucional e representativo, e as leis eram feitas por duas casas legislativas. O catolicismo romano era a religião do Estado, mas garantia-se liberdade religiosa, assim como

${ }^{116}$ [HRV]: na margem: marca vertical. 
legislativas, o Senado e a Câmara dos Deputados; o catolicismo ...

... de imprensa. Ele selecionou seu Conselho de Estado e o gabinete; sua maior força era o "poder moderador", pelo qual podia demitir ...

... o garantisse. Esses privilégios, ou alguns deles, foram incluídos pelo Ato Adicional de 1834, pois a Constituição começara otimista demais acerca da maturidade política do país.

De acordo com ele mesmo, era o homem mais republicano do Brasil e teria preferido ser presidente a imperador (depois de ser um intelectual, é claro).

... lealdades políticas, e nunca o Brasil teve homens de tão alto calibre nos cargos públicos, desde então. Todavia, ele subestimou demais - e, tendo em vista a sua experiência, o que ele poderia fazer? - o crescimento dos interesses comerciais e empresariais de seu país (e do mundo do século XIX), e sempre favoreceu a velha aristocracia latifundiária. No final de seu reinado muitos liberais, que o admiravam, por razões políticas se opuseram a ele acusando-o de "tirano" e de representante de uma monarquia decaída. liberdade de expressão e de imprensa. ${ }^{117}$ Os impostos eram proporcionais à riqueza. A força principal de D. Pedro era seu "poder moderador", sob o qual ele podia demitir quem bem entendesse, prorrogar o mandato dos congressistas ou dissolver a Câmara dos Deputados se considerasse que a situação do país o garantisse.

De acordo com os ministros mais liberais, ele abusava de seu "poder moderador" e substituía o governo com demasiada frequência, ao menos nos primeiros anos de seu reinado. Mas, à medida que envelhecia, ele se tornava mais paciente e mais liberal. Ele nunca exerceu vingança política. Nomeou homens com base em suas boas qualidades, pouco importando quais fossem suas lealdades políticas, e poucas vezes o Brasil teve homens de tão alto calibre nos cargos públicos, desde então. Todavia, ele subestimou demais o crescimento dos interesses comerciais e empresariais de seu país, e sempre favoreceu a velha aristocracia latifundiária.

${ }^{117}$ [HRV]: na margem: traço vertical junto a 'liberdade de expressão e de imprensa'. 
... a pessoa coroada mais popular

Depois de trinta anos no poder, D. Pedro II afinal permitiu-se viajar. Ele visitou a Europa e os Estados Unidos, e depois fez longas viagens pela Europa, pelo Egito e a Terra Santa. Durante as viagens sua filha mais velha, a herdeira do trono Princesa Isabel, permanecia como regente. Ele viajava incógnito, como D. Pedro de Alcântara, e seus modos democráticos, seu dom para línguas, bom humor e energia infinda tornaram-no "a pessoa real mais popular da Europa". Ele procurava grandes escritores onde quer que estivesse e conversava com eles em suas línguas. Victor Hugo chamou-o "um neto de Marco Aurélio". Ele era fascinado pelo estudo de religiões comparadas (o que chocava seus súditos mais devotos), e insistia em visitar sinagogas e ler em voz alta em hebraico.

EM 1876 D. Pedro II fez uma longa visita aos Estados

Em 1876 ele fez uma longa visita aos Estados Unidos, algo que desejara por muito tempo, e a Exposição de Filadélfia, celebrando os cem anos da independência norteamericana, pareceu um bom momento. Lastimava apenas não ter conhecido Lincoln, a quem admirava muito (como os brasileiros de hoje; "Lincoln" é um nome comum entre os meninos), e procurou encontrar Harriet Beecher Stowe. Ele havia se correspondido com os Transcendentalistas de Boston e com os
Unidos. Ele havia lido os Transcendentalistas e Abolicionistas de Boston, * correspondera-se com John Greenleaf Whittier e traduzira um de seus poemas - como fez com outros autores para o português. Chamava-se "O lamento de uma alma perdida". ${ }^{118}$ Quando encontrou Whittier, D. Pedro chocou o tímido poeta quaker quando tentou dar-lhe o abraço brasileiro. Ele também encontrou Henry Wadsworth Longfellow, ${ }^{119}$ que lhe ofereceu um jantar e depois descreveu seu convidado real como um "moderno Haroun-al-Raschid vagando para ver o grande mundo como um simples viajante,

\footnotetext{
* Boston Transcendentalists and Abolitionists. Por volta da metade do século XIX Boston era muitas vezes denominada "a Atenas da América", graças aos Transcendentalistas, um grupo de intelectuais formado por Ralph Waldo Emerson (1803-1882), Nathaniel Hawthorne (1804-1864) e Henry David Thoreau (1817-1862), entre muitos outros.

118 [HRV]: na margem: 'X' junto ao título do poema, "The Cry of a Lost Soul”. Whittier (1807-1892) foi um importante líder abolicionista dos Estados Unidos, e Bishop supôs que o poema se referisse à escravidão; depois, soube que "alma perdida" (ou "de caboclo") é um pássaro amazônico. Pedro II enviou dois espécimes empalhados ao poeta, com uma cópia autografada de sua tradução. (cf. The New York Times, 9 maio 1869).

${ }^{119}$ Henry Wadsworth Longfellow (1807-1882): poeta e tradutor, realizou longas viagens durante a juventude. O poeta compara Pedro II ao califa de Bagdá, personagem das Mil e uma noites.
} 
Abolicionistas (sua

correspondência é

atordoante), e traduziu alguns

de seus poemas.

Um deles foi o poema de

Whittier chamado "O

lamento de uma alma perdida" - não um poema contrário à escravidão, como seria de esperar, mas acerca de um pássaro amazônico, e D. Pedro enviou ao poeta uma caixa com esses pássaros, empalhados (ao menos não vivos, como as araras dos primeiros séculos). Mas o poema tinha seus sentidos abolicionistas, talvez, e D. Pedro pode ter sentido que expressava suas próprias esperanças acerca da libertação dos escravos. $\mathrm{O}$ pássaro "Levanta seus olhos para a calma estrelada dos céus;/ E, censurando todos os detestáveis gritos da terra,/ A Cruz $^{120}$ do perdão ilumina os céus tropicais!"

Ele visitou Yale, Harvard e Vassar, entre outras instituições educacionais, e parece ter encontrado todas as pessoas importantes do país. Um brasileiro protegido seu, exausto, chamou-o de "biblioteca sobre uma locomotiva".

Na Exposição de Filadélfia ele encontrou Alexander Graham Bell e foi dos primeiros compradores de telefones; instalou-os em todos os seus palácios no Brasil. Ele também levou várias máquinas-de-costura, recém-inventadas, para as damas de sua corte. Foi uma jornada triunfal por mais de 15 mil quilômetros. não um rei. Ele é uma pessoa amável, genial e nobre, muito liberal em suas ideias". 
... de triste, quase trágico nesse pequeno grupo com ar de estrangeiro, dominado pelo velho imperador muito alto, todo vestido com as roupas feias e convencionais do período, e que faz a visita convencional aos "pontos turísticos" convencionais e que tira a sua foto - algo do estado do Brasil naquele tempo, e de seus defeitos e virtudes. As influências estrangeiras mal digeridas mas ansiosamente buscadas, a tentativa de adoção das menos apropriadas (até mesmo no vestuário) e o desprezo ou ignorância pelas riquezas internas. D. Pedro era o "proprietário", pode-se dizer, de cataratas três ou quatro vezes maiores e mais magníficas que Niágara, mas inacessíveis, e apesar de toda a sua curiosidade e de suas viagens, ele nunca as viu. (Até hoje, os brasileiros de classe alta são surpreendentemente pouco familiarizados com seu próprio país, e mesmo sua geografia.)
Existe uma fotografia da comitiva real em sua visita às cataratas de Niágara. Há algo de triste, mesmo trágico nesse grupo com ar de estrangeiro que faz a visita convencional aos "pontos turísticos" convencionais e que tira a sua foto. A [p.45] situação é em certo sentido simbólica do Brasil do final do século XIX. As influências estrangeiras ansiosamente buscadas, a tentativa de adoção das menos apropriadas e o desprezo ou ignorância pelas riquezas internas - a velha fotografia sugere tudo isso. ${ }^{121} \mathrm{D}$. Pedro era o "proprietário" de uma catarata tão alta quanto Niágara e mais espetacular. ${ }^{122}$

Foi durante ${ }^{123}$ o longo reinado de D. Pedro que o progresso material do Brasil realmente começou. Em 1850 criou-se um Código Comercial que, ${ }^{124}$ com acréscimos, permanece em uso ainda hoje. Mais bancos se estabeleceram,

\footnotetext{
${ }^{121}$ [HRV]: a autora destaca 'As influências ... tudo isso', e insere ' $\mathrm{X}$ ' na margem.

${ }^{122} \mathrm{Na}$ carta aos Editores: "p.45, col. 1, linhas 7, 8 e 9: Por favor, veja meu texto. Deve constar 'waterfalls [cataratas] (plural) maiores e mais magníficas que Niágara' - e se você não pode provar que ele nunca as viu, a sentença deve [trecho cortado / ilegível] tão espetacular como Niágara? - chauvinismo ignorante!”. A alteração não foi feita no texto publicado. [1962, 1970]: 'uma catarata tão alta quanto Niágara e quase tão espetacular, mas poucas pessoas no Brasil lhe davam muita atenção'. Em [HRV] a autora rasura 'tão' e substitui 'quase tão' por 'mais'; elimina 'mas poucas pessoas no Brasil lhe davam muita atenção'; na margem: manuscrito ilegível. Nesta página (45) entra a ILUSTRAÇÃO: “Turista popular”.

${ }^{123}$ [1962, 1970]: 'Todavia, foi durante'. Em [HRV] a autora elimina 'Todavia'; na margem: '!'.

${ }^{124}$ Lei 556, 25 jun. 1850. Vários artigos foram revogados ao longo dos anos, mas o Código continua em vigor.
} 
... em 1854 - apenas 15 quilômetros, para começar, surgiu ...

... da preferência sempre demonstrada ...

... indiferente ao "progresso", e que ...

... preferiam ir a Paris, quando podiam.

... na maioria baronatos, mas, com uma grande exceção, todos eles eram ...
... e na Argentina. Ele foi a figura que marcou a mudança da economia puramente agrícola da monocultura para o mundo do capitalismo moderno e expansivo.

Todavia, quando se tornou nobre, ele também adotou um nome indígena, como quase todos os outros; era o período e o capital estrangeiro (ainda quase todo britânico) começou a chegar. Em 1854 surgiu a primeira estrada de ferro, para Petrópolis, a cidade favorita do Imperador. Instalou-se iluminação a gás nas ruas do Rio. Outras pequenas estradas de ferro foram construídas, embora o transporte fosse um dos maiores problemas, como ainda é hoje em dia.

O progresso foi lento, em parte por causa da preferência demonstrada por D. Pedro em relação à aristocracia latifundiária, conservadora e indiferente às "melhorias modernas", que desprezava a nova classe de comerciantes e banqueiros. As cidades ainda eram habitadas apenas por artesãos e por comerciantes portugueses; a aristocracia vivia em suas fazendas e muitos preferiam estar em Paris, quando podiam permitir-se esse luxo.

D. Pedro criou muitos títulos, na maioria baronatos. ${ }^{125}$ Muitos dos novos barões eram proprietários de terras enriquecidos com o açúcar ou o café - pois nesse tempo o café era o principal produto agrícola e o Brasil fornecia para todo o mundo. Uma exceção era Irineu ${ }^{126}$ Evangelista de Sousa, o Barão de Mauá, depois Visconde de Mauá. ${ }^{127}$ Algumas de suas muitas atividades refletem-se em seu extraordinário brasão, que reúne um navio a vapor, uma locomotiva e quatro postes de iluminação (como aqueles que ele instalou no Rio). Mauá era associado à grande família Rothschild e sócio de bancos em Londres, Nova York, no Uruguai e na Argentina. Sua carreira marca a transição, no Brasil, da economia agrícola do sistema de plantation para o mundo do capitalismo moderno e expansivo.

\footnotetext{
125 [HRV]: traço vertical junto ao parágrafo; na margem: manuscrito ilegível.

127 [1962, 1970]: Visconde de Mauá, o J. P. Morgan do Brasil. Em [HRV] a autora elimina o comentário.
} 
do Indianismo; era também considerado elegante ter um índio (de preferência, um chefe) entre os ancestrais. Os condes de Itaboraí, Tamandaré, os barões de Maracaju, Paranaguá - é como se os Estados Unidos tivessem tido seu conde Massachusetts ou barão Ohio. ${ }^{128}$

... pelos brasileiros com aversão, quase vergonha.

... cidadãos brasileiros no Paraguai, ...

A guerra também arruinou o visconde de Mauá, e uma das críticas mais severas contra D. Pedro indicava que ele poderia ter salvado Mauá com um empréstimo governamental, mas não o fez.
Houve duas guerras, a primeira em 1851-1852, em parte para livrar-se do regime brutal de Rosas, na Argentina. A segunda, contra o Paraguai, foi a única guerra de verdade em que o Brasil já entrou. Ela durou de 1865 a 1870 e ainda é lembrada pelos brasileiros com uma mistura de orgulho e vergonha. ${ }^{129}$ Seu início foi complicado, tendo a ver com os direitos dos cidadãos brasileiros no Uruguai, e foi instigada no país pelos sempre mais belicosos estados do sul. O Paraguai foi arruinado pela guerra. Mesmo tendo ${ }^{130}$ a Argentina e o Uruguai como aliados durante o conflito, as dívidas de guerra contraídas ${ }^{131}$ pelo Brasil pairaram sobre D. Pedro pelo resto de seu reinado.

O maior problema no governo de D. Pedro, no entanto, e sem dúvida em sua vida pessoal, ${ }^{132}$ foi a escravidão. A escravidão estava ligada de forma tão estreita com o Império e o imperador que o fim da monarquia e a morte de D. Pedro

\footnotetext{
${ }^{128}$ No original, a autora substituiu Hiawatha por Massachusetts, e Minnesota por Ohio; Hiawatha foi um líder indígena norte-americano, figura lendária que teria vivido no século XII, XV ou XVI, conforme a versão. Longfellow escreveu o poema "The song of Hiawatha” em 1855. O líder também dá nome a um parque nacional, em Michigan.

${ }^{129}$ [HRV]: a autora destaca 'vergonha' [shame] e insere '?' na margem.

130 [HRV]: a autora destaca 'Mesmo tendo' [even though] e insere ' $\mathrm{X}$ ' na margem.

131 [1970]: 'arruinado pela guerra. O Brasil e seus aliados, a Argentina e o Uruguai, venceram, mas foi uma vitória cara. As dívidas de guerra contraídas'.

132 [1970]: eliminou-se 'pessoal' [own personal].
} 
O imperador era contrário à escravidão, que ...

... teria de vir aos poucos, para não comprometer a economia do país, que, durante os primeiros anos de seu reinado, ...

... o comércio de escravos fora proibido em 1831, mas milhares ...

... com os ingleses, os quais procuravam navios brasileiros no mar e por vezes chegaram a bloquear portos ou desembarcar marinheiros em solo brasileiro. Os passos em direção à completa emancipação foram dados, quase sempre agitados pelos liberais e só votados quando

O passo seguinte, em 1887, foi a libertação de todos ...

... o Exército começou a desobedecer às ordens ... vieram logo após a emancipação. O imperador detestava a escravidão, que para ele era uma mancha vergonhosa sobre seu belo, amado país, e já em 1840 libertou todos os escravos que herdara. Mas ele também pensava que ${ }^{133}$ a emancipação [p.46] teria de vir aos poucos no país como um todo, para não comprometer a economia, que durante seu reinado era quase inteiramente dependente do trabalho escravo.

Já em 1826, em troca pelo reconhecimento do Império Brasileiro e por alguns tratados comerciais, D. Pedro I havia feito uma barganha com a Inglaterra: o comércio de escravos deveria acabar em 1830. No entanto, milhares de escravos continuaram a ser contrabandeados ${ }^{134}$ para o país todos os anos, e essa era uma fonte constante de problemas com os ingleses. Ao longo dos anos, leis que encaminhavam o país à abolição da escravatura foram pedidas com insistência: elas eram quase sempre agitadas pelos liberais e só eram votadas quando um governo conservador estava mais uma vez no poder. A lei do Ventre Livre decretou que todas as crianças nascidas de escravos após 1871 seriam livres, ${ }^{135}$ assim como todos os escravos que pertencessem à Coroa ou ao Estado. $\mathrm{O}$ passo seguinte, em 1885, foi a aprovação de uma lei pela qual todos os escravos deveriam ser libertados ${ }^{136}$ quando chegassem aos 60 anos. São Paulo libertou todos ${ }^{137}$ os escravos da cidade; vários estados começaram a libertar os seus, e o Exército começou a protestar contra as ordens para perseguir escravos fugidos.

A instituição estava sem dúvida condenada, mas os latifundiários em geral nada fizeram no sentido de se preparar para um futuro sem trabalho escravo. Houve algumas

\footnotetext{
133 [1970]: 'Mas ele também estava convencido de que'.

134 [1970]: 'No entanto, o tráfico continuou; milhares de escravos eram contrabandeados'.

135 [1970]: 'seriam libertados, assim como'.

136 [1970]: sempre freed, 'libertados', em vez de free, que consta no original e em 1962.

137 [1970]: 'São Paulo emancipou [emancipated] todos'.
} 
... a imigração. Alemães e suíços foram instalados ao norte do Rio, e depois, muitos italianos começaram a trabalhar nas enormes fazendas de café de São Paulo. Mas, como C. H. Haring diz, era difícil fazer trabalhadores virem para ...

... estava doente, diabético, ...

... ela assinou a proclamação da emancipação, no dia 13 de maio de 1888 - outro feriado nacional. Na realidade, de cerca de quatro milhões de negros, apenas $700 \mathrm{mil}$ restavam para serem libertados. Houve uma semana de celebração. $\mathrm{O}$ imperador estava muito doente, em Milão. Quando as notícias chegaram, ele disse que essa era a maior alegria de sua vida, e chorou, murmurando, "Que grande povo! Que grande povo!".

No entanto, os ricos fazendeiros haviam sido arruinados da noite para o dia, e $300 \ldots$ tentativas esporádicas para encorajar a imigração. Mas, como C. H. Haring diz, era difícil levar trabalhadores para um país “onde trabalho agrícola significava escravidão". ${ }^{138}$

EM 1887 D. Pedro viajou mais uma vez para a Europa, deixando a Princesa Isabel como regente. Ele estava exausto e diabético, e aparentava ser muito mais velho do que era. ${ }^{139}$ Isabel sempre fora abolicionista e agora, em parte por seu próprio desejo e em parte sob a pressão dos abolicionistas, ela assinou a proclamação que libertava os escravos. Foi no dia 13 de maio de 1888 . Houve uma semana de celebração. ${ }^{140}$

No entanto, essa lei arruinou a maior parte dos ricos fazendeiros, e 300 milhões de dólares que lhes pertenciam perderam seu valor. É claro que muitos dos latifundiários voltaram-se contra a monarquia e juntaram-se ao crescente movimento republicano. Havia, também, uma suspeita generalizada sobre o marido de Isabel, o Conde d'Eu, ${ }^{141}$ francês. Os brasileiros temiam a influência externa. A própria Isabel não era muito popular, e mesmo os mais devotados ao velho imperador sentiam-se inseguros acerca da coroação de

\footnotetext{
${ }^{138}$ Haring, Clarence Henry (1885-1960). Empire in Brazil. Harvard Univ. Press, 1958.

139 [HRV]: na margem: ' $\mathrm{X}$ ' junto a 'aparentava ser muito mais velho do que era'.

140 [HRV]: manuscrito ilegível.

${ }^{141}$ [HRV]: na margem: '?'.
} 
... mulher. O líder era

Benjamin Constant (Botelho de Magalhães), que se inspirava nas secas doutrinas de Auguste Comte, pois o movimento positivista era forte entre os intelectuais brasileiros. (Uma igreja positivista ainda sobrevive no Rio; e um de seus lemas, "Ordem e Progresso", está na bandeira verde e amarela, ao lado das estrelas do Cruzeiro do Sul.)

O fim veio de modo súbito, e foi uma completa surpresa para a maior parte da nação. Benjamin Constant maquinou uma pequena revolta militar e envolveu dois generais (um dos quais havia sido favorável ao imperador), e em 15 de novembro de 1889 proclamou-se a República. O imperador partiu numa noite escura e chuvosa, com toda ...

... uma grande pensão, mas, impecável e digno até o fim, ele recusou. A imperatriz morreu, provavelmente de um ataque cardíaco, logo depois, e ele viveu, a maior parte do tempo na França, por dois anos, estudando filosoficamente, como sempre: tupi, hebraico, árabe e sânscrito.

O país ainda era quase deserto, quase analfabeto e dividido entre os muito ricos e os pobres miseráveis. Apesar do seu respeito pela educação, ainda não havia universidades, as matrículas uma mulher. $\mathrm{O}$ movimento republicano era dirigido por Benjamin Constant Botelho de Magalhães, que se inspirava nas doutrinas de Auguste Comte, o filósofo francês cujas crenças positivistas foram muito difundidas e aceitas entre os intelectuais brasileiros.

O FIM da Monarquia foi súbito, uma completa surpresa para a maior parte da nação. O imperador retornou e recebeu boasvindas gerais. Mas Benjamin Constant e o Marechal Floriano Peixoto, que representava elementos descontentes do Exército, maquinaram uma revolta militar envolvendo o Marechal Deodoro da Fonseca (que havia sido um auxiliar devotado do imperador), e em 15 de novembro de 1889 proclamou-se a República do Brasil. O imperador partiu num navio com toda a família, alguns amigos e seu médico, numa noite chuvosa. Ofereceram-lhe uma grande soma de dinheiro, mas, impecável e digno até o fim, ele recusou. A imperatriz morreu logo depois, mas ele viveu ainda dois anos, a maior parte do tempo na França, e com calma prosseguiu em seus estudos de tupi, hebraico, árabe e sânscrito. Nunca se ouviu dele algum comentário amargo contra seus inimigos políticos.

Em vários aspectos D. Pedro falhou em seus projetos. O Brasil ainda era quase deserto, seu povo quase ${ }^{142}$ todo analfabeto e dividido entre os pouquíssimos muito ricos e os muitos pobres miseráveis. Apesar do respeito do imperador pela educação, ele não fundou nenhuma universidade. Poucos se matriculavam em escolas superiores, e o ensino era de

\footnotetext{
${ }^{142}$ [1970]: 'quase deserto, e seu povo continuava quase'.
} 
em escolas superiores eram raras, e o ensino era de baixa qualidade.

... de um país monárquico, escravocrata, primitivo e agrícola, do século XVIII, para uma República próspera graças ao comércio do café, com direitos iguais e atenta ao mundo externo (o qual também estava mais atento a ela). D. Pedro completou uma pequena parte de seus sonhos em relação ao Brasil - mas se tivesse havido mais monarcas como ele, a história seria, sem dúvida, uma leitura mais edificante. baixa qualidade. ${ }^{143}$

No entanto, o Brasil transformou-se de um país primitivo, agrícola, monárquico e escravocrata, do século XVIII, para uma República livre de escravos, próspera graças à nova riqueza do café e atenta ao mundo externo. D. Pedro completou apenas uma pequena parte de seus sonhos em relação ao Brasil - mas se houvesse mais monarcas como ele, a história ${ }^{144}$ seria uma leitura mais edificante. ${ }^{145}$

143 [1970]: 'e o ensino era medíocre. D. Pedro concretizou apenas uma pequena parte de seus sonhos relacionados ao Brasil. No entanto,'.

144 [1962]: 'a história do mundo [world history] seria'.

145 [1970]: nova redação para o último parágrafo: 'Todavia, o Imperador havia lançado a base para o nascimento de uma nação moderna. No final de seu reinado o Brasil havia se transformado de uma sociedade agrícola, escravocrata e primitiva, numa nova república próspera, livre de escravos e em crescimento, cada vez mais consciente do mundo exterior.' 


\section{Três capitais ${ }^{146}$}

O BRASIL teve três capitais - Salvador, Rio de Janeiro ${ }^{147} \mathrm{e}$, desde 1960, a nova cidade de Brasília. A sede do governo moveu-se à medida que o país mudava histórica e ${ }^{148}$ economicamente. A mudança da Bahia para o Rio teve razões lógicas, sugeridas pelo crescimento do país. A recente mudança ${ }^{149}$ do Rio para Brasília é muito mais um gesto de esperança que uma reação à necessidade; é uma abordagem idealista de velhos problemas - ocupação do interior e tentativa de assegurar um governo mais eficiente.

A Bahia, ou Salvador, foi a primeira capital do Brasil, apropriadamente, uma vez que foi no estado da Bahia que o país teve seu início. Cabral aportou primeiro na sua costa, e a primeira carta de Caminha a descreve. Um ano após Cabral, outra viagem foi feita, com Américo Vespúcio ...
A Bahia, ou Salvador, foi bastante apropriada como ${ }^{150}$ primeira capital, uma vez que o país teve seu início no estado da Bahia. A bahia, ou baía, foi descoberta em 1501 por uma expedição portuguesa cujo navegador era Américo Vespúcio (o qual batizaria o continente), e depois recebeu o nome abrangente de São Salvador da Bahia de Todos os Santos. ${ }^{151}$ Em 1534 a primeira sede foi estabelecida, um pequeno grupo [p.54] de cabanas cobertas de folhas, cercado por uma paliçada. Ela foi logo atacada e destruída pelos índios - que também comeram alguns dos infelizes aventureiros.

O primeiro governador-geral do Brasil, Tomé de Souza, chegou em 1549 trazendo várias centenas de soldados e exilados portugueses, com ordens do rei para fundar um

\footnotetext{
146 [HRV]: a autora substitui o título, "Mudanças nos centros de governo" [Shifting Centers for Government], pelo original.

${ }^{147}$ [1962] 'três capitais - Bahia, Rio de Janeiro e,'; [1970]: 'Bahia' é corrigida para 'Salvador', sempre que se referir à cidade.

148 [1970]: ‘à medida que o país mudava política e economicamente'.

149 [1970]: 'A mudança do Rio para Brasília'.

150 [1970]: 'Salvador (às vezes chamada de Bahia) foi bastante apta como'

151 Também em inglês: Holy Savior of the Bay of All Saints.
} 
... país. Ele trouxe um mapa da nova cidade, completa, com muros e bastiões, igrejas e edifícios públicos. De acordo com a tradição portuguesa, ela seria construída sobre os morros, supervisionando o mar, mais parecendo um forte que uma vila, para facilitar sua defesa. De acordo com os historiadores, o governadorgeral colaborou na construção com suas próprias mãos. Entre os mil homens, os primeiros habitantes eram principalmente índios "pacificados", a enorme família e os seguidores do mais famoso dos lendários chefes-degredados,

"Caramuru", o qual estava no Brasil desde 1510, e que havia se casado com uma princesa indígena, a bela "Paraguaçu".

... e 'baixa', como ainda é hoje. Funiculares e elevadores hoje conectam as duas cidades, e o principal elevador, que se tornou quase um símbolo da Bahia, é o Lacerda, com 70 metros de altura - construído em 1875. Protegida ...

... entrada de negros escravos, da Guiné, Moçambique e Angola. Embora provenientes de muitas nações africanas, de diferentes níveis culturais, muitos desses negros eram maometanos, bem-educados; supõe-se que alguns tenham alfabetizado seus próprios senhores. Eles sabiam trabalhar o ferro, criar gado - "grande e forte estabelecimento" que serviria como capital para o novo país. Buscando defender-se, a nova cidade foi construída sobre os morros próximos ao mar, mais parecendo um forte que uma cidade. Além dos portugueses, os primeiros habitantes eram quase todos índios "pacificados".

A vila cresceu tão rápido que ultrapassou os muros e estendeu-se até a beira do mar, criando as cidades 'alta' e 'baixa' que ainda existem. Protegida pelos vice-reis da Coroa portuguesa e tornando-se fabulosamente rica durante o boom do açúcar durante os séculos XVII e XVIII, a Bahia foi ${ }^{152}$ também o maior porto de entrada para escravos negros. Eles vinham de várias nações africanas e de todos os estágios culturais. Alguns deles eram maometanos educados; às vezes, dizem, chegaram a alfabetizar seus senhores. Havia escravos que sabiam trabalhar o ferro, criar gado e cozinhar; outros eram músicos, e outros sabiam cultivar a banana e as palmeiras.

${ }^{152}$ [1970]: 'XVIII, Salvador foi'. 
e cozinhar. Trouxeram artes, habilidades manuais, música; o cultivo da banana e da palmeira.

Embora tenha permanecido importante até que São Paulo a sobrepujou, como a capital do café, a construção em larga escala quase parou. Quando o "progresso" ou a arquitetura moderna chegou à Bahia, ...

... baianos que vêm para o Rio, completam ...

No Rio e em São Paulo, com seu crescimento ininterrupto, não houve tempo para que os prédios coloniais permanecessem até a velhice honrada. Cada década presenciou novas construções, edifícios derrubados e ruas e avenidas abertas - o feio preço do progresso.
A TRANSFERÊNCIA da capital para o Rio de Janeiro, em 1763, é uma das razões pelas quais a Bahia preservou tão bem seu caráter colonial. Ela permaneceu rica e importante por muitos anos, mas, quando deixou de ser a capital, interrompeu-se a construção em larga escala. Quando a onda da arquitetura moderna chegou à Bahia, ${ }^{153}$ os velhos prédios da cidade eram vistos como sagrados; protegidos por séculos de tradições, eles escaparam à destruição. Hoje, embora a Bahia continue crescendo, construindo e se modernizando, a parte velha da cidade permanece intocada e domina os bairros novos.

Os baianos são extremamente orgulhosos ${ }^{154}$ de sua cidade; eles a chamam de "a boa terra". ${ }^{155}$ Quando os cariocas se referem aos grandes contingentes de baianos 156 que todos os anos se deslocam para o sul, ${ }^{157}$ completam com ironia: "Sim, a Bahia é a terra boa - a Bahia lá, e eu aqui!".

Salvador é, ${ }^{158}$ muitas vezes, a primeira cidade brasileira avistada pelos viajantes que chegam de navio, e o

\footnotetext{
153 [1970]: 'chegou a Salvador,'.

154 [1970]: 'Os baianos, como os moradores de Salvador chamam a si mesmos, são orgulhosos'.

${ }^{155}$ Em inglês, the good place.

${ }_{156}^{156}$ [1970]: 'bahianos' atualizado para 'baianos', sempre.

157 [1962, 1970]: 'se deslocam para o sul, para sua cidade, completam'.

158 [1962]: ‘A Bahia é,'. Corrigido em [1970].
} 
... população negra cria uma primeira e permanente impressão forte como "tipicamente brasileira". Seus fortes antigos frente ao oceano, sua magnífica arquitetura barroca (seriam 300 igrejas), as multidões de todas as cores, as frequentes procissões religiosas, as roupas folclóricas que sobrevivem, os vendedores de rua, os restaurantes e os mercados ao ar livre, exemplos de arte folclórica é mais tipicamente "brasileira" do que qualquer outra cidade.

... ingredientes exóticos. As roupas das baianas, as mulatas, lembram as da Martinica, no estilo do Império Francês. Consistem em ...

... balangandã um conjunto de grandes amuletos, frutas, cruzes etc., que batem e chacoalham na cintura. Nos tempos ... grande porto, sua agitada vida em frente ao mar, o calor, os aromas penetrantes e a grande população negra criam uma impressão forte e duradoura. Seus fortes antigos frente ao oceano, seus edifícios barrocos, magníficos mesmo quando decadentes, as multidões negras e brancas, as frequentes procissões religiosas, os vendedores de rua, os restaurantes e os mercados ao ar livre, onde a melhor arte folclórica do Brasil está à venda - tudo isso combina para que ela pareça uma cidade "tipicamente brasileira".

A COZINHA baiana, influenciada pela África, é muito famosa, e faz uso de azeite de dendê, gengibre fresco, camarões secos, leite de coco e dúzias de outros ingredientes exóticos. As roupas das mulheres negras e mulatas da cidade recordam os tempos coloniais. Consistem em uma saia longa e estampada, uma camisa branca larga (normalmente de algodão, feita em casa), enfeitada de rendas artesanais, um turbante, brincos, colares e, às vezes, na cintura, um balangandã, ${ }^{159}$ um conjunto chacoalhante de amuletos de prata num cordão de prata. Nos tempos antigos os balangandãs eram às vezes feitos de ouro, e a riqueza de um proprietário se expunha nas joias usadas por sua escrava. Hoje, as baianas ${ }^{160}$ - mulheres da Bahia vestidas dessa maneira - são em geral vendedoras de rua. Com seus tabuleiros portáteis e pequenos fogareiros de carvão, elas são figuras familiares em São Paulo, no Rio e em outras cidades. Elas vendem cocada, pesados bolos de tapioca, misteriosos confeitos envoltos em palha de milho, espigas de milho cozido e outras especialidades do norte.

\footnotetext{
${ }^{159}$ [HRV]: na margem: '?' junto a 'balangandã'.

160 [1970]: 'bahianas' atualizado para 'baianas'.
} 
Sua roupa é considerada "tipicamente brasileira" (embora não o seja), e nos concursos de beleza ou nos bailes a fantasia, sempre que uma brasileira quer aparecer "caracterizada", veste-se à la baiana.

... Senhor do Bonfim, o patrono da cidade, o próprio Salvador. A pequena igreja do século XVIII é objeto de uma grande peregrinação todos os anos, logo após o Dia de Reis. Não é apenas a população negra ou as pessoas pobres que vão ao Bonfim; governantes, políticos, generais e milionários podem ser vistos nas procissões, carregando velas acesas nas mãos. $(\mathrm{O}$ outro grande destino de peregrinação anual no Brasil é a Basílica de Nazaré em Belém, e o maior de todos, o Santuário de Nossa Senhora Aparecida em São Paulo - a santa padroeira do Brasil.)

Com sua grande população negra e mulata, a Bahia é também o centro do candomblé e da macumba (religiões semelhantes ao vodu), essa mistura muito emocional e desenvolvida de cultos africanos e catolicismo. Da Bahia vêm os grandes "Pais-de-santo" * desses cultos, líderes de suas "igrejas" no Recife e no Rio.

O Rio tem sua beleza natural incomparável, Recife tem suas tradições flamengas, e São Paulo ostenta seu
A Bahia tem ${ }^{161}$ uma sequência ininterrupta de festas e peregrinações. A festa anual do Senhor do Bonfim ${ }^{162}$ é famosa em todo o Brasil. Não é apenas a população negra e as pessoas pobres que vão ao Bonfim; governantes, políticos, generais e milionários são vistos juntos nas procissões, carregando velas acesas em direção à famosa igrejinha do século XVIII que é o objeto de sua peregrinação.

Com sua grande população negra, a Bahia é ${ }^{163}$ o ${ }^{[p .55]}$ centro do candomblé, essa mistura muito emocional e desenvolvida de cultos africanos e catolicismo romano que, em outras cidades brasileiras, é conhecida como macumba. Os baianos também praticam a arte da capoeira, uma combinação de luta ${ }^{164}$ e jiu-jítsu em que apenas os pés são usados. É rápida e graciosa - outro item importado da África.

\footnotetext{
${ }^{161}$ [1970]: 'Salvador tem'.

162 [VAS]: (Lord of the Good Death); [1962, 1970]: (Lord of the Good End). A segunda opção é a correta, pois refere-se a fim (consecução) e não a morte.

* [VAS]: a autora refere-se aos pais-de-santo como Babylons [Babalaôs, obviamente] ou Holy fathers [santos pais], tradução literal que merece ressalva.

163 [1970]: 'negra, Salvador é'.

164 [1970]: pequena alteração: de 'form of combined wrestling' para 'combination of wrestling'.
} 
progresso - mas a Bahia é acima de todas a cidade romântica, a [em branco]

... mas as origens do Rio de Janeiro são mais parecidas com as de Boston, pode-se dizer - esta, um século depois. Ela foi estabelecida por volta de 1555 , na magnífica Baía de Guanabara, por um grupo de calvinistas franceses ...

... Villegaignon (a Ilha de Villegaignon ainda marca o seu lugar) e eles sonhavam em estabelecer no Novo Mundo uma "Utopia" de acordo com Thomas Morus.

... patrono da cidade que ele fundou no morro Cara-deCão, aos pés do Pão-deAçúcar. No intuito de defender-se, a vila transferiuse para o Morro do Castelo, mais para dentro da baía, e foi ali que a velha cidade colonial se desenvolveu.

... uma vila colonial suja. Os recém-chegados resolveram o problema habitacional de modo sumário: os oficiais requisitaram todas as melhores casas para os membros da corte. Um funcionário pintava sobre as portas as letras P.R. (Príncipe Regente).
Salvador ${ }^{165}$ foi construída para ser capital, mas as origens do Rio de Janeiro estão mais ligadas ao acaso. A primeira colônia foi estabelecida em 1555, na magnífica Baía de Guanabara, por um grupo de huguenotes franceses, sem a permissão dos portugueses. Por estar tão longe ${ }^{166}$ na direção sul, o estabelecimento foi chamado, sem modéstia, de "França Antártica", e seu líder era Nicolas Durand de Villegaignon, um religioso ${ }^{167}$ que sonhava fundar uma Utopia.

Para expulsar os franceses, aliados dos índios, o governador-geral da Bahia (1.200 km ao Norte) enviou seu sobrinho Estácio de Sá. Na batalha em que os portugueses venceram os franceses, Estácio, "um garoto de presença gentil", foi morto por uma flecha no rosto, tornando-se uma espécie de patrono da cidade - assim como São Sebastião é o santo padroeiro. No intuito de se defender, a vila portuguesa transferiu-se para o Morro do Castelo, e foi ali que a cidade colonial do Rio se desenvolveu.

QUANDO a corte portuguesa chegou, em 1808, o Rio ainda era apenas uma vila colonial. ${ }^{168} \mathrm{O}$ vice-rei e seu conselho resolveram logo o problema habitacional: os oficiais requisitaram as melhores casas para os nobres da corte. Um funcionário informava sobre a desapropriação pintando as letras P.R. (Príncipe Regente) nas portas das casas. Os

\footnotetext{
165 [1962]: 'A Bahia foi construída'; [1970]: 'Salvador foi construída'.

166 [1962, 1970]: 'tão longe da Europa na direção Sul'; [HRV]: a autora elimina 'da Europa'; na margem: '?'.

167 [1962, 1970]: 'um tirano religioso'; [HRV]: a autora elimina 'tirano'; na margem: manuscrito ilegível e '?'.

168 [1962, 1970]: 'uma vila colonial imunda'. [HRV]: a autora elimina 'imunda'; na margem: '!'.
} 
... Corcovado. A região de Copacabana deixou de ser um conjunto de praias quase desertas para tornar-se a superpovoada "zona sul", repleta de edifícios residenciais. Os bondinhos para o alto do Pão-de-Açúcar são desse período, assim como a pequena estrada-deferro funicular que sobe o Corcovado.

Entre os exuberantes paredões de pedras e das montanhas, de um lado, e os pântanos e mangues do outro, o Rio desenvolveu-se como uma grande cidade, mas isolada, e seus problemas de transporte sempre foram cariocas traduziram as letras ao seu modo, como Ponha-se na rua, ${ }^{169}$ e foi assim mesmo.

A cidade progrediu durante todo o período do Império, mas o crescimento mais importante veio após a consolidação da República. No período eufórico anterior à Primeira Guerra Mundial ela começou a assumir sua aparência atual. Os prefeitos da época destruíram muitas ruas e vielas - e, infelizmente, com elas, muitos prédios antigos, praças e fontes insubstituíveis. Eles removeram morros, aterraram trechos da baía e abriram avenidas. Construíram a longa sequência de docas e os belos armazéns de tijolos aparentes onde os estivadores negros trabalham hoje, usando apenas shorts rasgados e chapéus de palha. Os bondinhos para o alto da famosa montanha Pão-de-Açúcar são desse período, assim como a pequena estrada-de-ferro funicular que sobe até o pico do Corcovado. ${ }^{170}$ Entre 1930 e 1960, a região de Copacabana, de frente para o mar, deixou de ser um subúrbio distante, ${ }^{171}$ com uma praia semideserta, para tornar-se a hoje superpovoada "zona sul", com seus edifícios residenciais de 10 andares. ${ }^{172} \mathrm{~A}$ imagem do Cristo Redentor, com 33 metros de altura, do escultor francês Paul Landowski, foi construída no alto do Corcovado em $1931{ }^{173}$ para comemorar o primeiro centenário da independência política brasileira.

POR CAUSA dos extravagantes paredões das montanhas e pedras em suas costas, e dos pântanos e mangues à sua volta, o Rio desenvolveu-se como uma cidade isolada a despeito de seu tamanho, e os problemas habitacionais e de transporte sempre foram gigantescos. Existe apenas uma autoestrada

\footnotetext{
169 Também em inglês, 'Get out in the street'.

${ }^{170}$ Também em inglês: Hunchback.

${ }^{171}$ [1962]: 'deixou de ser pouco mais que um subúrbio,'; [1970]: 'deixou de ser um pequeno subúrbio,'.

172 [1970]: 'residenciais de grande altura'.

173 [HRV]: '?', junto a 1931.
} 
muito difíceis. Existe apenas uma autoestrada ligando o Rio ao interior; as avenidas e ruas principais passam entre morros, ou foram construídas sobre aterros, ao longo da baía. Quase todas as praças antigas haviam sido lagoas ou pântanos. ...

... Agora, no entanto, as condições sanitárias modernas alteraram tudo isso, e enormes subúrbios espalharam-se sobre os antigos pântanos.

A topografia do Rio é fantasticamente bela, mas tristemente inadequada para qualquer planejamento urbano geométrico ou matemático. A cidade se espalhou e penetrou como os dedos de uma mão entre os picos de granito e os morros íngremes, que permaneceram desabitados até o recente (20 anos) crescimento das notórias favelas. Embora as pessoas pobres tenham vivido sempre nos "morros", foi apenas nos últimos 20 anos que eles foram cobertos pelos barracos, muitos dos quais habitados por migrantes do Norte e do Nordeste Estima-se que um milhão dos 3 milhões de habitantes do Rio vive hoje nessas favelas, criando o pior dos muitos problemas da cidade. ligando o Rio ${ }^{174}$ ao interior; na cidade, mesmo as avenidas e ruas principais passam entre morros ou atravessam túneis sob eles, ou acompanham a baía sobre aterros. Muitas das praças antigas surgiram em lagoas e pântanos aterrados. A cidade não podia expandir-se ao longo da costa porque o mosquito da malária tornava os mangues próximos inabitáveis. Agora, no entanto, as condições sanitárias modernas alteraram esse panorama, e enormes subúrbios espalharam-se para o norte e o noroeste. ${ }^{175}$

A topografia do Rio é fantasticamente bela, mas desafia qualquer tipo de planejamento urbano sistemático. A cidade penetrou como os dedos de uma mão entre os picos de granito e os morros cônicos e íngremes. * Embora as pessoas pobres tenham vivido sempre nos morros, foi apenas durante os últimos 20 anos ${ }^{176}$ mais ou menos que essas montanhas foram cobertas pelos barracos ${ }^{177}$ chamados de favelas, muitos dos quais são habitados por migrantes do Nordeste. Estima-se que 700 mil dos 3,3 milhões de ${ }^{178}$ habitantes do Rio vivem hoje nessas favelas, criando assim o pior dos muitos problemas da cidade.

\footnotetext{
${ }^{174}$ [1970]: 'Existem poucas autoestradas ligando o Rio'.

175 [HRV]: '(proletários)?'.

* Respondendo a um elogio de May Swenson em carta, sobre essa referência aos dedos de uma mão, a autora explica que a imagem é de sua amiga Rachel de Queirós: “(Não me elogie por comparar o Rio a 'dedos' quem disse isso foi a Rachel de Queirós!)” (10 abr. 62, em Bishop, 1995, p.713).

176 [1970]: 'últimos 30 anos'.

177 [1962]: 'grupos de barracos'; [HRV]: manuscrito ilegível junto a 'Nordeste'.

178 [1970]: 'que 1 milhão dos 4 milhões e meio de'.
} 
... faltar. Embora a vida nas favelas pareça não oferecer nada, exceto as belas vistas e as brisas, para os pobres que chegam - assim que um projeto habitacional transfere mil favelados para bairros melhores, o mesmo número chega à cidade e ocupa os barracos vazios.

... aspectos, quando comparados com a mesma pobreza, mas associada ao tédio e ao isolamento da vida nas pequenas vilas do interior.
Os milhares e milhares de barracos empilham-se nas encostas, ou estendem-se para o norte sobre os aterros e depósitos de lixo. Os urubus, seus únicos carniceiros, pairam sobre eles. Os barracos não têm água corrente nem esgoto; ao longo de todo o dia as mulheres e as crianças fazem fila junto às poucas torneiras disponíveis, para encher velhas latas com água canalizada - que nesses lugares costuma faltar. As favelas são criadouros naturais de doenças, crime e agitação social. Todavia, assim que um projeto habitacional transfere mil favelados para bairros melhores, o mesmo número de migrantes nordestinos aparece misteriosamente, pronto para ocupar os barracos vazios.

São assim os atrativos ${ }^{179}$ que a vida da cidade, mesmo nos seus piores aspectos, oferece para essas pessoas. Nas pequenas cidades e vilas do interior existe a mesma pobreza, mas associada ao tédio e ao isolamento. ${ }^{180} \mathrm{Na}$ cidade ${ }^{181}$ existem as luzes brilhantes, o rádio e a televisão (é surpreendente a quantidade de antenas nos telhados dos barracos), futebol, ${ }^{182}$ as loterias, a constante excitação e o senso de participação - mesmo que apenas no pior nível - da vida de uma cidade grande. Tudo isso compensa a ${ }^{183}$ miséria e a sujeira, as filas à espera ${ }^{184}$ de água e as frequentes visitas da polícia.

O RIO é uma cidade de surpresas. Uma rua movimentada termina numa escadaria íngreme e sem fim. $\mathrm{O}$ aeroporto Santos Dumont - para pequenos aviões - fica perto do centro 185 da cidade. De frente para o final da avenida Rio Branco, a
O Rio é uma cidade de surpresas. De frente para o final da sua Quinta Avenida, avenida Barão do Rio Branco, desliza um gigantesco transatlântico.

\footnotetext{
${ }^{179}$ [1962, 1970]: 'Pois nada nega os atrativos'.

${ }^{180}$ [HRV]: '(indústrias?)', junto a 'isolamento'.

181 [1970]: 'No Rio existem'.

182 Também em inglês, 'soccer football'.

183 [1970]: 'Tudo isso ajuda a compensar a'.

${ }^{184}$ [1970]: 'standing in line' substituído por 'queuing up'.

185 [1970]: 'Dumont está situado junto ao centro'.
} 
Uma rua sem saída torna-se uma escadaria sem fim. Por causa de sua fisionomia peculiar, ou porque costumavam ser a única forma de chegar a algum lugar, túneis foram construídos em todas as direções, ou grandes cortes foram feitos nas montanhas de granito. Embora ainda contornado pelas mais antigas igrejas do Rio, pela Santa Casa, pelo Arsenal etc. - o morro do Castelo foi removido durante o primeiro centenário da Independência, 1922 - uma daquelas surpreendentes operações de movimentação de terra e de mudança de cena tão características da cidade e que surpreendem os visitantes. "O que aconteceu com o Rio?", pergunta com tristeza o carioca que esteve fora por dois ou três anos um que esteve fora por 12 anos teve de comprar o mais recente mapa da cidade para se localizar em sua cidade natal.

... das favelas, e são despertados pelo canto de galos, no $10^{\circ}$ andar, ou por bebês chorando - não os seus. Uma história, tida como verdadeira, ilustra essa intimidade e [em branco] dessa caótica mistura. Um casal que voltou para o seu apartamento no $8^{\circ}$ andar à noite ouviu pancadas e ruídos terríveis e pensou, "Ladrões!". Mas, quando abriram a porta, encontraram apenas um cavalo em pânico. As encostas de pedra e terra são tão próximas dos prédios principal da cidade, pode deslizar um gigantesco transatlântico. Velhos prédios e mesmo alguns morros estão sendo removidos para dar espaço a novas estruturas e novos desenvolvimentos, e embora os limites ${ }^{186}$ da cidade colonial ainda estejam demarcados pelas velhas igrejas coloniais e por outros prédios públicos, o próprio Morro do Castelo foi desmontado em 1922 numa das operações de mudança de cenário que são características da cidade e que assombram o visitante. "O que aconteceu com o Rio?", pergunta sempre o carioca que esteve fora por dois ou três anos. Um que esteve fora por 12 anos só conseguiu se localizar no centro de sua cidade natal depois que comprou um guia de ruas.

Os ricos moradores dos andares mais altos quase sempre estão a poucos metros das favelas. Às vezes, essa intimidade pode tornar-se caótica. Um casal que voltou para casa à noite, em seu apartamento no oitavo andar de um prédio no Morro da Viúva, ${ }^{187}$ ouviu pancadas e ruídos terríveis e pensou, "Ladrões!". Mas, quando abriram a porta, encontraram apenas um cavalo em pânico na sala de estar. Os prédios foram construídos tão próximo das encostas cobertas por pedras e vegetação que o cavalo deu um jeito de cair, de seu pasto minúsculo e oblíquo, direto no terraço.

\footnotetext{
186 [HRV]: a autora elimina 'limites'; na margem, '?'.

187 Também em inglês: Widow's Hill.
} 
que ele deu um jeito de cair, de seu pasto minúsculo, direto no terraço do casal - e isso é perfeitamente possível.

Hoje, Brasília é vista com grande aversão por muitas pessoas, e isso não acontece sem muito boas razões. Todavia, muito antes de o presidente Kubitschek iniciar a construção da nova capital, a mudança do Rio para o Planalto Central já era um sonho brasileiro, uma espécie de êxodo para a terra de Canaã, prometida desde os dias da Colônia, anunciandose que iria resolver ...

... Esse era o mito da cidade de ouro, ao menos com a possibilidade de fornecer riqueza e oportunidades para todos.

... José Bonifácio, conselheiro de D. Pedro, o Patriarca da Independência, que também sonhou com essa capital no interior; ele pode ser até mesmo ...

... e do São Francisco: mais ou menos onde Brasília está localizada. E a primeira Constituição da República, influenciada pelos positivistas, incluía a demarcação de um
HOJE o Rio não é mais a capital do país. O projeto atual de transferência da sede do governo para o interior surgiu em 1956, mas a ideia de fundar uma capital utópica existia por mais de um século. A mudança foi encarada como uma espécie de êxodo para a terra de Canaã, um golpe enorme, que iria resolver todos os problemas do país num passe de mágica. Construir a capital no interior seria uma repetição romântica das longas marchas dos bandeirantes através dos sertões, levando civilização para as áreas mais remotas, até atingir a fronteira no oeste. Esse era o mito da cidade de ouro, com a possibilidade de riqueza e oportunidades para todos. Num nível mais mundano, uma capital central aparentemente poderia oferecer ${ }^{188}$ melhores condições de vida e menos distrações para os funcionários públicos, e ajudaria a desenvolver aqueles grandes espaços vazios que assombraram o Brasil ${ }^{189}$ por tanto tempo.

Um dos primeiros líderes a sonhar com uma capital central foi José Bonifácio, conselheiro de D. Pedro I na [p.57] década de 1820. Bonifácio talvez seja até mesmo o responsável ${ }^{190}$ pelo nome "Brasília". Em meados do século XIX, o historiador brasileiro Francisco Adolfo de Varnhagen empenhou-se pela criação de uma capital localizada no ponto imaginário de encontro das principais bacias hídricas do Brasil - do Amazonas, do Paraná e do São Francisco. A cidade imaginária de Varnhagen ficaria mais ou menos onde Brasília foi construída. A primeira Constituição da República, de 1891, especificava a demarcação de um quadrilátero ${ }^{191}$ no

\footnotetext{
${ }^{188}$ [1962, 1970]: 'uma capital central poderia oferecer'.

189 [HRV]: a autora inclui 'os imigrantes ?', junto a 'Brasil'.

190 [HRV]: manuscrito ilegível; a autora elimina 'talvez ... responsável', mas não o substitui.

191 [HRV]: 'X' junto a 'quadrilátero'.
} 
quadrilátero no coração geográfico do Brasil, onde o futuro Distrito Federal deveria situar-se. Após a ditadura de Vargas, em 1945, a nova [em branco] propôs uma nova capital em Goiás, e ordenou que uma comissão preparasse a mudança. Todo candidato político em busca de popularidade, todo repórter oportunista falou contra os "caranguejos" que pretendiam agarrar-se ao litoral e ignorar o fértil interior. A "Marcha para o oeste" sempre foi uma aspiração nacional brasileira.

Assim, quando o governo Kubitschek quis marcar seu mandato com alguma obra pública sensacional e inesquecível, surgiu a ideia de tornar realidade o velho sonho de Brasília.

Kubitschek, otimista, vigoroso e entusiástico, recusou-se a ver as muitas dificuldades, ou, depois, a reconhecer a séria crise econômica e a espiral inflacionária em que o país estava entrando. Havia grande oposição a ela, e ainda existe. Mas ela foi construída, mesmo ao custo de mais de um bilhão de dólares e da destruição do orçamento nacional, passando por cima de tudo.
Planalto Central do Brasil, onde o futuro Distrito Federal deveria situar-se. Após a queda da ditadura de Vargas, em 1945, uma nova Constituição propôs a transferência da capital para uma cidade convenientemente localizada no quadrilátero prescrito no estado de Goiás, ${ }^{192}$ e ordenou o estabelecimento de uma comissão para preparar a mudança. Todo repórter oportunista, todo candidato político em busca de popularidade chamou de "caranguejos" aqueles que pretendiam agarrar-se ao litoral e continuar ignorando o fértil interior do país.

Quando o presidente Juscelino Kubitschek assumiu o poder em 1956, ele queria ${ }^{193}$ marcar seu mandato com alguma obra pública inesquecível. Um de seus primeiros atos como presidente consistiu em anunciar que tornaria realidade o antigo sonho da capital, ${ }^{194}$ e uma lei foi aprovada nas duas casas legislativas quase sem objeção. Para construir a capital, o governo escolheu um planalto desolado e quase estéril, onde Brasília está agora.

É ÓBVIO que o gosto arquitetônico de Kubitschek é sofisticado. O mundialmente famoso arquiteto brasileiro Oscar Niemeyer é ${ }^{195}$ seu amigo íntimo, já havia projetado edifícios para ele, e agora foi contratado para projetar todos os

\footnotetext{
192 [1970]: eliminou-se uma quebra em Go-ías, presente em [1962], mas manteve-se o acento incorreto.

193 [HRV]: a autora elimina 'queria'; ilegível.

194 [1962, 1970]: 'a capital tão longamente sonhada'; 'X' na margem.

195 [1962, 1970]: 'é notavelmente sofisticado, para um governante ... Niemeyer é há muitos anos seu amigo íntimo,'.
} 
... delas. O governo foi instalado no dia 21 de abril de 1960, e todos os funcionários governamentais tiveram de se mudar para lá - ou, ao menos, todos para os quais houvesse edifícios prontos. edifícios do governo na nova capital. Todos os outros prédios têm de receber sua aprovação. O plano dá à cidade ${ }^{196}$ o formato de um avião ou pássaro e é de um amigo e exprofessor de Niemeyer, Lúcio Costa, o mais experiente dos arquitetos brasileiros. ${ }^{197}$

Não havia estrada de ferro até lá, e apenas estradas de terra. ${ }^{198}$ A economia brasileira já estava num mau caminho, mas Kubitschek embarcou em seu plano monumental apesar de tudo, e a construção foi iniciada. Grande parte dos materiais de construção teve de ser transportada por via aérea - a um custo assustador. Uma cidade-dormitório espalhada e quase desabando, a "Cidade Livre", 199 para trabalhadores migrantes, cresceu ${ }^{200}$ próximo às obras. E as dificuldades surgiram na mesma hora, mas Kubitschek - otimista, vigoroso e entusiástico - recusou-se a conscientizar-se delas. Com grandes festas o governo foi instalado na nova capital em abril de $1960 .^{201}$

Os legisladores e membros de alguns ministérios executivos devem agora viver lá, por força de uma lei, ao menos parte do tempo, mas Brasília, até agora, foi apenas parcialmente concluída. ${ }^{202}$ A construção de muitos edifícios foi interrompida, e é difícil prever quando o país poderá retomar a construção em larga escala. A cidade já custou aos brasileiros mais de 600 milhões de dólares, o que aumentou [p.58] muito os problemas econômicos do país.

Os resultados de todo esse esbanjamento e de três anos de trabalho ininterrupto são controversos, para dizer o mínimo. ${ }^{203}$ Brasília foi construída - a maior parte dela está

\footnotetext{
${ }^{196}$ [1962, 1970]: 'do local, que dá à cidade'.

${ }^{197}$ Neste ponto incluiu-se o MAPA de Brasília.

198 [HRV]: a autora elimina 'de terra'; '!' na margem.

199 [1970]: 'Cidades-dormitório espalhadas e quase desabando, as cidades-satélite, para ...'

200 [1970]: 'migrantes, cresceram próximo ...'.

201 [1970]: a partir daqui, novo final para o capítulo. Ver Nota I, no final deste capítulo.

202 [HRV]: junto a 'parcialmente' consta '5\%' (talvez na intenção de anotar 50\%); manuscrito ilegível.

203 [HRV]: a autora sublinha 'para dizer o mínimo'; manuscrito ilegível.
} 
pronta -, um feito inegável de energia e determinação. Os edifícios são belos, mas a cidade como um todo deixa a desejar esteticamente. Parece estar fora de escala; os prédios se perdem na vastidão circundante, e mesmo dentro da cidade a sensação de estar em outro planeta - como todos dizem - é devastadora.

Alguns dos edifícios governamentais são pequenos demais, e anexos já foram construídos, ${ }^{204}$ ou terão de surgir. Os apartamentos para os funcionários do presidente, e para os que trabalham no primeiro grande hotel de Brasília, são subterrâneos. As "superquadras" de edifícios residenciais, tão fotogênicas, têm algumas características positivas, como piscinas e playgrounds, mas são tão próximas umas das outras quanto as quadras do Rio, embora colocadas num espaço que parece ser infinito.

A cidade foi projetada de modo a não ter cruzamentos de vias, nem semáforos. Depende da energia elétrica para os elevadores e de gasolina para os carros, é uma cidade construída para o automóvel, ${ }^{205}$ onde não se pode fazer quase nada a pé. Uma vez que ignora o pedestre, o que gosta de passear e o frequentador dos cafés, e dá poucas possibilidades para a vida em vizinhança ou para o convívio nas praças, Brasília tem sido chamada de cidade "ultrapassada", considerada ao menos 35 anos defasada pelos planejadores ${ }^{206}$ urbanos contemporâneos.

TALVEZ SEJA muito cedo para julgar Brasília de um ponto de vista prático, mas as evidências são desanimadoras. É difícil governar se a capital é uma cidade isolada, e os legisladores ${ }^{207}$ detestam a viagem a tal ponto que tem sido

\footnotetext{
${ }^{204}$ [HRV]: a autora reforça o comentário com ‘já'; [1962, 1970]: ‘e anexos foram construídos,'.

205 [HRV]: ' $\mathrm{X}$ ' junto a automóvel; manuscrito ilegível.

206 [1962, 1970]: 'por alguns planejadores'; [HRV]: manuscrito ilegível.

207 [HRV]: ilegível, junto a 'legisladores'.
} 
... lenta. Brasília foi culpabilizada até mesmo pelos eventos que levaram à renúncia do presidente Jânio Quadros.

A controvérsia ainda é forte. Mas deve-se, é claro, tentar distinguir entre os trágicos empecilhos à mudança, e aqueles que são apenas desconfortos temporários, como os que cercaram a construção de Washington.

Brasília também se tornou um símbolo do povo brasileiro, e um símbolo tão forte que mesmo políticos opostos a ela (e sabia-se que o candidato eleito, Quadros, também o era) não se atreveram a abandonar o projeto e transferir o governo de volta para o Rio. difícil haver quorum no Congresso. Senadores e deputados brigam por lugares nos aviões para o Rio ou São Paulo todos os fins de semana. ${ }^{208}$ As decisões da Justiça nos tribunais federais diminuíram quase até se paralisarem, e a administração do governo também se tornou lenta, de maneira melancólica. É até possível responsabilizar Brasília, ao menos em parte, pela súbita renúncia do presidente Jânio Quadros em 1961 (ver Capítulo 9). Nunca tranquilo consigo mesmo ou com seus colaboradores, Quadros parecia sentir-se isolado na nova capital. "Cidade maldita!”, teria dito no dia da renúncia.

Outra desvantagem que Brasília vai carregar por um longo tempo está na qualidade dos homens que ela vai trazendo à política. Antes, os políticos sentiam ${ }^{209}$ a atração do Rio como um lugar para educar os filhos, para estar em contato com as novidades no campo cultural, para escapar ${ }^{210}$ do provincianismo das regiões mais remotas do país. Mas hoje, eles não serão ${ }^{211}$ atraídos por Brasília.

\footnotetext{
${ }^{208}$ [HRV]: ilegível, junto a 'fins de semana'.

209 [HRV]: a autora assinala a repetição de 'sentiam' [felt].

${ }^{210}$ [HRV]: (cut), junto a 'escapar'.

${ }^{211}$ [1962, 1970]: 'Mas hoje, algumas pessoas sentem que tais homens não serão'.
} 
... o Rio vai tornar-se uma imensa Ouro Preto, vivendo de memórias do passado. No outro ...

... desenvolver-se. Sem os milhares de funcionários públicos, os burocratas e as pessoas das "províncias", eles dizem que o Rio vai funcionar melhor que hoje. Sua posição ...

... encantos e vantagens permanecem no Rio, e é muito mais fácil encontrar um Deputado ou um juiz do Supremo Tribunal no Rio que em seus lugares de residência oficial.

... da nova capital. O governo que está lá sente-se antes de tudo como um "governo no exílio". O Rio continua sendo o coração e a alma do país. São Paulo ultrapassou-o há pouco em poder econômico e em população, e no Rio ainda se diz que os bons "paulistas", quando morrem, vêm para o Rio.
A controvérsia continua. Mas, independentemente dos méritos e deméritos de Brasília, o país está preso a ela, e hoje poucos candidatos a cargos públicos a criticam, ao menos em público.

O QUE vai ser do Rio, agora que a capital transferiu-se para Brasília? A opiniões variam. Os pessimistas profetizam pobreza e decadência: na melhor das hipóteses, dizem eles, o Rio vai tornar-se um museu histórico, vivendo de memórias do passado e dependente do turismo. No outro extremo, os otimistas acreditam que a cidade, livre do excesso populacional que atraía enquanto era a capital do país, vai na realidade desenvolver-se. Esses dizem que sem os milhares de funcionários públicos o Rio vai funcionar melhor. Sua posição como a mais amada das cidades brasileiras e a capital cultural do país, a alegria natural dos cariocas, o carnaval, as praias todos esses encantos e vantagens vão permanecer intocados, a despeito dos terríveis problemas econômicos, da falta de água, do transporte inadequado e de outros males urbanos.

Até agora, o Rio não parece ter se conscientizado de que não é mais a capital. Os cariocas - e quase todos os brasileiros são potencialmente cariocas - escondem seus ciúmes em relação a Brasília, se é que os têm, e riem das atribulações a que estão sujeitos os que têm de ir para lá. O fato é que, por enquanto, ninguém está acostumado à ideia da nova capital. O Rio continua sendo o coração e a alma do país. 
Nota I) [1970]: O trecho referente a Brasília (p.57-58) foi reescrito.

Brasília custou ao país cerca de um bilhão de dólares, e ainda não está completa. Mas esse maciço gasto de energia e dinheiro já começou a ter, na economia do interior do Brasil, o efeito benéfico previsto pelos seus defensores. Cidades como Goiânia e Uberlândia, situadas mais ou menos entre Brasília e São Paulo, estão crescendo rápido. Belo Horizonte, uma parada obrigatória na estrada entre Brasília e o Rio, está recebendo novos investimentos que, se assim não fosse, jamais veria. Brasília é também uma importante ligação entre o sul do Brasil e a remota Bacia Amazônica, ao norte. O transporte por aviões a jato até Manaus, situada a 1.100 quilômetros da foz do Amazonas, tornou-se possível graças ao aeroporto intermediário de Brasília. A audaciosa estrada recém-construída de 1.800 quilômetros entre Brasília e Belém, o porto na foz do Amazonas, trouxe prosperidade à região em torno da capital.

BRASÍLIA passou por certa estagnação depois que Kubitschek deixou o governo, em 1961. A construção, em particular a das "superquadras" residenciais, constante nos planos de seus idealizadores, foi reduzida de maneira tão drástica que resultou numa terrível falta de moradias. Em determinado momento, mais de metade dos funcionários públicos federais estava listada como "sem residência", e apenas 20 dos 326 Deputados Federais viviam na nova capital. A maior parte dos negócios envolvendo o governo federal continuava a ser realizada no Rio.

Em 1964, todavia, o ritmo de construção acelerou-se, quando o novo regime militar aceitou, a contragosto, a lógica inevitável do sonho de Kubitschek. Para marcar o décimo aniversário da capital, em 1970, o governo decretou que os ministros deveriam daí em diante despachar apenas em Brasília. As embaixadas estrangeiras sediadas no Rio foram intimadas a transferir-se até 1972.

Se era difícil exigir que as classes média e alta deixassem a atmosfera cosmopolita da costa, a economia superaquecida da cidade que crescia atuou como um ímã poderoso para os pobres do país. Camponeses surgiam aos milhares, assentando-se em "cidades-satélite" que se espalhavam em torno de Brasília, a uma distância de 40 quilômetros. Segundo a previsão de Kubitschek, a cidade deveria conter uma sociedade "aberta", sem claras distinções de classe; banqueiros e deputados federais deveriam viver lado a lado com motoristas e funcionários do Congresso. No entanto, Brasília tornou-se uma das cidades mais estratificadas do mundo. Uma vez que a construção continuou atrasada, apenas altos funcionários tinham influência suficiente para morar nas superquadras com prédios altos; além disso, oficiais do Exército e da Marinha tenderam a reunir-se em uma superquadra; altos funcionários civis, em outra; deputados, em uma terceira. Funcionários públicos de nível mais baixo foram relegados para longas fileiras de casas geminadas. Motoristas e operários estabeleceram-se em favelas quase desabando, espalhadas muito além dos limites da cidade.

Aqueles que encontraram acomodações na área central de Brasília aproveitam tudo o que proporciona conforto. Uma rede de avenidas com seis pistas permite que cheguem em poucos minutos às quadras de tênis, aos campos de golfe ou ao lago artificial de 60 quilômetros quadrados. A principal reclamação entre os novos moradores é que eles sofrem de uma forma de choque cultural conhecida como "angústia de Brasília". As superquadras, enormes e autossuficientes, dispondo de lojas, escolas e igrejas, tendem a ser homogêneas e estéreis, desprovidas da fértil agitação urbana de cidades como Rio e São Paulo. 
Apesar de todas as reclamações de que Brasília é uma "cidade sem alma”, um número crescente de seus habitantes - que se espera cheguem a um milhão em 1980 - está começando a gostar de seu ritmo relaxado, clima excelente e boas condições de trabalho. Embora o processo possa demorar mais algumas décadas, Brasília parece destinada a tornar-se uma cidade em todos os sentidos.

O QUE vai acontecer com o Rio? Os pessimistas profetizam pobreza e decadência; na melhor das hipóteses, dizem eles, o Rio vai tornar-se um museu, vivendo de memórias do passado e dependente do turismo. No outro extremo existem aqueles que acreditam que a cidade vai progredir, e existem algumas boas razões para essa crença. O vigoroso ex-governador do estado da Guanabara, Carlos Lacerda, trouxe vida nova para a cidade construindo novas escolas e ruas, reparando o velho sistema de água e atraindo novas indústrias. O esforço continuou no governo de Francisco Negrão de Lima. Se o Rio não é mais a sede do governo federal, permanece como a mais amada das cidades brasileiras, com seus morros e enseadas estonteantes, suas lindas praias e a alegria natural de seus habitantes. 


\section{Animal, vegetal e mineral 212}

${ }^{213}$ EMBORA o Brasil permaneça sob vários aspectos um país agrícola - a agricultura é responsável por cerca de 30 por cento das divisas nacionais e emprega mais da metade da população ativa -, o ganho industrial está começando a sobrepujar o agrícola. Em 1960 o Brasil produziu mais de 134 mil veículos, com partes fabricadas quase inteiramente ${ }^{214}$ no país. A produção de aço está crescendo e hoje já passa de 2 milhões de toneladas por ano, enquanto logo após a Segunda Guerra Mundial esse número chegava a apenas 350 mil toneladas. Até mesmo utensílios domésticos começam a ser produzidos em grande volume.

Por mais notável que seja essa marca, ela não implica que o Brasil vá tornar-se em breve um colosso industrial. $\mathrm{O}$ país tem amplos recursos - seu potencial hidrelétrico é o maior do mundo: 80 milhões de quilowatts. Mas os brasileiros, dizem, "colhem a fruta sem terem plantado a árvore". Existe uma queda nacional por conseguir lucros rápidos em vez de lançar as bases ${ }^{215}$ para sólidas poupanças futuras. A história econômica brasileira quase poderia ser narrada em sua longa sucessão de booms espetaculares. A economia foi dominada pelo açúcar, depois pelo ouro e pelo

\footnotetext{
212 [HRV]: a autora substitui o título, "O lento despertar de um gigante" [The Slow Awakening of a Giant], pelo original. Nos arquivos da autora, em Vassar, não existem originais do Capítulo 5.

213 [HRV]: a autora rasura todo o primeiro parágrafo que consta em [1962, 1970]: "NO HINO nacional existem versos que os brasileiros sempre acharam engraçados. Eles falam de uma terra gigante 'deitada eternamente em berço esplêndido'. Os versos foram verdadeiros até pouco tempo atrás. Mas agora há sinais óbvios de que lentamente, a despeito de grandes problemas e de milhares de dificuldades, o gigante está finalmente despertando".

${ }^{214}$ [1970]: 'Aproximadamente 350 mil veículos estão sendo montados por ano, com suas peças feitas em grande parte ...'.

${ }^{215}$ [HRV]: a autora destaca 'conseguir ... bases' e inclui '!' na margem.
} 
café, com breves interlúdios devotados a outros produtos. Mas o país busca hoje diversificar, em vez de depender de um só produto agrícola ou industrial. ${ }^{216}$

Uma das mais antigas ocupações brasileiras foi a criação de gado, necessariamente importada. Os navegantes portugueses surpreenderam-se ao perceber que os índios não tinham animais domésticos, ou ao menos não tinham animais domésticos úteis. ${ }^{217}$ Os índios criavam muitos animais, chamados pelos portugueses bichos de estimação: cães, macacos e aves.

Portanto ${ }^{218}$ uma das primeiras e mais difíceis tarefas dos portugueses consistiu em trazer para o Brasil todos os animais domésticos aos quais estavam acostumados. Em meados do século XVI o gado foi trazido de Portugal e das ilhas de Cabo Verde para a Bahia. Eles foram os ancestrais do gado das planícies nordestinas.

O gado foi introduzido no Sul já em 1532. Os colonos que seguiam os bandeirantes levavam vacas, cavalos, porcos e cabras. Depois, eles levaram os descendentes desses animais através da única passagem que penetra a Serra do Mar, para os campos abertos a Oeste de São Paulo. Cavalos e vacas eram criados soltos. Como nos primeiros tempos no Oeste dos Estados Unidos, o roubo e a reunião de rebanhos selvagens na maioria desviados das missões jesuíticas - foram aspectos importantes da vida e da história lendária dessa região.

EMBORA desde o início o açúcar tenha sido o principal produto do Nordeste, a criação de gado constituiu um estímulo para a colonização e para a conquista de novas terras. Em busca de pastos para seus rebanhos, vaqueiros penetraram fundo no interior nordestino. A criação de gado deixou de ser

\footnotetext{
${ }^{216}$ [HRV]: na margem, anotação ilegível.

217 [HRV]: manuscrito na margem: 'tinham apenas'.

218 [HRV]: a autora destaca 'Portanto'; '!' na margem.
} 
um simples apêndice das grandes plantações e tornou-se uma atividade independente. Daí surgiu a chamada "civilização do couro" 219 que se desenvolveu por toda essa vasta região do Brasil durante os primeiros séculos de sua história. A criação de gado dependia do cavalo, ${ }^{220}$ animal hoje inseparável do gaúcho dos pampas e do vaqueiro do Nordeste, e que se aclimatou em todo o país. Hoje, o Brasil tem mais de oito milhões ${ }^{221}$ de cavalos.

No Nordeste a maior parte do gado descende dos rebanhos originais. Os animais são pequenos e dão pouco leite, mas são fortes e resistentes. Ao longo dos anos, o governo e os criadores progressistas melhoraram os rebanhos de todo o país cruzando-os com o zebu ou brâmane, trazido da Índia. Esse animal é bem adaptado às condições severas de calor, seca e pasto escasso do Nordeste, e ele sobrevive onde o melhor gado europeu morre ou adoece e degenera rápido. Zebus, com suas altas corcovas, crânios arredondados e orelhas longas e pendentes, tornaram-se comuns na maior parte do Brasil, adicionando uma nota exótica, mas de alguma maneira não incongruente, à paisagem.

NA VIRADA para o século XX os zebus foram levados para a vasta região de ótimas pastagens em Minas Gerais chamada de 222 “Triângulo Mineiro", e que é hoje o centro da criação intensiva. Eles se aclimataram tão bem que o zebu tornou-se uma paixão entre os criadores; os preços subiram, e a comercialização de zebu tornou-se uma forma de jogo, levando a uma especulação frenética. Na década de 1920 essa febre atingiu tal ponto que um só touro em boas condições chegava a 7.500 dólares, enquanto os touros europeus tinham um preço médio de 250 dólares.

${ }^{219}$ [HRV]: 'cultura', junto a 'do couro'

220 [1970]: inversão e simplificação: de 'upon which cattle raising depended, today inseparable' para 'indispensable to cattle raising and inseparable.'.

221 [1970]: 'de nove milhões'.

222 [1962, 1970]: 'em Minas Gerais que é chamada de'. 
Excetuando-se o Triângulo produtor de carne, o gado de Minas Gerais é leiteiro, e seus produtos, incluindo o queijo branco Minas, são vendidos ${ }^{223}$ por toda parte. $\mathrm{O}$ gado de corte requer grandes extensões de terra, e com a rápida e progressiva industrialização do Centro-Sul do país o gado está sendo transferido para as regiões mais inóspitas de Goiás e para o Pantanal de Mato Grosso, que oferecem condições favoráveis e estão mais próximos do maior consumidor de carne, o estado de São Paulo.

No Pará, sobretudo na Ilha de Marajó, o búfalo aquático indiano foi introduzido e parece sentir-se em casa. As áreas despovoadas e os rios e pântanos abundantes dessa ilha enorme fornecem o ambiente para a vida semi-aquática que esses animais semidomésticos preferem, ao passo que o gado comum, mesmo o zebu, não sobrevive ali. No entanto, às vezes o búfalo apresenta alguns pequenos problemas. Ele gosta de se apoiar nas coisas e meditar. ${ }^{224}$ Às vezes, eles se apoiam sobre as frágeis casas de pau-a-pique de seus donos, e elas caem.

NUM país com poucos refrigeradores, é muito importante a indústria do charque, uma carne seca e salgada que não se estraga facilmente e que costuma ser cozida com o arroz e o feijão da dieta básica. A indústria começou no Nordeste, mas também foi levada por imigrantes ao Rio Grande do Sul. Embora sobrepujado em número total pelo gado de Minas Gerais, esse estado agora tem a melhor carne do país e é um centro da indústria frigorífica. Com 72,8 milhões de cabeças, o Brasil é ultrapassado apenas pelos Estados Unidos no tamanho do seu rebanho de corte, mas não na produção de carne, sobretudo por causa do frágil controle de doenças, do

223 [1962, 1970]: 'queijo branco Minas, visto em quase todas as mesas ao menos uma vez por dia, são vendidos'; [HRV]: a autora elimina o trecho, e comenta: "não mais".

224 [HRV]: 'X', junto a 'meditar'. 
transporte inadequado e da falta de equipamentos de refrigeração, como também por causa dos métodos antiquados. $^{225}$

Os maiores rebanhos ${ }^{226}$ de ovinos - o Brasil tem cerca de 22 milhões de cabeças - também ${ }^{227}$ estão no Rio Grande do Sul, e a lã crua está se tornando um importante produto de exportação. Com o algodão, bem exportado há muito tempo, esses rebanhos fornecem material para a indústria têxtil, que cresceu enormemente na última década. ${ }^{228}$

O imenso litoral do país e os seus rios caudalosos deveriam tornar a pesca e a indústria pesqueira muito mais importantes do que elas são. Mas a exploração comercial começou há pouco, e a pesca ainda representa uma das grandes fontes de recursos ainda inexploradas do país. Nos estados do Pará e do Amazonas existe, por exemplo, o pirarucu, o "bacalhau da água-doce", que pesa até $250 \mathrm{~kg}$. O pirarucu é um item importante ${ }^{229}$ na dieta dos ribeirinhos.

A pesca comercial no Amazonas não passa de 90 mil toneladas por ano, em grande parte ${ }^{230}$ porque as técnicas utilizadas no rio ainda são primitivas, assim como acontece entre muitos pescadores da costa. As belas e tradicionais jangadas do Nordeste são feitas de ${ }^{231}$ meros troncos de madeira balsa amarrados. Elas têm uma vela, ${ }^{232}$ e todos os objetos a bordo devem ser bem amarrados ao deque. Os pescadores se aventuram em alto-mar a bordo das jangadas,

225 [1970]: 'do Sul. Esse estado agora é responsável pela melhor carne do país, e é um centro da indústria frigorífica. Com 90 milhões de cabeças, o Brasil já é o terceiro maior produtor mundial de gado de corte, ultrapassado apenas pelos Estados Unidos e pela União Soviética. Com um controle de doenças melhor, meios de transporte adequados e métodos de criação mais modernos, ele tem potencial para ultrapassar seus rivais'.

226 [1970]: substituição de herds por flocks, sinônimos no português: 'rebanhos'.

227 [1970]: 'cabeças - ovinos também'.

228 [1970]: 'está surgindo, com o algodão e o sisal, entre os maiores itens de exportação. O algodão, a lã, rayon e linho fornecem matéria-prima para a indústria têxtil brasileira, que cresceu enormemente nas últimas duas décadas'.

${ }^{229}$ [HRV]: 'X' junto a 'água-doce'; 'apenas' junto a 'importante'; 'X' na margem.

230 [1970]: 'Todavia, a pesca comercial no Amazonas permanece insignificante, em grande parte'.

231 [1970]: made of substituído por constructed of.

232 [HRV]: 'X' junto a 'vela'. 
mas as quantidades de peixe que eles trazem são tão pequenas que o melhor lugar para a pitoresca jangada, dizem, é o museu folclórico.

Tem havido alguma modernização na indústria da pesca. ${ }^{233}$ Várias empresas japonesas organizaram frotas motorizadas no Sul, especializadas em atum e baleia. Construiu-se uma grande indústria para processamento de carne de baleia em Cabo Frio, ${ }^{234}$ cidade costeira a leste do Rio. Baleias são abundantes, ${ }^{235}$ e sua carne tem sido anunciada para um público até certo ponto relutante, nos mercados litorâneos, como a carne mais barata que existe. A pesca de lagostas também vem crescendo, especialmente em Pernambuco e no Ceará. Fábricas de conservas têm sido construídas ao longo da costa. ${ }^{236}$

O CAFÉ sofreu tantos altos e baixos como qualquer outra fonte de riqueza brasileira, mas é certo que não foi vítima de subexploração. Durante muitos anos foi o produto brasileiro mais conhecido; o café tem sido o maior item de exportação e a maior fonte de divisas. O Brasil produziu quase 2 bilhões de toneladas em 1960. Supriu quase metade do café mundial, representando para o país 56 por cento de seu comércio exterior. $^{237}$

O café brasileiro teve origens modestas. Já no século XVIII, um brasileiro roubou mudas da Guiana Francesa, onde se havia iniciado sua plantação. As árvores foram cultivadas a princípio no estado do Pará. Depois, sementes e mudas foram distribuídas por todo o país. O cultivo permaneceu em

\footnotetext{
233 [1970]: 'Graças, em parte, a uma lei de 1967 que favorece investimentos na indústria pesqueira, tem havido alguma modernização.'.

${ }^{234}$ [1970]: 'baleia perto de Cabo Frio,'.

235 [HRV]: '?' junto a 'abundantes'.

236 [1970]: 'Várias empresas de porte entraram recentemente no ramo de lagostas e camarões, e estão construindo centros processadores ao longo das costas do Norte e do Nordeste.'.

237 [1970]: 'Durante a década de 1960 o país produziu, todos os anos, um terço do café mundial. Em dinheiro, essa quantia representou mais de um terço de toda a receita proveniente das exportações'.
} 
pequena escala até o século XIX, quando o café teve sua primeira grande fase no Rio de Janeiro e em Minas Gerais. O cultivo de café nesses estados, sobretudo no Rio de Janeiro, [p.72] dependia do trabalho escravo, e os lucros com o café fizeram a fortuna dos barões do Rio de Janeiro. Com a abolição da escravatura, em 1888, os barões foram à falência.

São Paulo não tinha muito trabalho escravo, e era sagaz a ponto de encorajar a imigração. Nos anos cruciais pouco antes e pouco depois da abolição, imigrantes sobretudo portugueses e italianos - vieram em grande número. Além desse suprimento de mão de obra, São Paulo tinha sua maravilhosa terra roxa, ${ }^{238}$ que, de acordo com os paulistas, Deus criou especificamente para o cultivo do café. Mas o café, que já foi chamado de "vampiro", uma vez que em poucos anos exauria o solo, havia declinado no estado do Rio. No ano da abolição, por exemplo, Rio e Minas produziram duas vezes mais café que São Paulo; dez anos depois, São Paulo estava produzindo muito mais que esses dois estados juntos. Todavia, mesmo com melhores métodos de cultivo, a terra roxa de São Paulo também começou a se exaurir. O café continuou sua marcha para o sul e para o oeste; no final da década de 1920 traços do precioso solo vermelho escuro foram encontrados nas terras selvagens do noroeste do Paraná. Como um exército verde triunfante, as árvores de café dos fazendeiros tomaram posse dessas terras, afastando a floresta virgem e empurrando os animais selvagens mais para o interior. À sombra dos cafeeiros surgiram novas vilas. Um exemplo típico é Londrina, uma cidade moderna e próspera localizada onde há poucas décadas havia a floresta intocada. Hoje, os cafeeiros estão penetrando o estado de Mato Grosso.

\footnotetext{
${ }^{238}$ Também em inglês: purple earth, mantendo-se o sentido consagrado no português. A terra é vermelha (rossa, na voz dos imigrantes italianos), e não roxa.
} 
COMO O PRINCIPAL item da economia brasileira, o café sofreu várias crises, durante as quais toda a vida nacional foi ameaçada. O aparecimento da África entre os produtores de café criou uma das mais sérias crises, na década de 1950. Embora ainda seja o maior produtor mundial, o Brasil teve de enfrentar uma competição antes desconhecida, e essa competição vai se tornando cada vez mais séria. O Brasil não consegue mais vender todo o seu café; em 1960 havia um estoque acumulado de quase três milhões de toneladas. ${ }^{239}$

As repetidas crises no mercado de café têm tido o efeito de despertar o país para a necessidade da diversificação agrícola; o Brasil vem buscando expandir suas exportações de outros produtos, como açúcar, tabaco e frutas. O problema com o café também tem estimulado o crescimento da industrialização, sobretudo em São Paulo, o mais próspero ${ }^{240}$ estado brasileiro. São Paulo conheceu um tremendo boom desde a Segunda Guerra Mundial. Não havia indústria de base antes da guerra; hoje existem mais de 45 grandes indústrias em São Paulo. Apenas em 1959, o estado produziu mais de 15 mil máquinas industriais. Produz 53 por cento do papel, 54 por cento dos tecidos e 58 por cento dos produtos químicos, e é um importante fornecedor para o mercado externo, exportando hoje mais de 1,6 milhão de toneladas de produtos manufaturados por ano. Em conjunto com o estado vizinho da Guanabara, São Paulo contribui com quase metade das entradas de divisas no país. ${ }^{241}$

239 [1970]: 'O Brasil ainda é o maior produtor mundial de café, mas a concorrência está se tornando cada vez mais acirrada. A despeito das geadas devastadoras de 1963, que destruíram dois terços dos cafeeiros, o Brasil ainda produz mais do que pode exportar. Mas até 1970 o estoque acumulado estava diminuindo rapidamente'.

240 [1962, 1970]: 'em São Paulo, hoje o mais próspero'.

241 [1970]: 'desde o final da Segunda Guerra Mundial. Não havia indústria pesada em São Paulo antes da guerra; hoje, existem centenas de fábricas. São Paulo produz a maior parte das máquinas industriais do país, bem como mais papel, mais tecidos e mais produtos químicos que a soma de todo o restante do país. Como exportador de bens manufaturados, São Paulo, como também seu vizinho, a Guanabara, tornou-se um importante fornecedor para o mercado externo. Juntos, os dois são responsáveis por cerca de metade das entradas de divisas no país'. 
NO CENTRO desse complexo industrial está a própria cidade de São Paulo. Apenas 80 anos atrás, ela era uma vila calma de 25 mil habitantes. Hoje, cobre 1.300 quilômetros quadrados 242 e, com população de 4,8 milhões, ${ }^{243}$ é a oitava metrópole do mundo. Seus problemas de trânsito são ainda piores que os de Nova York, e ela tem uma atmosfera agitada, cosmopolita, embora com seus arranha-céus brancos e modernos ${ }^{244}$ e os muitos parques ela permaneça bem brasileira. ${ }^{245}$

Em contraste com o próspero Sul, os estados do Nordeste permanecem agrícolas. Lá, o açúcar, que teve o apogeu da monocultura antes de ser destronado pelo café, ainda é a base de sua economia - embora o algodão e o cacau sejam cultivados em grandes quantidades. $\mathrm{O}$ açúcar desenvolveu-se à medida que o Brasil se desenvolvia; pode-se dizer que os primeiros portugueses trouxeram mudas de cana sob os braços. As ricas plantações de açúcar em Pernambuco e na Bahia atraíram a cobiça dos holandeses, que invadiram a região no século XVII. A maior parte do açúcar lucrativo vem hoje do Sul, mas em Pernambuco, Alagoas e na Paraíba, as [p.74] plantações de cana ainda se estendem até o horizonte. Grandes usinas, que começam a substituir as antigas, primitivas, estão melhorando a qualidade do produto. Mas os métodos de cultivo são primitivos, quase semifeudais; e ${ }^{246}$ os trabalhadores do açúcar estão entre os brasileiros mais pobres e mais sofridos. Existe hoje um forte movimento entre os brasileiros esclarecidos em favor da reforma agrária no Nordeste. Essa é, por sinal, uma área explosiva, perfeita para a exploração comunista. ${ }^{247}$

\footnotetext{
${ }^{242}$ Em 1970 considerou-se apenas o município $\left(640 \mathrm{~km}^{2}\right)$, e não a Grande São Paulo (37 municípios).

243 [1970]: ‘de 6,3 milhões,'.

244 [HRV]: a autora destaca 'brancos, modernos'; 'X?' na margem.

245 Na p.73, MAPA: Principais produtos do Brasil.

246 [1970]: 'extremamente atrasados, e os'.

247 [1970]: 'sofridos. Um programa federal de desenvolvimento para ajudar a região foi criado em 1959. Buscava auxiliar na organização e no financiamento da eletrificação e na construção de estradas e escolas, bem como
} 
Um dos produtos da cana é a aguardente, quase sempre chamada cachaça ou pinga. ${ }^{248}$ Essa bebida clara e fortíssima, feita desde os tempos coloniais, é conhecida como “o drinque do pobre". Agora, a cachaça está sendo exportada. Não existe ${ }^{249}$ produto brasileiro tão envolto em folclore quanto ela; todo um ciclo de canções lhe é dedicado. Os nomes pelos quais é chamada, em geral apelidos afetuosos "a avó", 250 "moça-loura", "fio-de-ouro" - mostram a estima dedicada ${ }^{251}$ à cachaça. Quando um homem toma uma dose no bar da esquina mais próxima, sempre cospe no chão um pouco do primeiro gole, como uma oferenda para seu santo padroeiro. $^{252}$

A BORRACHA também já desempenhou um papel econômico importante. Fonte de grande riqueza, embora breve, a borracha amazônica sofreu um baque em 1910, quando as plantações da Malásia e das Índias Orientais Holandesas começaram a produzir e baratearam seus preços no mercado mundial. As vilas que haviam florescido no vale do Amazonas em pouco tempo se transformaram em comunidades mortas ou agonizantes. A cidade de Manaus, situada junto à confluência do Solimões * com o rio Negro, foi a capital mundial da borracha até o colapso do mercado. Rica e luxuosa, com um grande teatro de ópera, ela importava troupes ${ }^{253}$ de músicos e dançarinos. Grandes navios atracavam em seu porto com regularidade. A leste de Manaus, Henry Ford estabeleceu plantações experimentais, Fordlândia

atrair novas indústrias. O plano ainda precisa elevar essa região até o nível do restante do país, mas a distância está diminuindo.' Trata-se da Sudene - Superintendência do Desenvolvimento do Nordeste.

248 [HRV]: na margem: 'Uísque do Norte'.

249 [1970]: 'como “o drinque do pobre”. Não existe'.

250 [1970]: 'dedicado. Seus apelidos afetuosos - "a vovozinha",

251 [1970]: substituído in which [em que] por with which [com a qual] is regarded.

252 [1962]: 'para o santo que imagina ser o padroeiro da bebida', corrigido em [1970] para a versão aqui adotada.

* Nas duas edições consta 'Amazonas', e não 'Solimões'. Na realidade, trata-se da confluência do Solimões com o Negro, formando o Amazonas.

253 [1970]: corrigiu-se troops of [grupo] para troupes of [troupes de artistas]. 
e Belterra, no final da década de 1920 e no início dos anos 30, mas abandonou o projeto por achá-lo pouco lucrativo. Hoje nas mãos do governo, o projeto ainda produz uma pequena quantidade de borracha.

Durante a Segunda Guerra Mundial, quando o Japão tomou as plantações da Malásia e das Índias Orientais Holandesas, a borracha amazônica ressuscitou por um breve período. Mas o Brasil hoje importa cerca de 40 milhões de dólares de borracha asiática por ano. ${ }^{254}$ A Amazônia, privada do mercado para sua principal riqueza, também vem procurando a diversificação, nos últimos anos. A área agora produz quantidades substanciais de castanha-do-pará, juta, madeira, cana-de-açúcar e óleos vegetais, assim como manganês. ${ }^{255}$

COMO OUTRAS riquezas brasileiras, a madeira já vem se desenvolvendo, mas também ela está longe de atingir seu limite. Apenas na Bacia Amazônica existem ao menos 200 bilhões de metros cúbicos de madeira, e há vastas florestas de madeiras excelentes no Sul. Um dos itens mais atraentes da paisagem brasileira é mais comum nos estados do Paraná e de Santa Catarina - os bosques de araucárias, o pinheiro brasileiro. São árvores belas e muito altas, com troncos retilíneos e galhos nus e arqueados, que terminam em característicos cachos de sementes pontudas. Além de bela, a araucária é muito útil; sua madeira constitui a principal riqueza da região em que ela cresce. Essa madeira foi tão cobiçada que o governo foi forçado a criar uma lei em 1942, proibindo o corte excessivo e promovendo o replantio.

Com mais de seiscentas variedades conhecidas, o Brasil tem mais palmeiras que qualquer outro país. Elas

\footnotetext{
${ }^{254}$ [1970]: 'de 21 milhões de dólares de borracha natural e sintética'.
}

255 [HRV]: traço vertical na margem. 
constituem ricas fontes de fibras, óleos e combustíveis. Das folhas da carnaúba, uma alta e elegante palmeira que cresce apenas no Nordeste, vem um líquido viscoso parecido com cera de abelhas, que, quando coletado, transformado em pó e dissolvido por um processo difícil e primitivo, resulta na famosa cera de carnaúba. Ela era usada ${ }^{256}$ na produção de discos, graxas e vernizes. ${ }^{257}$ A carnaúba é um dos principais recursos econômicos dos estados do Ceará, Piauí e Maranhão, e a população dos secos sertões diz que ela é a compensação [p.75] que Deus lhes deu pelos sofrimentos da seca - pois, quando o clima fica úmido, ${ }^{258}$ a palmeira não produz cera.

O fumo é cultivado na maior parte do Brasil, há séculos. É uma importante ${ }^{259}$ mercadoria para troca com os vendedores de escravos. Tornou-se uma indústria na Bahia, cujos charutos são famosos e tão bons que chegam a ser comparados aos de Cuba. Os cigarros da Bahia também são bem distribuídos, mas a maior parte das fábricas de cigarros fica no estado do Rio Grande do Sul.

A uva europeia, introduzida pelos imigrantes italianos, produz muito bem no Rio Grande do Sul. A indústria vinícola desenvolveu-se rápido, e hoje os brasileiros se orgulham de alguns de seus vinhos, champanhes e conhaques. Em 1960 cerca de 30 milhões de litros ${ }^{260}$ foram exportados para a França. ${ }^{261} \mathrm{O}$ trigo também é importante para o Rio Grande do Sul, embora a quantidade produzida esteja longe de tornar o Brasil autossuficiente. O país produz milho, feijão e arroz em volume suficiente para o consumo.

256 [1962, 1970]: 'Ela é usada'.

${ }^{257}$ [1970]: 'primitivo, produz cera de carnaúba, que é usada na produção de papel carbono, velas, graxas'.

258 [HRV]: a autora anota: 'existe chuva', junto a 'úmido'.

${ }^{259}$ [1962, 1970]: substitui 'Ele era importante'.

${ }^{260} 8$ milhões de galões.

261 [1970]: 'conhaques. O Brasil produz vários milhões de litros de vinho, por ano; suas exportações são pequenas, mas estão crescendo.'. 
Há pouco tempo surgiu um forte interesse pela exportação ou industrialização das frutas brasileiras. A laranja já é exportada em grande escala. O Brasil é o maior produtor mundial de bananas, sobretudo graças ao estado de São Paulo. O caju, do Nordeste, fornece ${ }^{262}$ uma valiosa castanha; a fruta é processada ${ }^{263}$ na forma de xaropes e pastas. E existe ainda a goiaba. ${ }^{264}$ Goiabada, acompanhada por queijo, é a sobremesa favorita em toda a América Latina. ${ }^{265}$

O FERRO é o mais importante recurso mineral do Brasil. Existem jazidas praticamente inesgotáveis no país, localizadas sobretudo no estado de Minas. Estima-se que existam 65 bilhões de toneladas de ferro no Brasil, 35 por cento das reservas mundiais. A falta ${ }^{266}$ de carvão de alta qualidade inibiu, até há pouco, o desenvolvimento de siderúrgicas ${ }^{267} \mathrm{em}$ número proporcional à quantidade do mineral. Todavia, o carvão de Santa Catarina, embora de qualidade inferior, tem sido bem explorado, e o ${ }^{268}$ resultado está na grande siderúrgica de Volta Redonda, cuja construção foi iniciada em 1942, com ajuda norte-americana. A siderurgia brasileira é hoje a maior indústria latino-americana, e a exploração das jazidas apenas começou.

O mesmo se aplica às outras reservas minerais. Existem depósitos de quase todos os minerais conhecidos, incluindo pedras preciosas e semipreciosas, espalhados por todo o país, alguns deles em grandes quantidades. Apenas com população mais densa nessas áreas e técnicas mais

\footnotetext{
${ }^{262} \mathrm{Na}$ carta aos Editores: “p.75, col. 1, par. 3: 'O fruto do caju contém a valiosa castanha de caju' - ele não 'contém' a castanha. A castanha fica do lado de fora do fruto". No texto publicado consta provides (fornece).

263 [1962, 1970]: 'a fruta é também processada'.

264 [1970]: 'castanha; e também existe a goiaba'.

265 [1962, 1970]: 'acompanhada por queijo branco, é a ... em todo o Brasil'.

266 [1970]: 'Minas. Uma empresa de mineração estatal explora as jazidas, transporta o material em sua própria estrada-de-ferro e carrega os navios em seu próprio porto, em Vitória. A falta'.

267 [1970]: 'o crescimento de siderúrgicas'.

268 [1970]: 'explorado ativamente, e o'.
} 
especializadas o Brasil poderá lucrar com essas riquezas escondidas. No Espírito Santo e em outras áreas o governo está hoje explorando areias monazíticas, ricas em materiais radiativos.

UM ASSUNTO muito controverso no Brasil é a extensão de suas reservas petrolíferas. Alguns geólogos afirmaram que as vastas bacias sedimentares do Amazonas e do Paraná, com cerca de 5 milhões de quilômetros quadrados, contêm grandes reservas. Mas, até agora, apenas vestígios de petróleo foram encontrados. ${ }^{269} \mathrm{O}$ medo da exploração estrangeira levou à restrição da exploração e da produção de óleo ${ }^{270}$ em 1953 , sob um monopólio ${ }^{271}$ estatal, a Petrobras. A despeito de uma corajosa prospecção ${ }^{272}$ a um custo de 50 milhões de dólares por ano, ${ }^{273}$ o Brasil produz apenas 30 por cento ${ }^{274} \mathrm{da}$ quantidade necessária de petróleo não refinado, a maior parte em poços na Bahia. ${ }^{275} \mathrm{E}$, mesmo que existam grandes reservas na região do alto Amazonas, os geólogos acreditam que elas estejam sob rochas, o que trará outros ${ }^{276}$ custos e dificuldades. O transporte não seria problemático, graças à proximidade do rio navegável. Na maior ${ }^{277}$ parte do país, no entanto, o transporte é um dos problemas básicos que o Brasil deve resolver antes de iniciar a verdadeira exploração de suas magníficas riquezas. Hoje, o Brasil tem cerca de 39 mil quilômetros ${ }^{278}$ de ferrovias, mas a maior parte delas é de

${ }^{269}$ [HRV]: '?' junto a 'encontrados'.

270 [HRV]: ‘óleo pesado' (heavy oil), junto a ‘óleo'; esse tipo de petróleo requer um processo especial de refino.

271 [1970]: 'Diante da falta de interesse dos capitais estrangeiros, em 1953 a exploração e a produção de petróleo foram colocadas sob a responsabilidade de um monopólio'.

${ }^{272}$ Em inglês, wildcatting: ação de procurar petróleo em zonas onde supostamente não o há; empreendimento de negócios duvidosos, pouco sólidos.

273 [1970]: 'de muitos milhões de dólares,'.

274 [1970]: ‘40 por cento'.

275 [1970]: 'refinado, todo proveniente da Bahia'.

276 [1970]: "na região da Bacia Amazônica, os especialistas acreditam que a formação geológica da área vai trazer outros'.

${ }^{277} \mathrm{Na}$ carta aos Editores: “p.75, col. 2, último par.: Novo parágrafo, iniciando com 'Throughout most of the country, however' (eliminar most). Deve ficar melhor”. Não foi alterado em 1962, apenas em 1970.

278 [1970]: 32 mil quilômetros. 
curta distância, são estradas que se estendem na direção lesteoeste e se afastam pouco da costa. Muitas delas são de diferentes bitolas, e existem poucas conexões ${ }^{279}$ norte-sul. A rede de rodovias, ainda em construção, vai sem dúvida resolver esse problema. Realmente, o gigante está despertando. ${ }^{280}$

${ }^{279}$ [1970]: simplificação: 'connections in any event' torna-se connections.

280 [1962]: 'despertando, mas antes que possa exercitar sua força ele terá de dar alguns passos que os brasileiros gostariam que tivessem sido dados muitos anos atrás'; a autora eliminou todo esse trecho em seu exemplar; [1970]: 'vai ajudar a resolver esse problema, que obviamente é apenas um entre muitos. O gigante está se movendo, mas antes que ele possa exercitar sua força o Brasil terá de dar passos que seu povo gostaria que tivessem sido dados muitos anos atrás'. 
... passado. O brasileiro do interior quase não tem nada, e recebe pouco dinheiro. Ele não é um "consumidor"; ainda faz muitas das coisas que veste ou usa. Sua vida se parece com a dos índios e dos africanos primitivos. Estas são algumas das razões pelas quais, longe das cidades costeiras, as artes e as habilidades manuais floresceram no Brasil, ao contrário do que aconteceu nos Estados Unidos desde os dias coloniais.

... o homem do interior também não tem ...

... ele ainda o produz: canções, baladas, danças antigas, às vezes bem elaboradas, peças teatrais folclóricas e rituais, de acordo com as estações e os dias santos. Ele tece a lã e o algodão que foi fiado em casa; trança palha e vime; faz

\section{As artes espontâneas ${ }^{281}$}

AS ARTES populares e o artesanato ainda florescem no Brasil rural, diferentemente do que acontece nos Estados Unidos desde os tempos coloniais. As artes mais sofisticadas, é claro, vêm das cidades. ${ }^{282}$ Das cidades, também, vêm os produtos manufaturados, bons ou ruins, artísticos ou sem valor, que o homem contemporâneo compra para satisfazer suas necessidades estéticas, em vez de fazê-los, como no passado. Mas os brasileiros pobres, a população rural da costa ou do interior, quase não tem renda e quase não compra nada. Eles ainda fazem muitos dos objetos que utilizam, e essas coisas têm, quase sempre, alto valor artístico.

Uma vez que o homem pobre também não tem entretenimento (ou não tinha, até o advento do rádio), ele o produz: música, poesia, danças e peças teatrais tradicionais, às vezes bem elaboradas, que surgem de acordo com os dias santos e as estações. Ele tece o algodão, trança palha e bambu, faz cerâmica e entalha madeira e pedra. A riqueza e a variedade dessas artes nativas devem-se em grande parte ao fato de que, assim como os próprios brasileiros, elas são

\footnotetext{
281 [HRV]: a autora substitui o título, "Habilidades graciosas e populares" [Graceful and Popular Skills], pelo original. Segue-se, aqui, a tradução de Paulo Henriques Britto em carta de Bishop (1995, p.715), com 'espontâneas' e não 'inconscientes'.

282 [HRV]: '?' junto a 'vêm das cidades'.
} 
cerâmica; entalha - e a riqueza e a variedade dessas artes nativas devem-se em grande parte ao fato de que, assim como o povo, elas são racialmente misturadas: portugueses e mouros, africanos e indígenas - e hoje, no Sul do Brasil, às vezes alemães, italianos e japoneses, também.

Um fato curioso acerca da cerâmica popular brasileira é que, embora familiar entre os portugueses há séculos, a roda de oleiro não é usada. Talvez isso ocorra porque os ceramistas atuais do Brasil aprenderam sua arte com os índios, e não com a tradição portuguesa. Mesmo sem a roda, por cerca de mil anos os índios fizeram - e continuam fazendo - tigelas, vasos e urnas, ...

Esses vasos são feitos pelo método de "cordas", uma técnica pela qual o ceramista põe longas tiras finas de barro, em círculo, uma sobre a outra, até que se atinjam a altura e o tamanho desejados, e as paredes são aplainadas. Os ceramistas do interior (mulheres, como entre os índios) fazem vasos muito elegantes por esse método primitivo, e os decoram em preto, branco e tons de terra; depois, fazem o polimento com uma [em branco] concha.

Além dos pratos e jarros para usos práticos, feitos por mulheres, os homens às vezes fazem estatuetas de barro, uma arte proveniente da África. Às vezes coloridas e esmaltadas, às vezes na cor do barro, essas pequenas estátuas ou grupos completos reproduzem todas as culturalmente misturadas: foram herdadas dos portugueses e dos mouros, e influenciadas pelos índios e pelos escravos africanos. Hoje, no Sul do país notam-se também influências de imigrantes alemães, italianos, japoneses e poloneses.

UM BOM exemplo dessa mistura é que na cerâmica popular brasileira não se usa a roda de oleiro, embora ela fosse familiar entre os portugueses, séculos antes de sua vinda ao Brasil. Isso ocorre porque os ceramistas populares atuais derivaram sua arte da tradição indígena, e não da portuguesa. Mesmo sem a roda, por mais de mil anos os índios fizeram magníficas tigelas e urnas, às vezes enormes: grandes vasos para fermentar bebidas, e urnas funerárias grandes o bastante para conter um corpo adulto sentado em posição fetal. Esses vasos são feitos "enrolando" o barro, uma técnica pela qual o ceramista estica longas tiras finas de barro, em círculo, até que se atinjam a altura e o tamanho desejados. Os ceramistas populares brasileiros fazem vasos menores muito elegantes por esse método primitivo e os decoram em preto, branco e tons de terra; depois, fazem o polimento com cascas de frutas.

Todos os vasos que se destinam a usos práticos são feitos por mulheres (uma convenção herdada dos índios), mas é muito comum os homens fazerem estatuetas de barro. Pintadas e esmaltadas, ou na cor original do barro, essas figuras reproduzem as personagens $\mathrm{e}$ as atividades da sociedade rural: vaqueiros, soldados, padres e caçadores; 
personagens e atividades de sua sociedade: os vaqueiros, soldados, padres, caçadores, um casamento, um funeral, a caça à onça, um grupo de bois etc. As mulheres às vezes fazem personagens e, em Ipu, no Ceará, são famosas por suas miniaturas de potes e panelas, pratos, animais e móveis brinquedos para as crianças, às vezes surpreendentemente semelhantes aos brinquedos gregos e romanos que sobrevivem nos museus. Da Bahia vêm galinhas sentadas, perus, cobras, árvores inteiras repletas de pássaros - muito coloridos e alegres. Pratos para bebês copiam em barro, com exatidão, os modelos usuais esmaltados, e os que têm o interior esmaltado custam um pouco mais que os não esmaltados.

Outra arte se desenvolveu nas zonas que os sociólogos denominam "cultura do couro" ou pastoril: uma grande variedade de artigos feitos em couro de bezerro. Os mais valiosos, no entanto, são feitos em couro de veado - e veados são muito comuns na mata de arbustos do Nordeste. As roupas de couro do vaqueiro são feitas para protegê-lo dos espinhos das folhas pontudas da caatinga, a mata de arbustos, e das suas variedades de cactos de crescimento lento e árvores com espinhos.

... chapéu de couro, com uma alça sob o queixo. Todas essas peças são decoradas de maneira elegante: bordadas, casamentos, funerais e caças à onça. As mulheres fazem brinquedos e, por vezes, também personagens. Em determinada vila no estado do Ceará, as mulheres fazem miniaturas: potes e pratos, móveis e animais, muitas vezes surpreendentemente semelhantes aos brinquedos gregos e romanos que sobrevivem nos museus. Artigos manufaturados, muito apreciados mas caros demais para que sejam comprados, são em geral copiados em barro - pratos para bebês, abajures, tanques, até mesmo relógios realísticos, de parede e de pulso.

Nas regiões de criação de gado, no Nordeste, trabalhos em couro foram bem desenvolvidos. Couro de boi e de bode são os materiais mais comuns, embora o couro de veado, mais flexível, seja o mais valioso. As roupas de couro do vaqueiro servem para protegê-lo das árvores espinhosas e dos cactos dessa região. Sua roupa lembra muito as armaduras medievais, mas em couro: as perneiras têm o mesmo uso daquelas dos caubóis norte-americanos, mas são justas e se estendem sobre os pés; ${ }^{283}$ um colete; um protetor do peito; e, por cima de tudo, um casaco de couro com mangas longas cobertas por luvas também de couro. Na cabeça, usa um chapéu de couro, com ornamentos de couro. Essas peças são quase sempre decoradas de maneira elegante: estampadas, bordadas ou costuradas com retalhos de diferentes cores.

283 Embora a redação tenha sido muito alterada, manteve-se o essencial. Em [VAS] a autora completa, 'se estendem sobre os pés, como polainas', comentário eliminado na publicação. 
costuradas com retalhos de diferentes cores, estampadas. Suas selas também são objetos de arte, como as longas capas forradas e os chicotes decorados, com belos cabos (feitos de vergalho de boi).

... com palha: esteiras, sacolas, cestas, chapéus. Numa parte do Ceará elas fazem chapéus de palha similares aos "Panamás" do Panamá e do Chile em maciez e beleza.

... Pará, sob influência dos portugueses que trabalham com vime, existe uma indústria caseira de móveis de bambu, junco, vime etc. Os viajantes na Amazônia surpreendem-se quando vendedores lhes oferecem grandes cadeiras-de-balanço de vime, empoleiradas sobre a popa de minúsculas canoas. * Os mais famosos trabalhos em palha, todavia, são as redes tecidas com cordões ou fios produzidos de inúmeras variedades de palmeiras. Essas redes são macias e flexíveis, cor de palha, belas como seda. Elas não são utilizadas para dormir, mas penduradas para as sestas em varandas sombreadas. Para dormir, as redes são de algodão, mais rústicas, estampadas em cores vivas (os portugueses gostam muito de tecidos estampados, como os escoceses, mas com estampas irregulares) ou
ALÉM da arte da cerâmica, as mulheres do Norte e do Nordeste herdaram de suas ancestrais índias a arte de trabalhar com palha. No estado do Ceará elas trançam cestas, armadilhas para peixes, peneiras e esteiras rústicas e belas, para serem usadas como teto sob as vigas nuas de suas casas. No estado do Pará, móveis de bambu são feitos em casa para serem comercializados. Os viajantes na Amazônia são às vezes surpreendidos ao ver uma grande cadeira-de-balanço de vime aproximando-se deles pela água, equilibrada sobre a proa de alguma invisível canoa - embora o viajante, nessa altura, não se pareça com um comprador de cadeiras-debalanço, ou de cadeirões para bebês, ou de sofás. Uma das mais belas e características artes dessa mesma região é a confecção de redes com fibras extraídas de folhas das palmeiras. Essas redes são macias e flexíveis, cor de palha, com desenhos em preto. Elas não são utilizadas para dormir, mas ${ }^{284}$ penduradas em varandas, à sombra, para exibição, para espreguiçar-se ou para conversas na hora da sesta. As redes para dormir são de algodão, estampadas em cores vivas ou apenas brancas - este é o tipo mais valioso. Na casa grande ${ }^{285}$ de um rancho ou fazenda, o número de arcas, nas quais dezenas de redes brancas como neve permanecem guardadas com ervas aromáticas, é usado como indicação da riqueza do proprietário. Uma casa grande no estado do Ceará

\footnotetext{
* A autora refere-se à sua experiência na viagem de 1960 pelo Amazonas. Em carta para Lota (28 fev. 1960), afirma, por exemplo: "Elas vendem as coisas mais incríveis - canoas cheias de cadeiras de balanço...".

${ }^{284} \mathrm{Na}$ carta aos Editores: "p.84, col. 2, 12 linha antes do final: sleeping in-por favor, elimine in the night-está perfeito sem isso". Mas o texto não foi corrigido.

${ }^{285}$ Também em inglês: or big house.
} 
apenas brancas - o tipo mais valioso. As longas bordas dessas redes (chamadas varandas), por si, constituem uma outra arte - padrões especiais em "tricô rendado", com longas franjas. Nas casas grandes dos sítios nos sertões as "arcas de redes" atestam a riqueza do proprietário grandes arcas de cedro ou outras madeiras aromáticas, onde dezenas de valiosas redes brancas como a neve são guardadas com ramos de manjerona entre elas.

... em 1850, sem nome. Um amigo do proprietário perguntou "Como vai fulano com a sua Califórnia?" (referindo-se à corrida do ouro norte-americana, de 1849), e assim ela foi nomeada "Califórnia". Junto às redes para 120 convidados que poderiam querer passar a noite ali, havia as especiais, "redes do padre", para as suas visitas periódicas. Suas "varandas" rendadas exibiam cruzes, lanças cruzadas (símbolos da Paixão), cachos de uvas e espigas de trigo (símbolos da Eucaristia). mantinha 120 redes em suas arcas para uso dos convidados, e além disso havia redes especiais para padres, cujas bordas [p.85] rendadas exibiam cruzes, lanças cruzadas e outros símbolos da fé católica romana. Esse rancho foi fundado em 1850 e seu nome era, um tanto por brincadeira e um tanto por esperança, "Califórnia", por causa das histórias relacionadas à descoberta do ouro naquela região, que então chegavam ao Brasil. O rancho ainda mantém esse nome.

Outra tradição ${ }^{286}$ herdada dos índios é a decoração das cabaças chamadas cuias, ${ }^{287}$ que são usadas para beber e para banhar-se. Elas são quase sempre esmaltadas em preto, numa fórmula secreta, transmitida de geração a geração. Depois de esmaltada a cabaça, grava-se a decoração. Elas também podem permanecer na cor natural, ou ainda ser pintadas em cores vivas. Trata-se de ${ }^{288}$ flores, frutas ou bandeiras, ou palavras exprimindo sentimentos como "Lembrança", "Amor

\footnotetext{
${ }^{286}$ Na carta aos Editores: “p.85, col. 1, linha 10 - deve ser 'outra arte'.”, mas o texto não foi alterado.

${ }^{287}$ [1962, 1970]: Acentuado, 'cúias'.

${ }^{288}$ Na carta aos Editores: "p.85, col. 1, linha 18 - elimine such subjects as [objetos tais como] - obviamente", antes de 'flores, frutas ou bandeiras...'.", mas o texto não foi alterado.
} 
Dos portugueses e também dos mouros, as mulheres ...

... raras e valiosas. As rendeiras de [em branco] em Mato Grosso também usam essa fibra delicada, uma arte aprendida com as índias paraguaias. Padrões desenhados, crochê e tricô, bordados - quando os velhos padrões não foram esquecidos ou vulgarizados também são belíssimos. As rendeiras mais famosas são as da vila de Aracati, no estado do Ceará, mas as rendas do estado de Santa Catarina, feitas por descendentes de imigrantes dos Açores, também são famosas.

... ourivesaria desenvolveuse, com muitos artesãos de talento, quase sempre mostrando influência moura em suas filigranas e arabescos. As pedras incrustadas ...

(Shakespeare fala dela, mas a figa é séculos mais antiga que Shakespeare.) materno" e "Feliz aniversário", ou ainda o lema histórico “Independência ou Morte!". 289

Dos portugueses, as mulheres brasileiras herdaram a arte da renda, belo e delicado trabalho que esgota os olhos e a paciência. Uma peça da largura da mão requer mais de um dia de trabalho. Rendas feitas com fibras da folha de bananeira e não com linhas comerciais são muito raras e valiosas. Crochê, tricô e bordados também são belíssimos, quando os velhos padrões não foram esquecidos ou vulgarizados. Existe um grupo de canções folclóricas dedicado às rendeiras; algumas delas relatam a saga de um notório bandido nordestino, Lampião, que foi morto em 1938. Por estranho que pareça, a canção dos seguidores ${ }^{290}$ de Lampião, durante as cavalgadas, era "Mulher rendeira": "Oiê, muié rendeira!/ Tu me ensina a fazê renda/ Que eu te ensino a namorar...". 291

NAS REGIÕES das minas de ouro de Minas Gerais, Goiás e Bahia, a arte da ourivesaria desenvolveu-se desde cedo. As pedras incrustadas nessas velhas peças são diamantes brutos ou algumas das muitas pedras semipreciosas brasileiras: águas-marinhas, topázios, ametistas e turmalinas. Ainda se fazem muitas peças na Bahia, com ouro e prata, marfim e coral, quase todas na forma de amuletos, sobretudo a figa. ${ }^{292}$ Essa imagem milenar de um punho fechado com o polegar surgindo entre o indicador e o médio é vista por toda parte no Brasil. Pequenas figas são penduradas em volta do pescoço dos bebês, com uma medalha sagrada. Figas maiores, em

\footnotetext{
${ }^{289} \mathrm{Na}$ carta aos Editores a autora pede que se transfiram as aspas para depois do ponto de exclamação. No texto publicado substituíram-se as aspas por itálicos, e o problema foi eliminado.

290 [VAS]: 'quadrilha' [bandits] de Lampião. No texto publicado, followers.

${ }^{291}$ [1962, 1970]: apenas em inglês, "The lacemaker": “Oh, lacemaker!/ Teach me to make lace/ And I'll teach you how to love...".

292 Também em inglês, fig.
} 
Os amuletos têm vários centímetros de comprimento: romãs, cajus, instrumentos musicais, símbolos fálicos e objetos usados nos rituais de macumba. De Goiás vêm rosários com contas de ouro, com os pai-nossos em coral ou em pérolas barrocas. madeira, são penduradas nas paredes. Também da Bahia são os balangandãs, conjuntos de amuletos com ruído de sininhos, que eram usados pelas escravas na cintura e hoje são muito valiosos. Os amuletos, com vários centímetros de comprimento, incluem romãs, cajus, instrumentos musicais, símbolos fálicos e objetos usados nos rituais de macumba. Outras peças relacionadas a esse culto são produzidas na Bahia, incluindo demônios em ferro e estandartes de seda magnificamente bordados, usados nas procissões das "igrejas".

A MACUMBA, ${ }^{293}$ também chamada de candomblé na Bahia, seu principal centro, é uma religião muito desenvolvida, lembrando o vodu do Caribe. Surgida dos cultos africanos trazidos para o Brasil pelos escravos, ela mistura deuses brancos e negros, deusas e santos num fantástico panteão meio pagão, meio cristão. São Jorge deve parte de sua popularidade no Brasil ao fato de se ter transformado num santo da macumba, e são várias as transformações similares.

Nos rituais da macumba, galos e outros animais são sacrificados, estados hipnóticos são induzidos pela música e pelo canto, e os membros da religião são "possuídos" por um deus específico, adquirem seus atributos e falam por ele. Pratica-se tanto a magia negra como a magia branca ou "boa". À noite, nas estradas rurais, ao longo das praias ou nos limites das cidades, é comum perceber-se a luz das velas. Uma vela preta, charutos e uma garrafa preta de cachaça, ou uma vela branca, com flores, uma galinha e uma garrafa clara de cachaça $^{294}$ - esses são as oferendas da macumba, testemunhos da devoção supersticiosa de milhões de brasileiros a esse culto.

\footnotetext{
${ }^{293}$ [VAS]: não existe essa nova referência aos cultos afro-brasileiros, apenas o comentário inicial, no capítulo 3.

${ }^{294} \mathrm{Na}$ carta aos Editores: "p.85, col. 2 - 'cachaca' - note a marca [cedilha] sob o último 'c'.” A correção foi feita.
} 
Na região do Cariri, até há pouco o "oeste selvagem" do Brasil, terra de bandidos e de fanáticos religiosos, artesãos se especializaram em fazer facas e navalhas. ...

A arte dos santeiros é tradicional, passada de pai para filho. Quase toda pequena capela caseira, ou oratório, tem suas imagens esculpidas em madeira pelo santeiro local. Antigamente, os corpos desses santos ...

... pessoa hipócrita. Imagens de santos, como as dos tempos do Aleijadinho, ainda são feitas no interior. Há pouco tempo, entretanto, os padres, infelizmente e sobretudo os padres estrangeiros, por não apreciarem o primitivo nas artes e precisando de dinheiro para suas igrejas, venderam ou trocaram essas notáveis peças de madeira por imagens contemporâneas, sentimentais, em gesso pintado, produzidas em indústrias, e é triste observar que o gosto de suas congregações rurais também está se deteriorando.
Em outras regiões do Nordeste, terra de bandidos assim como de fanáticos religiosos, os artesãos se especializaram em navalhas montadas em prata e com cabos achatados, para serem usadas no cano de botas altas, e punhais com cabos esmaltados, marfim ou filigrana em ouro. Essa [p.86] região é tão belicosa, ainda hoje, que durante uma partida de futebol amigável entre os times de duas vilas rivais, por sobre o aplauso e os gritos dos vendedores anunciando "pipoca!" e "suco de laranja", pode-se ouvir a voz de um homem apregoando as facas feitas em casa, numa cesta em suas costas: "Compre sua navalha para depois do jogo!".

A arte dos santeiros é tradicional no Nordeste. Há 295 poucos anos quase toda pequena capela caseira, nas áreas rurais, tinha suas imagens esculpidas em madeira pelo santeiro local. No século XVIII, os corpos dos santos eram às vezes ocos, para que pudessem esconder ouro ou diamantes dos inspetores do governo, e a expressão "santo do pau oco" ainda é usada para indicar uma pessoa hipócrita. Em algumas regiões, os santos ainda são esculpidos em madeira. Nos últimos vinte anos, entretanto, os padres, que não apreciavam o primitivo nas artes e precisavam de dinheiro para suas igrejas, venderam ou trocaram essas notáveis peças de madeira por imagens contemporâneas, sentimentais, em gesso pintado. É triste observar que o gosto de suas congregações rurais também se deteriorou, de modo que todos agora preferem essas estátuas produzidas em massa às peças antigas, originais.

\footnotetext{
${ }^{295}$ Na carta aos Editores: "p.86, col. 1, $2^{\mathrm{a}}$ linha do $2^{\circ}$ par.: elimine instead". A alteração foi feita.
} 
Por causa disso, muitos dos bons "santeiros" passaram a fazer "milagres", ex-votos, para serem oferecidos como pagamento por promessas atendidas por santos milagrosos dos mais populares santuários (N. S. de Nazaré em Belém, São Francisco do Canindé, no Ceará, Bom Jesus da Lapa, às margens do rio São Francisco, Nosso Senhor do Bonfim na Bahia, Nossa Senhora da Penha, no Rio, N. S. Aparecida, em São Paulo). Quase todas elevadas pela Igreja à categoria de basílicas, têm salas especiais para expor ex-votos, verdadeiros museus de arte popular: pernas, braços, corações, cabeças, orelhas e olhos, assim como órgãos internos, em madeira ou cera, cada um atestando uma cura milagrosa. E junto com eles existem quadros: barcos de pesca, jangadas, salvos de tempestades, caçadores salvos de animais selvagens ou de cobras mortais, almas salvas de bandos de demônios.

No campo da escultura, no entanto, a criação mais notável são as imagens usadas nos barcos cargueiros do rio São Francisco - um costume que está morrendo rápido. Algumas dessas cabeças são muito bem feitas, com alguns metros de altura, no alto da proa, e entalhadas num estilo que lembra a escultura do período românico, com sua força e simplicidade. Animais,
POR CAUSA disso, muitos dos santeiros passaram a fazer "milagres" - ou seja, representações de partes do corpo curadas de doenças pela milagrosa intervenção de um santo, e levadas em gratidão ao respectivo santuário. Cada um dos mais populares santuários do país tem salas repletas desses objetos, de modo que se tornam verdadeiros museus de arte popular. Pernas, braços, cabeças, orelhas e olhos, assim como corações e outros órgãos internos, em madeira ou cera, atestam curas milagrosas. Pode haver também belas ou, no mínimo, estranhas estátuas de animais domésticos curados de maneira milagrosa - cavalos, vacas, cabras e aves. E junto com elas existem pinturas retratando outros milagres: barcos de pesca salvos de tempestades, caçadores que escaparam de animais selvagens ou de serpentes mortais, e almas salvas de bandos de demônios que as perseguiam.

No campo da escultura popular, no entanto, sem dúvida o exemplo mais notável é a criação das imagens usadas nos barcos do rio São Francisco. Chamadas de carrancas, ${ }^{296}$ as cabeças representam animais, mulheres e personagens do folclore afro-brasileiro, mas uma das favoritas sempre é a "Cobra Grande", ${ }^{297}$ o mais terrível dos espíritos que vivem no rio. Algumas dessas figuras são muito bem feitas, projetam-se alguns metros acima da proa do barco e são

\footnotetext{
296 O termo 'carranca' não aparece no original, apenas no texto publicado, embora conste em carta de 1960 e a autora tenha uma, "de um metro e vinte de altura" (Bishop, 1995, p.710).

${ }^{297}$ [VAS, 1962, 1970]: Great Worm, grande verme ou minhoca, tanto no original como nas duas edições.
} 
mulheres e personagens do folclore afro-brasileiro - mas sobretudo a "Cobra Grande", o mais terrível dos espíritos que vivem no rio.

Uma especialidade que a industrialização ainda não alterou é a arte da carpintaria - herdada dos construtores de barcos portugueses - em especial a manufatura de [em branco] de moinhos, prensas para queijo ou para semente de algodão, [em branco] e outras [em branco] indústrias domésticas. São peças complicadas, porcas e parafusos, cilindros e raspadeiras, e [em branco] todos feitos em madeira rígida, e, em alguns casos, esse maquinário para fazer farinha de mandioca ou vinho ou pasta de caju não pode ter nenhuma parte em metal. Os grandes parafusos, com mais de dois metros de altura, são entalhados em espirais, em "madeira de lei", dura como ferro; as enormes rodas e os eixos, feitos de troncos inteiros, sem um único prego ou parafuso de metal, são mantidos juntos graças a um completo sistema de dobradiças e cavilhas de madeira. As únicas ferramentas do carpinteiro são o prumo, a serra, o enxó, o formão e suas duas mãos.

Como outros povos primitivos, os brasileiros do interior louvam seus poetas populares, denominados "cantadores".

... Eles aparecem nas festas talhadas num estilo forte e simples, que lembra as esculturas do período românico. Infelizmente, as carrancas vêm sendo usadas cada vez menos, e a arte de sua fabricação vai morrendo. 
rurais e travam duelos intermináveis de versos que às vezes duram vários dias, com os "cantadores" parando apenas para beber e comer. Os competidores tentam vencer os rivais em ideias, rimas e bom humor. Trata-se de uma arte que só pode desenvolver-se numa língua latina como o português, repleta de rimas e assonâncias. $\mathrm{O}$ perdedor do duelo é aquele que fica sem rima e, exausto, reconhece a derrota com uma homenagem, em verso, à superioridade de seu rival.

... pequenas comunidades do sertão. festas rurais e travam duelos de versos que às vezes duram até 24 horas, ${ }^{299}$ com os cantadores parando apenas para beber e comer. Eles tentam vencer os rivais em ideias, rimas e bom humor. O perdedor é aquele que fica sem rima.

Os cantadores são pessoas privilegiadas nessas pequenas comunidades. Eles também se orgulham muito de sua arte e de suas "memórias", o modo como se referem ao talento poético. Como anuncia um deles, ${ }^{300}$ "Não tem homem como o Rei/ Nem mulher como a Rainha/ Não tem santo igual a Deus/ Nem memória igual à minha....” 301

ANTES do advento do rádio, os cantadores eram os jornais do Antes do advento do rádio e da televisão, que agora competem com eles embora ainda não os tenham silenciado, esses cantadores eram os verdadeiros jornais do sertão; ainda hoje eles continuam a produzir relatos em verso, detalhados e dramáticos, ...

... vendido nas feiras semanais por todo o Brasil. A recente renúncia do presidente Quadros também foi transposta para os versos, sertão; ainda hoje eles continuam a produzir relatos em verso, imediatos e dramáticos, a respeito de todas as notícias mais sensacionais. Poucos dias após o suicídio do presidente Getúlio Vargas, em 1954, um "Escritor brasileiro" (como ele assinou) de Recife produziu um panfleto em forma de balada, chamado "Getúlio no Céu", que ainda é vendido nas feiras. O voo de Yuri Gagarin, o cosmonauta soviético, em 1961, foi logo transformado em versos, assim como a renúncia do presidente Jânio Quadros. Em geral os cantadores (que são

${ }^{299}$ Na carta aos Editores: "p.86, col. 2, linha 21 - POR FAVOR inclua que as disputas dos cantadores duram 24 horas ou mais - veja o texto. Eu tenho essa informação de uma fonte confiável. Alterar isso para 'grande duração' deixa a sentença quase sem sentido - pode significar meia hora ou duas horas etc. (Eu já alterei isso duas vezes.)". A solicitação foi atendida.

${ }^{300} \mathrm{Na}$ carta aos Editores: "Se os poemas vão ficar numa só linha, e não separados por versos, a pontuação no final dos versos deve ser / [barra] e não travessão". A solicitação foi atendida.

${ }^{301}$ Apenas em inglês: "There's no man like the King/ No woman like the Queen/ No saint like God Almighty/ And no memory like mine...". 
e o voo de Gagarin, e o maior e mais recente desastre aéreo. Em geral os "escritores" (que são analfabetos; alguém anota os versos para eles) cantam e declamam suas composições e depois as vendem para os espectadores, na forma de panfletos. As capas de alguns desses panfletos também são obras de arte; embora o texto seja mal impresso, em papel barato, repleto de erros de grafia e de impressão, a folha externa é ornamentada com rústicas mas comoventes gravuras.

O Natal (às vezes chamado "O Nascimento") e o AnoNovo, ou Ano-Bom, são celebrados por todo o Brasil com festas que variam de acordo com as tradições locais e o grupo racial predominante na região. No Norte e no Nordeste, com antigas tradições "pastoris", a celebração favorita é o Bumba-meu-boi. Um pequeno grupo de homens (como no teatro clássico, mulheres nunca atuam nesses espetáculos) apresenta uma história cujo herói é o boi, que dança, canta, fica doente, morre e depois retorna à vida em meio a grande alegria e mais músicas e danças. O boi, com dois dançarinos em seu interior, é seguido por outras personagens: Mateus, o vaqueiro, e o cavalo, o burro, o padre (que vem dar a extrema-unção ao boi moribundo), o médico (com uma enorme seringa, como uma personagem de Molière), analfabetos - alguém anota seus versos para eles) apresentam suas composições e depois as vendem para os espectadores, na forma de panfletos.

O teatro é outra arte folclórica ainda muito viva no Brasil. O Natal, o Ano Novo e vários dias santos são celebrados por toda parte com festas na forma de peças teatrais ou danças que variam de acordo com as tradições locais e o grupo racial predominante na região. No Norte e no Nordeste a celebração favorita é o Bumba-meu-boi. ${ }^{302}$ Como no teatro clássico elisabetano, mulheres não atuam no Bumba-meu-boi. Um pequeno grupo de homens apresenta uma história a respeito de um boi que dança, canta, fica doente, morre e depois retorna à vida em meio a grande alegria e mais músicas e danças. A figura estilizada do boi, com um ou dois dançarinos em seu interior, é seguida por outras personagens: o vaqueiro, o cavalo, o burro, o médico, o padre (que vem dar a extrema-unção ao boi moribundo) e palhaços. A ação é intercalada com músicas, e sempre existem muitos improvisos. ${ }^{303}$

\footnotetext{
302 Também em inglês, “Beat My $O x$ ”, no original e nas duas edições.

303 QUADRO: "Canção do interior", bilíngue: "Se eu não beber fico seco/ Seco não posso cantar./ E não cantando estou morto/ E morto não posso amar./ Não amando fico louco,/ E louco vão me amarrar ...”.
} 
o palhaço, e o coro de [em branco]. A música e a ação são intercaladas com canções, e nos diálogos sempre existem muitos improvisos, cuja inteligência e adequação podem fazer a fama de um Mateus ou de um palhaço.

Nas regiões costeiras, onde a influência portuguesa é mais forte, dança-se o Fandango ou Cheganças (chegadas): num barco construído no local ...

... datado do tempo do descobrimento do Brasil. E onde os negros predominam, a peça é um Congo, também um conto dramático: na corte de um rei do Congo, seus rivais traem o reino para favorecer os brancos invasores. O príncipe descobre o plano e é morto; em seguida, começa uma batalha, às vezes terminando em tragédia, às vezes com a vitória do rei Congo. Todas as personagens ...

Mas por toda parte, do norte ao sul do Brasil, no interior e nas cidades, encena-se o Presépio, o grupo de pastores em busca do menino Jesus, cantando e dançando em sua honra. Todas essas peças primitivas são tradicionais, com o texto passado de geração a geração, os diálogos, mesmo as piadas dos palhaços, assim como as canções.
Nas regiões costeiras, o povo executa danças baseadas em velhos fandangos e cheganças portugueses. Num barco cenográfico construído no local da festa, eles apresentam a história dramática da nau Catarineta, baseada em um antigo conto português em versos, datado do século XVII. Onde os negros predominam, a dança é quase sempre um "congo". Na corte do Rei Congo, seus rivais traem o reino e permitem a invasão dos brancos. O príncipe descobre o plano e é morto; em seguida, começa uma batalha. As personagens são vestidas com valiosos mantos de veludo, calções de cetim e coroas douradas. O embaixador dos brancos é sempre um negro imponente vestido como um almirante inglês, e usa um chapéu emplumado. Às vezes ele é Lorde Nelson, pois a narrativa confunde as histórias africana, portuguesa e britânica.

$\mathrm{Na}$ época do Natal, em várias partes do Brasil encenase o Presépio. ${ }^{304}$ Ela apresenta os pastores em busca do menino Jesus, cantando e dançando em Sua honra. Os textos, as canções e as brincadeiras dessas peças primitivas são tradicionais, passadas de pai para filho.

\footnotetext{
${ }^{304}$ No original, "Play of the Shepherds", história dos pastores; a autora refere-se à Folia-de-reis, ou Terno-dereis.
} 
Entretanto, todos esses festivais folclóricos (e existem muitos outros, incluindo uma variedade de "rodeio" no Nordeste), empalidecem diante da grande paixão brasileira, o Carnaval. O Carnaval chegou ao Brasil por meio do velho entrudo português, uma forma rude de Carnaval na Terça-feira Gorda, em que se usavam máscaras, e "limões perfumados" (bolas de cera colorida, cheias de água perfumada) eram jogados, mas a maior parte da diversão consistia em jogar bacias de água fria e sacos de farinha. No Brasil, nas cidades (e o Carnaval é uma celebração urbana), o entrudo foi aos poucos transformado num baile de máscaras envolvendo multidões, um enorme baile público com danças nas ruas e desfiles organizados. (Sem contar as centenas de bailes privados que acontecem ao mesmo tempo.) Os que desfilam pertencem a grupos, os "ranchos" (que significam distritos da cidade) * e as "escolas de samba", cada grupo vestindo sua fantasia, elaborada e quase sempre cara. As festividades se estendem por todas as três noites que precedem a Quarta-feira de Cinzas; e todo o restante pára: lojas, bancos, todo o trabalho. Os sambas do ano estão sempre no ar; as ruas são tomadas por multidões que, sambando, movem-se devagar, o ar fica pesado com confetes e serpentinas e com o odor de
Mas todos os espetáculos teatrais e os festivais - e há muitos mais, incluindo uma variedade de rodeio - são ofuscados diante do Carnaval - um frenesi grandioso e anual de música e dança, que dura três dias. Essa instituição mundialmente famosa, que acontece por todo o país, chegou ao Brasil com as velhas celebrações portuguesas da Terçafeira Gorda. A versão brasileira original era um evento simples, e a principal diversão consistia, em geral, em as pessoas atirarem bacias de água fria ou sacos de farinha umas nas outras. Nas cidades e vilas, a celebração que durava um dia foi aos poucos transformada no impressionante evento atual - um baile de máscaras envolvendo multidões, um enorme baile público com danças nas ruas e desfiles organizados. No Rio, centenas de bailes privados acontecem ao mesmo tempo. Os que desfilam pertencem a grupos de diferentes bairros, cada grupo vestindo sua elaborada - e quase sempre cara - fantasia. As festividades se estendem por todas as três noites que precedem a Quarta-feira de Cinzas, e toda a vida normal da cidade se interrompe. Os sambas do ano estão sempre no ar; as ruas são tomadas por multidões sambando, que se movem devagar. $\mathrm{O}$ ar fica pesado com confetes e serpentinas e com o odor de "lança-perfume" 305 frascos de éter perfumado que lançam um jato fino, que não apenas perfuma o ar, mas dá à pessoa que o recebe um choque momentâneo e gelado. Mulheres sambam com bebês subindo [p.88] e descendo solenes, no ritmo, em seus braços. A multidão é feliz e bem-humorada.

\footnotetext{
*No original, a autora associa o termo 'ranchos' a 'distritos' da cidade, comentário incorreto. No texto publicado permanece a associação aos bairros, sem que conste o termo 'rancho'.

${ }^{305}$ Existe, em inglês, a expressão ether spray, que a autora parece desconhecer. Ela usa perfume shooters, a tradução literal, entre aspas.
} 
"lança-perfume" - frascos de éter perfumado e comprimido que lançam um jato fino, que não apenas perfuma $\mathrm{o}$ ar, mas dá à pessoa que o recebe um choque momentâneo e gelado. Mulheres sambam com bebês subindo e descendo solenes, no ritmo, em seus braços.

A multidão feliz e bemhumorada era um dos grandes espetáculos do mundo. Era, e é isso mesmo, porque é triste ver, mas é verdade, que o Carnaval, nas grandes cidades, vem sendo destruído depressa - pelo rádio, em especial, mas também pelo comercialismo e por uma falsa ideia do que interessaria ao "turista". Os filmes de Hollywood exerceram um efeito ruim, também - poucos anos atrás, a fantasia de Carnaval favorita vinha de um filme recente e muito popular, e centenas ou milhares de Davis e rainhas de Sabá sambavam nas ruas com fantasias inadequadas e ridículas.

Além dos efeitos do rádio e de Hollywood, grande parte do divertimento foi destruída pela proibição de caricaturas políticas, ou ridicularizando a Igreja - algumas das fantasias mais interessantes eram inspiradas nesses velhos e infalíveis objetos de sátira.

Mas o rádio e os altofalantes é que fizeram o maior estrago. Talvez alguma coisa possa ser feita para salvar o Carnaval. Sua essência sempre esteve na espontaneidade e no fato de que todas as músicas e danças vinham do próprio povo.
O Carnaval é um dos maiores espetáculos populares que ainda restam no mundo. Ou talvez seja melhor dizer que "era", porque nas grandes cidades, ao menos, ele vem sendo destruído depressa. O comercialismo e uma falsa ideia do que interessaria aos turistas são, em parte, os culpados. Hollywood exerceu um efeito devastador, também. Por exemplo, poucos anos atrás o Carnaval parecia ter-se transformado num pesadelo cinematográfico. Um épico bíblico tinha feito sucesso, e milhares de Davis e rainhas de Sabá sambavam nas ruas com fantasias previsíveis, pouco originais.

GRANDE PARTE do divertimento carnavalesco também foi destruída pela proibição de fantasias e carros alegóricos relacionados aos políticos, à Igreja e aos militares. Algumas das melhores mostras de inteligência e humor eram inspiradas nesses velhos e infalíveis objetos de sátira.

Mas o rádio e os alto-falantes é que fizeram o maior estrago. A grande virtude do Carnaval sempre foi sua espontaneidade e o fato de que todas as músicas e danças estavam a cargo do próprio povo. Quando compositores comerciais começaram a compor para o Carnaval, e quando essas músicas passaram a ser divulgadas com meses de antecedência, todo o charme se perdeu. Além disso, quando 
... num ritmo diferente, em cada esquina, e eles são até mesmo interrompidos por anúncios comerciais - eles param de dançar e de cantar, e se arrastam como um rebanho de carneiros.

... fazem. Se não tem dinheiro, improvisa uma fantasia, por exemplo, um "monstro da floresta" apenas uma capa coberta com folhas, como penas, talvez para ficar parecido com um índio primitivo. Ou corta uma faixa de cabelo no alto da cabeça, pinta-a de vermelho e dá um jeito de aparecer.

Se nada disso for possível, ele pode sair em farrapos e pintado, como ... milhares de participantes, sambando e cantando o sambaenredo favorito, em uníssono, são confrontados com um altofalante que despeja o mesmo samba ou outro num ritmo diferente, todos os cantores e dançarinos param, e o povo se arrasta como um rebanho de carneiros. Anúncios comerciais nos alto-falantes interrompem a dança, e fotógrafos também vêm interferindo entre os sambistas, interrompendo até as performances premiadas para tirar boas fotos. No Rio, durante os dois últimos carnavais, os espectadores afinal assobiaram e vaiaram alguns fotógrafos detestáveis.

Nas pequenas cidades, no entanto, a festa ainda tem seu sabor autêntico e popular. O homem comum sai para brincar, ou para "botar pra quebrar", 306 como é costume referir-se ao divertimento. Se possível, ele vai se vestir de príncipe, de galo, índio, demônio, ou do sempre popular esqueleto. $\mathrm{Ou}$ vai se vestir de mulher, como milhares fazem. Os foliões mais modestos podem improvisar uma fantasia primitiva apenas tecendo um manto de folhas, o que talvez o torne parecido com um índio. Ele pode, também, cortar uma faixa de cabelo no alto da cabeça, pintá-la de vermelho e aparecer com um machado cravado no crânio. Pode ainda raspar todo o cabelo, e pintar a cabeça de azul ou verde. Com uma sombrinha, dança o frevo, uma dança frenética e acrobática, em que o dançarino permanece meio agachado. Se nada disso for possível, ele vai sair em farrapos, como um "sujo". 307

O Rio de Janeiro tem uma instituição original, as escolas de samba, muitas das quais ainda não destruídas pelo comercialismo. ${ }^{308} \mathrm{Na}$ realidade não são escolas, mas um tipo

\footnotetext{
306 Apenas em inglês, 'to break'.

${ }^{307} \mathrm{Na}$ carta aos Editores: "p.88, col. 2, linha 14 - dizer que eles go in rags [vão em trapos] não significa absolutamente nada. Por favor, veja o texto. Eu disse: rags and paint, simply as a 'dirty one' - the dirties [farrapos e tinta, simplesmente, como um 'sujo' - os 'sujos']. Por favor, não altere”. O trecho foi corrigido, mas faltou acrescentar 'tinta' e o nome do grupo, 'os sujos'.

${ }^{308}$ [1970]: 'samba, que felizmente permanecem até certo ponto intocadas pelo comercialismo.'.
} 
Uma fantasia muito comum parece vagamente inspirada em Luís XV, e não se economiza dinheiro. Em que outro lugar do mundo podem ser vistos trezentos negros vestidos em roupas de Luís $\mathrm{XV}, \ldots$

Depois deles vêm as mulheres, inclinando-se e cantando enquanto dançam usam cordões de contas de vidro prateado - e minúsculas lâmpadas brancas espalhadas em todas as fantasias elegantes, encantadoras e graciosas, sob uma música louca, saída de estranhos instrumentos - a terra da fantasia por uma noite. de clube, cujos membros (quase todos negros pobres das favelas) se encontram ao longo do ano para aprender as canções e danças para o próximo Carnaval. Muito tempo e muito dinheiro são investidos nessas escolas. As canções são realmente música do povo. Os temas são o amor (o mais importante) ou a crítica social: o governo, o custo de vida e a política. Um tema geral é proposto às escolas em cada Carnaval, como por exemplo "Rio no tempo dos vice-reis" ou “A descoberta do ouro". Buscando materializar o tema do "ouro", as mulheres de uma escola sambaram com enormes imitações de pepitas de ouro cintilando no alto da cabeça.

UMA FANTASIA muito comum, ano após ano, parece vagamente inspirada nas roupas utilizadas no tempo de Luís $\mathrm{XV}$. Em que outro lugar do mundo veem-se centenas de homens negros vestidos como Luís XV, em azul, ${ }^{309}$ branco e prata, com paetês e lantejoulas * sobre a roupa, usando perucas brancas e encaracoladas e chapéus emplumados, dançando no meio da avenida principal às 4 horas da manhã? Depois deles vêm as mulheres, com belos enfeites no cabelo. Vestem-se de cetim que reluz sob as mesmas luzes, e usam cordões de contas de vidro prateado e azul, cantando ao mesmo tempo em que dançam - elegantes, encantadoras e graciosas, flutuando sob uma música incessante, hipnótica, mas não muito rápida - a terra da fantasia por uma noite.

\footnotetext{
${ }^{309}$ [HRV]: 'X?', junto a 'azul'.

* No original e no texto publicado, consta "minúsculas lâmpadas brancas"; parece óbvia a referência a paetês, lantejoulas etc.
} 


\section{As artes sofisticadas ${ }^{310}$}

No campo das artes contemporâneas, o Brasil é sem dúvida mais conhecido por sua arquitetura. Nenhuma das cidades ...

... sobre as construções mais antigas - edifícios de três ou quatro andares -, que merece o título.

... linguagem contemporânea. Muitos são excelentes, e bem conhecidos, mesmo que apenas através das revistas de arquitetura, pelos arquitetos do mundo todo. A maioria, como em todos os outros lugares e em todos os períodos, talvez não passem de tentativas medíocres de seguir "a tendência".

Todavia, é bem possível que exista mais arquitetura contemporânea de qualidade no Brasil, hoje, do que em qualquer outro país subdesenvolvido mas em rápido crescimento.
POUCOS países mostram maior respeito pelas artes e pela cultura que o Brasil. ${ }^{311}$ Por exemplo, existe boa arquitetura contemporânea em maior quantidade que em qualquer outro país não industrializado. ${ }^{312}$ Nenhuma das cidades ao longo da costa, de Recife a Porto Alegre, deixa de ter seu pequeno mas sempre crescente grupo de modernos "arranha-céus". Um arranha-céu brasileiro não é necessariamente muito alto, $\mathrm{e}^{313}$ um edifício de 10 ou 12 andares eleva-se tão alto sobre as construções mais antigas que merece o título. E cada cidade tem também seus edifícios residenciais, casas, projetos habitacionais, hospitais e escolas, todos construídos na linguagem contemporânea. Embora a maioria possa ser, como nos outros lugares, apenas uma tentativa medíocre de seguir a tendência, muitos projetos são excelentes e bem conhecidos entre os arquitetos do mundo todo.

${ }^{310}$ [HRV]: a autora substitui o título, "Um respeito merecido pelas artes" [A Merited Respect for the Arts], pelo original. Segue-se, aqui, a tradução de Paulo Henriques Britto em carta de Bishop (1995, p.715): 'sofisticadas' e não 'intencionais' [Intentional arts].

${ }^{311}$ [1962, 1970]: “... que o Brasil - e em poucos países esse respeito é mais merecido.”. Eliminado em [HRV].

312 [HRV]: a autora elimina 'outro ... industrializado', mas não propõe novo final para o período.

${ }^{313} \mathrm{Na}$ carta aos Editores: "p.97, par. 1, linha 11: Eliminar 'MAS'. Use ponto-e-vírgula. Deve ficar 'Um arranhacéu brasileiro não é necessariamente muito alto; um edifício de 10 ou 12 andares eleva-se tão alto sobre as construções mais antigas etc.' O 'MAS' ALTERA COMPLETAMENTE O SENTIDO'. O trecho não foi alterado no texto publicado [1962, 1970]. 
... Mas os brasileiros em geral, ou melhor, os instruídos, conhecem mais sobre arquitetura do que os outros povos. Todo mundo parece ter opiniões firmes sobre arquitetura moderna, pró ou contra (na maioria, pró), e ser capaz de falar com segurança sobre brise-soleils (o termo francês é usado normalmente) ou ...

... Enquanto Washington, por exemplo, estava bem presa aos greco-romanos quando se projetou o novo edifício da Suprema Corte, o Brasil estava inaugurando o que ainda é considerado um dos melhores exemplos de arquitetura moderna, $o$ Ministério da Educação e Saúde, no Rio de Janeiro. Concursos para a construção de prédios públicos são exigidos por lei, e os prêmios costumam ser concedidos às propostas mais avançadas.

Nós já ouvimos falar de Oscar Niemeyer e Lúcio Costa, associados a Brasília, mas alguns outros arquitetos importantes devem ser mencionados. Jorge $\mathrm{M}$. Moreira é talvez o mais "europeu", conhecido por seu delicado senso de proporção e adequação, seu refinamento
Essa extraordinária façanha artística, a mais importante do Brasil, deve-se sobretudo a um grupo de arquitetos criativos, enérgicos, sofisticados e audaciosos, a maioria dos quais ainda jovens. Mas os brasileiros em geral - os instruídos - conhecem arquitetura num nível extraordinário. Todo mundo parece ter opiniões firmes sobre arquitetura moderna e ser capaz de falar com segurança sobre brise-soleils ou pilotis (os pilares que sustentam um edifício e o separam do chão), dois dos aspectos mais notáveis das construções modernas brasileiras.

O Brasil é também um dos poucos países onde a arquitetura contemporânea é incentivada - até mesmo favorecida - pelo governo. Enquanto os Estados Unidos, por exemplo, estavam bem presos aos greco-romanos quando projetaram o novo edifício da Suprema Corte, em Washington, na década de 1930, o Brasil estava inaugurando sua revolução arquitetônica com a construção do edifício do Ministério da Educação e Saúde, no Rio de Janeiro, ainda considerado um dos melhores exemplos de projeto 314 contemporâneo em todo o mundo.

OS JOVENS arquitetos que colaboraram para criar esse edifício beneficiaram-se tremendamente do auxílio e dos conselhos do arquiteto francês Le Corbusier, que na época visitava o Brasil. ${ }^{315}$ Hoje, eles ainda dominam a arquitetura brasileira. O grupo incluía Oscar Niemeyer e Lúcio Costa, que há pouco trabalharam ${ }^{316}$ em Brasília (ver o Capítulo 4). Outro

\footnotetext{
${ }^{314}$ Na carta aos Editores: “p.98, col. 1, final do $1^{\circ}$ par. Por favor, não use 'DESIGN' - 'um dos melhores exemplos de arquitetura contemporânea'. Eu discuti tudo isso em Nova York”. A solicitação não foi atendida; permaneceu design (projeto).

${ }^{315}$ [HRV]: comentário ilegível junto a 'Brasil'.

316 [1970]: 'que trabalharam'.
} 
... Os poucos edifícios finalizados são admiráveis, e esse trabalho enorme vai tornar-se, sem dúvida, a obraprima de Moreira.

... Pedregulho, com escola e playgrounds, que acompanha os contornos de um alto morro no subúrbio do Rio. Ele é também o projetista do novo Museu de Arte Moderna. Sergio Bernardes é, talvez, o mais imaginativo de todos; seu estilo muda de prédio para prédio; ele gosta do espetacular, dos novos materiais, de "brincadeiras", e seus melhores projetos, seus prédios - ou pontes, ou pavilhões -, têm alegria e coragem inconfundíveis.

... do Japão, até mesmo refugiados da China comunista. deles é Jorge M. Moreira, hoje reconhecido por seu delicado senso de proporção, seu refinamento nos detalhes e sua cuidadosa atenção com o acabamento - que infelizmente não se pode estender a tudo o que se faz no Brasil. Moreira projetou a enorme Cidade Universitária que está sendo construída no subúrbio do Rio, em atraso por causa da falta de fundos governamentais. Os poucos edifícios finalizados são admiráveis, e esse trabalho enorme vai tornar-se, sem dúvida, uma das obras-primas da arquitetura do século XX. Affonso Eduardo Reidy, outro membro do grupo que projetou o Ministério da Educação, sempre se interessou pelo ${ }^{317}$ aspecto sociológico da arquitetura; entre seus projetos está o grande conjunto habitacional popular de Pedregulho, onde a escola e os playgrounds acompanham os contornos de um morro no subúrbio do Rio. Reidy é também o projetista do novo Museu de Arte Moderna do Rio. Um arquiteto que se tornou famoso na última década é Sergio Bernardes, talvez o de imaginação mais divertida. Seu estilo muda de prédio para prédio; ele gosta do espetacular, e seus melhores projetos têm alegria e técnica inconfundíveis. Seu Pavilhão Brasileiro para a Exposição Mundial de Bruxelas, em 1958, venceu o grande prêmio de arquitetura dessa ${ }^{318}$ mostra.

Existem outros, é claro; e todos os arquitetos mais conhecidos têm discípulos - jovens da Europa, dos Estados Unidos ou do Japão, e mesmo um arquiteto da China comunista. Os arquitetos, em conjunto, parecem ser as pessoas mais livres e alegres, e as menos provincianas do país. Eles nunca ficam sem trabalho, e, a despeito de todos os altos e baixos do governo e dos negócios imobiliários, sua área prospera.

\footnotetext{
${ }^{317}$ [1970]: 'Educação, interessava-se pelo'.

318 [1970]: 'de projeto arquitetônico dessa'.
} 
Eles têm desvantagens, é claro. Por causa do atraso da indústria siderúrgica brasileira, a construção com estruturas em aço é pouco usada, e mesmo os edifícios mais altos são feitos de concreto armado. Até recentemente poucas peças eram padronizadas, por isso a construção era cara e demorada. O material para telhado, as cerâmicas etc. ainda não são muito padronizados - a qualidade é irregular, ou cores e acabamentos não são permanentes. Isso, combinado com os problemas econômicos, é a explicação verdadeira do que HenryRussell Hitchcock chamou de "incrível negligência na manutenção dos edifícios" no Brasil.

... os estrangeiros dificilmente conseguem perceber e ...

... Muitas casas antigas ainda não têm vidraças nas janelas, apenas folhas de madeira que se fecham à noite. E embora vejamos a região tropical como sujeita a uma invasão constante de nuvens de insetos, é possível, na maior parte do Brasil, permanecer à noite com as janelas abertas 0 ano todo. Nuvens ocasionais
A força da arquitetura é ainda mais surpreendente diante das péssimas condições em que os arquitetos são forçados a trabalhar. $\mathrm{O}$ atraso da indústria siderúrgica brasileira, por exemplo, impediu por muito tempo a construção com estruturas em aço; quase todos os edifícios mais altos são feitos de concreto armado. ${ }^{319}$ Até recentemente poucas peças eram padronizadas, por isso a construção era cara e demorada. Além disso, algumas partes - tais como o material para telhado - ainda sofrem com a qualidade irregular e a instabilidade das cores e do acabamento. O que um famoso crítico de arquitetura chamou de "incrível negligência na manutenção dos edifícios públicos" brasileiros é, na realidade, uma combinação de pouca durabilidade dos materiais com falta de dinheiro público, mais que indiferença em relação à aparência.

A CONSTRUÇÃO no Brasil tem, ainda, vantagens ${ }^{320}$ que os estrangeiros dificilmente percebem e que podem ser até certo ponto creditadas à bela e centenária tradição de bons e sólidos edifícios. A construção é simplificada de várias maneiras: não existem terremotos nem furacões a serem levados em conta, não há necessidade de aquecimento, telas ou isolamento rigoroso. Muitas casas antigas não tinham vidraças nas janelas, apenas folhas de madeira que se fechavam à noite. E embora a região tropical seja vista como sujeita a uma invasão constante de nuvens de insetos, é possível, na maior parte do Brasil, permanecer à noite com as janelas abertas o ano todo. Vagalumes irrequietos e nuvens ocasionais de mariposas ou de cupins não incomodam ninguém, e uma espiral queimando

\footnotetext{
${ }^{319}$ Na carta aos Editores: “p.98, col. 2, par. 3: deve ficar almost all the sky-scrapers are of reinforced concrete$\mathrm{O}$ que vocês disseram significa algo completamente diferente, implicando que os mais baixos têm estrutura em aço". É possível que a autora tenha se confundido na crítica, mas de qualquer maneira seu original era claro: even the highest buildings are of reinforced concrete. Em [HRV]: ' $\mathrm{X}$ ' junto a 'concreto armado'.

${ }^{320}$ [1962, 1970]: 'outras vantagens'; [HRV]: a autora elimina 'outras' e insere '?'.
} 
de mariposas ou de cupins, ou de vagalumes irrequietos, não incomodam ninguém, e uma espiral queimando (chamada Durma Bem) mantém os mosquitos afastados.

\section{A arquitetura não precisa} preocupar-se com porões, janelas complicadas e sistemas de calefação. $\mathrm{O}$ arquiteto ainda conta com um código de construção muito mais livre e pode erguer edifícios que, em países mais rigorosos, seriam considerados perigosos, ou proibidos por leis de zoneamento.

... ter quintais, e as casas se amontoam, eliminando as vistas umas às outras e as brisas.

A praia de Copacabana é o exemplo mais notável dessa especulação imobiliária irrestrita.
... do outro - e essa

desastrosa falta de planejamento está sendo repetida por todo o Brasil.

Junto com os arquitetos, menção especial deve ir para o paisagista ... ajuda a afastar os mosquitos.

Neste país semitropical o arquiteto não precisa preocupar-se com porões, janelas complicadas e sistemas de calefação. Ele também conta com um código de construção muito mais livre e pode erguer edifícios que em outros países seriam considerados experimentais demais ou proibidos por leis de zoneamento restritivas. Entretanto, uma especulação imobiliária selvagem o atrapalha, sobretudo nas cidades, onde os lotes são caros demais para que mesmo os ricos possam ter quintais, e as casas se amontoam, eliminando as brisas e as vistas umas às outras.

Copacabana, o bairro mundialmente famoso localizado numa das praias do Rio de Janeiro, é o exemplo mais notável dessa especulação imobiliária irrestrita. Uma sólida parede de edifícios residenciais elimina agora todo sopro do oceano, de modo que apenas os poucos privilegiados que vivem em frente ao mar podem receber o ar fresco; o resto desse bairro enorme, ${ }^{321}$ do tamanho de uma cidade, sufoca entre a parede de edifícios, de um lado, e as montanhas, do outro. Além disso, modelos desastrosos similares a esse estão sendo repetidos em outras partes do Brasil.

ENTRE todo esse mau uso dos recursos naturais, ${ }^{322}$ uma força positiva é representada pelo famoso paisagista e botânico Roberto Burle Marx. Como muitos outros especialistas brasileiros, Burle Marx é mais conhecido fora de

\footnotetext{
${ }^{321}$ A autora refere-se ao bairro como suburb; no texto publicado, torna-se development.

${ }^{322}$ [HRV]: a autora anotou '?' junto a 'naturais'.
} 
... muitas pessoas 0 consideram o maior paisagista desde Le Notre. Antes de Burle Marx, os jardins públicos (ou os grandes jardins particulares) nas regiões tropicais e subtropicais eram uma imitação das Tulherias, inadequada e amarelada pelo sol. Ele alterou esse costume introduzindo, pela primeira vez, uma profusão de plantas e árvores nativas com todas as suas cores exóticas, formatos e texturas, com tanques, [em branco] cascatas, quedas e espelhos d'água, e com rochas verdadeiras em vez de estátuas insípidas ou melodramáticas. Para Caracas, enriquecida com o petróleo, ele está criando um jardim público maior que o Central Park de Nova York; também está trabalhando em projetos públicos no Brasil, numa escala menor.

Uma de suas inovações é o uso de duas variedades de grama, dois tons de verde em padrões geométricos. As calçadas em mosaico do Brasil são famosas, sobretudo as de Copacabana, com ondas em preto e branco paralelas às ondas do oceano. Esse padrão foi copiado dos mosaicos de Lisboa, que relembram o grande terremoto de 1755 e o maremoto subsequente. seu país; muitas pessoas por todo o mundo o consideram o maior paisagista atual. Antes de Burle Marx iniciar seu trabalho, os jardins públicos e os grandes jardins particulares nas regiões tropicais e subtropicais eram uma imitação inadequada e amarelada pelo sol - das Tulherias. ${ }^{323}$ Burle Marx alterou esse costume introduzindo uma profusão de plantas e árvores nativas com todas as suas cores exóticas, formatos e texturas, com tanques, cascatas e quedas d'água, e com rochas verdadeiras em vez de estátuas insípidas ou melodramáticas. Para Caracas, na Venezuela, ele está criando um jardim público; também está trabalhando no projeto de um grande parque no Rio. ${ }^{324}$

Burle Marx inspirou-se ${ }^{325}$ nas famosas calçadas em mosaico da praia de Copacabana, que alinham suas ondas em preto e branco com as ondas verdadeiras. Esse padrão foi adaptado dos mosaicos de Lisboa, construídos após o grande terremoto de 1755 e o maremoto subsequente. Em um novo jardim, Burle Marx repetiu esse padrão em grama clara e escura, uma bela maneira de usar os materiais decorativos mais simples do mundo.

${ }^{323}$ [1962, 1970]: 'Tulherias, o grande parque solene no centro de Paris'.

${ }^{324}$ Na carta aos Editores: “p.99, col. 1, final: NÃO É 'REDESENVOLVIMENTO'! Deve ficar assim: 'Ele está fazendo grandes jardins públicos para Caracas, na Venezuela; também está trabalhando em outro projeto de um grande parque no Rio de Janeiro'.”. A solicitação não foi aceita, mas em [HRV] a autora faz a alteração. [1970]: "Em Caracas ... criou um jardim público; também projetou um grande redesenvolvimento urbano no Rio.”. Trata-se do Parque do Flamengo.

${ }^{325} \mathrm{Na}$ carta aos Editores: “p.99, col. 1, últimas linhas: 'Burle Marx também tirou inspiração de' etc. Isso é horrível. E por que TAMBÉM? Se você não pode usar o meu texto, por favor escreva: 'Uma de suas últimas inovações inspirou-se em...' etc.”. A substituição não foi feita. 
Embora o Brasil não tenha desenvolvido um estilo arquitetônico próprio (como o que surgiu na Nova Inglaterra, por exemplo), sua tradição é antiga e honrosa, e ainda está viva. Olhamos pela janela de um arranha-céu e vemos uma família construindo sua casa com barro e galhos, ou com barro e pedregulhos, com um telhado de palha ou folhas, segundo um modelo de milhares de anos, muito anterior ao descobrimento do Brasil. Essas cabanas e casas, pequenas lojas e bares, idênticas por todo o país, não poderiam ser mais simples nem mais pobres, mas, com sua cor branca - ou caiadas em rosa ou azul-claro, suas janelas pesadas e meiasportas, o efeito é muito agradável. Ao longo do Amazonas é mais comum ver casas feitas de folhas de palmeiras trançadas, ao estilo indígena, que se parecem com belas cestas. Mesmo os barracos nas favelas têm uma beleza melancólica e grotesca.

As grandes casas antigas das fazendas descendem das cabanas clássicas em barro e galhos, apenas em maior escala, com paredes mais grossas para isolar o calor e com os mesmos telhados de sapé, depois de telhas. Elas não são elegantes; não existem vestíbulos, e os quartos se abrem um para $o$
REALMENTE, os brasileiros em geral parecem ter um instinto para a criação de beleza com base nos materiais mais humildes. Casas de pau-a-pique, pequenas lojas e bares com coberturas de palha ou folhas, com paredes ${ }^{326}$ caiadas ou em rosa-claro ou azul-claro e janelas pesadas e meias-portas tudo isso causa um efeito muito agradável. ${ }^{327}$ Ao longo do Amazonas muitas paredes são feitas de folhas de palmeiras trançadas, ao estilo indígena, de modo que elas se parecem com belas cestas de vime. Mesmo as favelas nos morros do Rio e em outras cidades têm uma beleza delicada, embora melancólica. Construídos de velhas tábuas, latas, sacos, bambu e qualquer outro material disponível, os barracos são leves e graciosos, amontoados contra as encostas como ninhos de pássaros, pintados em cores desmaiadas e enfeitados com degraus, escadas, vasos de plantas e as inevitáveis gaiolas. ${ }^{328}$

As antigas casas-grandes das fazendas, construídas a partir do final do século XVI, são quase todas muito bonitas. Adaptações locais das casas de fazenda portuguesas, elas têm plantas simples: os quartos, com pé-direito alto, abrem-se um para o outro, e existem alcovas, ou quartos de dormir, onde as jovens filhas passavam sua vida melancólica. Existia também

${ }^{326}$ [1962, 1970]: 'pau-a-pique com coberturas de palha ou folhas, pequenas lojas e bares com paredes ...'.

${ }^{327} \mathrm{Na}$ carta aos Editores: “p.99, col.2, parágrafo seguinte, linhas 3-7 - foi bem embaralhado. O que eu escrevi foi: 'Essas cabanas e casas, pequenas lojas e bares, idênticos por todo o país, não poderiam ser mais simples ou mais pobres, e no entanto com esse branco-caiado, ou rosa-claro ou azul-claro, suas janelas pesadas e meias-portas, seu efeito é muito agradável'. Se vocês quiserem forçar a ligação desta com a sentença prévia, escrevam: 'Estas cabanas e casas com telhados de palha, feitas com barro e galhos,' etc. etc. Mas, da forma como está, significa algo bem diferente."

${ }^{328}$ [1962, 1970]: 'plantas e gaiolas.'. 
outro. Há os quartos de dormir interiores, escuros, onde as jovens virgens da família ...

... As casas das cidades são semelhantes a elas, apenas menores e mais altas. Mas as fachadas lisas, beirais de pedra e longos telhados inclinados, côncavos (um efeito oriental, proveniente de Macau), são atraentes, como (também de Macau) as filas de telhas ornamentadas nas cumeeiras e os canos para água da chuva, que se abrem como trompetes sobre as calçadas estreitas.

No século XVI Portugal já não tinha mais florestas, e era um país onde se construía com pedras, e parece que não ocorreu aos primeiros que chegaram ao Brasil usar madeira. As igrejas eram semelhantes às casas, e de início ...

... mais antigas têm adros calçados em frente, para as ocasiões em que a congregação era grande demais para caber dentro da igreja; às vezes, esses adros tornaram-se alpendres cobertos. O estilo jesuítico brasileiro floresceu nos séculos XVII e XVIII, e foram construídas centenas de belas igrejas, modestas ou suntuosas: Belém, Recife, Olinda, Bahia (que teria [espaço] igrejas), Rio, São Paulo, e, pouco mais tarde, numa última onda do estilo jesuítico, as igrejas de Minas Gerais. Existem 17 igrejas apenas em Ouro Preto, e uma capela, e quase sempre quarto e sacristia para um padre residente. E havia, sempre, quartos de hóspedes, talvez com a fechadura do lado de fora - pois, embora a hospitalidade fosse obrigatória, também era preciso ser precavido. ${ }^{329}$ As casas mais antigas das cidades são semelhantes a elas, apenas menores e mais altas. Suas linhas sóbrias, detalhes em pedra e longos telhados inclinados dão a elas um ar de solidez, conforto e elegância. A característica concavidade dos telhados é copiada dos edifícios observados pelos portugueses na China e no Japão.

A presença de pedras nas construções veio de Portugal, país em que esse material era de uso tradicional. As primeiras igrejas foram construídas como as casas, e de início as pedras talhadas foram importadas para uso nas fachadas de ambas; depois, surgiram bons entalhadores nativos. As igrejas menores e mais antigas tinham adros calçados ou alpendres cobertos, em frente, para as ocasiões em que havia gente demais. O estilo jesuítico brasileiro, uma forma do barroco, floresceu no final do século XVII e no início do século XVIII, quando foram construídas centenas de belas igrejas, modestas ou suntuosas. Elas surgiram em Belém, Recife, Olinda, Salvador, ${ }^{330}$ Rio e, pouco mais tarde, numa última onda do barroco, em Minas Gerais. Existem treze igrejas apenas em Ouro Preto, e as várias igrejas espalhadas pelas vilas que surgiram com a descoberta do ouro, hoje semidesertas, atestam tanto a riqueza como a devoção dos mineradores. ${ }^{331}$

\footnotetext{
${ }^{329}$ [HRV]: traço junto a 'precavido'.

${ }^{330}$ [1962, 1970]: 'Bahia', referindo-se a 'Salvador'.

331 [1962, 1970]: the mining people (mineradores); no original, 'mineiros', em português.
} 
todas as semidesertas vilas de Minas atestam a riqueza passada e a devoção dos mineiros.

... das igrejas, e às vezes também nas casas dos ricos. Nem sempre confinados ao azul e branco, às vezes em tons de marrom, amarelo e rosa, fachadas inteiras de casas foram cobertas com eles, sobretudo nas cidades do Norte. Esse material foi retomado na arquitetura brasileira contemporânea, e embora ele nem sempre seja usado com muito bom gosto, é uma solução para os sérios problemas de desgaste num clima tropical. ${ }^{332}$

... pela decoração, que se torna mais rica ...

Os escravos construíram suas próprias igrejas, e como o Rosário era sempre um objeto de sua especial devoção, a igreja de "Nossa Senhora do Rosário" - a igreja dos negros - é quase sempre a maior e mais deslumbrante de todas lançando uma estranha luz complementar sobre a instituição da escravidão no Brasil.
Como em Portugal, os azulejos - brancos e azuis desempenharam um papel importante na decoração das igrejas, e às vezes também na decoração das casas dos ricos. Nas cidades, fachadas inteiras foram cobertas com azulejos, não apenas em azul e branco, mas também em marrom, amarelo, rosa e outras cores. $\mathrm{O}$ uso de azulejos nas fachadas dos edifícios foi retomado na arquitetura brasileira contemporânea, e embora os azulejos nem sempre sejam usados com bom gosto, são um excelente material para acabamento num clima tropical.

AS IGREJAS barrocas existentes ${ }^{333}$ por toda a América espanhola são diferentes das brasileiras, simples e sólidas, até mesmo severas, e apenas recobertas pela decoração. A ornamentação torna-se mais rica ao longo do século XVIII, com mais volutas retorcidas, torres mais delicadas e janelas mais extravagantes.

\footnotetext{
${ }^{332}$ No original, esse parágrafo (relacionado aos azulejos) encontra-se depois dos comentários sobre o barroco mineiro.

${ }^{333}[1962,1970]$ : 'barrocas exageradas existentes'.
} 
... da arquitetura desse período é tão anônima como a da Idade Média, mas dois grandes escultores, ambos mulatos, são conhecidos pelo nome.

... Passeio Público (hoje vizinho de um trecho da cidade chamado, por razões óbvias, Cinelândia). A maior parte de suas obras desapareceu e o parque ...

O outro escultor é conhecido, mesmo fora do Brasil, como Aleijadinho, Antonio Francisco Lisboa (17301814), filho de um arquiteto e de uma negra. Acredita-se que Aleijadinho tivesse lepra, uma vez que perdeu ao menos o uso das mãos; mas ele continuou a trabalhar com as ferramentas amarradas aos pulsos. Na mesma época em que os Inconfidentes estavam sonhando com a independência e produzindo sua poesia imitativa árcade em Ouro Preto, Aleijadinho estava produzindo sua arte muito mais importante e original, embora também tardia. Projetos de igrejas, entalhes em madeira e em pedra - são tantas as obras atribuídas a Aleijadinho, que despertam ceticismo -; todavia, seu estilo inconfundível pode ser visto por toda a região de Minas.
Grande parte da arte e da arquitetura dos séculos XVII e XVIII é anônima, ${ }^{334}$ como na Idade Média na Europa, mas dois grandes escultores e arquitetos, ambos mulatos, são bem conhecidos. Mestre Valentim da Fonseca e Silva estudou na Europa e depois de retornar ao Brasil tornou-se empregado do vice-rei. Ele ajudou a projetar o velho Passeio Público, um jardim à beira-mar no Rio. A maior parte de suas obras dispersou-se e o parque foi lamentavelmente reduzido, mas dois maravilhosos jacarés em bronze, que ainda estão lá, são de "Mestre Valentim". O outro escultor, conhecido como Aleijadinho, ${ }^{335}$ foi Antônio Francisco Lisboa, filho de um carpinteiro português e de uma escrava negra. Acredita-se que Aleijadinho tivesse lepra: ele perdeu o uso das mãos, mas continuou a trabalhar com as ferramentas amarradas aos pulsos. Na mesma época em que os Inconfidentes, os revolucionários idealistas de Minas Gerais, estavam sonhando com a independência e produzindo sua poesia imitativa árcade, Aleijadinho estava criando sua arte mais importante e original. * O grande número de obras atribuídas a Aleijadinho - projetos de igrejas, entalhes em madeira e em pedra desperta ceticismo. Todavia, seu estilo inconfundível pode ser visto por toda a região de Minas.

O MATERIAL preferido de Aleijadinho era a pedra-sabão cinza-esverdeada de Minas, de corte fácil, mas que se torna

\footnotetext{
${ }^{334} \mathrm{Na}$ carta aos Editores: “p.100, col. 1, último par., linha 2 - elimine o almost [quase sempre]. Deve ficar 'Grande parte da arte e da arquitetura dos ... é anônima' - almost é outra tautologia”. A alteração não foi feita.

335 Também em inglês: Little Cripple, no original e nas duas edições.

* No original a autora afirma que a arte de Aleijadinho era belated: tardia, ou atrasada em relação ao que se fazia nos países mais adiantados da Europa. Essa observação não consta no texto publicado.
} 
... arroz. Seus últimos e mais famosos trabalhos estão em Congonhas do Campo, os doze Profetas em frente ...
... Brasil. Muitas igrejas se perderam, a começar por aquelas abandonadas após os ataques dos bandeirantes, e novamente após a expulsão dos jesuítas em [em branco].

... ruas. Em 1936, quando a revolução da arquitetura "moderna" se iniciou, houve demolições drásticas, ...

... SPHAN, para tentar salvar tantos edifícios ... mais resistente com o tempo. Ela ainda é muito usada na confecção de vasos e panelas, e os mineiros dizem que não há nada melhor que uma panela de pedra-sabão para cozinhar o arroz. ${ }^{336}$ Os trabalhos mais famosos de Aleijadinho são as estátuas de doze profetas que se encontram na escadaria dupla em frente à igreja de Bom Jesus de Matosinhos, em Congonhas do Campo. Vigorosos e ${ }^{337}$ dramáticos, eles gesticulam diante da igreja branca, com suas portas azul-claro, e do horizonte de montanhas nuas, repletas de minérios.

Ao longo de todo o século XIX vários edifícios sofisticados foram construídos no Brasil, quase sempre adaptações do estilo neoclássico francês. Muitos deles ainda existem. Até o fim do século, os projetos se deterioraram no estilo eclético e espalhafatoso, imitações de mau gosto da arquitetura de todo o mundo.

A apreciação da herança arquitetônica chegou tarde ao Brasil. Muitos edifícios antigos se perderam, a começar pelas missões jesuíticas abandonadas após as expedições de captura de escravos dos séculos XVII e XVIII. Mais tarde, igrejas foram às vezes demolidas para reutilização de seus materiais ou para abrir espaço para o alargamento de ruas. A década de 1930, ${ }^{338}$ quando a revolução da arquitetura moderna se iniciou, foi um período de demolições drásticas, mas viu o [p.101] estabelecimento do Serviço do Patrimônio Histórico e Artístico Nacional, ou SPHAN, que foi organizado para salvar tantos edifícios históricos brasileiros quanto fosse possível. O serviço vem sendo dirigido desde então por um homem, Rodrigo Mello Franco de Andrade, cuja modéstia, cultura e absoluta devoção a uma tarefa quase desanimadora têm sido

\footnotetext{
${ }^{336}$ [HRV]: a autora destaca (possivelmente para eliminar) 'Ela ainda ... o arroz.'.

337 [1962, 1970]: 'Grosseiros, mas vigorosos e ...'.

${ }^{338}$ Na carta aos Editores: "p.100, últimas linhas, e no alto da p.101. Eu disse 1936, que é perfeitamente correto. Se vocês têm de alterar isso para 'Os anos 30' - Mas POR QUÊ? - você vai ter de alterar was para were e it para they. Substantivo no plural e verbo no singular". A alteração não foi feita (a não ser nesta nossa tradução).
} 
... para tais projetos, e o povo é indiferente, ignorante e, como em todo lugar, rancoroso diante de interferências na propriedade privada.

Havia um bom arquiteto na Comissão Francesa convidada por João VI, Grandjean de Montigny, o primeiro professor de arquitetura na Academia Imperial. Muitos de seus edifícios, em estilo neoclássico francês, foram destruídos, mas sua influência pode ser vista em muitos edifícios do século XIX. As grandes casas nobres do início do século XIX, em estilo francês, decaíram, passando pelo nível de pensões, até o de cortiços. Pitorescas e miseráveis, abrigando inúmeras famílias, elas são conhecidas como "cabeças-de-porco" - áreas residenciais apenas um degrau acima dos barracos nas favelas.

Do estilo delicadamente balanceado e bem proporcionado de Montigny, o Brasil caminhou quase sem desvios para o horrível estilo neobarroco de edifícios públicos, tão comum por toda parte no mundo que quase passa despercebido.

O Art Nouveau também chegou ao Brasil, mas por um breve período. E então, no início do século XX, os muito ricos começaram a deixar corajosas e admiráveis. Existe muito pouco dinheiro disponível para tais projetos, e o brasileiro médio, como sua contraparte em qualquer outro país, é indiferente, ignorante ou 339 rancoroso diante de qualquer interferência na propriedade privada. É natural que os habitantes de um remoto vilarejo prefiram um novo posto de gasolina a uma fonte do século XVIII.

Embora o Brasil tenha construído belos edifícios desde seus primeiros dias, produziu muito pouca pintura notável até o século XX. Algumas das obras que sobreviveram nos tetos de igrejas são de alta qualidade, mas interessam apenas aos especialistas. Recife, sob o domínio holandês no século XVII, teve seu Frans Post, que em sua estada brasileira produziu paisagens leves e que ainda parecem familiares, e depois passou longos anos na Europa, pintando imitações delas. Com a Missão Francesa em 1816 vieram ilustradores de cenas de gênero - que mostram a vida cotidiana - e os mais notáveis entre eles foram Jean-Baptiste Debret e Nicolas Antoine Taunay. Eles e outros nos legaram grande quantidade de estudos fascinantes e detalhados de escravos, vestes, cenas de rua e edifícios do século XIX. A pintura de cavalete ${ }^{340}$ do século XIX é um monótono desperdício de realísticoromânticos bandeirantes, garotas escravas e cerimônias da corte, e paisagens que mais parecem lembrar a França ou a Inglaterra que o Brasil. Foi apenas com pintores como Cândido Portinari, Lasar Segall e Emiliano di Cavalcanti, no século $\mathrm{XX}$, que a pintura brasileira adquiriu vida.

\footnotetext{
${ }^{339}$ [HRV]: '!' junto a 'ou'; manuscrito ilegível.

340 [1962, 1970]: 'Mas a maior parte da pintura de cavalete ...'. Na carta aos Editores: “p.101, $2^{\circ}$ par., linha 17. MAS agora está errado por causa da interpolação. A sentença deveria ser 'a pintura de cavalete do século XIX, no entanto, é' etc... Por favor, elimine 'a maior parte'.”. A alteração não foi feita.
} 
suas fazendas e a construir suas casas na cidade, para agradar seus gostos sempre independentes, de castelos normandos a catedrais góticas e a banhos turcos, muitas vezes enfeitados com cópias das estátuas romanas que copiavam as gregas. Uma famosa mansão gótica (escura e dotada de ameias) é muito conhecida como "o dente podre". ${ }^{341}$ É de se esperar que algumas dessas monstruosidades interessantes sobrevivam e não sejam todas demolidas na ânsia por "Ordem e Progresso".

Até o presente século não há muito a ser dito acerca da pintura no Brasil. Mauritzstad teve seu Franz Post, que produziu paisagens leves e que ainda parecem familiares, durante sua estada no Brasil, e depois passou longos anos na Europa, pintando imitações delas. Com a Missão Francesa começaram a chegar os ilustradores de cenas de genre: Debret, Rugendas, Ribeirolles, e depois Ender, que nos deixaram volumes de estudos fascinantes e detalhados de escravos, vestes, cenas de rua e edifícios do século XIX. Parte das pinturas de igreja que sobreviveram é de grande qualidade, mas interessa apenas aos especialistas. Mas a pintura de cavalete do século XIX é um monótono desperdício de realísticoromânticos bandeirantes, garotas escravas, cerimônias da corte e paisagens que mais parecem lembrar a França ou a Inglaterra que o Brasil.

${ }^{341}$ Segundo o arquiteto e professor Hugo Segawa (em e-mail de 3 mar. 2008), a autora certamente se refere à mansão do milionário italiano Martinelli, situada na av. Osvaldo Cruz (Flamengo), projetada pelo arquiteto Antônio Virzi. A mansão foi demolida na década de 1970. 
Apenas com o surgimento de pintores como Emiliano Di Cavalcanti e Cândido Portinari se pode dizer que a pintura brasileira adquiriu vida própria.

Quando chega ao Brasil pela primeira vez, um estrangeiro - se ele estiver familiarizado com elas - ficará chocado com a semelhança entre $o$ cenário brasileiro e as primeiras pinturas de Portinari: os morros verdes redondos, quase cônicos, as negras carregando trouxas na cabeça, como formigas com seus ovos, as crianças jogando futebol, os cemitérios abandonados, estéreis mesmo detalhes como pipas, balões, e o jeito como o onipresente guarda-chuva é usado, dependurado na parte traseira da gola - tudo isso está nos primeiros trabalhos de Portinari.

Hoje, o movimento abstrato triunfa, acompanhado por uma importação antiquada e desanimadora, chamada "concretismo". (Este também foi produzido por alguns jovens poetas, cujos poemas lembram Eugene Jolas e a revista parisiense Transition, dos anos 20.) Os japoneses, entre os quais se destaca
AS PRIMEIRAS pinturas de Portinari são sobre as regiões ${ }^{342}$ cafeeiras no sul do Brasil. Existem os montes vermelhos como sangue, os cafeeiros verde-escuros, as negras carregando latas d'água na cabeça e as crianças jogando futebol. Ele também fez ${ }^{343}$ murais para edifícios públicos nos Estados Unidos. ${ }^{344}$

$\mathrm{Na}$ pintura brasileira atual o movimento abstrato triunfa, acompanhado por uma escola menos importante chamada neoconcretismo. 345 Entre os melhores abstracionistas estão Aloísio Magalhães ${ }^{346}$ e Iberê Camargo. Os nipo-brasileiros, entre os quais se destaca Manabu Mabe, têm trazido contribuições para o movimento abstrato, embora sejam mais próximos do estilo caligráfico oriental. Os

${ }^{342}$ [1962, 1970]: ‘são uma notável reflexão sobre as regiões ...'; [HRV]: além de eliminar esse trecho, a autora inclui '?' junto a futebol.

343 [1970]: 'Pouco antes de sua morte, em 1962, ele também fez ...'.

${ }^{344} \mathrm{Na}$ carta aos Editores: "Último par.: O que eu disse foi 'os morros verdes e redondos, quase cônicos, as mulheres negras carregando trouxas brancas na cabeça, como formigas com seus ovos, as crianças jogando futebol, os cemitérios estéreis, degradados - mesmo detalhes como pipas, balões, e o modo como o onipresente guarda-chuva é usado, dependurado na parte traseira da gola.... Seguramente isso é melhor que a sua versão. E quanto à transição? - Vocês não podem dizer 'jogando futebol. Ele também fez murais para edifícios...' etc. - Eliminar, ou abrir novo parágrafo". As alterações não foram feitas.

345 [1970]: 'abstrato domina, acompanhado por certos movimentos recentes tais como op e pop art'.

${ }^{346} \mathrm{Na}$ carta aos Editores: "p.101, col 2. Aloísio Magalhães agora está fora de lugar. Lembro-me de ter corrigido isso satisfatoriamente em Nova York". A alteração não foi feita. [HRV]: a autora anota 'X' junto ao nome. Desde 1960, Magalhães (1927-1982) dedicava-se predominantemente ao desenho industrial e gráfico. 
Manabu Mabe, têm trazido contribuições para o movimento abstrato, embora mais em seu estilo caligráfico oriental do que no estilo dos pintores de "ação" do Ocidente. Os melhores trabalhos atuais parecem ser em preto e branco. Existe no mínimo meia dúzia de bons gravadores em madeira e pedra: Fayga Ostrower, Roberto De Lamonica, Edith Behring, Anna Letycia; tipógrafos e pintores como Aloysio Magalhães.

A Bienal de São Paulo, iniciada em 1951 por Francisco Matarazzo, tornouse uma instituição como a Bienal de Veneza. Embora alguns tenham dúvidas acerca da reunião de mais de 4 mil obras de arte ao mesmo tempo, ela sem dúvida estimulou muito a pintura brasileira com seus muitos prêmios, bolsas para viagens de estudos e oportunidades que oferece para aqueles que não podem viajar, ...

... Os preços estão subindo, os colecionadores estão colecionando, e novas galerias estão sendo inauguradas num intervalo de poucas semanas, parece, em todas as grandes cidades.

A música "formal" ou "sofisticada" - é difícil saber qual o melhor termo a usar é um assunto complexo, embora o conjunto de obras não seja grande. Existem influências indígenas, melhores trabalhos atuais parecem ser em preto e branco. Existe no mínimo uma dúzia de bons gravadores em madeira e pedra, como Fayga Ostrower, Roberto De Lamonica, Edith Behring, Anna Letycia Quadros e Maria Bonomi.

$\mathrm{O}$ maior estímulo à arte nos últimos tempos foi a Bienal de São Paulo, uma grande exposição montada todos os anos ímpares desde 1951 e inspirada em sua similar de Veneza. Embora alguns critiquem o fato de se reunirem mais de 4 mil obras de arte, a exposição, patrocinada e promovida pelo industrial paulista Francisco ("Ciccillo") ${ }^{347}$ Matarazzo, sem dúvida vem dando impulso considerável à pintura brasileira, graças aos seus vários prêmios e às oportunidades que oferece, aos que não podem viajar, ${ }^{348} \mathrm{de}$ ver em primeira mão, e pela primeira vez, o que está sendo feito no resto do mundo. Hoje existe um verdadeiro boom de pintura no Brasil. Os preços estão subindo, e novas galerias parecem surgir em ${ }^{349}$ intervalos de poucas semanas, em todas as grandes cidades.

A MÚSICA sofisticada, também, teve um lento desenvolvimento no Brasil, e o conjunto de obras não é grande. Ela sofre influências indígenas, africanas e portuguesas, direta ou indiretamente originárias da enorme

347 [1962, 1970]: grafado 'Cicillo', e não o correto 'Ciccillo' (Francisco Matarazzo Sobrinho).

${ }^{348}$ Literalmente, for those who have to stay at home [para aqueles que têm de ficar em casa].

349 [1970]: 'do mundo. Durante a década de 1960 houve um boom na pintura brasileira. Os preços subiram e novas galerias foram inauguradas em'. 
africanas (e várias africanas, diferentes) e portuguesas nas obras, diretamente ou não, na surpreendente variedade de música popular. Os

Braganças, amantes da música, tinham compositores e instrumentistas na sua corte; os jesuítas tinham suas óperas sacras e sua música processional, das quais derivaram muitas das formas populares atuais. Há pouco tempo, uma grande coleção de música litúrgica do final do período barroco foi descoberta em Minas, e está sendo transcrita e gravada, e, sem dúvida, muito mais material ainda será descoberto e vai ajudar a completar alguns dos longos períodos de silêncio na história da música brasileira.

O principal nome da música brasileira do século XIX é Carlos Gomes, que foi favorecido durante toda a vida por D. Pedro II. Infelizmente, sua educação europeia é hoje considerada responsável pela diluição dos seus talentos naturais. Sua mais famosa ópera, $O$

Guarani, baseada na obra romântica de José de Alencar sobre um nobre índio guarani, teve considerável sucesso em 1870 , embora tenha sido cruelmente chamada de "a melhor obra de Meyerbeer". O salão de baile do grande teatro de ópera de Manaus, semiabandonado, é decorado variedade da música folclórica. Os jesuítas tinham sua música sacra, da qual muitas formas populares derivaram, e a chegada da Casa Portuguesa de Bragança, em 1808, trouxe um forte estímulo à música brasileira. O príncipe-regente, D. João, encantou-se com as composições sacras do padre mulato José Maurício Nunes Garcia, e os compositores de sua corte também enriqueceram a vida musical da capital. Uma grande coleção de música do final do período barroco foi descoberta há pouco em Minas, e agora está sendo transcrita e gravada. Sem dúvida, muito mais material ainda será descoberto. Se e quando ele vier a público, deverá ajudar a completar os longos períodos de silêncio na história da música brasileira. ${ }^{350} 351$

O principal nome da música brasileira do século XIX é Carlos Gomes. ${ }^{352}$ Favorecido durante toda a vida por D. Pedro II, que o enviou à Itália para completar sua educação musical, Gomes tinha um talento natural que hoje se sabe ter sido diluído pelo excesso de influências italianas. ${ }^{353}$ Sua mais famosa ópera - embora não seja a melhor - é Il Guarany, baseada na obra romântica de José de Alencar sobre um nobre índio guarani. Ela teve uma estreia espetacular em Milão, em 1870, e Gomes distingue-se por ter sido o primeiro músico do Novo Mundo aceito pela Europa como um compositor "maduro". O foyer do grande teatro de ópera de Manaus, hoje semiabandonado, é ${ }^{354}$ decorado por um mural com uma cena

\footnotetext{
${ }^{350} \mathrm{Na}$ carta aos Editores: "p.102, col.1: Por que não deixar como eu tinha escrito?: ‘ajuda a completar os longos silêncios na história da música brasileira.' - help certamente implica some, portanto some é outra tautologia". A alteração não foi feita.

351 ILUSTRAÇÃO: Xilogravura de Maria Bonomi.

${ }^{352}$ Na carta aos Editores: "Par. 2: Por que não deixar como eu tinha escrito?: 'O único grande nome ... é Carlos Gomez'. Certamente deve ser tempo presente, ele ainda é”. A alteração não foi feita. Note-se que a autora sempre grafa 'Gomez', e o erro só foi corrigido na edição de 1970.

${ }^{353}$ [HRV]: a autora elimina 'influências italianas', mas não propõe substituto.

354 [1970]: 'Manaus, hoje restaurado, é'.
} 
com cenas do Guarani, e bife-stek Carlos Gomes ainda consta nos menus dos restaurantes de Manaus.

O melhor compositor contemporâneo é Heitor Villa-Lobos. Ele era melódico, prolífico e fluente, talvez fluente demais, e fez pleno uso da riqueza das tradições musicais portuguesas, africanas, indígenas e populares; suas

Bachianas e o Ciclo

Brasileiro são bem conhecidos fora do Brasil. Villa Lobos também organizou um manual para uso nas escolas (usando velhas canções e jogos cantados como exemplos), Guia Practica, que é considerado um modelo do que esses livros devem ser.

$\mathrm{O}$ "poeta" é uma figura especial no Brasil, de maneira alguma parecida com a figura desconhecida e não lida ${ }^{359}$ que tem esse nome nos Estados Unidos. Existe uma longa tradição nos países latinos, tanto do Velho como do Novo Mundo, de poetas nos Ministérios de Relações Exteriores, como vice-cônsules, cônsules ou embaixadores. No Brasil do Guarany, e "bife-stek Carlos Gomes" ainda consta nos menus dos restaurantes da cidade.

O mais renomado compositor contemporâneo brasileiro é ${ }^{355}$ Heitor Villa-Lobos, falecido em 1959. Seu estilo é rítmico e melódico, e em suas numerosas óperas, sinfonias, concertos e outras obras ele faz pleno uso da riqueza das tradições musicais portuguesas, africanas, indígenas, folclóricas e populares. Suas Bachianas Brasileiras, contrapontísticas, e seus Choros, de influência popular, são apresentados frequentemente fora do Brasil. ${ }^{356}$ Villa-Lobos também ${ }^{357}$ organizou um manual para uso nas escolas públicas. Intitulado Guia Prático, ${ }^{* *}$ usa canções folclóricas e jogos cantados como exemplos e é considerado um livro escolar modelo. Outros compositores contemporâneos importantes ${ }^{358}$ são Camargo Guarnieri e Francisco Mignone.

O poeta é uma figura especial no Brasil, de maneira alguma parecida com a figura que tem esse nome nos Estados Unidos. Existe uma longa tradição nos países latinos, tanto europeus como americanos, de poetas servindo como vicecônsules, cônsules ou embaixadores. No Brasil a palavra "poeta" é hoje um termo de apreço. Um homem pode dirigirse afetuosamente a um amigo, seja este engenheiro ou político, chamando-o de "meu poeta". Talvez esse costume

\footnotetext{
" Em carta a Robert Lowell (22 abr. 1960), escrita logo após sua viagem a Manaus, a autora comenta: "Nunca ouvi $O$ guarani e desconfio de que seja ruim - mas no menu havia 'Bifstek Carlos Gomes' todos os dias" (Bishop, 1995, p.414).

355 [1970]: 'O jazz norte-americano influenciou a música contemporânea brasileira; ele contribuiu para a criação da Bossa Nova, um estilo de cunho jazzístico, pontuado por ritmos percussivos de samba. O mais ... brasileiro erudito é'. Em 1970 consta serious.

356 [VAS]: a própria autora substituiu 'populares' por 'bem conhecidos'. [1962, 1970]: 'apresentados frequentemente'.

${ }^{357}$ [1970]: 'populares. Villa-Lobos também'

** A autora grafa 'Guia Practica', provavelmente supondo que 'guia' seja feminino. Corrigido na publicação.

358 [1970]: 'compositores importantes'.

359 [VAS]: a própria autora eliminou o comentário 'usualmente não bem-vinda', relacionado à figura do poeta nos Estados Unidos.
} 
também, a palavra "poeta" é hoje um termo de apreço.

Mas, a despeito desse carinho associado à ideia de o poeta ser um homem com charme especial e privilégios, ele, a menos que esteja empregado no Ministério de Relações Exteriores, tem uma vida profissional ainda mais difícil que a de seus pares nos Estados Unidos. Escrever é uma atividade muito mal paga, e não existem fellowships e prêmios, apenas alguns empregos acadêmicos, comparados aos milhares que, nos Estados Unidos, fornecem uma renda regular para os escritores, tanto os de poesia como os de prosa. $\mathrm{O}$ escritor tem de ser médico, advogado, engenheiro ou jornalista profissional; o jornalismo toma o lugar ocupado pelo ensino nos Estados Unidos, e com um efeito enfraquecedor. Existe falta de boas revistas, especializadas ou não. Todo jornal tem sua página literária semanal, às vezes até mesmo diária, e é lá que se deve procurar o novo bom poema, $\mathrm{o}$ artigo ou conto original, meio perdido entre as discussões intermináveis, repetidas sem entusiasmo, sobre Baudelaire ou Valéry, sobre Tomás de Aquino e G. K. Chesterton, e traduções de Graham Greene ou Mauriac. seja um resquício dos dias em que todos os homens educados escreviam poesia; a escrita de poesia é, sem dúvida, mais comum entre os brasileiros que entre os norte-americanos.

Mas, a despeito do carinho associado à ideia de o poeta ser um homem com charme especial e privilégios, os escritores no Brasil, a menos que estejam empregados em algum departamento governamental, têm uma vida ${ }^{360}$ ainda mais difícil que a de seus pares nos Estados Unidos. Escrever é uma atividade muito mal paga, e existem poucos prêmios e fellowships. * Existem apenas alguns empregos acadêmicos, comparados aos milhares que, nos Estados Unidos, fornecem uma renda regular para os escritores, tanto os de poesia como os de prosa. O escritor no Brasil tem de ser médico, advogado, engenheiro ou jornalista. São poucas as revistas, especializadas ou não, ${ }^{* *}$ de boa qualidade. Todo jornal tem sua página literária semanal ou diária, e é lá que se deve procurar o novo poema, o conto original ou o artigo bem escrito, meio perdido entre ensaios sobre teoria política e econômica ou teologia, e discussões intermináveis sobre Baudelaire ou Valéry, Santo Tomás de Aquino, G. K. Chesterton ou William Faulkner. ${ }^{361}$

\footnotetext{
${ }^{360}$ [1962, 1970]: "têm profissionalmente uma vida".

* Bolsas de estudos concedidas por universidades, para desenvolvimento de pesquisas.

** Em inglês, magazines e reviews, respectivamente. Ou seja, as revistas especializadas [as reviews] e as demais.

361 [1962, 1970]: "sobre os poetas franceses Charles Baudelaire ou Paul Valéry, o filósofo Santo Tomás de Aquino, o ensaísta G. K. Chesterton e as narrativas de William Faulkner”.
} 
A língua portuguesa é uma barreira entre os escritores brasileiros e o público que eles merecem. Pois [em branco] americanos que estudam espanhol [em branco] estudam português. Mais traduções podem remediar essa situação no caso da prosa, mas a poesia é quase impenetrável à tradução, e é uma pena permanecermos ignorando grandes poetas contemporâneos como Manuel Bandeira (o patrono da poesia brasileira), Carlos Drummond de Andrade, Cecília Meireles, Jorge de Lima, Vinícius de Morais (autor do libreto para a ópera em que se baseou o conhecido filme Orfeu negro) e João Cabral de Melo Neto, provavelmente o melhor da geração posterior a Bandeira, o qual escreveu poemas de grande sensibilidade sobre os flagelados do Nordeste.

No Brasil, alguém que tenha sido criado como católico, ao modo usual, e deixa a Igreja, quando retorna é chamado de "convertido". Com algo desse mesmo sentido de conversão, o Brasil está agora redescobrindo os valores de sua mais antiga literatura provincial, romântica e humorística, assim como fizemos ao recuperar nossos Hawthornes e Twains, embora nunca na nossa escala estupenda e cara. Mesmo considerando as
A língua é, obviamente, uma barreira entre os escritores brasileiros e o público internacional que eles merecem. Mais traduções podem remediar essa situação no caso da prosa, mas a poesia é quase impenetrável à tradução bem-sucedida, e é uma pena que a maior parte do mundo permaneça ignorando grandes poetas contemporâneos como Manuel Bandeira ${ }^{362}$ (o patrono dos poetas brasileiros do século XX), Carlos Drummond de Andrade, Cecília Meireles, Jorge de Lima, Vinícius de Morais (autor da peça teatral em que se baseou o filme Orfeu negro) e João Cabral de Melo ${ }^{363}$ Neto, provavelmente o melhor da presente geração. Ele escreveu poemas de grande sensibilidade sobre os flagelados, ${ }^{364}$ como são chamadas as pessoas do Nordeste castigado pela seca. ${ }^{365}$

Em literatura, o Brasil está redescobrindo alguns dos seus primeiros escritores. Os escritores brasileiros podem ser divididos de modo grosseiro entre aqueles que olhavam para a Europa, a tradição e a "correção", e aqueles que eram atraídos pela natureza selvagem, pelos índios e pelo regional. Às vezes, como na literatura dos Estados Unidos, as duas correntes estão estranhamente entrelaçadas. ${ }^{366}$

\footnotetext{
362 [1962]: 'Bandiera', corrigido em 1970. No original, correto.

363 [1962]: 'Mello', corrigido em 1970. No original, correto.

364 Também em inglês, como beaten ones, derrotados.

365 [1970]: "como a falecida Cecilia Meireles e Jorge de Lima, o também falecido Manuel Bandeira (o patrono dos poetas brasileiros do século XX), Carlos Drummond de Andrade e João Cabral de Melo Neto, provavelmente o melhor de sua geração. Vinícius de Morais, outro ótimo poeta, é também o autor da peça em que se baseou Orfeu negro, o mais conhecido da série de filmes recentes que trouxeram renome internacional para os realizadores brasileiros.".

${ }^{366}$ [1970]: estão entrelaçadas.
} 
inevitáveis diferenças, quase toda a literatura brasileira nos é simpática: um colono compreende o outro. Com toda a sua ingenuidade, religiosidade (sermões e mais sermões) e sentimentalidade - ela tem muitas das características da literatura de nossos primeiros trezentos anos. E assim como a literatura norte-americana foi dividida entre "caras pálidas" e "peles-vermelhas", também a brasileira foi dividida, do mesmo modo grosseiro, entre a da cidade e a do campo, aqueles que olhavam para a Europa, a tradição e a "correção", e aqueles que eram atraídos pela natureza selvagem, pelos índios e pelo regional, e sentiam que apenas novas formas poderiam ser usadas para a experiência de um novo país. Às vezes, como em nossa literatura, as duas correntes estão estranhamente entrelaçadas.

Os poetas inconfidentes falavam de cupidos e cisnes e de uma fauna não-brasileira. Vejam-se alguns versos do melhor deles, Tomás Antônio Gonzaga, que Manuel Bandeira cita em sua Antologia dos poetas brasileiros da fase romântica. Gonzaga dirige-se ao seu grande amor, Marília de Dirceu:
OS POETAS da Inconfidência Mineira falavam de criaturas não brasileiras, ${ }^{367}$ como cupidos e cisnes. Vejam-se alguns versos do melhor deles, Tomás Antônio Gonzaga, que ainda hoje evocam o Brasil rural da mesma maneira como o faziam quando foram escritos, quase duzentos anos atrás:

\footnotetext{
${ }^{367}$ Na carta aos Editores: "p.103, col. 1, $3^{\circ}$ par. Eu escrevi 'fauna não brasileira', não 'criaturas'. Não é,
} seguramente, uma palavra forte demais?". A alteração não foi feita. Manteve-se, aqui, a opção dos editores. 
Não verás separar ao hábil negro

do pesado esmeril a grossa areia;

e já brilharem os granetes de ouro no fundo da bateia.

Não verás derrubar os virgens matos, queimar as capoeiras inda novas, servir de adubo à terra a fértil cinza, lançar os grãos nas covas.

Não verás enrolar negros pacotes das secas folhas do cheiroso fumo: nem espremer entre as dentadas rodas da doce cana o sumo. ... 368
You shall not see the skillful Negro

Separate the heavy emery from the coarse sand,

And the nuggets of gold already shining, In the bottom of the "bateia."

You shall not see the virgin forest destroyed,

Nor the burning of the still green underbrush

To fertilize the ground with ashes,

Nor the seeds being sown in the furrows.

You shall not see them rolling the black packets

Of dry leaves of fragrant tobacco,

Nor pressing out the sweet juice of the cane

Between the cog-wheels. ...
Esse é um raro momento de realismo e precisão, tão representativo do Brasil rural hoje como na época em que foi escrito. A bateia é um recipiente de madeira usado para separar o ouro. Ainda é usada, assim como o sistema destruidor de roçar e queimar, nas fazendas. O tabaco, fumo, ainda é vendido em rolos negros e longos nos mercados, e ...

As duas características mais notáveis dos poetas românticos brasileiros são suas saudades e seus sentimentos antiescravagistas. O fato de serem todos enviados a Coimbra para estudar tem algo a ver com a primeira. Eles sentiam falta da vida confortável e descompromissada dos jovens cavalheiros brasileiros e sofriam de saudades do lar tão agudas como os estudantes brasileiros sentem hoje na Boston "Tech" ou na Sorbonne, ou em Heidelberg.
Esse é um raro momento de realismo precoce e de precisão. A bateia é um recipiente de madeira ${ }^{369}$ em que o ouro é separado. Ainda é usada, e nas fazendas persiste o sistema destruidor de roçar e queimar. O tabaco ${ }^{370}$ continua sendo vendido em rolos negros e longos nos mercados brasileiros, e o caldo-de-cana, que mais parece um xarope doce, aguado e esverdeado, ainda é uma bebida popular.

Duas das mais notáveis características dos poetas românticos brasileiros do século XIX são suas eternas saudades e seus sentimentos antiescravagistas. Antônio Gonçalves Dias, um dos maiores românticos, escreveu a "Canção do Exílio" quando estudava em Portugal: "Minha terra tem palmeiras/ Onde canta o sabiá/ As aves que aqui gorjeiam/ Não gorjeiam como lá”. ${ }^{371}$ Casimiro de Abreu ecoou: "Se eu tenho de morrer na flor dos anos/ Meu Deus! Não seja já/ Eu quero ouvir na laranjeira, à tarde/ cantar o sabiá!". 372

\footnotetext{
${ }^{368}$ Tomás Antonio Gonzaga: "Tu não verás, Marília, cem cativos" (trecho). Apenas em inglês.

${ }^{369}$ Em português. Segundo o Dicionário Houaiss, bateias também são feitas em metal.

${ }^{370}$ [VAS]: também em português, 'fumo', junto a tobacco.

${ }^{371}$ Apenas em inglês: "My country has palm trees/ Where the sabia sings/ The birds don't warble here/ The way they do there".

372 Apenas em inglês: "If I must die in the flower of my youth/ My God, let it not be now!/ I want to hear the sabia sing/In the evening, in the orange tree!".
} 
Gonçalves Dias (1823-1864), um dos maiores românticos, é responsável pela "Canção do Exílio", o "My country, 'tis of thee" do Brasil: "

O sabiá, parecido com um tordo corpulento, é para a poesia brasileira o mesmo que o rouxinol para a poesia inglesa. Carlos Gomes usa seu canto no interlúdio da ópera $O$ Escravo; a literatura brasileira está repleta de sabiás.

Castro Alves (1847-1871)

foi o mais famoso poeta abolicionista. Seu longo poema dramático, "O navio negreiro", foi apresentado em forma de jogral no ano passado, no Rio e em São Paulo, e passou pelo teste de maneira muito satisfatória. Mesmo versos como [citação] recobraram importância e sua dignidade, depois de cem anos.

As duas maiores personalidades da literatura brasileira escrevem prosa, e, felizmente, os dois estão disponíveis, ao menos em parte, em inglês. O primeiro, Joaquim Maria Machado de Assis (1839-1908), é o maior escritor que o continente sulamericano produziu; alguns
O sabiá, parecido com um tordo corpulento, é para a poesia brasileira o mesmo que o rouxinol para a poesia inglesa. ${ }^{373}$ Carlos Gomes usa seu canto no interlúdio da ópera Lo Schiavo, e a literatura brasileira do século XIX está repleta de sabiás.

O mais famoso poeta abolicionista brasileiro foi Antônio de Castro Alves. Versos de seu longo poema dramático intitulado "O navio negreiro" 374 conservam a importância e a dignidade até hoje: "Existe um povo que a bandeira empresta/ P'ra cobrir tanta infâmia e covardia!.../ Meu Deus! Meu Deus! Mas que bandeira é esta?". 375

A DESPEITO da importância relacionada aos poetas e à poesia, as duas maiores personalidades da literatura brasileira escrevem prosa. Felizmente, obras dos dois estão disponíveis em inglês. O mais antigo deles, Joaquim Maria Machado de Assis, é talvez o maior escritor que a América do Sul já produziu; alguns críticos o consideram um dos maiores das

\footnotetext{
* Canção patriótica norte-americana, também conhecida como "America”, com letra do Rev. Samuel F. Smith (1831) sobre a música do hino nacional britânico ("God save the King/Queen”). Note-se que esse hino foi escrito por um estudante de teologia buscando "criar um hino nacional que permitisse ao povo norteamericano agradecer a Deus por seu país maravilhoso". Esse hino ganhou uma adaptação no Brasil em 1910, "Do meu país Brasil, ó terra varonil, é meu cantar".

373 [1962, 1970]: 'para o verso inglês'. Na carta aos Editores: “p.103, col. 2, $2^{\circ}$ par., linha 15. 'O sabiá... etc., é para a poesia brasileira o mesmo que o rouxinol para a poesia inglesa'. Por favor, repita a palavra 'poesia' aqui. CASO CONTRÁRIO, O SENTIDO SERÁ DIFERENTE”. Esse ponto provocou uma discussão entre a autora e os editores. Veja-se carta a May Swanson (10 abr. 62, em Bishop, 1995, p.715): “Quando ele mudou, na p.103, a segunda ocorrência da palavra poetry [poesia] para verse [verso] e me mandou um telegrama dizendo que não havia nenhuma diferença - desisti, e desde então não nos comunicamos".

${ }^{374}$ Apenas em inglês: "The Slave Ship".

375 Apenas em inglês: "Exists a people whose banner serves/ To hide such infamy and cowardice! .../ My God, My God, what a flag is this?”. [HRV]: '(cut)', talvez referindo-se à citação.
} 
críticos o consideram o maior dos dois continentes americanos, equiparando-o ao nosso Henry James. Filho de um pobre pintor de paredes negro e de uma portuguesa, nascido no Rio num dos morros hoje cobertos pelas favelas, ele trabalhou como tipógrafo e jornalista, casouse com uma portuguesa de classe média e publicou livros e livros de poemas, contos e romances. Tornou-se famoso, era muito respeitado e respeitável, e em 1897 fundou a Academia Brasileira de Letras, a qual presidiu até sua morte.

... romantismo. Seus melhores livros são Memórias póstumas de Brás Cubas (publicado em inglês sob o título The Diary of a Small Winner), Dom Casmurro, Quincas Borba e alguns de seus contos. Embora o período seja sempre a parte final do Império, e o cenário seja o Rio de Janeiro, o mundo de Machado de Assis é universal e suas personagens são reais - assim como a São Petersburgo de Tolstói é universal e Natasha não é apenas uma garota russa. duas Américas, equiparando-o ao norte-americano Henry James. Nascido em 1839 num dos morros que circundam o Rio de Janeiro, filho de um pobre pintor de paredes negro e de uma portuguesa, Machado de Assis trabalhou como tipógrafo e jornalista, casou-se com uma portuguesa de classe média e publicou ${ }^{376}$ poemas, contos e romances. Tornou-se famoso e era muito respeitável e respeitado, ${ }^{377}$ e em 1897 fundou a Academia Brasileira de Letras, a qual presidiu até sua morte, onze anos depois.

Machado de Assis é um escritor profundamente pessimista, cético e reservado; em seu estilo existe pouco da retórica latina e nada de seu romantismo. Entre seus melhores livros estão Memórias póstumas de Brás Cubas (publicado em inglês sob o título Epitaph of a Small Winner), ${ }^{378}$ Dom Casmurro, Quincas Borba ${ }^{379}$ e alguns de seus contos. Embora o período descrito por ele seja sempre a parte final do Império e o cenário seja a cidade do Rio de Janeiro, o mundo de Machado de Assis é universal e suas personagens são pessoas reais.

\footnotetext{
$376 \mathrm{Na}$ carta aos Editores: "p.103, col. 2, final - Por favor, elimine over the years [ao longo dos anos] naturalmente foi ao longo dos anos". A alteração não foi feita. [1962, 1970]: "classe média e ao longo dos anos publicou'.

${ }^{377}$ [1962, 1970]: 'era muito respeitado, e ...'.

378 [VAS]: a autora cita "Diary”, e não "Epitaph”, o correto.

379 [1970]: inverte-se a ordem de Dom Casmurro e Quincas Borba (certamente para seguir a ordenação temporal), e surge o título da versão inglesa de Quincas Borba: 'Philosopher or dog?'.
} 
O outro grande escritor de prosa, Euclides da Cunha, é o autor de um dos livros mais estranhos já escritos, Os sertões (publicado em inglês como Rebellion in the Backlands). Euclides da Cunha era engenheiro militar; seu livro é um relato de uma expedição militar formada em 1896 contra um fanático religioso, Antônio Conselheiro, "O Conselheiro", que se havia refugiado com todos os seus seguidores na pequena vila de Canudos, no sertão do estado da Bahia. Eles conseguiram repelir durante um ano os repetidos ataques dos regimentos brasileiros. $\mathrm{O}$ livro contém crônicas de fúteis manobras militares, secos relatos de sofrimentos e atrocidades (que remetem à famosa retirada em [em branco], ${ }^{*}$ de Hemingway), e também uma longa rapsódia geográfica. Toda a primeira parte, embora não seja um romance, faz pelos sertões o mesmo que o Ulisses de James Joyce faz pela cidade de Dublin. Quem quiser sentir a vida e a paisagem brasileiras em seus melhores e piores aspectos, mais grandiosos e mais desesperados, deve ler $O s$ sertões. O livro lembra uma igreja brasileira - planejada de maneira sólida e quase tosca, mas recoberta por uma profusão de ricos ornamentos e estranha vida, a ponto de ser repulsiva.
O OUTRO grande escritor, Euclides da Cunha, é o autor de um dos livros mais estranhos já escritos, Os sertões, que foi publicado 45 anos depois ${ }^{380}$ em inglês como Rebellion in the Backlands. Euclides da Cunha era engenheiro e tornou-se correspondente de guerra; seu livro é um relato das expedições militares formadas por tropas brasileiras entre 1896 e 1897 na tentativa de destruir ${ }^{381}$ um fanático religioso, Antônio Maciel, conhecido como $O$ Conselheiro, ${ }^{382}$ que se havia refugiado com os seus seguidores ${ }^{383}$ na pequena vila de Canudos, no sertão do estado da Bahia. O Conselheiro e seus homens conseguiram repelir durante quase três anos os repetidos ataques das forças governamentais. O livro contém crônicas de fúteis manobras militares, secos relatos de sofrimentos e atrocidades e uma longa rapsódia geográfica. Quem quiser experienciar a vida e a paisagem brasileiras em seus aspectos mais grandiosos e mais desesperados deve ler Os sertões. O livro lembra uma velha catedral brasileira planejada de maneira sólida e quase tosca, mas totalmente recoberta por uma profusão de ricos ornamentos e estranha vida, a ponto de ser perturbadora, ou mesmo repulsiva.

\footnotetext{
* Na referência deixada em branco, a autora certamente refere-se a Adeus às armas (1929).

${ }^{380}$ [HRV]: a autora anota '45 anos depois'. Na carta aos Editores: "p.104, col. 1, par. 3. 'Os Sertões (publicado em inglês como...)' etc. - tem de ficar entre parênteses, ou então alguma frase como '40 anos depois publicado em inglês como...'. Uma ou outra, mas como está implica que apareceu simultaneamente em português e inglês. Eu corrigi tudo isso em Nova York". A alteração não foi feita.

${ }^{381} \mathrm{Na}$ carta aos Editores: "Mesmo par.: to crush [destruir] ou against [contra] - NÃO in a final effort [em um esforço final] - uma vez que da Cunha descreve todos os esforços". A correção foi aceita.

382 Também em inglês, Counselor; no seu exemplar [HRV], a autora inseriu o artigo (The) também no inglês.

383 [1962, 1970]: ‘com todos os seus seguidores'.
} 
Cerca de trinta anos após a publicação de Os sertões surgiu um novo movimento literário que também tinha sua fonte nas terras devastadas do Nordeste. Inspirado pelo generalizado despertar social do período, o romance "regional" - ou romance do proletariado - focaliza a vida das pessoas pobres, ${ }^{384}$ trabalhadores dos engenhos, plantadores de cacau, vaqueiros, os negros, assim como os burocratas das pequenas vilas e os fazendeiros decadentes. Os quatro escritores mais talentosos desse movimento são ${ }^{385}$ Graciliano Ramos, José Lins do Rego, Jorge Amado e Rachel de Queiroz. ${ }^{386}$

O Modernismo no Brasil iniciou-se com a agora famosa "Semana de Arte Moderna" no Teatro Municipal de São Paulo, em 1922. Começando com a influência dos dadaístas e surrealistas, ele, também, logo se dividiu entre os de mente europeia e os nacionalistas. Houve até mesmo um pequeno movimento interno a ele, autodenominado antropófagos, em seu desejo de serem brasileiros nativos e nada mais, e que lançou o "Manifesto Antropófago". O nome de Mário de Andrade não pode ser omitido iniciando-se como um dos poetas modernistas, tornou-se uma das maiores forças na renascença artística brasileira. Em música, arte popular, poesia e prosa - quase tudo na vida artística
O movimento modernista brasileiro, tanto nas artes plásticas como em literatura, ${ }^{387}$ deve muito a Mário de Andrade, ${ }^{388}$ poeta que se tornou uma das maiores forças da renascença artística nacional. Ele ${ }^{389}$ se interessava por música, arte popular, poesia e prosa, e quase tudo na vida artística contemporânea brasileira continua ${ }^{390}$ a beneficiar-se de sua influência.

\footnotetext{
${ }^{384}$ [1970]: 'vida dos pobres,'.

385 [1970]: 'e fazendeiros. Quatro escritores cujos nomes estão fortemente ligados a esse movimento são'.

386 [HRV]: '(cut)', na margem, mas sem especificar o quê. [1970]: referência cruzada: 'ver Capítulo 8'.

387 Nas duas edições [1962, 1970] consta art and literature, como se esta não se classificasse naquela. Nesta tradução, explicitamente 'artes plásticas'.

388 [1970]: 'Os recentes sucessos em arte e literatura, no Brasil, devem muito a Mário de Andrade,'.

389 [1970]: 'nacional. Fundador de um movimento chamado Modernismo, que abrangeu todos os campos da criação artística, ele'.

390 [1970]: 'artística do país continua'.
} 
contemporânea brasileira tem um grande débito a Mário de Andrade, e embora ele tenha falecido em 1945, seu nome é sempre mencionado.

É verdade que no Brasil a cultura e as artes são mais respeitadas que em nosso país industrializado e de classe média. Talvez isso não se deva tanto à tradição europeia, como os brasileiros gostam de pensar, quanto ao fato de que, assim como no governo, o Brasil é uma grande família. A despeito dos exemplos da democracia das artes - Aleijadinho, Machado de Assis, Mário de Andrade e Portinari - a maioria dos escritores e artistas vem da pequena classe alta inter-relacionada e culta; em vários níveis todos eles são primos, o que resulta numa sociedade de admiração mútua. Como no governo, as querelas transformam-se em disputas familiares; os prenomes são usados mesmo em artigos críticos sérios; todo enfrentamento pende demais para o lado pessoal, e a atmosfera é curiosamente "feminina".

Embora esse caminho os preserve das flutuações abruptas e cruéis da reputação, a que os nossos artistas estão sujeitos, eles todavia sofrem pela falta de crítica séria e de competição. Às vezes, sente-se que um Samuel Johnson * brasileiro
A veneração brasileira pelas artes deve-se não apenas à tradição europeia, mas também ao fato de que a classe alta brasileira é uma grande família. ${ }^{391}$ A despeito de exemplos de democracia nas artes - Aleijadinho, Machado de Assis, Mário de Andrade, todos mulatos, e Portinari, filho de imigrantes italianos pobres -, muitos dos ${ }^{392}$ escritores e artistas vêm da culta e inter-relacionada classe alta. Em vários níveis todos eles são primos, o que resulta numa sociedade de admiração mútua. É fácil estabelecer boa reputação na juventude. Mas pequenas querelas literárias podem transformar-se em disputas familiares; os prenomes são usados mesmo em artigos sérios, e todo enfrentamento se faz no âmbito pessoal.

EMBORA os escritores e os artistas brasileiros estejam sujeitos às flutuações abruptas e cruéis da fama, comuns aos artistas de todos os lugares, eles sofrem ${ }^{393}$ ainda mais pela falta de competição e de crítica séria do que pela relativa limitação do público de literatura em língua portuguesa ou pelos efeitos enfraquecedores do jornalismo. ${ }^{394}$ Uma das

\footnotetext{
${ }^{391}$ [HRV]: a autora elimina 'veneração', mas não propõe substituto, e inclui '?'; 'X' junto a 'família'.

392 [HRV]: a autora elimina 'muitos dos', mas não propõe substituto.

* Samuel Johnson (1709-1784), escritor, crítico e lexicógrafo inglês.

393 [1962, 1970]: 'eles provavelmente sofrem'.

${ }^{394} \mathrm{Na}$ carta aos Editores: “p.104, col. 2 - seis linhas antes do final. Por favor, elimine easy [fácil, superficial]. Apenas journalism - ou talvez all-pervading [jornalismo que invade tudo; invasivo], ou, se isso for longo
} 
do século XX, com todo o seu dogmatismo, poderia fazer maravilhas pelas artes brasileiras - mas talvez isso seja tão ruim quando dizer que os países latinoamericanos precisam de ditadores.

Existem dois ditados, um anglo-saxônico e outro brasileiro, que parecem um pouco semelhantes, mas têm significados muito diferentes. Eles ilustram muito bem nossos diferentes pontos de vista acerca da carreira do artista. Nós dizemos, ao modo puritano: "Ele fez sua cama e deve deitar-se nela". Os brasileiros dizem, suavizando: Cria fama e deita-te na cama. [Em nosso modo de pensar,] ${ }^{396}$ um número excessivo de talentos genuínos ... poses prediletas dos escritores brasileiros em seus retratos consiste em deitar-se prazenteiramente numa rede com franjas. Grande quantidade de talentos brasileiros genuínos parece ir para cama - ou para a rede - cedo demais. ${ }^{395}$

demais, mediocre journalism [jornalismo medíocre]". A correção não foi feita. [HRV]: a autora elimina 'superficial' e anota '?' na margem.

395 [HRV]: a autora destaca (com um círculo) o final, ‘- ou para a rede - cedo demais', mas não o elimina.

396 [VAS]: a própria autora cortou 'No nosso modo de pensar', a respeito do comentário final. 
... engenheiro negro André

Rebouças, a própria princesa Isabel cruzou o salão ...
Em 1950, Katherine Dunham não pôde hospedarse num dos grandes hotéis de São Paulo, com a desculpa de que não havia quartos vagos. Da noite para o dia isso se transformou num escândalo nacional, e em [em branco] dias uma lei foi aprovada, contra qualquer tipo de discriminação no futuro. $\mathrm{O}$ fato de tal lei nunca ter sido pensada até então diz quase tudo o que se precisa saber sobre as atitudes do Brasil com relação aos negros.

\section{Grupos e indivíduos ${ }^{397}$}

EXISTE uma anedota que os brasileiros nunca se cansam de repetir para ilustrar sua atitude perante as relações raciais. Quando algumas damas da corte de D. Pedro II, no século XIX, recusaram-se a dançar com o famoso engenheiro mulato André Rebouças, * a princesa Isabel - herdeira do trono cruzou o salão e convidou-o para dançar com ela. É uma bela história, e verdadeira; também é verdade que Pedro II empregou vários negros e mulatos em altas posições, e que o devotado Rebouças acompanhou o imperador no exílio e acabou morrendo pobre. Infelizmente, essa história não prova a existência de tolerância racial, pois a princesa Isabel era uma verdadeira princesa e havia sido bem educada, ${ }^{398}$ como eles dizem.

Existe uma história melhor. Em 1950, a famosa dançarina Katherine Dunham não pôde hospedar-se num dos grandes hotéis de São Paulo, e a gerência comentou que a admissão de negros contrariava a política do hotel.

Presume-se que o hotel tenha agido assim em deferência aos preconceitos de sua clientela norte-americana. Mas da noite para o dia o incidente transformou-se num escândalo nacional, e, embora na Constituição brasileira já conste uma cláusula que torna essa discriminação uma ofensa, uma lei foi proposta

\footnotetext{
${ }^{397}$ [HRV]: a autora substitui o título, "Um cenário social em mudança” [A Changing Social Scene], pelo original. * Note-se que o 'negro' torna-se 'mulato' na versão publicada. Rebouças era neto de uma negra alforriada.

398 Também em inglês: well brought up.

** O incidente envolvendo Dunham (1909-2006) aconteceu no Hotel Esplanada; a lei a que se refere o texto é a Afonso Arinos (1951). Note-se que em algumas regiões dos Estados Unidos os hotéis não hospedavam negros, e sua companhia enfrentava problemas frequentes durante as turnês; em Hollywood, Dunham recusou um contrato importante porque teria de substituir alguns dos dançarinos de pele mais escura.
} 
... raciais. Ou melhor, sua atitude ...

... praticam. $\mathrm{O}$ antinegro ocasional, ou racista (e isso se aplica também para o ocasional antissemita) em geral agrupa-se em dois tipos: aquele que, inconsciente da "sociedade", entrou em contato com grupos antinegros ou com "sociedades" antijudeus em suas viagens, e perdeu sua tolerância brasileira nativa, ou, ainda mais triste - $\mathrm{o}$ imigrante europeu que vem ao Brasil tendo sofrido na terra natal por causa de sua raça ou pobreza e, sem dúvida desacostumado aos negros, despreza-os e é rude com eles.

A velha classe alta despreza a nova classe média, por causa de sua vulgaridade ou falta de boas maneiras, muito mais que os negros ou mulatos. Parte disso é nostalgia dos (e depois aprovada) transformando-a em crime. $\mathrm{O}$ fato de o governo ter reagido tão rápido diz muito sobre as atitudes do Brasil com relação aos negros.

Os brasileiros orgulham-se ${ }^{399}$ de sua boa fama ${ }^{400}$ nas relações raciais. Sua atitude pode ser mais bem descrita ${ }^{401}$ dizendo-se que quase toda a classe alta se orgulha de sua tolerância racial, ao passo que os brasileiros pobres não estão muito conscientes dessa tolerância - apenas a praticam. O racista ocasional quase sempre agrupa-se em dois tipos: a pessoa inconsciente que entrou em contato com grupos racistas em suas viagens e perdeu sua tolerância nativa; ou, ainda mais triste, o imigrante europeu que sofreu na terra natal por causa de sua raça ou pobreza e, desacostumado aos negros, despreza-os e é rude com eles. ${ }^{402}$

A VELHA classe alta - a aristocracia rural, a intelligentsia, o corpo diplomático e alguns outros grupos - guarda rancor da pequena, vibrante e nova classe alta ${ }^{403}$ - sobretudo a primeira e a segunda geração de descendentes de imigrantes que

${ }^{399}$ Na carta aos Editores: "p.114, col. 1, $2^{\circ}$ par. Eu escrevi 'Os brasileiros orgulham-se de sua boa fama em relações raciais'. Por que não manter assim? Vocês escreveram Brazilians have great pride in their fine record in race relations [Os brasileiros têm grande orgulho de...] etc. Altere para o que eu escrevi, ou altere have para take". A correção não foi feita.

400 [1970]: 'sua fama'.

401 [1970]: 'atitude tem sido descrita'.

402 [1970]: 'praticam. No entanto, o panorama não é tão cor-de-rosa. É verdade que em lugares públicos, nas ruas e nas praias, existe pequena evidência de intolerância racial. Mas ela existe. Por exemplo, contam-se pouquíssimos oficiais negros nas Forças Armadas, virtualmente não há negros em nenhum dos clubes 'exclusivos' e eles são poucos, se é que existe algum, nos corpos diplomáticos. Além disso, os estratos sociais no Brasil são claramente arranjados de acordo com a cor - quanto mais escura a pele, mais baixa a classe social.'

${ }^{403}$ [HRV]: a autora elimina 'alta' e a substitui por 'média?', com a interrogação. 
dias em que não havia classe média, parte é pressão econômica, e parte é esnobismo antiquado. É comum ter-se pena da pequena mas crescente classe média; o Brasil antiquado deveria ter mais paciência com ela. O sistema simples de divisões em classes e categorias parece o do século XIX - quase dickensiano, se um escritor tão remoto diante de tudo o que é brasileiro pode ser mencionado em conexão com o Brasil.

... A ideia de ser discriminado jamais the havia ocorrido. Também - e isso ilustra uma das grandes fraquezas brasileiras, seu provincianismo, construído ao longo de séculos em que o país permaneceu distante da Europa (eram necessários [em branco] dias num veleiro para ir do Brasil à Europa, comparados com [em branco] dias entre a América do Norte e a Europa) - esse mesmo jovem judeu espantou-se ao saber que os sofrimentos dos judeus sob Hitler tinham algo a ver com "ele", que nunca havia imaginado existir algo como solidariedade racial. fizeram fortuna nos negócios e na indústria. ${ }^{404}$ Nostálgicos dos velhos tempos em que o sistema de classes era mais rígido, eles desprezam aquilo que consideram falta de educação e de traquejo social dos novos ricos; mas os dois grupos estão se misturando aos poucos e formando um novo segmento da sociedade. ${ }^{405}$ Esses grupos estão recebendo membros da classe média formada por profissionais liberais e altos funcionários que, por sua vez, estão sujeitos aos mesmos ressentimentos à medida que buscam subir socialmente. No degrau mais baixo estão os "pobres" brancos, negros e mulatos, que são tratados, por um lado, com uma combinação de calor humano e intimidade, e, por outro, de uma maneira autocrática.

Essa discriminação apoia-se mais em fundamentos econômicos, sociais e educacionais que nos raciais. O país não tem antissemitismo. Um jovem empresário judeu brasileiro, inteligente, mas não muito culto nem viajado, espantou-se ao saber da existência de hotéis "restritos" nos Estados Unidos, quando planejou sua primeira viagem ao país. A ideia de ser discriminado pelo fato de ter um nome judeu jamais lhe havia ocorrido.

\footnotetext{
404 [HRV]: a autora destaca 'sobretudo a ... na indústria.', talvez no intuito de eliminar.

${ }^{405}$ [HRV]: '?' junto a 'sociedade'.
} 
É verdade que o negro ou mulato é um "cidadão de segunda classe", quase nunca encontrado ...

... Os negros querem ser claros, ter cabelo "bom" (liso) e nariz "bom" (não achatado). ${ }^{406}$ Eles são às vezes tratados com o humor condescendente $\mathrm{e}$ indulgente encontrado no sul dos Estados Unidos - e existem centenas de mitos e anedotas sobre negros - mas também isso não é muito diferente da forma pela qual as classes baixas brancas são tratadas. Eles têm iguais oportunidades e acesso à educação, mesmo que isso ainda não signifique muito; e nas artes, "Aleijadinho", Machado de Assis e Mário de Andrade todos eram mulatos. Depois da morte de Machado de Assis * um amigo visitou sua viúva. A senhora Machado de Assis lançou o olhar para a foto do marido sobre a mesa e fez seu único comentário conhecido acerca do fato de ela, uma mulher branca, ter-se casado com um mulato. "Pena que ele era tão escuro", disse ela.

... Mas - para um sul-africano ou norte-americano ou qualquer um que tenha vivido num país "colonial" - poder ouvir uma cozinheira negra chamando sua pequena e velha patroa branca de minha negrinha, como forma de afeto, é uma revelação - um sopro de ar fresco, afinal.
É verdade que o negro ou mulato brasileiro é em geral um cidadão de segunda classe, quase nunca encontrado em cargos importantes ou mesmo em bons empregos, e quase sempre é pobre. Mas, já que a maior parte da população está na mesma situação e sofre as mesmas privações, os sofrimentos dos negros não os marcam como alguém muito diferente dos outros. Os negros têm iguais oportunidades e acesso à educação, mesmo que isso ainda não signifique muito; e nas artes não existe discriminação. Três dos maiores e mais admirados artistas eram mulatos: o escultor “Aleijadinho", o escritor Machado de Assis e o poeta Mário de Andrade.

A pobreza geral, o atraso, a ignorância e o sofrimento no Brasil são trágicos; para milhões de habitantes, a vida significa fome e sujeira, é curta e cruel. Mas, para qualquer sul-africano ou norte-americano liberal, ${ }^{407}$ por exemplo, é uma revelação ouvir - como é possível, no Brasil - uma cozinheira negra chamando sua velha patroa branca de minha negrinha, ${ }^{408}$ como forma de afeto.

${ }^{406}$ [VAS]: a própria autora cortou 'Eles tentam casar-se com alguém mais claro'. Na linha seguinte, cortou 'e piadas, particularmente no norte'.

*Erro: a esposa, Carolina, morreu antes de Machado de Assis. É possível que a anedota se refira a outro escritor ou homem público.

${ }^{407}$ [HRV]: a autora elimina 'norte-' e inclui ' $\mathrm{X}$ ' junto a 'liberal'.

408 [VAS, 1962]: também em inglês, my little nigger. É importante observar que em 1970 altera-se para my black one (literalmente, 'minha preta'), que não tem no inglês o sentido agressivo e pejorativo de nigger (crioula), assim como no português aparece 'neguinha', e não mais 'negrinha'. 
Isso não foi planejado, apenas aconteceu. Mas agora o Brasil está se conscientizando de que a situação racial é um dos seus maiores recursos. As misturas raciais podem ser vistas por todo o país. No norte, na região amazônica, portugueses e índios produziram o caboclo, baixo, forte, com nariz reto, olhos brilhantes - um tipo físico muito atraente.

O nordestino, depois de gerações de dieta pobre, " produziu o cabeça chata, ${ }^{410}$ que também é quase sempre baixo, um tanto raquítico, com braços e pernas finos e cabeça grande, mas ágil, e sem dúvida prolífico. No sul, sob melhores condições de vida e pouca ou nenhuma mistura com os negros, o tipo é mais português, às vezes com sangue alemão, mais alto, mais bem proporcionado, com pele clara, mais calmo - embora belicoso, até mesmo inclinado à violência. É nas grandes cidade do Rio e São Paulo, e em torno delas, que se veem todos os tipos raciais misturados, juntos, tipos que perderam sua clareza ${ }^{* * *}$ racial com as velhas práticas agrícolas e as belas maneiras do "sertão".

Um homem em Goiás sabe o nome e os hábitos de todos os animais epássaros; ${ }^{* * *}$ mas as pessoas das regiões que sofreram com a decadência da agricultura são [ms ileg] maus fazendeiros,
Tal atitude não foi planejada, ela apenas aconteceu. Mas agora o Brasil está se conscientizando de que essa assimilação racial é um dos seus maiores recursos. As misturas raciais podem ser vistas por todo o país. ${ }^{409}$ A cada novo recenseamento, uma proporção crescente da população é classificada como branca.

${ }^{409}$ [HRV]: a autora destacou 'todo o país' e anotou 'X'.

* Em carta a Robert Lowell (16 dez. 1958), a autora descreve Cabral como "um típico nortista - meio desleixado, raquítico, cheio de verrugas - gerações de clima quente a má alimentação...”. (Bishop, 1995, p.707).

${ }^{410}$ Também em inglês, flat-head.

*** clarity: talvez a autora não tenha percebido o sentido subjacente em 'claro'.

**** Em carta à dra. Anny Baumann (28 jul. 1952, em Bishop, 1995, p.246), a autora diz que no Brasil existem "muitos pássaros, mas ninguém sabe o nome deles". 
doentios, para quem qualquer inseto é apenas um bicho, ${ }^{411}$ ou toda árvore é a "cincofolhas", e tudo está sujeito à destruição. A importância da nutrição * no Brasil percebese no fato de que quanto mais rica e velha a família, as pessoas são mais altas e com ossos maiores. ${ }^{* *}$ Às vezes, seus empregados domésticos do "norte" ou do "interior" parecem quase anões ao lado delas.

... por ano. Eles são operários e fazendeiros, empregados domésticos ou jardineiros. Além disso, algumas antigas profissões urbanas são tradicionalmente suas: comerciantes de jornais velhos e garrafas, afiadores de facas. Nas cidades, ...

Em inúmeras piadas o português aparece como absurdamente ingênuo e pouco perspicaz. No teatro brasileiro do século XIX e do início do século XX, ele era sempre representado como um homem grosseiro, vestido de maneira espalhafatosa,
OS PORTUGUESES naturalmente constituíram o maior grupo de imigrantes, e eles ainda vêm numa taxa de 17 mil por ano. As levas mais recentes ${ }^{412}$ trazem operários, fazendeiros, empregados domésticos ou jardineiros. Além disso, algumas profissões urbanas antigas cabem a eles: são afiadores de facas ou comercializam jornais velhos e garrafas. Nas cidades, muitas das entregas são feitas por carrocinhas, e esta também é uma prerrogativa dos portugueses. Hoje, o nome oficial desses carroceiros é burros-sem-rabo. ${ }^{413}$ Seu uniforme habitual consiste em tamancos, calças largas, camisetas e grandes boinas desajeitadas, e seus rostos são bonitos e impassíveis, comparados aos daqueles que vivem no Brasil há várias gerações, quase sempre feios, embora mais perspicazes e vívidos.

Em inúmeras piadas o português rural é sempre visto como absurdamente ingênuo e pouco perspicaz. No teatro brasileiro do século XIX e do início do século XX, o português de classe média era representado como um homem grosseiro, vestido de maneira espalhafatosa, amante de

\footnotetext{
${ }^{411}$ Apenas em português.

* Em carta de 1976, Bishop pede a Emanuel Brasil que transmita várias recomendações sobre alimentação infantil à empregada Vitória, de Ouro Preto, que estava grávida.

** Note-se que a expressão bigger-boned tem, também, o sentido de 'pessoa desajeitada'.

412 [1970]: 'numa taxa média de 15 mil por ano. As levas geralmente trazem'.

413 [VAS]: apenas em inglês, donkeys without tails. [1962, 1970]: em inglês e português. Segundo o Dicionário Houaiss, regionalismo (RJ e MG).
} 
amante de grandes relógios de ouro com pesadas correntes. Em Portugal, no mesmo período, o brasileiro era sempre representado no teatro como um homem grosseiro, vestido espalhafatosamente, amante de grandes relógios de ouro etc. etc.

Depois da abolição da escravatura, imigrantes europeus começaram a chegar em grandes levas, dirigindo-se em sua maioria para os estados de São Paulo, Paraná, Santa Catarina e Rio Grande do Sul. Eram alemães, italianos e, depois de 1908, japoneses. No sul do Brasil existem cidades e vilas inteiras de alemães. Hoje existem cerca de [em branco] japoneses no país, os quais estão contribuindo muito para o desenvolvimento da agricultura, sobretudo na produção de frutas, nos estados do Sul. São Paulo tem livrarias e armazéns japoneses, e até mesmo gueixas. Os [em branco] italianos ... grandes relógios de ouro com pesadas correntes. Em Portugal, no mesmo período, o brasileiro era representado ${ }^{414}$ da mesma maneira. ${ }^{415}$

DEPOIS da abolição da escravatura outros imigrantes europeus além dos portugueses começaram a chegar em grandes levas. Dirigiram-se em sua maioria para os estados de São Paulo, Santa Catarina, Rio Grande do Sul e Paraná. Eram alemães, italianos e, depois de 1908, japoneses. No Sul existem cidades e vilas totalmente povoadas ${ }^{416}$ por alemães. Os primeiros japoneses vieram sob um acordo firmado entre o governo de São Paulo e uma empresa colonizadora japonesa, para desenvolver o interior do estado; hoje, eles são cerca de meio milhão no país, e ${ }^{417}$ contribuem muito para o desenvolvimento da agricultura, sobretudo nas áreas que produzem frutas e legumes nos estados do Sul. São Paulo tem livrarias e armazéns japoneses, e até mesmo gueixas. Os cinco milhões ${ }^{418}$ de descendentes de italianos foram os que se adaptaram melhor, talvez porque o clima e as condições de trabalho no Brasil não são muito diferentes daqueles da Itália, e para eles é fácil aprender a língua portuguesa. $\mathrm{E}^{419}$ novos

\footnotetext{
${ }^{414}$ [1962, 1970]: 'o "colonial” que vivera no Brasil e havia retornado era representado'.

${ }^{415} \mathrm{Na}$ carta aos Editores: "p.115, col. 1, $2^{\circ}$ par.: A ironia foi destruída, novamente. (Eu corrigi isso em Nova York.) Deveria ser 'No teatro, em Portugal, no mesmo período, o brasileiro era representado como um homem grosseiro, vestido espalhafatosamente, amante de grandes relógios de ouro etc.'. Elimine on the other hand [por outro lado], que contradiz a sentença sintaticamente, e também elimine 'que vivera no Brasil e havia retornado'. POR QUÊ? Eles tinham um tipo 'português' no Brasil, e em Portugal, um 'brasileiro'. No teatro dos Estados Unidos eles costumavam ter um 'inglês', e no teatro inglês, sem dúvida, um 'americano'. Ninguém teve de 'retornar' etc. Eu não consigo entender por que isso foi alterado novamente depois de eu ter corrigido. Elimine a palavra 'colonial'.”. As alterações não foram feitas.

416 [1962, 1970]: 'totalmente dominadas por alemães'. [HRV]: a autora elimina 'dominadas' [dominated] e coloca '?', mas não sugere um termo substituto. Nesta tradução, 'povoadas'.

417 [1970]: 'são aproximadamente 600 mil no Brasil e'.

418 [1970]: 'Os seis milhões'.

${ }^{419}$ Na carta aos Editores: “p.115, col.1, final da página. 'Mas novos grupos continuam a chegar...'. POR QUE o MAS? POR FAVOR, ELIMINE. Não há razão para um MAS, aî”. A correção não foi aceita.
} 
... foi o general Cândido

Mariano Rondon. Ele veio de Cuiabá, capital do estado de Mato Grosso, e também era mestiço. Em 1907, quando era um jovem capitão, foi incumbido de estabelecer uma linha telegráfica para ligar Mato Grosso com o Amazonas e com o resto do mundo. Isso significava explorar milhares de quilômetros quadrados de mata intocada. A história de Rondon está repleta de heroísmo e autossacrifício. Ele acreditava que os índios deveriam e poderiam ser "pacificados", ao contrário de uma parte da opinião pública da época, que preferia exterminá-los. O lema que ele concebeu para o Serviço Índio era "Morrer se necessário for, matar jamais", e muitos dos seus tenentes, soldados e trabalhadores realmente fizeram isso. Ele procurou jamais interferir no modo de vida dos índios. grupos continuam a chegar, sobretudo os do Oriente Médio, que agora já ultrapassam os 400 mil.

O mais fascinante grupo minoritário brasileiro, entretanto, é constituído pelo meio milhão de índios, cuja proteção e bem-estar o governo vem tentando assegurar há vários anos. ${ }^{420} \mathrm{O}$ fundador e herói do Serviço de Proteção ao Índio foi o marechal Cândido Mariano da Silva Rondon, que veio de Cuiabá, capital do estado de Mato Grosso, e que também era mestiço. ${ }^{421}$ No posto de major do Exército brasileiro, Rondon foi incumbido em 1907 de estabelecer uma linha telegráfica para ligar Mato Grosso com Porto Velho, no rio Madeira, e assim com o resto do mundo. Isso significava explorar milhares de quilômetros quadrados de mata intocada. ${ }^{422}$ A história de Rondon reúne heroísmo e autossacrifício. Ele acreditava que os índios deveriam e poderiam ser "pacificados", mesmo que muitos brasileiros preferissem exterminá-los. O lema que ele concebeu para seu trabalho era ${ }^{423}$ "Morrer se necessário for, matar jamais" - e muitos dos homens de Rondon realmente fizeram isso. Ele procurou jamais interferir no modo de vida dos índios.

\footnotetext{
${ }^{420}$ [1970]: 'constituído por um número rapidamente decrescente de índios tribais, cuja proteção e bem-estar o governo tentou assegurar sem sucesso e nem sempre com empenho.'. Substituiu-se indians por tribal indians, literalmente 'índios tribais' ou 'índios que ainda vivem nas tribos'.

${ }^{421}$ [1970]: 'Rondon, que também era mestiço'.

422 [1970]: 'de mata'.

${ }^{423}$ [1970]: 'Seu lema era'.
} 
Pouco antes da Primeira Guerra Mundial, Theodore Roosevelt participou de uma expedição exploratória e de caça com Rondon. (Ele achou, é triste dizer, que havia um passatempo tão bom na América do Sul quanto qualquer um já feito na África.) Ele faz uma grande homenagem a Rondon em seu livro Through the Brazilian Wilderness, que atraiu a atenção do americano médio para o Brasil pela primeira vez desde a visita de D. Pedro II à exposição do Centenário da Independência, em Filadélfia. Rondon descobriu quinze grandes rios, um dos quais recebeu o nome de Roosevelt, estabeleceu mais de $22 \mathrm{mil}$ quilômetros de linhas telegráficas e descobriu muitas tribos antes desconhecidas.

Ainda existem histórias vergonhosas de homens ávidos por terra que enganam ou matam os índios, assim como lamentáveis "golpes publicitários" que os envolvem, mas Rondon estabeleceu um alto padrão de comportamento em relação aos homens primitivos. $\mathrm{O}$ território de Rondônia (maior que a França) tem esse nome em sua homenagem.
Pouco antes da Primeira Guerra Mundial, Theodore Roosevelt participou de uma expedição exploratória com Rondon. Ele faz uma grande homenagem a Rondon em seu livro Through the Brazilian Wilderness, ${ }^{424}$ que sem dúvida foi o que atraiu a atenção do maior número de americanos desde a visita de D. Pedro II, em 1876. Até sua morte, em 1958, Rondon descobriu quinze grandes rios (um dos quais recebeu o nome de Roosevelt), estabeleceu mais de 22 mil quilômetros de linhas telegráficas e contatou muitas tribos antes desconhecidas.

Hoje existem histórias ocasionais de homens ávidos por terra que enganam ou matam os índios, assim como lamentáveis golpes publicitários que os envolvem, mas Rondon estabeleceu um alto padrão de comportamento em relação aos homens primitivos. O estado de Rondônia 425 (maior que toda a Grã-Bretanha) tem ${ }^{426}$ esse nome em sua homenagem.

\footnotetext{
${ }^{424}$ Roosevelt, T. Através do sertão do Brasil. São Paulo: Cia. Ed. Nacional, 1944. 330p.

425 [1962]: 'território de Rondônia'. Em [HRV] a autora corrigiu para 'estado'.

${ }^{426}$ [1970]: 'desconhecidas. O território de Rondônia (maior que a Grã-Bretanha) tem'.
} 
... Mas os índios continuam a ser um problema. Tribos que nunca viram a "civilização" ainda estão sendo descobertas, e aquelas que já tiveram contato estão aos poucos morrendo por causa de doenças e se degradando. Às vezes o problema torna-se perigoso. Quando este texto estava sendo escrito, encontrou-se o corpo de um jovem explorador inglês, atravessado por sete flechas de índios caiapós. E os seringueiros isolados ou os criadores de gado de Mato Grosso ou do Pará, embora vivam na era atômica, ainda temem mais as flechas e as zarabatanas que as bombas.

... em conjunto pelos Estados Unidos e pelo Brasil em 1942 , e que logo passou ao controle brasileiro.
O HERDEIRO de Rondon como principal benfeitor dos índios é Orlando Villas Boas, que dedicou sua vida ao povo da floresta. ${ }^{427}$ Ele passou anos em locais remotos, sem contato com a civilização, e sem dúvida prefere viver com os índios a ser um administrador. Mas os índios continuam a ser um problema quase insolúvel. Tribos que nunca viram a civilização do homem branco ainda estão sendo descobertas, e [p.116] aquelas que já tiveram contato estão morrendo de doenças e sofrendo degradação. Às vezes o problema torna-se perigoso. Há pouco tempo encontrou-se ${ }^{428}$ o corpo de um jovem explorador inglês, atravessado por sete flechas identificadas como de índios caiapós. E os exploradores não são os únicos ameaçados. Os seringueiros isolados ou os criadores de gado de Mato Grosso ou do Pará, embora vivam na era atômica, ainda temem mais as flechas e as zarabatanas que as bombas. ${ }^{429}$

CERTA NOITE, a bordo de um navio que descia o barrento Amazonas, uma jovem médica contava suas histórias. Ela havia trabalhado quinze anos no Serviço ${ }^{430}$ Especial de Saúde Pública, fundado em conjunto pelos Estados Unidos e pelo Brasil em 1942, e que passou ao controle brasileiro em 1960. Ela tinha 23 anos quando entrou no SESP; foi para Santarém, depois navegou cerca de 150 quilômetros de lancha, levando seus instrumentos e alguns livros para iniciar a carreira numa pequena aldeia no rio Tapajós. Na primeira noite um grupo de homens selvagens e esfarrapados pediu a ela que fizesse o

\footnotetext{
${ }^{427}$ Na carta aos Editores: “p.115, col. 2, final da página. Deve-se afirmar que Villas Boas é, hoje, o chefe do Serviço [de Proteção ao] Índio". A inclusão não foi feita.

${ }^{428}$ [1970]: O problema pode ser perigoso. Há poucos anos encontrou-se'.

429 [1970]: 'bombas. Mas a ameaça aos brancos não deve ser exagerada. Na realidade, os índios é que sofreram durante anos o ataque sistemático dos homens "civilizados" ávidos por terras, os quais, assim como na América do Norte, enganaram-nos e os mataram, quase ao ponto da extinção total.'.

${ }^{430}$ Nas duas edições, Servico, sem cedilha.
} 
... distante meio dia em barco a motor. Ela amava seu trabalho. Achava que o Serviço de Proteção e o SESP eram os dois serviços mais bem administrados no Brasil.

Pequena, gorda, animada e de pele escura, ...

... spoiled, de acordo com a noção anglo-saxônica); tudo gira em torno do cabeça da casa ou do filho, quase sempre referido apenas como "o homem". O homem, o macho, é o todo-importante, todo-admirado, principal. As mulheres são: "a mãe dos meus filhos", "aquela que leva o meu nome", e "religião é para mulheres".

... cabeça, mesmo que as Páginas Femininas nos jornais sejam de uma inacreditável monotonia, e mesmo que os homens permaneçam numa sala atestado de óbito de um amigo deles, cujo corpo havia sido encontrado no rio. Os homens disseram que o homem havia se afogado. A médica pediu que a deixassem sozinha com o corpo e percebeu que, embora tivesse permanecido na água por algum tempo, ele havia morrido por causa de uma facada nas costas. Praticamente sozinha, à noite, e consciente de que o assassino (ou assassinos) deveria(m) estar naquele grupo de homens ameaçadores, ela recusou-se a assinar o atestado e ordenou que alguém fosse ao posto policial mais próximo, distante meio dia em barco a motor. E assim se fez.

Pequena, animada e de pele escura, sem dúvida com sangue índio, essa médica era uma mulher brasileira "moderna". Não existem muitas como ela, mas seu número vem crescendo.

O Brasil é uma terra de homens. A diferença entre os sexos não poderia ser mais nítida. Meninos pequenos são mimados (estragados, spoiled, como diriam os anglosaxônicos), e tudo gira em torno do cabeça da casa ou do filho mais velho, quase sempre referido apenas como "o homem". Nesse mundo masculino as mulheres são classificadas como "a mãe dos meus filhos" ou "aquela que leva o meu nome".

Mas nada é muito simples. Mesmo que as mulheres pobres andem atrás dos homens, carregando o bebê nos braços e a lata d'água na cabeça, as coisas mudaram muito desde que os primeiros portugueses seduziram as meninas índias. Nos velhos tempos havia poucas mulheres, mantidas numa reclusão semelhante à dos haréns, espreitando o mundo 
durante as festas, discutindo política e negócios imobiliários, enquanto as mulheres ficam em outra, tagarelando sobre empregadas e bebês, as coisas mudaram muito ...

... espreitando as ruas da cidade através dos muxarabis ou dos quartos internos e escuros das velhas casas das fazendas.

... divertiam-se nos quartos das escravas. Após várias gerações nesse tipo de vida, os homens não tinham muito espírito empreendedor, e as esposas é que, na realidade, administravam as plantações de açúcar ou café, sentadas em suas almofadas, sendo abanadas, costurando, ...

... passaram a estudar, no Brasil, e mesmo hoje as meninas mais pobres, ainda mais que os meninos, têm sorte se conseguem frequentar a escola por um ou dois anos. As meninas da classe alta vão a colégios de freiras, alguns bons, outros não. Mas pode-se apenas perceber que as freiras encorajaram a complacência e o esnobismo, não noblesse oblige. A despeito da amabilidade geral ... através dos muxarabiês ou ${ }^{431}$ janelas com treliças, ou de dentro das alcovas ou quartos internos das velhas fazendas. Por trezentos anos poucas delas se alfabetizaram, e as meninas de 12 anos casavam-se com vizinhos, primos ou mesmo tios. Houve casos de meninas pequenas que ganharam bonecas para aceitarem casar-se com homens muito mais velhos. Todos os antigos viajantes falaram da timidez das brasileiras e da raridade com que elas eram vistas pelos visitantes homens. Elas cresciam pálidas e gordas nos quartos escuros, quase não caminhavam, balançavam-se em redes ou sentavam-se com as pernas cruzadas sobre almofadas, fazendo as tarefas domésticas, enquanto os maridos, segundo inúmeros relatos, divertiam-se nos quartos das escravas. Mas às vezes o que parecia ser ${ }^{432}$ uma vida indolente ${ }^{433}$ era na realidade uma vida responsável, e a esposa podia administrar uma infinidade de serviços caseiros sentada em suas almofadas, costurando, dando uma série de ordens ao longo do dia.

FOI APENAS nos últimos cem anos que as mulheres brasileiras passaram a receber algo próximo de uma educação formal, e mesmo hoje as meninas mais pobres, que nesse aspecto são menos afortunadas que os meninos, têm sorte se conseguem frequentar a escola por um ou dois anos. As meninas da classe alta vão a colégios de freiras, alguns bons, outros não. A despeito da amabilidade geral dos brasileiros, muitas mulheres da classe alta ainda tratam suas empregadas ou as mulheres mais pobres ao velho estilo do século XVIII e permitem que seus filhos façam o mesmo.

\footnotetext{
431 [1970]: 'muxarabiês, ou de'.

432 [HRV]: a autora destaca 'parecia ser' e inclui 'às vezes'.

${ }^{433}$ Na carta aos Editores: "p.116, col. 2, final do $2^{\circ}$ par.: Pode alterar a última sentença para But sometimes what seemed like an indolent life... [Mas às vezes o que parecia ser uma vida indolente...] etc.? - faz um pouco mais de sentido". Continuou faltando but sometimes, mas, em 1970 houve outra mudança: seemed like an foi substituído por appeared to be an.
} 
... permaneceram analfabetas, naturalmente não houve escritoras.

... estrangeiras. Um pouco do talento que se desperdiçou pode ser imaginado. O Diário de Helena Morley (Alice Brant) é um diário autêntico escrito em Diamantina nos anos 80 por uma menina, certamente uma romancista manquée.

As mulheres são agora importantes nas letras brasileiras. Cecília Meireles é um dos melhores poetas brasileiros. Clarice Lispector é uma contista e romancista de grande originalidade, $\mathrm{e}$ existem muitas outras. A mais conhecida é Rachel de Queiroz, que aos 18 anos escreveu um pequeno e brilhante romance sobre o Ceará, chamado $O$ Quinze, o ano de uma seca particularmente terrível. Ela veio para o Rio e escreveu peças teatrais e romances, e por [em branco] anos teve uma página em $O$ Cruzeiro, a maior revista semanal, na qual esteve de maneira consistente e corajosa no lado
Uma vez que as mulheres permaneceram em sua maioria analfabetas por tantas gerações, quase não houve escritoras. Podemos conhecer a face feminina da vida do século XIX graças a viajantes como a inglesa Maria Graham, ou graças às cartas de muitas governantas estrangeiras empregadas por brasileiros ricos. Um pouco do talento que se desperdiçou pode ser imaginado na leitura de um livro como o Diário de Helena Morley, ${ }^{434}$ um diário autêntico escrito em Diamantina na década de 1890 por uma adolescente ${ }^{435}$ que sem dúvida tinha talento suficiente para tornar-se uma romancista de alto nível.

Mas as mulheres são agora importantes ${ }^{436}$ nas letras brasileiras. Cecília Meireles é um ${ }^{437}$ dos poetas brasileiros mais importantes, e Clarice Lispector é uma contista e romancista de grande originalidade. Existem muitas outras. A mais ${ }^{438}$ conhecida é Rachel de Queiroz, que aos 19 anos escreveu um pequeno e brilhante romance sobre o estado do Ceará, chamado $O$ Quinze, em que descreve o ano de uma seca particularmente terrível. Ela mudou-se para o Rio e escreveu romances, e há muitos anos tem uma ${ }^{439}$ página em O Cruzeiro, a mais importante revista semanal brasileira, na qual tem lutado de ${ }^{440}$ maneira consistente e corajosa pelas causas políticas e sociais. ${ }^{*}$ Em 1961, o presidente Jânio Quadros convidou-a para o Ministério da Educação. ${ }^{* *}$ Ela recusou, mas essa foi a primeira vez que uma mulher teve essa

\footnotetext{
${ }^{434}$ Em inglês: Diary of Helena Morley. Trata-se do nome com o qual foi publicada, em Nova York, a tradução de Elizabeth Bishop para Minha vida de menina, de Alice Dayrell Caldeira Brant. Em [VAS] consta 'anos 80', mas no texto publicado corrigiu-se para 'década de 1890'. Os diários referem-se aos anos 1893-1895.

${ }^{435}$ Na carta aos Editores: “p.117, col. 1, alto da página. NÃO USE A PALAVRA TEENAGE. POR QUE SER VULGAR? Eu disse young girl". A substituição não foi feita. [HRV]: a autora substitui teenage girl por young girl.

436 [1970]: 'Mas no passado recente as mulheres tornaram-se importantes'.

437 [1970]: 'Meireles era um dos'.

438 [1970]: 'originalidade. A mais'.

439 [1970]: 'e por muitos anos teve uma'.

440 [1970]: 'uma das mais importantes revistas semanais brasileiras, na qual ela lutou de'.

* No original, right side, que além de significar 'lado correto' pode ter conotações políticas (direita). No texto publicado substituiu-se a expressão.

** Na realidade, o MEC reunia "Educação e Cultura".
} 
correto das causas políticas e sociais. Durante a ditadura de Vargas, quando muitos intelectuais foram presos ou exilados, ela passou seis meses na cadeia, incomunicável. Em 1961, o presidente Quadros convidou-a para o Ministério da Educação, e depois para uma embaixada. Embora tenha recusado os dois cargos, essa foi a primeira vez que uma mulher teve essa honra no Brasil.

As mulheres foram admitidas nas universidades em [em branco]. Hoje existem mulheres no governo, no Congresso, advogadas, médicas, psicanalistas e engenheiras. A presidente do Museu de Arte Moderna do Rio é uma engenheira: Carmen Portinho, e o elegante viaduto de Canoas, no Rio, é o trabalho de outra engenheira, Bertha Leitchik. Vimos como elas são ativas nas artes. A pianista Guiomar Novaes é mundialmente famosa há muito tempo. Um crédito especial deve ser dado para as centenas de anônimas normalistas brasileiras, as jovens que se tornam professoras todos os anos, muitas delas em vilas remotas, em escolas que se restringem a um quarto numa casa, em condições comoventes.

... países. Mas o casamento aos 17 ou 18 anos, e a inflexível corrida pela procriação são o destino até mesmo das ricas e educadas. As próprias mulheres em honra no Brasil. Hoje existem mulheres no governo e no Congresso, e existem advogadas, médicas, psicanalistas e engenheiras. Odete de Carvalho foi embaixadora em Israel e na Costa Rica.

A DESPEITO dos avanços, as mulheres brasileiras ainda não alcançaram o status atingido em outros países. Elas ainda se casam por volta dos 17 ou 18 anos, e mesmo as ricas e educadas quase nunca podem esperar mais que uma vida dedicada aos filhos. As próprias mulheres em geral são 
geral são contrárias à introdução do divórcio. Segurança para elas e para seus filhos é o que mais importa na vida.

Embora as brasileiras votem no Brasil desde 1934, elas ainda não têm todos os direitos legais.

[linhas em branco] *

... as americanas "fazem o serviço doméstico", cuidam dos filhos, ou sustentam-se, e parecem agitadas e sobrecarregadas.

Além das carreiras para mulheres, outra novidade no Brasil são os esportes. Apenas trinta anos atrás, o futebol era um esporte amador, jogado como passatempo por membros das classes altas. Hoje, como o beisebol nos Estados Unidos, tornou-se um grande negócio, com altos salários, compra e venda de jogadores, e populares heróis nacionais. Todos os jornais dedicam ao menos uma página a esse esporte todos os dias. Em 1958 o Brasil tornou-se campeão mundial de futebol. (É interessante notar que para cada jogador, na viagem à Europa, destinaram-se 15 contrárias ao ${ }^{441}$ divórcio, uma vez que a segurança para elas e para seus filhos é o que mais importa.

Embora as brasileiras votem desde 1932, elas ainda não têm todos os direitos legais. Concordam com seus maridos. Aceitam as infidelidades do marido como um fato consumado. Algumas delas insistem em que são mais felizes que as norte-americanas - mas isso em geral acontece depois de visitarem os Estados Unidos e verem que as americanas fazem a maior parte do trabalho sem a ajuda de empregadas, cuidam dos filhos, sustentam-se, ou parecem ser agitadas e sobrecarregadas. ${ }^{442}$

NESTE país em que tanta coisa está mudando, os esportes de massa são outra novidade. ${ }^{443}$ Desses, o mais popular é sem dúvida o futebol. Apenas trinta anos atrás, ${ }^{444}$ o futebol era um esporte amador, ${ }^{445}$ jogado por membros das classes altas. Hoje, como o beisebol nos Estados Unidos, tornou-se um grande negócio, com altos salários, compra e venda de jogadores e surgimento de heróis nacionais. Todos os jornais dedicam ao menos uma página ao futebol todos os dias, e os jogos importantes geram uma excitação que beira a histeria. Os jogadores são de todos os tons, do branco ao preto retinto, elegantes, nervosos e incrivelmente ágeis, e estão entre os melhores do mundo. Durante anos, todavia, a glória internacional os traiu; ${ }^{446}$ cada vez que havia um jogo crucial,

\footnotetext{
441 [1970]: ‘são contrárias à legalização do’.

*Várias linhas em branco, no original. Parecem indicar trecho apagado, e não deixado intencionalmente assim.

442 [HRV]: a autora anota '?' em 'são agitadas e sobrecarregadas'. Em [VAS] ela já havia substituído 'são' por 'parecem'.

443 [HRV]: a autora elimina o primeiro período, mas não propõe nova abertura para o subcapítulo.

444 [1970]: 'Ainda na década de 1930,'.

445 [1962]: 'esporte estritamente amador'; [1970]: 'esporte amador,'.

446 [1970]: 'todavia, as vitórias internacionais os traíram;'.
} 
quilos de feijão preto.) Os jogadores são de todos os tons, do branco ao preto retinto, elegantes, nervosos e incrivelmente ágeis. Durante anos faltou a eles senso de cooperação, de equipe.

[Heróis populares * - "O Diamante Negro", "Pelé", a história de Carolina Jesus aqui. Em 1958 os campeões de basquete do ano. Maria Ester. Bruno Hermanny.]

... proteger do sol. O homem da Kibon, com seu carrinho amarelo, o carrinho de algodão-doce ... os jogadores pareciam perder o senso de equipe. ${ }^{447}$ Em 1958 , afinal, a seleção brasileira, acompanhada por um dentista e um psicólogo entre outros especialistas, foi ${ }^{448}$ à Suécia e venceu o título mundial. Sua recepção no retorno ao Rio foi tumultuada. ${ }^{449}$

Aos domingos, a população de todas as pequenas cidades vai assistir aos jogos dos times de futebol locais. Os grandes campos verde-claros são cercados por pessoas em suas melhores roupas, trazendo seus bebês e carregando sombrinhas para se proteger do sol. Existe o sorveteiro da Kibon, ${ }^{450}$ com seu carrinho, e o homem do algodão-doce com seu carrinho feito em casa, sobre um triciclo. Urubus e delicadas pipas equilibram-se lá no alto, e os jogadores com shorts e camisetas listradas em cores fortes correm sem parar.

Também é uma cena comum o varal da lavadeira com os uniformes de um time, camisetas listradas como vespas uma cena alegre - às vezes tendo ao fundo um depósito de lixo, ${ }^{451}$ com mais urubus e mais pipas pairando no alto.

Em apenas uma coisa o Brasil insiste com firmeza, como a Rússia, em que realmente foi o primeiro, é na invenção do avião. [Santos Dumont aqui?]

\footnotetext{
${ }^{447} \mathrm{Na}$ carta aos Editores: "p.117, col. 2 - por favor, altere para lose their sense of team play [perdiam o senso de equipe] - all sense [todo o senso] parece desnecessariamente severo". A correção não foi feita, mas em [HRV] a autora elimina 'perder todo o senso de equipe', sem indicar substituto.

448 [1970]: 'acompanhada por um psicólogo, foi'.

449 [1970]: 'tumultuada. Eles repetiram o feito em 1962 e em 1970, tornando-se o Brasil o primeiro país a ganhar o título permanente da Copa do Mundo.'.

* A autora anota, aqui, os nomes de alguns 'heróis populares' ligados ao esporte: os jogadores de futebol 'Diamante Negro' (Leônidas) e Pelé, a tenista Maria Esther Bueno e o nadador Bruno Hermanny. Note-se que ela pretendia falar de Carolina Maria de Jesus, a autora de Quarto de despejo (1960), junto aos heróis negros do futebol. Note-se, também, que ela se confunde e cita campeões de 'basquete' (e não de futebol), em 1958.

${ }^{450}$ [1970]: 'o sorveteiro, com'.

${ }^{451}$ [HRV]: anotação ilegível em 'lixo'.

** Depois do lembrete relacionado a Santos Dumont, existe um comentário manuscrito ilegível no original.
} 


\section{A luta por uma democracia estável ${ }^{452}$}

O POVO dos Estados Unidos do ${ }^{453}$ Brasil desejou a democracia durante muito tempo. Mas ${ }^{454}$ vários fatores impediram que o país alcançasse um governo estável e democrático. A democracia no mundo contemporâneo requer, entre outras coisas, um povo educado e informado. Até agora o Brasil não teve isso. ${ }^{455}$ Analfabetismo, comunicações ineficientes e uma consequente falta de consciência do povo tornam possível que determinados grupos de homens controlem os negócios do país sem a aprovação geral - ou mesmo o conhecimento - do povo brasileiro. Os militares brasileiros, diferentemente do que ocorreu em outros países sul-americanos, jamais quiseram ficar para sempre no poder. Nas situações em que eles tomaram o poder, nunca o mantiveram por muito tempo. Mas o Brasil sofreu sob uma ditadura. Entre ${ }^{456} 1930$ e 1945 e de 1951 a 1954, um homem, Getúlio Vargas, dirigiu o país ${ }^{457}$ como presidente, ditador, ou ambos. O grande grupo de homens que ansiavam o poder e que eram seus seguidores e a máquina política que ele ajudou a montar provocaram um dano inestimável ao país.

Não apenas o Brasil retrocedeu politicamente por causa de Vargas, mas Vargas fez pouco para aumentar o respeito pelo governo. Quando ele subiu ao poder, esperava-se que fosse abrir a participação no governo e fazer as reformas

\footnotetext{
${ }^{452}$ Bishop não rasurou o título do capítulo em [HRV]. Em [1970], novo título: "Militarismo versus democracia". 453 [1970]: 'O povo da República Federativa do'.

${ }^{454}$ Na carta aos Editores: "p. $127,1^{\circ}$ período - pode ser combinado com o $2^{\circ}$ período". A alteração não foi feita.

${ }^{455}$ [1970]: 'informado, algo que o Brasil simplesmente não tem.' .

${ }^{456}$ [1970]: 'povo brasileiro. Entre 1930'.

${ }^{457}$ [1970]: Brazil substituído por the country.
} 
O Império e o Imperador, Pedro II, foram sinônimos. A principal causa da queda da Monarquia foi, sem dúvida, o medo em relação ao que aconteceria se a princesa Isabel herdasse o trono. Os brasileiros suspeitavam de seu marido, o príncipe francês, conde D'Eu (neto do rei Luís Felipe); ele era um "estrangeiro". Mesmo o grande gesto da princesa Isabel, a emancipação dos escravos, não conseguiu acalmar a crescente ansiedade acerca do domínio "francês" que, estavam certos, se seguiria à morte do imperador, doente e prematuramente envelhecido. Essa é a explicação pela qual um Império que havia durado 65 anos pôde cair sem protesto e sem luta.

... Mas a República começou com uma colaboração havia muito necessárias. Hoje, como sempre, desconfia-se do governo em geral, impostos são desviados, e nos assuntos ligados à política prevalece uma atmosfera de suspeita e cinismo. O presidente Jânio Quadros, um homem contrário a Vargas que foi eleito em 1960 apenas para renunciar de repente depois de sete meses, ${ }^{458}$ deu ao país uma nova e breve esperança. Essa esperança também falhou. Desde então, o Brasil vem tentando desesperadamente encontrar seu caminho. $^{459}$

PARA compreender o que produziu o regime de Vargas e a atmosfera política contemporânea é necessário examinar as forças que dominaram a República em seus primeiros tempos. Depois ${ }^{460}$ da queda do Império em 1889 (ver o Capítulo 3), a

\footnotetext{
${ }^{458}$ Na carta aos Editores: "p.128, col. 1, 'eleito em 1961 e repentinamente renunciou, depois de sete meses no cargo.....". A versão only to turn in a suddenly resignation [apenas para renunciar subitamente], mais forte que a da autora, foi mantida.

459 [1970]: novo trecho desde 'O grande grupo...', no parágrafo anterior, até 'seu caminho'. Ver Nota II, no final deste capítulo.

${ }^{460}$ [1970]: 'a atmosfera política repressiva que dominou o Brasil, é necessário examinar os primeiros anos da República. Depois'.
} 
improvisada de elementos mal combinados: o grupo positivista, o grupo militar comandado pelo marechal Deodoro e os grandes proprietários rurais que haviam sido arruinados pela Abolição. (Isso explica o grande número de "barões" e outros títulos que soam estranhos entre os nomes proeminentes da jovem República.) Foi uma colaboração ocasional, feita para romper-se, e isso aconteceu logo em seguida.

... governo. "Esta não é a

República dos nossos sonhos!", eles reclamaram. Mas deixaram seu lema Ordem e Progresso na nova bandeira, e outros aspectos do novo regime foram influenciados pelo pensamento positivista. $\mathrm{O}$ general Deodoro foi o próximo a sair. Embora tenha proclamado a nova República, ele relutava em abrir mão de seu poder como um velho general do Império; discordava de muitos de seus antigos aliados, discutia com o já forte movimento de oposição no parlamento. Tentou dar um golpe militar, dissolveu a Assembleia e acabou "renunciando" - a primeira "renúncia" presidencial.

$\mathrm{O}$ vice-presidente, marechal Floriano Peixoto (apelidado de "Marechal de Ferro", por causa de sua
República Velha começou como uma colaboração improvisada de elementos mal combinados: o grupo positivista que ${ }^{461}$ sonhava estabelecer uma utopia política; o grupo militar comandado pelo primeiro presidente, o marechal Manuel Deodoro da Fonseca; e os grandes proprietários rurais, muitos dos quais haviam sido arruinados pela abolição da escravatura. Foi uma colaboração ocasional, feita para romper-se; e isso aconteceu logo em seguida. ${ }^{462}$

Os positivistas foram os primeiros a dissociar-se do novo governo. $\mathrm{O}$ mundo da política prática era muito diferente do que eles haviam imaginado. "Esta não é a República dos nossos sonhos!", eles reclamaram, e partiram, deixando apenas seu lema Ordem e Progresso na bandeira. O marechal Deodoro foi o seguinte. Embora tenha proclamado a República, relutava em abrir mão de seu poder como velho marechal do Império. Ele discordava de muitos de seus antigos aliados, e, diante de uma rebelião armada e de forte oposição no Congresso, tentou dar um golpe militar, dissolveu o Congresso e acabou renunciando ao posto - um exemplo do hábito brasileiro de sair andando do gabinete sem muito aviso prévio, quando acossado por forte oposição. ${ }^{463}$

Os mandatos de seus sucessores imediatos foram um pouco mais ${ }^{464}$ calmos. A presidência do "Marechal de Ferro", Floriano Peixoto, que sucedeu a Deodoro em 1891, foi agitada

\footnotetext{
461 [1970]: 'grupo positivista, idealístico, que'.

462 [1970]: 'ocasional, e ela rompeu-se logo'.

463 [1970]: 'Deodoro foi o próximo a sair, mas contra sua vontade. Arrogante e caprichoso, ele entrou em desacordo com muitos de seus aliados, e após oito meses no poder dissolveu o novo Congresso e tentou governar por decreto. Em 1891, uma rebelião levou-o a renunciar.'

464 [1970]: 'imediatos não foram mais'.
} 
rigidez), assumiu o poder. Seu mandato como presidente foi marcado por guerras civis e rebeliões, duas das quais muito importantes: o levante dos "Federalistas" no Rio Grande do Sul (sempre o nascedouro de rebeliões), e a revolta da marinha, que jamais aceitara a queda da Monarquia e estava enciumada com a proeminência do exército no novo governo. O "Marechal de Ferro" estava quase só, mas, com o povo ao seu lado, saiu vitorioso nessas lutas. A marinha afinal reuniu forças com os sulistas, os almirantes rebelados com os gaúchos. $\mathrm{Na}$ sangrenta batalha final o chefe da marinha [em branco], almirante Saldanha da Gama, foi morto.

Estranhamente, Saldanha da Gama é hoje venerado como o modelo de oficial naval - a Academia Naval brasileira tem o seu nome.

O presidente seguinte era um civil de São Paulo, Prudente de Morais, que tentou restaurar a ordem no país, dividido e exausto após as lutas dos "Florianistas". Foi um período difícil. Não houve mais revoltas nas cidades, nem declarações de militares descontentes, mas um novo fenômeno: guerra religiosa na sua forma mais brutal. Um estranho líder "do interior", uma espécie de santo rústico, apareceu, e atraiu uma quantidade imensa de fanáticos religiosos nas planícies áridas do Nordeste. Era Antônio Maciel, chamado $O$ Conselheiro por seus discípulos. De início, seu por ${ }^{465}$ uma rebelião de oficiais da Marinha e por uma guerra civil * no Sul. O seguinte era um civil de São Paulo, Prudente José de Morais Barros. Durante seu mandato ocorreu a única "guerra religiosa" da história brasileira, a pequena porém macabra e sangrenta guerra de Canudos. Um louco místico de nome Antônio Maciel, chamado Conselheiro, apareceu no sertão da Bahia e atraiu um grande grupo de fanáticos religiosos. De início, o movimento do Conselheiro era puramente religioso: rezas, penitências e peregrinações do bando sempre crescente através das regiões áridas e desertas da caatinga. Então o Conselheiro anunciou um novo dogma: o governo da República era o governo do Anticristo, e seus seguidores deveriam lutar pelo retorno da Monarquia.

\footnotetext{
465 [1970]: 'Deodoro, foi marcada por'.

* Note-se a expressão civil war, que consta tanto no original [VAS] quanto no texto publicado. A historiografia brasileira considera esse episódio uma 'revolta'.
} 
movimento teve lances religiosos: rezas, penitências, perdão de pecados e peregrinações em massa do grupo sempre crescente através das regiões áridas da caatinga, as matas de arbustos. Então o Conselheiro anunciou seu novo dogma: a República era o governo do Anticristo, e eles deveriam lutar pelo retorno do "Rei" em outras palavras, D. Pedro II.

Uma longa e trágica batalha se iniciou. No primeiro momento, pensou-se que uma pequena operação policial, com poucos homens, poderia interromper $\mathrm{o}$ movimento. Mas os seguidores fanáticos do Conselheiro levantaram tamanha resistência que a operação quase assumiu as proporções de uma guerra civil. Mais e mais tropas foram dizimadas pelos jagunços (um nome que originalmente significava "rufião", mas que depois foi usado pelos habitantes do "sertão" em geral), entrincheirados na fortificação de Canudos, na região mais inóspita da Bahia.

Muitos soldados e oficiais foram mortos - até mesmo um general. Alarmado, o governo organizou uma expedição de guerra em grande escala, e Canudos foi afinal destruída, com seus defensores; quase não houve sobreviventes. Hoje, uma grande represa no rio Vazabarris inundou o velho campo de batalha sangrento de Canudos. E o único monumento remanescente é o famoso livro de Euclides da
Uma longa batalha começou. No primeiro momento, o governo pensou que uma pequena operação policial poderia interromper o movimento do Conselheiro. Mas seus seguidores levantaram tamanha resistência fanática em sua fortificação de Canudos que a operação quase assumiu as 466 proporções de uma guerra civil. Depois de grandes perdas, o governo organizou uma expedição em grande escala, e em 1897 Canudos e seus defensores foram destruídos.

${ }^{466}$ [1970]: 'operação chegou a assumir quase as'. 
Cunha, Os sertões (uma ${ }^{467}$ das obras-primas da literatura brasileira), que teve seu início nos simples relatos de um correspondente de guerra.

O presidente seguinte, Campos Sales, lançou-se à recuperação da situação financeira caótica do país. Sob os dois primeiros presidentes e durante a guerra civil, " o país havia entrado num período de grande desordem, que culminou no [em branco] O povo reclamou e fez piadas amargas, mas apertou os cintos. Chamavam o presidente Sales de Presidente selos, por causa das altas taxas (e dos selos associados a elas). Entretanto, a ordem foi restaurada, a moeda se estabilizou, e iniciou-se um período de prosperidade. Esse período marcou o início de um notável progresso de São Paulo, auxiliado pela onda de imigração europeia que esse estado vinha encorajando desde o início do século XIX. Mas a jovem República ainda tinha de produzir um corpo de homens de Estado; e houve muitas disputas e renúncias no grupo de homens idealistas ou ressentidos que provocara a queda de D. Pedro. Portanto, é natural que, restaurando-se a ordem e com o país começando a prosperar, os homens do velho regime imperial, mais dotados e mais bem preparados para a tarefa, tenham voltado ao poder. Com ironia, os jornais chamaram essa nova classe dirigente "o governo dos
EMBORA a jovem República já tivesse produzido alguns homens de Estado, a situação antiga aos poucos se restabeleceu. Inevitavelmente, os homens do Império - em geral conhecidos como "Conselheiros", porque muitos deles haviam tido esse título no Império - voltaram ao poder. Isso não deveria surpreender. Eles eram os mais dotados e os mais bem preparados para a tarefa.

\footnotetext{
${ }^{467}$ Aqui, a autora inclui earlier [anteriormente], entre colchetes, talvez por já ter comentado a obra no capítulo 7. * Mais uma vez, a referência a civil war.
} 
Conselheiros", uma vez que muitos deles realmente haviam sido Conselheiros durante o Império. $\mathrm{O}$ primeiro foi o novo presidente, outro paulista, o antigo Conselheiro Rodrigues Alves, que fez muito para embelezar a cidade do Rio e promover seu saneamento.

Outro Conselheiro, embora famoso republicano, foi uma figura de grande importância por meio século: Rui Barbosa (1849-1923), uma das grandes figuras da história brasileira. Ele tinha muitos talentos: grande $\mathrm{e}$ poderoso orador, jurista do mais alto calibre, escritor de estilo puro e clássico. Ele devotou todos os seus talentos aos governos democráticos e ficou famoso por sua recusa em admitir tudo o que se aproximasse de um governo ditatorial, por sua defesa dos que eram social e economicamente excluídos. Baixo e magro, com uma voz fraca e anasalada, mesmo assim ele era um formidável oponente, respeitado não só por líderes populares mas também por famosos generais. Muitos políticos temiam competir com ele, ou talvez temessem sua intransigência. Toda a nação lamentou sua morte. $\mathrm{E}$ até hoje, em discussões políticas, o homem que consegue citar Rui Barbosa para fundamentar suas opiniões é aquele que tem a última palavra.

Outra figura que emergiu durante o Império e depois se tornou um anjo da guarda da República foi José Maria da Silva Paranhos, o barão do Rio Branco. Com a proclamação da República, ele foi enviado para o exterior, numa posição 
diplomática de pouca

importância. Lá ele

permaneceu até que o

governo o chamou de volta,

requisitando seus serviços

como técnico e conhecedor,

para resolver a antiga disputa

relacionada à fronteira

argentina. Rio Branco, um

grande estudioso de história, arguiu o caso tão bem que

convenceu o árbitro (o

presidente americano Grover

Cleveland) de que o Brasil

estava correto, e a solução foi

favorável ao país. Em honra

ao presidente Cleveland, uma

extensa área do território

recuperado recebeu o nome

de Clevelândia, que

permanece até hoje.

Outras questões

envolvendo disputas de

fronteiras ficaram a cargo de

Rio Branco, e também foram

definidas favoravelmente $\mathrm{e}$

com honra para o Brasil. O

governo de Alves tornou-o

ministro das Relações

Exteriores, e os presidentes

seguintes, não importando de

que partido fossem,

mantinham o irremovível

Barão no Itamaraty (esse

Ministério). ${ }^{468}$ Quando ele

morreu, em 1912, seu funeral

foi o maior que o país havia

visto até então. Toda cidade

no Brasil tem seu nome em

uma das ruas principais (A $5^{\mathrm{a}}$

Avenida do Rio é a "Avenida

Barão do Rio Branco.); um

dos enormes "territórios"

(que ainda não são estados)

chama-se Rio Branco; ${ }^{*} \mathrm{e}$

mesmo uma província do

Uruguai tem o nome de Rio

Branco, em honra ao homem

que estabeleceu sua fronteira.

Outro grande homem do

${ }^{468}$ Em inglês, 'Department of State'. State Department é o equivalente ao Ministério das Relações Exteriores.

* O Território de Rio Branco, desmembrado do estado do Amazonas em 1943, passou a chamar-se Território Federal de Roraima em 1962; em 1988 foi transformado em estado. 
Império que também serviu à República, sobretudo na diplomacia, foi Joaquim Nabuco, famoso abolicionista, depois embaixador nos Estados Unidos por muitos anos.

Com o retorno dos "Conselheiros" o Brasil entrou num período de grande progresso; com o lema "Civilizar o Rio", a velha cidade de D. João VI começou a abrir avenidas e instalar [em branco] Com a ajuda de uma equipe de jovens técnicos, sobretudo o engenheiro Pereira Passos e o médico Oswaldo Cruz, a cidade começou a livrar-se de seu [em branco] colonial. A febre amarela, que havia chegado ao Brasil por volta de 1850 , durante muito tempo foi um flagelo na cidade; os "cariocas" a denominavam "a patriota", porque ela parecia preferir os estrangeiros. Mas foi agora eliminada para sempre por uma [em branco] campanha por saneamento melhor. A vacinação compulsória contra varíola foi introduzida, e até levou a revoltas e derramamento de sangue nas ruas. Os pobres e ignorantes tinham medo da inoculação e os remanescentes dos intelectuais positivistas apoiaram as massas, dizendo que a vacinação compulsória era um "ataque à integridade física do cidadão".

Esse período foi a era dourada do republicanismo no Brasil. O país prosperou, a moeda valorizou-se e o café mantinha o controle da economia. Os presidentes
Embora a economia tenha permanecido basicamente agrícola, as cidades começaram a se expandir. Com o lema "Civilizar o Rio", a velha capital de D. João VI começou a abrir avenidas e melhorar as instalações portuárias, perdendo sua atmosfera provinciana. Medidas sanitárias erradicaram a febre amarela, durante muito tempo um flagelo na cidade. Os cidadãos denominavam essa doença "a patriota", porque ela parecia preferir os estrangeiros que habitavam a cidade. Uma campanha de vacinação destruiu o horror da varíola.

Sob os Conselheiros, o país permaneceu estável por um breve período. A moeda valorizou-se e o café se mantinha sob controle. Mas havia pouca mudança de base na natureza do sistema governamental. Seguindo a tradição imperial, os 
abandonaram toda a tradição parlamentarista do Império e ligaram-se à chamada "política dos governadores", que transformou o Congresso em subsidiário do poder Executivo. Sob esse regime, os grandes estados dominavam os menores, e dois deles dominavam todos os demais: São Paulo e Minas Gerais. Durante muito tempo a Presidência alternou-se entre homens desses dois estados. Como São Paulo era famoso por seu café e Minas Gerais por seus laticínios, esse arranjo político era conhecido como café com leite, a bebida usual no caféda-manhã brasileiro.

Apenas depois da Primeira Guerra Mundial, com a onda de agitação social produzida por ela, o Brasil começou a tornar-se "socialmente consciente". Reformas foram demandadas, sobretudo as eleitorais, uma vez que o voto universal e a verdadeira democracia não passavam de frases. Tais sentimentos eram partilhados por muitos oficiais militares, que tradicionalmente se viam como guardiães da moralidade pública, e foi no exército que a verdadeira agitação começou.

Os problemas começaram entre os militares; liderados por alguns generais mais ambiciosos ou mais avançados politicamente, os jovens oficiais despertaram. No ano de 1922 comemorava-se o primeiro presidentes mantinham o Congresso como subsidiário do Poder Executivo. Como sempre, os grandes estados dominavam os menores, e dois deles - São Paulo e Minas Gerais - dominavam todos os demais. A Presidência alternava-se entre homens desses dois estados. Como São Paulo era famoso por seu café e Minas Gerais por suas grandes fazendas de gado e por seus laticínios, ${ }^{469}$ esse arranjo político era conhecido como café-com-leite, ${ }^{470}$ a bebida mais comum no café-da-manhã brasileiro.

DURANTE e após a Primeira Guerra Mundial, brasileiros educados, influenciados pela onda de agitação social produzida pela guerra, começaram a sentir necessidade urgente de reformas políticas e sociais, sobretudo eleitorais, uma vez que, sem o voto universal, a democracia não passava de uma palavra. Tais sentimentos eram partilhados por muitos oficiais militares, que tradicionalmente se viam como guardiães da moralidade pública, e foi no Exército que a verdadeira agitação começou.

No ano de 1922 comemorava-se o primeiro centenário da Independência, celebrado com grandes festividades públicas. No dia 5 de julho, jovens oficiais rebeldes e idealistas do Forte de Copacabana, no Rio, dispensaram suas próprias tropas e marcharam sozinhos para enfrentar as forças

\footnotetext{
${ }^{469}$ Na carta aos Editores: “p.129, col. 1, 1 par.: 'Uma vez que São Paulo era famoso por seu café e Minas Gerais por seus laticínios, esse arranjo político...'. Por favor, elimine was renowned [variação para 'era famoso'] ou repita famous [famoso], se necessário; vast cattle ranches [grandes fazendas de gado] deve ser eliminado, também. Que ligação eles estão fazendo aí? dairy products [laticínios] é perfeitamente claro, e vast ranches implica criação de gado de corte, de qualquer maneira". As alterações não foram feitas.

${ }^{470}$ [VAS, 1962, 1970]: cafe, não acentuado.
} 
centenário da Independência, celebrado com grandes festividades públicas, e no dia 5 de julho daquele ano aconteceu a famosa marcha para a morte dos " $18 \mathrm{de}$ Copacabana", o primeiro episódio sério de rebelião. Dois anos depois, também no dia 5 de julho, estourou uma revolução em São Paulo.

A principal queixa dos rebeldes era a de que a República estava se tornando burocrática; ela ainda não se livrara do políticos corruptos que haviam derrubado o Império; e o poder político ainda estava nas mãos dos velhos chefes do interior, sem levar em conta a força crescente das cidades. Foi nessa época que surgiram as primeiras agitações operárias no Brasil e formaram-se os primeiros grupos de extrema esquerda, os anarquistas. $\mathrm{O}$ presidente era Artur ${ }^{471}$

Bernardes, de Minas Gerais, rígido e tacanho; ele pediu ao Congresso que decretasse estado de sítio durante todo o seu mandato. E desse "segundo 5 de julho" de 1924 surgiu um movimento revoltoso que em 1930 derrubaria a "República Velha". As tropas rebeldes, forçadas a recuar até o Rio Grande do Sul, iniciaram um dos movimentos mais singulares da história das revoluções brasileiras: a marcha da "Coluna Prestes".

Cerca de dois mil homens, soldados e civis, recusaram render-se ao governo quando os generais o fizeram. Eles eram comandados por um grupo de oficiais que governamentais. Quase todos esses jovens oficiais conhecidos como "os 18 de Copacabana" - foram mortos, mas a marcha foi o primeiro episódio sério de rebelião. Dois anos depois, no aniversário da marcha dos "18 de Copacabana”, estourou uma revolução em São Paulo.

A principal queixa dos rebeldes paulistas, assim como dos oficiais rebeldes, era a de que a República era burocrática demais e que ela deveria livrar-se das oligarquias conservadoras das fazendas, as velhas famílias do interior. Nas cidades, novos grupos - trabalhadores, pequenos comerciantes e funcionários - estavam emergindo, e sendo ignorados. Desse segundo "5 de julho" de 1924 surgiu um movimento revoltoso que ajudaria a derrubar a República Velha. As tropas rebeldes, forçadas a recuar até o Rio Grande do Sul, iniciaram um dos movimentos mais dramáticos da história do Brasil.

CERCA de dois mil homens, soldados e civis, recusaram render-se ao governo. Eles eram comandados por um grupo de oficiais que desde então deixaram suas marcas na história do Brasil. O líder era Luís Carlos Prestes, depois chefe dos

\footnotetext{
${ }^{471}$ A autora grafa 'Arturo'.
} 
deixaram suas marcas na história moderna do Brasil, porém o mais importante no momento, uma vez que se tornou depois chefe dos comunistas brasileiros, é Luís Carlos Prestes. Eles deixaram o Rio Grande do Sul, esconderam-se nas florestas do estado de Santa Catarina e atingiram o Mato Grosso. Depois, como os bandeirantes do século XVII, a coluna embrenhou-se pelo interior do Brasil, a maior parte nem mesmo mapeada na época. Prestes os levou através do Nordeste inóspito, do Piauí até a Bahia. Não foi um exército de agressão; eles apenas se defendiam quando atacados. Respeitaram o povo com o qual tiveram contato e não pediram mais do que $o$ necessário, comida e cavalos, dando recibos de tudo o que tomavam, para ser pago na "vitória da revolução". Em geral, a população os recebia com simpatia ou ao menos não se opunha a eles. Prestes tornou-se uma figura lendária e os jornais lhe deram o apelido de "Cavaleiro da Esperança". Depois de quase dois anos de marcha pelo interior do Brasil, cobrindo 25 mil quilômetros, a coluna dividiu-se em duas partes, uma das quais buscou asilo na Bolívia, e a outra, no Paraguai.

Todos os líderes da "Coluna" retornariam como vitoriosos em 1930. Todos exceto Prestes, que, durante seu exílio ligou-se ao marxismo, ${ }^{472}$ tornou-se membro do Partido Comunista e foi para a Rússia. Ele aparece mais uma vez como líder do movimento comunistas brasileiros. A Coluna Prestes deixou o Rio Grande do Sul e por mais de dois anos deslocou-se pelo interior do Brasil, através de terras que, na época, ainda nem estavam mapeadas. Em geral, a população recebia os homens de Prestes com simpatia. O próprio Prestes, apelidado de "Cavaleiro da Esperança", tornou-se figura lendária. Depois de percorrer milhares de quilômetros pelos sertões, a coluna dividiu-se em duas partes, uma das quais buscou asilo na Bolívia, e a outra, na Argentina.

\footnotetext{
${ }^{472}$ [VAS]: a própria autora substituiu 'iniciou o estudo do marxismo' por 'ligou-se ao marxismo'.
} 
pró-Comunista de 1935, que forneceu o pretexto para o estabelecimento da ditadura Vargas.

... Minas obviamente ressentiu-se com essa quebra de acordo em favor de seu estado rival e alinhou-se com os sempre presentes militares rebeldes. Eles conseguiram o apoio do governador do Rio Grande do Sul, Getúlio Vargas, um político até então quase desconhecido do resto do país, e revoltaram-se contra o presidente Luís. A "Velha República" chegara ao fim dos seus dias, e diziase que ela estava "caindo de madura". Um a um, os governadores dos estados foram derrubados pelos revoltosos. Os oficiais exilados tornaram-se os líderes do movimento e de início pareceu que o governador de Minas seria capaz de tomar o poder conforme planejado. Mas eles não haviam levado em conta as qualidades de liderança do gaúcho Vargas, que de pronto rompeu com todos os seus companheiros iniciais e tornou-se presidente do governo provisório.
Em 1930 o presidente era Washington Luís Pereira de Souza, de São Paulo. Mas, em vez de seguir o consenso do "café-com-leite" e, sendo ele um homem do "café", escolher para sucedê-lo um do "leite" - um presidente de Minas -, Washington Luís conseguiu fazer de um outro paulista o seu sucessor. O poderoso estado de Minas ressentiu-se com essa decisão em favor de seu estado rival e alinhou-se com os sempre presentes militares rebeldes. Os políticos mineiros escolheram como candidato Getúlio Vargas, governador do Rio Grande do Sul. Prometendo reformas profundas, Vargas conseguiu o apoio dos oficiais exilados e de um grande grupo de estudantes, operários e outros trabalhadores. ${ }^{473}$ Mas, quando os votos foram contados, Vargas foi declarado perdedor. A revolta começou. ${ }^{474}$

Uma junta militar assumiu o controle da capital e expulsou Washington Luís, enquanto as tropas sublevadas do norte e do sul marchavam para lá. Um a um, os governadores foram derrubados pelas forças rebeldes. Um dos emissários de

\footnotetext{
473 [1970]: 'exilados e dos novos grupos emergentes nas cidades.'.

474 [1970]: 'perdedor. Alegando fraude, os aliados de Vargas iniciaram a revolta.'.
} 
Vargas deu a entender à junta militar no Rio que as tropas revolucionárias atacariam a capital se o poder não fosse entregue a Vargas. A junta cedeu. Vargas entrou no Rio de maneira triunfal e foi nomeado presidente de um governo provisório. A Era Vargas começava. Para aqueles que o haviam apoiado, o presidente Vargas parecia ser o homem que executaria todas as reformas por tanto tempo esperadas.

A ditadura de Vargas havia começado. Prometeram-se eleições imediatas, mas Vargas sempre as adiava. São Paulo (o estado mais rico do Brasil) estava impotente e humilhado pelos vencedores, que o deixaram à mercê dos "Tenentes" da revolução. Em 1932, sob o complicado lema de "Constitucionalização", São Paulo preparou-se para lutar. Falou-se em secessão. Os paulistas pegaram em armas em conjunto, mas o restante do país não os apoiou, e Vargas, tendo o controle do exército, esmagou os "Constitucionalistas".

Enquanto isso, ele estava tendo problemas para manter sua ditadura, e em 1934 teve de permitir eleições para um novo Congresso. Esse Congresso votou uma nova Constituição, muito liberal, que incorporava vários dos pedidos dos revolucionários de 1922, 1924 e 1930: o voto secreto, o voto feminino e a representação de todas as classes. Esse mesmo Congresso então nomeou Vargas presidente da "Nova República por um período de quatro anos. Os liberais e os tenentes revolucionários
PROMETERAM-SE eleições imediatas, mas o novo presidente sempre as adiava. O estado de São Paulo, embora o mais rico do Brasil, foi humilhado pelos vencedores, que o deixaram à mercê dos "Tenentes" 475 da revolução. Em 1932, sob 476 o lema de "Constitucionalização", os paulistas pegaram ${ }^{477}$ em armas. O restante do país não os apoiou, e Vargas, tendo o controle do Exército, esmagou a revolta.

A pressão oposicionista, no entanto, forçou Vargas a permitir a instalação de uma Assembleia Constituinte. Em 1934 a Assembleia votou uma nova Constituição, que incorporava muitos dos pedidos dos revolucionários de 1922, 1924 e 1930 - o voto secreto, o voto feminino e a representação de todas as classes no governo. Por fim, a Assembleia elegeu Vargas presidente da nova República por um período de quatro anos. Durante algum tempo pareceu que os liberais e os líderes revolucionários haviam triunfado. Mas Vargas, o "homem forte" da fronteira, não levou em consideração as restrições que a nova Constituição lhe

\footnotetext{
${ }^{475}$ [VAS, 1962, 1970]: apenas aqui Officers [Tenentes] aparece entre aspas.

476 [1970]: 'as adiava. Em 1932, sob'.

477 [1970]: 'os insurgentes no estado de São Paulo pegaram'.
} 
haviam triunfado; tudo parecia estar no melhor dos mundos. Mas Vargas, o caudilho da fronteira, não levou em consideração as restrições que a nova Constituição lhe impunha e começou a pôr as mangas de fora. Os comunistas promoveram um movimento único de todos os esquerdistas, sob o nome de "Aliança Libertadora" e, liderados por Prestes, que retornara da Rússia, conseguiram iniciar a revolução no Rio e no Nordeste. Vargas logo esmagou também essa revolta, desta vez com severidade. "

Era o tempo do poder fascista: Hitler na Alemanha, Mussolini na Itália, Franco na Espanha e Salazar em Portugal. Vargas aliou-se ao partido fascista do Brasil, os "Integralistas". Protegido pelo "estado de guerra" decretado por ele para combater os esquerdistas, em segredo ordenou que seus auxiliares escrevessem uma Constituição de cunho fascista (copiada, dizia-se, da polonesa); enviou emissários a todos os estados para garantir o suporte dos governadores e mandou para a cadeia, en masse, como prisioneiros políticos, todos os intelectuais e políticos que tivessem alguma influência sobre o povo. No dia $10 \mathrm{de}$ novembro de 1937, num movimento inesperado, ele ordenou que as tropas cercassem as duas casas do Congresso, fechou-as e impunha, e em 1935 surgiu a oportunidade pela qual ele esperava. Os comunistas reuniram os esquerdistas num movimento denominado Aliança Nacional Libertadora. Liderados por Luís Carlos Prestes, que se tornara comunista depois de um período na Rússia, eles conseguiram iniciar a revolução no Rio e no Nordeste. Vargas decretou "estado de sítio" e logo derrotou a revolta.

Protegido pelos poderes de seu "estado de sítio", em segredo ele ordenou que seus auxiliares escrevessem uma nova Constituição, enviou emissários a todos os estados para garantir o suporte dos governadores e prendeu intelectuais e políticos que tivessem alguma influência entre o público. No dia 10 de novembro de 1937, num movimento inesperado, ordenou que as tropas cercassem as duas casas do Congresso, fechou-as e colocou em prática a Constituição secreta. Vargas era agora, sem disfarces, o ditador do Brasil.

\footnotetext{
* Nos originais consta 'Azambuja' em manuscrito, referência a Marcos Castrioto de Azambuja, funcionário do Itamaraty (e futuro embaixador) que atuou como consultor da edição. Consta agradecimento dos editores a ele na p.156 em [1962] e [1970].
} 
promulgou sua Constituição secreta. (O povo logo a denominou "A polaca". *) Sob o nome de "Estado Novo", o fascismo chegava ao Brasil.

... brasileiros; todavia, é verdade que a despeito dos abusos de poder, ele nunca carregou (ao menos não abertamente) os piores aspectos do fascismo europeu. Era "fascismo ao estilo brasileiro", ou seja, "fascismo adocicado". ${ }^{478}$ Não houve execuções públicas, fuzilamentos nem campos de concentração. Depois dos primeiros meses, muitos dos prisioneiros políticos foram libertados; apenas alguns líderes, condenados pelo inquisitorial "Tribunal de Segurança", permaneceram na prisão. Outros líderes se exilaram. Os próprios "Integralistas", que haviam sido ridicularizados por Vargas e destituídos de todo o poder, revoltaram-se; também essa revolta foi esmagada de modo brutal.
A ideia de ditadura era intolerável para a maioria dos brasileiros. Mas o modelo brasileiro não carregava os piores aspectos das ditaduras europeias. Os oponentes do regime ofensivamente o chamavam de "fascismo ao estilo brasileiro", ou "fascismo adocicado". Os direitos individuais foram reduzidos, houve ${ }^{479}$ prisões arbitrárias e a imprensa foi controlada. Mas não houve execuções públicas, fuzilamentos nem campos de concentração. Depois dos primeiros meses muitos dos prisioneiros políticos foram libertados; apenas alguns líderes permaneceram na prisão. Permitiu-se ${ }^{480}$ que outros se exilassem. Em 1938, o partido de extrema-direita brasileiro, os Integralistas, iniciou uma revolta. Suas forças cercaram o palácio presidencial e tentaram assassinar Vargas. Protegido pelo Exército, Vargas sufocou a revolta. O líder dos Integralistas exilou-se.

Getúlio (os líderes políticos brasileiros são em geral conhecidos por seus primeiros nomes) foi um oportunista e um político perspicaz, e tornou-se amado pelas massas. Ele instituiu ${ }^{481}$ os sindicatos nas fábricas, estabeleceu o salário mínimo e a carga de trabalho semanal máxima. Seu programa de previdência social era avançado no papel, mas poucos dos

\footnotetext{
* A autora não comenta (e possivelmente desconheça) a associação de 'polaca' a 'prostituta'; Polish, em inglês, não tem essa conotação.

${ }^{478}$ A própria autora eliminou, no original, o comentário: 'como eles dizem a respeito do café'.

${ }^{479}$ [1970]: “"adocicado”. Todos os partidos políticos foram extintos, houve’.

480 [1970]: 'prisioneiros foram libertados. Permitiu-se'.

481 [1970]: 'massas, dando a elas pela primeira vez consciência de seu poder político. Até 1930, o país praticamente não havia tido legislação social; Getúlio instituiu'.
} 
benefícios realmente chegaram aos trabalhadores. ${ }^{482}$

No início da Segunda Guerra Mundial, Vargas não escondeu suas simpatias pelas potências do Eixo, e as primeiras vitórias nazistas apoiaram sua atitude. Mas a opinião pública, mesmo silenciada pela ditadura, aproveitou cada oportunidade para mostrar sua inclinação pelos Aliados. O presidente Roosevelt fez todo o possível para conseguir o apoio do Brasil para os aliados, sobretudo após Pearl Harbor. O Brasil cedeu bases militares para os americanos; a "ponte aérea" foi estabelecida entre Natal e Dacar, e por ela grandes números de tropas americanas e grandes quantidades de suprimentos cruzaram o oceano.

Com o afundamento de navios brasileiros por submarinos alemães, ${ }^{484}$ campanhas nos jornais e manifestações nas ruas, Vargas foi forçado a declarar guerra contra as potências do Eixo. Um contingente de soldados brasileiros foi enviado para lutar na Itália e sofreu perdas [em branco]

No fim da guerra, em 1945, o Brasil, a despeito de Vargas e da ditadura, estava orgulhoso por fazer parte dos vitoriosos Aliados.
FOI A Segunda Guerra Mundial que permitiu a queda da ditadura. No início da guerra as simpatias de Vargas não estavam claras; ele fez gestos amigáveis em ambas as direções. ${ }^{483}$ Mas, depois que navios mercantes brasileiros foram afundados por submarinos nazistas, o que provocou uma série de campanhas nos jornais e manifestações nas ruas, Vargas declarou guerra contra o Eixo. O Brasil cedeu suas bases aéreas e navais para os Estados Unidos. De Natal, muitas tropas e grandes quantidades de suprimentos partiam para atravessar o Atlântico até Dacar, na África ocidental. Uma divisão brasileira lutou ao lado do $5^{\circ}$ Exército norteamericano na Itália.

482 [1970]: 'máxima. O trabalho infantil foi proibido na indústria; mulheres receberam direitos salariais idênticos aos dos homens. Essas medidas foram as primeiras, no Brasil, a diminuir a vasta distância que separava os ricos dos pobres.'.

${ }^{483} \mathrm{Na}$ carta aos Editores: “p.130, col. 2, final da página. Vocês alteraram isso novamente, e agora está completamente falso. O que eu disse foi: 'No início da Segunda Guerra Mundial Vargas não escondeu suas simpatias em relação às potências do Eixo, e as primeiras vitórias nazistas apoiaram sua atitude'. Esta é a simples verdade. Por que vocês insistem em absolver ditadores?". A correção não foi feita.

${ }^{484}$ [VAS]: a própria autora substituiu nazi por german. 
... "Estado Novo", tipicamente fascista, mesmo que moderado, após o entusiasmo que o Brasil demonstrou pelos Aliados e por seus próprios soldados que retornavam. Os Estados Unidos fizeram discreta pressão para que Vargas permitisse eleições livres. A imprensa, numa só voz, começou a desobedecer à censura governamental, e Vargas foi incapaz de reimpor suas ordens. Em outubro de 1945, afinal, os mais importantes oficiais militares, percebendo que a ditadura estava vacilando, depuseram Vargas e o exilaram, não no exterior, mas em sua distante fazenda no Rio Grande do Sul.

Houve eleições. O candidato da oposição era o brigadeiro general Eduardo Gomes, o único remanescente dos "18 de Copacabana" de 1922, heróis nacionais. Porém, mesmo sem Vargas, a
Não seria fácil manter o autoritário "Estado Novo", como Vargas denominou seu regime, após o entusiasmo que o Brasil demonstrou pelos aliados e por seus próprios soldados que retornavam da Itália. Os Estados Unidos fizeram discreta pressão para que Vargas permitisse eleições livres. A imprensa começou a desobedecer à censura governamental, e Vargas foi incapaz de restaurá-la. Em outubro de 1945 os oficiais militares mais graduados, percebendo que a ditadura estava fragilizada, depuseram Vargas e o exilaram em sua distante fazenda no Rio Grande do Sul.

Já era hora. Depois de quinze anos sob Getúlio, o país ainda estava endividado e industrialmente subdesenvolvido. A dignidade do Brasil e de muitos dos brasileiros havia sido afrontada por sua ditadura. Mas o balanço não era apenas negativo. Ao estabelecer ${ }^{485}$ uma siderúrgica em Volta Redonda com ajuda norte-americana durante a guerra, Vargas ${ }^{486}$ havia lançado as bases para a futura industrialização do país. ${ }^{487}$

Após a saída ${ }^{488}$ de Vargas houve eleições. As forças contrárias a ele escolheram como candidato um brigadeiro da Aeronáutica, general Eduardo Gomes, conhecido por ser o único remanescente dos "18 de Copacabana" de 1922. Mas a

485 [1970]: 'Embora a dignidade do Brasil e de muitos brasileiros tenha sido afrontada pela ditadura de Vargas, o balanço não foi inteiramente negativo. Além de suas medidas sociais, Vargas iniciou a construção de escolas e reformou o sistema educacional. Ao estabelecer'.

486 [1970]: 'guerra e encorajar a industrialização em outros lugares, Vargas'.

487 [1970]: 'bases sobre as quais uma economia forte eventualmente poderia ser construída.'.

488 [1962, 1970]: "após a expulsão de Vargas". Na carta aos Editores: "p.131, col. 1, par. 3. 'Depois da saída de Vargas' - COMO EU PEDI MUITAS VEZES EM NOVA YORK - POR FAVOR, NÃO USE A PALAVRA OUSTER [EXPULSÃO]". A correção não foi feita. Na carta, a palavra said [disse] foi cortada pela autora e substituída por asked [pedi]. 
máquina política da ditadura ainda funcionava, e os mesmos líderes que haviam apoiado o "Estado Novo" ainda estavam no poder. Eles conseguiram eleger seu candidato, general Eurico Dutra, ex-ministro da Guerra de Vargas, que havia sido chamado de "chefe de polícia do Estado Novo".

Surpreendentemente, uma vez no poder, Dutra respeitou a nova Constituição (havia agora uma Constituição liberal) e não se mostrou interessado em ter poder pessoal nem em permitir excessos militares. Mas ele era um amigo, aliado do ditador deposto. Os direitos políticos de Vargas não haviam sido revogados; a necessária reforma eleitoral não foi realizada. Assim, no final do mandato de 5 anos de Dutra, "Getúlio" concorreu de novo. Ele usou todas as vantagens do paternalismo emocional que a enorme máquina de propaganda do Estado Novo vinha repetindo ao povo durante oito anos - e que o governo Dutra, desta vez, não desmascarou. E em 1951, Vargas, numa vitória esmagadora, voltou ao poder, como presidente legalmente eleito. máquina política de Vargas ainda funcionava, mesmo sem ele, e os líderes do "Estado Novo" permaneceram no poder. ${ }^{489}$ Foi eleito o seu candidato, general Eurico Gaspar Dutra, exministro da Guerra de Vargas que havia sido chamado de "chefe de polícia do Estado Novo".

Surpreendentemente, Dutra ${ }^{490}$ mostrou respeito pela nova Constituição liberal promulgada após a queda de Vargas e não se mostrou interessado em ter poder pessoal nem em permitir excessos militares. Mas as necessárias reformas eleitorais não foram feitas, e os direitos políticos de Vargas não foram revogados. Em 1950, quando terminou o mandato de Dutra, Getúlio concorreu à Presidência. Com sua velha máquina trabalhando firme e com uma forte campanha por todo o país, de uma intensidade jamais vista no Brasil, ele venceu com ${ }^{491}$ grande maioria e assim tornou-se presidente legalmente eleito.

Porém, os tempos haviam mudado. Dutra havia governado com honestidade e respeitara as leis. O grupo que retornou ao poder com Vargas tinha sede de poder, fama e

${ }^{489}$ [VAS]: a própria autora eliminou o complemento: permaneceram no poder 'em todos os estados'.

490 [1970]: 'Dutra mostrou'.

491 [1970]: 'Mas Vargas criou uma nova organização política, o Partido Trabalhista Brasileiro, e concorreu novamente à presidência em 1950. Seu apelo pessoal entre as massas pobres ainda era grande. Enfatizando os problemas sociais, ele voltou ao governo com'. 
... dinheiro. A presidência estava cercada por uma corrupção profunda. A oposição lutava áspera e violentamente contra Vargas e o "Getulismo". Carlos Lacerda, editor do jornal oposicionista Tribuna da Imprensa, era seu oponente mais conhecido, e expunha as fraudes e as tramoias nos círculos governamentais e mesmo entre os membros da família de Vargas.

(Acreditava-se que Vargas fosse honesto, mas iludido, e cada vez mais isolado.) Membros da guarda pessoal de Vargas tentaram assassinar Lacerda. O atentado falhou; Lacerda escapou com um tiro no pé, mas um jovem major da aeronáutica, Vaz, que estava com Lacerda para protegê-lo desse tipo de ataque, foi morto.

Esse assassinato político gerou um ${ }^{494}$ escândalo nacional. Lacerda acusou o presidente como o instigador do crime. (Depois provou-se, no entanto, que Getúlio ignorava tudo.) A aeronáutica estava determinada a encontrar o responsável pela morte de seu camarada, e prendeu o culpado no próprio palácio presidencial.

Membros importantes das Forças Armadas pediram que o presidente renunciasse, numa cena dramática na madrugada de 24 de agosto dinheiro. Getúlio estava cercado por uma corrupção tão profunda que, ao conscientizar-se de sua extensão, ele mesmo falou de "mar de lama". (Acreditava-se que Vargas fosse honesto, mas intocável, isolado por seus auxiliares.) Críticos diretos lutaram asperamente contra Vargas e o "Getulismo". ${ }^{492}$ Carlos Lacerda, editor do jornal Tribuna da Imprensa, era seu mais conhecido opositor e expunha as fraudes e as tramoias nos círculos governamentais, mesmo entre os familiares de Vargas. Membros da guarda pessoal de Vargas tentaram assassinar Lacerda. Um jovem major da Aeronáutica, Rubens Florentino Vaz, guarda-costas de Lacerda, foi morto; Lacerda escapou com ${ }^{493}$ um tiro do pé.

ESSE assassinato político gerou, é claro, um escândalo nacional. Lacerda acusou o filho do presidente de ter instigado o crime. Depois provou-se, no entanto, que Getúlio e seu filho ignoravam tudo. A Aeronáutica ${ }^{495}$ perseguiu o homem responsável pela morte do major - o chefe dos guarda-costas da Presidência - e um grupo de oficiais da Aeronáutica prendeu-o no próprio palácio. Membros importantes das Forças Armadas pediram que o presidente renunciasse, numa cena dramática, na madrugada de 24 de agosto de 1954. Vargas, ainda de pijamas, aparentemente aceitou renunciar;

492 [1962, 1970]: getúlismo, acentuado.

493 [1970]: 'Lacerda conseguiu escapar apenas com'.

494 A própria autora eliminou o adjetivo 'medonho', junto a 'escândalo nacional'.

495 Na carta aos Editores: "p.131, col. 2, par. 1 e 2: AERONÁUTICA deve ficar em maiúscula [a letra inicial], sempre. A sentença sobre Lacerda, aqui, soa abrupta, e seria melhor, se possível, se outra frase pudesse ser inserida, como esta: 'Lacerda publicamente acusou o filho do presidente de ter instigado o crime, a única de suas acusações infundada, pois Vargas e seu filho posteriormente provaram' etc.". A alteração não foi feita, e Air Force [Aeronáutica] permaneceu com iniciais minúsculas. Esta tradução padroniza iniciais maiúsculas em Exército, Marinha e Aeronáutica. 
de 1954. Ainda de pijamas e de robe, Vargas aparentemente aceitou renunciar; retirou-se para seu quarto - e matou-se com um tiro no coração.

Felizmente, com o admirável talento brasileiro para resolver as piores crises pacificamente, o país não mergulhou no caos após o suicídio do presidente. $\mathrm{O}$ vice-presidente, Café Filho (Coffee, $J r$.), tomou posse como se o posto tivesse ficado vago de modo mais normal. (A piada comum, obviamente, era: "O que o mordomo diz quando bate na porta do presidente, de manhã? Hora do café".) No final de seu mandato haveria novas eleições. $\mathrm{O}$ candidato do velho grupo "Getulista" era Juscelino Kubitschek, de Minas Gerais; o da oposição era um general, Juarez Távora, um dos "jovens tenentes" de 1930, que depois se voltou contra Vargas. Todavia, mais uma vez a máquina de Vargas foi poderosa, a despeito do suicídio - ou talvez por causa dele. Vargas havia sido a figura paternal das massas de pobres, sobretudo nas cidades. Seu funeral no Rio, ou melhor, a procissão que carregou seu caixão pelas ruas até o aeroporto, para ser levado de volta ao Rio Grande do Sul, foi uma amostra assustadora e tocante de histeria de massa.

Kubitschek venceu as eleições por uma pequena retirou-se para seu quarto - e matou-se com um tiro no coração. Ele deixou uma carta extraordinária cuja autenticidade é até hoje discutida no ${ }^{496}$ Brasil. Ela afirma seus bons serviços em favor do país, e adverte de maneira sombria a respeito de forças internacionais.

O sucessor imediato de Vargas foi o vice-presidente, João Café Filho, que completou o mandato de Vargas. Em 1956 subiu ao poder Juscelino Kubitschek, ex-governador de Minas Gerais e um dos homens de Vargas. ${ }^{497}$ Kubitschek venceu as eleições com o apoio da máquina varguista. Quando [p.132] a vitória - embora legal - foi questionada, um grupo de líderes militares tomou o poder por um breve período através de um golpe preventivo, num esforço para que se obedecesse à Constituição. Declarando o país em estado de sítio, eles garantiram a posse de Kubitschek e saíram de cena. ${ }^{498}$

\footnotetext{
${ }^{496}$ [1970]: 'discutida acirradamente no'.

497 [1970]: 'Juscelino Kubitschek, ex-governador de Minas Gerais e um dos homens de Vargas, tornou-se presidente em 1956, após a eleição seguinte.'.

${ }^{498}$ QUADRO: A carta-testamento de Vargas.
} 
margem; e assim que os

soldados e os civis que apoiavam Távora começaram a questionar a legalidade da eleição, os generais "Getulistas", com todos os meios sob seu comando, deram um golpe preventivo, declararam o país em estado de sítio por [em branco] dias e garantiram a posse de Kubitschek.

... ambicioso. Lançou-se à sua grande obra, a construção da nova capital, Brasília. Encorajou a industrialização e iniciou a construção de grandes represas, buscando aumentar o fornecimento de energia elétrica ao país. Mas seu governo, mais que qualquer outro, era favorável à corrupção e às fraudes. Toda a riqueza do país permaneceu nas mãos de poucos grupos políticos e econômicos. A inflação, que começara a crescer no tempo de Vargas, agora subia a níveis de pesadelo. $\mathrm{O}$ custo de vida aumentava todos os dias; afinal se desvendou a falsa prosperidade do "desenvolvimento" tão louvado de Kubitschek. No final de seu mandato de cinco anos o Brasil estava [em branco]

[quadro da TIME aqui] *
No governo, Kubitschek não mostrou rancor. Ele era ${ }^{499}$ hiperativo, otimista e ambicioso, e prometeu que ${ }^{500}$ o país avançaria "cinquenta anos em cinco". Lançou-se à sua grande obra, a construção da nova capital, Brasília. Sob Kubitschek, a industrialização realmente começou: as exportações de ferro duplicaram e iniciou-se a indústria automobilística brasileira. Ele criou um ambicioso programa de construção de rodovias e de grandes represas para aumentar a geração de energia elétrica. Mas o governo Kubitschek estava sujeito à corrupção e às fraudes. Alguns brasileiros diziam que a corrupção suplantava até mesmo a dos tempos de Vargas. O controle do país permanecia nas mãos de poucos e poderosos grupos políticos e econômicos. Enquanto o Sul permanecia rico e próspero, o Nordeste ainda continuava profundamente pobre. A inflação, que se iniciara com Vargas, agora crescia a níveis de pesadelo - em parte como resultado da rápida industrialização. Estima-se que Kubitschek tenha gastado 600 milhões de dólares em Brasília. ${ }^{501}$ Em resumo, os problemas crônicos do país permaneceram sem solução. Mas o programa

\footnotetext{
* Apesar da observação manuscrita, não foi incluído nenhum quadro nesse capítulo.

499 [1970]: 'Kubitschek era'.

500 [1970]: 'prometeu a realização de seu slogan de campanha, de que'.

${ }^{501}$ Na carta aos Editores: “p.132, col. 1, final da página. 'Inflação... agora crescia a níveis de pesadelo...'. Não diga 'em parte como resultado da rápida industrialização'. Por favor, elimine. É verdade, de acordo com Gudin e outros economistas, que a industrialização pode contribuir para uma pequena parte da inflação, mas a sua implicação aqui é completamente fora de proporção com a escala da inflação no Brasil. Também de acordo com as melhores estimativas daqui, Brasília custou no mínimo um bilhão de dólares. Onde vocês
} 
Houve eleições. O candidato oficial foi um dos generais do golpe preventivo que havia assegurado a posse de Kubitschek, Henrique Lott. O outro candidato era o ex-governador do estado de São Paulo, Jânio Quadros, um jovem político (poucos meses mais jovem que 0 presidente Kennedy) cuja carreira havia sido meteórica. Ex-professor de história, ele subiu todos os degraus da política em [em branco] anos, de vereador a candidato presidencial - sem ter completado ao menos um mandato. (No Brasil, um homem não pode concorrer a um cargo enquanto estiver em outro, portanto Quadros renunciava sempre.)

Quadros foi eleito por uma imensa maioria, na maior eleição já realizada no Brasil. O povo queria mudanças, queria respeito à lei e austeridade, também para escapar da espiral inflacionária e dos longos anos do regime de Vargas e de seu sucessor - [em branco] anos, no total. Havia uma atmosfera de esperança e orgulho. Nos primeiros sete meses de sua presidência, Quadros pareceu estar cumprindo suas promessas eleitorais e o país já sentia os efeitos de sua administração. de desenvolvimento de Kubitschek colocou o Brasil num rumo que no futuro poderia trazer grande riqueza para todos os cidadãos. ${ }^{502}$

O candidato do ainda forte grupo varguista nas eleições de 1960 foi o general Henrique Lott, um dos responsáveis pelo golpe preventivo que havia permitido a posse de Kubitschek em 1956. O outro candidato era o exgovernador do estado de São Paulo, Jânio Quadros, um exprofessor de 43 anos cuja carreira política havia sido meteórica. Como governador de São Paulo, Quadros combateu as fraudes, equilibrou o orçamento, triplicou a malha rodoviária e iniciou um programa de construção de represas num montante que excedia toda a capacidade energética brasileira.

Quadros afirmava ser a "nova vassoura" que iria varrer para sempre a corrupção dos tempos de Vargas e de Kubitschek; o símbolo de sua campanha era uma vassoura em miniatura. Na maior eleição já feita no Brasil, ele venceu com a tremenda vantagem de 1,7 milhão de votos. Quando foi empossado, em 1961, havia uma nova atmosfera no Brasil. O povo queria mudanças, queria moralidade no governo e também austeridade. Queria qualquer coisa que permitisse escapar da espiral inflacionária e dos longos períodos de corrupção governamental e desperdício. O Brasil estava esperançoso, afinal.

E, no início, tudo deu certo. Assim como fizera no

encontraram 600 milhões, e por que vocês deveriam estar mais corretos que os economistas brasileiros acerca dessa estimativa necessariamente grosseira?". As alterações não foram aceitas.

502 [1970]: nova redação, daqui até o final do capítulo. Ver Nota III, no final deste capítulo. 
estado de São Paulo, Quadros ordenou investigações sobre as fraudes e demitiu os funcionários desnecessários. E ele era igualmente enérgico em outras áreas. Iniciou um programa rodoviário de um bilhão de dólares e projetos hidrelétricos de dois bilhões de dólares. Anunciou planos para melhorar ${ }^{503}$ a educação primária, com o objetivo de aumentar a alfabetização de 48 para 70 por cento em cinco anos, e programas para duplicar a produção de aço e desenvolver outras indústrias. Outras políticas de Quadros, no entanto, sobretudo as propostas das reformas fiscal e agrária, enfrentaram forte resistência de seus opositores no Congresso. Além disso, houve grande alvoroço quando Quadros condecorou Ernesto ("Che") Guevara, o líder comunista ${ }^{504}$ e ministro da Economia de Cuba, com a Ordem do Cruzeiro do Sul, a mais alta distinção brasileira para estrangeiros. Quadros sofreu ataques crescentes de Carlos Lacerda, agora governador do estado da Guanabara, o antigo Distrito Federal, onde se situa a cidade do Rio de Janeiro. Ao mesmo tempo Quadros começou a sondar os líderes do Congresso sobre a possibilidade de lhe assegurarem poderes adicionais - um pedido ao qual o Congresso era totalmente contrário. No final de agosto, Lacerda anunciou num discurso transmitido por televisão e rádio que ele havia sido procurado pelo ministro da Justiça e que o presidente estava planejando assumir poderes adicionais. Lacerda é um homem polêmico, mas sua honestidade é inquestionável. O discurso gerou comoção nacional.

\footnotetext{
${ }^{503}$ Na carta aos Editores: "p.132, col. 2, final da página. NÃO DIGAM STEP UP EDUCATION [melhorar a educação] - Por que SER VULGAR? He spoke of a school-building program that would increase literacy... [Ele falou de um programa de construção de escolas que aumentaria a alfabetização...] etc.”. A alteração não foi feita.

504 [1962, 1970]: 'líder de tendência comunista'. Na carta aos Editores: "p.133, col. 1, alto da página. 'Ele fez concessões crescentes para a extrema esquerda, e houve violenta reação pública quando concedeu a Ordem do Cruzeiro do Sul... etc. para... o ministro da Economia de Cuba, comunista'. Se vocês estiverem com medo de usar a palavra comunista, digam apenas 'para o ministro da Economia Cubano'. NÃO DIGAM COMMUNIST-LEANING [de tendência comunista], PELO AMOR DE DEUS! - Eu discuti tudo isso muitas vezes em Nova York. Por que não dizer a verdade?”.
} 
* Conhecido como homem difícil e temperamental, ele já havia "renunciado" uma vez durante sua campanha, mas reconciliara-se com os partidos que o apoiavam ...

[9 linhas em branco]

... e o país foi sacudido pela notícia de que o presidente havia "renunciado" e no dia seguinte ele estava a caminho da Inglaterra.

$\mathrm{O}$ vice-presidente era João ("Jango") Goulart, um protegido de Vargas desde o exílio de Vargas no Sul e chefe dos "sindicatos" operários desde a época de Vargas. Ele estava na China quando Quadros renunciou, e era, segundo os chefes militares, supostamente vermelho. ${ }^{507}$ Eles vetaram seu retorno para assumir a Presidência, e durante uma semana as coisas permaneceram num impasse: Goulart seria presidente ou não? O Rio Grande do Sul, como sempre, parecia em estado de guerra (e seu governador era cunhado de Goulart), pelo "conterrâneo". Eles se prepararam para a
Na manhã de 25 de agosto, Quadros escreveu uma carta de renúncia. Os comandantes do Exército, da Marinha e da Aeronáutica ${ }^{505}$ correram ao palácio e pediram que ele mudasse de ideia, mas o presidente estava inflexível. Ele enviou a carta ao Congresso e voou para Cumbica, a base aérea militar próxima à cidade de São Paulo. Sua carta, assim como a supostamente deixada por Vargas sete anos antes, insinuava a existência de misteriosas forças estrangeiras e clamava a devoção de Quadros aos interesses do Brasil e do seu povo. Ele esperou por cinco horas no avião, aguardando que o chamassem de volta, mas isso não aconteceu. $\mathrm{O}$ Congresso aceitou a renúncia. ${ }^{506}$

Assim começou a mais séria crise da história brasileira recente. $\mathrm{O}$ vice-presidente, que de acordo com a Constituição se tornaria presidente, era João "Jango" Goulart. Protegido de Vargas que ainda controlava o Partido Trabalhista, fundado por Vargas, ele era visto como demagogo, oportunista, esquerdista e uma incógnita política. No momento em que Quadros renunciou, ele havia acabado de deixar a China comunista, onde estivera preparando um acordo comercial Brasil-China. Goulart era inaceitável para os comandantes das Forças Armadas, os quais anunciaram que ele seria preso em seu retorno ao Brasil. No Rio, as tropas foram para as ruas. Censores tomaram os jornais, o rádio e a televisão. ${ }^{508}$ Enquanto Goulart retornava ao país por escalas cautelosas, os

\footnotetext{
* As nove linhas em que a autora se referia à renúncia de Jânio foram apagadas, no original.

${ }^{505} \mathrm{Na}$ carta aos Editores: "p.133, col. 1, $2^{\circ}$ par. - Exército, Marinha e Aeronáutica devem ter a inicial em maiúscula". A solicitação não foi aceita.

${ }^{506}$ QUADRO: O bilhete de renúncia de Jânio Quadros.

${ }^{507}$ Red. É a única vez que a autora utiliza esse termo, neste livro, referindo-se aos comunistas.

${ }^{508} \mathrm{Na}$ carta aos Editores: "p.133, col. 2, alto da página - In Rio, censors took over press, radio, and television for 3 days, and troops were ordered into critical zones of the city [No Rio, censores tomaram os jornais, o rádio e a televisão por três dias, e tropas foram colocadas nas zonas críticas da cidade]. Do modo como vocês deixaram, implica que todo o país estava sob censura por um período indefinido, e que o Rio estava repleto de soldados - o que é completamente falso. Mais uma vez, eu discuti tudo isso em N[ova] Y[ork]". As correções não foram feitas.
} 
guerra civil sob o lema de "Legalidade" e "respeito à Constituiçãa". Os oficiais militares do norte não queriam uma guerra civil, é claro, mas eles temiam a política esquerdista de Goulart. Afinal, a crise foi mais uma vez resolvida pelo "talento para o acordo" (a expressão, como "terra de promessas não cumpridas", é quase uma bandeira vermelha para um brasileiro, hoje).

O Congresso aprovou uma mudança para

"parlamentarismo", que permitiu a Goulart assumir o cargo de presidente, mas seus poderes foram reduzidos pela introdução de um primeiroministro - um sistema copiado mais ou menos daquele da Alemanha Ocidental. O novo gabinete foi escolhido. (E o governo logo foi chamado de "bifocal".) O país voltou a ter um Parlamento, o responsável pela grandeza do Império, alguns dizem, e, dizem outros, o responsável por sua queda.

Ainda é cedo demais para prever os resultados da mudança. aliados em seu estado, o Rio Grande do Sul, onde seu cunhado era governador, prepararam-se para a luta. Seguiram-se treze dias de incerteza. Mas havia um forte sentimento para que se preservasse a Constituição.

Depois de consideráveis manobras nos bastidores, o Congresso aprovou uma emenda constitucional que alterava o sistema de governo, até então presidencial, como o dos Estados Unidos, para parlamentar, semelhante ao da Alemanha Ocidental. (Esse governo logo foi chamado de "bifocal".) Um primeiro-ministro tornou-se o novo chefe de governo, e os poderes do presidente foram reduzidos. Goulart foi empossado e, com a aprovação do Congresso, escolheu Tancredo Neves como o novo primeiro-ministro. Neves havia sido ministro da Justiça no governo Vargas.

A crise foi abortada, e o Brasil mostrou mais uma vez seu grande "talento para o acordo" - uma frase frequentemente usada pelos brasileiros mesmo que, assim como a frase "terra de promessas não cumpridas", ela esteja começando a irritar. 
Nota II) [1970]: Incluído no capítulo 9 um trecho referente ao período 1962-1970 (p.127-128).

Durante esses anos Vargas procedeu a algumas reformas necessárias havia muito tempo. Mas ele adiou o desenvolvimento da democracia responsável no Brasil. Depois de seu suicídio, em 1954, o país afundou numa confusão política e econômica.

As crises seguiram-se umas às outras, durante anos. As esperanças surgidas quando o presidente reformista Jânio Quadros assumiu o governo em 1961 foram perdidas quando ele subitamente renunciou após sete meses. Depois de um período de lutas internas, um herdeiro de Vargas, João Goulart, surgiu como presidente. Mas durante seus 31 meses de governo a inflação disparou, os serviços básicos entraram em colapso e a agitação esquerdista cresceu. O Brasil parecia caminhar para o colapso, talvez para uma revolução comunista.

Em março de 1964 as Forças Armadas brasileiras reuniram-se para impedir essa eventualidade. Goulart foi afastado, e o marechal Humberto de Alencar Castelo Branco, primeiro de uma sucessão de líderes militares, foi nomeado presidente. Comprometendo-se a manter a ordem antes de retornar para os quartéis, os militares assumiram todo o poder. Toda a oposição foi silenciada ou posta na clandestinidade. Na aparência, a vida permaneceu relativamente calma, mas, na realidade, oprimida pela sombra escura da censura à imprensa. Os militares e as forças policiais contiveram as bombas terroristas, os sequestros e assassinatos com prisões sumárias, torturas e execuções.

Nota III) [1970]: O trecho final do capítulo 9 (p.132-133) foi reescrito. Refere-se ao período 19621970.

O candidato do ainda forte grupo varguista nas eleições de 1960 foi o general Henrique Lott, que havia permitido a posse de Kubitschek em 1956. Opunha-se a Lott Jânio Quadros, um ex-professor de 43 anos de idade que propalava seus sucessos como governador de São Paulo e que, em sua campanha, dizia ser a "vassoura nova" que iria varrer para sempre a corrupção das eras Vargas e Kubitschek. O povo escolheu Quadros pela tremenda margem de 1,7 milhão de votos.

O Brasil estava esperançoso quando Quadros foi empossado, em 1961, e no início tudo correu bem. Assim como fizera em São Paulo, Quadros ordenou investigações a respeito de corrupção, dispensou funcionários públicos supérfluos e iniciou reformas e programas de desenvolvimento. Os líderes do Congresso preocuparam-se, no entanto, quando Quadros começou a falar acerca da possibilidade de ter poderes adicionais. No final de agosto, Lacerda fez a revelação sensacional de ter sido convidado por Quadros para apoiá-lo numa conspiração que fecharia o Congresso.

Quadros redigiu um bilhete de renúncia que, assim como a carta supostamente deixada por Vargas sete anos antes, jurava devoção ao Brasil e acusava ameaças de misteriosos poderes estrangeiros. Ainda se debate com empolgação se Quadros realmente pretendia renunciar ou se ele estava apenas fazendo um pedido dramático por mais poder. Qualquer que seja o caso, a renúncia foi apresentada ao Congresso e aceita. 
De acordo com a Constituição, o vice-presidente João ("Jango") Goulart deveria sucedê-lo imediatamente na presidência. O protegido de Vargas que ainda controlava o Partido Trabalhista, fundado por Vargas, Goulart era, no entanto, visto como demagogo, oportunista, esquerdista e uma incógnita política. Ele tinha, de fato, acabado de deixar a China comunista, onde estivera negociando um tratado comercial. Era detestado pelos comandantes das forças armadas, é claro, mas depois de muita manobra política estes foram persuadidos a aceitá-lo.

Mas se Goulart teve sucesso em seu papel como político, sua ineficiência como líder nacional justificou o antigo temor dos militares. Ele mostrou-se incapaz de enfrentar a inflação galopante, a falta de alimentos e as greves que sempre tumultuavam a economia.

No início de 1964, o Brasil se aproximava do colapso econômico. Percebendo o perigo da extrema esquerda, um pequeno mas influente grupo de civis e militares vinha secretamente definindo os detalhes de um golpe. O que provocou a ação foi, afinal, um motim de marinheiros que Goulart, num arroubo esquerdista, pareceu apoiar. No dia 31 de março, tropas do Exército começaram a marchar em direção ao Rio. Nas 24 horas seguintes, todos os principais comandantes militares e líderes políticos, tais como Carlos Lacerda, então governador do estado da Guanabara (Rio), anunciaram seu apoio ao levante. Vendo-se abandonado, Goulart exilou-se no Uruguai. Em 48 horas, praticamente sem disparar suas armas, os soldados controlaram a situação.

O marechal Castelo Branco, antigo comandante do Exército conhecido por sua integridade, foi nomeado presidente revolucionário. O novo governo começou a livrar o país de elementos corruptos e subversivos, e a tomar atitudes econômicas emergenciais. De início, não fechou o Congresso nem restringiu a imprensa, e prometeu restaurar a democracia em 1966. A pressão de direita, no entanto, forçou Castelo Branco a recuar em sua promessa. A anunciada eleição presidencial livre foi substituída por uma eleição indireta, a cargo dos dóceis congressistas. Como resultado, seu antigo ministro da guerra, marechal Costa e Silva, tornou-se candidato único à Presidência e foi empossado em 1967. Costa e Silva mostrou-se um governante inadequado. Quando ele sofreu um derrame em agosto de 1969, um triunvirato militar já impaciente tomou o poder, afastando ilegalmente o vice-presidente civil. Os generais escolheram entre seus pares o general Emílio Garrastazu Médici como novo presidente, e reuniram o Congresso, que havia estado em "recesso" por 10 meses, numa sessão para ratificar sua escolha. Como a maioria dos seus colegas militares, o general Médici estava certo de que apenas os militares sabiam o que era melhor para seu país. "Deve haver liberdade", ele declarou certa vez, "mas não deve haver licença para que se contrariem os desejos políticos da nação".

Médici foi empossado em outubro, apenas um mês após o governo ter sofrido o embaraçoso sequestro do embaixador norte-americano C. Burke Elbrick, por terroristas. O sequestro de Elbrick era parte de uma campanha de guerrilha urbana que incluía roubo a bancos e ataques com bombas, com a finalidade de derrubar o regime militar. Ele foi solto em troca de 15 prisioneiros políticos, mas apenas depois de longas disputas entre os generais em busca de uma decisão.

Como seus predecessores, o general Médici fez grandes promessas ao assumir o poder. "No final do meu governo, espero deixar a democracia definitivamente instalada em nosso país", ele proclamou. Mas os porta-vozes do governo se apressaram em destacar que a palavra mais importante naquela frase era "espero". E ter esperança era tudo o que os brasileiros poderiam fazer. 


\section{Uma nação perplexa e indecisa ${ }^{509}$}

${ }^{510}$ Os Estados Unidos e o Brasil têm muitas coisas em comum além de estarem ambos no Hemisfério Ocidental e partilharem o nome de Américo Vespúcio. É hora de conhecermos e apreciarmos melhor um ao outro; hora de os Estados Unidos darem ao Brasil mais que empréstimos e aqueles traços menos atrativos de nossa cultura, que ${ }^{511}$ se considera estarem "americanizando" o mundo. Os Estados Unidos e o Brasil têm mais em comum que café e Coca-cola, embora tenhamos, agora, muito dos dois.

Somos dois grandes países e muito conscientes de nossa dimensão. Talvez números, gigantismo, o "maior" isso ou aquilo signifiquem demais para nós. Culturalmente, também, embora tenhamos tradições tão diferentes, há similaridades. Tanto os Estados Unidos como o Brasil permaneceram como imitadores cautelosos por duzentos anos ou mais, e ambos sofreram com (não vamos negar!) sentimentos de inferioridade em diferentes períodos de nossas histórias. Mas rimos das mesmas piadas, gostamos dos mesmos filmes e temos quase as

${ }^{509}$ O título original era "Uma nova esperança?", mas a própria autora o eliminou. [1970]: o capítulo foi reescrito, embora o título tenha permanecido inalterado. Ver Nota IV, no final deste capítulo.

${ }^{510}$ [VAS]: os dois parágrafos iniciais não constam no texto publicado [1962, 1970].

511 [VAS]: a própria autora cortou 'corretamente ou não', que constava antes de 'que se considera'. 
mesmas lendas sobre a "fronteira", chefes indígenas, corridas do ouro, pioneiros, caçadores e animais selvagens. Americanos e brasileiros são igualmente rápidos na simpatia, no apoio aos que são destituídos nos planos econômico e social, hospitaleiros e gentis; ambos temos um senso de destino nacional, de grandes coisas à frente, e a palavra "democracia" ainda pode nos tocar profundamente.

\footnotetext{
512 Sempre grafado 'parliamentarismo'.

${ }^{513}$ [HRV]: ' $\mathrm{X}$ ' junto a 'em seguida'.

514 [HRV]: '?' junto a 'mas como um'.
}

A ESTRANHA renúncia do presidente Jânio Quadros desencadeou outra crise política no Brasil. A nova forma de governo, parlamentarismo, ${ }^{512}$ pareceu representar muito pouco, e o sentimento dominante no país era de melancolia, quase de desespero. Não houve melhora visível nos problemas perenes do país. Muitos dos velhos líderes dos dias de Vargas ainda estavam no governo. O custo de vida continuava subindo; a inflação, chegando a uma taxa de 30 por cento ao ano, ainda era alarmante; e nas cidades havia greves constantes e interrupção nos serviços públicos. Ninguém sabia o que iria acontecer em seguida ${ }^{513}$ - embora todos, é claro, tivessem suas teorias.

O ex-presidente Quadros não poderia concorrer à Presidência até 1970, mas poderia concorrer a outros cargos. Ele ainda mantinha grande apelo popular como o "homem comum" que mostrou saber falar para os homens comuns: não como um demagogo, mas como um ${ }^{514}$ homem com reputação de honestidade que não fazia falsas promessas. Ele nunca pertenceu aos círculos íntimos ou à "família" das figuras poderosas que sempre reaparecem na política brasileira e das quais o crescente eleitorado suspeita. Goulart era uma 
incógnita, e ele pareceu insatisfeito sob o parlamentarismo. $\mathrm{O}$ aspecto mais perigoso da cena era que o novo sistema político recém-imposto poderia mostrar-se impraticável, permitindo que um pequeno grupo de pessoas ousadas tomasse o poder e fizesse as coisas à sua maneira. Enquanto isso, o resto do mundo observava com ansiedade, consciente de que qualquer mudança profunda na cena política brasileira provocaria forte repercussão nas Américas Central e do Sul. ${ }^{515}$

HAVIA outros dilemas. Brasília foi criticada como quase impraticável e um sorvedouro do dinheiro público, mas ela continua lá - e continua sendo um sorvedouro. A velha capital, o Rio, por causa de seu tremendo crescimento populacional e falta de dinheiro, ${ }^{516}$ está numa situação quase desesperadora; muitos anos e muito dinheiro serão necessários para que a cidade tenha um abastecimento adequado de água, assim como para que resolva seus problemas de transportes e comunicação. A situação das favelas está cada vez pior - e é claro que o problema não se restringe ao Rio. ${ }^{517}$ Recife tem um problema com favelas quase tão grande quanto o do Rio, assim como todas as cidades grandes. Brasília acomoda os milhares de trabalhadores que ela atraiu alojando-os num enorme acampamento. A pobreza dos trabalhadores rurais no Nordeste continua a piorar.

Além dos problemas no governo das cidades e dos estados, o Brasil ainda está indeciso em relação ao que fazer

${ }^{515} \mathrm{Na}$ carta aos Editores: “p.146, col. 1, final do $1^{\circ}$ par.: ‘forte repercussão por todas as Américas'. Isso parece completamente absurdo, do jeito como está agora, e as repercussões atingiriam os Estados Unidos, também”. A alteração foi feita, e em [1962] consta throughout Central and South Americas; todavia, na edição de 1970 surge novamente a generalização throughout Americas [nas Américas].

${ }^{516} \mathrm{Na}$ carta aos Editores: "Próximo par.: because of its tremendous population increase and lack of money... [por causa de seu tremendo crescimento populacional e falta de dinheiro...] ou lack of government funds [falta de fundos governamentais] - a população não deve ser responsabilizada". A alteração não foi aceita. [HRV]: anotação ilegível em 'populacional'.

517 [HRV]: anotação ilegível junto a 'ao Rio'. 
com a "fronteira deserta" 518 - os intermináveis "espaços vazios" 519 que permanecem no interior do país, os "espaços" entre as cidades costeiras e entre as pouquíssimas cidades do interior, espaços que nunca foram ocupados, ou que foram abandonados à medida que os pioneiros avançavam através e para além deles. Brasília supostamente representa um novo e nítido avanço no sentido de ocupar-se o interior, e existem fracos indícios de que ela tenha gerado algum efeito: pequenas vilas cresceram ao longo das novas rodovias que vão a Brasília do Norte e do Leste. As novas rodovias constituem um empreendimento notável; a estrada que corta a floresta desde Belém, no Norte, atravessa matas tão densas que os viajantes a chamam de "passeio da onça". Mas algumas das estradas ainda estão em mau estado. Aquela que liga o Rio a Brasília já foi cenário de numerosos desmoronamentos e outros problemas.

Os problemas brasileiros, quase sem exceção, parecem ter sido causados por muitos anos de negligência por parte de governos ineficientes. É claro, os brasileiros sempre censuram a si mesmos por esperarem demais do governo e por acreditarem que o governo resolverá problemas que seriam mais bem administrados de outras maneiras.

Por uma combinação de boa sorte e boa gestão, os Estados Unidos resolveram muitos dos problemas administrativos e econômicos da democracia capitalista antes do Brasil. Mas não podemos permitir que isso nos cegue para as muitas coisas valiosas no "estilo de vida" brasileiro.

\footnotetext{
${ }^{518}$ Na carta aos Editores: "p.146, col. 1, último par.: Vocês podem dizer 'O Brasil ainda estava descontente [unhappy] por causa de sua fronteira deserta' etc. Eu discuti isso interminavelmente em Nova York, e provavelmente não poderei discutir mais. Mas, por favor, não digam undecided [indeciso] - isso não faz nenhum sentido". A alteração não foi aceita. Em [HRV] a autora elimina 'indeciso', embora não faça a substituição.

${ }^{519}$ [HRV]: a autora inclui aspas em 'espaços vazios'.
} 
... mundo. O Brasil está enfrentando seu problema indígena ao menos tão bem talvez até de maneira melhor - quanto os Estados Unidos. E os problemas sociais e raciais remanescentes dos tempos da escravidão estão sendo resolvidos de maneira mais digna, e com menos sofrimento, no Brasil do que em qualquer outra parte do mundo. Talvez nunca sejamos capazes de resolver nossos problemas raciais ao modo brasileiro, mas ao menos devemos ser capazes de pensar nisso com calma.

Nas relações pessoais, seu código moral menos dominado pela culpa e sua atitude mais franca em relação a sexo e casamento parecem mais adultos que os nossos, e afastam os problemas relacionados à adolescência prolongada e ao excesso de romantismo.
Qualquer julgamento de um país, no entanto, deve levar em conta todas as qualidades que o favorecem. ${ }^{520}$ No caso brasileiro elas são qualidades ${ }^{521}$ que sem dúvida auxiliarão a guiar o país em qualquer crise futura. Os brasileiros têm vocação para relações humanas. ${ }^{522}$ No Brasil, as tensões sociais e raciais ${ }^{523}$ remanescentes dos dias da escravidão estão sendo resolvidas de maneira mais digna, e com menos sofrimento, do que em qualquer outra parte do mundo. O país está enfrentando o problema indígena tão bem - talvez até de maneira melhor - quanto qualquer país com problema similar relacionado a habitantes nativos. Países que não contem com o comportamento livre e simples ${ }^{524} \mathrm{em}$ relação a outras raças e culturas que os brasileiros vêm tendo há tanto tempo, nem com o respeito inato dos brasileiros diante de outros povos, ${ }^{525}$ talvez não consigam resolver seus problemas raciais ao modo brasileiro. Mas o feito merece análise séria e a mais alta admiração.

\footnotetext{
${ }^{520}$ Na carta aos Editores: “p.146, col. 2, $2^{\circ}$ par.: ‘... deve levar em conta todas as qualidades que o favorecem.' O que vocês escreveram é totalmente condescendente”. [1962]: o trecho foi mantido: 'algumas das'.

${ }^{521}$ [HRV]: ' $\mathrm{X}$ ' junto a 'qualidades'.

522 [1962]: 'Por exemplo, os brasileiros têm vocação para o que se costuma chamar de relações humanas'. Na carta aos Editores: "Mesmo par.: ELIMINE A FRASE WHAT IS CALLED [o que se costuma chamar de]. Diga apenas 'uma vocação para relações humanas'.”.

${ }^{523} \mathrm{Na}$ carta aos Editores: "Mesma linha: Elimine a palavra Any [quaisquer] e comece o próximo período com 'As tensões sociais e raciais...' etc.". A alteração não foi feita.

524 [HRV]: a autora elimina 'livre e simples', embora não aponte substituto.

$525 \mathrm{Na}$ carta aos Editores: "Mesmo par. - Elimine a frase nor with the innate Brazilian respect for other peoples [nem com o respeito inato dos brasileiros diante de outros povos]". A alteração não foi feita.
} 
... eles ainda não chegaram à difícil equação de tanto dinheiro ${ }^{526}$ e tanto pagamento. Embora isso possa ser o preço inevitável da industrialização futura, talvez os brasileiros possam de alguma maneira torná-lo menos severo e imperativo do que foi entre nós.

Não há terremotos no Brasil, nem furacões. Existe muito espaço. Não há pena de morte. O Brasil não tem inimigos reais, não teve nenhuma guerra por quase cem anos, e jamais se envolveu numa guerra de conquista. O Brasil não tem bombas atômicas, e até agora jamais expressou algum desejo de tê-las. Embora ...

... na última crise governamental.

Talvez porque não existe uma classe média, ou porque o país está dividido há tanto tempo entre os pouquíssimos ricos e os muitos pobres, ele é mais democrático, no sentido popular dessa palavra, do que muitos outros países.
A FALTA de agressividade dos brasileiros, sua boa vontade em relação a acordos, a viver e deixar viver, amar e deixar amar, e seu agudo senso de ridículo e de presunção nas vidas pública e privada - o mundo deveria fazer mais uso de todas essas qualidades. Sua alegria de viver ainda não foi destruída pela cobiça; eles ainda não chegaram ao ponto em que se associa a quantidade de trabalho com a quantidade de dinheiro, de maneira automática. Embora esse tipo de cálculo possa ser o preço inevitável da industrialização, talvez os brasileiros possam de alguma maneira torná-lo menos severo e competitivo do que ele tem sido em nações capitalistas mais desenvolvidas.

O Brasil é, em vários aspectos, um país de moderação. O extremismo é desprezado. Não existe pena de morte. O Brasil não tem inimigos reais e jamais se envolveu numa grande guerra de conquista. Embora as forças armadas tenham às vezes ajudado a colocar um presidente no poder, ou a tirálo de lá, o Brasil jamais teve uma ditadura militar, e os militares não dão sinais de desejar uma - e isso foi demonstrado mais uma vez, de maneira clara, na crise governamental que se seguiu à renúncia do presidente Jânio Quadros.

ESSE senso de moderação beneficiou o país no aspecto social, também. Embora não exista uma classe média considerável um pré-requisito para a estabilidade nacional - e embora o país esteja dividido há tanto tempo entre os pouquíssimos ricos e os inúmeros pobres, o estilo de vida ${ }^{527}$ parece mais democrático ${ }^{528}$ que em muitos outros países. Existe pouca ou

\footnotetext{
${ }^{526} \mathrm{O}$ erro foi corrigido no texto publicado: trabalho versus pagamento, e não dinheiro versus pagamento.

${ }^{527}$ [HRV]: a autora inclui ' $X$ ?' junto a 'estilo de vida'.

${ }^{528} \mathrm{Na}$ carta aos Editores: "p.147, col. 1, $2^{\circ}$ par.: the way of life seems more democratic... [o estilo de vida parece mais democrático...]. EU NUNCA DISSE ISSO. Mude para the atmosphere of Brazil seems more democratic... [a atmosfera do Brasil parece mais democrática...]. Ou the manners and atmosphere of Brazil seem very democratic [os hábitos e a atmosfera do Brasil parecem muito democráticos]. PONTO, e elimine than that of many other countries [que em muitos outros países], sem sentido". As alterações não foram feitas; note-se que a comparação constava em [VAS].
} 
Além disso, embora existam velhas famílias aristocráticas orgulhosas, elas nunca tiveram extrema riqueza e poder durante longos períodos de tempo, para que possam considerarse autocratas naturais. Ninguém é tão rico no Brasil. Tem havido instabilidades políticas em excesso; muitas famílias foram arruinadas pela emancipação dos escravos. Não existem enormes fortunas, nem indústrias que dominem o mundo, nem "óleo para as lâmpadas da China”.

Os Integralistas, o único partido protofascista do Brasil, existiu por pouco tempo há vinte anos. Existem comunistas e nacionalistas [em branco]

[9 linhas apagadas]

Houve lemas de pouca duração como "O petróleo é nosso" - mesmo que pareça não existir muito petróleo no país. nenhuma consciência em relação a todos os graus insidiosos de sentimento de classe dos quais a humanidade é capaz. Ainda é possível e natural para um jovem - homem ou mulher - empreendedor nas profissões ou nas artes, mover-se de um extremo ao outro da sociedade sem ficar constrangido nem merecer a condescendência de quem quer que seja.

Os Integralistas, o único partido fascista ${ }^{529}$ do país, existiu por pouco tempo há mais de vinte anos, e o partido comunista tornou-se ilegal em 1947. O Brasil tem comunistas e ultranacionalistas hoje, e ambos representam possibilidades políticas incertas. O número exato de comunistas verdadeiros no Brasil não é publicamente conhecido, embora tenha sido estimado pelo governo norte-americano em $50 \mathrm{mil}$, no ano de 1958. Nas cidades existem grupos de estudantes inspirados ou liderados por comunistas, e existem comunistas ou simpatizantes nas forças armadas. Mas é difícil dizer até que ponto qualquer um deles representa uma ameaça. A pobreza generalizada em muitas áreas fornece solo fértil em que os comunistas podem atuar, sem dúvida. Em muitos casos seu proclamado comunismo parece mais oportunismo político

\footnotetext{
${ }^{529}$ [1962]: 'partido pseudo-Fascista'. Em [HRV] a autora elimina 'pseudo-' e inclui '?'.
} 
O nacionalista antiamericano quase sempre se divide em dois tipos. Como os poucos "racistas" ou antisemitas no Brasil, o primeiro vem quase sempre da classe dos nouveau riche e quase nunca é brasileiro, em geral é um imigrante recente ou de primeira geração. (Muitas ...

... mais se o seu produto for inferior, ou se os seus lucros forem desproporcionais.

O outro tipo de nacionalista antiamericano é, como em qualquer país, o homem que sente que pode responsabilizar os outros por todos os seus problemas: judeus, negros, ou outra nação. Nos cargos políticos esse homem pode fomentar sentimentos antiamericanos entre os pobres e os ignorantes com facilidade. Mas, uma vez que os Estados Unidos * não representam quase nada para a maioria dos muito ignorantes e pobres no Brasil, uma terra remota como Atlântida, a responsabilidade costuma recair num político local. E devemos lembrar que nas duas guerras mundiais o governo brasileiro esteve ao lado dos Aliados. que, numa crise, pode voltar-se para qualquer outra direção, à esquerda ou à direita, aquela que pareça acenar com o maior ganho ou poder pessoal.

O mesmo se dá com os ultranacionalistas - aqueles cuja xenofobia pode apenas impedir que o Brasil tenha o desenvolvimento econômico e político merecido. Os nacionalistas antiestrangeiros quase sempre dividem-se em dois tipos. ${ }^{530} \mathrm{O}$ primeiro surge quase sempre entre os novos ricos, em geral imigrantes de primeira ou segunda geração. (Muitas das novas fortunas surgiram entre os imigrantes.) Seu negócio deve ter crescido com o apoio de privilégios e por forte proteção governamental. ${ }^{531}$ É natural que ele tenha medo da competição externa, sobretudo da competição em larga escala dos americanos, ainda mais se ele for ineficiente, ou se os seus lucros forem desproporcionais.

O outro tipo de nacionalista antiestrangeiro é - algo verdadeiro em qualquer país, é claro - o homem que sente que pode responsabilizar as outras nações por todos os problemas de seu país. Esse homem pode fomentar sentimentos antiamericanos entre os pobres e os ignorantes com facilidade. Mas, uma vez que os Estados Unidos representam muito pouco para os ignorantes e os pobres no Brasil - ou seja, a maioria da população -, a responsabilidade por todos os problemas costuma recair nos políticos locais ou simplesmente no governo. ${ }^{532}$

\footnotetext{
${ }^{530}$ [HRV]: anotação ilegível junto a 'dois tipos'.

531 [HRV]: anotação ilegível junto a 'governamental'.

* Esta é a única referência aos Estados Unidos como 'América', nestes originais.

${ }^{532}$ [HRV]: a autora inclui '?' junto à última linha.
} 
É difícil, quase impossível, para os muito ricos entenderem os pobres - algo que ...

... toda parte, na China ou no Brasil. Em tudo aquilo que um estrangeiro questiona no Brasil, da ineficiência à sujeira, dos edifícios públicos degradados aos hábitos urbanos, dos meios de transporte ruins à mortalidade infantil - antes de responsabilizar o clima, a preguiça, ou o caráter nacional em geral, ele deveria antes de tudo perguntar-se: "Isso não se deve simplesmente à pobreza?". Em nove entre dez casos, sim.

Mas não é apenas de dinheiro que o Brasil precisa - longe disso. Como Eugênio Gudin, o mais respeitado economista brasileiro e ministro da Fazenda no governo do presidente Dutra, escreveu em um belo artigo em $O$ Globo, o influente jornal vespertino do Rio:
É DIFÍCIL, talvez impossível, para as nações ricas entenderem as pobres, e isso é algo que os norte-americanos, com todas as suas boas intenções, quase nunca conseguem perceber. A pobreza nacional pode produzir os mesmos sintomas e reações por toda parte - na Sicília ou na Índia, por exemplo, assim como no Brasil. Em tudo aquilo que um estrangeiro questiona no Brasil - da ineficiência à sujeira, dos edifícios públicos degradados aos motoristas de ônibus grosseiros, dos meios de transporte ruins à falta d'água - ele costuma responsabilizar "o caráter nacional", ou a falta de preocupação governamental com o bem-estar do povo. Mas, antes, ele deve perguntar-se: isso não se deve simplesmente à pobreza? Em nove entre dez casos, sim.

Para aliviar os males que o assolam e para permitir que mantenha seu crescimento econômico, o Brasil precisa de ajuda financeira. Mas isso não é tudo. Como Eugênio Gudin, um dos mais respeitados economistas brasileiros e ministro da Fazenda no governo Café Filho, escreveu em $O$ Globo, o influente jornal vespertino carioca:

A causa principal do subdesenvolvimento econômico brasileiro reside na grande ausência, em todos os níveis, de homens preparados para a tarefa de aumentar a produtividade nacional, desde engenheiros, empreendedores e administradores de alto calibre a trabalhadores especializados. Nosso objetivo principal, portanto, deve ser a formação de um núcleo de homens educados. Para tanto nós precisamos ... importar centenas de técnicos e professores e enviar milhares de estudantes para o exterior, não apenas nos campos das ciências mas especialmente nos vários ramos da engenharia e das técnicas industriais. 
Gudin responsabiliza a construção de Brasília e os gastos do governo

Kubitschek, em grande parte, pela inflação e pela triste situação atual. Os Estados Unidos ajudaram a construir Brasília, assim como nós ajudamos [em branco]

Grandes empréstimos para um governo federal corrupto e extravagante, para vagas áreas de atividade, não fazem bem. A única maneira prática de ajudar o Brasil é ajudar o "núcleo educado" e as indústrias e os desenvolvimentos que vão afinal aumentar a entrada de divisas no país.

Não existem problemas no Brasil que um bom governo, boa administração, não possa resolver. Esse fato, sozinho, torna o Brasil único entre as nações do mundo. Sob um bom governo, o progresso industrial e material sem dúvida vai alcançar uma velocidade tremenda porque todas as características essenciais estão lá.

Mas, antes de condenar o Brasil por não ter tido bons governos até agora devemos distinguir "progresso", "cultura" e "civilização", coisas muito diferentes. A ideia de "civilização" nunca esteve
Gudin responsabiliza a construção de Brasília e os gastos do governo Kubitschek pela inflação atual e pela situação atual, tão instável. A tarefa mais importante, segundo ele, é a eliminação do desperdício e do mau uso das riquezas nacionais. Mas, além disso, esforços especiais devem ser feitos para encorajar o apoio, público e privado, à criação de um "núcleo educado" e aos desenvolvimentos que vão afinal aumentar a entrada de divisas e satisfazer as necessidades urgentes do povo.

POIS, acima de tudo, o Brasil sente falta de um governo bom e seguro, e isso pode ser alcançado apenas elevando-se o nível da sociedade como um todo através da educação e do bemestar material. Se isso for feito, não haverá problema no Brasil que um bom governo não possa resolver. ${ }^{533}$ Sob boa administração, o progresso industrial e material sem dúvida vai alcançar uma velocidade tremenda - porque muitas outras características essenciais estão lá.

Mesmo sem um bom governo, ${ }^{534}$ o Brasil já fez muito. "Progresso" nem sempre coincide com “civilização", e muitos países mantiveram altos padrões artísticos e sociais sem os benefícios de um bom governo. O Brasil tem um conjunto impressionante de obras literárias e artísticas sofisticadas, e

\footnotetext{
${ }^{533}$ Na carta aos Editores: "p.148, col. 1, par.3: If that can be done, there would be no problem in Brazil that good government could not resolve [Se isso for feito, não haverá problema no Brasil que um bom governo não possa resolver]. Pare aí! O que vocês dizem depois não faz nenhum sentido e deve ser um erro de impressão por uma coisa, because the government would then be rejection (reflection?) of a healthy body politic [porque o governo seria, então, rejeição (reflexo)? de um corpo político saudável]. Por favor, elimine essa frase". A alteração não foi feita; apenas rejection [rejeição] foi corrigido para reflection [reflexo]. [HRV]: a autora elimina 'governo seria, então, reflexo de um corpo político saudável'.

${ }^{534} \mathrm{Na}$ carta aos Editores: "No par. seguinte, $1^{\mathrm{a}}$ linha: por favor, elimine of course [é claro]. 'Mas, mesmo sem um bom governo, [é claro,] o Brasil ...' será melhor”. A alteração não foi feita.
} 
muito conectada com aquela de bom governo. Se alguém tivesse de escolher: o "mau" governo é muito pior que o "bom" governo que leva a grandes guerras? Um assassinato ocasional (embora o Brasil tenha tido muito poucos), ou uma revolução quase sem derramamento de sangue, pior que a morte de milhares de soldados inocentes? O Brasil tem um conjunto considerável de cultura sofisticada e de cultura popular ainda viva. Tem muitas qualidades de caráter e sociedade, que só combinam com alta civilização. Não se devem fazer reivindicações culturais ou sociais exageradas para o Brasil - os gregos combinavam com maus governos, assim como os italianos da Renascença - e ninguém os critica muito por causa disso, hoje.

Obviamente, excetuandose algum desastre mundial, o Brasil está se industrializando e se esforçando nesse sentido. Por enquanto, ele ainda é um país onde o homem "humano", por mais pobre que possa ser, ainda é considerado mais importante que o homem produtor, ou o homem consumidor, ou o homem político. uma cultura popular riquíssima. Tem muitas qualidades de caráter e sociedade, que só combinam com alta civilização. Não se devem fazer reivindicações culturais ou sociais exageradas para o Brasil; mas, política à parte, ele tem se saído extraordinariamente bem. ${ }^{535}$

Obviamente, excetuando-se algum desastre mundial, o Brasil está se industrializando e se esforçando nesse sentido. Sem dúvida ele vai tornar-se um dia uma grande potência mundial; a questão é, que tipo de homens estarão dirigindo o país nesse dia, e que tipo de país ele será? Será que o Brasil pode vencer a corrida contra o tempo? As reformas políticas e sociais serão implementadas rápido o bastante, e o progresso econômico será eficiente, ou as demandas do povo por uma vida melhor levarão a uma revolução social? Por enquanto, o Brasil ainda é um país onde o homem "humano" ainda é considerado mais importante que o homem produtor, ou o homem consumidor, ou o homem político. 
Todos os que visitam o Brasil concordam em que os brasileiros são um povo maravilhoso: calorosos, bemhumorados, espirituosos e pacientes - incrivelmente pacientes. Vê-los parados em filas por horas, por horas mesmo, em filas que vão e voltam duas ou três vezes no comprimento de um quarteirão - apenas para embarcar num ônibus deteriorado, dirigido de maneira inconsequente, e voltar para suas minúsculas casas suburbanas onde a rua não foi consertada, nem o lixo recolhido, e talvez falte água - ver isso é maravilharse com sua paciência. Parece que deveria haver uma revolução por mês. Eles nunca tiveram o governo que merecem, e ninguém sabe quanto tempo ainda vai demorar para que o tenham.
TODOS os que visitam o Brasil concordam em que os brasileiros são maravilhosos, calorosos, bem-humorados, espirituosos e pacientes - incrivelmente pacientes. ${ }^{536}$ Vê-los parados em filas por horas, por horas mesmo, em filas que vão e voltam duas ou três vezes no comprimento de um quarteirão, apenas para embarcar num ônibus deteriorado, dirigido de maneira inconsequente, e voltar para suas minúsculas casas suburbanas onde a rua continua esburacada e o lixo não foi recolhido, e talvez falte água - ver isso é maravilhar-se com sua paciência. ${ }^{537}$ Outros povos, sujeitos a esses sofrimentos, fariam uma revolução por mês. Pode ainda haver mais de um golpe, na tentativa de alterar o curso do governo - porque sem dúvida existe uma determinação crescente, entre os brasileiros, para ter um governo melhor. Se essa determinação trouxer conflitos, ${ }^{538}$ esperemos que elas possam ser resolvidas com a moderação brasileira usual. Os brasileiros nunca tiveram o governo que merecem; não se sabe quanto tempo ainda vai demorar para que o tenham. ${ }^{539}$

Nota IV) [1970]: O capítulo 10 (p.145-148) foi reescrito; seu título permaneceu inalterado.

DEPOIS de três anos na presidência, João Goulart havia feito pouco mais que estabelecer-se como mais um desafortunado bode expiatório para os males crônicos do Brasil: greves, escassez de alimentos, inflação e corrupção. Assim, quando a revolução o exilou, em 1964, milhares de pessoas saíram às ruas no Rio, no Recife e em São Paulo, não para erguer barricadas mas para aplaudir.

O momento não foi menos crítico para os militares, que haviam posto de lado seu tradicional respeito pela Constituição no intuito de depor Goulart. Para eles e sobretudo para o novo presidente honesto e moralista, Castelo Branco, a revolução representava uma oportunidade inestimável de quebrar, para sempre, os maus

\footnotetext{
${ }^{536}$ [HRV]: ' $\mathrm{X}$ '.

${ }^{537}$ Na carta aos Editores: "p.148, último par.: Por que mudar wonder para marvel em wonder at their patience [maravilhar-se com sua paciência]? Eu prefiro wonder". A correção não foi feita. [HRV]: a autora faz um traço vertical na margem.

${ }^{538} \mathrm{Na}$ carta aos Editores: "Perto da última sentença - Elimine BUT [MAS] - Apenas, 'If this determination brings conflicts' [Se essa determinação gerar conflitos] (melhor que troubles [revoltas, problemas], seguramente)". A alteração não foi feita no texto publicado.

${ }^{539} \mathrm{Na}$ carta aos Editores a autora pede que se substitua there is no knowing [não se sabe] por no one can say [ninguém pode dizer]. A alteração não foi feita.
} 
hábitos desenvolvidos durante a era Vargas. Uma vez iniciadas amplas reformas sociais, econômicas e políticas, eles pensavam que um Brasil honesto e mais disciplinado surgiria rápido. O país deveria tornar-se grande, afinal.

Buscando a recuperação econômica urgentemente necessária, Castelo Branco criou o Ministério do Planejamento e escolheu Roberto Campos, um hábil economista e diplomata, para o posto. Prometendo basear seus atos em conceitos "históricos, não histéricos", Campos procurou diminuir a inflação e levar o Brasil de volta a um grau saudável de crescimento econômico. Outros de seus objetivos eram restabelecer a confiança dos investidores estrangeiros, eliminar os funcionários desnecessários nos ministérios, aumentar a eficiência dos negócios públicos e reorganizar toda a estrutura de taxas e impostos.

A tarefa política mais urgente para o novo governo era eliminar os focos de subversão que ainda restavam após a revolução e atacar o problema da fraude eleitoral e do coronelismo.

HOUVE CERTAS vitórias nessas frentes. Inquéritos militares descobriram alguns casos de corrupção e subversão, e as eleições de 1965 para 11 governadores foram as mais honestas na história recente do país. O controle rígido de salários e preços, em conjunto com disciplina nos orçamentos, interrompeu a espiral inflacionária. Houve melhoria na administração pública, e a produtividade começou a crescer devagar. Auxiliado por uma entrada maciça de capital estrangeiro, público e privado, a maior parte do qual proveniente dos Estados Unidos, o governo começou a mover o país em direção ao equilíbrio fiscal. Até 1970, depois de seis anos de esforço revolucionário, o produto interno bruto mostrava um impressionante crescimento anual entre oito e nove por cento.

Esses grandes avanços e o sangue-frio necessário para realizá-los, no entanto, custaram aos governos militares a perda de popularidade de que haviam desfrutado no início. Se as reformas econômicas prometiam melhores condições para um progresso duradouro, o grau de austeridade a elas associado trouxe consideráveis dificuldades durante o período de transição. Aqueles que deveriam suportá-las - as classes média e baixa sofreram cortes no salário real. Um corte no crédito restringiu a expansão empresarial, o que ajudou a aumentar o desemprego.

A repressão, que por vezes parecia desnecessária, também marcou a era pós-revolução. Muitas vezes os soldados confundiam patriotas democráticos com subversivos e os sujeitavam a inquéritos humilhantes e prisões sumárias. Estudantes e entidades trabalhistas tornaram-se opositores do regime quando suas liberdades foram restringidas. A censura pesada enfureceu os intelectuais. Até mesmo a Igreja Católica, que até os anos 60 mostrava um espírito novo e progressista no Brasil, sofreu intenso ataque dos militares.

E, em dezembro de 1968, a revolução assumiu uma face especialmente cruel. Depois de um ano de agitação social, sobretudo por parte dos estudantes que enfrentavam a polícia em batalhas nas ruas, um grupo ativista de jovens oficiais militares forçou o presidente Artur da Costa e Silva, sucessor de Castelo Branco, a agir. Ele assinou o Ato Institucional número 5, sob o qual assumiu poderes ditatoriais plenos, fechou o Congresso e cancelou o direito de habeas corpus para qualquer "violação da segurança nacional", o que na realidade significava tudo o que o governo visse como tal, o que transformou o Brasil num Estado policial de um dia para o outro. Seguiu-se uma onda de prisões e expulsões. Muitos políticos tiveram seus direitos suspensos, e mais de cem professores foram arbitrariamente expulsos das universidades federais. Pior ainda, relatos de torturas de prisioneiros políticos começaram a tornar-se numerosos demais para serem ignorados. Com isso, os 
brasileiros ficaram cada vez mais desencantados com seu governo, cuja reputação internacional também sofreu forte declínio.

HISTORICAMENTE, essas medidas duras não combinam com o padrão brasileiro. Até então, os militares haviam participado da política apenas o tempo suficiente para restaurar a ordem. Agora, no entanto, os militares anunciavam que teriam de ficar no poder tempo bastante para criar uma base inteiramente nova para o desenvolvimento econômico e político. Além disso, sob os militares, os administradores mais progressistas foram afastados, substituídos por burocratas medíocres. Apenas a economia reflete algum tipo de liderança criativa, e existem poucos indícios de que o governo, como anunciou, possa atrair o talento necessário para administrar o país de maneira eficiente.

No final dos anos 60 o Brasil também defrontou-se com vários problemas urgentes e não relacionados à política. A agricultura, ignorada durante o esforço desordenado de industrialização da década anterior, permanecia num estado dolorosamente primitivo. Fazendeiros não tinham crédito suficiente para assistência técnica, e o sistema de distribuição de alimentos era tão antiquado e ineficiente que um terço de toda a produção colhida estragava antes de chegar ao consumidor final.

Mantiveram-se os esforços públicos e privados para desenvolver e industrializar o empobrecido Nordeste. Mas, apesar de mantido com vigor, esse programa não mostrou resultados reais durante muitos anos. Enquanto isso, a migração do Nordeste para as regiões mais prósperas do centro e do sul representou um esforço adicional para a já sobrecarregada infra-estrutura dos centros urbanos. ${ }^{540}$

O RIO DE JANEIRO e São Paulo, com taxas de crescimento de 5 por cento ao ano, foram as cidades mais tristemente afetadas. Um quarto da população do Rio continuou a viver em suas favelas pestilentas. Além do problema habitacional, todos os centros urbanos do Brasil sofriam com infra-estrutura inadequada de transporte, comunicações e educação e com falta de medidas básicas de segurança pública.

Os brasileiros perceberam há muito tempo que a melhor maneira para facilitar a resolução de sua crise urbana crescente estava na aceleração do desenvolvimento da “fronteira deserta”. É com esse intuito que Brasília foi concebida, e até o final dos anos 60 esse grande programa começava a mostrar resultados. Novas estradas e projetos de colonização foram aos poucos abrindo o território antes inacessível. Até mesmo em Brasília, os funcionários do governo, que de início haviam lutado para permanecer no litoral, foram sendo vencidos pelas vantagens óbvias da cidade moderna, com suas numerosas opções de lazer e, ao menos para o padrão do Rio ou de São Paulo, suas habitações espaçosas e confortáveis.

Como na maioria dos países subdesenvolvidos, a chave para muitos dos problemas brasileiros é a educação. Hoje, o sistema educacional público permanece mal equipado para produzir os líderes e técnicos necessários para garantir as grandes mudanças que o Brasil deve implementar. Em muitas regiões do interior, a educação primária simplesmente não existe. Mesmo nas maiores cidades, as taxas de frequência e abandono são alarmantes. Embora a população do país esteja perto de 100 milhões, as universidades brasileiras hoje formam apenas cerca de 30 mil estudantes por ano. A maioria recebe uma instrução fraca, voltada para temas arcaicos,

540 Até este ponto, texto novo, específico sobre o período pós-64. Daqui até o final, aproveitam-se trechos da edição original [1962], reorganizados. 
definidos para uma época passada na qual a educação superior não era uma necessidade nacional urgente, mas apenas um privilégio das classes altas.

Muitos brasileiros dedicados e incansáveis lutaram por anos para ultrapassar tais deficiências, mas o progresso é lento. A ineficiência governamental e a negligência são as maiores barreiras, mas existem outros problemas. Um deles é a falta de um grande núcleo bem treinado de homens e mulheres, capazes de administrar o árduo desenvolvimento nacional. Também é fundamental a crônica falta de dinheiro disponível para que os governos brasileiros concretizem seus planos.

O que permanece no lado positivo da balança pode ser atribuído ao caráter brasileiro. Por exemplo, o povo brasileiro tem vocação para o que se costuma chamar de "relações humanas". Tensões sociais e raciais remanescentes dos dias da escravidão estão sendo resolvidas de maneira mais digna, e com menos sofrimento, no Brasil que em qualquer outra parte do mundo. É verdade que até poucos anos atrás o país não tinha uma classe média consistente - um pré-requisito comum para a estabilidade nacional -, e o desnível entre ricos e pobres sempre foi muito alto. Todavia, o estilo de vida do brasileiro parece mais democrático que em muitos outros países latino-americanos. Ainda é possível para uma pessoa jovem e empreendedora, em quaisquer profissões ou nas artes, mover-se de um extremo ao outro da sociedade sem ficar constrangida nem merecer a condescendência de quem quer que seja.

A FALTA de agressividade dos brasileiros, sua falta de compromisso, o viver e deixar viver, amar e deixar amar, e seu agudo senso de ridículo e de presunção nas vidas pública e privada - todas essas são qualidades das quais o mundo poderia fazer mais uso. Sua alegria de viver ainda não foi destruída pela paixão por fazer dinheiro; eles ainda não chegaram ao ponto em que se associa a quantidade de trabalho com a quantidade de dinheiro, de maneira automática. Esse pode ser o preço da industrialização futura, mas é possível que o Brasil nunca se torne tão competitivo como os países capitalistas mais desenvolvidos.

O extremismo não é popular no Brasil. Os Integralistas, o único partido pseudofascista do país, existiu por pouco tempo há mais de vinte anos. O partido comunista tornou-se ilegal em 1947 e, embora o núcleo comunista tenha continuado atuante, sua fraqueza demonstrou-se na facilidade com que os militares tomaram o poder em 1964.

Os sequestros sensacionais de diplomatas estrangeiros e os numerosos roubos a bancos iniciados no final da década de 1960 por terroristas contrários ao regime militar ganharam manchetes por todo o mundo. Mas na realidade os terroristas, cujo objetivo expresso é derrubar o regime militar e substituí-lo por algum tipo de governo socialista, não passam de algumas centenas. Por natureza, a maioria dos brasileiros coloca-se ao lado dos terroristas contra o governo ditatorial, mas seu apoio vai apenas até certo ponto, baseado sobretudo na empatia pelos aventureiros política e socialmente injustiçados.

O NACIONALISMO extremo, todavia - o tipo de xenofobia que poderia impedir ao país o desenvolvimento econômico e político de que ele tanto necessita -, parece estar ganhando força. O Brasil não tem inimigos naturais e nunca se envolveu numa grande guerra de conquista. Mas para um grupo crescente de oficiais militares linha-dura cujo poder cresce a cada ataque terrorista bem sucedido, o nacionalismo parece ser a única causa à disposição para conquistar a solidariedade das massas brasileiras. Eles sabem que, a menos que os militares possam ganhar apoio popular de alguma forma, a revolução está destinada a falhar. Todavia, os 
políticos brasileiros e outros líderes nacionais muitas vezes adotaram, no passado, tais atitudes por razões oportunistas, e, assim que uma crise era ultrapassada, mudavam de direção, procurando a que prometesse o maior ganho pessoal. Em todo caso, enquanto a pobreza generalizada persistir (e não há nenhuma melhora imediata no horizonte), ela sempre vai fornecer um campo fértil para o crescimento da propaganda radical, tanto de esquerda como de direita.

É de um governo estável, responsável e receptivo que o Brasil precisa acima de tudo. Um bom governo não pode, é claro, resolver todos os problemas do país de um dia para o outro. Não pode, por exemplo, alfabetizar de uma só vez toda a população do país, nem pode conferir a todo o eleitorado a sofisticação política que é essencial para o processo democrático.

Todavia, com um longo período de administração correta, o progresso industrial, agrícola e material vai alcançar uma velocidade tremenda - porque muitas outras características essenciais estão lá. Mesmo sem um bom governo, é claro, o Brasil já fez muito. "Progresso" nem sempre coincide com "civilização", e muitos países mantiveram altos padrões artísticos e sociais sem os benefícios de um bom governo. O Brasil tem um conjunto impressionante de obras artísticas e literárias sofisticadas e uma cultura popular riquíssima. Tem muitas qualidades de caráter individual e social que só combinam com alta civilização. Não se devem fazer reivindicações culturais ou sociais exageradas para o Brasil; mas, política à parte, ele tem se saído extraordinariamente bem.

EXCETUANDO-SE algum desastre mundial, o Brasil, com seus amplos recursos e matérias-primas, está se industrializando e se esforçando nesse sentido. Sem dúvida ele vai tornar-se um dia uma grande potência mundial. A questão é, que tipo de homens estarão dirigindo o país nesse dia, e que tipo de país ele será? Será que o Brasil pode vencer a corrida contra o tempo? As reformas sociais e políticas serão implementadas rápido o bastante, e o progresso econômico será eficiente, ou as demandas do povo por uma vida melhor levarão a uma revolução social?

Não importa o que o futuro irá trazer, deve-se esperar que os problemas sejam resolvidos com as características brasileiras de moderação e humanidade. Hoje, ao menos, o Brasil permanece o único país onde o homem social ainda é considerado mais importante que o homem produtor, ou o homem consumidor, ou o homem político. 


\section{ÍNDICE}

(com a paginação de 1962)

Abreu, Casimiro de, 103

Academia Brasileira de Letras, 104

Aço, indústria do, 69, 75, 79, 98, 131, 132

Açúcar: áreas, 29, 72, 74; importância, na economia brasileira, 29, 45, 54, 70, 72; trabalho, 74, 142

Aérea, Força, 131

África: escravos da, 54; rivalidade pelo café, 72; tropas brasileiras na, na Segunda Guerra Mundial, 131

Africanas, influências, 54-55; no folclore e na música, 84, 86, 101, 102; na religião, 55, 85,89

Agrária, Reforma: demanda pela, 142; planos de Jânio Quadros para, 132

Agricultura, 69, 72; açúcar, 70, 72, 74; café, 70, 71-72; cereais, 75; frutas e legumes, 75 , 115; métodos, 74; necessidade de diversificação da, 72, 74; pecuária, 29, 70-71; tabaco, 75; trabalho, 69, 74, 142, 146

Água, falta de, 146, 147

Ajuda econômica: necessidade de, 147-148; dos Estados Unidos, 75, 131

Alagoas, 74

Alcoólicas, bebidas, 14-15, 74

Aleijadinho (Antônio Francisco Lisboa), 100, 104, 114

Alemães, imigrantes, 84, 115

Alemanha (Ocidental), 133

Alencar, José de, 102

Algodão, indústria do, 71, 72

Aliança de Libertação Nacional, 130

Alimentação: dieta básica, 15, 71, 75; dos índios, 37; falta de, 11, 28; ignorância sobre, 11; indústrias, 70, 71, 75; transporte de alimentos, 11, 71

Amado, Jorge, 104

Amazônica, Bacia: clima, 28; habitação na, 99; produtos da, 74, 75

Amazonas, estado, 71
Amazonas, rio, 57; cidades no, 12, 20, 59, 74; dados físicos, 30; navegação, 29; origem do nome, 30; pesca, 71

Americana, Revolução, 31, 42

Analfabetismo, 10, 46, 118, campanha contra, 132

Andes, 28

Andrade, Carlos Drummond de, 103

Andrade, Mário de, 104, 114

Andrade, Rodrigo Mello Franco de, 101

Angola, 30

Aquecimento (calefação), falta de, 14

Araras, 26

Araucária, 74

Argentina, 15, 42, 45, 129

Aristocracia: colonial, 44, 45, 46, 50; elite sobrevivente, 50

Armadas, Forças: comunistas nas, 147; e emancipação dos escravos, 46; golpes, 129, 131, 132, 147; na Segunda Guerra Mundial, 130-131; oposição a Goulart, 133,138

Arquitetos, 97-98

Arquitetura: de Brasília, 57, 109; condições da, 9899; contemporânea, 97-98, 100, 109; destruição da, 55, 56, 100- 101; estilo jesuítico e barroco, 100; igrejas, 100; materiais, 98, 99-100; o século XIX neoclássico, 100; a sobrevivência do estilo colonial, 98, 99-100

Artes, 97-104, 148; Bienal de São Paulo, 101; clima das, 104, 105; escultura, 100; pintura, 101; respeito pelas, 97, 104; tolerância racial nas, 104 , 114; trabalho em preto e branco, 101. Ver também Arquitetura; Folclore; Literatura; Música

Artesanato, 83, 86

Atômicas, reservas, 29, 75

Automobilística, indústria, 19, 132

Bahia, estado, 12, 26, 53, 85; economia, 29, 70, 72, 75 ; rebelião religiosa na, 104,128

Balangandãs, 54, 85

Baleias, pesca de, 71

Banana, 29, 75

Banco do Brasil, 43

Bandeira, Manuel, 103 
Bandeirantes, 30-31, 56, 70

Baudelaire, Charles, 102

Behring, Edith, 101

Belém, 12, 100, 146

Bernardes, Sérgio, 98

Biblioteca Nacional, 42

Boa Esperança, cabo da, 29

Bolívia, 129

Bonfim, festa do Senhor do, 54

Bonifácio, José, 56-57

Bonomi, Maria, 101

Borracha, 74

Bragança, Casa de, 41, 44, 101

Brasil: descoberta, 25; geografia, 28-29; origem do nome, $25-26$

Brasília, 53, 57-58, 98, 132, 146, 148

Brazilian Wilderness, Through the, de Roosevelt, 115

Bresilium, 25

Bruxelas, Exposição Mundial de, 98

Búfalos, 71

Bumba-meu-boi, 87

Burle Marx, Roberto, 99

Cabo Frio, 71

Cabo Verde, ilhas de, 26, 70

Caboclo, 28

Cabral, Pedro Álvares, 25-26, 28

Cabral de Melo Neto, João, 103

Cachaça, 74

Café: áreas, 71-72; exportação, 71, 76; importância, 45, 46, 70, 71-72, 76; mercado mundial, 76

Café Filho, João, 131, 148

Camargo, Iberê, 101

Caminha, Pero Vaz de, 26-28

Camponesa, Liga, 142

Canção do Exílio [Exile's song], de Gonçalves Dias, 103

Candomblé. Ver Macumba

Canudos, guerra de, 104, 128

Capitais, 53-58. Ver também Brasília; Rio de Janeiro; Salvador
Capitalismo, 45

Capitanias, 29, 53-54

Capoeira, 55

Caracas, 99

Cariocas, 12, 58

Carnaúba, cera de, 74-75

Carnaval, 11, 87-88

Carne, indústria, 70, 71

Carrancas, 86

Carvalho, Odete de, 117

Carvão, reservas, 29, 75

Casamento, 11, 14, 116, 117; amor extramarital, 11, 13; inter-racial, 10, 28, 84

Castanha-do-pará [Brazil nuts], 29, 74, 75

Castro, Fidel, 142

Castro Alves, Antônio de, 103

Catequese, 30

Católica Romana, Igreja: 30, 44, 123; e cultos africanos, 55; missionários da, 28, 30, 100

Catolicismo, 10, 123. Ver também Igreja Católica Romana

Cavalcanti, Emiliano di, 101

Cavalos, 70

Caiapós, índios, 116

Ceará, 28, 71, 74, 84, 117

Cerâmica, 84

Charque, 71

Chesterton, G. K., 102

China comunista, 133

Chuvas, 28

Cidades, 16, 20, 59, 72; capitais, 53-58; coloniais, 29, 31; destruição de edifícios antigos nas, 55, 56, 100, 101; do Império, 45; migração para, 16,56 ; modernização das, 128 ; problemas das, 146; sobrevivências de edifícios antigos nas, 100

Civis, direitos, 114; abolição da escravatura, 45-46; cancelamento, sob Vargas, 132; sob Pedro II, 44; voto, 130; voto feminino, 117

Classe alta, 14, 56, 104, 114; mulheres da, 116

Classe média, 114, 118, 147

Classes sociais, 147; familiaridade entre, 12-13; média, 114, 118; alta, 14, 56, 104, 114, 116. Ver também Aristocracia; Trabalho 
Clima, 28

Colombo, Cristóvão, 25, 26

Colonização, 29-31, 54, 70

Comercial, código, 45

Comércio: colonial, 29, 30; exterior, 71, 72, 74, 75, 76, 132; tratado Brasil-China, 133

Comte, Auguste, 46

Comunicações, 29, 45, 129. Ver também Transportes

Comunistas, 129, 130, 147

Conceição, Maria da (Conceiçãozinha), 9-10

Congonhas do Campo, 100

Congresso: altera o sistema de governo (1961), 133, 137; autoriza a construção de Brasília, 57; e Jânio Quadros, 133; fechado por Vargas, 130; sob os "Conselheiros", 129

Conselheiro. Ver Maciel, Antônio

"Conselheiros", 128-129

Constant Botelho de Magalhães, Benjamin, 46

Constituições: emendas 1961, 133, 137; Império, 43; de 1934, 130; de 1946, 57, 114, 131; de Vargas, 130

Constituinte, Assembleia, de 1934, 130

Construção, indústria da, 98

Copacabana, 55, 99; Dezoito do Forte de, 129, 131

Corcovado, 55

Costa, Lúcio, 57, 98

Costa Rica, 117

“Couro, Civilização do", 70

Couro, trabalhos em, 84

Cozinha, 15, 54

Crianças, 10-11

Cruzeiro, $O$, revista, 117

Cruzeiro do Sul, 26; Ordem do, 26, 133

Cuba, 75, 133

Cuiabá, 115

Cultura, 97, 105, 148; índios primitivos, 30; mistura de várias influências na, 84,105 ; nas cidades mineiras coloniais, 31; no Império, 42-43. Ver também Arquitetura; Artes; Folclore; Literatura

Cumbica, 133

Cunha, Euclides da, 104
Dacar, 131

Dança, 87, 88, 92

Debret, Jean-Baptiste, 101

Degredados, portugueses, 28

De Lamonica, Roberto, 101

Democracia, 13, 127, 129, 135

Deodoro da Fonseca, Manuel, 46, 128

D'Eu, Conde, 46

Diamantes, 29, 30, 31

Diamantina, 31, 117

Diário de Helena Morley, 117

Ditadura de Vargas, 57, 127, 130-131

Divórcio, ausência de, $11,13,117$

Doenças, 28, 128-129

Dom Casmurro, Machado de Assis, 104

Dunham, Katherine, 113

Dutra, Eurico Gaspar, 131

Economia, 69-75, 132; colonial, 30; efeito de Brasília na, 57-58, 146, 148; efeitos da abolição da escravatura na, 46, 72; história da, 70; Império, 45, 46; inflação, 132, 145, 148; na República Velha, 128, 129; necessidade de ajuda externa, 147-148; razões para o subdesenvolvimento da, 147-148. Ver também Agricultura; Exportação; Indústria; Reservas

Educação, 118; igualdade na, 114; no Império, 46; Jânio Quadros, ações em, 132; necessidade, para ultrapassar o subdesenvolvimento, 148; para mulheres, 116. Ver também Analfabetismo

Eleições: de 1930, 129; de 1934, 130; de 1945, 131; de 1950, 131; de 1955, 131-132; de 1960, 132

Eleitorado, 119, 135, 145, 151

Eletricidade, 132

Empregados, 12-13

Entretenimento: dos pobres, 56, 83, 86, 88, 92; futebol, 12, 56, 117. Ver também Feriados

Escolas, 118

Escolas de samba, 88, 90

Escravidão, 14, 29-30, 45, 54; abolição da, 46, 72, 128; hábitos remanescentes, 12-13

Escravo, O, Gomes, 103 
Escravos, libertação dos, 45-46

Escritores, 102-104; mulheres, 117

Esculturas, 100; parques, 25, 55; populares, 84, 86

Espanha, 26, 27, 41

Espírito Santo, 75

Esportes: capoeira, 55, futebol, 12, 56, 117

"Estado Novo", de Vargas, 131

Estados Unidos: ajuda econômica dos, 75, 131; comparações culturais com o Brasil, 98 , 102; comparações sociais com, 14, 114, 117; e o regime de Vargas, 130-131; pecuária, comparada com a do Brasil, 70, 71; relações com, 147; sistema de governo dos, comparado com o do Brasil, 133; visita de Pedro II aos, 44, 115. Ver também Americana, Revolução

Estradas, 11, 29, 75, 132, 146

Estradas de ferro, 29, 45, 75

Estudantes comunistas, 147

Exportação: café, 71, 76; algodão e lã, 71; diversificação das, 72; frutas e vinho, 75; reservas de ferro, 132

Extramaritais, relações, 11, 13

Extremistas políticos, 147

Família: laços, 10, 11, 13; vida doméstica, 14

Fascismo, 147

Faulkner, William, 102

Favelas, 9, 11, 56, 99, 146

Fazendas. Ver Agricultura

Febre amarela, 128

Feriados, 54; Carnaval, 87-88; rurais, 86, 87

Ferro: exportação, 132; indústria, 42, 75; reservas, 29,75

Festivais. Ver Feriados

Florestas, 29, 32, 74; exploração das, 74

Folclore, 83-87, 92, 148; artesanato, 83-86; dança, 87, 88; escultura popular, 84 , 86; música, $85,86-88,101$; poesia do interior, 86,87 ; teatro, 87

Fonseca e Silva, Valentim da, 100

Ford, Henry, 74

França, 75

Francesa, tentativas de colonização, 29, 30, 55

Frutas, 29, 75
Futebol [Soccer], 12, 56, 117

Gagarin, Yuri, 86

Gaúchos, 70

Getulismo, 131

Globo, 0,148

Goiás, 30, 57, 70, 85

Golpes. Ver Revoltas

Gomes, Carlos, 102, 103

Gomes, Eduardo, 131

Gonçalves Dias, Antônio, 103

Gonzaga, Tomás Antônio, 103

Goulart, João, 133, 138, 145-146

Governo: atitudes em relação ao, 127-128; corrupção no, 132; crise (1961), 133, 137; necessidade de aperfeiçoamento no, 148 ; pós-Vargas, 132; sistema atual de, 133, 137, 145-146; o sistema dos "Conselheiros", 129; sob Pedro II, 44; sob Vargas, 130-131

Graham, Maria, 117

Grã-Bretanha, 42, 46

Greves, 145

Guanabara, Baía de, 55

Guanabara, estado da, 72, 133

Guarani, O, Gomes, 102

Guarnieri, Camargo, 102

Gudin, Eugênio, 148

Guerra Mundial, Primeira, 129

Guerra Mundial, Segunda, 74, 130

Guevara, Ernesto "Che”, 133

Guia Prático, Villa-Lobos, 102

Guiana Francesa, 71

Habitação, 56, 98, 99, 146; em Brasília, 58, 146. Ver também Favelas

Haring, C. H., 42, 46

Hidrelétrica, energia, 69, 132

História: chegada dos portugueses, 25-28; colonial, 29-31, 53-54; ditadura de Vargas, 130-131; Império, 42, 43-46; paradoxos da, 11-12; rebelião contra Portugal, $31,41,43$; República, 46, 128-130, 131-133

Holandesa, tentativas de colonização, 29, 30, 72 
Holandesas, Índias Orientais, 74

Hospitais, 10, 11

Hugo, Victor, 44

Humor, 15

Igrejas, 100

Iguaçu, cataratas do, 45

Ilegítimos, filhos, 13

Imigração, 46, 72

Imigrantes, 84, 114-115, 147

Império do Brasil, 42, 43-46, 130

Impostos: na colônia, 30; no Império, 44; evasão de, 128; planos de reforma, 132

Imprensa, 119; sob Vargas, 130-131

Inconfidência Mineira [Minas Conspiracy], 31, 103

Independência: 43; luta pela, 31, 41

Índia, 70, 71

Índio, Serviço de Proteção ao, 38, 115

Índios: na chegada dos portugueses, 26-27, 29-30, 54, 70; conversão dos, 30; discussão do problema dos, 38, 115, 146; dizimados por doenças, 30, 37, 116; influências dos, no folclore e na música, 84, 85, 101 102; sobreviventes, $12,115-116$

Indústria, 69, 72, 75, 78-79, 81; nos tempos coloniais, 30; no Império, 42

Industrialização, 72, 131, 132

Infantil, mortalidade, 10,11

Inflação, 132, 145, 148

Integração racial, 113-114, 146

Integralistas, 130, 147

Intelectuais, 15

Interior: 29, 32; colonização do, 70; “fronteira deserta", 146; mudança do governo para, 56-57; povo do, 12, 86

Ipiranga, 43

Isabel, Princesa, 44, 46, 113

Israel, 117

Itália, 131

Italianos, imigrantes, 72, 75, 84, 115

James, Henry, 103

Jangada, 71
Japoneses, imigrantes, 84, 101, 115

Jefferson, Thomas, 31

Jesuítas, 30, 100, 101

Joalheria, 85

João VI, rei de Portugal e do Brasil, 42, 43, 101, 128

Jornais, 102, 119

Judeus, 114

Kimberley, jazidas de, 31

Kubitschek, Juscelino, 57, 131-132, 148

Lã, exportação de, 71

Lacerda, Carlos, 131, 133

Lampião, cangaceiro [bandit], 85

Landowski, Paul, 55

Laticínios, 70

Lazer. Ver Entretenimento; Feriados; Esportes

Le Corbusier, 98

Lévi-Strauss, Claude, 29

Liberalismo, 44

Lima, Jorge de, 103

Língua, 12; português versus espanhol, 13

Lins do Rego, José, 104

Lisboa, 42, 43, 99

Lisboa, Antônio Francisco. Ver Aleijadinho

Lispector, Clarice, 117

Literatura: "Arcadismo" mineiro, 31, 100, 103; mulheres escritoras, 117; poesia, 102-103; prosa, 103-104; romance "regional", 104

Londrina, 72

Longfellow, Henry Wadsworth, 44

Lott, Henrique, 132

Loyola, Inácio de. Ver Santo Inácio

Luís Pereira de Souza, Washington 129

Mabe, Manabu, 101

Machado de Assis, Joaquim Maria, 103-104, 114

Maciel, Antônio, 104, 128

Macumba, 55, 85, 89

Madeira, 74 
Madeira, gravuras em, 86

Madeira, rio, 115

Magalhães, Aloísio, 101

Malásia, 74

Manaus, 35, 59, 69, 74, 102

Manuel I, rei de Portugal, 26

Máquinas, indústria de, 72

Marajó, ilha, 71

Maranhão, 74

Maria I, rainha de Portugal, 42, 43

Maria (da Glória), 11, rainha de Portugal, 43-44

Marvelous journey, de Putnam, 31

Matarazzo, Francisco, 101

Mato Grosso, 16, 30, 115, 116; produtos de, 70-71, 72

Mauá, Visconde de, 45

Maurício, Padre José, 101

Maximiliano, Imperador do México, 42

Meireles, Cecília, 103, 117

Memórias póstumas de Brás Cubas [Epitaph of a small winner], de Machado de Assis, 104

México, 42

Mignone, Francisco, 102

Miguel, príncipe de Portugal, 44

Militares e poder político, 127, 128, 129, 147. Ver também Armadas, Forças

Minas Gerais, 12, 32, 131; arte e cultura nas cidades mineiras de, 31, 85, 97, 100; colonização de, 30; economia de, 70, 71, 72, 75; importância política de, 129

Mineração, 75, 76, 79

Minerais, reservas, 29, 30, 75, 78-79

Minorias, $114-116$

Miscigenação, 10, 28, 84

Missionários, 28, 30, 100

Mississippi, rio, 29, 30

Moeda, 26

Monarquia, 42, 128; pretendentes, 41, 47

Morais, Vinícius de, 103

Morais Barros, Prudente José de, 128

Moreira, Jorge M., 98

Morley, Helena, 117
Morro do Castelo, 55

Mortalidade, taxa de, 11

Muçulmanos, 54, 84

Mulatos, 54, 113, 114

Mulheres, 116-117; carreira das, 117; direito de voto das, 117,130

Música, 101-102; folclórica, 83, 85, 86-88, 92

Nacionalismo, extremo, 147

Nações Unidas, 106

Napoleão Bonaparte, 42, 43

Natal, 130

Natalidade, controle de, 11

Natalidade, taxa de, 11

Navegação, 29

Navio negreiro, $O$ [Slave ship, The], de Castro Alves, 103

Negros: na Bahia, 54-55; como escravos, 29, 30, 54 (ver também Escravidão); influências culturais dos, $84,85,86,89,101$; posição dos, $113,114,146$

Neves, Tancredo, 133

Niágara, cataratas de, 40, 44

Niemeyer, Oscar, 57, 63, 98

Olinda, 29, 100

Ordem de Cristo, 26

Oriente Médio, imigrantes do, 115

Ostrower, Fayga, 101

Ouro, 28, 29, 70; descobertas de, 30

Ouro Preto, 31, 59, 100

Paisagens, pintura de, 98-99, 109

Paisagismo, 98-99, 109

Palha, artesanato em, 84

Palmeiras, 74

Pantanal, 70

Pão de Açúcar [Sugar Loaf Mountain], 55

Papel, indústria de, 72

Pará, 71, 84, 116

Paraguai, 45

Paraguai, rio, 29 
Paraíba, 74

Paraná, estado, 72, 74, 76, 115

Paraná, rio, 57, 75

Parlamentarismo, 145-146

Partidos políticos, 135, 147

Pascoal, Monte, 26

Pau-brasil [Dyewood], 25, 26, 29

Paulo Afonso, cachoeira de, 29

Pecuária, 29, 70-71

Pedregulho, 98

Pedro I, imperador, 42, 43-44, 46, 57

Pedro II, imperador, 44, 46, 102, 113, 115

Peixoto, Floriano, 46, 128

Pernambuco, 71, 72, 74, 142

Pesca, indústria da, 71

Petrobrás, 75

Petróleo, reservas de, 29, 75

Petrópolis, 45, 50

Piauí, 74

Pintura, 101

Plantation, sistema de, 29, 45, 46

Pobreza, 11, 56, 114, 132, 140, 146; forças revolucionárias movidas pela, 74, 147

Poesia, 102-103; dos árcades, 31, 100, 103; folclórica, 86-87; romântica, 103

Poloneses, imigrantes, 84

População, 11

Portinari, Cândido, 101, 104

Porto Alegre, 12, 97

Porto Velho, 115

Portugal: como potência colonial, 26-28, 29, 43, 54, 70; imigrantes de, 72, 114-115; revolta contra, 31, 41, 43

Portuguesas, influências: na arquitetura, 99-100; no folclore, 84, 85, 87; na música, 101, 102

Positivista, movimento, 46, 128

Post, Frans, 101

Povo: caracterização do, 10, 11, 12-15, 28, 146, 148; miscigenação racial, 10, 28, 84, 113, 146; variedade do, 12

Presidência, 127-128, 129; acordo "café com leite", 129; sob o novo sistema parlamentarista, 133. Ver também Governo
Prestes, Luís Carlos, 129, 130

Pretendentes do trono, 41, 47

Previdência Social, 130

Primeiro-ministro, cargo de, 133

Produto Interno Bruto, 69, 72

Protestantes, 30

Putnam, Samuel, 31

Quadros, Anna Letycia, 101

Quadros, Jânio, 58, 86, 117, 128, 132-133, 145, 146

Química, indústria, 72

Quinze, $O$, Rachel de Queiroz, 117

Ramos, Graciliano, 104

Rebouças, André, 113

Recife, 11, 86, 97, 100, 101, 146

Refrigeração, falta de, 11, 71

Regionalismo, 12, 129, 130

Reidy, Affonso Eduardo, 98

Relações raciais, 113-114, 146. Ver também Miscigenação

Religião, 10, 44, 123; Ver também Catequese; Macumba; Igreja Católica Romana

Rendeiras, 85

República do Brasil, 46, 128-130, 131-133

Republicano, movimento, 46, 128

Reservas, 11, 28; florestas, 29, 74; hidrelétricas, 69, 132; minerais, 29, 30, 75

Revistas, 102

Revoltas: ausência de grandes, 15, 41; Comunista (1935), 13; golpe preventivo (1956), 132; Inconfidência Mineira [Minas Conspiracy], 31; Integralista (1938), 130; de 1889, 46, 128; de 1922 e 1924, 129; de 1930, 129-130; queda de Vargas, 131; religiosa, 128; de São Paulo (1932), 130

Rio de Janeiro, cidade: arquitetura contemporânea no, 98, 99; atual, 54, 55-56, 58; capital, 4243, 53, 54, 55; Carnaval no, 87, 88; favelas do, 9, 11, 56, 146; fundação do, 30, 55; mencionado, 9, 11, 48, 50, 79, 103, 109, 117, 120, 123, 124, 133, 148, 149; modernização do, 128; população do, 56, 146; problemas municipais no, 146; Revolta Comunista no (1935), 130

Rio de Janeiro, estado, 71-72 
Rio Grande do Sul, 71, 75, 115, 129, 131, 133

Rio Negro, 74

Rios, 29, 69, 71, 115

Riqueza, 11, 47, 132

Rondon, Cândido Mariano da Silva, 115

Rondônia, 115

Roosevelt, Theodore, 115

Rurais, proprietários: hoje, 47; no Império, 44, 45; no movimento republicano, 46,128

Sá, Estácio de, 55

Sailing alone around the world, Slocum, 14-15

Salvador, Bahia, 31, 42, 119; história de, 54-55; igrejas em, 100

Santa Catarina, 74, 75, 115

Santa Cruz, 26

Santarém, 28, 116

Santeiros, 86

Santo Inácio de Loyola, 28

Santo Tomás de Aquino, 102

Santos, 25, 29, 124

São Francisco, rio, 29, 57, 86

São Jorge, 85

São Paulo, cidade, 16, 29, 54, 81; Bienal de artes em, 101 ; crescimento de, 72; emancipação dos escravos em, 46; mencionada, 14, 25, $70,106,113,133$

São Paulo, estado, 12, 30, 71, 115; economia do, 72, 75, 76; governo de Jânio Quadros em, 132; importância política do, 129 ; revoltas em (1924, 1932), 129, 130

São Salvador da Bahia, 53. Ver também Salvador

São Sebastião do Rio de Janeiro, 30. Ver também Rio de Janeiro

São Vicente, 29

Saúde, 10, 28; campanhas contra doenças, 128-129; clínicas, 10, 11; desnutrição, 11 ; expectativa de vida, 11 ; mortalidade infantil, 10, 11

Saúde, Serviço Público de, 116

Segall, Lasar, 101

Sertão, 74, 86. Ver também Interior

Sertões, Os [Rebellion in the Backlands], de Euclides da Cunha, 104
Sesp, 116

Sindicatos, 130

Sindicatos operários, 130

Slocum, Joshua, 14-15

Sousa, Irineu Evangelista de. Ver Mauá, Visconde de

Sousa, Octavio Tarquínio de, 42

Souza, Tomé de, 54

Soviética, União, 130

Sphan, 101

Tabaco, indústria do, 75

Tapajós, rio, 116

Taunay, Nicolas Antoine, 101

Teatro, folclórico, 87

Têxtil, indústria, 42, 71, 72

Tiradentes (Joaquim José da Silva Xavier), 31

Tordesilhas, Tratado de, 26

Trabalhista, Partido, 133

Trabalho: agricultura, 69, 74, 142, 146; cidades, crescimento das, 129; escravos, 29-30, 46, 72; greves, 145; leis de Vargas, 130; sindicatos, 130

Trabalho, atitude em relação ao, 14, 146

Transportes, 29, 45, 69, 75, 132; de alimentos, 11 , 71

Triângulo Mineiro, 70

Tribuna da Imprensa, 131, 139

Tristes trópicos, de Claude Lévi-Strauss, 29

Tupi, índios, 26

Universitária, Cidade, Rio de Janeiro, 98

Uruguai, 45

Uruguai, rio, 29

Valentim, Mestre. Ver Fonseca e Silva, Valentim da Valéry, Paul, 102

Vargas, Getúlio, 57, 86, 129, 135; carta de suicídio, 132, 133; ditadura de, 127, 130-131; seguidores políticos de, permanência no poder, 132, 133, 138, 145

Varíola, 129

Varnhagen, Francisco Adolfo de, 57 
Vaz, Rubens Florentino, 131

Vegetação, 29, 74

Venezuela, 99

Ventre Livre, Lei do, 46

Vera Cruz, Terra da, 26

Vespúcio, Américo, 53

Vida, expectativa de, 11

Vila Rica (hoje Ouro Preto), 31

Villa-Lobos, Heitor, 102

Villas Boas, Orlando, 115

Villegaignon, Nicolas Durand de, 55

Vinho, indústria do, 75

Violência, ausência de, 15, 146-147

Volta Redonda, 75, 131

Voto, direitos de, 117, 130

Washington, George, 42

Whittier, John Greenleaf, 44

Xavier, Joaquim José da Silva. Ver Tiradentes

Zebus, 70, 71 


\section{5}

\section{Fragmentos de um outro Brasil}

Reúnem-se, aqui, traduções de cinco textos de Elizabeth Bishop relacionados ao Brasil, escritos nas décadas de 1950 e 1960. Apenas um deles foi publicado enquanto a autora estava viva - justamente o único escrito sob encomenda. Todos se encaixam no projeto que Bishop manteve durante anos, de escrever "um livro de prosa sobre o Brasil". Sob o título provisório de Black beans and diamonds (Feijões pretos e diamantes), como afirmou em entrevista de 1966, deveria ser "uma combinação de um livro de viagem, uma memória e um livro de fotos" (em Monteiro, 1996, p.29). Os cinco textos estão preservados nos arquivos da autora, onde se encontram, também, anotações e rascunhos de traduções diversas. Algumas dessas anotações, que envolvem desde ensaios arquitetônicos e históricos até notícias de jornal, trazem explícita sua intenção, como por exemplo a lista de doces onde consta um comentário, "para o capítulo de Ouro Preto". Nos arquivos existem anotações até mesmo de 1972, pois a autora manteve esse projeto numa época em que já estava retornando definitivamente aos Estados Unidos. 


\section{Suicídio de um ditador (moderado) [1954]}

Elizabeth Bishop escreveu este breve esboço logo após a morte de Getúlio Vargas, em 1954, baseando-se no que viu em um cinejornal, como informa no rodapé dos originais. Pretendia editar o relato em seguida a um poema de mesmo título, também abandonado. O texto em prosa foi publicado em The Georgia Review (inverno de 1992), por iniciativa de Thomas Travisano, e reproduzido em 2006, na edição de "poemas esparsos, rascunhos e fragmentos" reunidos e anotados por Alice Quinn, onde também consta o quinto e último rascunho do poema, que seria dedicado a Carlos Lacerda, o principal opositor de Vargas. (A pesquisadora lembra que todos os poemas de cunho explicitamente político foram abandonados por Bishop.) Ainda na semana do suicídio do presidente, a autora comentou em carta: "O Brasil e meus amigos brasileiros têm sido muito bons comigo. Tão bons que durante dois dias esconderam de mim o fato de que estava havendo manifestações antiamericanas, com medo de ferir minha suscetibilidade! E até agora não consegui que me mostrassem uma cópia da carta escrita pelo Vargas antes de se suicidar, na qual, imagino, ele deve acusar os Estados Unidos" (Bishop, 1995, p.317). O texto oferece um bom exemplo do olhar perspicaz da autora: ela descreve minuciosamente o que vê no cinejornal, filmado no Palácio do Catete e no aeroporto. Segundo Jaguaribe (1998, p.106), são "páginas de avaliação sarcásticas”, nas quais o caixão "desmaterializa-se como emblema vazio de um processo de mitificação coletiva”. A descrição, entretanto, é pontuada com comentários nos quais transparece o conhecimento acumulado por Bishop em quase três anos de Brasil. Alice Quinn informa que incorporou ao texto todas as frases manuscritas legíveis presentes no original. Nesta tradução mantiveram-se os cortes abruptos e as repetições de palavras, bem como os travessões característicos da autora.

"Suicide of a (moderate) dictator". Originais em Vassar College, Special Collections. Publicado em Bishop, 2006, Appendix, p.194-196. 
Parece que a multidão se reuniu em duas ou três ruelas laterais - não muito compacta ainda; assombrados, alguns olhando para a câmera, uma mulher ou duas apenas, todos os outros eram homens, como é usual aqui, quando a multidão vai ficando cada vez mais apertada. As palmeiras esguias e altas, altas demais, devaneavam atrás deles, um dia quente e nublado, como se estivessem crescendo depressa. Camisas abertas, suor, tudo cinzento. Dois ou três soldados impecáveis, com capacetes e fuzis. Uma ambulância branca solta fumaça e vira uma esquina, entre barricadas. O que será que essa enorme cruz vermelha tem a ver com isso? As tomadas seguintes - mais ou menos uma hora depois - parece que de dentro do pátio - as Pessoas Importantes chegando, vestidas de preto e preocupadas, com óculos de armação de tartaruga ou óculos escuros e ternos pretos ou uniformes de popeline cáqui - entrando. Aranha ${ }^{1}$ muito bonito e alto, de cabelo branco. Depois a cena do caixão, breve - G. ${ }^{2}$ bem apertado nele - ao menos segundo a nossa ideia norte-americana sobre essas coisas - nenhum dos nossos estofamentos em seda, travesseiros etc. - o rosto encostado à tampa do caixão, de vidro - como se tivesse sido forrado com papel - bem apertado, tudo junto $\ldots{ }^{3}$ As filas passando rápido dos dois lados, espreitando ou lambuzando o vidro com um beijo, carregando um longo copo-de-leite ou uma câmera com flash. (Alguém reparou agora nas narinas do presidente morto, com algodão.) O caixão sai pela porta - ergue-se porta afora - ergue-se é a palavra a partir de agora. Aparafusado em toda a parte de cima - não muito grande. Uma tomada de um grande Cadillac com o filho, que realmente se parece com personagem de desenho animado, gordo demais, fumando, e que empurra uma mulher em vestido preto e blusa branca, e óculos escuros, para dentro dele à sua frente, acomoda-se e acelera com seu braço em volta do encosto, sem olhar para a câmera.

O caixão parece ser carregado pela multidão, como um tronco numa enchente, mas sempre com a parte da cabeça inclinada para o alto. Milhares e milhares de pessoas surgem depressa, sempre, ao longo da avenida à beira-mar até o aeroporto - parece que o caixão está sobre algum tipo de suporte - como é que eles o mantêm ali não se pode ver ou imaginar. Milhares de soldados agora, também, mas nenhuma "desordem", apenas se aproximam, e gritos e guinchos - homens e mulheres chorando - homens e mulheres soluçando e uivando, apertando seus lírios molengos de hastes longas - como as palmeiras que se agitam lânguidas mas, às vezes, bem rápido, no fundo - Uma tomada muito longa no fundo dos olhos de uma

\footnotetext{
${ }^{1}$ Oswaldo Aranha (1894-1960), ministro da Fazenda, amigo de Vargas e uma das figuras mais importantes de seu governo.

${ }^{2}$ Getúlio Vargas.

${ }^{3}$ Este é o único ponto em que permanece um salto, na edição de Alice Quinn.
} 
menina negra, um tanto resplandecentes. Mulheres chorando abraçadas. Então as mulheres começam a desmaiar. E a coroa de flores aparece - um círculo enorme de lírios e folhagens verdes que misteriosamente flutuam juntos e também sacodem juntos, como um gigantesco salva-vidas enfeitado - primeiro aqui, depois lá - onde e como - sobe - escorrega para os lados - nunca pode alcançar a ponta de cima da mística pluma preta em que o presidente se transformou, mas parece lutar para alcançá-lo e nunca o apanha. Mas são pessoas embaixo. E embaixo das pessoas estão as flores. A avenida está coberta por elas, agora. Motocicletas, soldados, empurram também - como uma represa que se abriu - uma inundação repentina. Como o caixão anda rápido!

No aeroporto ${ }^{4}$ as coisas começam a ficar tumultuadas. Vão deixar que a pluma chegue até o pássaro místico ou não? Os soldados começam a usar seus cassetetes. Ambulâncias se aproximam e mulheres são deitadas em macas à esquerda e à direita. E existe a coroa de flores. Como foi que ela chegou aqui? Agora ela está à direita - não, está caindo atrás - não, está lá, inclinando-se na crista de uma onda. Mas ela não tomba nunca. É um salva-vidas patenteado. Flutua tão bem quanto o caixão. O caixão alcança a porta do avião - o pior momento - inclinando-se e oscilando, quase se debatendo, vai e volta, de alguma maneira consegue entrar - a câmera dá um suspiro.

Vemos a esposa, amparada por duas parentas muito comuns - óculos escuros - sua boca torcida num jeito de extrema autopiedade. Mãos tentam alcançá-la - uma menina beija seu pulso - ela murmura alguma coisa. De volta para o avião, que faz uma decolagem hábil e rápida através da neblina brilhante, passa a água e os morros da Baía de Guanabara - para longe e para cima e para longe - oh, dúvida! Onde está a sua coroa de flores?

Cinejornal que eu vi dia $1^{\circ}$ ou 2 de setembro - o suicídio aconteceu na manhã do dia $24 .^{5}$

\footnotetext{
${ }^{4} \mathrm{O}$ presidente foi enterrado em sua terra natal, São Borja (RS).

${ }^{5} \mathrm{O}$ esboço do poema de mesmo título, editado por Alice Quinn (Bishop, 2006, p.104; republicado em Bishop, 2008, p.236), foi comentado por Regina Przybycien (1993, p.60) e Marcelo Coelho (2006). Cada um traduziu alguns versos. Em versão livre: "Este é um dia em que as verdades virão à tona, talvez;/ vazarão de telefones dependurados/ sugando as forças de mesas telefônicas enfeitadas;/ vão cair das janelas, soprar dos parapeitos,/ - o conteúdo vago e desinteressante/ de cinzeiros se esvaziando; vão manchar nossos dedos/ como a tinta dos jornais não revisados,/ desbotando como as fotografias mal-enfocadas/ de rostos tortos, que sujam nossos casacos/ nossos casacos de peso tropical, como mariposas mortas.// Hoje, os que trabalham estão de folga. Aqueles que se divertiram devem trabalhar/ e depressa, também, para terminar o serviço / com alguma dignidade ou nenhuma./ Os jornais foram vendidos; as bancas/ já estão fechadas. Mas de algum modo, durante a noite,/ as manchetes se escreveram sozinhas - veja - nas ruas/ e nas calçadas por toda parte; um sedimento se esparramou/ até mesmo no primeiro andar dos prédios de apartamentos.// Este é um dia que está bonito também,/ e quente e claro. Às sete da manhã eu vi/ os cachorros sendo levados para passear pela praia famosa/ como sempre, numa aurora de brilho verde e cinzento,/ deixando pegadas na areia úmida./ A linha da arrebentação estava calma e/ o arco-íris rosado, em pedaços, pairava sobre ela./ Às oito, dois meninos empinavam pipas."
} 


\section{Uma nova capital, Aldous Huxley e alguns índios [1958]}

Elizabeth Bishop escreveu este artigo logo após sua breve viagem a Brasília - ainda em construção - e a um posto do Serviço de Proteção ao Índio, às margens do Xingu, em agosto de 1958. A figura central do grupo de excursionistas era o escritor inglês Aldous Huxley (1894-1963), convidado do Ministério das Relações Exteriores. O jornalista e escritor Antônio Callado (1917-1997), outro dos companheiros de viagem, publicou uma reportagem no Correio da Manhã, do Rio de Janeiro, do qual era redator-chefe. Bishop, que cita o texto de Callado, escreveu seu longo artigo na esperança de vê-lo publicado na New Yorker, a revista que costumava aceitar seus poemas, mas desta vez sua colaboração foi recusada. Em vez de questionar os editores, a autora preferiu afirmar que "o material simplesmente não combinava, Huxley não dissera nada de interessante”, concluindo que seria "estupidez de minha parte perder tanto tempo com isso”. Assim, o artigo permaneceu inédito por mais de quarenta anos, até julho de 2006, quando surgiu na Yale Review com uma breve introdução de Barbara Page. O cuidado de Bishop em contextualizar tudo a que se refere permitiu que o artigo fosse bem compreendido pelo público norte-americano, tanto que não houve inclusão de notas. (Republicado em 2008, recebeu apenas três notas.) Entre os trabalhos em prosa reunidos neste conjunto que pretende investigar o Brasil de Elizabeth Bishop, este artigo e aquele sobre o quarto centenário do Rio de Janeiro, de 1965, são os únicos finalizados e enviados para publicação. Este, no entanto, além de muito mais longo, foi escrito por iniciativa da autora, ao passo que o texto de 1965 resultou de uma encomenda. Por suas características, este certamente poderia servir de base para um capítulo do livro que Bishop pretendia escrever sobre o Brasil.

“A new capital, Aldous Huxley, and some indians". Originais em Vassar College, Special Collections. Publicado com introdução de Barbara Page em The Yale Review, New Haven, v.94, n.3, p.76-114, jul. 2006. Republicado em Bishop, 2008, p.365-401. 
Quando Aldous Huxley e sua mulher visitaram o Brasil há pouco tempo, a Divisão de Cultura do Itamarati, o Ministério das Relações Exteriores brasileiro, planejou uma viagem a Brasília, a nova capital do país, além de um passeio adicional mais para o interior para ver os índios Uialapiti. O Ministério das Relações Exteriores é sempre chamado de Itamarati ${ }^{1}$ porque sua sede ocupa a antiga casa dos barões de Itamarati no Rio de Janeiro, uma bela e sólida residência, um verdadeiro palácio em pequena escala. Por trás de seus altos muros há magníficas palmeiras imperiais, um jardim e um tanque clássico com cisnes, em torno do qual são servidos os banquetes.

A nobreza brasileira criada pelos dois imperadores era ferozmente nacionalista e orgulhosa de seu país semicivilizado, e sempre escolheu para seus títulos topônimos indígenas, tais como Itaboraí, Tamandaré ou Itamarati. Podemos grafar a história moderna do Brasil num brevíssimo resumo com os três nomes conectados pela viagem de Huxley: partindo de Itamarati para a segura e democrática insipidez do nome "Brasília", e depois mais além, até as tribos que estão definhando ao longo do rio Xingu, também este um nome indígena, pois tanto aqui como nos Estados Unidos, muitos marcos geográficos mantiveram seu nome original, ou variações dele.

Dez pessoas fizeram a viagem: Huxley e sua mulher italiana; dois homens do Itamarati, um deles chefe da Divisão Cultural, José Meira Penna; ${ }^{2}$ Antônio Callado, redatorchefe do maior matutino carioca, ${ }^{3}$ e sua mulher inglesa; uma jovem polonesa-brasileira ${ }^{4}$ que trabalha com arquitetura no Rio; um jovem inglês da embaixada britânica; uma garota que estivera trabalhando como intérprete para os Huxleys no Rio; e eu, a única norte-americana. Todos eles foram a Brasília de avião, desde Minas Gerais, onde os Huxleys visitaram uma ou duas vilas coloniais. Eu deveria encontrá-los à hora do almoço num sábado, no grande e novo hotel projetado por Oscar Niemeyer.

Brasília fica a cerca de mil quilômetros ao noroeste do Rio, no estado de Goiás; hoje, a ferrovia mais próxima termina em Anápolis, uma pequena cidade a 140 quilômetros de distância. São necessários três dias, em trens de bitola comum e bitola estreita, para ir do Rio

\footnotetext{
${ }^{1}$ Neste parágrafo, consta duas vezes "Itamariti”, no texto publicado.

${ }^{2}$ O embaixador José Oswaldo de Meira Penna (1917).

${ }^{3}$ O escritor e jornalista Antônio Callado (1917-1997) foi redator-chefe do Correio da Manhã entre 1954 e 1960. Suas viagens ao Xingu forneceriam material não apenas para reportagens e textos esparsos (como "A doce república do Tuatuari”), mas também para o romance Quarup (1967). Em “A doce república...” diz ele: "Assim se vive naquela república dos irmãos Villas Boas, para onde viajo quando o Brasil exagera". Callado conheceu sua mulher, Jean Maxine Watson, quando trabalhou na BBC, durante a Segunda Guerra Mundial.

${ }^{4}$ Maya Osser.
} 
de Janeiro a Anápolis; de lá, caminhões e jipes vão até Brasília. Até agora apenas dois trens carregados com material para a nova capital conseguiram fazer essa viagem; todo o resto - a inacreditável quantidade de cimento, tijolos, aço, vidro e madeira necessária para iniciar a construção de uma cidade moderna - foi por autoestradas, por autoestradas ruins - tudo, ou seja, aquilo que não foi de avião. Uma vez que a gasolina é o maior item de importação do Brasil, responsável por $24 \%$ dos gastos do país em dólares, essa tentativa de construir uma cidade antes de construir uma ferrovia até lá é uma das críticas mais sérias que se fazem à nova capital do presidente Juscelino Kubitschek.

A mudança de capital consta na Constituição brasileira desde 1891, e falava-se dela já em 1820. Entre as razões invocadas naquele tempo para a mudança está a de que o Rio de Janeiro, por situar-se na costa, ficava exposto a ataques por mar; uma capital situada mais a oeste abriria as vastas extensões despovoadas do interior para colonizadores permanentes, algo que nenhum pioneiro foi (ou é) capaz de fazer. A primeira razão desapareceu, é claro, com o surgimento dos aviões, mas a segunda ainda é o principal argumento do grupo favorável a Brasília. Existem outras, algumas delas similares às apresentadas para a fundação de Washington: a legislação, dizem os favoráveis a Brasília, será seguida de maneira muito mais eficiente e imparcial longe das pressões das cidades rivais, Rio e São Paulo; e se a capital é a sede do governo, senadores e deputados irão até lá para conduzir os negócios da nação e depois retornar aos seus estados de origem, e não serão seduzidos pelas atrações do Rio. Hoje, muitos deles vivem ali por anos e veem seus eleitores às vezes, quando muito. Além disso, o Rio está superpovoado, sofrendo com a escassez de água, e seus cortiços estão se multiplicando, à medida que mais e mais migrantes miseráveis chegam das áreas mais pobres ou castigadas pela seca, em busca de trabalho. Muitos deles, dizem, serão atraídos por Brasília; e é verdade que alguns milhares já foram para lá.

Enquanto todos os brasileiros que já pensaram no assunto concordam em que o interior do país tem de ser aberto de uma forma ou de outra, e quanto antes melhor, aqueles que se opõem a Brasília sentem que isso poderia ser feito de maneira mais modesta e econômica, mais adequada ao desesperador estado financeiro do Brasil. O país precisa de escolas, estradas e rodovias, acima de tudo; depois, cuidados médicos, melhores métodos agrícolas, e represas e energia elétrica, sobretudo no Nordeste castigado pela seca. Essas coisas, pensam eles, deveriam ser atacadas de modo mais enérgico e sistemático, devagar se necessário, antes de se tentar construir uma capital luxuosa, uma extravagante vitrina, a três horas de avião da faixa de cidades ao longo do litoral. A fundação de pequenas vilas e cidades no interior, e o auxílio a suas indústrias e à agricultura - especialmente por ferrovias e 
melhores estradas, uma vez que hoje $50 \%$ de toda a produção se estraga antes de chegar aos mercados -, isso, os contrários a Brasília dizem, é o que desenvolveria o interior, e não uma nova capital. E por que construir uma nova capital, perguntam eles, quando já têm uma das capitais mais belas do mundo, completa, com todos os edifícios governamentais - mesmo que ela precise de uma restauração total neste momento? Pensam que levará anos até que as embaixadas estrangeiras sejam construídas - embora todas já tenham comprado terrenos, por intenção verdadeira ou apenas para agradar ao governo -, e que mesmo os senadores e deputados se convençam a permanecer em Brasília por algum tempo.

O tempo dirá quem está certo, mas Brasília é o sonho do presidente Kubitschek. Ele anunciou que alguém teria de cumprir a promessa feita ao país na Constituição de 1891, e a está cumprindo agora. Restam ainda dois anos de seu mandato de cinco; em 21 de abril de 1960 o governo espera realizar a grande mudança.

Cheguei sozinha numa tarde de sexta-feira, empunhando um pedaço de papel onde se lia o nome do homem, parente de alguém importante, que deveria vir me encontrar, mas que não apareceu. A primeira coisa que se apresentou aos meus olhos assim que saí do avião foi uma banca de engraxates com três cadeiras, junto à parede do pequeno prédio do aeroporto. Naquele momento eu não precisava engraxar meus sapatos, algo muito necessário para todos os passageiros, na hora da partida. É verdade que estávamos nos últimos dias da época seca, mas no final do inverno de $1958^{5}$ a primeira e última impressão de Brasília consistia em milhas e milhas e milhas de poeira vermelha.

Do lado de dentro, o aeroporto era um bom exemplo da atmosfera comum na maior parte de Brasília à época - a de uma pequena estação rodoviária nos Estados Unidos, uma estação no extremo oeste. Homens com calças jeans, chapéus de feltro de abas largas e botas altas, tomavam café e cerveja e comiam salgadinhos amanhecidos. (Mulheres ainda são raras em Brasília, e eu era a única no avião.) Numa pequena loja, latas amassadas de leite, sardinhas e palmito, linguiça vermelha ressequida, garrafas de cachaça, óculos de sol, comprimidos para dor de cabeça e jornais do dia anterior. Na parede, uma fila de pequenas bandeiras em seda ostentavam a palavra mágica BRASíLIA, e vendiam-se placas de plástico

\footnotetext{
${ }^{5}$ A autora escreve "final do verão", referindo-se ao Hemisfério Norte (agosto). Na realidade, trata-se do final do inverno, a época seca, em Brasília.
} 
dourado com a mesma palavra e, em perfil, numa mancha também dourada, a cabeça de onde tudo isso saiu: Juscelino Kubitschek de Oliveira.

Os quatro ou cinco homens que chegaram comigo e pareciam ser engenheiros - um deles carregava uma grande régua-T sob o braço - entraram em jipes e partiram em meio a nuvens de poeira. Afinal desisti de esperar por meu guia e entrei no microônibus Volkswagen creme onde se lia "Brasília Palace Hotel" e fui embora também, a única passageira. São cerca de 18 quilômetros entre o aeroporto e o hotel; era um dia quente e claro, e fomos muito depressa pela estrada esburacada e suja.

Brasília está localizada num planalto vazio, estéril e um pouco ondulado, 1.200 metros acima do nível do mar. Já me haviam descrito o lugar, mas eu não estava preparada para tanta melancolia e desolação: comparado com quase qualquer outra parte habitável deste país fantasticamente belo, parece sem atrativos e desanimador. Não existem montanhas, nem ao menos morros de verdade, nem rios, ao menos visíveis (existe um pequeno rio a algumas milhas, e dois córregos), nenhuma árvore de nenhum tamanho, nenhuma sensação de altura, nem de grandeza, nem de segurança, nem de fertilidade, nem ao menos de paisagem pitoresca; nenhuma das qualidades consideradas capazes de dar charme ou caráter a uma cidade. Isso me lembrou - e a outros membros do grupo, pelo que me disseram depois - a paisagem deprimente em torno de Madri. As duas dádivas que a Mãe Natureza parece ter reservado para Brasília são céu e espaço, e quando alguém imagina esses planaltos sem fim cobertos por edifícios governamentais brancos e modernos, monumentos, arranha-céus, lojas e prédios de apartamentos, como deverão ficar, a única beleza natural restante é o céu. É claro que haverá um lago artificial; existe mesmo um iate clube marcado no mapa da cidade, e amigos que estiveram lá na estação chuvosa dizem que é bonito ver as tempestades se aproximando através do planalto, por vários quilômetros. Mas para alguém acostumado à beleza hiper-glamourosa do Rio de Janeiro, onde quilômetros de praias brancas, ou mesmo uma vista da baía no final de uma rua, podem suplantar a maioria das deficiências da cidade, Brasília parece ser uma triste queda.

Existem alguns grupos de palmeiras aqui e ali, mas em geral a vegetação consiste em arbustos esparsos, sobretudo uma variedade conhecida como "abricó", que produz pequenos frutos silvestres, sem relação, todavia, com o verdadeiro abricó. ${ }^{6}$ Tão longe da estrada quanto os olhos podem alcançar, essas árvores e o mato grosso estão cobertos de poeira vermelha levantada a todo momento pela passagem dos caminhões. Crescendo em quase todos os

\footnotetext{
${ }^{6}$ Este, muito mais próximo do pêssego ou damasco.
} 
troncos finos, a meia altura, horrível e maior que a cabeça de um homem, há um cupinzeiro. Quando perguntei sobre eles ao motorista, um jovem deprimido e coberto de poeira, ele disse de maneira ríspida que os cupins os construíam a meia altura para ficarem mais perto das frutas. A quilômetros dali, podem-se ver alguns conjuntos de telhados, colônias dos operários e outros novos habitantes. O maior deles, de longe, é o "Núcleo de Pioneiros" - ou "Portabandeiras", 7 para traduzir seu romântico nome literalmente -, que, em geral, é chamado apenas de Cidade Livre. ${ }^{8}$ Ela foi fundada em fevereiro de 1957, com quatrocentas pessoas, e hoje tem - um dado incrível e que inspira confiança - 45 mil. "Tudo feito de madeira", disse o motorista, e nós ouvimos essa frase muitas vezes porque num país latino de pedra, mármore, azulejos e gesso, é curioso ver uma cidade inteira construída em madeira. "E ela é livre, é claro", ele completou, e esse foi seu último comentário até chegarmos ao hotel.

Oscar Niemeyer, arquiteto famoso no mundo inteiro, é amigo do presidente Kubitschek desde que projetou uma casa para ele, a primeira casa modernista em Belo Horizonte, quando era prefeito dessa capital. Depois, quando Kubitschek foi eleito governador do estado de Minas Gerais, contratou Niemeyer para construir o conjunto da Pampulha, ${ }^{9}$ próximo a Belo Horizonte. Agora Niemeyer é responsável pelo projeto de todos os edifícios públicos a serem construídos em Brasília. Em 1956 organizou-se um concurso que escolheria o "plano-piloto" para a nova cidade de 500 mil habitantes. Era o sonho de qualquer arquiteto transformado em realidade, e dúzias de planos foram apresentados, alguns muito bem elaborados e detalhados, focalizando até os subúrbios e os cinturões agrícolas. Lúcio Costa, o mais importante dos arquitetos brasileiros mais antigos, amigo e incentivador de Niemeyer desde seus tempos de estudante, sentiu que naquele estágio inicial não se deveria propor nada de muito detalhado. Ele apresentou apenas cinco ou seis esboços que pareciam ter sido desenhados às pressas, em pequenas folhas de papel barato. Mas seu plano-piloto logo foi reconhecido como um brilhante e pequeno tour de force, tendo recebido por unanimidade o primeiro prêmio, equivalente a 14 mil dólares.

De acordo com ele, a cidade é desenhada na forma de um avião, ou talvez um pássaro, voltado para o leste, tendo o corpo 11 ou 12 quilômetros de comprimento. As asas, com 12 quilômetros de comprimento, irão abrigar os bairros residenciais; o centro comercial fica na

\footnotetext{
${ }^{7}$ Flagbearers (porta-bandeiras), o sentido original de Bandeirantes. O nome correto dessa cidade-satélite de Brasília é Núcleo Bandeirante.

${ }^{8}$ Para incentivar a vinda de comerciantes, a localidade estava livre do pagamento de impostos. Daí a origem do nome Cidade Livre.

${ }^{9}$ Impresso "Pampuhla". O erro remete ao comentário de Bishop nos originais do livro Brazil: "O $h$ depois de uma consoante é uma das coisas que fazem o português parecer tão estranho aos nossos olhos" (Vassar College, Special Collections, cap. 1).
} 
cauda; o corpo contém bancos e edifícios de escritórios; ao longo do tórax ficam os ministérios, ${ }^{10}$ e na cabeça está a "Praça dos Três Poderes": ${ }^{11}$ Judiciário, Legislativo e Executivo - e este último é, no papel, o mais ambicioso e espetacular projeto de Niemeyer até hoje. Fora do avião ou pássaro, a leste de sua cabeça, estão o Brasília Palace Hotel e o Palácio da Alvorada, a residência presidencial, os dois únicos edifícios grandes já completos; aliás, excetuando-se uma pequena igreja e as fundações ou esqueletos de cinco blocos de apartamentos, são eles os únicos edifícios permanentes.

Para um número recente de Módulo, a revista brasileira de arquitetura, ${ }^{12}$ Niemeyer escreveu um artigo chamado "Depoimento", num tom solene mas algo incoerente, acerca de seu trabalho em Brasília. Ele é comunista e nesse "depoimento" censura seus erros passados e promete fazer melhor no futuro, no melhor estilo comunista. Diz que ainda acredita "que sem uma justa distribuição da riqueza - capaz de atingir a todos os setores da população - o objetivo básico da arquitetura, ou seja, o seu lastro social, estaria sacrificado, e a nossa atuação de arquitetos relegada apenas a atender aos caprichos das classes abastadas". ${ }^{13}$ Confessa ter feito isso no passado, ter imaginado a arquitetura como um "jogo" ${ }^{14}$ e mesmo ter projetado casas com excentricidades e extravagâncias apenas para que seus ricos proprietários "falassem delas". ${ }^{15}$ Mas de agora em diante, diz ele, as coisas serão diferentes; ele espera que seus trabalhos em Brasília possam todos ser "qualquer coisa de útil e permanente, e capaz de transmitir um pouco de beleza e emoção". 16

Pode surpreender um visitante crítico o fato de que em dois anos milhares de operários tenham construído casas ou barracos de madeira para eles próprios, enquanto os dois primeiros edifícios a se completarem serão chamados de "Palácios". Entretanto, é preciso reconhecer que, além da Cidade Livre, vêm sendo feitas tentativas buscando fornecer habitação digna para operários e funcionários de escritório. Dois blocos, cada um com quinhentas casas "geminadas", projetados por Niemeyer, já foram construídos pela Fundação

\footnotetext{
${ }^{10}$ A autora afirma que aí se localizam os foreign ministries, corpos diplomáticos. Corrigimos nesta tradução.

${ }^{11}$ No original, "Esplanada dos Três Poderes", sem dúvida por influência de "Esplanada dos Ministérios", embora os projetos originais já a denominassem como "praça". Corrigimos nesta tradução.

${ }^{12}$ Fundada e dirigida por Oscar Niemeyer, a revista Módulo surgiu em março de 1955. No entanto, a publicação foi interrompida em 1965, após a instalação do regime militar, quando sua redação foi invadida e os exemplares, apreendidos. Voltou a ser editada entre 1975 e 1989.

13 Niemeyer, Oscar. "Depoimento". Módulo, Rio de Janeiro, n.9, p.3-6, fev. 1958. Republicado em Xavier, Alberto (Org.). Depoimento de uma geração. São Paulo: Abea; FVA; Pini, 1987. p.221-224. p.221.

${ }^{14}$ Niemeyer diz "exercício que se deve praticar com espírito esportivo". Ibidem, p.221.

15 Niemeyer diz que "era incentivado pelos próprios interessados, desejosos de dar a seus prédios maior repercussão e realce". Ibidem, p.222.

${ }^{16}$ Ibidem, p.224.
} 
da Casa Popular, ${ }^{17}$ e cinco "superquadras" de apartamentos estão surgindo agora, financiadas por cinco dos institutos ${ }^{18}$ brasileiros, uma forma peculiar de sindicato que administra pensões, hospitalização e empréstimos, e funciona, como neste caso, como um banco.

Ao final de quatro anos, quando houver habitações suficientes, a Cidade Livre deverá ser derrubada; na realidade, nessa época uma parte do lago artificial deverá cobrir suas ruas. Os que se opõem com mais violência a Brasília predizem com cinismo que a Cidade Livre jamais será derrubada; que ela vai permanecer e crescer, um subúrbio pobre da futura cidade, como os barracos que crescem de maneira selvagem e incontrolável em torno do Rio de Janeiro. ${ }^{19}$

(Também é preciso explicar que embora a palavra "palácio" para a residência de um presidente possa parecer estranha aos ouvidos norte-americanos, nos países latinos a palavra não carrega os significados de realeza que tem entre nós. Pode significar apenas "mansão", e palacete, "pequeno palácio", é muito usado para casas grandes).

Entre todos os chefes de governo, Kubitschek deve ser, sem dúvida, o de gosto mais sofisticado em arquitetura. Brasileiros educados percebem que têm motivos para orgulhar-se de sua arquitetura contemporânea, embora o país esteja passando por um difícil período de transição, retrocedendo em muitos aspectos, e talvez não tenha nada muito impactante nas outras artes. O belíssimo edifício do Ministério da Educação, no Rio, iniciado em 1937, é o primeiro e ainda um dos pouquíssimos edifícios governamentais encomendados no estilo moderno internacional. (Chandigarh só foi iniciada em 1947.) ${ }^{20}$ Afinal, Kubitschek poderia ter decidido construir uma capital em velho estilo colonial, ou em estilo neoclássico, ou mesmo no estilo monstruoso de chalé suíço que às vezes tem sido considerado apropriado para o Brasil. No que diz respeito a suas escolhas estilísticas, entretanto, as únicas objeções que ouvi provieram do exército, o qual não aceita que um edifício arejado, transparente ou flutuante possa representar sua visão das coisas. Mas é possível que, em segredo, todos os generais sonhem com ameias e pontes levadiças.

\footnotetext{
${ }^{17} \mathrm{O}$ nome da Fundação consta apenas em português.

${ }^{18}$ Em português.

${ }^{19}$ Em 2005 o Núcleo Bandeirante, uma das menores cidades-satélite de Brasília, alcançou 40 mil habitantes.

${ }^{20}$ Cidade indiana, capital dos estados do Punjab e de Haryana, Chandigarh foi projetada por Le Corbusier e inaugurada em 1953. No original consta que a cidade foi iniciada "há 15 anos".
} 
Uma amiga minha, decoradora de interiores no Rio, que acabara de trabalhar no novo hotel, havia feito reservas para mim por radioamador. O Brasília Palace Hotel tem um só bloco, com 135 quartos, é da largura de um quarto e tem três andares; apenas uma pequena parte central fica no nível térreo, o restante do prédio, dos dois lados, é suportado por pilares de concreto cobertos com alumínio anodizado em preto. À noite esses pilares quase desaparecem e o hotel parece flutuar como um navio de luxo, um efeito que hoje parece agradar Niemeyer.

A entrada, que me recorda vagamente a entrada de uma estação de metrô novaiorquina, fica no final de um lance de escadas que leva a um lobby subterrâneo; sobre ele, no nível térreo, existe uma sala grande e agradável, repleta de cadeiras do Saara e mesas de café com tampo de mármore. Os três andares de quartos estão voltados para leste, para o Palácio da Alvorada; três corredores se estendem por todo o comprimento da fachada oeste. Existe uma escada social, com cerca de um metro e meio de largura, e dois pequenos elevadores (um deles não estava funcionando durante nossa passagem por lá), cada um com capacidade para no máximo seis pessoas, portanto é certo que haverá sérios problemas de tráfego quando o hotel estiver lotado com sua cota de trezentos hóspedes. Toda a fachada oeste é feita de grandes placas de cimento, com cerca de 8 centímetros de espessura, e a cada placa existem fileiras de copos redondos - copos de verdade, os porteiros gostam de informar - com seus fundos circulares vedando a parede do lado de fora. Eles deixam a luz entrar, criando milhares de pontos nas paredes e nos carpetes cinza dos corredores. O efeito é belíssimo, mas, desde o momento em que o sol começa a descer no lado oeste do céu e até a madrugada do dia seguinte, confere ao lugar um calor diabólico. Além disso, eu imagino como é que se poderia limpar o interior de todos esses copos. O tipo mais comum de hóspedes já começou a deixar pontas de cigarro e outras coisinhas nesses espaços. Entre os andares, uma fileira de placas foi deixada sem vidros; os vãos se abrem para o ar livre no alto dos vestíbulos, onde pequenas aberturas emolduradas se alternam com luminárias ao longo do teto. Espera-se que isso forneça ventilação, mas nenhum sopro de ar passava pelos vãos, e uma noite, quando eu atravessava o corredor até o meu quarto, lá no final, fiquei tonta por causa do calor, antes de chegar à minha porta de fórmica branca. O teto do banheiro tem furos que o ligam, também, a essa mesma coluna de ar, com o triste resultado de que é possível ouvir, com todos os detalhes, o homem do quarto ao lado tomando banho. Os quartos, entretanto, são grandes e frescos, e, exceto pelas penteadeiras, bem decorados. Nos espelhos da penteadeira, uma mulher de altura mediana (eu) vê apenas seu queixo. 
Entre o edifício do hotel e a ala do restaurante existe um pequeno espaço do tamanho de uma quadra de tênis onde havia grama, e ela estava sendo regada. Mas, em frente e na parte de trás do hotel, e pelos oitocentos metros que o separam do palácio presidencial, a poeira vermelha se espalhava à vontade. (Mais ou menos uma semana depois, quando o presidente Gronchi, da Itália, visitou Brasília, uma fina camada de cimento foi espalhada sobre a área em frente ao Palácio.) A poeira penetrava no hotel, tingindo os tapetes e as roupas, e polvilhava o piso de mármore cinza da sala de estar. Eu vi um funcionário tentando limpar esse piso com uma enceradeira. Depois de desenhar algumas espirais grandes, circundadas por montinhos de areia vermelha, ele desistiu.

Esse piso, em particular, termina numa rampa curva que desce um metro e meio até o piso do restaurante, para o qual a sala de estar se abre. Plantas e cactos se escondem tímidos sob a rampa, invisíveis da sala de estar. A única ocasião em que vi Aldous Huxley nitidamente irritado durante nossa viagem foi quando, assim que chegou no dia seguinte, ele veio descendo da sala de estar, contra a luz, e quase caiu da rampa. Ele mostrou nítidos sinais de irritação, ao seu estilo, e comentou que o corrimão vem sendo usado há milhares de anos e que parecia "triste abandonar uma invenção tão útil".

Em frente ao restaurante fica a maior piscina que eu já vi: oval, com azulejos azuis, como se estivesse sem água. A piscina presidencial, do outro lado do Palácio, é maior que uma piscina olímpica, e esta é muito maior que aquela. Ainda não foram construídos aposentos permanentes para os funcionários do hotel. Depois da piscina existe uma cerca de madeira, circundando um conjunto de cabanas também de madeira. Camareiras, porteiros e cozinheiros com seus chapéus brancos circundam a piscina azul e desaparecem nesses alojamentos miseráveis que ficam defronte ao restaurante.

Escondidos atrás de uma parede negra e curva no nível do restaurante existem um bar e um espaço para coquetéis, com algo que também provocou certa irritação no grupo de Huxley - uma música barulhenta, o equivalente brasileiro da muzak, tocada por duas horas durante o almoço e o jantar. A comida não era ruim, considerando-se que todos os ingredientes tinham de ser trazidos por caminhão ou avião no mínimo desde Anápolis; quase não havia legumes e verduras, mas sempre abacaxis ou papaias trazidos de avião para nos suprir de vitaminas, assim como tenras maçãs vermelhas, tão onipresentes aqui como nos Estados Unidos.

$\mathrm{Na}$ noite daquela sexta-feira dois casais vindos de bem longe e eu jantamos sozinhos no grande restaurante. A música enlatada nos atingia como o consomê enlatado, e os garçons desocupados observavam. Depois do jantar apareceram na sala de estar dois casais jovens; um 
deles trazia um bebê numa cesta, e o outro, um menino pequeno. Uma das mães, com calça xadrez, corria com o filhinho; a outra balançava a cesta do bebê com o pé e lia um romance policial.

Essa vida familiar pacífica continuou, sem a presença dos pais, por toda a manhã seguinte. Por volta de meio-dia, quando eu estava esperando a chegada de meus companheiros, vários carros surgiram, vindos da direção do aeroporto, e ao menos quarenta pessoas muito bem vestidas desceram, fazendo muito barulho, o lance de escada até o lobby subterrâneo. Eles tinham vindo de São Paulo num voo especial, para um banquete e baile que o presidente Kubitschek ofereceria a eles no hotel, naquela noite. A sala de estar quase deserta, estranhamente doméstica, de repente fervilhava com mulheres portando joias e vestidos saco e com homens de ternos risca-de-giz. Festas como essa, disseram, aconteciam quase todo fim de semana; numa versão "era-do-jato" do velho costume hospitaleiro de "mostrar a casa para as visitas", comum no Brasil, Kubitschek convida grupos do Rio de Janeiro, de São Paulo, Porto Alegre e outras cidades. Uma vez, toda uma escola de meninas chegou num voo especial, para ver as coisas a convite do presidente. As histórias relacionadas a essas festas de fim de semana, é claro, apenas aumentam a indignação dos que se opõem a Brasília no aspecto econômico - além das despesas com entretenimento, dizem eles, muito mais gasolina vem sendo usada, somando-se aos milhares de litros queimados pelos caminhões e aviões que trazem os materiais de construção.

Cinco ou dez minutos depois os Huxleys e seu grupo chegaram: muito quietos, carregavam livros e câmeras, e mostravam um pouco de cansaço, mas pareciam alertas e interessados, em comparação com o grupo frívolo que ainda zunia em torno dos camareiros. Laura Huxley ${ }^{21}$ e Maya Osser, ${ }^{22}$ a arquiteta polonesa-brasileira, são velhas amigas minhas. Alguns do grupo eu já conhecia; dos outros, tinha ouvido falar.

Huxley é alto, pálido e magro, é claro, mas sem dúvida parece ser ainda mais alto, pálido e magro no Brasil, onde a maioria dos homens, ao menos para os padrões anglosaxônicos, é baixa e morena. Além disso, enquanto os brasileiros ainda consideravam a estação como "inverno" e, apesar da temperatura, estavam usando ternos e gravatas pretos,

\footnotetext{
${ }^{21}$ Nascida em Turim (Itália), a violinista, escritora e cineasta Laura Archera (1911-2007) havia se casado com Aldous Huxley em 1956.

${ }^{22}$ Maria Laura [Maya] Osser (Varsóvia, 1922) formou-se em arquitetura na Universidade do Brasil e trabalhou no escritório do arquiteto Henrique Mindlin, tendo sido correspondente, no Brasil, da revista Architecture D’Aujourd'hui (Falbel, s.d.). Depois, transferiu-se para Quebec, no Canadá (McClatchy, 1994).
} 
Huxley sempre usava ternos em tons de bege ou cinza-claro, ou jaqueta esportiva branca, com uma echarpe longa demais, de seda clara, estampada com cavaleiros persas. Seu cabelo longo, penteado para trás, é de um marrom-acinzentado uniforme; suas feições são grandes, mas bem desenhadas; ele tem belos dentes. Laura Huxley é uns vinte anos mais nova que o marido, pequena, alegre e loira; sua cabeça é grande e os olhos são enormes, verde-acinzentados e afastados, num notável estilo Campigli ${ }^{23}$ de belos rostos italianos. Ela é fina, agradável e animada, em francês, italiano ou inglês, conforme a necessidade. Compartilha o interesse apaixonado de Huxley por remédios, mescalina e propaganda subliminar, mas num nível mais pessoal e prático; de fato, ela adora curar as pessoas e às vezes distribuiu suas várias pílulas especiais para alguns membros do grupo. Sobre Huxley, é difícil dizer quanto ele está vendo e, uma vez que costuma falar muito pouco, o que está pensando. Por meio de prolongada autodisciplina, um desapego original britânico parece ter sido recoberto por um desapego oriental, ou apenas místico. Existe um leve desvio no seu olho defeituoso, e essa característica, que eu sempre achei estranha e atraente, no caso de Huxley vem se somar ao seu olhar velado e sonhador. Quando examina alguma coisa de perto, uma fotografia ou um quadro, ele às vezes usa uma pequena lupa com armação de tartaruga, ou, para objetos distantes, um telescópio em miniatura, e é comum sentar-se e descansar seu olho bom cobrindo-o com a mão. Ele é paciente num grau infinito, nunca parece cansado (quando alguém se mostrou apreensivo por causa disso, sua mulher nos assegurou que ele nunca se cansa), e, sorrindo com doçura, às vezes mostra explosões moderadas de interesse. Mas ele dava a impressão de estar, no fundo, absorvido em meditação, muito longe das cenas talvez frívolas que o brasileiro do Ministério de Relações Exteriores nos mostrava, sobre os esforços do ser humano, e nós todas, em graus diferentes que variavam de acordo com nossos temperamentos, nos comportávamos com ele um pouco como anfitriãs nervosas.

Depois do almoço e de duas horas de descanso fomos levados num breve passeio pelos principais pontos de Brasília, começando pelo Palácio da Alvorada. Kubitschek, enquanto isso, havia chegado para a festa em seu Viscount particular. Ele enviou o velho Lincoln conversível que usa, em Brasília, para os convidados de honra. Os Callados foram com eles; o resto do nosso grupo subiu no microônibus creme, e os seguimos de perto. Em torno do Palácio existe uma cerca de arame farpado e, junto ao portão, uma guarita onde dois soldados com capacetes prateados carregam fuzis debaixo do braço. $\mathrm{O}$ carro presidencial passou pelo portão aberto, mas as sentinelas, que não haviam sido avisadas sobre o outro veículo,

\footnotetext{
${ }^{23}$ Massimo Campigli (1895-1971), pintor italiano, participou da $1^{\text {a }}$ Bienal de São Paulo. Rostos amplos e redondos são característicos de seus quadros.
} 
recusaram-se a permitir que entrássemos e fecharam o portão na cara do ônibus. O motorista tentou explicar, mas o jovem soldado dizia "Não, não!" de modo firme e, depois, irritado, abraçando sua arma. O jovem inglês saltou do ônibus e exclamou: "This is outrageous!" "Isso é ridículo!" - na maneira tradicional inglesa. Então alguém voltou ao hotel, pegou o passe, ou ao menos a permissão para que entrássemos, e assim fomos admitidos, para nos reunirmos aos outros.

O Palácio da Alvorada é uma caixa de vidro grande, retangular e esverdeada (por causa do Ray-Ban), emoldurada em toda a extensão por colunas que parecem mergulhar no chão, esbranquiçadas, dez no lado de trás, numa série contínua, e oito no lado da frente, abrindo espaço para a entrada. Do lado de fora é sem dúvida um dos mais belos edifícios projetados por Oscar Niemeyer. As colunas, em particular, são um triunfo arquitetônico: tratase, afinal, da invenção de uma nova “ordem”. Se alguém imaginar uma sequência de grandes pipas brancas equilibradas de cabeça para baixo, depois agarradas por mãos gigantes e apertadas nos quatro lados até que seu desenho se atenue de maneira elegante, terá conseguido visualizar essas colunas. Elas são cobertas com placas de um mármore cristalino brasileiro, e suas bases, ou seja, as pontas das pipas que estão de cabeça para baixo, teoricamente se estreitam até zero; na realidade, a parte que está no nível do chão tem apenas 10 centímetros de largura. Em seu artigo na revista Módulo, Niemeyer diz que por meio dessas dimensões delicadas ele espera ter dado ao Palácio "leveza e dignidade - como se pousasse no solo, suavemente". E nisso ele teve pleno sucesso. Mesmo que a atmosfera extraterrestre de toda Brasília agora venha em sua ajuda - os soldados inconvenientes, o hotel estranho e canhestro, as cabanas e palmeiras a esmo, tudo pode ter "apenas pousado", também -, o efeito obtido no Palácio é original e aceitável de imediato como uma obra-prima de leveza e graça.

Essas colunas fascinaram a todos nós; foram acariciadas, fotografadas e discutidas por algum tempo, e Huxley e outros até desceram das longas varandas para vê-las de baixo. (Bem depressa elas se transformaram num símbolo de Brasília. Aparecem a toda hora em jornais e revistas, assim como nas bandeirinhas de seda, no papel de carta do hotel e nas sacolas pretas de zíper, em imitação de couro, que os hóspedes receberam como brinde.)

De cada lado da entrada existem espelhos d'água quadrados do mesmo mármore das colunas; um deles contém a estátua em bronze de duas figuras femininas vazadas, do escultor brasileiro Ceschiatti, ${ }^{24}$ o outro uma laje fina, como uma placa indicativa de direção,

\footnotetext{
${ }^{24}$ Grafado Ceschiattil, no texto publicado. O escultor Alfredo Ceschiatti (1918-1989) consolidou sua fama ao criar esculturas para os prédios projetados por Niemeyer, em longa parceria iniciada em Belo Horizonte, sua cidade natal, com um baixo-relevo para a igreja da Pampulha. Em Brasília, criou, além das Banhistas do
} 
ostentando uma inscrição em bronze. Também em frente ao Palácio vimos uma árvore de magnólia, de quase um metro de altura, que havia sido plantada pelo secretário Dulles ${ }^{25}$ alguns dias antes. (Cerca de uma semana depois o presidente Gronchi plantaria um cipreste italiano em Brasília. ${ }^{26}$ Havia planos para o plantio de palmeiras imperiais agrupadas junto ao Palácio, mas depois a variedade foi substituída pelo buriti regional, não tão alto nem tão elegante, mesmo assim uma árvore de boa aparência.) A varanda ou galeria do Palácio se estende além dele no lado esquerdo, depois se enrosca em si mesma e cresce numa pequena e exuberante capela em formato de cobra - uma espécie de aceno ou gesto de conclusão etéreo, latino, para a dança estática das colunas reunidas. Ao menos essa é a ideia; a capela chocou a maioria de nós por estar fora de escala, talvez uma sombra pequena demais para as colunas. Sua fachada em forma de caracol é encimada por uma esbelta cruz de cobre que parece perfeita, mas a pequena janela cortada no mármore abaixo dela, um vão quadrado aberto para o espaço, parece um pouco teatral, embora relembre, sem dúvida, as pequenas janelas das igrejas das primeiras missões no Brasil.

Assim que entrei no Palácio, sinto dizer, o efeito de frescor e graça tênue desapareceu. A decoração foi feita por Niemeyer e sua filha; as cores são quase sempre berrantes e a mobília parece escassa e mal arranjada - mas é claro que vai sofrer muitos acréscimos e substituições. Caminhamos sobre carpetes vermelhos e quentes, extra-espessos ("Nylon foam?" - "Espuma de Nylon"? - alguém perguntou à secretária que nos estava guiando), que repousam entre paredes de espelhos e placas de ouro resplandecente. Uma rampa sem corrimão, com carpete vermelho (soubemos que o secretário Dulles quase caiu aí) sobe à direita, até o Salão Nobre. ${ }^{27}$ Aqui existem um piano de cauda, alguns grupos de sofás e cadeiras estofadas, de couro e metal, algumas das quais, num primeiro olhar, lembraram a cadeira Barcelona, de Mies van der Rohe, mas que, descobrimos ao sentar, são uma cópia menor e não muito confortável.

Talvez possamos dizer que o Brasil, assim como a Itália, a Espanha ou Portugal, jamais partilhou de nossas ideias setentrionais sobre conforto em casa. Até há pouco todas as camas eram muito duras, às vezes feitas de couro ou palha, porque camas duras são mais frescas num clima quente; os pisos eram de pedra ou cerâmica ou tábuas de jacarandá

Palácio da Alvorada, a Justiça para o Supremo Tribunal Federal e os Anjos e Evangelistas para a catedral. Também lecionou escultura e desenho na Universidade de Brasília (1963-1965).

${ }^{25}$ O secretário de Estado John Foster Dulles (1888-1959), uma das figuras mais importantes no cenário norteamericano durante e após a Segunda Guerra Mundial.

${ }^{26}$ Giovanni Gronchi (1887-1978), presidente da Itália (1955-1962), visitou a cidade em setembro de 1958, quando afirmou: "Brasília é uma obra digna dos tempos romanos".

${ }^{27}$ Em português. 
simples; e cadeiras e sofás, quando copiados de modelos estrangeiros, quase sempre usavam palha trançada em vez de estofamento. As grossas paredes, os tetos altíssimos e as pequenas janelas com venezianas dos tempos coloniais eram frescos e apropriados; o interior "moderno", com sua mobília leve e baixa, cores claras e grandes áreas de vidro, não foi bem adaptado (ainda) ao clima brasileiro.

É possível que tenhamos sido muito severos em nossas críticas enquanto passávamos de um cômodo para outro; penso que só Huxley deixou de comentar sobre o calor e a luz ofuscante. Ao longo de cada extremidade da caixa de vidro que é o Palácio existe uma longa sala, com cadeiras e uma grande mesa. Uma é a sala de jantar formal, a outra é a Sala de Despachos. Ambas têm cortinas apenas na lateral, ou seja, nas extremidades da caixa, e o sol vespertino penetra através da fachada de vidro do prédio; a madeira das mesas já estava trincando. As paredes internas são recobertas por grandes painéis quadrados de jacarandá vivamente estampado, a madeira mais bela do Brasil. Na parte superior e sombreada das paredes, o efeito é muito bonito, quase como casca de tartaruga, mas a parte inferior, castigada pelo sol, também parece ressequida e sem brilho. Transpirando e por vezes deixando cair uma gota de suor nas cadeiras mais próximas, perguntamos num tom seco à nossa guia sobre ar condicionado, mas ela respondeu que não era necessário.

Uma escada suspensa sai do Salão Nobre e também ela tem carpete espesso em vermelho vivo. No andar superior, os vestíbulos têm as paredes recobertas de delicado "paumarfim". ${ }^{28}$ Vimos apenas um quarto de dormir, parecido com qualquer quarto de hóspedes, com duas camas e forrado de chintz. O banheiro anexo era magnífico, com metais cromados e espesso mármore cinza, e tinha uma banheira quadrada de bordas inclinadas das pontas para o meio, como uma cama de casal. Sob as janelas do quarto de dormir que se abrem para a piscina, passa uma galeria sombreada, recoberta com placas polidas de um rico mármore verde, um belo material mas que não combina com a estrutura leve do prédio e com os painéis delicadíssimos logo ali, do lado de dentro.

Por enquanto as paredes do Palácio estão quase nuas; no térreo existem duas tapeçarias e alguns quadros pequenos de Emiliano ${ }^{29}$ Di Cavalcanti. Essa austeridade e a falta de ornamentação fizeram Huxley recordar um passeio muito diferente, pelo Palácio de Buckingham, onde cada polegada de espaço da parede está recoberta por quadros, e cada mesa está repleta de fotos que comemoram acontecimentos na vida da família real. O grupo se

\footnotetext{
${ }^{28}$ A autora inclui, entre aspas, a tradução literal, ivory wood, junto ao nome comum em inglês, satin wood.

${ }^{29}$ No texto publicado (tanto em 2006 como em 2008) consta Emilio. Em Brasília, o pintor carioca Emiliano Di Cavalcanti (1897-1976) também pintou as estações da via-sacra para a Catedral, a convite de Niemeyer.
} 
reuniu ao seu redor no quente vestíbulo do andar superior, enquanto ele falou durante algum tempo, de modo muito divertido, sobre a arrumação do quarto de dormir do rei George V.

Do lado de fora, operários estavam assentando azulejos em azul turquesa na piscina cavernosa enquanto três ou quatro soldados com seus fuzis os observavam atentos - por curiosidade ou tédio, ou quem sabe fossem essas as ordens recebidas. No meio da piscina existe uma imitação de ilha ou rocha, alta e recortada, sobre a qual se pretende plantar um jardim - num ângulo agudo. Entretanto, depois eu soube que Niemeyer não gostou desse detalhe "moderno" mas curiosamente gótico, e deve alterá-lo.

À direita ficam os aposentos dos empregados, uma asa longa e mergulhada no solo, coberta por uma laje e com uma fileira de janelas estreitas logo acima do chão, conectada ao Palácio por uma passagem subterrânea. Esta parece ser uma solução inadequada, para não dizer deprimente, para o problema de onde alojar os quarenta e tantos funcionários do Palácio. A caixa de cristal não é para eles, mas existe espaço suficiente em qualquer direção e parece haver o dinheiro necessário para ao menos deixá-los viver sobre o solo, como seus patrões. Nos velhos tempos, os escravos viviam nos porões úmidos das casas cariocas; ainda hoje, os quartos e banheiros de empregados nos modernos e luxuosos apartamentos de Copacabana chocam a sensibilidade dos estrangeiros - mas em Brasília, às vezes chamada de "a cidade mais moderna do mundo", Niemeyer, justamente ele, não deveria ter achado necessário alojálos no subsolo.

Quando estávamos saindo do Palácio, percebi que seus aspectos que mais me desapontaram lembravam, em algum sentido, a residência que Niemeyer construiu para si em 1954, numa encosta próxima ao Rio, e quando voltei para casa reli o que Henry-Russell Hitchcock havia escrito sobre ela no seu livro Latin American Architecture. ${ }^{30}$ Confirmando minhas próprias suspeitas de amadora, encontrei isto: "O pavilhão contém apenas as principais áreas de estar e a cozinha. Todas as outras áreas de serviço estão escondidas sob o terraço, sem nenhuma relação com o pavilhão superior. É possível que apenas o projetista e sua família considerem essa residência confortável...". A casa de Niemeyer, é claro, não se parece de maneira alguma com o Palácio da Alvorada, em Brasília, e foi projetada "em resposta à paisagem" num conjunto de curvas entrelaçadas, "em harmonia entre o perfil audaciosamente arredondado dos morros e as curvas sinuosas de sua planta". A resposta de Niemeyer aos espaços vazios e planos de Brasília foi essa caixa transparente, sustentada de maneira graciosa, mas severa em sua essência; e em ambos os casos sua solução para os

\footnotetext{
${ }^{30}$ Henry-Russell Hitchcock (1903-1987), historiador da arquitetura norte-americano, havia publicado em 1955 o livro Modern Architecture in Latin America since 1945, em edição do Museu de Arte Moderna de Nova York.
} 
problemas práticos parece ter sido a mesma: colocá-los sob a terra, como uma dona de casa preguiçosa que empurra a tralha da casa para longe da vista, sob uma enganadora cama bem arrumada.

A sudeste do Palácio, um pequeno triângulo branco ao longe é a "Ermida de São João Bosco", cópia fiel em mármore branco de uma tenda indígena - indígena norte-americana, ou seja, com a porta triangular -, mas com a cruz no alto em lugar dos paus de sustentação cruzados. Um dos livretos sobre Brasília explica a presença dessa capela surpreendente:

No livro Memórias biográficas, v. XVI páginas 385 e 395, encontra-se a profecia de São João Bosco. Consta que Dom Bosco, no dia 30 de agosto de 1883, teve uma visão durante um sonho. Citaremos a parte relacionada a Brasília:

"Entre os paralelos 15 e 20, num lugar onde se formou um lago, nascerá uma grande civilização e isso acontecerá na terceira geração. Aqui será a terra prometida".

Estamos exatamente na terceira geração. A grande civilização que se constrói (e que é Brasília) localiza-se entre os paralelos 15 e 20 . O lago será formado pelos riachos Torto e Gama. Assim o sonho profético de Dom Bosco se tornará realidade.

Laura Huxley estava familiarizada com a vida desse santo italiano, o fundador da ordem dos Salesianos (muito ativa no Brasil), e ansiosa para caminhar até a "ermida". No entanto, constava que a capela estava situada a cerca de um quilômetro e meio do Palácio, e naquele momento a luz começava a mudar para um rosa uniforme e claro, o início do repentino pôr-do-sol subtropical. Enquanto saíamos, um grupo de pequenos soldados, membros da Guarda Especial ${ }^{31}$ de Brasília, marchava solene na troca da guarda, com suas botas pesadas; em uniformes verdes amarrotados, eles sempre se parecem com vagens murchas.

$\mathrm{Na}$ sala de estar do hotel, antes de sairmos, Maya, a garota polonesa, havia se encontrado por acaso com outra ex-refugiada polonesa, a condessa Tarnowska, que nos convidou a todos para ir ao Hotel Santos Dumont, na Cidade Livre, para um drinque antes do jantar. Alguns anos antes a condessa Tarnowska havia inaugurado um cinema em Anápolis, e logo após o início da construção de Brasília abriu outro na Cidade Livre. Havia, na época,

\footnotetext{
${ }^{31}$ Em português.
} 
trezentas pessoas na vila, e seu cinema funcionava num galpão de madeira; agora ela tem o maior prédio do lugar, com estrutura de ferro, onde cabem trezentos espectadores sentados, e já existe um concorrente. Ela é jovem e bonita; em excelente inglês, comentou num tom displicente: “Adoramos este lugar! É claro que temos muitos incêndios. O banco vizinho pegou fogo ontem. Nós ficamos com um pouco de medo por causa do cinema, mas tudo acabou dando certo. Pena que vocês perderam essa agitação!”. Com calças jeans, chapéu de palha bem preso com uma faixa branca que dava a volta em seu pescoço, ela e sua bela filha de olhos negros, também com jeans e blusa cáqui, pareciam duas heroínas de um velho filme de faroeste, um filme em sépia, mesmo porque ambas estavam cobertas com a poeira usual.

Fomos até a cidade, à cabeça do pássaro, onde será a Praça dos Três Poderes. ${ }^{32}$ Por enquanto ela é uma cena confusa e barulhenta de movimentação de terra, caminhões e escavadeiras, com trabalho dia e noite. Alguém atrás de mim tentava explicar o layout da Esplanada. "Veja, é um triângulo retângulo", ele dizia. O inglês tentava encontrar o terreno comprado por seu país para a futura embaixada, e quando lhe apontaram uma área indefinida na terra miserável, infestada por cupins, ele disse "Oh! Estou tão desapontado!", de um jeito tão abatido que todos riram.

Passamos pelas "superquadras" de apartamentos, que estavam sendo construídas pelos institutos; ${ }^{33}$ é difícil dizer algo sobre esses esqueletos de aço e cimento, exceto que eles eram muito altos e se distribuíam muito perto uns dos outros. Mais uma vez, com espaço infinito em todas as direções, é difícil compreender por que eles deveriam ficar próximos, com jardins e passagens não muito maiores que os do Rio - mas nestes isso se explica porque lá existe muito pouco espaço livre, e os terrenos são mais caros que em Nova York.

As ruas de Brasília foram planejadas para que não existam semáforos, graças a viadutos e passagens subterrâneas. Como a velha capital é famosa pela velocidade terrível de seu trânsito, pelo desrespeito aos semáforos, por motoristas de ônibus loucos e altos índices de acidentes, essa inovação é bem-vinda na opinião de todos.

Estava escurecendo quando chegamos à Cidade Livre, mas não escuro demais para vêla: quase aquela antiga e familiar vila da fronteira da Metro-Goldwyn-Mayer, mas real, e

\footnotetext{
${ }^{32}$ Mais uma vez, a autora chama a praça de "Esplanade of the Three Powers", confundindo seu nome com o da Esplanada dos Ministérios.

${ }^{33}$ Em português.
} 
muito expandida. As ruas largas e sujas não têm calçadas - "Imagine como fica quando chove!", dissemos uns aos outros -, e as casas de madeira, com telhados pontudos e, às vezes, frontões, são construídas lado a lado, de todas as formas, tamanhos e cores. Passamos pelo cinema de ferro e por um grande galpão vermelho onde estava escrito IGREJA PRESBITERIANA em letras brancas, sobre a porta. O trânsito é sobretudo de caminhões, de todos os tipos e idades, e jipes, jipes, jipes, americanos, ingleses e brasileiros, com poucos carros velhos e até mesmo alguns homens a cavalo, todos levantando espessas nuvens de poeira.

O Hotel Santos Dumont é um prédio baixo, que não se distingue dos demais exceto pela placa e por algumas cadeiras de varanda, em metal, dispostas numa estreita faixa de cimento no nível da rua. Uma vez dentro do hotel, no entanto, parecíamos ter sido transportados para uma pequena e nova boîte ou café em Greenwich Village - nova porque todas as cores eram brilhantes e frescas, quase as mesmas cores frescas que eu vi por toda Brasília. Era uma sala retangular com cerca de dez metros de comprimento, um bar de bambu envernizado e dois garotos com jaquetas amarrotadas; as toalhas de mesa eram em tom escarlate, havia cadeiras pretas "de farmácia", e enfeites brilhantes em verde e amarelo em volta das janelas. Estavam tocando música; olhei em volta e encontrei discos de Villa-Lobos, Stravinsky e Bartók sobre a vitrola. Tudo isso havia sido transportado por mil quilômetros ou mais, de caminhão. Modesto, o Santos Dumont estava fazendo o possível para ser chique e acolhedor, e eu acho que todos nós torcemos para que ele consiga.

Mesas foram reunidas, e a condessa Tarnowska, agora elegante depois de um banho, ${ }^{34}$ num vestido estampado indiano e com uma bandana, pediu whiskey sours. Mas o nosso grupo, pequeno e sóbrio, talvez um pouquinho intimidado por Huxley (ele havia falado uma ou duas vezes a respeito da bebida e do fumo desnecessários que existem nos Estados Unidos), quase todo, recusou álcool e bebeu suco de laranja, misteriosamente disponível. A condessa Tarnowska, sua filha e um cavalheiro polonês pesado e loiro que também estava hospedado no hotel acabavam de voltar de uma caçada de três semanas, mais para o oeste, e ela começou a nos contar. Eles tinham tido má sorte; buscavam uma onça, mas não encontraram nenhuma, e em seu lugar mataram uma grande quantidade do que chamavam, com olhos faiscantes, de "veados". ${ }^{35}$ Havia sido a primeira caçada de sua filha, e a mãe anunciou com orgulho: "Ela matou 12 jacarés". Da caçada a condessa Tarnowska passou a falar sobre as tendências homicidas que ela havia observado no Brasil em geral e em Brasília, em particular. "Eles gostam de matar", ela assegurou a Huxley, com bela vivacidade, e contou uma anedota acerca

\footnotetext{
${ }^{34}$ A autora faz um jogo de palavras com "lavada e polida": "now clean and polished...".

${ }^{35}$ No original, "stags".
} 
dos recentes crimes sem motivo. Na minha ponta da mesa, os Huxleys, Maya, o inglês e eu éramos todos contrários ao uso de armas, dirigidas a homens ou a animais (e a minha experiência com brasileiros é de que eles são o povo menos sanguinário do mundo), e a conversa começou a tornar-se um tanto monótona. Huxley, que não tinha falado quase nada até então, encobriu os olhos com a mão e pareceu perder-se em meditação sobre seu misterioso suco de laranja.

Ela então contou uma história sobre seu cinema que ilustrou o caráter nacional um pouco melhor. Os quarenta e cinco mil habitantes da Cidade Livre vieram em sua maioria do interior, o "norte" ou o "sul" - e é difícil imaginar o peso de desconhecimento, ou de pouco conhecimento, que essas indicações comuns de direção ainda podem carregar no Brasil pessoas simples, antiquadas, de origem rural, chamadas de candangos. ${ }^{36} \mathrm{Um}$ dos filmes exibidos pouco tempo antes havia sido E Deus criou a mulher. O público, homens em grande maioria, assistiu em silêncio, pensando sabe-se lá em quê, até que chegou a cena de nudez. Assim que Brigitte Bardot abriu um botão, o filme de repente parou e as luzes se acenderam. O homem da projeção, que já vira a cena, é claro, disse: "Por favor, todas as senhoras e senhoritas ${ }^{37}$ queiram sair e esperar do lado de fora". E elas saíram, sem demora, e ficaram do lado de fora na rua poeirenta, uma pequena multidão. As luzes foram apagadas e os homens assistiram à cena de amor que se seguiu. Mais uma vez interrompeu-se o filme, as luzes foram acesas, e as mulheres foram convidadas a entrar para ver o resto do espetáculo "para público misto".

Perguntamos qual era o espetáculo aquela noite, com a vaga ideia de ir ver. Era um show itinerante de esquetes, música e dança, e a condessa Tarnowska, que tinha visto um ensaio, não o recomendou.

Saímos do hotel e caminhamos pela rua principal. Quase todos os edifícios tinham seu gerador de eletricidade (usando mais gasolina preciosa a cada minuto), de modo que existe uma música de fundo, feita de ruídos pulsantes de motor, e as luzes variam de um prédio para o outro, amarelas, azuladas ou cinzentas, às vezes o amarelo escuro dos lampiões de querosene ou o clarão azul e branco das lanternas a gasolina. Ficamos em volta observando as barbearias e as pharmácias (ambas com grande movimento), mercearias, armazéns, sapatarias e bancas de engraxate - botas, em geral, uma vez que a população masculina de Brasília usa botas altas, quase todas com uma parte sanfonada acima do tornozelo, que imita rugas.

\footnotetext{
${ }^{36}$ No original, condangos. Interessante notar que no livro de John dos Passos, publicado em 1963, a palavra também vem sempre grafada de maneira incorreta, mas como candongos.

${ }^{37}$ Em português.
} 
Pensões, dormitórios e restaurantes; bancos e agências das companhias de aviação davam um falso ar de cidade, graças a painéis de madeira e uma palmeira em vaso. Algumas lojas de móveis tinham modelos novos, mas em sua maioria estavam abarrotadas com móveis de segunda mão e baixa qualidade, ${ }^{38}$ e sempre havia os guarda-roupas típicos dos países onde não existe quarto de vestir. No Açougue do Bom Jesus, ${ }^{39}$ a carne suspensa era de um tom violeta iridescente sob a luz de lâmpadas a gasolina sibilantes. (E de onde ela veio?) E pequenas lojas com portas de vidro, iguais a outras lojas desse tipo por todo o Brasil: camisas ordinárias e blusas e roupa de baixo em rosa e azul, bolsas e cintos de plástico, e, penduradas em frente, fileiras de guarda-chuvas, pretos para os homens e coloridíssimos para as mulheres - porque no Brasil todo mundo, rico ou pobre, com a possível exceção dos índios que estávamos indo visitar, tem um guarda-chuva. E roupas para bebês, sapatinhos de tricô e babadores, e até vestidos de batismo, em pequenas pilhas resplandecentes como marshmallow, porque também não importa o grau de pobreza, os brasileiros gastam dinheiro na elegância de seus bebês. Uma canção popular, em inglês, soava em volume excessivo numa loja de rádios e vitrolas.

Enquanto andávamos, compramos maços de cigarros, caixas de fósforos e Salva Vidas, ${ }^{40}$ para ir ao encontro dos índios no dia seguinte. Antônio Callado, o mais experiente com os índios em nosso grupo, entrou numa loja repleta de botas, chapéus de feltro, facas e armas de fogo, e voltou com anzóis e linhas de nylon para pesca. O rádio do posto indígena para onde estávamos nos dirigindo havia quebrado um mês antes e não havia meio de avisar que estávamos chegando; portanto, ele também trouxe linguiça para o caso de o suprimento de comida por lá estar baixo.

Boa parte do nosso grupo se encontrou num bar pequeno, de esquina, pintado de verde-mar escuro. Dentro dele, atraente como uma sereia em sua caverna, havia uma jovem rechonchuda, mal-humorada e bonita, com cabelo em tranças e um suéter muito decotado. Sobre o balcão, duas crianças pequenas e de faces rosadas, um menino e uma menina, sem dúvida seus filhos, encaravam o único freguês, um homem que bebia cerveja. Laura Huxley decidiu tirar uma fotografia das crianças com sua câmera Polaroid Land, usando os faróis do ônibus Volkswagen para iluminar, e elas posaram, tímidas e piscando. De vez em quando o marido da garota passava a cabeça através de uma cortina florida no fundo do bar e olhava

\footnotetext{
${ }^{38}$ No original, "second-hand Brasilian Grand Rapids", referência à cidade de Michigan conhecida como "a cidade dos móveis".

39 The Butcher Shop of the Good Jesus.

${ }^{40}$ Também em inglês: Life Savers. Espiral inseticida.
} 
para nós. Os pais da garota eram imigrantes libaneses; ela falava um pouco de francês. Perguntamos se gostava de morar em Brasília, ou na Cidade Livre, e ela respondeu sem hesitar: "Je le déteste! - Mas meu marido gosta e tudo bem”. Eram de São Paulo e ela sentia saudades daquela cidade; era de uma classe urbana nova e sofisticada, sem os modos antiquados e formais dos candangos. ${ }^{41}$ Quando saímos, ela ficou em pé de um jeito lânguido, segurando a foto que secava, e quase se esqueceu de dizer "Obrigado". Brigitte Bardot não $a$ teria surpreendido.

Voltamos ao hotel, 20 e poucos quilômetros (e as distâncias parecem ainda maiores porque os pontos de referência são raros), para um jantar que terminou depois das onze horas. A notícia de que Huxley estava no hotel havia se espalhado entre os hóspedes vindos de São Paulo; antes do jantar o homem mais alto do Itamarati e uma das mulheres do nosso grupo haviam sido confundidos com Huxley e sua esposa, e alguém pediu que ambos dessem autógrafos. Quando o engano se desfez, Huxley e Laura assinaram seus nomes nos cardápios do jantar (Bife Stroganoff). Huxley não se importou por não ter sido reconhecido; durante o jantar ele nos falou de outra experiência recente de confusão de identidade. Antes de viajar ao Brasil ele havia ido ao dentista em Beverly Hills, e quando saiu do elevador uma mulher entrava. Ela o olhou, voltou-se surpresa e perguntou: "Perdão, mas o senhor não é o marido de Theda Bara?".

Depois da meia-noite, sem poder dormir por causa das músicas dançantes no restaurante do hotel, onde prosseguia a festa do presidente, fiquei na cama estudando o aquário verde-azul e iluminado do Palácio da Alvorada, meio apagado pela distância. Concluí: é uma pena que as colunas em forma de pipa não sejam iluminadas à noite. Do jeito como estão, seu efeito se perde depois do anoitecer porque elas permanecem apenas como sombras disformes na caixa de vidro iluminada. Mas, sem dúvida, no futuro elas serão iluminadas.

O dia seguinte, domingo, foi reservado aos índios. Às seis e meia nos encontramos do lado de fora do hotel no úmido e frio amanhecer; o ônibus Volkswagen deveria estar lá, mas, com a confusão talvez incidental relacionada à fundação de uma nova cidade, ele nos deixou esperando por quase uma hora, e para nos aquecermos demos rápidas caminhadas pelo

\footnotetext{
${ }^{41}$ Mais uma vez, publicado condangos.
} 
estacionamento cimentado. As pernas de cegonha de Huxley caminhavam mais rápido que as de qualquer outro de nós, sem nenhum esforço, e ao ver aqueles passos gigantescos, todo o nosso pequeno grupo friorento, carregado com livros, cestas e chapéus, murmurou em português que ele parecia “jovem para sua idade". Éramos um grupo de intelectuais. A caminho de vermos o povo mais primitivo do mundo, excetuando-se os pigmeus africanos, tínhamos conosco: The eclipse of God [O eclipse de Deus], de Martin Buber, The doors of perception [As portas da percepção] e Heaven and hell [Céu e inferno], ambos de Huxley, em português, e Grey eminence [Eminência parda], este em inglês. Também para preencher o tempo durante a viagem havia um livro grosso em francês intitulado apenas Plato [Platão] e uma edição de bolso de The Mill on the Floss [O moinho do rio Floss]. ${ }^{42}$

Afinal o ônibus chegou e refizemos o longo caminho vermelho até o aeroporto. Alguns pássaros cantavam, mas não muitos, e os cupins trabalhavam duro em seus ninhos feios e vermelhos. Plumas de avestruz vermelhas de poeira levantavam-se às vezes, caminhões passavam com suas cargas de cimento, vigas ou terra, e o som importuno de escavadeiras vinha da direção da Praça dos Três Poderes. ${ }^{43}$

Às 8 decolamos num DC-3 da Força Aérea Brasileira. Era um avião agradável, se é que se pode usar esse termo para um avião novo, sem nenhum dos estofamentos e cortinas habituais, mas com acentos de pelúcia azul, cujos encostos podiam ser reclinados. Nele cabiam 24 passageiros, e embora vários homens desconhecidos tivessem se reunido ao grupo ainda havia tantos assentos vazios que podíamos baixar encostos alternados e colocar os pés em cima, assim como fazíamos nos trens, quando crianças.

O continente passou por baixo de nós no sentido oeste, um mapa em baixo-relevo, cor parda e tamanho natural. As árvores crescem ao longo dos rios; os córregos menores são verde-oliva opaco. Às vezes, as terras mais altas transformam-se em rochas esmigalhadas, parecidas com fortalezas, talvez as formações - Callado nos disse - que deram origem à lenda da cidade perdida que o coronel Fawcett buscou; ${ }^{44}$ estávamos voando sobre o território de Fawcett. Depois de algum tempo avistamos um grande rio azul, o Araguaia, correndo para o norte, como todos os rios, para encontrar o Amazonas, depois de mil e quinhentos quilômetros. Callado, vestido hoje com tecido de algodão cáqui, veio pelo corredor dando a cada um de nós uma pílula anti-malária tirada de uma enorme garrafa: "Sobretudo pelo efeito

\footnotetext{
${ }^{42}$ Romance de George Eliot.

${ }^{43}$ Mais uma vez, nomeada "Esplanade of the Three Powers".

${ }^{44}$ O coronel Percy Harrison Fawcett (1867-1925), arqueólogo e explorador britânico, desapareceu na selva do Mato Grosso quando partiu, acompanhado do filho Jack e de um amigo, em busca de uma cidade perdida na região da Serra do Roncador.
} 
psicológico", ele disse, "embora possamos encontrar alguns mosquitos da malária". Enquanto não ficou muito quente, os homens da Força Aérea continuaram vestindo seus elegantes casacos de lã azul-cinzenta com quepes combinando. Eles eram simpáticos e hospitaleiros, e começaram a nos alimentar no mesmo instante: sanduíches, depois balas de goma e gelatina, depois copinhos de papel com café preto e doce, no mínimo três vezes, mas isso é de rigueur em qualquer avião brasileiro, às vezes até mesmo nos ônibus. ${ }^{45}$ Depois, o avião foi inundado pelo perfume de laranjas que um aviador prestativo descascou para nós, de uma bandeja repleta.

Mergulhamos em nossos vários livros e os trocamos pelo corredor; mudamos de lugar para conversar com todos os outros, como numa dança. A jovem intérprete comeu uma grande barra de chocolate e dedicou-se à leitura de uma revista chamada Lady (que se pronuncia "Lah-dee"). ${ }^{46}$ Ela a estendeu para mostrar Huxley. Havia uma fotografia dele de página inteira numa recente entrevista coletiva no Rio, protegendo os olhos e parecendo muito abatido. Sua mulher ficou indignada com sua expressão: "Oh, por que eles sempre o fotografam desse jeito? Ele não é assim, de jeito nenhum!". Eu me incomodei mais por causa da enorme legenda: O VELHO HUXLEY DIZ - alguma coisa a respeito da paz mundial. Embora Huxley não saiba português, conhece espanhol, e é possível que tenha reconhecido a palavra similar para old. Discuti comigo mesma se deveria tentar explicar ou não, e decidi morder a língua. Nesse caso eu senti que a palavra foi usada com afeto, que "velho" constava ali apenas no sentido de que Huxley já é famoso há vários anos. (Por duas semanas Huxley tivera uma boa impressão do Rio; as prateleiras estavam repletas de seus livros, em cinco línguas, e ele só recebeu aplauso e consideração irrestritos da imprensa.)

Um dos homens que agora faziam parte do grupo era um sujeito exuberante, que não podia ficar parado e desfilava sem parar pelo corredor com um chapéu de couro, de gaúcho, preso sob o queixo. Outro era velho e magro, com grandes orelhas e olhos tristes. Este, eu descobri, era o homem que deveria ter ido ao aeroporto encontrar-se comigo, dois dias antes; naquele exato momento, ele confessou, deveria estar recebendo um grupo vindo do Rio, mas num impulso preferiu vir conosco. Ele carregava uma prancheta com várias folhas de papel, e "Aldous Huxley" estava impresso em maiúsculas na primeira delas. Mostrou-a a Huxley e

\footnotetext{
45 Assim que chegou ao Brasil, Bishop comentou em carta sobre o cafezinho servido nos ônibus que ligavam Petrópolis ao Rio: "tem uma espécie de kitchenette ao lado do motorista, e enquanto o ônibus desce a serra um garoto de jaleco branco fica enchendo umas xícaras pequenas e servindo-as aos passageiros, junto com caixinhas de biscoito onde está escrito: 'Oferta'” (Bishop, 1995, p.237).

${ }^{46}$ Em suas cartas, a autora ironiza a pronúncia brasileira, por exemplo, de jeep (jeepy), Time (Time-y) e hi-fi, "que aqui se pronuncia ee-fee" (Bishop, 1995, p.378). Tanto em hi-fi quanto em Lady, o comentário parece incorreto: é possível que ela tenha levado a sério a pronúncia irônica e forçada de algum de seus amigos.
} 
perguntou se escreveria uma mensagem nela - suas impressões sobre Brasília, qualquer coisa afinal - para uma coleção dessas mensagens que ele estava reunindo, com todas as celebridades que por ali passavam, a ser colocada num futuro museu da cidade. Huxley pegou sua caneta, lançou-se ao trabalho e, depois de rasgar duas ou três folhas de papel, produziu algumas frases sobre a interessante experiência de voar do passado (as vilas coloniais de Minas) para o futuro, a nova cidade de Brasília. Dois dias depois isso apareceu nos jornais do Rio como se fosse um telegrama enviado por Huxley ao presidente Kubitschek, dando uma estranha impressão do que seria o estilo telegráfico de Huxley.

Agora estávamos voando mais para o norte que para o oeste, e o cenário tinha se alterado aos poucos. Voamos sobre o rio das Mortes, depois sobre o rio das Almas. Eram áreas do que Callado chamava de "florestas de couve-flor". Vistas de cima, árvores da floresta parecem couves-flores amontoadas, ou mais, brócolis, embora não tão compactas nem de um verde tão vívido como as da região amazônica. Afinal alguém exclamou: "Olha! Uma aldeia indígena!", e é verdade que lá, numa clareira junto a um riozinho lamacento, havia cinco telhados de folha de palmeira redondos e dois ou três barcos parecidos com bengalas, arrastados para a margem. Mais além ficava a pista de pouso, dois ou três centímetros de fita vermelha desbotada, caída na floresta. Esse era o posto de Xavantina, batizado assim por causa dos índios Xavante, ${ }^{47}$ em outras épocas guerreiros ferozes, os índios que nos são familiares pelas fotografias em que aparecem apoiando-se sobre uma das pernas, com os cabelos em longas mechas. No entanto, estávamos indo mais além, até os Uialapiti do Posto Capitão Vasconcelos, num pequeno afluente do rio Xingu.

Callado, que era o responsável por essa parte da excursão de Huxley, começou a ter um leve ataque dos nervos. Disse que não esperássemos demais dos índios que iríamos ver; afinal, eles estão num Posto, são um grupo misturado, às vezes até cinco tribos estarão visitando o lugar, e aqueles que vivem ali permanentemente são de certo modo “desinteressantes", disse ele, e não como aqueles que vivem isolados em suas próprias aldeias. Alguns deles às vezes usam uma camisa ou calças (mas o único motivo que compreendem para usar roupas é que elas servem para afastar os mosquitos), e um homem já havia sido levado ao Rio para ver o Carnaval.

Afinal uma outra pista de pouso apareceu, e outra clareira e outro riozinho, desta vez com água clara, e os telhados de folha de palmeira eram ovais. Circulamos sobre palmeiras

\footnotetext{
${ }^{47}$ A autora informa, entre parênteses, que " $x$ is pronounced $s h$ ".
} 
buriti e sobre um alto ipê ${ }^{48}$ todo florido, sem uma única folha - uma das árvores brasileiras mais adoráveis. Assim que pousamos, pudemos ver índios vindo das casas, correndo por uma estrada tosca desde a aldeia para nos encontrar, e quando saímos do avião cinco ou seis homens já estavam lá, e mulheres com bebês formavam a retaguarda. Estavam muito contentes por nos ver, com sorrisos radiantes, procurando com avidez por nossas mãos, esquerda ou direita, e apertando-as; dois ou três dos homens disseram "Bom dia, bom dia" em português. Outros continuavam chegando, correndo, apertando nossas mãos ou agitando-as de modo hesitante, sorrindo com expressões encantadoras, francas e agradáveis, mostrando dentes quadrados e bem espaçados.

Os Uialapiti são baixos, mas bem proporcionados, os homens quase rechonchudos, com músculos lisos, ombros largos e tórax grande e liso. Eles estavam nus, exceto pelos colares de sementes e pelos cintos de contas ou sementes em volta dos quadris; as mulheres usam um cache sexe simbólico de folha de palmeira dobrado na forma de um pequeno retângulo de cerca de três centímetros de comprimento, preso por uma delicada cordinha tecida da mesma palmeira. Essa vestimenta quase invisível é importante; às vezes elas param e mexem as costas para ajustar a cordinha. Seu cabelo é muito grosso mas surpreende, pois é delicado e lustroso; as mulheres usam cabelo longo, com franjas; os homens usam um corte do tipo tigela. Quase não têm pêlos no corpo; o pêlo ocasional é arrancado. A maioria dos homens tinha mechas de cabelo ou toda a parte superior da cabeça coberta com uma tinta vermelha, brilhante e pegajosa que eles fazem com a árvore de urucum, o único tingimento que possuem; alguns estavam polvilhados com urucum, orelhas, pescoço, peito, vermelho vivo. Sua pele é delicada e macia, de uma cor parda escura. Algumas das crianças, meninas, tinham duas linhas paralelas desenhadas do lado de fora das pernas, de alto a baixo, e uma menina pequena tinha a testa em vermelho brilhante, sugerindo uma dor de cabeça terrível. Tanto os homens como as mulheres carregam os bebês, e além dos colares de sementes muitos deles usam cordinhas de contas de vidro azul e branco. Um bebê, uma menininha de uns dez meses, não se encantou com nada além de seis cordões de grandes pérolas Woolworth. Eles são limpos e têm um odor adocicado (nadam várias vezes por dia) - mas as crianças tinham as faces enlameadas, imundas. Entretanto, isso não impedia que os homens da Força Aérea arrancassem os bebês (incluindo a que usava o colar de pérolas) dos braços dos pais e os levassem para longe. Havia uma agradável atmosfera de visita ao velho lar. Callado e os pilotos conheciam a maioria dos homens; alguns deles falavam um pouco de português, e

\footnotetext{
${ }^{48}$ Grafado îpé.
} 
uma conversa simples e repetitiva, logo iniciada, continuou sem cessar durante toda a nossa visita. Huxley foi apresentado como um grande capitão, ${ }^{49}$ e consentiu em ser apalpado com admiração.

O tempo estava seco e muito quente; atravessamos a clareira até um grande espaço muito pisado onde havia quatro casas. Uma grande leitoa preta com leitõezinhos fugiu correndo quando nos viu, e havia muitos cães macilentos. Mais índios continuavam chegando para nos conhecer e observar e pegar nossas mãos com as suas, firmes e quentes, e às vezes nos afagar discretamente para verificar se éramos homens ou mulheres, uma vez que as mulheres do grupo usavam calças. Todos os índios estavam nus, exceto um velho que usava uma camisa do Exército e duas jovens que usavam vestidos de algodão floridos em vermelho e branco. Uma dessas, de 14 ou 15 anos, estava no final da gravidez, e a outra, a mais velha, era anã ou corcunda, uma figura estranha, pequena e triste que vimos passar alvoroçada pela aldeia durante toda a nossa visita, como se ela trabalhasse mais que as outras, ou quisesse dar a impressão de que era tão ativa quanto qualquer outra.

De repente apareceu um homem branco de meia-idade, magro, com barba preta de uma semana no rosto pálido, usando calças e camisa, mas descalço. Ele era o homem encarregado do Posto Capitão Vasconcelos, Cláudio Villas Boas, ${ }^{50}$ um dos três irmãos que vêm trabalhando para o Serviço de Proteção ao Índio ${ }^{51}$ há vários anos. Por causa do rádio quebrado ele não sabia que estávamos vindo, até que ouviu o som do avião, mas não mostrou nenhum traço de surpresa até que seus olhos se iluminaram ao ver Huxley, que foi apresentado, com Laura, a ele. Em português, numa voz fraca, Villas Boas exclamou: “O Huxley, do Contraponto?", 52 e por um momento pareceu a ponto de desmaiar. Pegou a mão de Huxley e falou com ele em português, com seus olhos cheios de lágrimas. Nesse momento um outro homem branco vestido e descalço apareceu do nada, um homem alto, bonito, com cara de menino e uma barba preta e cerrada. Ele também exclamou, mas com a pronúncia de um inglês de classe alta: "Huxley! I certainly never expected this!" - "Huxley! Eu certamente nunca esperei por isso!". Era um historiador formado em Cambridge, que ficaria um mês nesse posto. Estava trabalhando numa tese sobre os efeitos do contato entre duas culturas

\footnotetext{
${ }^{49}$ Em português.

50 Os sertanistas Orlando (1914-2002), Cláudio (1916-1998) e Leonardo Villas Boas (1918-1961) foram os principais responsáveis pela criação do Parque Nacional do Xingu (1961), a primeira terra indígena homologada pelo governo federal.

51 O Serviço de Proteção ao Índio (SPI), fundado em 1910, seria transformado na Fundação Nacional do Índio (Funai) em 1967.

${ }^{52}$ Refere-se ao romance Counter Point (1928), traduzido para o português por Érico Veríssimo.
} 
diferentes, e também escrevendo um livro, "Ou talvez seja melhor escrevê-lo assim que eu o venda", ${ }^{53}$ disse ele.

Com Villas Boas nos guiando, todos nos reunimos no sombreado interior de uma das casas; esta se ligava a outra, menor, com paredes de meia altura e uma grande mesa, e uma terceira cabana anexa a ela servia como uma espécie de cozinha. Huxley foi até uma das redes e deitou-se (o que lhe fez muito bem); Villas Boas agachou-se junto a ele, ao modo indígena, e com duas ou três pessoas como intérpretes, começou a falar com Huxley numa voz rouca e agitada, como se estivesse querendo falar com ele havia anos. Nós nos reunimos em volta para escutar, e essa breve cena foi pouco espontânea, mas comovente: a grande cabana sombreada, o conjunto estranho de brancos ali reunidos e vestidos de maneira descombinada, o círculo de índios nus e sorridentes, e Huxley, balançando de leve para frente e para trás, com as longas pernas deslizando sobre o chão, passivo e atento. Villas Boas disse que tinha lido todos os seus livros já traduzidos para o português, o quanto tinham significado para ele, e passou a falar dos livros escritos pelo avô de Huxley, também. Depois falou sobre os seus anos no Serviço de Proteção ao Índio, sobre como é difícil ajudar os índios, uma batalha perdida contra a doença e a corrupção; como apesar do auxílio dos médicos do Exército ele vive com pavor das infecções trazidas de fora, caso do sarampo, por exemplo, que pode dizimar aldeias completas. Os índios não possuem terra; não existem reservas para onde eles possam se transferir caso as terras em que vivem sejam vendidas. Mesmo que isso não aconteça por um longo tempo, a terra está sujeita a especulação, e a fundação de Brasília aproximou essa possibilidade em mil quilômetros. Em toda a região do Xingu ele pensa existirem cerca de 3.500 índios, apenas.

Laura Huxley tinha passeado pelo lado de fora e estava abrindo um estúdio com sua câmera Polaroid; esses índios sabiam tudo a respeito de câmeras e ficaram muito contentes em posar, lado a lado, com os braços em torno do pescoço dos outros. Os que estavam do lado de dentro se apinharam contra nós, sem pedir de maneira ostensiva, mas ávidos pelos presentes que sabiam que devíamos ter, e, meio embaraçados, entregamos nossos miseráveis cigarros, fósforos e Salva Vidas. Uma mulher ficou me beliscando, perguntando de modo gentil: “Caramelo? Chocolate? Caramelo?”, ${ }^{54}$ e eu fiquei triste por não ter conhecido antes as suas preferências por doces. As redes foram sendo ocupadas; o homem com o livro intitulado Plato reclinou-se numa, um piloto ficou brincando com um bebê em outra, e o homem com chapéu de gaúcho ficou em outra, com outro bebê, que agora usava o chapéu. Eu

\footnotetext{
53 "Or I'd better be, since I've already sold it."

${ }^{54}$ Em português.
} 
me deitei numa rede, também, e olhei para o alto. Os altos telhados que nos davam sombra são muito bem feitos, de folhas de palmeiras dobradas sobre galhos horizontais, em camadas sobrepostas, e o grande domo é fixado em cima com uma armação de galhos não descascados. Pombos se empoleiravam ali, arrulhando, e um par de periquitos. Uma arara deslumbrante, azul e amarela, pousou na parede da cabana de jantar, observando-nos e falando em $\mathrm{Nu}$-aruak, talvez - o grupo linguístico ao qual os Uialapiti pertencem. Vários mutuns, um tipo de peru preto e lustroso, com partes de verde pálido em cada lado da cabeça pequena e elegante, e cuja crista se parece com esses pentes que têm bolinhas nas pontas dos dentes, passeavam em volta cacarejando sob nossas pernas. A penumbra, as vozes delicadas, as carícias e sorrisos e as redes balançando, tudo isso era tranquilo e nos fazia devanear, era simples e chão, e até mesmo nos trazia, nostálgicos, de volta à terra, ${ }^{55}$ depois de três horas no avião.

Pude ouvir um índio questionando o homem da Força Aérea na rede ao lado. Ele perguntava o nome de Huxley, qual de nós era a sua mulher, e quantos filhos eles tinham. $\mathrm{O}$ homem respondia; o índio analisou Huxley, sorrindo, perguntou tudo mais uma vez, e recebeu as mesmas respostas. (Sua conversa, alguém me disse, move-se como uma geleira. Uma simples história pode estender-se por horas, até mesmo por dias.) Como sabem todos os que já viram fotos de Huxley nas orelhas de seus livros, ele é um homem muito bonito, de porte aristocrático, mas a opinião final do índio, expressa numa voz intencionalmente baixa, foi "Feio... feio...". ${ }^{56}$ E, naquelas circunstâncias, Huxley parecia não feio, mas alto demais, branco, refinado e deslocado demais.

Depois de certo tempo saímos e descemos até o rio, onde alguns de nós nadaram, e os índios, amáveis, nos acompanharam. As aldeias, para se livrar dos mosquitos, quase sempre ficam a mais de um quilômetro dos rios, e toda a aldeia vai nadar atravessando a floresta em fila, pela manhã, ou pela manhã e à tarde.

Um jovem índio era visitante, um Caiapó, tribo que estava em contato com os brancos havia apenas dois anos. (Novas tribos ainda estão sendo contatadas, enquanto algumas outras são conhecidas há duzentos anos.) O visitante apareceu de calça e camisa, o cabelo caído nas costas e preso por uma fita branca; no lábio inferior tinha uma placa oval de madeira lustrosa, com seis centímetros de largura, a face inferior tingida de vermelho. Ele era um rapaz falador e agradável ("Encantador, mas louco", disse Callado); quando pediram que posasse para uma foto, polidamente tirou a roupa. Nadando conosco numa espécie de nado de peito, ele jogou

\footnotetext{
${ }_{55}$ A autora justapõe down-to-earth (simples, realista) e back-to-earth (de volta à terra).

56 "Homely... homely...". Bishop repetirá esse e outros comentários em carta a Robert Lowell de 28 de agosto (1995, p.389).
} 
água na boca com a placa de madeira e bebeu como um pato. O rapaz inglês o chamou de "Ronny", 57 que era bem próximo de seu nome indígena cheio de vogais.

Por estarmos no fim da estação seca, o riozinho só chegava à nossa cintura, e seu fundo estava limpo e arenoso; havia elevações verdes, trepadeiras e grupos de delicadas palmeiras, tudo como nas gravuras que ilustravam os velhos livros dos exploradores. O barco de "Ronny" estava na margem, cheio de feixes de folhas de palmeira, pronto para voltar à sua aldeia. Ele é construído de maneira simples, cortado no tronco de uma árvore na direção do comprimento e escavado em uma só peça com o uso de cunhas; a casca é então retirada com gravetos, as pontas são escavadas e inclinadas para cima, e ele é deixado para secar. Assim, quase sem dificuldade você tem uma canoa leve e muito bonita. Ficamos passeando pela margem, tirando mais fotos. Os índios amaram as fotos Polaroid (de fato, uma câmera Polaroid e uma grande quantidade de filme devem acompanhar qualquer um na floresta), quase tivemos de afastá-los com força para ver os resultados; o bolso de Huxley foi desfiado com habilidade por algumas fotos ruins que Laura guardou nele. Um grande número de borboletas Sulphur amarelas, de tom pálido, pousou, batendo as asas, na lama úmida da beira do rio, como na partida de uma corrida náutica; entre elas havia algumas magníficas, de uma variedade que desconheço. As asas fechadas imitam com perfeição uma grande folha morta cinza-prateada, e quando abertas reluzem como duas faixas de puro veludo rosa-avermelhado, surpreendente. Huxley teve grande prazer ao observar essas borboletas e esticou-se muito acima de sua elevada altura para examiná-las de perto com a lupa.

Então fomos chamados para o almoço: a linguiça que havíamos trazido, uma panela de feijão roxinho e duas travessas de arroz mal cozido. ( $\mathrm{O}$ alimento habitual é a mandioca; o arroz havia sido uma aquisição recente.) "Ronny" pôs as calças e ajudou a nos servir, enchendo canecas de alumínio com água, distribuindo generosamente o feijão escorrido e agitando sua placa labial para cima e para baixo de maneira amável. A arara azul e amarela foi proibida de saltar sobre a mesa, e os índios ficaram em volta, observando com atenção cada bocado e gargalhando sempre que alguém percebia seus olhares. Eu estava usando pequenos brincos de ouro, e a toda hora o lóbulo da minha orelha era beliscado de leve. Depois do feijão com arroz vieram mais cafezinhos; acendemos cigarros para os índios, eles com muito cuidado acenderam cigarros para nós, e a languidez pousou sobre todos.

Depois de uma sesta de meia hora fomos convidados para ver uma luta, realizada em nossa honra. Dois dos jovens de pele mais lisa começaram, e o resto da população sentou-se

\footnotetext{
${ }^{57}$ Trata-se do futuro cacique Raoni Metuktire, que se tornaria mundialmente famoso no final da década de 1980 por sua campanha contra a invasão das terras indígenas.
} 
nas faixas de sombra ao longo das casas, para assistir. Os homens se agacham e quase ficam de quatro, apertam as mãos uns dos outros num movimento forte, agarram-se pela nuca e se mantêm presos, ainda curvados e grunhindo em voz alta - os únicos sons, dos que ouvimos deles, que poderiam ser chamados de "selvagens". O objetivo da luta é ficar sobre o oponente e apertar seus ombros contra o chão, mas, se um homem percebe que é o mais forte, quase nunca força uma conclusão. Apenas deixa a luta prosseguir, depois eles se levantam, sorriem, e se afastam depressa, cada um numa direção. Os homens nus, ágeis e manchados de vermelho, batendo e gritando na poeira que recende a urina, parecem acima de tudo galos de briga.

Então fomos ao banheiro na maior das casas, com 12 ou 13 metros de comprimento, escura e coberta de fuligem. Homens estavam balançando nas suas redes, e as mulheres lidavam com mandioca e panelas de barro no chão. Os homens pediram mais cigarros, e para satisfazer a eles eu acendi um cigarro para cada um com o meu isqueiro. $\mathrm{O}$ único homem velho sorriu de maneira travessa e eu vi, enfiados na rede entre seus pés escuros e rijos, quatro maços inteiros de cigarros que ele já havia coletado, e várias caixinhas azuis de fósforos Fiat Lux. Numa das extremidades da casa havia uma cerca da altura de um homem, feita de galhos e folhas de palmeira. O estudante de Cambridge nos disse que atrás dessa cerca, no escuro, uma menina estava passando por sua iniciação na puberdade. "Vocês podem olhar pela cerca; esta não é a parte realmente secreta”, ele disse. Examinando na escuridão pudemos visualizar um pequeno cômodo, com pouco mais de meio metro de largura, junto à parede do fundo. Nele, silenciosa e invisível, a menina deve ficar por três meses, ou seis meses em algumas tribos, saindo apenas à noite para respirar um pouco de ar fresco. Quando a iniciação se completa, elas estão muito fracas e muito mais claras que seu tom normal. A anã de vestido escarlate entrou correndo com uma panela de água e outra de arroz e as depositou no chão, em silêncio. Pendendo das vigas sobre nossas cabeças havia uma enorme cabaça preta e polida, e alguém perguntou ao homem de Cambridge o que ela estava fazendo lá. "Oh, eles gostaram, só isso", ele nos informou, e completou, inocente: "Eles também são seres humanos, você sabe".

Nessa região as noites são bem frias. Os índios nus se aquecem construindo pequenas fogueiras bem debaixo de suas redes e, além disso, a fumaça mantém afastados os mosquitos da malária. Uma mulher estava segurando um bebê muito doente, o único índio doente e magro que vimos; todos os seus pequenos ossos estavam visíveis, e a tosse lembrava bronquite. Penso que todos sentimos o mesmo horror e ânsia por fazer alguma coisa, mesmo não sabendo fazer nada. Os índios adultos eram todos jovens, e o homem com camisa do 
Exército era o único com cabelo grisalho e sem dentes. Eles vivem pouco e têm poucos filhos, e a alta mortalidade infantil restringe as famílias a um ou dois filhos por casal. Notei vários daqueles pequenos frascos usados para injeções espalhados por lá, e todo traseiro arredondado e pardo trazia uma marca de vacina (seus traseiros arredondados e as pernas lisas como as de crianças, em ambos os sexos, são muito bonitos).

A uns oitocentos metros da aldeia eles cultivam uma roça de mandioca, seu único empreendimento agrícola, e a mandioca, encharcada e picada, estava secando em armações do lado de fora das casas na forma de bolos brancos e de cheiro azedo. Mandioca e peixe formam a dieta básica; eles não têm sal e quase não comem carne. Uma pequena fruta silvestre, dura e oleosa, chamada pequi, ${ }^{58}$ dizem que contribui com algo essencial para a dieta, mas ninguém sabe o quê. Callado pediu em vão que nos servissem certo prato, um tipo de panqueca fina de mandioca tostada, com recheio de peixe e pimenta vermelha - o único dos seus alimentos, disse ele, que é palatável para o homem branco. Mas naquela semana aconteceria uma grande cerimônia fúnebre com duração de vários dias, por isso estavam defumando e guardando todo o peixe disponível. A morte, nesse caso a de um chefe de outra aldeia, havia ocorrido algum tempo antes, mas as festividades tiveram de esperar até que o suprimento de peixe fosse suficiente.

Todos nós sentimos não tê-los visto pescar com arco e flecha; eles eram muito hábeis em atingir peixes que se movem em águas também móveis, fazendo ajustes de ângulo relacionados à refração; quase nunca erram. As crianças brincam com arcos e flechas feitos com cuidado, e suas flechas têm na ponta pequenas cabaças perfuradas, de modo que fazem um ruído longo e agudo durante o voo. Os Uialapiti não fazem cerâmica, nem cestas. Durante séculos uma tribo fez apenas um artigo, potes, arcos e flechas, cestas, colares de sementes etc., e o trocou pela especialidade de outra tribo. Eles não trabalham, no sentido do que consideramos trabalho; de fato, como os portugueses perceberam logo cedo na história do Brasil, quando sujeitos a qualquer tipo de trabalho fixo eles logo adoecem e morrem. São amáveis entre si e com os filhos; de tal modo que na beira do rio, quando uma mãe começou a esfregar o rosto de um menininho e ele começou a gritar de um modo bem normal, o som raro, inesperado, nos assustou a todos. Nunca batem nas crianças, nem as castigam; de fato, não têm ideia do que seja castigo. Se um índio mata outro, todos ficam muito tristes; o assassino fica muito triste, também, e talvez dê presentes à viúva, mas não se faz nada além disso. Toda propriedade é comunitária, e o próprio Serviço de Proteção ao Índio segue a

\footnotetext{
${ }^{58}$ Grafado pequis.
} 
atitude diplomática de, ao menos, parecer que não deixa nada trancado; eles trancam, é claro, mas permitem que os índios mexam em muitas das coisas que pertencem ao Serviço.

Nossos pilotos queriam voltar a Brasília antes do anoitecer, se possível, uma vez que o campo de pouso não era muito bem iluminado, e assim, por volta de quatro da tarde, nós nos reunimos sem muita vontade e voltamos para o avião. Quando chegamos, faltava alguém; a jovem intérprete havia desaparecido com o rapaz de Cambridge. Assim, nos sentamos à sombra de uma asa e esperamos, nós e toda a população da aldeia que coubesse espremida conosco na sombra, conversando da melhor maneira possível. O homem com chapéu de gaúcho trazia uma grande quantidade de arcos e flechas e duas lanças. Estávamos com sede e cansados; desviamos o olhar quando se exibiu numa dança de guerra vigorosa que ele mesmo inventara. Nosso piloto apareceu, nu da cintura para cima, muito orgulhoso, com um pequeno papagaio verde no ombro; ele havia dado a camisa em troca. Uma menininha com riscas pretas na lateral das pernas reclinou-se sobre meus joelhos e o homem que tanto havia admirado meus brincos inclinou-se sobre meu ombro e perguntou meu nome pela décima vez, enquanto um amigo que parecia mais esperto o repetia com perfeição. "Laura" era fácil para eles; "Aldous" deu problemas, e eles repetiram seus próprios nomes várias vezes, apontando e arrulhando como pombos. O aficionado por brincos examinou meu relógio de pulso e perguntou uma vez mais se eu era solteira. Apontou para o próprio peito e disse que era viúvo, então falou em Nu-aruak com o amigo mais esperto, que começou a rir. Ele havia perguntado se eu gostaria de ficar e ser sua mulher. Isso produziu um grande alvoroço na tribo, e embora eu estivesse vaidosa por ter sido escolhida, temia que ele apenas não quisesse ser o índio que "desperdiçou a pérola", uma mulher mais rica que toda a sua tribo. ${ }^{59}$

Além da pequena lupa e do telescópio em miniatura, Huxley tinha óculos estranhos de plástico preto, com inúmeros furinhos, como peneiras, no lugar das lentes. Isso, ele nos disse, era uma antiga invenção dos chineses, útil para míopes e hipermétropes. Laura comentou que os achava muito úteis também para dormir, e quando afinal entramos no avião ela os colocou e imediatamente adormeceu. Os outros também cochilaram, beberam água morna e acabaram com os sanduíches; todos nós parecíamos um pouco exaustos e distantes. Tentamos ler Grey eminence, The Eclipse of God e Lahdee, ${ }^{60}$ mas sem muito sucesso. Lembro-me de ter discutido The Mill on the Floss como em sonho, e de ter conversado com Huxley, gentil como

\footnotetext{
${ }^{59}$ Na carta a Robert Lowell, Bishop comenta: "Outro, viúvo, convidou-me para ficar e me casar com ele. Foi uma distinção um tanto ambígua; mas as outras mulheres que estavam comigo ficaram todas com ciúme" (Bishop, 1995, p.389).

${ }^{60}$ Mais uma vez, a autora ironiza a pronúncia brasileira de Lady.
} 
sempre, sobre Ezra Pound e T. S. Eliot, ou melhor, sobre suas lembranças deles. Ele então falou sobre Utopia, o tema de seu próximo romance. ${ }^{61}$ Sua Utopia está localizada numa ilha, penso que no Oceano Índico, numa combinação do que há de melhor nas culturas ocidental e oriental. É uma sociedade "onde os homens podem realizar suas potencialidades de um modo como nunca foram capazes em nenhuma civilização passada ou presente”. Parecia natural ouvir sobre isso a dois mil metros de altura, abandonando uma das sociedades mais primitivas da terra, correndo em direção a uma nova tentativa na "cidade mais moderna do mundo".

Pouco depois do anoitecer estávamos em casa, casa em Brasília, melhor dizendo. Nosso microônibus não apareceu para nos buscar, e fomos levados de volta ao hotel num caminhão novo, amarelo brilhante, com bancos na carroceria. De repente passou a fazer muito frio; o Cruzeiro do Sul brilhava; o motorista errou o caminho e circundamos o Palácio da Alvorada mais uma vez.

Limpos, quietos, pedindo uns aos outros Cafiaspirinas, alguns com os cabelos úmidos depois de lavados com xampu, nos reunimos para outro jantar servido tarde da noite, enquanto a música enlatada berrava só para nós. Nossa mesa balançava - todas elas balançavam -, e o garçom mais velho, italiano, correu para colocar um calço de papel sob ela, exclamando com desgosto: “Tutti moderni! Tutti moderni!", e depois conversou apaixonadamente com os Huxleys, em italiano, sobre esse assunto.

Durante o jantar Antônio Callado, do seu jeito divertido e em seu belo inglês, nos contou mais acerca do Serviço de Proteção ao Índio e sobre os três irmãos Villas Boas. De uma família paulista de classe média, apenas com educação primária e contra a vontade dos pais, todos os três cresceram com a mesma paixão pelos índios e dedicaram suas vidas a eles. Os índios parecem inspirar uma afeição profunda em quase todos com quem convivem; todos nós percebemos como os homens da Força Aérea foram gentis e amáveis com eles. Ou, talvez isso se deva em parte ao charme infantil dos próprios índios, e em grande parte ao talento colonizador dos antigos portugueses. Estes eram (e são) quase livres de preconceitos de cor ou raça, e tratavam qualquer raça estranha com a qual se encontravam com a mesma familiaridade divertida e carinhosa que tinham pelas outras. Callado também falou sobre o fundador do Serviço de Proteção ao Índio, o famoso mestiço de branco com índio general

\footnotetext{
${ }^{61}$ Island, publicado em 1962.
} 
Rondon (que era capitão Rondon quando acompanhou Theodore Roosevelt numa caçada pelo Brasil); ele havia morrido alguns meses antes. ${ }^{62}$ Huxley ficou muito impressionado com o lema de Rondon para o Serviço: "Morrer se necessário for, matar jamais".

Na manhã seguinte nós fomos mais uma vez, animados e pontuais, para o pequeno aeroporto atravancado. Três mulheres da alta sociedade paulista, que não haviam ido embora depois da festa presidencial, estavam lá, dizendo umas às outras, em êxtase, quanto haviam gostado de Brasília. Os Huxleys viajariam antes, para São Paulo; os demais iríamos em outro avião para o Rio. Alguns de nós carregavam as sacolas pretas, um pouco fúnebres, que ganhamos no hotel. Os Huxleys tinham uma dessas e várias sacolas de empresas aéreas, também, e Huxley disse que esse era o jeito como o homem contemporâneo deveria viajar, apenas um conjunto dessas sacolas amarradas, no ombro. O chefe da Divisão Cultural do Itamarati estava fazendo o possível para arrancar de Huxley, antes de sua partida, alguma frase final que resumisse Brasília, mas não estava tendo muita sorte. Huxley apenas se permitiu dizer que gostaria de voltar em dez anos. Eu senti, no entanto, que em dez ou em vinte anos tudo seria igual: Brasília, os Uialapiti, o próprio continente sul-americano, estariam sendo vistos sub specie aeternitatis. ${ }^{63}$

Uns dias depois, no seu Correio da Manhã, Antônio Callado publicou um relato sobre a viagem intitulado "Um sábio entre bugres". ${ }^{64}$ Sobre Brasília ele disse, entre parênteses:

É uma Cidade de Consumidores, plantada num deserto onde não se vê um pé de couve. Durante muito tempo vai sugar, com o mata-borrão daquele seu pó vermelho, as energias do país ... Mas a cidade não começa pelas ferrovias e pelas hortas? Brasília vive em grande parte de uma ponte, como Berlim ao tempo do assédio russo. Por outro lado só tem palácios e as favelas da "cidade livre", old fashioned no bar do hotel e cachaça nos verdadeiros "saloons" de uma fantástica Praia do Pinto. No entanto, em outros setores, há uma teutônica preocupação com problemas que ainda não nasceram: o aeroporto fica a milhas de tudo, a prevenir futuros congestionamentos, quando um aeroporto provisório podia ficar no quintal do hotel... ${ }^{65}$

\footnotetext{
${ }^{62}$ Marechal Cândido Mariano da Silva Rondon (1865-1958), falecido em janeiro.

${ }^{63}$ Em latim no original, "do ponto de vista da eternidade".

${ }^{64}$ Bishop traduz o título para o inglês: "A Sage among the Savages".

${ }^{65}$ Antônio Callado. "Um sábio entre bugres". Correio da Manhã, 21.ago.1958, p.4.
} 
Outro autor inglês, mais franco que Huxley, escreveu:

Eu tenho uma forte impressão de que nenhum homem pode determinar que naquele lugar se construa uma cidade grande e próspera. Nenhum homem pode determinar isso, mesmo que ele deixe ... prestígio suficiente para prender os sucessores aos seus desejos.

Existe muita terra desolada no país, mas penso que nenhuma é tão desolada como três quartos do terreno em que se pretende construir a cidade ... Existe um mapa detalhado, e com esse mapa nas mãos durante os deslocamentos qualquer um pode perder-se pelas ruas ... como acontece nos desertos da Terra Santa. No centro, ninguém sabe onde fica o que se procura, nem está seguro de sua existência, e entre as localizações possíveis a terra é selvagem, sem caminhos, sem pontes, desabitada e desolada.

Eu não acredito em cidades feitas desse modo. O comércio, penso eu, deve decidir o local de todas as grandes concentrações humanas. De algum modo misterioso elas conseguem o que querem, e, tendo conseguido, atraem homens aos milhares em torno de suas propriedades.

Estes são alguns dos comentários mais gentis de Anthony Trollope acerca da cidade de Washington, em 1861. ${ }^{66}$ Os Estados Unidos do século XIX e o Brasil do século XX não são, talvez, muito comparáveis; todavia, Trollope e a mãe dele, e todos os muitos outros profetas da falência estavam errados a respeito de Washington, e convém que os americanos sejam bem cuidadosos nas previsões relacionadas a Brasília. Mas o tom dos comentários de Callado parece ecoar os sentimentos de todos os brasileiros inteligentes que eu conheço, sobre esse assunto. Sem muita esperança mas resignados, eles torcem para que tudo dê certo. Todos nós devemos, talvez, guardar um pouco de esperança para os índios.

\footnotetext{
${ }^{66}$ Anthony Trollope (1815-1882), viajante e escritor inglês.
} 


\section{Uma viagem pelo Amazonas [1960]}

Elizabeth Bishop viajou à Amazônia em fevereiro de 1960, em companhia de sua amiga Rosinha [Rosalina] Leão e do sobrinho desta, Manoel, de 16 anos. Como sempre fazia quando Lota não a acompanhava em suas viagens, escreveu duas cartas à companheira, ${ }^{1}$ que ficara no Rio de Janeiro. Na primeira, Bishop informa que também está escrevendo "um relato completo de tudo, só para me lembrar e assim fazer uma carta sem fim para você quando eu chegar aí”. Detalhista, comenta: "Ah, tenho que deixar de lado os pássaros e os macacos - gastaria páginas". Na outra, refere-se ao relato já iniciado: "Datilografei cerca de 15 páginas sobre a viagem - ainda estou dois dias atrasada”. Trata-se deste rascunho, preservado em seus arquivos sob o título de "Trip on the Amazon (On the 'Lauro Sodré')", em que descreve o percurso desse barco de Manaus a Itacoatiara, Uricurituba, Oriximiná, Óbidos, Juriti e Alenquer. O relato se interrompe antes da chegada a Belém e nunca será retrabalhado. Em carta ao amigo Robert Lowell, escrita dois meses depois, a escritora mostra-se fascinada com a Amazônia, informa que tirou slides e já preparou uma "pequena conferência” sobre a região (Bishop, 1995, p.414-415). Além disso, manterá durante anos o sonho, jamais realizado, de refazer a viagem, desta vez descendo o rio desde a fronteira com o Peru. Tanto nas cartas como neste relato, a atenção de Bishop abrange os rios, a fauna e a flora, a arquitetura de Manaus e das vilas, e detém-se tanto na rica família Sabbá, que a recebe na cidade, como nas personagens anônimas que povoam o hotel, o restaurante e o barco. Notem-se os cortes abruptos e os inúmeros travessões, característicos também nos esboços de seus poemas.

Originais em Vassar College, Special Collections; Box “Prose Unpublished”, Folder 55.4, 9p. Datilografado; sem data (1960); título ms: "On the Lauro Sodrê".

\footnotetext{
${ }^{1}$ Essas duas cartas escaparam à destruição da correspondência promovida pela irmã de Lota após a morte desta, em 1967, o que aumenta sua importância. Estão preservadas nos arquivos da autora (Vassar College, Special Collections), e foram traduzidas e comentadas em Ferreira, 2003, p.142-162.
} 
Deixamos o Rio dia 17 de fevereiro - 8:30 - e voamos para Belém, onde paramos por uma hora, e voamos Amazonas acima até Manaus, chegando por volta de 7:30. ${ }^{2}$ Fomos recebidos por três da Família Sabbá - o Rei do Amazonas, Isaac Sabbá, ${ }^{3}$ e dois sobrinhos, um chamado Moisés Israel, o nome do outro eu não guardei. A viagem do Rio a Belém, cansativa - pouco a ser visto lá embaixo, morros amarronzados sem fim e manchas esverdeadas - O aeroporto novo, "moderno" e já muito degradado - do lado de fora uma confusão, dentro também - muitos balcões, quiosques para venda de livros etc., nunca usados - (duas pequenas caboclas $^{4}$ olhando fixamente para mim na porta). Um belo e extenso mosaico, feito por Douglas Marques de Sá, ${ }^{5}$ mostrando peixes e animais amazônicos, e um barco a vapor - A viagem desde Belém até Manaus foi espetacular - sem ver o corpo do rio, mas milhares de tributários, um vasto sistema de veias. O dia estava cinza, com o sol aparecendo às vezes - as clareiras pareciam escuma verde, brilhante e amarelada, trechos de floresta mais escuros, cinza metálico, cinza azulado, veias metálicas, e depois outras cor de lama brilhante em todos os tons de amarelo - depois enormes manchas como de machucados - nuvens pesadas, prateadas embaixo - um vasto mau humor na face do paraíso - e imensos céus -

Desde o aeroporto até Manaus - com Isaac. Manoel e eu não fazíamos ideia de sua importância e cometemos gafes horríveis. Primeiro eu dei um grito diante da beleza das favelas. - A estrada atravessa várias pontes sobre vales profundos. Esses regos estão repletos de barcos usados como moradia - naquela hora quase todos encalhados na lama, em todas as posições. Tetos em folhas de palmeira, alguns num trabalho muito bonito, ou em zinco alguns com portas quadradas, como a arca de Noé - e centenas deles tristemente encalhados na lama e no capim alto. - Estava começando a escurecer - o sol estava se pondo - e desses vales de barcos encalhados vinha fumaça - Fumaça cor-de-rosa, desses longos e profundos vales cheios de barcos encalhados - barcos ofegantes - leve fumaça azulada - talvez todos estivessem cozinhando o jantar - A luz no oeste era cor-de-rosa clara, como melão; o ar, cheio de fortes e agudos cantos de sapos - um tipo de sapo diferente daquele de Petrópolis - o

\footnotetext{
2 Da noite.

${ }^{3}$ Isaac Benayon Sabbá, o patriarca dessa família judia riquíssima, construiu a refinaria de petróleo localizada em Manaus. Uma semana antes da viagem, ele havia sido objeto de reportagem de capa na revista Visão, sob o título de "Rei do Amazonas". O vínculo com a família Leão surgiu porque o pai de Manoel e irmão de Rosinha, engenheiro, havia trabalhado no projeto e na construção da refinaria.

${ }^{4}$ Em português.

5 A autora o nomeia como "Marques Sá".
} 
Sr. Sabbá perguntou a Rosinha se ela gostaria de ver a refinaria - e eu comecei a compreender quem ele era quando Rosinha ${ }^{6}$ respondeu, com falso entusiasmo, que adoraria.

Não estava tão quente quanto o Rio em nossa partida. O hotel é um lixo - deve ter sido bom quando foi aberto, em $1947^{7}$ - mas sem dúvida está afundando - Ficamos com o melhor quarto, exceto por uma suíte ou duas para políticos etc., no último andar - nós estávamos no $4^{\mathrm{o}}$ - na verdade, o $6^{\circ}$ - no canto sudoeste, com o maior ar-condicionado do mundo, e ele funcionava. Os outros aparelhos, usuais, de parede, não estavam funcionando muito bem. Duas camas - e dois ganchos para rede. Uma varanda sobre algumas casas, na direção do rio - o mercado estava atrás delas - e à direita o cais. Três grandes navios estavam lá. Um, de aparência cansada, era o "Almirante Alexandrino", 8 em que Rosinha voltou da Europa em 1935. Do porto, uma pequena estrada de ferro sobe por um cais flutuante, e pequenos trens de vagões-plataforma abertos são puxados por ela para descarregar os navios - bem devagar tudo é lento demais em Manaus - um homem no alto de uma torre de pedra cinza e branca move alavancas, lânguido, para frente e para trás, comandando a estrada de ferro. Aquela noite nós jantamos no hotel e tentamos sair para caminhar. Quase não havia iluminação pública na rua. Algumas lojas e armazéns têm lâmpadas fracas - de 40 watts, eu diria - em frente. As ruas são calçadas com pedras, quase sempre com muito esmero - mas às vezes não - é comum tropeçar, no escuro, e o desnível para a calçada às vezes é de 60 centímetros, às vezes de $15 \mathrm{~cm}$ - e se você não ficar alerta pode cair direto num bueiro sem grade - de 60 por $30 \mathrm{~cm}$ e sem fundo -

Ainda ${ }^{9}$ no caminho para a cidade. Parte da estrada de terra, parte calçada (macadame) - através de um bairro pobre que depois descobri chamar-se EDUCANDOS - porque antigamente havia uma escola para marinheiros ali. ${ }^{10}$ Nos dois lados, filas de pequenas casas de madeira - como as casas de favela no Rio, embora mais bonitas - quase sempre belas, pintadas em cores fortes, com muitos detalhes na madeira, nas varandas, ripas e janelas azuis e verdes brilhantes, cor-de-rosa - muitas inscrições - algumas ornamentadas com plantas em vasos e latas - meio parecido com a antiga Key West, ${ }^{11}$ o bairro negro, exceto

\footnotetext{
${ }^{6}$ Aqui, e várias vezes ao longo do texto, apenas 'R' para designar Rosinha Leão.

${ }^{7}$ Data em branco, no original. Esse pequeno hotel, projetado por Paulo Antunes Ribeiro, foi considerado "um bom exemplo de aclimatação tropical dos princípios gerais da arquitetura moderna". Combinou, por exemplo, "meios mecânicos e naturais de refrigeração: a boa orientação e disposição dos espaços ... contribui para amenizar a temperatura" (Cavalcanti, 2001, p.318-319). A decadência apontada por Bishop durou vários anos, até que o hotel foi transformado em prédio de apartamentos. As lojas no térreo foram mantidas.

${ }^{8}$ A autora grafa "Alexandrina".

${ }^{9}$ No original, a autora abre parênteses (que não serão fechados) neste início de parágrafo.

10 "Educandos e Artífices", escola criada no século XIX, voltada à educação profissionalizante.

${ }^{11}$ A autora viveu em Key West, na Flórida, durante a década de 1940.
} 
pelas cores brilhantes - e parecido com o Haiti, também - ornamentos exagerados. Mas as daqui são mais bonitas que essas. Cães por toda parte - dormindo no meio da rua - e a maior quantidade de gatos que eu vi no Brasil, e mais bem alimentados - Eles podem arranjar peixe, mas sem dúvida são necessários para eliminar os ratos - de qualquer maneira, parecem muito mais felizes que os gatos do Rio. Esteiras e mesas estavam colocadas do lado de fora - poucos bancos - muita comida sendo feita, em conjunto com a fumaça azul - oleados brilhantes, xícaras de cafezinho ${ }^{12}$ todas arrumadas de cabeça para baixo, homens sentados jantando quase nenhuma mulher nesses lugares - e as camisas brilhantes, calças brancas, telhados de folha de palmeira - comidas de aparência estranha - tudo muito parecido com as pinturas primitivistas brasileiras.

Quinta-feira, 18 de fevereiro

Encontramos algumas amigas do Rio no lobby do hotel aquela noite - Maria Clara Machado, ${ }^{13}$ Anna Letícia (Eu vi suas gravuras na Bienal) ${ }^{14}$ e uma outra jovem chamada Etelvira. ${ }^{15}$ Durante a manhã Manoel teve um pequeno mal-estar provocado pela viagem - eu saí para procurar uma farmácia, a Pharmacia Fink - enorme, sombria, como um celeiro remédios mais caros que no Rio - carvão a 90 centavos? - lotada mesmo às 8:30 - há várias farmácias grandes por toda a cidade. - Às 10:30 uma dos Sabbás veio nos buscar para mostrar a cidade. Era uma jovem chamada Cynthia, muito bem vestida, muito alta e gorda, com pele branca, cabelos pretos, face e expressão infantis, tímida e nervosa, e tentando ser educada e fina. Ela estava num grande carro preto estofado em couro vermelho - um Capri alguma coisa, com um pequeno motorista caboclo ${ }^{16}$ chamado Francisco, que era agradável mas muito informal, e sobre o qual ela parecia não ter muito controle. (Nós percebemos depois que todos os empregados tratavam Cynthia como se fosse criança.) Primeiro, ela nos levou até a Praça da Matriz, ${ }^{17}$ logo atrás do cais - a Catedral é grande, simples e desinteressante, mas bonita, pintada com ornamentos em azul pálido e branco - Nós entramos e percebemos que ela não se ajoelhou nem fez o sinal-da-cruz. ${ }^{18}$ Do lado de fora, contra a parede azul-clara, um fotógrafo

\footnotetext{
${ }^{12}$ Em português.

${ }^{13}$ Não só a dramaturga e diretora Maria Clara Machado (1921-2001), como também seu pai, o escritor Aníbal Machado (1884-1964), conviviam com Lota e Bishop no Rio de Janeiro.

14 Anna Letícia Quadros (1929); "Bienal" grafada "Bienale".

${ }^{15}$ A autora deixa um espaço para o sobrenome, depois de Etelvira.

${ }^{16}$ Em português.

${ }^{17}$ A autora deixou em branco, "Praça de .......".

18 Aparentemente, Bishop só percebeu que seus anfitriões eram judeus durante o passeio. Em sua carta a Lota, escreve: "eles são judeus e aparentemente muito odiados pela maior parte da cidade - judeus, muito praticantes e muito ricos, em termos daqui” (em Ferreira, 2003, p.150).
} 
havia montado sua barraca com os painéis de fotografias para amostra - pequenas faces escuras olhando fixamente para a câmera - uma "brincadeira" em que a cabeça se encaixava no lugar correspondente, na nota de um conto ${ }^{19}$ - Ele tinha um pano de fundo quadrado, numa moldura - um delicioso tecido cor-de-rosa, e estava sentado sobre um banquinho em frente a ele, com olhos pretos e pequenos - eu perguntei se poderia tirar sua foto e é claro que ele ficou irritado, porque gostaria de tirar nossas fotos, a 125 cruzeiros cada...

Essa praça contém um pequeno parque tradicional, cheio de bancos de cimento tão altos que não vejo como alguém possa usá-los - eles não parecem usá-los muito - os pés balançam 25 centímetros acima do chão. Pequenos canteiros de plantas ornamentais (cóleos) etc., um ou dois caminhos de areia, e então a fonte - uma peça magnífica, em cores brilhantes - um grande tanque, hexagonal ${ }^{20}$ - nos cantos, anjos de tamanho natural com cântaros etc. cor de pele escura - assustadores quando vistos do outro lado da rua - no meio, uma grande aglomeração de anjos, homens barbados, mulheres, instrumentos musicais, sombras de lâmpadas peroladas - filetes de água do Amazonas caindo no tanque enlameado - Na base de cada anjo a inscrição "Sun Company Glasgow 1900”, e só quando eu cheguei perto o suficiente para ler é que percebi que toda a fonte era de ferro fundido -

Cynthia nos levou para passear pela cidade - ela é mais cheia de morros do que eu esperava - maravilhosas mangueiras, enormes, todos os tipos de palmeiras - os prédios em geral feios, mas alguns bonitos, sempre em cores brilhantes - parece mais portuguesa que as outras cidades brasileiras - e não muito velha - a maioria dos bons prédios data dos tempos do boom ${ }^{21}$ e são em estilo ornamentado - muitos azulejos, algum trabalho muito bonito em ferro - frontões falsos, vitrais, estátuas de cerâmica portuguesa por toda parte - Muitos urubus $^{22}$ - Nas ruas e nos prédios, em grupos - às vezes eles se parecem com vasos, ou talvez às vezes os vasos se pareçam com urubus - E cães por toda parte - um ou dois sempre na recepção do hotel, sob os balcões cheios de bugigangas da STERNS ${ }^{23}$ - joias num e lembranças do Amazonas no outro - jacarés empalhados, livros de bolso - uma pequena coleção de pássaros mal empalhados, mas belos pássaros - Um prédio de três andares perto do hotel coberto com cerâmica verde-escura, brilhante, em volta da cumeeira - um bom conjunto de grandes lírios aquáticos e folhas - Portas de todas as cores, muito desbotadas mas a favorita parece ser rosa claro com azul transparecendo, ou vice-versa - Rosinha disse:

\footnotetext{
${ }^{19}$ Em português. A foto se encaixava no lugar da imagem de Pedro Álvares Cabral.

${ }^{20}$ A interrogação consta no original.

${ }^{21} \mathrm{O}$ período áureo da borracha, na virada para o século XX.

${ }^{22}$ Em português.

${ }^{23}$ A joalheria "H. Stern".
} 
“como se eles não pudessem decidir-se" - Uma nova coleção de nomes de políticos e slogans - "Gilberto" (Gilberto Mestrinho Tavares Raposo ${ }^{24}$ ), o governador atual. Cynthia ${ }^{25}$ recitou uns versos sobre ele - eu não consigo lembrar, exceto as rimas óbvias - esperto, e aberto (o cofre) - e se você fosse esperto não teria deixado sua mulher perto de Gilberto... ${ }^{26}$ Houve outro governador (eu acho) chamado "o Pensador" 27 - talvez porque ele só pensava e não agia. Muitos cartazes dizendo “Depois do 'pensador' - GILBERTO!” ${ }^{28}$ Também um hospital chamado "Pensador".

Em seguida voltamos por uma área descampada - três prédios amarelos, estreitos, muito próximos, com altas mansardas e ferragens pintadas de branco e longas janelas vazadas - em um milharal, terra vermelha - grandes árvores nas bordas da clareira - e eu imediatamente pensei em Van Gogh - um pouco o estilo de seus quadros, o da prefeitura, ${ }^{29}$ apenas os edifícios mais altos - pareceu natural quando Cynthia disse, desculpando-se, quando eu lhe perguntei (ela não iria dizê-lo): "É o asilo dos loucos". Ela nos levou a um ponto na margem, sobre o rio - o final de uma rua de barracos - as casas miseráveis tinham cortinas bordadas e enfeitadas - cortinas na última moda - plantas em latas, e crianças nuas e os cães - Podíamos ver um bom trecho do Rio Negro nos dois sentidos -

(Acabamos de cruzar o AUGUSTO MONTENEGRO - igual ao nosso barco - e repleto de gente na mesma formação - todos ao longo do convés superior em fila única, nos dois conveses inferiores, na popa, massas de pessoas e de redes - assobios) - ${ }^{30}$

Abaixo de nós havia um velho navio preto, preto e enferrujado, como uma fábrica - a usina elétrica da cidade - velha e inadequada, é claro - comprada no México - E voltamos cruzando mais praças - outra fonte maravilhosa em ferro fundido, uma praça ${ }^{31}$ menor muito bonita exceto por conter o maior prédio da cidade num dos cantos - branco e com cinco ou seis andares - a escola técnica, ou algo assim. Esse e a fábrica de cerveja ${ }^{32}$ - alta, branca, e semi-gótica, com uma torre pontuda em um dos lados, como um velho cofrinho - estragam a vista da cidade de qualquer ângulo - sobretudo do rio, em frente. Esquentou muito até meio-

\footnotetext{
${ }^{24}$ Grafado "Raposa".

${ }^{25}$ Aqui, e várias vezes ao longo do texto, apenas 'C' para designar Cynthia.

26 "Esperto", "aberto", "cofre" e "perto" em português.

${ }^{27}$ Em português. Trata-se do governador Eduardo Ribeiro. Maranhense de nascimento, foi governador do estado entre 1892 e 1896, no auge da prosperidade econômica.

${ }^{28}$ Em português. A autora grafa "Depois o "pensador""

${ }^{29}$ Em português. Grafado preifetura.

${ }^{30}$ Note-se que a autora redige o rascunho durante a viagem pelo rio, e não em Manaus.

${ }^{31}$ Praças e praça em português.

${ }^{32}$ Cervejaria Miranda Correia.
} 
dia. Cynthia parou num restaurante do qual os Altmans ${ }^{33}$ haviam falado - um dos dois melhores da cidade. Seu nome havia sido A Acadêmica, e às vezes ainda era chamado assim. Então a mulher do proprietário morreu e ele lhe deu o seu nome, Olimpia... Ficava numa esquina, fora do centro - subimos alguns degraus até um pequeno pátio com uma videira espalhada sobre ele, com muito mais fios elétricos e soquetes balançando e velhas lâmpadas coloridas, do que galhos - em toda a volta, balcões pintados de azul envelhecido - portas quebradas, vazios - no meio, um "aquário" (foi o que disseram) com as bordas em vitral de todas as cores e com luzes por dentro, suponho, metade das quais queimadas - alguns posters de turismo de Portugal e da Espanha em volta - um lugar horroroso - mas nós ficamos sentados sob a videira. Do lado de dentro era muito pior - várias salas sujas, todas com pinturas medonhas - Napoleão olhando para um Jesus pálido e várias outras cenas religiosas também onças,${ }^{34}$ florestas - tudo em paredes azuis ou cinzentas.

Rosinha foi ao banheiro e voltou pálida e agitada. Eu tentei lavar minhas mãos numa pia do lado de fora - a água pingava, mas isso era tudo - Havia quatro, talvez cinco jovens que perambulavam e falavam sem parar - de chinelos e com roupas descombinadas - toda Manaus parecia gostar de estampas misturadas - saia de um tipo, blusa de outro, padrões grandes e vistosos - Essas garotas chegaram bem perto e ficaram olhando fixamente para nós, inertes - a mais velha falava demais, e a que deveria nos servir parecia tímida e falou num sussurro, de modo que tivemos de gritar com ela - todas eram horríveis, relaxadas, e tinham o rosto cheio de espinhas. A mais velha tinha uma bela coleção de feridas - e uma cabeça cheia de sexo. Algumas eram irmãs. A família tinha vindo para Manaus de Portugal dois anos atrás - elas vieram do leste, ${ }^{35}$ da fronteira com a Espanha. Eu nunca tinha visto alguém tão desavergonhadamente, naturalmente, espontaneamente ${ }^{36}$ sujo -

$\mathrm{O}$ tanque de vidro era marrom-acinzentado escuro - não pensei que fosse vidro até que a irmã mais velha (como a mais velha nos contos de fadas) me disse, e no fundo daquele tanque amedrontador havia tartarugas e peixes... Eu pedi uma "peixada" 37 - tucunaré servido numa sopeira, num caldo fino, o peixe em fatias grossas e com pele. Sobre a mesa havia farinha de mandioca, ${ }^{38}$ mas amarela, da cor do milho, e granulosa, como migalhas de broa, apenas dura como serragem - mas não era ruim - parecia ser a variedade usual, ali. Uma

\footnotetext{
${ }^{33}$ Os amigos de Bishop tinham estado pouco tempo antes em Manaus.

${ }^{34}$ Em português.

${ }^{35}$ No original, "oeste", erro óbvio.

${ }^{36}$ Grifo no original.

${ }^{37}$ Em português.

${ }^{38}$ Em português.
} 
garrafa de azeite de oliva verdadeiro e uma molheira com molho de pimenta forte. Em seu prato de sopa você faz um molho - a moça das feridas o fez para mim - misturando azeite, mandioca ${ }^{39}$ e a pimenta forte - tudo mexido como um mingau diabólico - depois coloca-se o caldo; depois, o peixe. Não era ruim, e pode ser maravilhoso, sem dúvida - todavia o peixe tinha um sabor que lembrava barro - Mas essa foi a nossa primeira refeição deprimente até então, e mal pudemos esperar para ir embora. Manoel ${ }^{40}$ foi à calçada para chamar um táxi e nós ficamos esperando - a garota das feridas disse "Ele foi atrás de uma menina - não volta mais" etc. etc. - risadinhas. Uma garota repulsiva.

Cochilamos - eu saí para fotografar a fonte - às 4, Cynthia chegou vestida num modelo completamente diferente, para sairmos de novo.

Cidades ao longo do rio:

Manaus a Itacoatiara

Itacoatiara? - lugar na noite? para - Uricurituba ${ }^{41}-$

Quarta-feira de manhã - Parintins - Juriti - tarde da noite - ORIXIMINÁ

7:30 - ÓBIDOS ${ }^{42}$

\section{ITACOATIARA?}

URICURITUBA - Acordei por volta das duas da manhã - e vi que estávamos muito perto da margem, muito alta, movendo-nos rio acima e não abaixo. Nada a ver exceto uma enorme ${ }^{43}$ mangueira redonda, perfeita, vindo em minha direção no escuro - depois uma luz - uma pequena casa sem pintura ao lado direito da árvore - uma réstia de luz - tudo escuro e tranquilo, ao som de sapos - Dois homens apareceram em silêncio sobre a margem, uma cabeça surgiu na janela, e duas mulheres e algumas crianças pequenas etc. - cinco ou seis, era quase impossível ver. Uma corda foi atirada e parece que um menino amarrou o barco ao varal da casa - no seu quintal, é claro. A proa ainda permanecia movendo-se rápido na água barrenta - uma passagem abriu-se nela. Um minúsculo cais - duas tábuas alinhadas, estendidas ao lado do barco, perto da água, como um dedo, devagar, sem fim, até que o barco

\footnotetext{
${ }^{39}$ Em português.

${ }^{40}$ Aqui, e várias vezes ao longo do texto, apenas ' $M$ ' para designar Manoel.

${ }^{41}$ Grafado "Urcurituba". Interrogações no original.

42 Oriximiná e Óbidos não acentuados.

${ }^{43}$ Grifo no original.
} 
afinal tocou a lama - $\mathrm{O}$ barco de ...... ${ }^{44}$ estava encostado à margem. $\mathrm{O}$ menino correu pelo cais e escalou o paredão, arrastando-se, segurando em plantas e pedras. Ele parecia prestes a cair e ser engolido a cada segundo. O capitão apareceu sobre nossas cabeças, na escada, de pijama branco, e atirou na margem o que parecia ser um envelope grosso - por que ele não o entregou ${ }^{45}$ ao menino é um mistério. O menino agora parecia ter uma lanterna, e arrastou-se perigosamente ao longo do topo do paredão, escorregando e caindo e olhando para o envelope - como num estranho jogo - os moradores silenciosos e sonolentos, observando conosco o rio que corria de maneira furiosa e para trás, mesmo - Afinal ele o pegou. - $\mathrm{O}$ capitão gritou: "Leve para o Correio", 46 e o menino correu para a escuridão. Cinco minutos depois ele apareceu de volta - sob o paredão, sobre o pequeno cais, que foi retirado assim que ele passou - a corda foi solta de seu amarradouro ${ }^{47}$ doméstico e começamos a nos afastar - e isso foi tudo o que vimos de URICURITUBA -

PARINTINS - onde todos vieram em barcos sob a chuva pesada - tirei fotografias deles uma máquina de costura foi embarcada e um belo zebu ${ }^{48}$ puxou rua abaixo um carro contendo três cadeiras-de-balanço - duas grandes e uma para criança - para serem embarcadas, também - As pessoas ficaram paradas, acotovelando-se - uma senhora muito velha juntou-se a nós - uma menina desembarcou carregando uma pequena penteadeira - ou a parte superior de uma penteadeira - uma cadela que estava no barco preparou-se para sair e depois saltou e nadou o resto do caminho - e na mesma hora (como a Mimosa) encontrou um lugar na relva e aliviou-se com ar de grande prazer - suponho que ela tenha viajado a noite inteira entre as redes, pobre cadela -

Na terra firme - uma grande casa de pedra, muito feia - um portal e uma grande janela aberta sobre ele no segundo andar. De repente um homem com uma barba enorme apareceu depois vários deles - monges, eu acho -, mas um deles estava usando um suéter listrado estava de folga. Nosso pequeno amigo da terceira classe, Manoel Augusto, disse que eles eram padres americanos - vieram sem barba, ele disse, depois deixaram crescer - eram enormes. ${ }^{49}$ Agora chovia mais forte, e um padre apareceu na calçada em frente à casa, para indicar a um menino como abrir um buraco na parede para que a água escorresse - O padre

\footnotetext{
${ }^{44}$ Em branco. Manuscrito: '?'.

${ }^{45}$ Grifo no original.

${ }^{46}$ Grifo no original.

${ }^{47}$ No original, espaço em branco junto a "doméstico", certamente "amarradouro" ou "cais".

${ }^{48}$ Grifo no original.

${ }^{49}$ Grifo no original.
} 
usava branco-amarelado - muito gordo - sapatos pretos e meias cor de cereja - suas calças marrons estavam enfiadas nas meias e ele segurava a batina branca com uma das mãos, como uma mulher, e um grande guarda-chuva preto sobre a cabeça, com a outra. O menino estava vestido em rosa e azul, com um grande chapéu de palha amarelo - e o cão usual observava. Ficamos ali pouco tempo - a cidade não era muito bonita.

Ah, agora eu me lembro de Itacoatiara - chegamos quando estava escurecendo - a estrada descia da direita - alguns habitantes vieram nos ver, de bicicleta - havia um grande armazém de pedra chamado Ilidio e Irmãos ${ }^{50} \mathrm{e}$, junto a ele, uma pequena casa chamada Bebida ${ }^{51}$ Xexuá - Descarregamos sacas e sacas de castanhas - nós achamos - as sacas eram descarregadas e amontoadas no cais com um inconfundível som de cascas - mas o que é que eles querem com castanhas-do-pará, ali, não temos ideia - eles já devem ter muitas - Elas foram carregadas para o armazém dos Irmãos - Rosinha disse que talvez façam a Xexuá com elas $-{ }^{52}$

JURITI ${ }^{53}$ - um lugar muito pequeno, na outra margem - margem esquerda - uma rua larga, muito curta - com calçadas em degraus de cimento no mínimo 1,20 m mais altas que a rua afastando-se do rio. Juta crescendo entre a margem e a vila - dois pequenos bares perto da água - um tinha as janelas - por onde se fazia a venda - muito altas, e longos bancos, ou plataformas, cerca de $60 \mathrm{~cm}$ acima do chão e abaixo delas, para as pessoas ficarem - fora da água durante as enchentes - Os homens devem remar até o botequim e desembarcar nas plataformas - Grande agitação - aqui eu tirei uma foto - os habitantes da cidade descendo um a um, ou em grupos de três ou quatro, até a margem do rio - À noite um campo de juta com as plantas cortadas e amarradas e deixadas para amolecer na água antes de limpar - um adorável verde brilhante. Mais cães nadadores - tentei tirar uma foto da juta com um menino de chapéu de palha vermelho para dar vida - assim que eu consegui me preparar ele remou para longe (Os remos são belos e eu quero comprar um - vimos alguns com as lâminas pintadas - foi em Óbidos - apenas a lâmina - um vermelho e o outro branco) -

\footnotetext{
50 "Ilidio Hermãos".

${ }^{51}$ Em português.

52 Anotação ilegível no rodapé: "movimento"?

${ }^{53}$ Grafado duas vezes em seguida, como "Juruti" e "Juriti".
} 
ORIXIMINÁ ${ }^{54}$ - por volta de 4 ou $5^{55}$ - O lugar mais bonito que vimos até agora - saímos do caminho para chegar lá, seguindo um rio longo e estreito - Trombetas ${ }^{56}$ - a cidade estendida numa longa fileira de pequenos prédios, com mangueiras deixando-as na sombra uma ou duas casas azuis ajudaram muito - uma igreja azul-cinzenta - nós desembarcamos no cais por alguns minutos - de repente, estava assustadoramente ${ }^{57}$ quente - todos os rostos que eu vi tinham gotas de transpiração no lábio superior - guarda-chuvas pretos - Manoel andou um pouco ao longo da margem e viu sob uma mangueira as peles de 15 capivaras, secando. Havia montes de coisas à venda - pássaros em cestas de vime - Então tivemos de esperar por alguém que iria embarcar - fiquei com medo de que eles estivessem desertando ${ }^{58}$ - Crianças muito bonitas, uma menininha, a menina mais linda que eu vi até hoje - cabelo comprido, pele bronzeada pálida e olhos esverdeados - um rosto largo e doce, vestido azul com barra amarela - nós queríamos levá-la para casa, para Mary ${ }^{59}$ - Alguns menininhos - mamelucos ${ }^{60}$ com as faces estreitas e escuras, feições angulosas, um deles bonito, parecendo ex-votos, primitivas cabeças de madeira com olhos pretos - Do outro lado veio um barco - dois homens remando - três ao todo - com 11 tartarugas - seis grandes viradas para baixo nas seis divisões do barco (não era uma canoa escavada num só tronco) mudas e passivas - como seis mártires cristãos - na popa, cinco menores - uma com a barriga amarela - o caboclo ${ }^{61}$ estava tendo problemas com ela e empurrou suas pernas com firmeza para dentro, e pôs seu grande pé preto sobre ela como se fosse um banquinho, e remou - Alguém as comprou - um passageiro. Essa cidade era belíssima - fizemos uma grande volta no rio. (O Trombetas ${ }^{62}$ é de um verdemar intenso, de águas claras - e ele se esticou de novo, sob o último raio de sol.) ${ }^{63}$

Mais tarde nós estávamos sentados no convés traseiro e as tartarugas apareceram levadas na cabeça pelos marinheiros, pelo convés, uma a uma. No convés posterior, entre as caixas de garrafas de Coca-cola, garrafas de cerveja, garrafas de guaraná, bebês, pessoas, cadeiras, lixo, sujeira etc. - existem dois botes salva-vidas. Os marinheiros puxaram as cobertas dos botes - um deles estava já com água pela metade - e pôs as tartarugas nele trouxe as grandes e encheu pela metade o segundo (e último) bote salva-vidas. As tartarugas

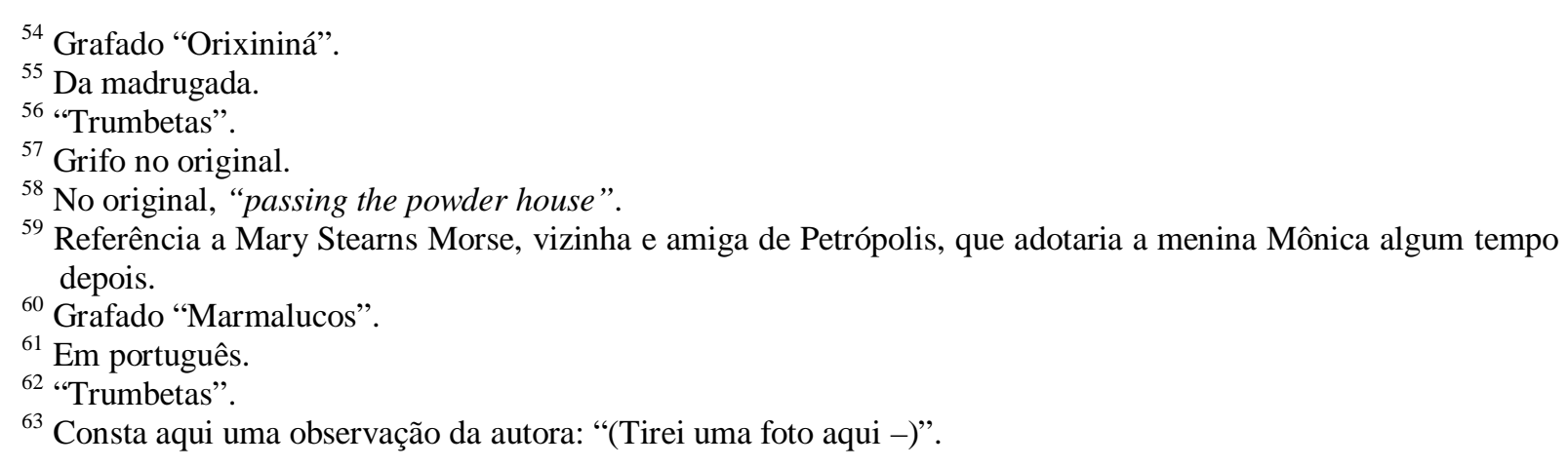


estão indo para Belém, para serem “criadas" eu acho - uma velha amável, que parece índia, me disse $-{ }^{64}$

À noite, depois de Óbidos, embarcaram galinhas e um cão que fica latindo, mais tartarugas, eu acho que um peru - e inúmeras pessoas a mais, que agora estão pendurando suas redes no convés posterior - (algumas, mais tarde)

ÓBIDOS - chegamos depois do anoitecer - pudemos perceber apenas uma igreja muito grande com duas torres - a oeste - depois uma longa fileira de casas e luzes, um pouco como Cabo Frio à noite - Então a maior e mais barulhenta multidão e mais coisas para vender - na primeira fila da multidão, menininhos carregando jacarés empalhados.

ÓBIDOS - 8 da noite do dia 24 - paramos muito tempo durante a noite porque o canal está muito difícil - e fomos para ALENQUER por volta das 6 da manhã do dia 25 - ficamos lá até 1 da tarde - para carregar carne (Tirei várias fotos - uma horrível, uma de Alenquer ao amanhecer - e duas da carne sendo embarcada em frente ao Matadouro ${ }^{65}$ - )

Óbidos - algo a ver com os mortos, ou é só porque ficamos pensando em "Obituário"? ${ }^{66}$ todavia, os habitantes mais alegres que vimos ao longo do rio. Os jacarés são anunciados como "empalhados" 67 ou "embalsamados" 68 - 300 - 400 cruzeiros - também cestas, mas não muito boas. Um menino parou muito perto da borda do cais com um peru preto num barbante - ele e o peru um pouco mais longe, olhando interessados, observando em volta - de vez em quando ele se movia para um ponto de observação melhor, levantava o peru, que não reclamava, pegava-o sob as asas, depois o colocava de novo no chão, e lado a lado eles foram observando o que acontecia. Porcos pretos - cachorrinhos - um quati? ${ }^{69}$ numa caixa Despedidas afetuosas, beijos, lágrimas - alguém chamando Mary Lou sem parar - Tentamos desembarcar, mas a multidão estava tão compacta e fazia tanto calor, e a subida do barco para a borda carcomida do cais, de 1,20 m, tão difícil, que desistimos - Nos degraus, um homem frenético com um grande chapéu de palha e roupas de algodão azul brilhante, disse, quando nos apertamos uns aos outros - "Vocês querem comprar quarenta galinhas?" - Muitas risadas

- "Alguém quer comprar quarenta galinhas?"

\footnotetext{
${ }^{64}$ Consta aqui uma observação da autora: "(Tirei uma foto dela - a 25a)".

${ }^{65}$ Grafado "Matadura".

${ }^{66}$ A cidade portuguesa que lhe emprestou o nome foi assim batizada por ser uma "cidade fortificada" (do termo latino oppidum).

${ }^{67}$ Em português.

${ }^{68}$ Em português, grafado embalsamabdos.

${ }^{69}$ Interrogação no original.
} 
Uma menina disse a Manoel que ele se parece com Rock Hudson. Ele veio nos contar que lhe haviam dito que ele se parecia com "Wock Hoodson" - "é claro que a pobre menina não consegue pronunciar Wock Hoodson" - outra lhe disse que ele tem cílios muito longos ele fica ruborizado ao nos contar. Em Óbidos ${ }^{70}$ nós o mandamos à terra firme arranjar bananas ou qualquer coisa que encontrasse - depois de um tempo ele apareceu com uma dúzia - nós o mandamos de volta para buscar mais - desta vez ele demorou muito. Rosinha e eu ficamos em pé na amurada, conversando, até que comecei a me preocupar terrivelmente e tudo o que eu podia pensar era sobre a morte do pequeno menino que foi para terra firme na "Inocente Viagem". Afinal ele apareceu - eu quase não conseguia falar e então percebi que Rosinha estivera pensando o mesmo que eu, apenas coisas um pouco mais graves - que alívio! - ele tinha contratado um menininho para encontrar bananas por 5 cruzeiros.

A noite foi muito estranha - um canal, sem fim e estreito - muito próximo à margem do nosso lado (porto) - um sonho sem fim - água corrente, marrom escura - então paramos por um longo tempo; então choveu - Rosinha dormiu o tempo todo - a chuva parecia marrom, também; casas sombrias, telhados de folhas de palmeira, pássaros nos acompanhando junto à água - vagos ruídos de pássaros - maravilhosos - levantei por volta das cinco - estávamos fazendo uma curva diante de Alenquer ${ }^{71}$ - tomei um banho de chuveiro (só água fria neste barco, mas é quente o bastante, portanto agradável - Rosinha toma quatro banhos por dia - eu tomo 2 ou 3) Alenquer ao amanhecer, é demais! ${ }^{72}$ - Dois grandes prédios de madeira junto ao cais, originalmente pintados de amarelo, com as bordas dos telhados trabalhadas em madeira em estilo gótico, agora caindo - belos prédios - com dois medalhões sob os beirais - sobre um deles havia sido colado um anúncio de sal de fruta ENO, e sobre o outro um de Emulsão de Scott - chuva cinza-azulada - os cantos pantanosos do porto em verde pastel - um belo veleiro - cerca de 20 pés - o mastro muito inclinado - azul e branco - esse é o tipo usado aqui, embora não existam muitos deles - às vezes uma embarcação com vela latina ${ }^{73}$ - Uma cena que parece desanimadora - longa, molhada, baixa - casa azul-cinzenta, verde - abaixo de nós um grande barco velho todo encharcado, empapado e podre - no alto dele duas galinhas, uma em uma dessas cestas feitas aqui, a outra numa caixa de madeira - grande apenas o suficiente para que os pintinhos passem entre as ripas - Sobre o telhado da cabine, num leito de folhas verdes (o barco deve ter passado sob uma árvore muito baixa - coisas

\footnotetext{
${ }^{70}$ Apenas 'O'.

${ }^{71}$ Grifo no original.

72 Grifo no original.

${ }^{73}$ Vela triangular.
} 
jogadas, um pouco de lixo, garrafas de grãos espalhadas etc., os dois ou três pintinhos ficavam correndo em volta enquanto as galinhas chamavam, frenéticas - peep-peep peep-pee cheep um som matutino, enquanto a aurora chegava triste a Alenquer - Homens e mulheres, todos molhados, no cais - eu tirei uma fotografia que talvez não vai saia por causa da luz tênue e do movimento dos barcos.

Ela ficava mais bonita à medida que clareava - embora nunca fique muito claro lá. Depois do café da manhã (temos Francisco, o camareiro, e graças a Deus o bom camareiro é nosso) temos água quente e leite, às sete - ele traz café e pão, também, mas depois da primeira tentativa nós não conseguíamos tocar em nenhum dos dois. Fazemos Nescafé com leite - este é em pó e bom, embora muito fraco, e comemos Cream Crackers com geleia parece delicioso, também - exatamente no nascer do dia - por que a luz do dia chega tão tarde, eu não sei) - fomos para terra firme - por volta das 8 - Rosinha, Manoel, e Eu ${ }^{74}$ - o holandês e a menina americana, Helen Prosnick? ${ }^{75}$ - que parecia estar se encaminhando para a guilhotina. Uma caminhada muito longa até o cais - sobre piers - sobre o pântano e a água

(Oh, eu esqueci - na noite anterior, enquanto escurecia, Rosinha exclamou de repente - Oh, veja os pássaros - todos nós estávamos na cabine - estávamos perto da margem de um canal - poucas casas quase sobre a água, e vacas - Numa grande árvore morta, cinzenta, de um cinza prateado, desfolhada, no mínimo umas 150 garças brancas estavam pousadas contra um céu azul-escuro de tempestade - Sob aquela luz elas se destacavam, luminosas incandescentes - não - misteriosas, branco-prateadas - alisando-se em seu pedestal cinzaprateado - sobrenaturais. - Depois houve outras, mas nenhuma com o efeito elétrico das primeiras. Eu nunca vi uma cena mais encantadora. Os pássaros pareciam muito grandes - e quando eles pousavam numa árvore menor, percebia-se de onde vêm as cerâmicas da Bahia aquelas com grandes pássaros todos empoleirados em pequenas árvores - pássaros brancos)

No início do píer havia algumas carroças puxadas por zebus - os dois primeiros muito bonitos e grandes, brancos e cinzentos - calmos, molhados, também - o primeiro com as rédeas nos chifres, não na argola do nariz - os chifres quase sempre pintados de vermelho Foi aqui que vimos o cartaz - não, foi antes - sobre uma loja, FORMOSA BARATEIRA. ${ }^{76}$

\footnotetext{
74 'R. M. I.'.

${ }^{75}$ Interrogação no original.

76 Grafado "BRATEIRA".
} 
Estávamos procurando comida de verdade - mas ela não era promissora. Todavia, encontramos um lugar muito bonito - lembrava o Dutchman of Holland é claro, tão plano e verde e úmido, e com vacas e zebus parados em volta. Percorremos toda a rua principal - ou a meia rua de frente para o rio - e encontramos vários prédios coloniais, muito antigos, dois com adoráveis fachadas de azulejos. Todas as casas tinham tetos altíssimos e uma sala enorme, ou às vezes uma sala e um pequeno vestíbulo que dava para outra sala alta, um tipo de pátio sem teto - tudo numa escala muito grande, embora tão pobre, miserável. As salas pareciam cheias de roupas esfarrapadas, quadros pendurados num canto ou bem longe da parede, no alto, e máquinas-de-costura ${ }^{77}$ às 8:30 as mulheres da cidade, vagarosas e gordas e felizes pareciam estar costurando umas para as outras - cortinas, parece - Afinal entramos numa casa - a mulher estava à porta e Rosinha falou com ela de um jeito muito cordial e ela nos convidou a entrar. A casa parecia estar sobre a rua - a mais bela fachada de azulejos imensa, na verdade - mas parece que ela foi construída depois da enchente de 53 - ficavam falando sobre ela, e esperam outra este ano. A água passou por dentro da casa - Penso ${ }^{78}$ que ela disse que um boto ${ }^{79}$ nadou por ela - eles elevaram o piso da casa, quebrando muitos dos azulejos - mas ainda esperam sofrer inundações. "Vamos para a casa da minha sogra", disse a mulher. Fomos ao quarto dos fundos - teto de azulejos, gaiolas, cacarecos, a máquina-decostura, e dez crianças perambulando, sorrindo para nós. Perguntamos quantos filhos ela tinha. Disse que tinha oito e olhou para o grupo, e disse: "Mas nenhum destes é meu". Então o marido apareceu; nós todos demos as mãos - ele era grande e muito simpático - ela era muito gorda, também - eles gostavam de falar sobre o rio, e eram muito amáveis - belas maneiras. O homem olhou em volta procurando alguma coisa para nos dar e acabou cortando um grande pedaço de queijo (eu comi um pouco hoje e ele é excelente - eu não tinha gostado da sua aparência, por isso não tinha experimentado antes) e três bananas-da-terra ${ }^{80}$ - tudo o que tinham - e sua mulher as embrulhou para nós. Mais apertos de mão, abraços - Nós fomos ao mercado - muito ruim, mostrando o quanto era pobre o lugar, eu suponho - nenhum ovo nenhum queijo - pão horrendo - alguns legumes. Rosinha comprou 6 espigas de milho e o homem nos deu mais uma - eu vi umas belas almofadas de palha esverdeada - cerca de um metro por meio metro - usadas como sela - tecidas com longas tiras de palha, e concordamos em que Lota pensaria em fazer alguma coisa com aquilo, mas não conseguíamos imaginar o

\footnotetext{
${ }^{77}$ Grifo no original.

${ }^{78}$ Grifo no original.

${ }^{79}$ Em português.

${ }^{80}$ Em português, grafado "bananas de terra".
} 
quê. Em outra loja, mais adiante, encontramos grandes travessas de barro - Manoel e eu compramos uma cada um, por C\$30 cada - passeamos pelo lugar - mais algumas casas bonitas e algumas horríveis em verde-pistache - as casas dos ricos. Na praça, uma clínica para maternidade ${ }^{81}$ e pronto socorro ${ }^{82}$ - outra clínica da Igreja, aberta, com pessoas esperando de volta para o barco - nenhum café para tomar - fomos a um outro tipo de bar e bebemos cerveja e Pepsi-cola (O Amazonas é a terra da Pepsi, mais que da Coca-cola - ) ${ }^{83}$

\footnotetext{
${ }^{81}$ Em português.

${ }^{82}$ Em português, grafado "pronto soccoro".

${ }^{83}$ Original interrompido aqui.
} 


\section{No trem do Encantado [1965]}

No início de 1965 Elizabeth Bishop foi convidada pelo New York Times para escrever um artigo sobre o quarto centenário do Rio de Janeiro. Aproveitou a oportunidade para "provar a si mesma que podia escrever prosa jornalística rapidamente” (Millier, 1993, p.362), e o artigo foi produzido em três semanas. Bishop, entretanto, criticou as fotos e até mesmo o título dado pelos editores ao texto: para remeter à peça teatral Um bonde chamado Desejo, de Tennessee Williams, utilizou-se o nome de um bairro, o Encantado, citado no verso de um samba. Aliás, os sambas publicados deixam claro o posicionamento político da autora: abrigam desde um pedido ao "ilustre Marechal [Castelo Branco]", até um estribilho com “cassa o mandato dele”, em que a tradução de Bishop desperdiça uma referência irônica à repressão política: "Eu vou pra Espanha; você vai pr'a Uruguay” - a rua que leva ao quartel, não o país. Note-se que nos rascunhos constavam comentários e citações de tom bem diferente, como a referência a um samba em que a jovem vai à praia "vestindo só uma serpentina”. Também desaparecem, na versão publicada, a referência a Clementina de Jesus e a citação de poemas de Bandeira e Drummond, anunciadas nos rascunhos. Neste artigo encontra-se uma das frases mais citadas de Bishop, "Não, não é uma cidade maravilhosa; é apenas o cenário mais maravilhoso para uma cidade”, que provocou a ira dos cariocas. $O$ Correio da Manhã publicou uma crítica feroz à autora, que estaria "trepada nas muletas do seu racismo superioritário" (Castro, 28 mar. 1965), o que a desgostou profundamente. Afinal, segundo Carmen Oliveira (1995, p.147), “o leitor brasileiro não conhecia o seu texto, cheio de ironias e understatements, apenas aquela leitura abusada”. Bishop escreveu uma carta ao jornal, traduzida por Lota e publicada um mês depois, buscando, sem sucesso, desfazer o mal-estar.

"On the railroad named Delight". Publicado em The New York Times Magazine, March 7, 1965, p.30-31, 84-85. Nos arquivos da escritora (Vassar College, Special Collections, Box 47, Folder 1) constam anotações e rascunhos relacionados a esse artigo, num total de 15 páginas, arquivados como rascunhos para o livro "Brazil [1960-1962]". Republicado em Bishop, 2008, p.438-448. 


\section{No trem do Encantado ${ }^{1}$}

No Hemisfério Ocidental a comemoração dos quatrocentos anos de uma cidade é um evento raro, por isso o Rio de Janeiro está celebrando seu quarto centenário durante todo o ano de 1965.

Tudo começou na noite de Ano Novo, à meia-noite, ou mesmo algumas horas antes. Houve um grande desfile de bandas e dançarinos pela Avenida Getúlio Vargas, no centro da cidade - e à meia-noite (hora do Rio) o Papa Paulo VI apertou um botão no Vaticano e iluminou, com um novo conjunto de holofotes, a figura do Cristo Redentor que contempla a cidade do topo do Corcovado. Aviões da Força Aérea lançaram uma "chuva de prata" de pedaços de papel metalizado, nos quais constava o nome do Banco do Estado.

Aquela era, também, a noite de Iemanjá, deusa do mar, e seus devotos apinharam Copacabana e as outras praias. Trincheiras de formato cabalístico foram cavadas acima da linha de maré alta, e acenderam-se milhares de velas brancas dentro delas. Por toda a areia foram espalhadas flores brancas, em geral lírios, e consumiram-se grandes quantidades de bebida alcoólica "branca", chamada cachaça. Filas de meninas e mulheres, todas de branco, mãos dadas, e homens de branco, sozinhos, entraram na água e caminharam em direção às ondas, cantando hinos em louvor de Iemanjá e jogando seus feixes de flores o mais longe possível.

Esse conjunto de eventos formava uma mistura carioca - ou seja, do Rio de Janeiro completa: latina e africana, católica e pagã; suavemente militar, com um toque de progresso; um pouco desorganizada, mas com grande dose de beleza inesperada.

\footnotetext{
${ }^{1}$ No New York Times, abaixo do título, consta: "Os trabalhadores do Rio de Janeiro vivem reclamando, mas amam sua cidade, que faz 400 anos". Em seguida, apresenta-se a autora, que "vive no Brasil desde 1952". Na carta em resposta à crítica publicada no Correio da Manhã, Bishop diz: "São criticadas as fotografias e as legendas que apareceram junto com meu artigo. No meu caso, não tive nada a ver com esta seleção. Não a aprovo. Três semanas antes de ler o que o sr. Castro escreveu, aliás, escrevi ao New York Times reclamando delas, e também do título, que não é de minha autoria" (Bishop, 27 abr. 1965). As fotos reunidas em duas páginas receberam esta legenda: "Nenhuma outra cidade do mundo pode superar a beleza do cenário do Rio de Janeiro. Mas a atração do Rio deve-se, também, ao seu povo e à vida agitada da cidade. Cariocas ensaiam para os desfiles de Carnaval deste ano. Uma favela no alto de um morro (com vista); um condutor de ônibus irrita-se com o 'troco', sintoma da inflação brasileira; crianças na praia de Copacabana, e, supervisionando a cidade, um marco, a estátua do Cristo Redentor". Em outra página: "Os bondes do Rio estão sempre lotados. A topografia da cidade transforma o transporte num pesadelo".
} 
Agora, a maior festa anual - o Carnaval, os quatro dias que precedem a Quarta-feira de Cinzas - já veio e passou. Como sempre, a primeira noite, sábado, foi reservada aos bailes de gala - e o mais luxuoso é o do Teatro Municipal. Esses bailes são na verdade concursos de fantasia. Ninguém economiza, e os vencedores sempre estão vestidos com o mais extravagante mau gosto. $^{2}$

Na noite de domingo tivemos os desfiles de dançarinos - primeiro, os frevos, uma dança frenética do Norte em que as pessoas se agacham, depois dúzias de "escolas" de samba, cada uma com centenas de membros em verde e rosa, prata e azul, vermelho e branco. $\mathrm{Na}$ tradição do Carnaval, os desfiles estendem-se por toda a noite (e deve-se lembrar que esta é a estação chuvosa no Rio), com as melhores escolas reservadas para o final, dançando bravamente pela avenida ao nascer do sol.

Na noite de terça-feira vieram os ranchos, enormes carros alegóricos, muitos dos quais mecanizados exibindo rodas que giravam, flores que se abriam e gigantes com olhos que piscavam. Este ano, em honra ao quarto centenário, muitos retrataram cenas reais ou imaginárias da história do Rio.

Durante todo esse período ninguém trabalhou. Edifícios públicos, bancos e lojas estavam todos fechados. Embora a moda atual, entre os mais ricos e mais sofisticados, seja abandonar o Rio durante o Carnaval, as ruas estavam abarrotadas todas as noites. Durante o dia, a população se recuperava em casa. E houve uma quantidade muito baixa de bebedeiras ou desordens. Este ano, os tradicionais lança-perfumes, frascos que espirram um fino jato de éter aromatizado, provocando um choque agudo e uma sensação de gelo sobre a pele, foram banidos por serem considerados perigosos. Eles já foram banidos antes - também com pouco efeito.

Os visitantes no Rio de Janeiro costumam exclamar: "Que cidade maravilhosa". Porém, cedo ou tarde os mais atentos acabam dizendo: "Não, não é uma cidade maravilhosa; é apenas o cenário mais maravilhoso para uma cidade".

\footnotetext{
${ }^{2}$ Comenta Fernando de Castro (28 mar. 1965): “as concorrentes à linda competição de fantasias de alto luxo, e requintado bom gosto, são postas pela cronista do New York Times Magazine no pelourinho de uma crítica severa".
} 
A Baía de Guanabara é uma das maiores enseadas naturais do mundo, e muitos viajantes a consideram a mais bela. Picos agudos de granito elevam-se à sua volta quase direto da água, numa série de fantásticos formatos que sugeriram nomes simples aos primeiros navegantes portugueses que aqui chegaram: Pão de Açúcar, Gávea, Leme, Dois Irmãos, Corcunda (ou Corcovado).

As montanhas ficam tão perto do oceano que a umidade dos ventos marítimos se condensa rápido e nuvens flutuam muito baixo em torno delas. Isso produz umidade considerável; os mais implicantes reclamam que a prataria escurece rápido e que seus sapatos emboloram nos armários. Mas a umidade também dá à atmosfera uma leveza que constitui um dos charmes do Rio. Mesmo com o tempo aberto, os objetos distantes são banhados por uma luz rósea ou azulada - sonhadora e delicada.

Os picos de granito também abrigam todo tipo de vegetação tropical. Cipós pendem das árvores e palmeiras selvagens balançam nos topos - entre os bairros e sobre eles - com um efeito romântico que a diferencia de qualquer outra cidade.

Com toda essa beleza, o cenário não se sujeita ao planejamento urbano. Por quatrocentos anos a cidade cresceu devagar entre os picos, em todas as direções - e tomou a forma de uma estrela-do-mar assimétrica.

Assim como na maioria das capitais (e o Rio foi uma delas até que o governo transferiu-se para a recém-construída Brasília, em 1960), a maioria da população parece ter vindo de outro lugar. Os brasileiros mais pobres - do Norte e do Nordeste - chegam em levas crescentes há vinte anos ou mais. Agora eles vêm acotovelados em velhos ônibus ou em caminhões repletos de bancos chamados paus-de-arara. ${ }^{3}$

Uns arranjam trabalho; outros ficam desempregados. Alguns mudam-se mais uma vez. Mas pouquíssimos voltam para casa, porque a vida na cidade - que pode ser bem miserável ainda assim é mais divertida e satisfatória que a vida nas pequenas cidades e vilas mortas de onde eles vêm.

Essas pessoas saturam as tristes e notórias favelas ${ }^{4}$ do Rio. Pessoas mais prósperas e ambiciosas, jovens brilhantes em busca de diplomas universitários, jovens burocratas e

\footnotetext{
${ }^{3}$ Em português, arraras [sic].

${ }^{4}$ Em português, favellas [sic].
} 
políticos também se dirigem em grande número para o Rio. Mesmo entre os cariocas "verdadeiros" existem muitos que são cariocas há apenas uma ou duas gerações - quando a família deixou a velha fazenda ${ }^{5}$ (ou propriedade rural) e mudou-se para a cidade definitivamente.

Embora São Paulo seja hoje uma cidade bem maior e mais rica, muitos intelectuais preferem viver aqui. O Rio ainda é a capital intelectual do país. Em seus extremos de riqueza e pobreza, ele espelha a inflação trazida pelo arriscado processo de industrialização do expresidente Juscelino Kubitschek e pela corrupção que floresceu sob o seu governo e o de seu sucessor, João Goulart. É a cidade que reflete as incertezas da nação inteira desde que um golpe militar, em março e abril do ano passado, derrubou Goulart e instalou o marechal Humberto Castelo Branco na presidência. Além disso, depois de quatrocentos anos, é uma cidade que cresce e se degrada.

Houve uma campanha "Pinte o Rio": nos jornais, saíram fotos dos presidentes de empresas de tintas doando galões para as freiras que dirigem orfanatos. A arrumação é muito necessária: mesmo o glamouroso bairro de Copacabana está repleto de edifícios residenciais de dez andares com as paredes manchadas e descascadas.

Algumas partes da cidade ganharam nova sinalização, também muito necessária. Ela acende à noite, o que é muito útil, porque o Rio é uma cidade sombria nesta época, mas traz anúncios além dos nomes das ruas, e foi considerada comercial e de mau gosto.

Em contraste com a decrepitude geral existe o novo Parque do Flamengo, com uma nova praia, jardins, coreto e pista de dança, um teatro de marionetes e um play-ground. É sem dúvida o melhor presente de aniversário da cidade para os seus habitantes, e, embora só três quartos do parque estejam completos, dezenas de milhares de pessoas já o frequentam.

O Parque do Flamengo é estreito, mas tem quase seis quilômetros de comprimento e se estende do centro comercial da cidade para sudoeste, ao longo da Baía de Guanabara. Agora ele lembra um atol tropical, verde, surgido da água, mas é o resultado de três anos de trabalho duro sobre uma desesperançada e medonha faixa de lama, sucata, canos e vias expressas que foi conhecida, durante muito tempo, como "o aterro". Essa é a única contribuição estética do governo Carlos Lacerda para a cidade e seus subúrbios.

A maioria das praias foi um pouco recuperada. Copacabana acaba de assistir à demolição de seus "postos" de salva-vidas - tão depressa como os marcos desaparecem em

\footnotetext{
${ }^{5}$ Em português.
} 
Nova York. Durante anos, os cariocas disseram: "Eu vivo entre o posto três e o posto quatro", ou: "Me encontre no posto seis", e será estranho não ter mais esses pontos de referência.

Por causa do quarto centenário, os hotéis estão lotados de turistas brasileiros e estrangeiros. Velhas senhoras americanas com roupas estampadas e óculos de sol caminham determinadas pelas calçadas de mosaico, em busca de algo para fazer. O problema é que não existe nada, ou quase nada, para fazer. O Rio ainda não está pronto para o turismo ${ }^{6}$ de larga escala. O trocadilho atual consiste em falar do Quarto Centenário como o Quarto Sem Ter Nada. ${ }^{7}$ Falando depressa, as duas expressões soam muito parecidas. Enquanto isso, dois ou três navios de luxo chegam toda semana com mais turistas.

Lançou-se um barco para passeio pela cidade, algo que o Rio necessitava há muito tempo, uma vez que sua maior atração ainda é a fabulosa baía, com suas ilhas. Oito gôndolas foram encomendadas para a Lagoa, uma grande e fechada extensão de água ao sul da cidade. De acordo com os jornais, essas gôndolas foram "copiadas de um modelo em bronze que o governador Lacerda trouxe da Itália" e terão "uma cobertura em veludo vermelho". Estão previstos motores, também, para quando estiver quente demais para remar. Dois novos bondinhos vão fazer a viagem até o topo do Pão de Açúcar. Ainda de acordo com os jornais, a "visibilidade" destes será melhor em comparação com os antigos. Mas isso é difícil de acreditar: como é que o panorama pode ser melhorado ${ }^{8}$

Embora o ritmo da cidade se acelere cada vez mais, no Rio ainda é possível parar e ficar observando. Os homens permanecem em grupos nos bares do Centro ou junto às bancas de jornal, para discutir as últimas notícias políticas ou para ver as jovens que passam. Os

\footnotetext{
${ }^{6}$ Em português, tourismo [sic].

${ }^{7}$ Em português, com a explicação: without a thing.

${ }^{8}$ Fernando de Castro (28 mar. 1965), diante da ironia de Bishop, escreve: "Mas o que muito impressionou Mrs. Bishop foi o anúncio dos novos bondinhos do Pão de Açúcar, que prometem uma vista melhor do panorama. Ela não pode compreender como é possível melhorar a paisagem ... e ninguém lhe explicou que o panorama será sempre o mesmo, e que a melhoria anunciada é a dos bondinhos, que propiciarão, naturalmente, um ângulo melhor à visão...".
} 
visitantes sempre se surpreendem com a quantidade de homens que estariam - na expressão de Henry James - no downtown em Nova York, mas, aqui, estão nas praias às 10 da manhã nos dias úteis. Isso não significa que os cariocas não trabalhem duro, quando eles trabalham. Os cariocas apenas agem de um modo diferente. ${ }^{9}$

Na realidade, muitas pessoas têm um segundo emprego. Com a inflação atual, é difícil imaginar como os trabalhadores ou a classe média conseguiriam sustentar-se, se todos, até a mais humilde babá ou o vendedor de bilhetes de loteria, não tivessem algum pequeno "negócio" além do seu trabalho.

Surgiram algumas propostas para se estender o Carnaval para uma semana inteira, em honra ao Quarto Centenário, em vez dos usuais quatro dias, mas afinal até mesmo o Rio desanimou e a ideia foi abandonada. Os sambas do Carnaval, no entanto, já estavam no ar semanas antes; todas as noites, grupos passavam cantando e dançando pelas ruas com seus tambores, ensaiando. O trânsito parava, ou desviava em torno deles, e meninos iam acompanhando. Nenhum carioca resiste a esse ritmo: a cozinheira samba na cozinha, e os convidados na sala movem-se inconscientemente (a palavra é rebolar ${ }^{10}$ ) enquanto continuam conversando.

Os sambas, as marchas e outras músicas de Carnaval são a poesia viva dos cariocas pobres. (As palavras "rico" e "pobre" ainda estão em uso aqui, embora tenham saído de moda nas partes mais abastadas do mundo.) Suas canções sempre foram compostas sobre algo que estivesse na cabeça deles: obsessões, modas passageiras, fantasias e queixas; amor, pobreza, bebida e política; seu amor pelo Rio, mas também os três problemas perpétuos do Rio: água, luz e transporte. ${ }^{11}$ Como diz um velho samba:

\footnotetext{
${ }^{9}$ Fernando de Castro (28 mar. 1965) comenta apenas as primeiras frases: "Simplória, simplória mais que o normal, também a cronista não pode compreender como há tantos homens 'desocupados' às portas dos cafés, olhando as moças que passam ... ou às 10 horas da manhã, tomando gostosos banhos de sol nas areias de Copacabana".

${ }^{10}$ Em português.

${ }^{11}$ Os quatro sambas traduzidos por Bishop foram incluídos em The complete poems (Bishop, 1983, p.263-264; reproduzidos em Bishop, 2008, p.300), na seção Translations, como "anônimos", embora todos os compositores sejam conhecidos. Tanto no New York Times como nas duas coletâneas consta apenas a tradução de Bishop; aqui, foi incluída a letra original. Nos Complete poems consta este comentário antes dos sambas: "No Rio de Janeiro, dúzias de novos sambas são compostos todo ano, para o Carnaval. Embora os sambas relacionados ao amor sejam mais numerosos que todos os demais, alguns sempre se referem a eventos mundiais, tais como a descida do homem na lua, a política brasileira e a vida em geral. Esta amostra de 1965, um ano após a revolução 'de direita' [the 'rightist' revolution], comenta ou ridiculariza as faltas de luz, as
} 
Rio de Janeiro,

My joy and my delight!

By day I have no water,

By night I have no light
Rio de Janeiro,

Cidade que me seduz!

De dia falta água,

De noite falta luz. ${ }^{12}$

Um dos sambas deste ano mostra a reação honesta das massas à "revolução" do ano passado:

Kick him out of office!

He's a greedy boy!

I've nothing to investigate,

What I want is joy!

Justice has arrived!

"Pull” won't work again!

Some have fled to Uruguay;

Some have fled to Spain!

Kick him out of office!
Cassa o mandato dele!

Eu que não tenho nada

Pra ninguém fiscalizar

Eu quero é gozar!

A justiça chegou!

Não há filho pra pai

Eu vou pra Espanha;

Você vai pr'a Uruguay

Cassa o mandato dele! ${ }^{13}$

E aqui está a última versão do comentário que se repete todos os anos sobre a Central, o trem de subúrbio que transporta milhares de pessoas dos enormes subúrbios na Zona Norte para o trabalho. Ela é endereçada ao presidente Castelo Branco:

Marshál, Illustrious Marshál,

Consider the problem

Of the suburbs on the Centrál!

I'm sorry for poor Juvenal,
Marechal, ilustre Marechal,

Olha o problema

Do subúrbio da Central

Eu tenho pena do Juvenal,

trocas no governo e os péssimos trens urbanos" (1983, p.263-264). Note-se que o primeiro dos quatro é "um velho samba" (de 1954), como a própria autora afirma no New York Times, e não de 1965.

${ }^{12}$ Este primeiro é "Vagalume", de Vitor Simon e Fernando Martins, lançado em 1954: "Rio de Janeiro/ Cidade que me seduz/ De dia falta água/ E de noite falta luz// Abro o chuveiro/ Não cai um pingo/ Desde segunda/ Até domingo.../ Eu vou pro mato/ Ai, pro mato eu vou/ Vou buscar um vagalume/ Pra dar luz ao meu chatô".

13 "Cassa o mandato dele", marcha, letra e música de Paquito, Romeu Gentil e Moreira da Silva, gravação de Moreira da Silva. Na versão de Elizabeth Bishop para o inglês perde-se um dado irônico fundamental. Os versos originais dizem: "Você vai pr'a Uruguay", referindo-se ao Quartel da Polícia do Exército, na rua Barão de Mesquita, Tijuca, junto à rua Uruguai, um dos locais onde se interrogavam e detinham, no Rio de Janeiro, prisioneiros políticos naquela época. A tradução de Bishop seria, literalmente: "Cassa o mandato dele! / Ele é um rapaz ganancioso! / Não tenho nada pra investigar, / O que eu quero é gozar! / A justiça chegou! / Não vai trabalhar de novo! / Uns fugiram pro Uruguai; / Uns fugiram pra Espanha!" 
Hanging in the old Central

All year long

He works in Leblon

And lives in Delight,

And gets to work mornings

Late at night.
Pendurado o ano inteiro

Num vagão da Central

Trabalha no Leblon

E mora no Encantado, ${ }^{14}$

Chega sempre

No trabalho atrasado. ${ }^{15}$

Por causa de sua topografia difícil, mas vigorosa, os problemas de trânsito no Rio são um pouco piores que nas outras grandes cidades. O governador Lacerda nomeou um homem valente da aeronáutica, coronel Fontenelle, para ver se ele resolve os problemas. Primeiro, para confusão e irritação de todos, ele inverteu a direção de quase todas as ruas de mão única; depois, atacou o estacionamento em filas duplas, triplas e - alguns juram - quádruplas. Seu sistema é simples: a polícia esvazia os pneus dos carros estacionados de maneira irregular.

Pode-se dizer que essa medida, considerada "dura" demais pelos cariocas despreocupados, foi até certo ponto bem-sucedida. Por falar nisso, as viagens de ônibus pela cidade ficaram mais rápidas. Este ano ao menos três sambas se referem à campanha do coronel Fontenelle (com os ruídos apropriados). O mais estranho é que esses sambas foram compostos, e na maioria das vezes são cantados (e assobiados), por pessoas que nunca tiveram e nem sonham em ter carro.

As letras dos sambas dependem sempre da música, e alguns dos mais perenes e musicalmente mais belos têm as letras mais corriqueiras. O amor - amor leve ou sério infidelidade, prostituição, perseguições policiais e filas (o assunto de um samba muito bonito este ano), luar, praias, beijos, desilusão amorosa, e mais uma vez o amor:

Come, my mulatta,

Take me back.

You're the joker

In my pack,

The prune in my pudding,
Vem cá, mulata

Tem paciência

Você é o coringa

Da minha sequência

Pimenta do meu pastel

\footnotetext{
${ }^{14}$ Uma nota do New York Times explica, neste ponto, que os dois bairros (Leblon e Encantado) estão situados "Nos extremos opostos da cidade".

${ }^{15}$ Samba "Juvenal", de Wilson Batista e Jorge de Castro, cantado por Angelita Martinez. A tradução de Bishop seria, literalmente: "Marechal / Ilustre Marechal / Considere o problema / Dos subúrbios da Central / Eu tenho pena do pobre Juvenal / Pendurado no velho trem da Central / O ano inteiro ... / Ele trabalha no Leblon / E mora no Encantado / E sai pro trabalho de manhã / Antes do sol raiar". Note-se que Bishop traduz "Encantado", incorretamente, por delight. O nome do bairro significa "Enfeitiçado" (bewitched, por exemplo), uma vez que deriva do desaparecimento misterioso de um português, com sua carroça, no rio Faria.
} 
Pepper in my pie,

My package of peanuts,

The moon in my sky.
Ameixa do meu pudim

Você é a lua do meu céu

Meu pacotinho de amendoim. ${ }^{16}$

É impossível dizer quanto tempo ainda o samba vai conseguir enfrentar o comercialismo, a televisão e o rádio; já existem sinais de deterioração. A nova prática de transmitir os sambas com alto-falantes mesmo durante o Carnaval é catastrófica, uma vez que o povo não pode, ou não consegue, cantar da maneira tradicional.

Ironicamente, o que pode ser o beijo da morte sobre a espontaneidade do samba é que os jovens ricos, depois de anos de devoção ao jazz norte-americano, o descobriram. Poucos anos atrás eram raros os brasileiros, na maioria intelectuais, que se importavam com sua cultura popular e levavam o samba a sério, ou iam aos ensaios das grandes escolas nos morros. Este ano, multidões de jovens fizeram esse trajeto, um dos sintomas, talvez, de uma nova consciência social surgida após a "revolução". E alguns dos sambas desta safra mostram uma autoconsciência, ou mesmo uma autopiedade, que há muito haviam sido removidas do velho espírito do samba.

Os poetas também estão compondo música popular, inspirados talvez por Vinicius de Morais, que escreveu as canções do filme "Orfeu Negro". ${ }^{17}$ Agora ele vem se apresentando numa boate, a Zumzumzum, cantando suas músicas. Um jovem imitador de Yevtushenko, do Sul, declamou seus poemas para uma casa lotada no Rio, vestindo pulôver vermelho e calças brancas, sem meias, com o cabelo caindo sobre os olhos. Seu livro chama-se A geração traída. ${ }^{18}$ De fato, a convicção mais ou menos nítida e mais ou menos justificável de ter sofrido uma "traição" parece ser a atitude tanto dos ricos como dos pobres, enquanto para os jovens ricos uma leve subversão é considerada chique. O Castelinho é uma nova boate em

\footnotetext{
16 "Vem cá, mulata", marcha de Fernando Roberto, José Garcia e Jorge Martins, gravada por Gilberto Alves (1964). A tradução de Bishop seria, literalmente: "Vem, minha mulata / Volta pra mim / Você é o coringa / Na minha mão / É a ameixa no meu pudim / Pimenta na minha torta / Meu saco de amendoim / A lua no meu céu."

${ }^{17}$ Filme dirigido por Marcel Camus, vencedor do Oscar de Melhor Filme Estrangeiro e da Palma de Ouro em Cannes.

18 Lindolf Bell (1938-1998), poeta catarinense. Em 1959 entrou na Faculdade de Ciências Sociais da Universidade Federal do Rio de Janeiro. Na realidade, seu primeiro livro teve como título Os póstumos e as profecias (São Paulo: Massao Ohno, 1962).
} 
Ipanema, e sua rica e jovem clientela é chamada de "Comunistas do Castelinho" - ou esquerdistas de salão.

O show mais visto por várias semanas foi "Opinião", mesmo nome de um samba de Zé Kéti, um compositor negro das favelas. O elenco é formado por Nara Leão, uma das primeiras jovens cantoras de "boa família" a surgir no Rio, representando a classe alta; o próprio Zé Kéti, que representa as favelas; e um jovem negro do Norte, João Batista do Vale, representando o trabalhador alienado que vem para a cidade grande. Os três se conhecem, contam suas histórias, cantam, caminham pelo palco, sentam-se sobre caixotes etc., sob o acompanhamento de percussão, flauta e violão. Joan Baez e Pete Seeger são populares agora, por isso alguns spirituals norte-americanos irrelevantes e canções de presos foram incluídos. A sentença de morte de Tiradentes, o herói nacional que foi condenado por rebelião contra Portugal em 1792, é lida em voz alta. Há piadas como esta: "Vermelho? Essa cor está fora de moda".

O que deprime os norte-americanos no público do "Opinião" não é a vaga "mensagem" (considerada audaciosamente de esquerda no Rio) ou o seu amadorismo (que é simpático). É a súbita, triste, estranha sensação de déjà $v u$ : tudo relembra peças montadas por estudantes universitários por volta de 1930 mostrando mineiros do Kentucky, punhos cerrados e poses desajeitadas.

As outras peças continuam em cartaz. ${ }^{19}$ "Todos os meus filhos", de Arthur Miller, é uma delas, e "Como ter sucesso no trabalho sem fazer força" ${ }^{20}$ fez muito sucesso. ${ }^{21}$ Temos "Mirandolina", ${ }^{22}$ de Goldoni, e, é claro, peças como "A moral do adultério", "Vamos nos apaixonar em Cabo Frio" e "Quanto mais nua, melhor". O teatro no Rio está em geral muito

${ }^{19}$ Fernando de Castro (28 mar. 1965) comenta: "Referindo-se ao nosso teatro, nossa hóspede amiga da onça, destaca traduções de peças de autores norte-americanos (está visto!), e faz questão de frisar o sentido baixo, e amoralista, do material da lavra dos autores brasileiros".

${ }^{20}$ Comédia musical de Frank Loesser, escrita em 1961 (cf. nota em Bishop, 2008, p.942).

${ }^{21} \mathrm{Na}$ carta ao Correio da Manhã, a autora diz: "Eu mencionei o título de duas ou três peças americanas baratas ou medíocres que estavam então sendo exibidas no Rio de tal forma que achei que o meu pouco caso delas era evidente por si mesmo. Entretanto, tomou-se o fato de eu mencioná-las como significando que eu só admiro peças que venham dos Estados Unidos... Acho deplorável que peças brasileiras, baratas ou medíocres, sejam produzidas no Rio, mas acho mais deplorável que peças baratas ou medíocres sejam importadas dos Estados Unidos e produzidas no Rio" (Bishop, 27 abr. 1965).

22 "La Locandiera", comédia escrita em 1753, também conhecida pelo nome da protagonista, Mirandolina (cf. nota em Bishop, 2008, p.942). 
defasado em relação às outras artes, e a atuação está num tipo de "bolsão" histórico, por milagre inalterada desde 1910, mais ou menos.

Uma questão está sempre no ar: quando teremos eleições? Elas deveriam ser realizadas este ano; agora foram postergadas para 1966, e ninguém sabe precisar a data, ou o ano. Carlos Lacerda é o único candidato presidencial até agora, pois o ex-presidente Kubitschek está num exílio autoimposto - a maior parte do tempo em Paris - com seus direitos políticos cassados por dez anos.

Se os seus partidários conseguirem encontrar um meio de contornar essa situação, ele sem dúvida ficará muito feliz por concorrer mais uma vez. Embora seus inimigos critiquem o aumento da inflação causado pela política de "progresso industrial a qualquer custo" de Kubitschek e pela construção de Brasília, e acreditem que seu governo tenha sido completamente corrupto, todos concordam em que ele fez alguma coisa. E seus muitos partidários, sobretudo aqueles que enriqueceram durante seu governo, esperam com ansiedade sua volta.

A propaganda a favor de Kubitschek atingiu um grau absurdo. Pobre, pobre Kubitschek, ele foi embora, ele vive num pequeno apartamento em Paris, dirige seu carro e a pior privação de todas para os brasileiros, tão ligados à família - ele ainda não viu seu neto mais novo. Seus inimigos deram a esse movimento o nome bastante carioca de "Operação Coitadinho", um esplêndido exemplo do diminutivo de coitado, "pobrezinho", uma das exclamações mais frequentes nos lábios dos generosos, mas irônicos, brasileiros.

Muitas pessoas se desapontaram quando o presidente Castelo Branco anunciou que não iria se candidatar para um mandato completo. Esperavam que o fizesse, ou ao menos lamentaram que tenha tomado essa decisão cedo demais. Castelo quase não tem apelo demagógico entre as massas, e não procura cultivá-lo. É um homem triste, que ainda lamenta a morte da mulher, ocorrida um ano antes de sua chegada à Presidência, e trabalha firme nesse cargo tão difícil, que ele relutou em aceitar.

Castelo Branco sempre foi respeitado; agora parece estar crescendo a admiração e a confiança nele. Sua dignidade infalível, a recusa em fazer política ou promessas ou belos discursos, sua preferência pela obediência às leis e não às emoções nas emergências - tudo é algo novo no Brasil, e um alívio bem-vindo após a atmosfera histérica dos últimos anos. 
A imprensa é livre, apesar de precipitada, imprecisa e muitas vezes difamatória, e as prisões políticas, que floresceram ${ }^{23}$ após o golpe do ano passado, praticamente acabaram. Quase não se fala mais sobre tortura e brutalidade da polícia e do exército, e pode-se apenas esperar que os brasileiros estejam considerando que uma desgraça nacional foi afinal interrompida, de maneira firme.

A inflação cria uma atmosfera diferente de qualquer outra. Percebe-se até mesmo na maneira como o dinheiro é manuseado: velhas notas amassadas, formando grandes maços. Motoristas de ônibus não dão mais o troco exato e nem esperam pelo valor correto; não existe troco. No entanto, os lojistas dão aos filhos dos clientes um pedaço de doce. O preço do táxi subiu tantas vezes que os medidores estão muito defasados. Agora, o preço é o dobro do que o taxímetro anuncia, durante o dia. À noite, é mais ou menos o que o motorista cobrar.

No Rio, a inflação quase perdeu a capacidade de chocar; ao menos, as pessoas não falam dela a toda hora, como faziam há mais ou menos um ano. O salário mínimo foi elevado seguidas vezes, mas nunca o suficiente. Os pobres encaram a inflação de maneira mais resignada que qualquer outra classe, uma vez que nunca puderam poupar. Alguns ricos estão ficando, sem dúvida, mais ricos. É a minúscula classe média que vem sofrendo mais. Todos os olhos estão fixos nos movimentos do dólar, como num tipo de Estrela Polar, e os humores podem ser descritos como entorpecidos, mas um pouco mais esperançosos que no passado.

Pela primeira vez, o governo brasileiro está aderindo a um esquema de planejamento econômico; houve novas entradas de capitais externos e o ritmo da inflação deve ter diminuído. Os preços da gasolina e do pão estão subindo, porque o governo eliminou os subsídios altos, insustentáveis. A luta contra a inflação deve ser lenta e cautelosa no Brasil. Por causa da ignorância e do analfabetismo - e do permanente ceticismo também - nenhuma medida forte contra a inflação pode ser explicada ao povo. O governo não pensa em interromper projetos de obras públicas, mesmo que eles estejam drenando o Tesouro; isso seria considerado "duro" demais. Salários e preços continuarão subindo durante algum tempo, embora se espere sua estabilização este ano.

\footnotetext{
${ }^{23}$ A autora relaciona "florescer" com o fato de o golpe ter ocorrido na "última primavera" (do Hemisfério Norte).
} 
Mas a despeito do abandono, das deficiências, das súbitas e desconcertantes mudanças para pior, em produtos básicos, e da inflação, a vida no Rio tem compensações. O Carnaval já passou, mas logo chegará o dia de São João, o segundo feriado mais importante do ano; depois, o dia de São Pedro. Para os intelectuais, uma grande exposição de pintura contemporânea francesa será aberta em julho, em honra do Quarto Centenário, e depois a Espanha vai mandar um balé e uma ópera de De Falla. Teremos também uma série de concertos com composições do padre José Maurício, o padre-compositor carioca do século XVIII.

Muito mais duradoura e importante que esses pequenos divertimentos, numa cidade que é hoje essencialmente provinciana, é outra compensação para aqueles que têm de enfrentar as dificuldades da vida no Rio. Um exemplo vai esclarecer a questão. Há pouco tempo, um grande anúncio mostrava uma jovem cozinheira negra maravilhada com um novo fogão a gás, inclinada sobre um dos lados do fogão, na direção da sua patroa branca, que, por sua vez, se inclinava sobre o outro lado, e se beijavam no rosto. ${ }^{24}$

Uma vez que a situação não é utópica, em termos sociais, e que o anúncio é bobo poderia ter aparecido em outdoors ou em jornais de Atlanta, Geórgia, ou até de Nova York? No Rio, passou totalmente despercebido, de um jeito ou de outro. ${ }^{25}$

\footnotetext{
${ }^{24}$ Os comentários de Bishop sobre esse anúncio foram analisados por John Gledson no ensaio "Brasil: cultura e identidade" (2006, p.359-380), onde afirma que a autora é "a visitante mais sensível e perceptiva que o Brasil talvez já tenha recebido" (p.369).

${ }^{25} \mathrm{Na}$ carta que enviou ao Correio da Manhã, Bishop diz que o seu artigo termina da seguinte maneira: "Muito mais duradoura e importante do que outros prazeres (referindo-se a concertos e exibições de arte), é esta outra compensação para os que têm que enfrentar as dificuldades da vida no Rio. Um exemplo demonstrará o que digo. Recentemente, um grande anúncio mostrava uma jovem cozinheira de cor, feliz pelo prazer de ter um novo fogão, beijando a sua jovem patroa no rosto... Fato é que esta situação não é, socialmente falando, utópica, apesar do anúncio ser simples, mas poderia ele jamais ter aparecido em cartazes ou jornais de Atlanta, Ga, ou mesmo em Nova York? No Rio esse anúncio passou totalmente despercebido, de uma maneira ou de outra". E completa: "A resposta a esta minha pergunta retórica seria: não, um anúncio como este não poderia aparecer nos Estados Unidos, o que é uma pena. $\mathrm{O}$ fato de que ninguém no Rio sequer comentou este anúncio, contra ou a favor, que eu saiba, tomei como uma bonita e clara demonstração do fato de que o Brasil já atingiu a um estágio avançado e altamente civilizado de integração racial. E a moral da história, que deve ser óbvia a qualquer um, é que as relações inter-raciais são melhores no Brasil do que nos Estados Unidos. Mas, foi interpretada como prova de minhas 'convicções racistas'.” (Bishop, 27 abr. 1965).
} 


\section{Uma viagem pelo rio São Francisco [1967]}

Elizabeth Bishop viajou pelo rio São Francisco num "gaiola", de Pirapora (MG) a Petrolina (PE), em maio de 1967, e assim surgiu o último de seus esboços em prosa sobre o Brasil. Sua relação com o país, que já vinha se deteriorando, iria piorar sensivelmente pouco depois, com a morte de Lota. Embora interrompido, nota-se que o esboço foi retrabalhado e já começa a tomar a forma dos textos em prosa que Bishop apresentava para publicação. Nesse sentido, é bem diferente da narrativa de 1960, sobre a "Viagem pelo Amazonas", repleta de lacunas e frases soltas. No texto sobre o São Francisco a autora chega a traçar alguns paralelos com a viagem anterior. Apoia-se nas informações contidas em reportagem da revista Quatro Rodas, seu "único livro-guia confiável”, e as confronta com o que vê. Numa carta escrita em Salvador ao final da viagem, dirá que "teria desistido se fosse possível voltar atrás. Depois começou a melhorar - e agora, em retrospecto, e tendo passado três dias colocando tudo no papel, gostei de ter feito o que fiz” (Bishop, 1995, p.509). Comenta, nessa carta, que nunca viu "tanta miséria”, e completa, entre parênteses: "vou ter que falar nisso no meu artigo", embora "esse tipo de coisa deixe os brasileiros muito tristes e zangados, o que é compreensível” (p.510). Dez anos depois, recordará em entrevista: "Eu gosto de viagens sossegadas, monótonas. Oito dias no barco, indo até onde é possível” (em Monteiro, 1996, p.78). Embora afastada do Brasil há muito tempo, Bishop ainda demonstra

preocupação com o futuro do São Francisco, que "está desaparecendo porque estão usando as quedas d'água para gerar energia hidrelétrica. Já existem poucos barcos, e a água está diminuindo" (p.78).

Originais em Vassar College, Special Collections; Box "Prose Unpublished”, Folder 55.4, 8p. Datilografado; sem data; título datilografado: "A trip on the Rio São Francisco". 
Como todo cidadão norte-americano cuidadoso em viagem, na manhã seguinte à minha chegada a Salvador, no estado da Bahia, Brasil, eu lavei algumas roupas no meu quarto de hotel e as pendurei em cabides, nos suportes das cortinas do chuveiro, nas fechaduras das janelas. Só algumas, porque eu havia feito uma viagem de nove dias pelo Rio São Francisco, sem serviços de lavanderia para os passageiros, embora a metade feminina da população ao longo das margens parecesse despender a maior parte do seu tempo lavando roupas, louças ou crianças no rio. Mesmo depois de duas lavagens com Flocos LUX - Indispensável ${ }^{1}$ e de vários enxágues, a última água ainda estava amarelo-amarronzada, a cor das águas do rio, ou talvez um tom mais claras que elas, e dois tons mais claras que a maior parte dos bancos de lama nas margens, secos nesta estação. Essa era também a cor da maioria das roupas que eu vi, estendidas ao longo de mil e quinhentos quilômetros em cada uma das margens; a cor de muitas das pessoas, da maioria das casas, e de tudo mais - cavalo, cão, porco, galinha; casa, igreja ou coreto, que haviam nascido brancos, ou que no início haviam sido pintados de branco.

O rio tem cerca de três mil quilômetros de extensão e é o maior do país, depois do imenso Amazonas. Ele nasce no leste, no estado de Minas Gerais, e corre quase em linha reta para o norte até o estado de Pernambuco, onde se volta para sudeste, seguindo nessa direção até encontrar o Atlântico. Eu naveguei num barco a vapor com rodas de pás, desde o ponto em que ele se torna navegável, em Pirapora, Minas, até Petrolina e Juazeiro, cidades gêmeas, uma em cada margem, uma em Pernambuco, a outra na Bahia. Abaixo de Juazeiro o rio deixa de ser navegável, exceto para barcos muito pequenos, até abaixo da Cachoeira de Paulo Afonso. (Dizem que o cenário abaixo dessa cachoeira é soberbo, ${ }^{2} \mathrm{e}$ as próprias quedas são um “magnífico horror". O explorador Richard Burton, em The Highlands of the Brazil, ${ }^{3}$ chama-a de "a rainha das cachoeiras", e diz que ela lhe deu uma impressão de "Poder tremendo, inexorável, irresistível". Ele estava correto acerca do poder, uma vez que lá existe, agora, a maior hidrelétrica do Brasil. Mas a impressão fornecida pelos trechos superiores do rio é sem dúvida muito diferente, como eu tentarei mostrar.) ${ }^{4}$

\footnotetext{
${ }^{1}$ Em português.

2 No alto, manuscrito: "\& algum dia eu tenho de ver essa região".

${ }^{3}$ Explorations of the Highlands of the Brazil: with a full account of the Gold and Diamond mines. Also canoeing down 1,500 miles of the great river São Francisco, from Sabará to the Sea. By Captain Richard F. Burton F.R.G.S. etc., London: Tinsley Brothers, 1869; Publicado no Brasil como Viagens aos planaltos do Brasil, 1868, tradução de Américo Jacobina Lacombe. São Paulo: Cia. Ed. Nacional, 1941.

${ }^{4}$ A autora rasurou o final, "tentarei mostrar".
} 
Cheguei a Pirapora uma noite no meio de maio, de ônibus, após uma viagem de um dia desde Belo Horizonte. Eu estava com outras catorze pessoas, um "passeio guiado" (embora também o guia nunca tivesse visto o rio, antes disso), porque esse parecia ser o único meio possível de fazê-lo, no estado atual de navegação no rio, para tomar um barco, e também porque me haviam prometido uma cabine com banheiro. (Um apartamento ${ }^{5}$ - qualquer quarto-com-banheiro no Brasil é um apartamento.) O passeio era oferecido para trinta e seis pessoas, que ficariam na primeira classe, ou seja, teriam o convés intermediário só para elas, mas éramos apenas quinze. Todos eram brasileiros, de São Paulo ou de seus arredores, exceto por mim e por um jovem sueco de Santos. Ele era, por uma grande diferença, o mais alto de nós, e nós dois éramos os únicos de olhos azuis a bordo. Ele era também o mais jovem, com a possível exceção de um par de irmãs sem idade definida, que pareciam quase idênticas. Por outras razões raciais misteriosas, ou talvez apenas por questões de dieta, todos exceto o sueco e eu eram gordos, em alguns casos extremamente gordos. Eu menciono esse fato porque ele se tornaria importante durante nossa longa, longa e fantástica viagem juntos, rio abaixo.

Pouco antes de Pirapora nosso ônibus atravessou o rio, muito largo e raso nesse ponto, por uma ponte com no mínimo um quilômetro e meio de comprimento, com sete vãos de ferro; viramos à esquerda para o norte, e assim chegamos à minúscula "cidade". Percorremos uma das suas duas ou três ruas mal pavimentadas com pedras e uma outra de fina areia do rio, até chegarmos a um barco a vapor amarrado à margem enlameada. Um pôr do sol espetacular estava começando. (E não é necessariamente correto o que os viajantes costumam relatar, que o sol se põe em poucos minutos nos trópicos, e a noite cai de imediato. Esse pôr do sol pareceu estender-se por horas.)

Minha primeira impressão de Pirapora - e também a última, quando partimos no dia seguinte, ao meio-dia - consistiu em porcos, muitos, muitos porcos, a maioria preta, mas por vezes brancos com manchas pretas. Eles apareceram em todas as paradas ao longo do rio, mas os maiores estavam em Pirapora. Uma grande leitoa branca com manchas pretas e oito leitõezinhos pretos chegou antes dos demais para nos ver; logo eles estavam acompanhados por alguns cães vira-latas. A leitoa e os cães sentaram-se em fila e nos olharam; os leitõezinhos fuçaram a areia excitados, grunhindo. Havia também muitas cabras brancas e pretas. Essa cena se repetiria inúmeras vezes antes de chegarmos a Juazeiro, e o único aspecto que a tornava interessante era o estranho olhar humano de inteligente curiosidade que os animais nos dirigiam, e a forma como eles se alinhavam, da mesma maneira como as pessoas

\footnotetext{
${ }^{5}$ Em português.
} 
o faziam, para nos absorver pelos sentidos, para aproveitar ao máximo nossas curtas paradas. Também é importante destacar que os vira-latas, quase sempre com pêlos compridos, pareciam ter notáveis expressões doces e nunca latiam para nós. De vez em quando um grande cachorro perseguia um pequeno porco, ou vice-versa, ou um peru tinha uma crise histérica, mas em geral uma espécie convivia com as demais, pacificamente.

O rio em Pirapora estava repleto de pedras pretas; corredeiras rasas e quedas surgiam brancas entre elas, em meio ao amarelo-marrom geral da água. Ele era pontilhado com pequenas ilhas verdes e moitas de altas taquaras; com cuidado talvez fosse possível caminhar através delas. Mulheres ainda estavam lavando roupa; peças estranhas ainda estavam secando nas margens e sobre as pedras próximas, enquanto o maravilhoso pôr do sol se aproximava. $\mathrm{O}$ céu se tornava mais brilhante e vermelho a cada minuto, e a água, vermelha e espelhada. As roupas a serem lavadas estavam róseas, e as grandes bacias de alumínio, nas cabeças das mulheres que voltavam para casa, captavam a luz. Esse início de nossa viagem foi pacífico, grandioso, mas em algum sentido triste, talvez porque quase em total silêncio.

Certa vez eu fui ao Brasil num cargueiro americano, um navio mal cuidado e sujo. ${ }^{6}$ Na primeira vez que nos reunimos para a demonstração dos botes salva-vidas eu notei entre a tripulação - que quase nunca usava algum tipo de uniforme - um marinheiro muito desarrumado. Ele era gordo e de meia-idade, com grandes bigodes, e vestia um boné sujo de linho branco, uma camisa listrada grande demais, algo que se parecia com calções de tweed antiquados e sapatos brancos - no conjunto, o melhor exemplo de "marinheiro de água doce" que eu já vi. Mais tarde cheguei a conhecê-lo um pouco. Era brasileiro e tinha nascido em Pirapora. Nunca voltou para casa em vinte anos. Era um homem agradável, encantador, feliz por ter encontrado alguém que falava um pouco de português e que já ouvira falar de Pirapora. Pela manhã, nos encontramos no convés, sob um vento gelado, uivante. Ele usava um suéter azul e o boné de linho caído para um lado. Seu cumprimento era, sempre, "Bom dia! Fresquinho, não é?" 7 - no sentido de que estava "um pouquinho fresco". Penso que foi então que eu decidi visitar Pirapora algum dia.

O nome significa "peixes saltando" na língua dos índios Cariri, desaparecidos há muito tempo. De acordo com um artigo sobre o São Francisco na Quatro Rodas, ${ }^{8}$ a revista mensal brasileira dedicada aos automóveis e às viagens, deve-se chegar à cidade domingo à

\footnotetext{
${ }^{6}$ Trata-se de sua primeira viagem à América do Sul, no "Bowplate", realizada no final de 1951.

${ }^{7}$ Em português, com Fresquinho grafado Frescinho.

8 “Sete dias nas águas do sertão". Texto e fotos de José Roberto Penna. Quatro Rodas, São Paulo: Ed. Abril, ano 7, n.79, fev. 1967, p.82-101.
} 
tarde, quando é possível acompanhar o esporte local favorito, rinha de canários. Havia ali, como por todo o Brasil, gaiolas penduradas do lado de fora em quase todas as casas, ou nas árvores próximas. (Tínhamos várias no convés inferior.) Elas continham uma grande variedade de pássaros, mas os "canários" que eu vi eram todos do tipo verde-amarelo nativo do Brasil, muito parecidos com o canário doméstico embora mais gordos e com um canto mais breve. Eles são pássaros charmosos na gaiola, mas famosos por sua ferocidade, e eu me tranquilizei por termos chegado numa segunda-feira, de modo que não poderíamos vê-los lutar. Também em Pirapora, de acordo com a Quatro Rodas, meu único livro-guia confiável, pode-se "ver chegar ou partir vapor, ou consultar o sobrinho do medium Arigó, milagreiro que não nega fogo. E ainda, de quebra, visitar o boteco ${ }^{9}$ de Dona Bela, provar e levar a melhor e mais velha cachaça ${ }^{10}$ da região, de vinte anos para cima".

Não fizemos nada disso naquela noite, todavia, exceto beber cachaça ou batida, ${ }^{11} \mathrm{um}$ tipo de coquetel feito com a mesma bebida misturada com suco de limão e açúcar. Nós e nossas bagagens fomos acomodados nos quartos, o que tomou um longo tempo, e depois todos nos reunimos de novo em terra firme com nosso guia, para ir a um restaurante ao ar livre sob um teto de folhas de palmeiras chamado "Bambuinha", sobre o rio, quase dentro dele. O último clarão vermelho do sol estava se apagando no rio quando chegamos, e depois disso algumas luzes surgiram, onde homens estavam pescando. O Bambuinha era um lugar agradável, limpo, e imerso no som da água corrente. Comemos vários tipos de peixes do rio, a maioria deles muito bons, ou o bife ${ }^{12}$ usual, e afinal caminhamos de volta para o barco. Nossos passos levantavam a fina areia ao longo do caminho, e assim subia o cheiro que iria predominar em todos os portos ou em todas as paradas, nos oito dias seguintes: o odor de poeira, enlaçado com um ocasional gosto doce, de jasmim ou de outras flores aromáticas, que nunca ocultava o mau cheiro discreto, por vezes discreto mas solidamente presente, de urina e fezes.

Nosso barco chamava-se Venceslau Brás. Esse foi o presidente do Brasil no tempo da Primeira Guerra Mundial, e, de acordo com tudo o que ouvi, um bom presidente. Mas nosso barco, que tinha uns setenta anos, deve ter tido no mínimo um outro nome anterior. Ele foi construído nos Estados Unidos e, a princípio, usado no Amazonas. Existem dezessete desses

\footnotetext{
${ }^{9}$ Em português, mas grafado bodega. Na revista consta boteco (p.90).

${ }^{10}$ Em português.

${ }^{11}$ Em português.

${ }^{12}$ Em português.
} 
vapores ainda em uso no São Francisco, é o que dizem, mas eu vi apenas quatro deles durante a viagem e não faço ideia do paradeiro dos outros. Existem também algumas lanchas a diesel e dois rebocadores, aqui chamados "empurradores", ${ }^{13}$ embora estivessem rebocando, quando os vi. Um deles puxava uma grande chata feita de troncos de balsa; o outro, dois barcos menores. No Amazonas veem-se longos comboios de dez ou doze pequenos barcos sendo rebocados, com toldos de folhas de palmeiras protegendo as pessoas, e muitas vezes, também, todo tipo de embarcação. O que era estranho, e deprimente, no Rio São Francisco, uma das mais importantes vias fluviais do país, era o vazio sem fim.

Os velhos vapores são chamados gaiolas, ${ }^{14}$ por causa da (não muito próxima) semelhança das rodas - pás estreitas de madeira preta encharcada, dispostas sobre uma estrutura de ferro - com uma gaiola. Gaiolas costumam levar 36 passageiros na primeira classe, e 150 na segunda - é o que o livro-guia diz; é difícil imaginar onde é que eles se alojam, mas pelo jeito a segunda classe se arranja com redes, a acomodação usual nas viagens por essas partes, acima da carga (até oitenta toneladas) que um gaiola também pode transportar, ou no meio dela. Os barcos são movidos a lenha, e eu perdi a conta do número de vezes que paramos para nos reabastecer de madeira, às vezes numa cidade ou vila, às vezes na margem, às vezes até mesmo num banco de areia, mas ela sempre estava esperando por nós, empilhada com perfeição, como na Nova Inglaterra. Nós espiávamos o lugar enquanto os marinheiros demoliam rápido essas pilhas de lenha, amontoando tronco após tronco na proa. Isso provocava grande barulho, é claro, e minha cabine ficava exatamente acima das batidas e pancadas que aconteciam com regularidade, tanto à noite como durante o dia. Depois de carregarem o barco, os marinheiros reconstruíam outra pilha, perfeita e fácil de desmontar. Para citar a Quatro Rodas mais uma vez, a fornalha era "insaciável". ${ }^{15}$

Exceto pela proa um pouco erguida (uma grande âncora balança, pendurada do lado de fora, à frente, e existe uma de reserva), o convés inferior permanece quase no nível do rio. De fato, quando enfrentamos fortes ventos de proa nos últimos dois dias a água varreu a parte central do barco, lavando o chão da cozinha e os pés negros e descalços dos nossos cozinheiros em seu caminho.

Gaiolas têm calado de apenas um metro, e um longo leme logo à frente das rodas, controlado por um timão na pequena ponte de comando, localizada no convés superior. $\mathrm{O}$ mecanismo era simples o bastante para que eu - tão avessa à mecânica - o entendesse. Uma

\footnotetext{
${ }^{13}$ Na Quatro Rodas (p.89) também consta o termo 'empurradores'.

${ }^{14}$ Em português. A Quatro Rodas refere-se a esses barcos tanto no masculino como no feminino.

15 "Lenha e mais lenha, que a fornalha do vapor é insaciável" (p.96).
} 
pesada vara de ferro, conectada a esse leme, percorria todo o convés superior e girava para um lado e para o outro, à medida que o piloto girava o timão - era preciso ter cuidado ao pisar nela. A fornalha e a caldeira, embora parecessem algo preservado para a posteridade no museu Smithsonian, pareciam ainda funcionar muito bem. Eu as examinei em vão, em busca do nome do fabricante, ou de uma data.

O principal charme de um gaiola, além da madeira - e de outros ruídos mais "modernos" - é sua quietude; enquanto serpenteávamos devagar rio abaixo o barco fazia ppph...ppph...ppph... com suavidade, como uma foca emergindo em busca de ar. E a roda fazia um ruído leve, rítmico, mas que só podia ser ouvido junto à popa.

Tínhamos uma chaminé alta, pintada e repintada com tinta amarelo-alaranjada. À noite ela expelia um jato de grandes fagulhas; durante o dia parecia um lápis de cera amarelo em movimento, como se uma criança estivesse traçando o curso do Rio São Francisco numa aula de geografia.

No convés superior ficavam a sala do timão e as cabines dos comandantes; o espaço restante estava coberto por um toldo e mobiliado com cadeiras de jardim em plástico e metal, e, infelizmente, um alto-falante para os "turistas", uma vez que o Venceslau Brás é o único barco "equipado" no rio, hoje. Uma fileira de oito luzes coloridas acendia-se à noite, e havia luzes vermelhas dispostas nos cantos do convés, onde, dizia o livro-guia, deveríamos dançar. Eu nunca vi ninguém dançando, e, uma vez que o chão era remendado, coberto de piche, um pouco arqueado, e parecia-se com um velho cobertor sob nossos sapatos, era difícil imaginar alguém dançando ali. O convés intermediário tinha uma sala estreita atravessando a proa, e duas cabines "de-luxe", uma das quais era a minha. Ela media cerca de três metros quadrados ${ }^{16}$ e as paredes e o teto eram cobertos por um compensado barato cheio de furos, como um estuque antiquado. Uma das paredes era cor-de-rosa, outra azul, o resto cinza. Havia uma espécie de armário atrás de uma cortina, uma minúscula privada e um chuveiro. $\mathrm{O}$ efeito era o de uma triste casa de veraneio alugada. Eu tinha um colchão de viúva, mas ele havia sido colocado num estrado de solteiro, por isso ficava arqueado. Virando-me uma noite durante o sono, acordei com metade do corpo entalada entre o colchão inclinado e a parede. Entretanto, eu tinha três janelas, e minhas acomodações eram muito boas comparadas com as outras cabines - com beliches em todas elas, quase sem espaço para mover-se e uma só janela. Durante a sesta podíamos ver solas de pés descalços através dessas janelas.

\footnotetext{
${ }^{16}$ No original, 8 pés quadrados, ou seja, menos de $1 \mathrm{~m}^{2}$, erro óbvio. Essas cabines tinham cerca de $3 \mathrm{~m}^{2}$.
} 
Na popa havia um bar ao ar livre onde um marinheiro chamado José às vezes servia cachaça ${ }^{17}$ ou cerveja, mas ele passava a maior parte do tempo pescando, hora após hora, e conversando com a única mulher da tripulação, Raimunda. Quase sobre as rodas havia um minúsculo salão. Fui até lá apenas para ver as rodas e ouvi-las, mas um grupo de quatro passageiros passou ali quase toda a viagem, jogando canastra. Um cartaz dizia que era proibido jogar, mas ninguém lhe dava atenção. De fato, nosso guia, que chamarei de Maurício, mostrou-se o maior jogador de cartas de todos e ganhou o equivalente a quatro ou cinco dólares a cada noite. Depois sua sorte mudou e ele se mostrou um mau perdedor; é claro que este seria um dos assuntos usuais de conversa e zombaria.

De cada lado do salão havia um banheiro com chuveiro, damas e cavalheiros. As pias para lavar o rosto, do menor tamanho possível, ficavam do lado de fora, no convés, brancas, diante de paredes de fórmica azul brilhante, com espelhos emoldurados em branco sobre elas. Os homens se barbeavam aí, à vista de todos, exceto Sven, o rapaz sueco, que tinha um barbeador elétrico. Ele tinha de ir até a cabine do Comissário, a única que dispunha de tomada elétrica.

Brasileiros são pessoas extremamente limpas, como regra geral, tanto os ricos como os pobres. Os pobres podem ser forçados a viver na miséria e na imundície, mas de alguma maneira conseguem manter-se limpos. Nas cidades, um encanador ou marceneiro jamais chegará para fazer um serviço em roupas de trabalho. Ele chega arrumado, com suas roupas de trabalho numa maleta, e troca-se, e é claro que o deixarão usar o chuveiro do banheiro da empregada e trocar-se antes de sair. As favelas ${ }^{18}$ cheiram mal, mas é raro que isso aconteça com o povo, mesmo sob um sol tropical. Os brasileiros das classes altas ficam chocados com os hábitos de outras nações. Uma de minhas amigas matriculou o filho numa ótima escola preparatória inglesa, e quase o trouxe de volta quando descobriu que os meninos tomavam banho apenas duas vezes por semana, e que vários deles tinham de usar a mesma água. Durante uma viagem em que eu desci o Amazonas, vários anos atrás, o barco tinha mais de seiscentos passageiros dormindo em redes, e todos eles pareciam saídos do chuveiro, de alguma maneira, todas as tardes, com camisas limpas ou vestidos de algodão, e penteando o cabelo molhado. Uma criança chorava muito e sua jovem mãe me disse que era porque ela estava acostumada a três ou quatro banhos diários, e era impossível banhá-la no barco. Eu tinha uma bacia feita de latas esticadas, que havia comprado como peça folclórica, e desde então o bebê tomou dois banhos por dia na minha bacia de lata. Os quatro banhos diários e a

\footnotetext{
${ }^{17}$ Em português.

${ }^{18}$ Em português.
} 
limpeza dos passageiros mais pobres, que tanto me assombraram, talvez se devam em parte à mistura de sangue indígena na população amazônica. Os índios ribeirinhos banham-se várias vezes ao longo do dia, e uma aldeia a dois ou três quilômetros do rio implica uma caminhada diária, em grupo, para o banho. Mas no Rio São Francisco os passageiros de classe média, brancos, estavam sempre a caminho dos chuveiros ou das pias, com toalhas, sabão e escovasde-dente, as mulheres vestindo robes de chambre coloridos em tons brilhantes, chamados chambreys. E todos exalavam odor de talco ou de água-de-colônia.

O fato estranho acerca dessa fanática limpeza pessoal é que, ao mesmo tempo, os banheiros brasileiros são os mais imundos que já encontrei. Eu sou - gosto de pensar assim uma boa viajante, e posso tolerar desconforto, aborrecimentos, comida ruim, até mesmo barulho excessivo, e mesmo assim me divertir. No Brasil eu aprendi a ter sempre comigo uma lanterna, remédios, um suprimento extra de comida, e uma lâmpada de 60,75 ou, se eu quiser arriscar, 100 watts. Os brasileiros parecem capazes de ler no escuro, e a lâmpada comum é de 40 watts $-{ }^{19}$

\footnotetext{
${ }^{19} \mathrm{O}$ original é interrompido aqui.
} 


\section{Bibliografia}

\section{Obras de Elizabeth Bishop}

BISHOP, Elizabeth. The complete poems 1927-1979. New York: Farrar, Straus \& Giroux, 2006. 288p. ( $1^{\text {st }}$ printing, 1983). . The collected prose. (Edited, with an introduction, by Robert Giroux.) $7^{\text {th }}$ printing. New York: Noonday (a division of Farrar, Straus \& Giroux), 2000. 278p. ( $1^{\text {st }}$ printing, 1984). . One Art. Robert Giroux (Ed.). New York: Noonday (a division of Farrar, Straus \& Giroux), 1994. 668p. Edgar Allan Poe \& The Juke-box. Uncollected Poems, Drafts, and Fragments (Edited and annotated by Alice Quinn). New York: Farrar, Straus \& Giroux, 2006. 366p. (1.ed.). Poems, prose and letters. (Edited and annotated by Robert Giroux \& Lloyd Schwartz). New York: Literary Classics of the United States, 2008. 980p. (The Library of America, 180). BISHOP, Elizabeth \& The Editors of LIFE. Brazil. New York: Time Incorporated, 1962. 160p. (Coll. Life World Library.) [1.ed.] [O primeiro capítulo, “A Warm and Reasonable People”, foi republicado em Bishop, 2008, p.427-437.]

BISHOP, Elizabeth \& The Editors of LIFE. Brazil. New York: Time Incorporated, 1970. 160p. (Coll. Life World Library.) [Com alterações nos textos e nas ilustrações, mantém-se a coautoria.]

\section{Obras de Elizabeth Bishop traduzidas para o português}

BISHOP, Elizabeth. Uma Arte. As cartas de Elizabeth Bishop (incluindo inéditos). Seleção com base na edição americana (One Art): Carlos Eduardo Lins da Silva e João Moreira Salles; Tradução: Paulo Henriques Britto. São Paulo: Companhia das Letras, 1995. 792p. Esforços do afeto e outras histórias. Prosa reunida. Tradução de Paulo Henriques Britto (Original: The collected prose, 1984). São Paulo: Companhia das Letras, 1996. 308p. Poemas do Brasil. Seleção, introdução e tradução de Paulo Henriques Britto. Edição bilíngue. São Paulo: Companhia das Letras, 1999. 192p. . O iceberg imaginário e outros poemas. Seleção, introdução e estudo crítico de Paulo Henriques Britto. Edição bilíngue. São Paulo: Companhia das Letras, 2001. 370p. 


\section{Textos de Elizabeth Bishop traduzidos para este trabalho}

BISHOP, Elizabeth. "Suicide of a (Moderate) Dictator" [1954]. In: . Edgar Allan Poe \& The Juke-box. Uncollected Poems, Drafts, and Fragments (Edited and annotated by Alice Quinn). New York: Farrar, Straus \& Giroux, 2006. p.194-196.

. "A new capital, Aldous Huxley, and some indians" [1958]. [introd. by Barbara Page]. The

Yale Review, New Haven, v.94, n.3, p.76-114, July 2006. [Republicado em Bishop, 2008, p.365401].

“"A trip on the Amazon" [1960]. Vassar College, Special Collections, Elizabeth Bishop, Box "Prose Unpublished", Folder 55.4, 9p. Datilografado; sem data; título manuscrito: "On the 'Lauro Sodré'”. (Inédito).

. "On the Railroad named Delight". The New York Times Magazine, March 7, 1965, p.30-31,

84-85. [Republicado em Bishop, 2008, p.438-448.]

. "A trip on the Rio São Francisco" [1967]. Vassar College, Special Collections, Elizabeth

Bishop, Box “Prose Unpublished”, Folder 55.4, 8p. Datilografado; sem data; título datilografado. (Inédito).

\section{Obras organizadas ou traduzidas por Elizabeth Bishop}

BISHOP, Elizabeth; BRASIL, Emanuel (Ed.) An anthology of $20^{\text {th }}$ Century Brazilian Poetry. (Edição bilíngue, com Introdução dos editores). Wesleyan University Press. Boston, Mass.: Univ. Press of New England, 1994. (1.ed.: 1972)

MORLEY, Helena. The diary of Helena Morley. Transl. Elizabeth Bishop. 1.ed. New York: Farrar, Straus and Giroux, 1957. (O Prefácio, "The book \& its Author", foi republicado em The Collected Prose (1984), p.81-109, e em Poems, prose, and letters (2008), como "Introduction to The Diary of Helena Morley", p.342-364. Sua tradução para o português foi incluída em Esforços do afeto e outras histórias (1996) como "O diário de 'Helena Morley': o livro e a autora", trad. Paulo Henriques Britto, p.105-134).

\section{Sobre Elizabeth Bishop}

ALMEIDA, Sandra R. Goulart; GONÇALVES, Glaucia R., REIS, Eliana L. de Lima. (Ed.) The Art of Elizabeth Bishop. Belo Horizonte: Ed. UFMG, 2002. 292p.

ANASTÁCIO, Sílvia Maria Guerra. O jogo das imagens no universo da criação de Elizabeth Bishop. São Paulo: Annablume, 1999. 260p. 
BELL, Pearl Kazin. Dona Elizabetchy: a memoir of Elizabeth Bishop. Partisan Review, winter 1991. (Em espanhol em Letras Libres, 2001. Disponível em: www.letraslibres.com/index.php?art=8451).

FERREIRA, Armando Olivetti. Pontos cordiais: as cartas brasileiras de Elizabeth Bishop. São Paulo, 2003. 250p. Dissertação (Mestrado em Comunicação e Letras) - Universidade Presbiteriana Mackenzie.

GÓES, Martha. Um porto para Elizabeth Bishop. (Teatro). São Paulo: Terceiro Nome, 2001. 64p.

JAGUARIBE, Beatriz. Diamantes e feijão preto: Elizabeth Bishop e o Brasil. In: Fins de século: cidade e cultura no Rio de Janeiro. Rio de Janeiro: Rocco, 1998. p.76-118.

MILLIER, Brett C. Elizabeth Bishop. Life and the memory of it. Los Angeles: University of California Press, 1993. 602p.

MONTEIRO, George (Org.). Conversations with Elizabeth Bishop. (Literary Conversations Series). Jackson: University Press of Mississippi, 1996. 164p.

NOGUEIRA, Nadia Cristina. Invenções de si em histórias de amor: Lota \& Bishop. Rio de Janeiro: Apicuri, 2008. 264p.

Lota Macedo Soares e Elizabeth Bishop: amores e desencontros no Rio dos anos 1950-1960. Campinas, 2005. 306p. Tese (Doutorado em História) - IFCH, Unicamp.

OLIVEIRA, Carmen L. Flores raras e banalíssimas: a história de Lota de Macedo Soares e Elizabeth Bishop. Rio de Janeiro: Rocco, 1995. 222p.

PRZYBYCIEN, Regina Maria. Feijão preto e diamantes: o Brasil na obra de Elizabeth Bishop. Belo Horizonte, 1993. 296p. Tese (Doutorado em Letras, Literatura comparada) - Universidade Federal de Minas Gerais.

SANTIAGO, Silviano. O estatuto do poema descritivo de Elizabeth Bishop. Trabalho apresentado na conferência internacional “The art of Elizabeth Bishop”, Ouro Preto, 19 a 21 de maio, 1999.

SÜSSEKIND, Flora. A geleia \& o engenho: em torno de uma carta-poema de Elizabeth Bishop a Manuel Bandeira. In: Papéis colados. Rio de Janeiro: Ed. UFRJ, 1993, p.331-365.

TREVISAN, João Silvério. A mulher que descobriu o Brasil. In: Devassos no paraíso. (3.ed. revista e ampliada). Rio de Janeiro: Record, 2000. p.93-106.

\section{Bibliografia geral (interpretação do Brasil, viajantes, edição de textos etc.)}

ABDALA Jr., Benjamin; CARA, Salete de Almeida. Moderno de nascença: figurações críticas do Brasil. São Paulo: Boitempo, 2006. 240p.

ANDRADE, Mário de. Macunaíma (O herói sem nenhum caráter). 6.ed. São Paulo: Círculo do Livro, s.d. 228p.

O turista aprendiz. (Estabelecimento de texto, introdução e notas de Telê P. A. Lopez.) 2.ed. São Paulo: Duas cidades, 1983. 
BASTIDE, Roger. Brasil, terra de contrastes. Trad. Maria Isaura Pereira Queiroz. 2.ed. São Paulo: Difusão Europeia do Livro, 1964. 262p. [Ed. original: Brésil terre des contrastes. Paris: Hachette].

BINZER, Ina von. Os meus romanos: alegrias e tristezas de uma educadora alemã no Brasil. Trad. Alice Rossi e Luisita da Gama Cerqueira. 6.ed. São Paulo: Paz e Terra, 2004. 172p.

BOSI, Alfredo. Camus na festa do Bom Jesus. Tempo Social, USP, v.10, n.1, p.49-63, maio 1998.

BUENO, Eduardo. Lacerda e o calvário de Castilho. In: Caixa: uma história brasileira. São

Paulo: Metalivros/Buenas Ideias, 2002. p.142-3.

CAMUS, Albert. A pedra que cresce. In: O exílio e o reino. (Contos). Trad. Valérie Rumjanek. 4.ed. Rio de Janeiro: Record, s.d. p.131-71. . Diário de viagem. Trad. Valérie Rumjanek. 4.ed. Rio de Janeiro: Record, 1997. 126p.

CANDIDO, Antonio. O discurso e a cidade. São Paulo: Duas cidades, Rio de Janeiro: Ouro sobre Azul, 2004. 288p. . Iniciação à literatura brasileira. Rio de Janeiro: Ouro sobre Azul, 2004. 136p. . Literatura e sociedade. 8.ed. São Paulo: T.A.Queiroz, 2000. 196p.

CENDRARS, Blaise. A aventura brasileira de Blaise Cendrars. Alexandre Eulálio (Org.), 2.ed. revista e ampliada por Carlos Augusto Calil. São Paulo: Edusp, Fapesp, 2001. 628p.

COGEZ, Gérard. Présentation. In: Les écrivains voyageurs au XXe siècle. Paris: Ed. du Seuil, 2004. p.11-33.

DAMATTA, Roberto. Carnavais, malandros e heróis: para uma sociologia do dilema brasileiro. 6.ed. Rio de Janeiro: Rocco, 1997. 350p.

ENZENSBERGER, Hans Magnus. "Nós" e "Eles", ou: a herança colonial. In: Com raiva e paciência: ensaios sobre literatura, política e colonialismo. (Seleção e introdução de Wolfgang Bader; trad. Lya Luft; rev. técnica Marijane Lisboa). Rio de Janeiro: Paz e Terra, 1985. p.205-310.

FREYRE, Gilberto. Casa-grande e senzala. 37.ed. Rio de Janeiro: Record, 1999. 570p. Ingleses no Brasil: aspectos da influência britânica sobre a vida, a paisagem e a cultura do Brasil. 3.ed. Rio de Janeiro: Topbooks, 2000. 412p.

. Interpretação do Brasil. Org. de Omar Ribeiro Thomaz. São Paulo: Companhia das Letras, 2001. 356p.

FROTA, Lélia Coelho. Madalena Santos Reinbolt escreve o mundo nos seus quadros de lã. In: Mitopoética de nove artistas brasileiros. Rio de Janeiro: Fontana, 1975. p.113-126. [Ensaio sobre a artista plástica, antiga empregada de Bishop e Lota].

GLEDSON, John. Brasil: cultura e identidade. In: Por um novo Machado de Assis. (Ensaios). São Paulo: Companhia das Letras, 2006. 452p. p.359-380.

HOLANDA, Sérgio Buarque de. Raízes do Brasil. 26.ed. 11.reimpr. São Paulo: Companhia das Letras, 2001. 220p. Visão do paraíso. São Paulo: Publifolha, 2000. 452p. 
HOUAISS, Antônio. Elementos de bibliologia. São Paulo: Hucitec; Brasília: INL; Pró-Memória, 1983. $332+198$ p. (Reprod. facsimilar da primeira edição, Rio de Janeiro: INL, 1967. 2v.).

KOHUT, Andrew; STOKES, Bruce. America against the world: how we are different and why we are disliked. New York: Times Books, 2006. 262p.

LAMBERT, Jacques. Os dois Brasis. 4.ed. São Paulo: Cia. Ed. Nacional, 1969.

LÉVI-STRAUSS, Claude. Tristes trópicos. São Paulo: Companhia das Letras, 2001.

LISBOA, Karen Macknow. Viagem pelo Brasil de Spix e Martius: quadros da natureza e esboços de uma civilização. Revista Brasileira de História, Anpuh, v.15, n.9, p.73-91, 1995.

MEIHY, José Carlos S. B. Warren Dean: um brasilianista acima de qualquer suspeita. Revista Brasileira de História, v.14, n.27, p.205-211, 1994.

MONTES, Maria Lucia. As figuras do sagrado: entre o público e o privado. In: NOVAIS, Fernando A.

(Org.), SCHWARCZ, Lilia Moritz. (Org. do volume) História da vida privada no Brasil: contrastes da intimidade contemporânea. v.4. São Paulo: Companhia das Letras, 1998, p.64-171.

MORAES, Marcos Antonio de. Orgulho de jamais aconselhar: a epistolografia de Mário de Andrade. São Paulo: Edusp; Fapesp, 2007. 248p.

MORLEY, Helena. Minha vida de menina. 1.ed. 6.reimpr. São Paulo: Companhia das Letras, 2000. 336p.

MÚSICA BRASILEIRA deste século por seus autores e intérpretes, A. (Org. J. C. Pelão Botezelli; Arley Pereira). São Paulo: Sesc, 2000. v.2. 256p.

NOVAIS, Fernando. Caio Prado Jr., historiador. Novos Estudos Cebrap, v.2, n.2, p.66-70, jul. 1983.

OLIEVENSTEIN, Claude; LAPLANTINE, François. Um olhar francês sobre São Paulo. Trad. Maria Carneiro da Cunha. São Paulo: Brasiliense, 1993. 94p.

PARADA, Maurício B. A. A fundação do Museu de Arte Moderna do Rio de Janeiro: a elite carioca e as imagens da modernidade no Brasil dos anos 50. Revista Brasileira de História, Anpuh, v.14, n.27, p.113-28, 1994.

PASSOS, John dos. Brazil on the move. (The Armchair Traveller Series). New York: Paragon, 1991. 206p. [1.ed.: Garden City (NY): Doubleday, 1963].

PRADO, Luís André do. Cacilda Becker: fúria santa. São Paulo: Geração Editorial, 2002. 622p.

PRADO, Paulo. Retrato do Brasil. Ensaio sobre a tristeza brasileira. 8.ed. Org. Carlos Augusto Calil. São Paulo: Companhia das Letras, 1997.

PRADO JUNIOR, Caio. Formação do Brasil contemporâneo. Colônia. 2.ed. São Paulo: Brasiliense, 1945. 390p.

RIBEIRO, Darcy. Uma introdução a Casa-Grande \& Senzala. In: Sobre o óbvio. Rio de Janeiro: Guanabara, 1986. p.109-173. 
SAUNDERS, Frances Stonor. The cultural Cold War: the CIA and the world of arts and letters. New York: The New Press, 2000. 510p. [Originalmente publicado como Who paid the piper? London: Granta Books, 1999. Edição brasileira: Quem pagou a conta? A CIA na Guerra Fria da cultura. Trad. Vera Ribeiro. Rio de Janeiro: Record, 2008. 560p.]

SCHWARZ, Roberto. Duas meninas. 1.reimpr. São Paulo: Companhia das Letras, 1997. 148p. . Que horas são? São Paulo: Companhia das Letras, 2002. 180p. (1.ed.: 1987) . Revisão e autoria. In: . O pai de família e outros estudos. 2.ed. São Paulo: Paz e Terra, 1992. p.123-125. . Sequências brasileiras. São Paulo: Companhia das Letras, 1999. 250p. . "A letra escarlata" e o puritanismo. In: A sereia e o desconfiado. Rio de Janeiro:

Civilização Brasileira, 1965.

SEVCENKO, Nicolau. Jardim de Pindorama: manifesto para o século 21. (Apresentação) In:

Pindorama revisitada: cultura e sociedade em tempos de virada. São Paulo: Peirópolis, 2000. (Série Brasil Cidadão). 120p.

SILVEIRA, Joel. Grã-finos em S. Paulo e outras notícias do Brasil. (Reportagens). São Paulo: [Cruzeiro do Sul], 1946.

SPINA, Segismundo. Introdução à Edótica. São Paulo: Cultrix; Edusp, 1977. 154p.

STEIN, Gertrude. A autobiografia de Alice B. Toklas. Porto Alegre: L\&PM, 2006. 264p.

SÜSSEKIND, Flora. O Brasil não é longe daqui: o narrador; a viagem. 1.ed. 1.reimpr. São Paulo: Companhia das Letras, 2000. 320p.

TOUSSAINT-SAMSON, Adèle. Uma parisiense no Brasil. Rio de Janeiro: Capivara, 2003.

TIME-LIFE LIVROS, Editores de. Brasil. Rio de Janeiro: Abril Livros, 1992. 160p. [Edição original: Brazil. New York: Time Life Inc., 1984. 2.ed., 1987].

VELOSO, Caetano. Verdade tropical. São Paulo: Companhia das Letras, 1997. 524p.

VERISSIMO, Érico. Gato preto em campo de neve: romance de uma viagem aos Estados Unidos. Porto Alegre: Globo, 1941. 424p.

VERNE, Júlio. Viagem à Inglaterra e à Escócia. Trad. Luís S. Krausz. São Paulo: Nobel, 1990. 236p.

ZWEIG, Stefan. Brasil, um país do futuro. [1942] Prefácio de Alberto Dines; Trad. Kristina Michahelles. Porto Alegre: L\&PM, 2006. 264p. . Journaux, 1912-1940. Ed. Knut Beck; trad. Jacques Legrand. Paris: Pierre Belfond, 1986. [Rio de Janeiro, p.261-270]. 


\section{Sobre arquitetura e urbanismo}

ARANTES, Otília Beatriz Fiori. Lúcio Costa e a "boa causa" da arquitetura moderna. In: ARANTES, Paulo. Sentido da formação: três estudos sobre Antonio Candido, Gilda de Mello e Souza e Lúcio Costa. Rio de Janeiro: Paz e Terra, 1997. p.113-133.

CAVALCANTI, Lauro. Moderno e brasileiro: a história de uma nova linguagem na arquitetura (193060). Rio de Janeiro: Jorge Zahar, 2006.

Quando o Brasil era moderno. Guia de arquitetura 1928-1960. Rio de Janeiro: Aeroplano, 2001. 468p.

. Sergio Bernardes: herói de uma tragédia moderna. (Perfis do Rio, 41). Rio de Janeiro: Relume Dumará, 2004. 126p.

Entrevista a Evelise Grunow. Projeto Design, São Paulo, n.338, abr. 2008, p.12-15.

COHEN, Alberto A.; FRIDMAN, Sergio A. Rio de Janeiro: ontem \& hoje. v.1. (Fotografias: Ricardo Siqueira). Rio de Janeiro: Amazon, 1998. 128p.

FALBEL, Anat. Arquitetos imigrantes no Brasil: uma questão historiográfica. Disponível em: www.docomomo.org.br/seminario\%206\%20pdfs/Anat\%20Falbel.pdf.

LISPECTOR, Clarice. Brasília de ontem e de hoje. (Originalmente publicada no Jornal do Brasil, Rio de Janeiro, 7 out. 1972). In: A descoberta do mundo. Rio de Janeiro: Rocco, 1999. p.426-428.

Nos primeiros começos de Brasília. (Originalmente publicada no Jornal do Brasil, Rio de Janeiro, 20 jun. 1970). In: A descoberta do mundo. Rio de Janeiro: Rocco, 1999. p.292-295.

MINDLIN, Henrique E. Arquitetura moderna no Brasil. Prefácio de S. Giedion. Org. da ed. brasileira: Lauro Cavalcanti; trad. Paulo Pedreira. Rio de Janeiro: Aeroplano, Ministério da Cultura, Iphan, 1999. (Tradução de Modern Architecture in Brazil. New York: Reinhold, 1956).

NIEMEYER, Oscar. Depoimento. In: XAVIER, Alberto. (Org.) Depoimento de uma geração: arquitetura moderna brasileira. São Paulo: Abea; FVA; Pini, 1987. p.221-224. [Originalmente publicado em Módulo, Rio de Janeiro, n.9, p.3-6, fev. 1958].

\section{Sobre jornalismo}

AMARAL, Luiz. A objetividade jornalística. Porto Alegre: Sagra; DC Luzzatto, 1996. 98p.

BAITZ, Rafael. Um continente em foco: a imagem fotográfica da América Latina nas revistas semanais brasileiras (1954-1964). São Paulo: Humanitas/FFLCH-USP, 2003. 202p.

CHAPARRO, Manuel Carlos. Pragmática do jornalismo: buscas práticas para uma teoria da ação jornalística. São Paulo: Summus, 1994. 134p. 
COSTA, Helouise. Aprenda a ver as coisas: fotojornalismo e modernidade na revista $O$ Cruzeiro. São Paulo, 1992. Dissertação (Mestrado em Artes) - ECA/USP. 190p. (Especialmente o capítulo I.2, "A Fotorreportagem: A arquitetura de uma forma jornalística", p.53-68).

JUNQUEIRA, Mary Anne. Ao sul do Rio Grande: imaginando a América Latina em Seleções - oeste, wilderness e fronteira (1942-1970). Bragança Paulista (SP): Edusf, 2000. 292p.

MEDINA, Cremilda. Notícia, um produto à venda: jornalismo na sociedade urbana e industrial. 2.ed. São Paulo: Summus, 1988. 190p.

MORAIS, Fernando. Chatô: o rei do Brasil. A vida de Assis Chateaubriand. São Paulo: Companhia das Letras, 1994.

POLACOW, Patrícia Ozores. Conspiração patrocinada: a versão de Assis Chateaubriand sobre os acordos Time-Life. São Bernardo do Campo (SP), 2000. Dissertação (Mestrado em História) Umesp.

A REVISTA NO BRASIL. São Paulo: Abril, 2000. 250p.

WAINER, Samuel. Minha razão de viver: memórias de um repórter. 8.ed. Rio de Janeiro: Record, 1988. 284p.

\section{Textos jornalísticos sobre Elizabeth Bishop}

ALMINO, João. Elizabeth Bishop: a poeta vê o Brasil. Folha de S. Paulo, 24 set. 1995, Mais!, p.5-7.

ARENDT, Hannah. "Você precisa conhecer a amiga brasileira de Bishop" (Carta). Trad. Sieni Campos. Folha de S. Paulo, 18 jun. 1995, Mais!, p.5-5.

ASCHER, Nelson. Uma carta de Bishop a Lota. Folha de S. Paulo, 24 set. 1995, Mais!, p.5-6.

Poesia de Elizabeth Bishop ganha tradução à sua altura. Folha de S. Paulo, 19 maio 2001, Ilustrada, p.E4.

BISHOP, Elizabeth. Cartas à redação. Correio da Manhã, Rio de Janeiro, 27 abr. 1965, p.7.

CALLADO, Antonio. Um sábio entre bugres: Huxley visita os índios do Xingu. Correio da Manhã, Rio de Janeiro, 21 ago. 1958, p.16, p.8. . Há uma mulher invisível no Aterro. Folha de S. Paulo, 16 set. 1995, Ilustrada, p.5-9. . Poeta deu trégua à angústia em Petrópolis. Folha de S. Paulo, 11 jun. 1994, Ilustrada, p.5-8.

CASTRO, Fernando de. Paternalismo e antiamericanismo. Correio da Manhã, Rio de Janeiro, 28 mar. 1965, p.4.

COELHO, Marcelo. Inéditos de Elizabeth Bishop. Disponível em: http://marcelocoelho.folha.blog.uol.com.br/, 5 ago. 2006.

COELHO, Sérgio Salvia. Sob olhar estrangeiro, Bishop define Brasil. Folha de S. Paulo, 15 jun. 2001, Ilustrada, p.E2. 
DIAS, Maurício Santana. As aspas da tradução. [Entrevista com Paulo Henriques Britto, tradutor de Elizabeth Bishop]. Folha de S. Paulo, 27 fev. 2000, Mais!, p.5-30-31.

FELINTO, Marilene. Prosa completa esclarece vida e obra de Bishop. Folha de S. Paulo, 5 out. 1996, Ilustrada, p.4-8.

GABEIRA, Fernando. Nuvem envolveu Elizabeth Bishop e Lota. Folha de S. Paulo, 5 fev. 1996, Ilustrada, p.4-5.

GASPARI, Elio. Elizabeth Bishop. Folha de S. Paulo, 23 maio 1999, p.1-12.

GOMES, Álvaro Cardoso. “A pessoa mais solitária que jamais viveu”. Jornal da Tarde, São Paulo, 18 ago. 2001.

HACKER, Marilyn. A doubled good read. [Resenha de Edgar Allan Poe and the Juke Box..., organizado por Alice Quinn]. Poetry London, Summer, 2007.

HORTA, Nina. Bishop fazia geleia de jabuticaba em 53. Folha de S. Paulo, 17 jun. 1994, Ilustrada, p.Especial-2.

LOGAN, William. "I write entirely for you". [Resenha de Words in air, correspondência completa entre Bishop e Robert Lowell, org. por Thomas Travisano e Saskia Hamilton, New York: Farrar, Straus \& Giroux, 2008, 875p.]. The New York Times, 31 out. 2008.

MCCLATCHY, J. D. Letters from a lonely poet. [Resenha de One art..., 1994]. The New York Times, 17 abr. 1994.

MOURA, Rodrigo. Expressão popular - Coleção Cesar Aché. Folha de S. Paulo, 6 ago. 2001, Ilustrada, p.E-4. [Refere-se a Madalena Reinbolt, artista plástica, antiga empregada de Lota e Bishop].

NIGRI, André. O humor aguçado que escondia a depressão. Jornal da Tarde, São Paulo, 4 jun. 2001. [Inclui entrevista com o artista plástico José Alberto Nemer, amigo de Bishop].

NUSSBAUM, Emily. The love of her life. [Resenha de Rare and commonplace flowers, de Carmen Oliveira]. The New York Times, 9 jun. 2002.

OLIVEIRA, Carmen L. A poeta do desterro. Bravo!, São Paulo, ano 1, n.6, mar. 1998, p.66-70.

ORR, David. Rough gems. [Resenha de Edgar Allan Poe and the jukebox...]. The New York Times, 2 abr. 2006.

PEREIRA, Stella Baptista. Carta publicada no Painel do Leitor. Folha de S. Paulo, 4. out. 1995, p.1-3.

PIZA, Daniel. A natureza de Elizabeth Bishop. O Estado de S. Paulo, 15 jul. 2001.

REZENDE, Marcelo. Cartas resgatam exílio brasileiro de Bishop. Folha de S. Paulo, 11 jun. 1994, Ilustrada, p.5.1.

RICH, Motoko. New Elizabeth Bishop book sparks a controversy. [Resenha de Edgar Allan Poe and the jukebox...]. The New York Times, 1 abr. 2006.

SCHWARTZ, Lloyd. Entrevista concedida a Rodrigo de Souza Leão. s.d. Disponível em: www.gargantadaserpente.com/entrevista/lloydschwartz.shtml 
SILVA, Carlos Eduardo Lins da. Cartas comprovam excelência como prosista. Folha de S. Paulo, 11 jun. 1994, Ilustrada, p.5.9.

TOLEDO, Roberto Pompeu de. "Uma atmosfera vaga e majestosa". Veja, 15 ago. 2001, n.1713, p.158.

\section{Textos jornalísticos gerais}

CARVALHO, Mario Cesar. Ridentes trópicos. Folha de S. Paulo, 16 dez. 2001, Mais!, p.4-11. [Inclui entrevista com o antropólogo Luiz de Castro Faria].

COELHO, Marcelo. Com apetite por escândalo e detalhe, livro tem o efeito de "lista negra" ao contrário. [Resenha de The cultural Cold War, de Frances S. Saunders]. Folha de S. Paulo, 26 jan. 2008, p.E.2.

DO RIO OU NÃO, dez cariocas definem 400 anos de boa vida. Folha de S. Paulo, 1 mar. 1965, p.5.

DULANY, Peggy. Por que alguns odeiam os americanos? Folha de S. Paulo, 21 out. 2001, p.A-3.

FREIRE, Ricardo. Autoimagem. Jornal da Tarde, São Paulo, 20 jul. 2001.

GULLAR, Ferreira. Certa noite no Opinião. Folha de S. Paulo, 21 out. 2007, p.E16.

HAMERMAN, Conrad. Roberto Burle-Marx: a última entrevista. The Journal of Decorative and Propaganda Arts, v.21, 1995. [número dedicado ao Brasil]. Adendo (em português), p.76-85.

MORAES, Marcos Antonio de. O percurso de um poeta suíço na terra brasileira. Jornal da Tarde, São Paulo, 11 ago. 2001, Caderno de Cultura.

SETE DIAS nas águas do sertão: roteiro do rio São Francisco. (Texto e fotos de José Roberto Penna). Quatro Rodas, São Paulo, ano VII, n.79, fev. 1967, p.82-101.

SIMÕES, Eduardo. Cultura \& CIA. Folha de S. Paulo, 26 jan. 2008, p.E1-2. [Contém entrevista com Frances S. Saunders, autora de The cultural Cold War].

SHIRTS, Matthew. Histórias de gringos, sotaques e poesias. O Estado de S. Paulo, 6 ago. 2001.

WEINBERGER, Eliot. Ninguém fala português. (Entrevista concedida a Odile Cisneros). Sibila, São Paulo, n.2, 2002. Disponível em: sibila.com.br/numero2.html.

\section{Filmes - documentários}

Olhar estrangeiro. Direção: Lucia Murat. Produção: Europa Filmes. Rio de Janeiro, 2005. 90 min.

Zweig: a morte em cena. Direção: Sylvio Back. Produção: Usina de Kyno; Goethe Institut. Brasil, 1995. $43 \mathrm{~min}$. 